Edited by Mario Damen and Kim Overlaet

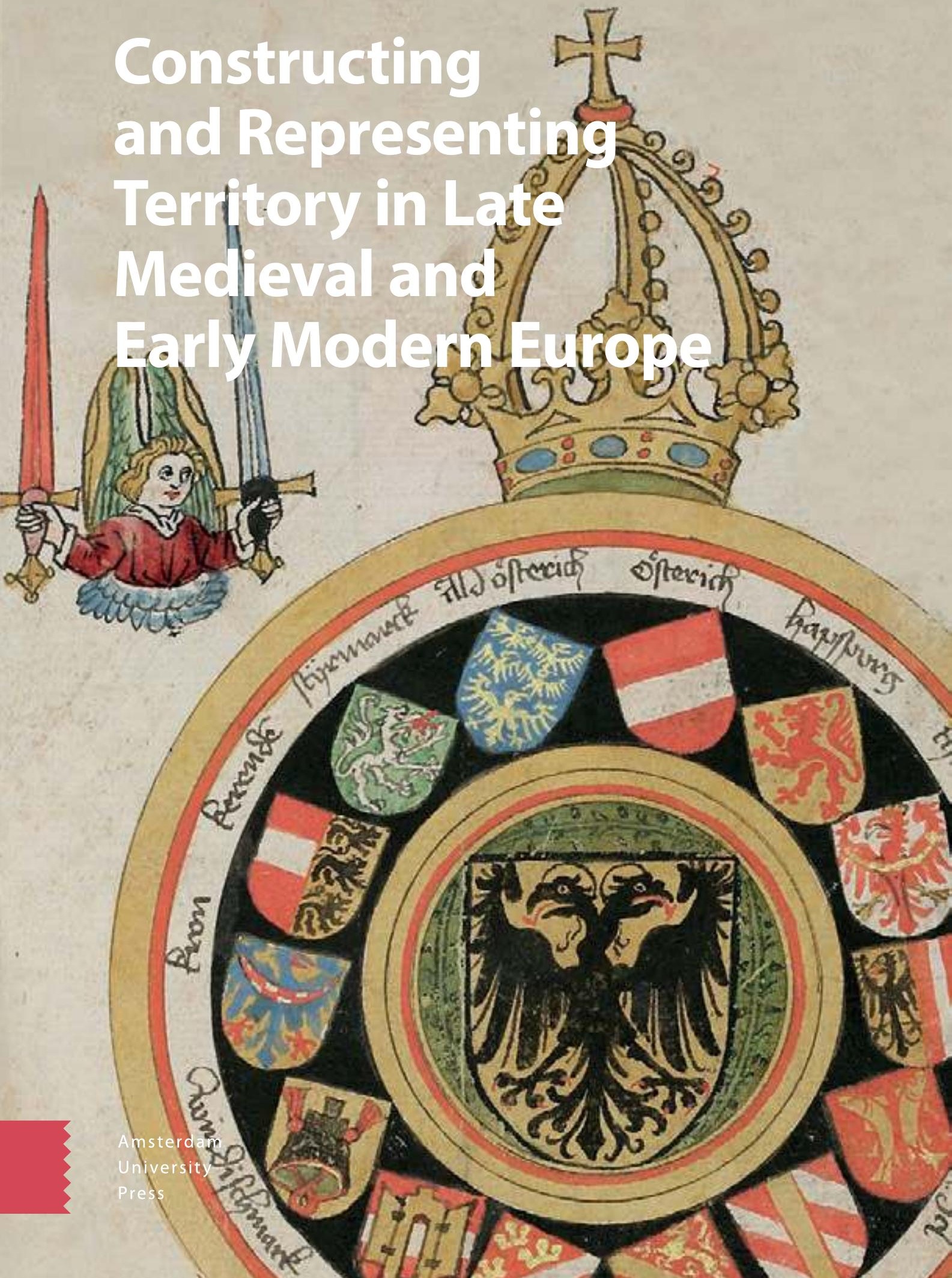


Constructing and Representing Territory in Late Medieval and Early Modern Europe 



\title{
Constructing and Representing Territory in Late Medieval and Early Modern Europe
}

\author{
Edited by \\ Mario Damen and \\ Kim Overlaet
}


This collection of essays is the result of a research project financed by the Dutch Research Council (NWO), entitled Imagining a Territory: Constructions and Representations of Late Medieval Brabant (project nr. 360-50-100), and carried out at the University of Amsterdam. NWO also funded the publication of this volume in Open Access.

Cover illustration: Illumination dedicated to Emperor Frederick III, showing the arms of Habsburgian territories around a shield of the imperial arms, in the fifteenth-century Haggenberg armorial. St Gall, Stiftsbibliothek, Cod. Sang. 1084.

Cover design: Coördesign, Leiden

Lay-out: Crius Group, Hulshout

$\begin{array}{ll}\text { ISBN } & 978 \text { 94 6372 613 9 } \\ \text { e-ISBN } & 978 \text { 90 } 48551804 \\ \text { DOI } & 10.5117 / 9789463726139 \\ \text { NUR } & 684\end{array}$

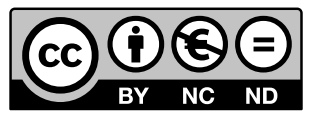

Creative Commons License CC BY NC ND

(http://creativecommons.org/licenses/by-nc-nd/3.o)

@ All authors / Amsterdam University Press B.V., Amsterdam 2022

Some rights reserved. Without limiting the rights under copyright reserved above, any part of this book may be reproduced, stored in or introduced into a retrieval system, or transmitted, in any form or by any means (electronic, mechanical, photocopying, recording or otherwise).

Every effort has been made to obtain permission to use all copyrighted illustrations reproduced in this book. Nonetheless, whosoever believes to have rights to this material is advised to contact the publisher. 


\section{Table of Contents}

Acknowledgments

List of Figures and Tables

Constructing and Representing Territory in Late Medieval and

Early Modern Europe: An Introduction

Mario Damen and Kim Overlaet

\section{Part 1 The Multiplicity of Territory}

1. Were There 'Territories' in the German Lands of the Holy

Roman Empire in the Fourteenth to Sixteenth Centuries?

Duncan Hardy

2. Beyond the State: Community and Territory-Making in Late Medieval Italy

Luca Zenobi

3. Clerical and Ecclesiastical Ideas of Territory in the Late

Medieval Low Countries

Bram van den Hoven van Genderen

4. Marginal Might? The Role of Lordships in the Territorial Integrity of Guelders, c. 1325-c. 1575

Jim van der Meulen

\section{Part 2 The Construction of Territory}

5. Demographic Shifts and the Politics of Taxation in the Making of Fifteenth-Century Brabant

Arend Elias Oostindiër and Rombert Stapel

6. From Knights Errant to Disloyal Soldiers? The Criminalisation of Foreign Military Service in the Late Medieval Meuse and Rhine Regions, 1250-1550 
7. Conquest, Cartography and the Development of Linear

Frontiers during Henry VIII's Invasion of France in 1544-1546 Neil Murphy

8. From Multiple Residences to One Capital? Court Itinerance during the Regencies of Margaret of Austria and Mary of Hungary in the Low Countries (c. 1507-1555)

Yannick De Meulder

\section{Part 3 The Representation of Territory}

9. Heraldry and Territory: Coats of Arms and the Representation and Construction of Authority in Space

Mario Damen and Marcus Meer

10. The Territorial Perception of the Duchy of Brabant in

Historiography and Vernacular Literature in the Late Middle Ages 277

Bram Caers and Robert Stein

11. Imagining Flanders: The (De)construction of a Regional

Identity in Fifteenth-Century Flanders

297

Lisa Demets

12. Mapping Imagined Territory: Quaresmio's Chorographia and Later Franciscan Holy Land Maps

Marianne Ritsema van Eck

Constructing and Representing Territory in Late Medieval and Early Modern Europe: A Conclusion

Mario Damen and Kim Overlaet

Index 


\section{Acknowledgments}

This collection of essays is the result of a research project financed by the Dutch Research Council (NWO), entitled Imagining a Territory: Constructions and Representations of Late Medieval Brabant (project nr. 360-50-100), and carried out at the University of Amsterdam. We want to thank first and foremost NWO, which also funded the publication of this volume in Open Access. Furthermore, we want to thank the Amsterdam School of Historical Studies (ASH) as the host institution of the research project. Of course, we highly appreciate the willingness of the authors to contribute to this volume and adapt their chapters according to the comments of the editors and the anonymous reviewer, to whom we are grateful for the careful reading of the manuscript and the insightful comments. All the people from Amsterdam University Press, especially Chantal Nicolaes, Lucia Dove and Louise Visser, facilitated the editing and production of the volume. Others who contributed to the realisation of this volume are, in alphabetical order, Bastiaan van den Acker, Dirk Lueb, Bente Marschall, Arend Elias Oostindiër and Maria Sherwood-Smit.

Mario Damen and Kim Overlaet

Leiden and Antwerp, 12 March 2021

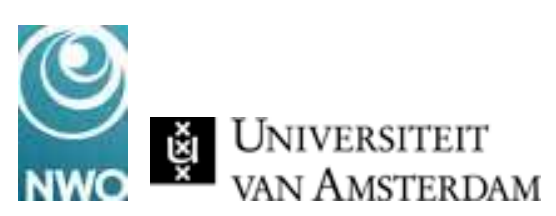





\section{List of Figures and Tables}

Figure 3.1. Map of the dioceses in the Low Countries before 1559.

101

Figure 3.2. Map of the (arch)dioceses in the Low Countries after 1559 .

Figure 4.1. The Duchy of Guelders, with the high lordships of the Nijmegen Quarter (fourteenth-sixteenth centuries).

Figure 4.2. Sixteenth-century 'map' of the border area between the lordships of Ooij and Gendt (1544). 133

Figure 5.1. Urban and rural status of the Duchy of Brabant.

Figures 5.2a-b. Cartogram maps of the Duchy of Brabant, by share of the census.

Figure 5.3. Difference in a community's share of the census between 1374 and 1437/1438.

Figure 5.4. Percentage of poor households per fiscal category for each of the four quarters of the Duchy of Brabant (1437/1438)

Figures $5 \cdot 5 \mathrm{a}-\mathrm{b}$. Cartogram maps of the Duchy of Brabant, by share of the aid.

Figure 5.6. Difference in the share in the aids of $1383 / 1386$ and 1436-1442, relative to the share of the censuses of 1374 and 1437/1438, respectively.

Figure 5.7. Ducal and seigniorial administrative divisions, based on the 1383/1386 aid report.

Figures 5.8a-h. Cartogram maps of the Duchy of Brabant, by share of the census.

Figures 5.9a-c. Cartogram maps of the Duchy of Brabant, by share of the aid.

Figure 6.1. The Meuse and Rhine Regions, 1400-16oo.

Figure 6.2. Overview of people prosecuted for foreign service in the Bailiwick of 's-Hertogenbosch, 1393-1550.

Figure 8.1. $\quad$ Cities most frequented by Mary of Hungary in percentages of sample years based on the accounts of her treasurer.

Figure 8.2. Days spent per month in the most frequented cities during Margaret of Austria's second regency (1518-1530). 
Figure 9.1. J Jan of Bavaria, uncle of Willem VI, and Jacoba of Bavaria.

Figure 9.2. Late-sixteenth-century painting of John of Gaunt, showing the English royal arms with the label of a third son and an inescutcheon of pretence with the arms of Castile/Leon.

Figure 9.3. Jan I van Brabant with the quartered coat of arms of Brabant and Limbourg in the Codex Manesse (c. 1300-1340).

Figure 9.4. Illumination dedicated to Emperor Frederick III, showing the arms of Habsburgian territories around a shield of the imperial arms in the centre of the folio, in the fifteenth-century Haggenberg armorial.

Figure 9.5. First pages of the marche of Brabant in the Bergshammar armorial. 256

Figure 9.6. Royal seal of Władysław II Jagiełło (1386), with coats of arms of the Kingdom of Poland's territories set around the figure of the king. 260

Figure 10.1. L Line of descent in Brabantine genealogies. 282

Figure 10.2. Dukes of Lower Lotharingia (970-1129), according to Brabantine historiographical tradition.

Figure 11.1. Imago Flandriae of Lubert Hautscilt by Jacob Van Oost II and Pieter De Brune.

Figure 12.1. Grid map of the Holy Land c. 1321 by Pietro Vesconte

Figure 12.2. Map of the Holy Land in Quaresmio's Terrae Sanctae Elucidatio (1639).

Figure 12.3. Frontispiece of Quaresmio's Terrae Sanctae Elucidatio (1639).

Figure 12.4. Chorographia Terrae Sanctae in Angustiorem Formam Redacta (1632) by Jacques Tirin.

Figure 12.5. Map of the Holy Land in Adrichem's Theatrum Terrae Sanctae (1593).

Figure 12.6. Itinerary of the twelve tribes on their way out of Egyptian Captivity (Exodus) as represented on the map of the Holy Land in Quaresmio's Elucidatio (1639).

Figure 12.7a. Map of the Holy Land in Roger's La Terre Sainte (1646). 
Figure 12.7b. Map of the Holy Land in Surius's Den Godtvruchtighen Pelgrim (1665).

Figure 12.8. Map of the Holy Land in Zwinner's Blumenbuch des H. Lands Palestinae (1661).

Figure 12.9. Map of the Holy Land in Gonsales's Hierusalemsche Reijse (1673).

Figure 12.10. Map of the Holy Land in Goujon's Histoire et voyage (1670).

Table 4.1. High lordships in the Nijmegen Quarter, c.

Table 5.1. Summary of differences in the share of the aids of $1383 / 1386$ and $1436-1442$, relative to the share of the censuses of 1374 and 1437/1438, respectively. $\quad 158$

Table 5.2. Summary of counted and computed units. $\quad 166$

Table 5.3. Summary of the aids in 1383/1386 and 1436-1442, as well as the $100^{\text {th }}$ penny of $1569-1572$.

Table 5.4. Differences in the share of the aids of $1383 / 1386$ and 1436-1442, aggregated using the administrative classification of $1383 / 1386$.

Table 8.1. $\quad$ Cities most frequented by Margaret of Austria in percentages of her two regencies.

Table 9.1. $\quad$ Representation of coats of arms of different principalities of the Low Countries in armorials. $\quad 258$

Table 10.1. Titles used in the genealogies. 283 



\title{
Constructing and Representing Territory in Late Medieval and Early Modern Europe: An Introduction
}

\author{
Mario Damen and Kim Overlaet
}

Over the past few decades, geographers, sociologists, and political scientists have shown an increasing interest in the layered meanings of the concept of territory in specific historical and geographical settings. ${ }^{1}$ Taking 'territory' to mean the relationship between people, power and space, this volume sets out to explore the methodological challenges faced by historians studying the development, government, perception, and representation of territory in different city-states, principalities, kingdoms, and empires in late medieval and early modern Europe. Indeed, one of the most intriguing questions raised by scholars, such as the political theorist and geographer Stuart Elden, is to what extent the concept of territory can be used as an analytical tool to study the spatial dimensions of power relations between (political or other) actors in historical periods prior to the cartographic innovations of the sixteenth and seventeenth centuries. ${ }^{2}$ Remarkably enough, though the term 'territory' is often used by medieval and early modern historians, they rarely clarify what exactly they mean by the concept. In research on the centralising ambitions of kings, princes, and lords in late medieval and early modern Europe, for instance, 'territory' is commonly used to designate an enclosed geographical area ruled by a central government. In other instances, however, historians use the term as a synonym for designations of geographical entities such as region or area, or even as a label for a substate.

1 Especially in the field of geography the number of publications is vast, including a dedicated journal called Territory, Politics, Governance, published by the Regional Studies Association since 2013. For a concise overview of most recent publications by geographers on territory and territoriality, see Antonsich, 'Territory and Territoriality'.

2 Elden, The Birth.

Damen, M. and K. Overlaet (eds.), Constructing and Representing Territory in Late Medieval and Early Modern Europe. Amsterdam: Amsterdam University Press, 2022 DOI 10.5117/9789463726139_INTRO 
As a rule, current political historiography is dominated by a state-centric notion of territory. 3 This can be explained at least in part by the influence of the definition of 'state' by Max Weber (†1920), who considered territory as one of the three keystones of a state, along with population and a legal system:

Staat ist diejenige menschliche Gemeinschaft, welche innerhalb eines bestimmten Gebietes - dies: das 'Gebiet', gehört zum Merkmal - das Monopol legitimer physicher Gewaltsamkeit für sich (mit Erfolg) beansprucht. ${ }^{4}$

Several renowned historians working on state-formation processes were clearly and often quite explicitly inspired by Max Weber. The well-known French historian Bernard Guenée, for example, defined the state as follows: 'Il y a État dès qu'il y a, sur un territoire, une population obéissante à un gouvernement. 5 In anglophone historiography, the influential American historian and sociologist Charles Tilly likewise defined the state in 1975 as an 'organisation which controls the population occupying a defined territory'. Admittedly, he later acknowledged the existence of 'non-national states' such as empires or city-states, expanding his understanding of the state to an organisation 'governing multiple contiguous regions and their cities by means of centralised, differentiated, and autonomous structures' ${ }^{6}$ Still, Tilly focused on the state as the end result of a process of warfare and bureaucratisation developments, rather than on the spatial character of state-formation processes. As Jeppe Strandsbjerg stated in a recent reevaluation of the application of Tilly's theories in historiography: '[T]here is a profound lack of attention given to how space itself is transformed over time, and how this spatial transformation played a significant role in state formation. ${ }^{7}$ Moreover, Tilly is by no means a unique case. Even today, many scholars devote their research on state formation almost exclusively to the last two sections of Weber's triad (territory-population-legal system), and generally consider the spatial dimension as a given or even as insignificant.

In a much-cited article from 1994, the British-American political geographer John Agnew famously called this aspatial approach the 'territorial trap'. 
In his opinion, definitions of the state are heavily influenced by modern geographical assumptions. According to Agnew, state territories are too often considered as 'vast units of sovereign space' and as a 'container of society'. Such definitions fail to grasp the complex reality of pre-modern European societies. During the Middle Ages, Agnew states, 'regional networks of kinship and interpersonal affiliation left little scope for fixed territorial limits'. Likewise, 'communities were united only by allegiances and personal obligations rather than abstract individual equality or citizenship in a geographically circumscribed territory'. Such communities constitute what in German historiography since the 1930 s has been labelled a Personenverbandstaat, a state structured around bonds of personal loyalty. The constantly changing political alliances between princes, nobles, and urban elites were more hierarchical than territorial and led to widespread violence. There were no 'fixed' boundaries, and space was organised around many centres, although sovereignty was associated closely with the authority of the prince. Moreover, in pre-modern Europe, before the rise of nation states, sometimes the greatest power was exercised in relatively small city-states, such as Venice, Florence, and Lübeck. ${ }^{8}$

Of course, scholars have already made attempts to redefine the concept 'territory' to allow for its application in studies on late medieval and early modern European societies. In Boundaries: The Making of France and Spain in the Pyrenees, for instance, the American historian Marcel Sahlins tried to avoid the ahistorical use of the concept by distinguishing between jurisdictional and territorial sovereignty. He considered the Middle Ages as an important period of transition. According to Sahlins, in medieval Europe the juridical relationships between rulers and their subjects (expressed in oaths of loyalty) were far more important than territorial bonds. Moreover, rulers exercised authority in a wide range of areas, from taxation to military affairs, and from justice to economic policies. Each of these domains was geographically determined, but these geographical areas of influence did not necessarily coincide with each other, and seldom coincided with the 'political' boundaries of a ruler's polity. Finally, rulers could win or acquire (or lose or sell) a diverse set of domains with a different juridical character, such as fiefs, bishoprics, towns, and villages. ${ }^{9}$

8 Agnew, 'The Territorial Trap', pp. 6o, 64. For a discussion of the problems of the concept of Personenverbandstaat, see Althoff, Friends, pp. 4-22, and the contribution of Duncan Hardy in this volume.

9 Sahlins, Boundaries, pp. 28-29. 
In-depth analyses of late medieval sources as diverse as administrative documents, account books, chronicles, and heraldic records confirm that both princes and other political actors, and even inhabitants, shared a certain awareness about the spatial extent and limits of specific areas of control (be they jurisdictional, fiscal, military, etc.). This is apparent, for example, in discussions between princes and other political actors on the maintenance of borders and on the spatial validity of privileges. These observations have caused an important shift in historiography: most historians now agree on the idea that medieval 'territories' were not top-down constructions that can be compared to modern states (i.e. nation states). This shift is also largely due to the so-called spatial turn, which has stimulated medievalists and early modernists since the 1980 s to causally link power relations between individuals and groups to the space(s) where these took place - and vice versa. Inspired by the conceptual framework of Henri Lefebvre, the French sociologist and philosopher, more and more historians are considering space as an important analytical tool. Following on his book La production de l'espace (1974), space is understood as being both produced and defined by the interactions of individuals and groups, while it - in turn - produces and defines social agency for all actors involved. ${ }^{10}$ Indeed, public as well as private space is much more than the mere physical or material setting for political, social, and cultural actions.

Germany in the first decennia of the twentieth century saw the emergence of the branch of historiography known as Landesgeschichte, with Otto Brunner as its most prominent representative. The most important conclusion of his writings was that the German territories had not been constructed from above, but were the result of the acts of both the princes and the so-called Landesgemeinde: the political communities of these lands. ${ }^{11}$ It was only from the 1970s that studies of Raumbewusstsein and especially Landesbewusstsein became popular. Of course, it is very difficult to translate this 'awareness' among political actors (of varying rank and status) of the spatial extent of specific regions to identity-formation processes. Jean-Marie Moeglin argued that 'between the objective realities constructed by the political and institutional structures and the processes of consciousness which lead to identity formation, there is a dialectical and complicated relationship'. Indeed, analyses of narrative sources such as (urban and dynastic) chronicles show that identity formation in medieval Europe had

10 Lefebvre, Production of Space. A good introduction to the work of Lefebvre is Elden, 'Space', pp. 262-267. See also the viewpoint of urban historians on Lefebvre in Arnade, Howell and Simons, 'Fertile Spaces', pp. 517-518, 527, 541-542; Boone and Howell, 'Introduction', pp. 2-3.

11 Brünner, Land und Herrschaft; Werner, 'Zwischen politische Begrenzung'. 
important geographical connotations, and that the dynasty commonly functioned - and was perceived - as the link between the land and its citizens. Most of these medieval texts focus on the specific qualities and beauty of the land and landscape, as well as on the good deeds and character of the area's inhabitants, princes, saints, etc. Often, however, rather than aiming to construct group identities, such descriptions of specific regions mainly wanted to emphasise the fact that (future) rulers were expected to respect and maintain the 'age-old' privileges obtained by a land's inhabitants. In addition to written texts, symbols and emblems were made and used to represent what Moeglin has called 'land consciousness'. In this process, the different political elites played a crucial role, although their strategies could differ. ${ }^{12}$

Len Scales's book about the shaping of German identity in the thirteenth and fourteenth centuries, as well as Andrea Ruddick's study on the relationship between identity and political culture in fourteenth-century England, follow up on this argument. Both authors show how medieval clerks, chroniclers, and heraldic painters tried to construct and visualise territorial units and their boundaries, and to disseminate these representations among the population. Moreover, these researchers scrutinise and problematise the words used in narrative and administrative sources to describe the territories people were living in, such as lant, regnum, and patria. ${ }^{13}$ Both historians pay due attention to the concept of 'political community' - 'the community of political actors with and through whom a monarch was bound to rule', to quote Scales's definition - which was formed through history and closely connected to the territory. ${ }^{14}$ In French historiography, too, increasing attention has been paid to themes such as space, borders, and territories, on both a regional and a supra-regional level. ${ }^{15}$ For instance, in his book Le royaume des quatre rivières, Léonard Dauphant describes several techniques employed in late medieval France to represent space, which - in his opinion - led to a growing consciousness of what geographical space entailed for contemporaries. ${ }^{16}$

Moeglin, 'Land, Territorium und Dynastie'.

13 For the terms regnum and communitas regni see the seminal book by Susan Reynolds, Kingdoms and Communities, especially chap. 8, and a recent collection of essays by Barthélémy et al., Communitas regni.

14 Scales, The Shaping of German Identity, p. 189; Ruddick, English Identity.

15 Bührer-Thierry, Patzold and Schneider, Genèse des espaces politiques; Péquignot and Savy, Annexer?; Lienhard, Construction.

16 Dauphant, Royaume des quatres rivières, pp. 115-224. On pp. 158-164 Dauphant pays special attention to the Livre de la description du pays of Berry Herald from 1453, the oldest geographical 
For the late medieval Low Countries, urban historians especially have used space as an analytical tool, inspired by the conceptual framework of Lefebvre. Socio-economic space as well as the ideological and political representation of space have been studied in some detail. ${ }^{17}$ Recently, Robert Stein and Lecuppre-Desjardin convincingly demonstrated that the formation of the Burgundian composite state, a conglomerate of principalities and autonomous cities and lordships situated on the fringes of the Holy Roman Empire and France in the course of the fifteenth century, had important spatial dimensions. ${ }^{18}$ The Burgundian dukes knew that they were not sovereign princes and that they had to share their juridical competences with the Holy Roman Emperor on the one hand, and the king of France on the other. As a consequence, the maintenance of the borders with - particularly - the kingdom of France, was of utmost importance in Franche-Comté and in the southern principalities of the Low Countries. ${ }^{19}$ Interestingly, both authors used the 'space' and 'territories' of the Burgundian duke in fairly different ways. Stein has a more institutional approach, scrutinising the relationship between the titles of dukes with the actual principalities they came to possess. Lecuppre-Desjardin, in turn, focuses rather on the political or even 'imagined' community along the lines of Moeglin and Scales, paying attention to the 'territorial consciousness' not only amongst the dukes and their administrators but also amongst their (urban) subjects.

The present volume aims to contribute to ongoing debates on the nature and character of territory as a meaningful spatial category and analytical tool. It does so by confronting the ideas of geographers with a variety of pre-modern administrative sources, such as fiscal account books, and narrative texts, such as chronicles. Central to this volume is the conviction that an analysis of the notion of territory in a pre-modern setting can only be achieved through an analysis of territorial practices: practices that relate people and power to space. The main inspiration for this hypothesis is a recent (re-)examination of the changing historical meanings of the concept

description of France. Here Dauphant follows in the footsteps of P.S. Lewis, whose 1967 book on later medieval France sets out to answer the same question: 'What was France in the later Middle Ages?' Lewis, Later Medieval France.

17 Boone and Stabel, Shaping Urban Identity; Boone and Howell, The Power of Space; Lichtert, Dumolyn and Martens, Portraits of the City.

18 Stein, Magnanimous Dukes; Lecuppre-Desjardin, Le royaume inachevé.

19 Lecuppre-Desjardin, 'Annexions'. 
of territory by the political theorist and geographer Stuart Elden in The Birth of Territory. The central idea, inspired by Michel Foucault, is that territory is simultaneously a word, a concept, and a practice. ${ }^{20}$ Through an in-depth reading of philosophical texts written by famous authors and thinkers such as Plato, Cicero, Augustine, Machiavelli, and Locke, Elden aims to reconstruct the 'genesis' and evolving meanings of the word 'territory' in Western political thought, to gain insight into the relation between space and power in the past. ${ }^{21}$

In classical Antiquity, the word territorium could be understood as farming land near a city, but it was also used to refer to the jurisdiction of a town's magistrate. By the first half of the sixth century, territorium had become a common term to refer to jurisdictional space, for instance, in the Corpus Iuris Civilis, a large collection of laws and jurisprudence compiled by order of Emperor Justinian. Over the succeeding centuries, the link between territorium and jurisdictio became widespread in legal texts. However, in European regions such as France, the word territoire was rather uncommon until the seventeenth century. ${ }^{22}$ In Italy, on the other hand, jurists like Bartolo da Sassoferrato (1314-1357) had already entered into lively discussions about the meaning of the concept. He considered territory as 'the very thing over which political power is exercised', and based this conceptualisation on the use of the term in Roman Law. Bartolo defined territory as a res immobilis ('unmovable thing'), as land and buildings. In addition, he pointed to the etymological origins of territorium: it was derived from the Latin verb terrere, meaning 'to frighten' or 'to intimidate'. An army could act in a 'terrifying and dictatorial way' over a certain area and consider that its territory. In other writings Bartolo argued that jurisdiction and practical technological resources, such as geometry, were necessary for a better understanding of the ownership rights of land.

According to Elden, Bartolo failed to fully grasp the complexity of the concept of territory because of his focus on its politico-economic and military-strategic aspects. ${ }^{23}$ In Elden's view territory is closely correlated with the geographical concepts of 'land' and 'terrain'. Land is concerned with property, something that can be bought or sold, and primarily reveals something about property relationships. Where land is a politico-economic

22 Somaini, 'Territory, Territorialisation, Territoriality', pp. 24-25; Elden, The Birth, pp. 63-64; Elden, 'Land, Terrain, Territory', pp. 8o6-8o7.

23 Elden, The Birth, pp. 220-229. 
concept, terrain is more a politico-strategic concept. Therefore, terrain refers to more than the 'physical aspects of the earth's surface': it is the stage where conflicts over land take place and land is administered and governed. ${ }^{24}$ Although land and terrain are closely related to territory, Elden points out that they should be considered as two separate analytical categories. To study the relationship between people, power, and space in the past, he proposes a new approach to the concept of territory, which focuses on the techniques and laws applied ('the legal and the technical'), including advances in geometry, cartography, and land surveying. ${ }^{25}$ In other words, according to Elden, each 'territory' must be seen (and studied) as a 'bundle of political technologies' and 'techniques for measuring land and controlling terrain'. ${ }^{26}$ Moreover, such an approach could help historians to grasp the spatial dimension of power struggles in the past, as these techniques and technologies did exist (and sometimes even originated) in medieval European societies. To tackle this important question and methodological challenge, we invited scholars to study territorial practices in medieval and early modern Europe, and to explore the perception and representation of land and terrain through the use of a broad range of sources: from administrative texts to maps, from stained glass windows to chronicles.

Although Elden claims that 'territory is not a term that is specifically helpful in making sense of the Middle Ages, ${ }^{27}$ we do want to make an effort in this volume. Whereas Elden concentrates on the 'big political thinkers' of medieval Europe, we want to go beyond their conceptual frameworks. It that sense it does not matter that they did not use this exact term 'to describe the object of political rule. ${ }^{28}$ The first section of this volume, therefore, contains contributions problematising the use of the concepts of territory, territorial practices, and 'territorial integrity' in specific historical and geographical contexts, such as the Holy Roman Empire, Italy, and the Duchy of Guelders in the Low Countries. All articles discuss the ways in which sources such as fiscal documents, maps, and constitutional charters can reveal pre-modern conceptions and thinking about the link between certain spatial settings and political power, as well as economic, social, and cultural interactions. In addition, the widespread use in current historiography of 'a territorial vocabulary' is confronted with the contemporary use and interpretation 
of spatial concepts such as terra $(e)$ and land $(e)$ in administrative sources produced by the most important political actors of medieval Europe: kings and princes, the nobility, the church, as well as urban authorities. Indeed, all authors share the idea that any kind of 'spatial stability' in (late) medieval Europe was the result of the dynamics between the various power groups involved, who discussed, maintained, and defended their areas of jurisdiction.

In this context, the first section of this volume introduces two often neglected political actors - the nobility and the clergy - who could also, and sometimes surprisingly independently, control and manage 'land'. Interestingly, both geographers and historians often tend to focus on 'secular space' and territories of (city-)states, kingdoms, and empires. The territory of the Church, 'ecclesiastical space', is relatively understudied, although it can be argued that this was one of the best documented and most stable spatial organisations of medieval Europe. The geographical boundaries of the (jurisdictional, fiscal, and political) power base of bishoprics, parishes, convents, and churches were relatively well known from late Antiquity onwards. Indeed, as Devroey and Lauwers put it in their conclusion to a volume on the construction of space in the Middle Ages, "[the] medieval cleric was at the same time a producer of traces (texts, signs, material objects) illustrating practices and a constructor of "holy" or "framed" spaces'. ${ }^{29}$ This section poses questions such as the following: What was the impact of an advanced feudal organisation of society? Whose 'territories' were at stake? How did the presence or absence of a central monarchical authority influence the relationship between power and space?

If we consider pre-modern territories as political, jurisdictional, and/or socio-economic constructions which linked people and power to space, it follows that the concept of territory had different meanings for different people and social groups, in different times, and in different places. As we have mentioned before, in late medieval Europe the struggle for power was often defined by claiming specific rights and authority over specific spaces and their inhabitants. The question is how the inhabitants, trespassers, and conquerors of pre-modern towns, principalities, and composite states experienced these areas' political, jurisdictional, and socio-economic rights, privileges, and spatial boundaries. Which rights were important for which actors (e.g., the prince, the nobility, urban elites, and ecclesiastical elites), and to what extent were these rights and privileges spatially determined? 
What techniques were used to define, claim, and negotiate specific rights in and over specific areas and their inhabitants?

To tackle these questions, the second part of the volume concentrates on the construction, management, and contestation of space (whether by military or other means) by various stakeholders and political actors as it is expressed in princely and urban administrative sources, as well as in cartography and legislation. A combination of traditional analytical methods with more recent digital applications, such as GIS, allows us to gain insight into various aspects of the spatial organisation of late medieval societies and royal courts in Brabant, the Meuse region, France, and the Low Countries at large. These aspects involve the construction of fiscal boundaries, and the perception of 'foreigners' during warfare, peace negotiations, and military service, as well as the creation of linear frontiers in the context of the ambitious expansion politics of the Tudor king, Henry VIII. Most importantly, all contributions pay considerable attention to the impact of the movements of both individuals and groups in times of peace and warfare. This approach not only yields promising insights in the pre-modern perception of fiscal, military, and economic boundaries, but also allows for the problematisation of concepts such as 'foreign' and 'frontier'. Moreover, it allows us to nuance the idea that itinerant courts were the principal alternative to having a single capital city in the late medieval Low Countries.

The drawback of focusing on the concept of territory as manageable land or terrain is that this fails to do justice to the concept's important imaginative connotations. In the wake of the spatial turn, we understand territories simultaneously as physical spaces (land), political, jurisdictional spaces (terrain), and lived spaces, which could be perceived (and imagined) quite differently by different actors, in different contexts. The question central to the third and final part of the volume is how inhabitants (and visitors) of principalities, lordships, and towns perceived and represented the territories (and the boundaries of the territories) they were living in or travelling through vis-à-vis the (composite) state they formed part of. $3^{30}$ Indeed, territories in late medieval Europe were not only structured and divided by administrative, fiscal, or jurisdictional boundaries, but also by traditions, myths of origin, and cultural differences (e.g., linguistic or religious differences). With few exceptions, even the most ambitious European rulers failed to establish a centralised government in the late medieval period. In general, the autonomy of the constituent principalities, 
lordships, and towns was protected by various socio-economic, political, and jurisdictional privileges.

In recent decades, scholars have paid much attention to the relationship between these local privileges and processes of identity formation on a local, regional, or even 'national' level. To tackle this important aspect of modern or pre-modern thinking about territory, the final chapters of this volume explore representations of territories by way of analyses of diverse narrative and pictorial sources - from chronicles, charters and travel narratives, to heraldry, to maps and paintings. First, through a close comparison of the (often strategic) use of heraldic signs in two specific geographical settings, the contributors to this third section demonstrate the importance of the communicative functions of heraldry in noble, clerical, and urban milieus. Second, they add important nuances to assumptions about the driving forces and motives behind identity politics in the late medieval Low Countries through an in-depth reconstruction and analysis of all actors involved in the production (or reproduction) of contemporary historiography and literature. Last but not least, they pose the question of to what extent people's religious affiliation might influence their perception and representation of space. In addition to broadening the scope of this volume, the analysis of Franciscan maps of the Holy Land shows that late medieval cartography, rather than aspiring to accuracy and 'realism', aimed to represent and even negotiate imagined spaces. ${ }^{31}$ In short: this volume shows how various administrative, jurisdictional, fiscal, socio-economic, cultural, and even religious territorial practices linked these imagined spaces to very real people and considerable power. Moreover, it aims to cut across traditional geographical and chronological boundaries by considering territory over a time span of several centuries, bridging the traditional medieval/early modern divide.

\section{Bibliography}

Agnew, John, 'The Territorial Trap: The Geographical Assumptions of International Relations Theory', Review of International Political Economy 1, no. 1 (1994), 53-80. Althoff, Gerd, Family, Friends and Followers: Political and Social Bonds in Early Medieval Europe (Cambridge: Cambridge University Press, 2004).

Antonsich, Marco, 'Territory and Territoriality', in International Encyclopedia of Geography, ed. by Douglas Richardson et al. (Oxford: Wiley-Blackwell, 2017), pp. 6989-6998. 
Arnade, Peter, Martha Howell and Walter Simons, 'Fertile Spaces: The Productivity of Urban Space in Northern Europe', The Journal of Interdisciplinary History 32 (2002), 515-548.

Barthélemy, D., et al., eds, Communitas regni la 'communauté de royaume' de la fin du $X^{e}$ siècle au début du XIV siècle (Angleterre, Écosse, France, Empire, Scandinavie) (Paris: Sorbonne Université Presses, 2020).

Boone, Marc, and Martha Howell, 'Introduction', in The Power of Space in Late Medieval and Early Modern Europe, ed. by M. Boone and M. Howell (Turnhout: Brepols, 2013), pp. 1-10.

Boone, Marc, and Martha Howell, eds, The Power of Space in Late Medieval and Early Modern Europe (Turnhout: Brepols, 2013).

Boone, Marc, and Peter Stabel, eds, Shaping Urban Identity in Late Medieval Europe (Apeldoorn: Garant, 2000).

Brünner, Otto, Land und Herrschaft: Grundfragen der territorialen Verfassungsgeschichte Südostdeutschlands im Mittelalter (Vienna: R.M. Rohrer, 1943).

Bührer-Thierry, Geneviève, Steffen Patzold and Jens Schneider, eds, Genèse des espaces politiques (IX ${ }^{e}$-XII ${ }^{e}$ siècle): autour de la question spatiale dans les royaumes francs et post-carolingiens (Turnhout: Brepols, 2017).

Cohen, Meredith, and Fanny Madeline, eds, Space in the Medieval West: Places, Territories and Imagined Geographies (Farnham: Ashgate, 2014).

Dauphant, Léonard, Le royaume des quatre rivières: l'espace politique français (1380-1515) (Champ Vallon: Seyssel, 2012).

Devroey, Jean-Pierre, and Michel Lauwers, 'Lespace des historiens médiévistes: quelques remarques en guise de conclusion', Actes des congrès de la Société des historiens médiévistes de l'enseignement supérieur public 37 (2006), 435-453.

Elden, Stuart, The Birth of Territory (Chicago: University of Chicago Press, 2013).

Elden, Stuart, 'How Should We Do the History of Territory?', Territory, Politics, Governance 1, no. 1 (2013), 5-20.

Elden, Stuart, 'Land, Terrain, Territory', Progress in Human Geography 34, no. 6 (2010), 799-817.

Elden, Stuart, 'Space', in International Encyclopedia of Human Geography, ed. by Rob Kitchin and Nigel Thrift, 12 vols (Oxford: Elsevier Science, 2009), vol. 10, pp. 262-267.

Guenée, Bernard, L'Occident aux XIV et $X V^{e}$ siècles (Paris: Presses universitaires de France, 1993).

Lecuppre-Desjardin, Élodie, 'Annexions, conquêtes, héritages: réflexions sur la perception du complexe territorial bourguignon (XIV -XV siècle)', in Annexer? Les déplacements de frontières à la fin du Moyen Âge, ed. by Stéphane Péquignot and Pierre Savy (Rennes: Presses universitaires de Rennes, 2018), pp. 141-157.

Lecuppre-Desjardin, Elodie, Le royaume inachevé des ducs de Bourgogne (XIV $-X V^{e}$ siècles) (Paris: Belin, 2016). 
Lefebvre, Henri, The Production of Space (London: Wiley, 1992).

Lewis, Peter Shervey, Later Medieval France: The Polity (London: Macmillan, 1968).

Lichtert, Katrien, Jan Dumolyn and Maximiliaan Martens, eds, Portraits of the

City: Representing Urban Space in Later Medieval and Early Modern Europe (Turnhout: Brepols, 2014).

Lienhard, Thomas, ed., Construction de l'espace au Moyen Âge: pratiques et représentations. [actes du] 37. Congres de la SHMES [Société des historiens médiévistes de l'enseignement supérieur public], Mulhouse, 2-4juin 2006 (Paris: Publications de la Sorbonne, 2007).

Lilley, Keith D., Mapping Medieval Geographies: Geographical Encounters in the Latin West and Beyond, 300-16oo (New York: Cambridge University Press, 2014). Moeglin, J.-M., 'Land, Territorium und Dynastie als Bezugsrahmen regionalen Bewußtseins am Beispiel Flanderns', Vorträge und Forschungen 61 (2005), 17-52. Péquignot, Stéphane, and Pierre Savy, eds, Annexer? Les déplacements de frontières à la fin du Moyen Âge (Rennes: Presses universitaires de Rennes, 2016).

Reynolds, Susan, Kingdoms and Communities in Western Europe, 900-130o (Oxford: Clarendon Press, 1984).

Ruddick, Andrea, English Identity and Political Culture in the Fourteenth Century (Cambridge: Cambridge University Press, 2013).

Sahlins, Peter, Boundaries: The Making of France and Spain in the Pyrenees (Berkeley: University of California Press, 1989).

Scales, Len, The Shaping of German Identity: Authority and Crisis, 1245-1414 (Cambridge: Cambridge University Press, 2012).

Somaini, Francesco, 'Territory, Territorialisation, Territoriality: Problems of Definition and Historical Interpretation', Plurimondi 10 (2012), 19-47.

Stein, Robert, Magnanimous Dukes and Rising States: The Unification of the Burgundian Netherlands, 1380-148o (Oxford: Oxford University Press, 2017)

Strandsbjerg, Jeppe, 'The Space of State Formation', in Does War Make States? Investigations of Charles Tilly's Historical Sociology, ed. by Lars Bo Kaspersen and Jeppe Strandsbjerg (Cambridge: Cambridge University Press, 2017), pp. 127-153. Tilly, Charles, Coercion, Capital, and European States, AD 990-1992 (Cambridge, MA: Blackwell, 1990).

Tilly, Charles, 'Reflections on the History of European State-Making', in The Formation of National States in Western Europe, ed. by Charles Tilly and Gabriel Ardant (Princeton: Princeton University Press, 1975), pp. 3-83

Weber, Max, Politik als Beruf(Berlin: Duncker \& Humblot, 1982).

Werner, Mathias, 'Zwischen politischer Begrenzung und methodischer Offenheit. Wege und Stationen deutscher Landesgeschichtsforschung im 2o. Jahrhundert', in Die deutschsprachige Mediävistik im 20.Jahrhundert, ed. by Peter Moraw and Rudolf Schieffer (Ostfildern: Thorbecke, 2005), pp. ???-???. 
About the authors

Mario Damen is a Senior Lecturer at the University of Amsterdam. He has published widely on the social and political history of the late medieval Low Countries and is the PI of the research project 'Imagining a Territory: Constructions and Representations of Late Medieval Brabant', financed by the Dutch Research Council (NWO).

Kim Overlaet worked from 2016 to 2019 as a Postdoctoral Researcher at the University of Amsterdam on the research project 'Imagining a Territory: Constructions and Representations of Late Medieval Brabant', financed by the Dutch Research Council (NWO). She currently works as a research manager in the Department of History at Antwerp University. 


\section{Part 1}

The Multiplicity of Territory 



\title{
1. Were There 'Territories' in the German Lands of the Holy Roman Empire in the Fourteenth to Sixteenth Centuries?
}

\author{
Duncan Hardy
}

\begin{abstract}
This chapter provides an overview of the historiography on the political composition of the late medieval Holy Roman Empire, especially regarding "territoriality" and the rival theories and criticisms that have since emerged. It also illustrates the complexities of political ideas and practices at multiple levels within the Empire, drawing on a selection of evidence from throughout the German lands, from the bishoprics and principalities of the North and Baltic Sea littorals to the kaleidoscopic lordships and communes of upper Germany. Building on the latest research into the intersection of local, regional, and imperial ideologies and structures of power, it concludes with some brief proposals about how a more nuanced understanding of "territorial" power can be understood within the Empire's wider political culture.
\end{abstract}

Keywords: Holy Roman Empire; Germany; German historiography; territories; Landesgeschichte

\section{Introduction}

In 146o Peter von Andlau, the illegitimate child of an Alsatian knight and a professor of law at the newly founded University of Basel, attempted to summarise the hierarchy of power and jurisdiction in the Holy Roman Empire. The resulting Libellus de Cesarea monarchia ('little book on the imperial monarchy') presented a history and juridical theory of imperial

Damen, M. and K. Overlaet (eds.), Constructing and Representing Territory in Late Medieval and Early Modern Europe. Amsterdam: Amsterdam University Press, 2022 DOI 10.5117/9789463726139_CHO1 
monarchy from Antiquity to his own time, highlighting the translation of the imperial dignity to the German people and the ideal form and functioning of the Romano-German body politic under the emperors' oversight. Andlau drew on a rich array of authorities, from Gregory the Great to Poggio Bracciolini, harmonised to the best of his ability within a canonist and Thomist framework. These sources emphasised a Justinianic view of the imperial monarchy as enjoying a plenitude of power, delegated conditionally to princes and nobles. However, Andlau had to acknowledge in places the gulf between this monistic, top-down ideal and the realities of political structures and political life in the fifteenth-century German lands of the Empire. In his explanation of how the feudal order of nobles (Heerschildordnung) was supposed to assist the emperor in protecting and administering his realm, he recognised that they had landed possessions of their own to manage:

All the aforesaid princes and nobles were installed to assist and serve the Holy Empire, through which earthly monarchy may most perfectly be constituted. To them falls the obligation to govern political affairs in their own entrusted lands. ${ }^{1}$

To whom did the princes' and nobles' 'own entrusted lands' truly belong? In the sense that the emperor was the ultimate source of jurisdiction in the Holy Roman Empire, and presided over all ranks of aristocrats and cities within it, the Libellus seeks to give the impression that they stemmed from the monarchy. To the extent that this was true, the Empire resembled most other European kingdoms in which lands and powers were held by parties other than the monarch, but under his ultimate notional authority. Yet Andlau's wry comments elsewhere about the failure of the nobility to live up to its assigned role within the Empire, and the corresponding weakness of the Roman kings and emperors, hint at an exceptionally sharp division between lands within the Empire (and specifically in Germany - Germania or Alamania) ruled by princes, nobles, and cities, and lands directly appertaining to the monarchs. ${ }^{2}$ Traditionally, the power bases of these princes, nobles, and cities - what Peter von Andlau called their terrae - have been described by historians as 'territories'.

1 'Omnes autem predicti principes nobilesque in auxilium ministeriumque sacri imperii sunt instituti, ex quibus terrena perfectissime constituitur monarchia. Quorum proprium est officium rempublicam in terris sibi commissis [...] regere.' Andlau, Kaiser und Reich, p. 258.

2 Ibid., pp. 150-168. 
The aim of this article is to explore whether the concept of 'territories' is useful for making sense of the authorities below the monarchy that existed in the late medieval and early modern Holy Roman Empire. Before considering the applicability of the term to political elites' terrae, it is important to establish how widespread Andlau's division between these last and the monarchical layer of authority was. It is certainly evident in more prosaic narratives and legal documents. Already the mid-fourteenth century chronicle of Heinrich Taube von Selbach, a cleric in Eichstätt, drew an acute distinction between the lands of Emperor Ludwig IV (r. 1314-1347), of the Wittelsbach house of Bavaria, and the wider components of the Empire. 'In the whole time of his reign', claimed the chronicler, 'his own land [terra sua propria] met his financial needs; the cities and lands of the Empire [civitates et terre imperii] provided very few funds'. ${ }^{3}$ As vernacular sources rendered this multivalent term terra $(e)$ in German as Land $(e)$, and developed a related web of labels for their owners and rulers, this cleavage deepened. From the second half of the fifteenth century, and throughout the sixteenth, documents produced by monarchs, princes, and cities customarily contrasted the 'German land(s)' (teutsche lande, Teutschsland), the imperial 'estates' or 'members' (stende, glider), or the 'German nation' (teutsche nation) on the one hand, and the emperors' own power bases on the other. ${ }^{4}$ These were known by the time of Maximilian I (r. 1486-1519) as the 'hereditary lands' (erblande) - that is, the Habsburg patrimony located mainly in Austria and the Burgundian Low Countries. 5 The power and pervasiveness of this conceptual divide has inspired historians of the late medieval and early modern Empire to speak of an 'institutionalised dualism' within its constitutional system. ${ }^{6}$

By the Late Middle Ages, then, and into the early modern period, there was a clear and constitutionally significant distinction in Germany between 'lands' belonging to the Romano-German monarch and those controlled by other elites in the Holy Roman Empire (German princes and prelates, nobles, and cities and communes). As noted above, the tendency in modern German historiography has been to describe the latter as 'territories' (Territorien), and the process by which a large proportion of the German lands became increasingly autonomous of the monarchy under their local rulers has been

3 Die Chronik Heinrichs Taube, p. $5^{8}$.

4 E.g. Deutsche Reichstagsakten. Ältere Reihe, vol. 22, p. 250; Deutsche Reichstagsakten unter Kaiser Karl V., pp. 115-117.

5 E.g. Urkunden zur Geschichte des Schwäbischen Bundes, vol. 1, p. 213.

6 Notably Moraw, Von offener Verfassung, pp. 161, 236. 
dubbed 'territorialisation' (Territorialisierung). ${ }^{7}$ Although adherents of this view have not always defined what they mean by 'territory', often implicit within it is eighteenth-century German jurists' understanding of what they called a territorium clausum: an unambiguously spatially bounded zone, integrated under the undisputed jurisdiction of a single discrete administration. ${ }^{8}$ In recent decades, some historians within and beyond German-speaking scholarly circles have begun to criticise and unpick this well-worn narrative and theoretical framework. Mostly absent from this long-running discussion, among either proponents or opponents of territorialisation, is a consideration of whether any meanings of 'territory' could be applied to late medieval and early modern Germany that do not necessitate the existence of spatially delineated units. Here Stuart Elden offers a new perspective of potential relevance to the German debate, with his call to stop taking for granted that territory must be equated with a homogeneously governed 'bounded space', and instead to treat it as a contextually contingent 'political strategy'. ${ }^{9}$ We will have occasion to consider the applicability of this more nuanced approach as we examine local and regional imaginings and configurations of power in the Holy Roman Empire.

In the sections that follow, this article will consider whether the possessions and approaches to lordship and government of the imperial elite should indeed be considered 'territories' in any sense, in light of the surviving evidence and its implications for the vocabulary we might employ to apprehend the Empire's political configuration in the fourteenth to sixteenth centuries. As this question is, at its heart, historiographical in nature, the first half of the article consists of a survey of the narratives and interpretations that have constructed the idea of late medieval and early modern German Territorien. We shall see how these have changed over time, and the criticisms that they have received from some quarters. Taking up some of the points made by recent scholarship, the article will then briefly explore the ways in which local and regional forms of authority and community did - or did not - correspond with possible notions of territory between about 1300 and 1600 . It will examine this at the discursive level, through the terminology and connotations of 'territory'-esque words found in primary sources. The more concrete underpinnings of lordship and government in all their forms will then be considered, including the financial resources and transactional systems available to political actors, the tenurial formats (pledges, fiefs, etc.) 
through which they apportioned and held land-based authority, and the personnel involved in wielding power on a regional and local level. Finally, the article will highlight the interdependence among notionally autonomous actors that exercising authority over almost any defined 'territorial' space in the German lands entailed. Needless to say, an article of this length does not aspire to exhaustivity either in its treatment of the historiography or of the potentially relevant historical evidence. Rather, the point is to highlight where the debate about 'territories' in the German lands - or alternative models to them - stands in 2021, and to indicate through an unsystematic tour d'horizon of relevant themes and types of evidence how less plausible assumptions and narratives might be modified by alternative perspectives. Only then will it be possible to determine the applicability of 'territorial' vocabulary for this area of Europe in this period.

\section{Narratives of German territorialisation and their discontents}

\section{Teleologies of territorial statehood to the mid-twentieth century}

On the eve of the Holy Roman Empire's dissolution in 1806, political power within it was largely exercised by princes who claimed 'territorial supremacy' or quasi-'sovereignty' (superioritas territorialis, Landeshoheit), concepts popularised from the later seventeenth century onwards. The state-like character of these territorial entities was complicated only by their existence within the broader framework of the Empire - a situation that had already irritated the influential jurist Samuel von Pufendorf in the 1660 s. $^{10}$ Since the early nineteenth century, this post-Westphalian end point of German Kleinstaaterei has shaped the way in which historians write about the earlier political configurations in the Empire.

As we have already seen, the practical absence of central, monarchical authority over the Holy Roman Empire has been inextricably bound up with the notion that other actors held power over fragmented terrae or Lande within Germany. In the nineteenth and early twentieth century, this observation generally elicited despair and negativity in nationalist German scholars. It lay at the heart of the notion that Germany had followed a 'special path' (Sonderweg)..${ }^{11}$ The Empire, so the story went, had missed the opportunity 
to form the kernel of a German nation state. The splendour and might of the earlier medieval emperors presaged the centralisation of a Reich with a predominantly German character, but this project foundered on quixotic dreams of universal authority and the parochial greed of the princes. It had never been the case, of course, that any medieval emperors ruled directly and uniformly over a bounded imperial space. But through a combination of the alienation of prerogatives and assets attached to the monarchy, its reconfiguration as an elected office influenced by the seven prince-electors, and the rise of a wider princely elite, a devolution and layering of authority within the Empire became starkly apparent. The acquisition of power and resources by princes, nobles, and towns in the German localities - or at least the greater clarity with which we can observe their position as the source material becomes more abundant over time - is called 'territorialisation' in the historiography of the Holy Roman Empire. ${ }^{12}$ An important subset of scholars, beginning in the late nineteenth century and continuing into the late twentieth, even ventured to identify the subsidiary powers within the Empire as 'territorial states' (Territorialstaaten). ${ }^{13}$

A parallel scholarly tradition also adopted a territorial vocabulary to discuss social, political, and cultural dynamics in Germany - but, in contrast to the nationalist interpretation, tended to see 'territorialisation' as a positive development. This was regional history (Landesgeschichte, and its interdisciplinary counterpart Landeskunde). The very same Kleinstaaterei and cultural particularism bemoaned by nationalists stimulated the creation of a plethora of regional history societies and journals, often under the patronage of princes and kings (before 1871) and, subsequently, federal states. ${ }^{14}$ In this framework, the emergence of politically coherent territories was a process to be celebrated. LandeshistorikerInnen strained to identify markers of territorialisation that seemed to point to the subsequent rise of the princely territorial states or Bundesländer that existed in their own time, such as jurisdictional consolidation, the rise of fiscality, the creation of districts and office-holding administrators, and so on. Regional historians have therefore been even less hesitant to ascribe to medieval and early modern entities the characteristics of nascent statehood with territorial dimensions. As late as 1986, Alois Gerlich could discern in what he identified

12 For a recent overview, see Reinle, “"Meistererzählungen”', pp. 61-64.

13 On the Territorialstaat narrative, and for a critique of these scholarly traditions, see Groten, 'Erforschung', pp. 192-195.

14 See Werner, 'Zur Geschichte des Faches'. 
as medieval territories a 'primitive statehood predicated on a defined area of land' ('flächenbezogener Primitivstaatlichkeit'). ${ }^{15}$

While most strands of German historiography have been united in placing territorialisation at the heart of their interpretations, there has been less agreement over when this process began in earnest. Some of the dominant historians of the nineteenth century - Leopold von Ranke and Heinrich von Treitschke, for instance - saw the pre-modern Territorium as lacking the trappings of true statehood, which it supposedly acquired in the sixteenth and seventeenth centuries, alongside the Reformation and other ostensible signs of incipient modernity. ${ }^{16}$ Others were less hesitant to read medieval sources teleologically, with the post-Westphalian sovereign states in mind. In a historical compendium of constitutional law published in 1872 , Hermann Schulze situated Prussia's origins in medieval Brandenburg, which he already termed a Territorialstaat, albeit one with an 'unfinished form'. For Schulze, the putative jurisdictional supremacy of the medieval margraves already formed the 'essential core of sovereignty ["Landeshoheit"]'. ${ }^{17}$

The view that territorial statehood developed in the Middle Ages gained in prominence into the middle of the twentieth century. In Theodor Mayer's much-cited thesis, an early medieval Personenverbandsstaat (a state defined in relation to its ruling elite) gave way to a more territorialised form of statehood (defined by spatial boundaries under given authorities) in the eleventh and twelfth centuries. ${ }^{18}$ His interpretation elicited many criticisms. Most notably, Otto Brunner supported the regional basis for authority in the German-speaking lands, but rejected the abstract language of statehood as anachronistic, preferring to define the Land as the product of an aristocratic legal culture predicated on the right to feud in defence of one's honour and patrimony and the rise of late medieval 'territorial' elite communities or estates (Landschaften, Landstände). ${ }^{19}$ Brunner's landmark legal-cultural and communitarian insights have influenced virtually all subsequent historiography of politics in the late medieval German lands, but his radical rejection of étatiste concepts, and post-medieval vocabulary more generally, failed to gain much traction. The idea of the Territorialstaat persisted in the German scholarly conversation, despite disagreements about its applicability to specific time periods. 


\section{Shifting post-war interpretations of territorialisation}

After 1945, the negative nationalist view of the division of the Reich into territories as a failure of central government mostly fell out of favour. However, the narrative of 'territorialisation' in Germany endured, and in some respects gained strength. There are several reasons for this. German historiographical debates tend to centre on long-standing abstract and ideal-typical concepts (Begriffe). Historians have expended great intellectual energy on preserving terms like Territorialisierung, albeit in modified form as new research challenges old assumptions. This is especially the case in legal and constitutional history (Rechts-/Verfassungsgeschichte). The focus on putative territories was also stimulated by a resurgence in interest in tracing and comparing pathways of state formation across pre-modern Europe ${ }^{20}$ In this context, it has become a cliché of late medieval and early modern German scholarship that although the Holy Roman Empire itself did not 'achieve' centralised statehood on the Western European model, this process did occur at the devolved level of the princely territories or territorial states. ${ }^{21}$ Finally, Landesgeschichte - institutionalised in West German universities - flourished in the post-war decades. Sometimes it took on a more critical and self-reflective guise, applying new methodologies to local topics. Nevertheless, the 'territorial' paradigm has persisted in regional history, since it naturally lends itself to research at this scale. The words 'territory' (Territorium) and the more explicitly statist Flächen-/Territorialstaat therefore remain central (if sometimes ill-defined) components of the scholarly vocabulary of historians of the Holy Roman Empire in the fourteenth to the sixteenth centuries and beyond. ${ }^{22}$

Alongside this longevity, there have also been important changes in the scholarly orthodoxy about how the specificities of the territorial configuration of the German lands should be interpreted. In the 1970s-2000s a new wave of medieval and early modern scholarship, spearheaded by Peter Moraw and Volker Press, criticised the blinkered emphasis on the territorial level of politics alone, arguing that historians had ignored the importance of the Reich within which these territories were located, and

20 For instance, the European Science Foundation funded the comparative 'Origins of the Modern State in Europe' programme from the 1980s, yielding several comparative volumes: https:/global.oup.com/academic/content/series/o/the-origins-of-the-modern-state-in-europe13th-to-18th-centuries-omse (accessed 12 January 2020).

21 Bahlcke, Landesherrschaft, pp. 1-8, 56-76.

For some influential post-war studies within this model, see Patze, Territorialstaat. 
artificially separated regional and imperial history. ${ }^{23}$ While maintaining an interest in the growth of territorial structures, Moraw in particular sought to integrate the history of the German localities within what he saw as the Empire's evolving 'constitution' or 'political system'. More recently, Barbara Stollberg-Rilinger has emphasised the importance of the early modern Reich as a symbolic fount of legitimacy for its constituent authorities. ${ }^{24}$

In light of this wider focus and new advances in regional case studies, late medievalists have begun in the last couple of decades to shy away from the idea that the Empire contained territorial states. (This is much less true of early modern historiography, not least because of the 'confessionalisation' schema in Reformation studies, which posits the emerging territorial state as a key actor in shaping and entrenching confessional identities in Central Europe.) Instead of territorial statehood, historians of regional powers have embraced the less anachronistic concept of Landesherrschaft ('territorial/landed lordship'). In the earlier twentieth century this described the development of late medieval territories out of the power bases of the post-Carolingian nobility. Historians have broadened its meaning in recent decades, and redefined Landesherrschaft according to the specific entity under study, whether the fourteenth-century March of Brandenburg or the sixteenth-century archbishopric of Trier. ${ }^{25}$ In this respect its flexible usage anticipates a key criticism of the 'territorial' model, namely that it implies that all German political units had similar characteristics, whereas recent scholarship has emphasised the diversity of forms and pathways taken by the various 'territories'. This extreme variation arguably throws into question the value of 'territorial lordship' as a catch-all label, but certain common characteristics are typically assumed within it. An oft-repeated definition of Landesherrschaft holds that it consisted of the 'bundling' (Bündelung) of rights and powers related to property, jurisdiction, and authority over hierarchies of subordinates and subjects in the hands of a specific lord (usually a prince). Crucially, these bundled rights and powers were exercised within a spatially defined and increasingly discrete and cohesive area (hence this form of lordship fits neatly within the narrative of German territorialisation over time). ${ }^{26}$

23 A perspective summarised in Moraw and Press, 'Probleme'. See also Moraw, Von offener Verfassung.

24 Stollberg-Rilinger, Emperor's Old Clothes.

25 Winkelmann, Brandenburg; Eiler, Landesherrschaft.

26 For overviews, see Schubert, Territorium, pp. 19-26; Heinemeyer, Reich und Region, pp. 20-46; Rutz, Beschreibung, pp. 58-75. 


\section{Critiques of territorial models}

In recent years even the Landesherrschaft paradigm has been called into question from multiple perspectives. By far the most important critic is the late Ernst Schubert, whose seminal book Fürstliche Herrschaft und Territorium im späten Mittelalter (first published in 1996) remains the definitive overview of the themes and problems related to putative territorial authority in this period. Schubert's critique dismantles some of the comfortable assumptions about the German territories from several angles. In the primary sources the word Land, which underpins so many 'territorial' concepts employed in the scholarship, rarely denoted a coherent political space that a German prince claimed to rule. ${ }^{27}$ Historians who hope to sidestep the anachronism of the word 'territorial state' must reckon with the unwieldiness of Landesherrschaft, which remains so broad and ill-defined as to be almost meaningless as an analytical category. ${ }^{28}$ Crucially, Schubert argues that fundamental elements of politics in the fourteenth to sixteenth centuries were not 'territorial'/spatial in character. The unrelenting focus on territorialisation misses the significance of dynastic (i.e. interpersonal and biological) factors, for instance, while the undeniable bureaucratisation of princely government was more about the growth of courts and chanceries and their select personnel than the uncontested administration of spatially defined territorial zones.

Other more recent criticisms of territorial paradigms have also been proposed. Christine Reinle has highlighted the deterministic beliefs that underpin territorialisation, such as the notion that pre-modern actors always sought to maximise their power and property (Machtmaximierung), which ignores the many other complex and culturally specific values that motivated them. ${ }^{29}$ In an important study of the construction of borders within the pre-modern Reich, Andreas Rutz has shown that spatial conceptions of topographies, societies, and cultures certainly existed in Germany, including in the form of local administrative units. However, these were highly contingent, friable, and rarely amounted to cohesive delineations of princely territorial units as implied in conventional narratives of territorialisation. ${ }^{30}$ 
Where, then, does this leave the concept of 'territory' in the context of the late medieval and early modern German lands? Clearly, it has been taken for granted for too long, and the use of 'territorial' vocabulary and the assumptions that lie behind it is rightly being challenged. At the same time, some power wielders in the Empire undeniably were consolidating their authority in this period, and sometimes that consolidation had spatial dimensions. The second half of this article will therefore examine some of the specificities of politics in the Empire, and consider whether the term 'territory' is ever justified, even in the open-ended and context-sensitive Eldenian sense.

\section{The many meanings of Land and contemporary conceptualisations of power wielders}

Many narratives of German territorialisation rely on the presence of a land-related discourse in the primary sources. This is true of the notion that terrae/Lande denoted princely territorial states-in-the-making, for example, and - from a rather different perspective - Otto Brunner's argument that the pre-modern Empire was made up Lande defined by a mix of princely lordship and customary noble communities. But did the term Land and its cognates necessarily denote a discrete, politically delineated unit ruled by a prince? Recent research has dismantled this central plank of the territorialisation thesis.

Perhaps the main resonance of the word Land in late medieval sources was in reference to the local customs (also called 'lantsit') of groups of people, with only a fuzzy connection to a defined space. German rulers employed the universal phrase '[our] land(s) and people(s)' (Land und Leute) in charters and treaties to refer not to a territorial zone but a cluster of communities of custom under their authority. ${ }^{31} \mathrm{~A}$ related but larger-scale use for Land was to refer to cultural-linguistic zones such as Alsace, Westphalia, Swabia, or Franconia, which were fragmented among many autonomous rulers between 1300 and 1600 , and can in no way be considered territories in any political sense of the word. Some of these had once been loosely encompassed within now-defunct - or, in the case of Saxony, much-reduced and displaced - duchies. ${ }^{32}$

The rulers and entities that constituted the members and estates of the Holy Roman Empire, within and beyond these cultural-linguistic Lande, 
were almost never designated using a territorial or spatial vocabulary in this period. In ordinances issued at imperial diets by the monarchs and estates, the power wielders in the Empire were not addressed as rulers of 'lands' or 'territories', but as title-holding individuals or bodies under a collective imperial umbrella (electors, spiritual and secular princes, counts, barons, knights, cities, and communes, and their vassals, officers, and subordinates). ${ }^{33}$ A similar level of abstraction is evident in symbolic and idealised representations of the Empire's head and members known as Quaternionen, that emerged in the fifteenth century and became ubiquitous in the sixteenth. Here the imperial body politic appears as an amalgam of its emperor, seven electors, and sets of four representatives of various types of imperially immediate status holders, from dukes to villages, each status holder embodied by its heraldic arms. ${ }^{34}$

The 'territorialised' understanding of the Empire as a patchwork of enclosed geopolitical spaces within the Reich's borders was evidently alien to pre-seventeenth-century Germans. This is clear from the problems contemporaries faced when sub-imperial authorities had to be precisely defined in spatial terms, as in the attempts to resolve divisions between Lutherans and Catholics from the $15^{20}$ onwards. The solution of the 1555 Diet of Augsburg that subordinates and subjects should adhere to the confession of their ruler, distilled in 1586 in the phrase cuius regio eius religio, provoked decades of judicial and juridical disputes. Neither regio nor Land referred to uncontested administrative zones into which all Germans could be sorted, for the simple reason that the Empire did not consist of discrete territorial blocs or 'states'. 35

It is, however, clear that in some regional contexts terra, territorium, or Land could have a more clearly spatial and governmental resonance, and these resonances gradually increased over time. Through the modalities explored in the sections below, some princes and cities exercised authority over explicitly bounded districts in this period. Administrative and legal sources sometimes employed terra or Land to describe small districts around a castle or settlement (also called Ämter, Kreise, Zirkel, Flecken, and Vogteien, among other terms), which were ruled by one or more lords represented by local officials. ${ }^{36}$ Slowly and fitfully, this 'landed' vocabulary came to be deployed in specific circumstances to describe larger agglomerations of 
rights and properties in the hand of one ruler or set of rulers, symbolically anchored to a princely dynasty that identified itself with a local toponymic title. This was the case with the accumulated possessions of Albrecht 'Achilles' (1414-1486), margrave of Ansbach and Kulmbach and later elector of Brandenburg. In seeking to give coherence to his splintered archipelago of assets and jurisdictions in Franconia, he dignified it with the term 'our "territorum" [sic]' in a 1449 letter. ${ }^{37}$ His enemies, who disputed some of Albrecht's rights in the region, contested the applicability of such language. In 1461 Duke Ludwig 'the Rich' of Bavaria-Landshut argued of Albrecht 'that he has no "land" [...] and if he purports to have a "land", it would be seemly for him to clarify what it is called' $3^{38}$ At this time, Duke Ludwig claimed to rule a large portion of a relatively well-delineated political space that was sometimes called the Land Bayern. Ludwig's contention was that Albrecht could not make a similar claim about his possessions in highly fragmented Franconia.

Such usages offer insight into the gap between ideal and reality in claims to rule a Land in this sense, that is, a cluster of rights and powers exercised by princely administrations in at least an approximately defined space - in other words, something approaching a 'territory'. Even the dukes of Bavaria, who could argue that their patrimony constituted a Land in a way that other princes' did not, did not exercise anything approaching uncontested authority within the putative boundaries of a single Bavarian duchy until well into the sixteenth century. Before 1506, even Bavaria consisted in practice of multiple separate 'part-duchies' under different warring branches of the Wittelsbach family. ${ }^{39}$ The unqualified word Land thus appeared rarely even in Bavarian sources, which in this period favoured more abstract (and less explicitly spatial) terms like 'duchy' and 'principality' (Herzogthum, Fuerstenthum), reserving Land- as a prefix for vassals and estates (Landsessen, Landschaft $).{ }^{40}$ Even in the second half of the $1300-1600$ period, then, the closest approximations we have of concepts of 'territory' as imagined in the territorialisation narratives were strategically deployed claims (in the sense suggested by Elden), valuable as arguments with rival power wielders but always open to contestation, rather than stable features of political discourse and political life. 


\section{3. 'Territorial' structures? Political economy, lordship and administration}

In the classic model of territorialisation, two forms of lordship were united under 'territorial lords' (Territorialherren) in the fourteenth to sixteenth centuries, amounting to their increasingly coherent power bases. Grundherrschaft, seigneurial rights and property over land and its inhabitants at the local level, continued to be exercised by a variety of lords, but these were increasingly 'mediatised' under the authority of the highest-ranking rulers (mostly princes). Gerichtsherrschaft, meanwhile, consisted of a cluster of 'higher' jurisdictional powers and regalian rights wielded by princes and others over lower-ranking lords and communities. Through the coercive and centralising agency of local officers and courtly, judicial, and fiscal institutions, the imperial elites wove these assets and rights together within spatially delineated zones, turning the German political landscape into a patchwork quilt of increasingly discrete and intensely ruled territories. ${ }^{41}$

This narrative of cohering 'territorial' formations is paradoxical, because there is abundant evidence that the period 1300-1600, and even the two centuries that preceded it, saw the disaggregation and dispersal of even the smallest-scale clusters of rights and properties in the German politico-seigneurial landscape. The unitary manors (Villikationen) of earlier medieval Germany, to the extent that they ever truly existed in this form, had crumbled and segmented by around 1300, with a diverse array of lords of vastly diverging wealth and status having some stake in Grundherrschaft for the rest of the late medieval and early modern periods. ${ }^{42}$ 'Higher' fiscal, jurisdictional, and regalian powers and privileges within a given zone could be similarly divided, albeit among a narrower range of potential exercisers (mostly princes, the upper nobility, cities, and cathedral chapters and monasteries). Well into the sixteenth century, therefore, assets and powers ranging from the revenues from a mill to the right of safe conduct (Geleit) that were located in the same area could be in the hands of multiple independent lords. ${ }^{43}$ Only a small number of princely administrations towards the end of our period, such as Saxony and Bavaria, could claim at least an indirect authority over the most significant lands and rights within a demarcated

41 See, e.g., the contributions in Jeserich, Verwaltungsgeschichte.

42 Rösener, 'Grundherrschaft', pp. 62-68.

43 For examples from Upper Germany, see Hardy, Associative Political Culture, chap. 4. For a specific example of safe conduct and other rights held by others in Nuremberg's sphere of influence, see Rutz, Beschreibung, p. 428. 
zone that could meaningfully be called a territory in the sense implied by the secondary literature.

The fragmented character of lordship in the German lands was enabled by a financialised political economy in which any asset, revenue, or jurisdiction could be treated like a commodity and isolated, transferred to another party, and recombined within a new patrimony. The exchange of components of lordship was facilitated by sophisticated credit networks, in which not only urban patricians and merchants but also nobles played prominent roles as lenders to one another and to princes. ${ }^{44}$ There is growing evidence that a commercialised credit economy even extended to the level of tenant farmers. ${ }^{45}$ In this context, the building blocks of lordship could be transferred between and divided among any number of potentially autonomous owners and exercisers, in transactions ranging from simple sales to exchanges of loans for tenure of pledged assets, rights, or offices (Pfandschaften) or of fiefs (Lehen), not to mention transfers within elite familial networks through vehicles such as inheritances, dowries, and jointures.

Consequently, even at a very local level, the notion that the Holy Roman Empire was divided into political spaces ruled evenly by individual lords with growing monopolies of jurisdiction seems questionable. A perusal of registers of possessions and/or incomes (Urbare) compiled by princely and monastic regimes in these centuries underlines this point. For example, in 1427 the priory of Reichenbach in southern Germany produced an Urbar. Few of its possessions were entire villages. Instead, it owned hundreds of tiny fragments of land and buildings, with or without appertaining lower jurisdictions, often held in fief by prominent villagers. ${ }^{46}$ Some of these holdings were co-ruled with otherwise autonomous authorities. The entry for Hochdorf near the river Neckar, for instance, states that the village court should hold two annual sessions, and that jurisdiction over them was held jointly ('dieselben [...] zway gericht seind gemein') with the minor noble lords of Enzklösterle, such that they and the prior of Reichenbach wielded the judicial rod together ('den stab gemein hand'). ${ }^{47}$ To complicate matters further, Reichenbach was a dependency of the imperial abbey of Hirsau, and advocatial rights over it were disputed between the counts of Eberstein, the margraves of Baden, and the counts (later dukes) of Württemberg. ${ }^{48}$ 
Who, then, was the 'territorial lord' of Hochdorf? The limitations of the territorialisation paradigm are clear in such situations.

Arguably the less densely populated north-eastern regions of Germany, which also had less developed traditions of communal government at the village level, tended to enable the fief-holding nobility to exercise more cohesive and intensive control of spaces in and around settlements and their increasingly servile inhabitants, exploited under a regime dubbed Gutsherrschaft. Yet this did not translate automatically into unitary territorial power for the princes from whom these nobles held their fiefs. In the fourteenth and fifteenth centuries more and more higher (e.g. capital) jurisdictions were alienated from the dukes of Mecklenburg to their noble estates, for instance. ${ }^{49} \mathrm{~A}$ recent study of Brandenburg has argued that the margraves' authority over their putative northern possessions was largely symbolic, and would not rest on jurisdictional and fiscal structures buttressed from below by an obedient nobility until late in our period..$^{\circ}$

Forms and configurations of tenure and office holding under secular and spiritual princes (and, less often, under city councils) could also mitigate against the formation of spatially coherent political authority, rather than contributing to 'territorialisation'. Fiefs and pledges (Pfandschaften) issued by a prince could be held by vassals or subordinates who might simultaneously hold other parts of their patrimony from a different lord - a particularly common situation in regions such as the Upper Rhine and Franconia, where many imperially immediate actors existed in close proximity. In 1428 Count Palatine Ludwig III noted that 'we and other princes, counts, barons, knights, and squires, and also urban communes, rub up against each other on many sides, and in places are almost mixed together..$^{1} \mathrm{~A}$ unitary and areal conception of power - an essential prerequisite of territorial authority as exercised within an enclosed and uncontested space - was difficult to maintain when one's vassals or officers were simultaneously independent imperial nobles embedded in power-sharing leagues and knightly societies and serving other princes in similar capacities. Over time some noble families in the orbit of some princes (such as the dukes of Saxony) came to benefit from service at one specific court, exerting a centripetal effect within their networks, but this was by no means the case everywhere..$^{2}$ Recent research has noted that some princes welcomed pluralistic tenure and office holding by their 
noble clients, since this opened informal opportunities for advantageous interpersonal contact with peers mediated through common vassals and officers. ${ }^{53}$

The most unambiguous trend towards greater coherence and consolidation can be detected in the 'central' institutions and organisms that developed around princely regimes. The court (curia, Hof) has been intensively studied as a social, political, and cultural entity that emerged in the Late Middle Ages and became the focal point of institutional continuity and expansion for German princely governments. ${ }^{54}$ High-ranking prelates led the way: the archbishops of Trier had advisory councils (Räte) and permanent chancery personnel by the fourteenth century, courtly ordinances and officers by the early fifteenth, and, by c. 1450, aulic courts of appeal (Hofgerichte) with increasing popularity among litigants in lower courts connected in some way to the ecclesiastical principality. ${ }^{55}$ Similar institutions crystallised around the dukes of Bavaria, Saxony, and Württemberg and the counts palatine on a slightly later timeline..$^{6}$

These central institutions, particularly through their capacity to outlive individual princes, undoubtedly made it possible to think in the abstract about principalities and other political entities within the Holy Roman Empire, such as 'the Palatinate' (Pfalzgrafschaft) or the 'Duchy of Bavaria' (Herzogtum Bayern). These abstractions could have spatial content. For example, princely personnel sometimes defined the jurisdictions of higher courts or the applicability of tolls and irregular taxes in relation to topography and the borders of (typically piecemeal) districts and settlements. ${ }^{57}$ This partially 'zonal' authority was never uncontested, and was often in tension with the plural and overlapping nature of local power noted above; yet its existence at a conceptual level is undeniable. But did these political abstractions that developed out of central institutions equate to 'territories', as the territorialisation narratives have defined them? We have seen that this was not straightforwardly the case in contemporary terminology. For secular principalities, dynastic dynamics and the need to provide for heirs, often by dividing patrimony, repeatedly entailed the partition of 'central' jurisdictional and fiscal regimes and the spaces in which they were

Heinemeyer, Reich und Region, pp. 529-534.

54 See the long-running Residenzforschung series edited by the Residenzen-Kommission der Akademie der Wissenschaften in Göttingen: https://www.thorbecke.de/residenzenforschungc-310_138_248.html (accessed 12 January 2020).

55 Holbach, 'Trier'.

56 See Schubert, Territorium, pp. 67-70.

57 For examples of this in the Prince-Bishopric of Basel, see Weissen, 'An der stuer'. 
supposed to hold sway, leading to multiple princely courts with their own institutions. ${ }^{8}$ Treaties and alliances of inheritance, partition, or condominium within a dynastic zone could be brokered, often with input from councillors or estates, and to this extent we can see that the abstractions of Land, Herzogtum, etc., had some purchase as labels for groups of elites with a stake in a princely regime. These were, however, interpersonal (we might say 'corporative', 'multilateral', or 'associative') conceptions of the political units created by German princes, rather than spatial/territorial ones.

Indeed, far from constituting bureaucratised organs intent on demarcating and controlling territorially conceived spaces, the courtly and representative institutions of late medieval and sixteenth-century principalities were largely ad hoc meeting points between princes and other regional elites. In contemporary terms (often found in the treaties that framed relations between the 'members' or 'estates' of principalities), these institutions underpinned reciprocal ties between prominent political actors justified in relation to the common good, custom, and justice, and functioned as sites for the performance of social and ritual processes through which these ties were maintained..$^{59}$ Often the political actors who participated in regional diets and princely councils and other courtly institutions were not straightforward subjects whose actions fit the narrative of cohesive territorialisation. In this respect a tendency to focus disproportionately on the appointment of small numbers of jurists educated in civil law, ostensibly as harbingers of rationalisation and territorial state formation in these centuries, has missed the enduring importance of princely institutions as nodal points in aristocratic networks. ${ }^{60}$

Princes' staff and councillors could be nobles with substantial autonomy, or even imperially immediate neighbours who, though less powerful and influential and lower in the social hierarchy, were de jure peers of the princes they counselled. The Rat (council) of the fifteenth-century counts and dukes of Württemberg, for instance, included at various times the prince-bishops of Constance and Augsburg and members of the independent comital houses of Helfenstein, Zollern, and Oettingen. ${ }^{61}$ The counts palatine signed repeated 'protection treaties' (Schirmverträge) with the bishops of Speyer in this period, some of whom even served as chancellors of the Palatinate, yet the properties and jurisdictions of the prince-bishopric remained formally

59 See Hardy, Associative Political Culture, chaps 7-8.

6 o See Widder, Kanzleien, esp. chap. 2.

61 Hardy, Associative Political Culture, p. 171. 
independent until the nineteenth century. ${ }^{62}$ To describe the political entities in the Holy Roman Empire primarily in the language of geographical or political space - as 'territories' - risks missing these fundamental interpersonal ties and their attendant socio-economic and cultural contexts, which structured lordship and administration into overlapping and dynamically disaggregating-then-recombining configurations rather than discrete units, at both local and central levels.

\section{Conclusion: The limitations of territorial concepts and the importance of the imperial framework}

In the abundant sources that survive from the fourteenth- to sixteenthcentury German localities, it is clear that the authority of political actors could be conceived in theory and wielded in practice in ways that related explicitly to spatially defined zones. Mostly these were small in scale: longstanding customary village jurisdictions, or official districts (Ämter, etc.) that became fitfully more consolidated for fiscal and judicial purposes. We have also seen that even at this very local level, such notional units could in practice be fragmented and governed through a plurality of lords and agencies. By the mid-fifteenth century, a larger-scale sense of terra, territorium, or Land could also be deployed to refer to and claim coherence for the accumulated possessions of a powerful prince. Again, however, the unity and integration claimed for such political spaces was more rhetorical than tangible in practice, and always had to be negotiated with subsidiary actors, who might have stakes in multiple other princely or urban power bases. Because these recognisably spatial aspects of government below the level of the imperial monarchy did exist in the German lands, and because of the long tradition of applying 'territorial' concepts to them, the term 'territory' is likely to endure as a label for the constituent parts of the Empire, particularly in general-audience and synthetic literature.

Yet, abstract concepts that encapsulated an array of dynastic, noble, or custom- or estate-based solidarities and relationships predominate in the sources over unqualifiedly territorial vocabulary - for good reason, as we have seen from this brief survey of the complex contours of Germany's political landscape in this period. As the impossibility of reconciling the evidence of disaggregation and overlap with the Territorialstaat paradigm has become more apparent, it has come under sustained scholarly attack. 
Before we consider whether any definition of 'territory' is helpful, it has to be acknowledged that the long-standing narrative of territorialisation as a kind of unitary state formation simply does not take account of the fragmented-yet-overlapping configuration of the German lands in this period, nor of the variety of religious, aristocratic, and communitarian logics that motivated their inhabitants. A neat territorium clausum as imagined by eighteenth-century jurists and subsequent historians cannot be found even in the more consolidated principalities such as Brandenburg, Saxony, or Bavaria before 1600 .

This lack of exclusively spatially defined power begs the question of what other frameworks, conceptual and material, gave coherence to local and regional politics in the German lands in this period. Here the renewed focus on the Holy Roman Empire as an overarching polity since the 1970s, liberated from some of the nationalist baggage that had accompanied its study in earlier eras, furnishes persuasive answers and models. Many of the governmental functions managed 'internally' within a conventionally defined political territory operated at 'trans-' or 'supra-territorial' levels in Germany. ${ }^{63}$ In particular, new research has emphasised the plethora of interactions that princes, nobles, and cities engaged in with each other, often within treaty-bound leagues, alliances, and other associations with varying degrees of connection to the Empire's overarching institutions. These could regulate spheres of joint governmental activity as diverse as troop provisioning in times of war and the value of coinage. ${ }^{64}$ Landfrieden (peacekeeping) is a clear example. While stemming in theory from the monarchy's obligations and prerogatives, and increasingly also from ordinances issued at imperial diets, late medieval defence of travellers and prosecution of certain kinds of criminals or troublemakers (particularly declarers of feuds) was organised within regional alliances of imperially immediate authorities. From the early sixteenth century these alliances were supplemented or supplanted by the horizontally organised imperial circles (Reichskreise) that transcended any individual lord. ${ }^{6}$ Similarly, judicial activity involving princes, nobles, and cities, and sometimes even their more humble subjects, tended to take the form of arbitration by political peers, later formalised and juridicised in collectively managed imperial courts like the Reichskammergericht. ${ }^{66}$

63 Bahlcke, Landesherrschaft, p. 101.

64 Hardy, Associative Political Culture, chaps 5-6, 8.

65 Ibid., pp. 102-104, 148-150, 240-243, with further references.

66 Ibid., pp. 244-252. 
Even the wealthiest princes from the most prestigious houses in Germany were also members and estates of the Empire and vassals of its monarch. The Reich was not only the ultimate symbolic source of the political legitimacy that they claimed, but a dynamic superstructure within which they had to engage with other imperial estates, particularly when problems arose (such as the security of shared roads, external invasions from the east and west, and internal confessional strife) which were insurmountable for any individual lord. The ties between the authorities in the Empire's heartlands thus became increasingly enmeshed within its developing institutions as this period wore on, crystallising a multilayered and multilateral structure for a variety of governmental functions that mitigated against the formation of unitary territorial states, as the less subtle territorialisation narratives posit. ${ }^{67}$

What vocabulary should we use to apprehend the subsidiary components of a pre-modern polity of this kind, in which forms and configurations of authority could legitimately be claimed - and jointly exercised - by a diverse cast of actors at multiple intersecting levels, from portions of villages and castles to the imperial diets and judicial bodies, via princely courts and municipal governments? The present author's preference, unwieldy though it may seem to some, is to employ generic terms such as 'status holders', 'political actors', 'entities', or 'imperial elites', which can encompass the power bases of every rank of prince, and a spectrum of nobles, towns, and communes too. This leaves open the possibility of specifying that claims to authority could have spatial, even geopolitical (and hence potentially 'territorial') dimensions in specific situations, without overriding the many non-space-contingent ways in which the inhabitants of the German lands conceived of and exercised power. If, following Stuart Elden, we seek to move beyond viewing territorial power as a matter of 'bounded space' and see claims to rule a territorium, such as that made by Margrave Albrecht Achilles in 1449, as deployments of a 'calculative category' that was situationally useful but not the only or primary understanding of authority in this period, the word 'territory' can find a meaningful place in the terminology of the historian of pre-modern Germany. ${ }^{68}$ But, in the case of the German-speaking regions of the Holy Roman Empire at least, even an emerging calculated discourse of the Land/terra/territorium qua 'political technology' was only one of several logics of power within a broader framework, whose constituent parts cannot be studied in isolation from it.

67 See Moraw's influential concept of gestaltete Verdichtung in the Empire: Moraw, Von offener Verfassung, pp. 411-421.

68 Elden, 'Land, Terrain, Territory', pp. 799, 810-812. 


\section{Bibliography}

\section{Primary sources}

Andlau, Peter von, Kaiser und Reich. Libellus de Cesarea monarchia, ed. by Rainer Müller (Frankfurt a. M.: Insel, 1998).

Baierische Landtags-Handlungen in den Jahren 1429 bis 1513, ed. by Franz von Krenner, 18 vols (Munich: F.S. Hübschmann, 1803-1805).

Das älteste Urbar des Priorats Reichenbach von 1427, ed. by Regina Keyler (Stuttgart: Kohlhammer, 1999).

Deutsche Reichstagsakten. Ältere Reihe, ed. by Julius Weizsäcker et al., 22 vols (Gotha: Perthes/Göttingen: Vandenhoeck \& Ruprecht, 1867-2013).

Deutsche Reichstagsakten unter Kaiser Karl V. Der Reichstag zu Augsburg 1555, ed. by Rosemarie Aulinger et al. (Munich: Oldenbourg, 2009).

Die Chronik Heinrichs Taube von Selbach, ed. by Harry Bresslau, Monumenta Germaniae Historica. Scriptores rerum Germanicarum. Nova series, vol. 1 (Berlin: Weidmann, 1922).

Urkunden zur Geschichte des schwäbischen Bundes (1488-1533), ed. by Karl Klüpfel, 2 vols (Stuttgart, 1846-1853).

\section{Secondary sources}

Bahlcke, Joachim, Landesherrschaft, Territorien und Staat in der Frühen Neuzeit (Munich: Oldenbourg, 2012).

Brunner, Otto, Land und Herrschaft. Grundfragen der territorialen Verfassungsgeschichte Österreichs im Mittelalter, $5^{\text {th }}$ ed. (Darmstadt: Wissenschaftliche Buchgesellschaft, 1965 [first published 1939]).

Bünz, Enno, 'Das Land als Bezugsrahmen von Herrschaft, Rechtsordnung und Identitätsbildung: Überlegungen zum spätmittelalterlichen Landesbegriff', in Spätmittelalterliches Landesbewußtsein in Deutschland, ed. by Matthias Werner (Ostfildern: Thorbecke, 2005), pp. 53-92.

Eiler, Klaus, Stadtfreiheit und Landesherrschaft in Koblenz: Untersuchungen zur Verfassungsentwicklung im 15. und 16. Jahrhundert (Wiesbaden: Steiner, 1980).

Elden, Stuart, 'Land, Terrain, Territory', Progress in Human Geography 34, no. 6 (2010), 799-817.

Gerlich, Alois, Geschichtliche Landeskunde des Mittelalters. Genese und Probleme (Darmstadt: Wissenschaftliche Buchgesellschaft, 1986).

Ghosh, Shami, 'Rural Commercialisation in Fourteenth-Century Southern Germany: The Evidence from Scheyern Abbey', Vierteljahrschrift für Sozial- und Wirtschaftsgeschichte 104, no.1 (2017), 52-77. 
Grosses vollständiges Universal-Lexikon aller Wissenschafften und Künste, 64 vols (Halle/Leipzig: Johann Heinrich Zedler, 1732-1754).

Groten, Manfred, 'Die Erforschung des hochmittelalterlichen Adels im Rheinland. Bilanz und Perspektiven', in Verortete Herrschaft. Königspfalzen, Adelsburgen und Herrschaftsbildung in Niederlothringen während des frühen und hohen Mittelalters, ed. by Jens Lieven et al. (Bielefeld: Verlag für Regionalgeschichte, 2014), pp. 191-210.

Hardy, Duncan, Associative Political Culture in the Holy Roman Empire: Upper Germany, 1346-1521 (Oxford: Oxford University Press, 2018).

Heinemeyer, Christian, Zwischen Reich und Region im Spätmittelalter. Governance und politische Netzwerke um Kaiser Friedrich III. und Kurfürst Albrecht Achilles von Brandenburg (Berlin: Duncker \& Humblot, 2017).

Holbach, Rudolf, 'Trier, Erzbischöfe von', in Höfe und Residenzen im spätmittelalterlichen Reich. Ein dynastisch-topographisches Handbuch, ed. by Werner Paravicini et al., 2 vols (Ostfildern: Jan Thorbecke, 2003), vol. 1, pp. 421-427.

Jeserich, Kurt, ed., Deutsche Verwaltungsgeschichte. Band I. Vom Spätmittelalter bis zum Ende des Reiches (Stuttgart: Deutsche Verlags-Anstalt, 1983).

Mayer, Theodor, 'Die Ausbildung der Grundlagen des modernen deutschen Staates im Mittelalter', in Herrschaft und Staat im Mittelalter, ed. by Hellmut Kämpf (Darmstadt: Wissenschaftliche Buchgesellschaft, 1956 [first published 1939]), pp. 284-331.

Moraw, Peter, Von offener Verfassung zu gestalteter Verdichtung. Das Reich im späten Mittelalter 1250 bis 1490 (Berlin: Propyläen, 1985).

Moraw, Peter, and Volker Press, 'Probleme der Sozial- und Verfassungsgeschichte des Heiligen Römischen Reiches im späten Mittelalter und in der Frühen Neuzeit (13.-18. Jahrhundert)', Zeitschrift für historische Forschung 2 (1975), 95-108.

Patze, Hans, ed., Der deutsche Territorialstaat im 14. Jahrhundert, 2 vols (Sigmaringen: Thorbecke, 1970-1971).

Reinle, Christine, “"Meistererzählungen” und Erinnerungsorte zwischen Landes- und Nationalgeschichte. Überlegungen anhand ausgewählter Beispiele', in Handbuch Landesgeschichte, ed. by Werner Freitag et al. (Berlin: De Gruyter, 2018), pp. 56-71.

Rösener, Werner, 'Die Grundherrschaft als Forschungskonzept: Strukturen und Wandel der Grundherrschaft im deutschen Reich (10.-13. Jahrhundert)', Zeitschrift der Savigny-Stiftung für Rechtsgeschichte: Germanische Abteilung 129 (2012), 41-75.

Rutz, Andreas, Die Beschreibung des Raums. Territoriale Grenzziehungen im Heiligen Römischen Reich (Cologne/Weimar/Vienna: Böhlau, 2018).

Scales, Len, The Shaping of German Identity: Authority and Crisis, 1245-1414 (Cambridge: Cambridge University Press, 2012).

Schneider, Joachim, “Ehrbare Mannschaft”: Die Beziehungen zwischen den sächsischen Herzögen und dem Niederadel', in (Un)Gleiche Kurfürsten? Die Pfalzgrafen 
bei Rhein und die Herzöge von Sachsen im späten Mittelalter (1356-1547), ed. by Jens Klingner and Benjamin Müsegades (Heidelberg: Winter, 2017), pp. 207-220. Schubert, Ernst, 'Der rätselhafte Begriff "Land” im späten Mittelalter und in der frühen Neuzeit', Concilium medii aevi 1 (1998), 15-27.

Schubert, Ernst, Fürstliche Herrschaft und Territorium im späten Mittelalter, $2^{\text {nd }}$ ed. (Munich: Oldenbourg, 2006).

Schulze, Hermann, Das preussische Staatsrecht auf Grundlage des deutschen Staatsrechts (Leipzig: Breitkopf \& Härtel, 1872).

Scott, Tom, Society and Economy in Germany, 1300-160o (Basingstoke: Palgrave, 2002). Spieß, Karl-Heinz, Familie und Verwandtschaft im deutschen Hochadel im Spätmittelalter 13. bis Anfang 16. Jahrhunderts, $2^{\text {nd }}$ ed. (Stuttgart: Steiner, 2015).

Stollberg-Rilinger, Barbara, The Emperor's Old Clothes: Constitutional History and the Symbolic Language of the Holy Roman Empire, trans. by Thomas Dunlap (New York/Oxford: Berghahn, 2015).

Weissen, Kurt, 'An der stuer ist ganz nuett bezalt'. Landesherrschaft, Wirtschaft und Verwaltung in den fürstbischöflichen Ämtern in der Umgebung Basels (1435-1525) (Basel: Helbing \& Lichtenhahn, 1994).

Werner, Matthias, 'Zur Geschichte des Faches', in Handbuch Landesgeschichte, ed. by Werner Freitag et al. (Berlin: De Gruyter, 2018), pp. 3-23.

Whaley, Joachim, Germany and the Holy Roman Empire, 2 vols (Oxford: Oxford University Press, 2012).

Widder, Ellen, Kanzler und Kanzleien im Spätmittelalter: eine Histoire croisée fürstlicher Administration im Südwesten des Reiches (Stuttgart: Kohlhammer, 2016).

Winkelmann, Jan, Die Mark Brandenburg des 14. Jahrhunderts: markgräfliche Herrschaft zwischen räumlicher 'Ferne' und politischer 'Krise' (Berlin: Lukas, 2011). Zeilinger, Gabriel, 'Anwesenheit und Abwesenheit. Hoffeste, Kriege und die "Verdichtung" des Reichs im 15. Jahrhundert', in Stand und Perspektiven der Sozial- und Verfassungsgeschichte zum römisch-deutschen Reich. Der Forschungseinfluss Peter Moraws aufdie deutsche Mediävistik, ed. by Christine Reinle (Affalterbach: Didymos, 2016), pp. 165-176.

Zmora, Hillay, 'Princely State-Making and the "Crisis of the Aristocracy" in Late Medieval Germany', Past \& Present 153, no. 1 (1996), 37-63.

\section{About the author}

Duncan Hardy is Assistant Professor of History at the University of Central Florida, specialising in late medieval and early modern Europe. He has published widely on the political and cultural history of the Holy Roman Empire and its neighbouring regions. 


\title{
2. Beyond the State: Community and Territory-Making in Late Medieval Italy
}

\author{
Luca Zenobi*
}

\begin{abstract}
Textbooks on the Late Middle Ages often feature the same map: a colourful jigsaw showing the respective territories of European states. While the spatial dimension of these polities is now being reassessed, it is crucial to realise that territoriality was never the state's exclusive domain. Communities of all shapes and sizes, from individual villages to federal associations, constructed territories of equally diverse form and format. Inspired by the reflections of contemporary jurists, this essay looks to challenge these assumptions by surveying different scales and processes of territory-making in late medieval Italy. In so doing, the essay seeks to shift the focus away from the supposed territory of the state and provide a more accurate picture of the spatial fabric of a late medieval society.
\end{abstract}

Keywords: state formation; territorialisation; jurisdiction; corporation; communalism

Open any textbook on the Late Middle Ages and you will be faced with the same map: a jigsaw of colourful areas marking the clear-cut boundaries and mutually exclusive territories of European states. In part, this is due to the necessity of presenting the spatial dimension of pre-modern polities in a way that specialists and non-specialists alike may appreciate. Equally,

* I would like to record my thanks to the volume's editors, Mario Damen and Kim Overlaet, for their insightful comments on a first draft of this essay. I am also extremely grateful to the colleagues, friends and mentors who helped me improve its initial content: Daniele Dibello, Michele Baitieri, Andrea Gamberini and Isabella Lazzarini.

Damen, M. and K. Overlaet (eds.), Constructing and Representing Territory in Late Medieval and Early Modern Europe. Amsterdam: Amsterdam University Press, 2022 DOI 10.5117/9789463726139_CHO2 
however, this traditional mapping of late medieval states reflects long-held assumptions about the spatiality of pre-modern power, and particularly the notion that the degree of territoriality accomplished or even just craved by the rulers of the time was really no different from that exhibited to this day by modern nation states. Indeed, territoriality has long been upheld as one of the defining features of the process of state formation in late medieval Europe. Drawing on classic works of human geography, this could be defined as the capacity to 'affect, influence, and control people, phenomena, and relationships, by asserting control over a geographic area.' Narratives vary across regions and disciplinary traditions, but they all share an appreciation for the ability of late medieval rulers to coalesce diverse political and social bodies into a spatial whole, and ultimately to exert their authority with a certain degree of uniformity over it. To name but one example, in his search for the 'medieval origins of the modern state', Joseph Strayer saw the 'natural conclusion' of the process of state formation as the turning of 'scattered islands of political power' into a 'solid block of territory in which one ruler had final authority'.

This points to an inescapable fact: territories define states and their formation. Better still, they define our understanding of the process through which they came into being. They do so physically, by embodying the spatial dimension of state authority - by reifying the interface through which the relationships between the rulers and the ruled were articulated; but they also do so symbolically, in our collective imagination, to the point that we have no qualms about adopting the same modes of representation to map both modern and pre-modern polities. This is neither the place to question whether the spatiality of late medieval power should be reassessed, nor the appropriate platform from which to call for a new mapping of pre-modern states. Rather, this is to note that the opposite of what has been said above is also true: just as territories give shape to states in our imagination, states shape our conception of what territories should be. To start, by positing that territoriality is the exclusive domain of the state, we fall into what geographers call 'the territorial trap', which is the assumption that the spatiality of power comes down only to its highest level. ${ }^{3}$ When looking at late medieval Europe, this translates into the notion that all territories

1 For this essay's purposes, I have adopted the definition of Sack, Human Territoriality, p. 19. More recent developments and alternative definitions from the same field are discussed in Johnston, 'Out of the "Moribund Backwater"'.

2 Strayer, On the Medieval Origins, p. 31.

3 The term was famously coined by Agnew, 'The Territorial Trap'; for more recent reflections, consider Shah, 'The Territorial Trap'. 
were constructed in the same way, that is, from above and by the same sort of dominant actor (a duchy, a kingdom, an empire - in a word, by states) and, by extension, that only 'sovereign' polities were truly 'territorial'. The first few pages of Thomas Ertman's ambitious account of the 'birth of the leviathan' provide a vivid illustration of such tendencies. Here, a preliminary distinction is drawn between what the author calls small 'nonterritorial' polities (including city-republics, private estates and confederal entities) and large 'sovereign' - and thus properly 'territorial' - states. ${ }^{4}$

While equivalent convictions inform much research into processes of polity formation, late medieval thinkers would have found them rather restrictive. Unlike us, they did not associate the word 'territory' with the idea of the state, but with that of community. In truth, the very word territorium was used only sporadically in the Early and Central Middle Ages. ${ }^{5}$ Between the thirteenth and the fourteenth centuries, however, the revival of Roman law at the hands of generations of Italian jurists established territorium at the very heart of the intellectual discussion surrounding the nature of power over space, where it arguably has remained ever since. More than on territorium itself, the debate centred around the idea of iurisdictio. Originally understood as the authority of the judge, the ability to state principles (ius dicere) which could settle legal disputes, iurisdictio was later redefined by medieval jurists as the capacity of exerting power over a defined space. At first, they only adopted iurisdictio to qualify the degrees of authority wielded by different power holders: from the emperor (the theoretical owner of the highest jurisdiction) to the range of magistrates and institutions nominally ruling in his name. ${ }^{6}$ Soon, though, they went on to make the case that the emperor was not the ultimate source of jurisdictional power, but rather just one of several subjects with legitimate authority. In their view, all communities of people (universitates) capable of making their own laws and electing officers who could then enforce them were the true owners of a bundle of jurisdictional rights over their respective territories. ${ }^{7}$ As with the magistrates and institutions once understood to be wielding different degrees of the emperor's power, the place of universitates in the political and legal order could be defined by the degree of iurisdictio they exerted within their spaces. Thus, just as territories are now imagined as

4 Ertman, Birth of the Leviathan, p. 5 .

5 An early history of the concept and its uses has been traced by Khan, 'Territory and Boundaries'; and, more extensively, Elden, The Birth, pp. 97-210.

6 On these first developments, see Perrin, 'Azo, Roman Law'; and broadly Costa, Iurisdictio.

7 On these later developments, see Canning, 'The Corporation'; and generally Najemy, 'Stato, comune e "universitas"'. 
the embodiment of state sovereignty, territoria were then conceptualised as the jurisdictional spaces of communities of people. ${ }^{8}$

It is widely acknowledged that jurists formulated these theories to make sense of the 'realities' of their time - to provide an intellectual platform everyone could use to frame the relationships between the many political and social bodies featured by their society. ${ }^{9}$ As such, they not only contain valuable clues as to how people conceived territories and territoriality at this time, but also a number of methodological pointers as to how we should write their history. The first is that, prior to becoming the tangible attribute of state formation, territoriality was seen as a predicate of communal agency. It is thus at communities, rather than states, that we should first look when studying processes of territory formation in the medieval period. The second is that unlike the territories of modern states, which are nothing but vast homogenous spaces subject to a supreme legislator, one who can freely subdivide them into provinces in order to mould a population's duties towards them, medieval territories were inseparable from the prerogatives of their communities - they were the products of people's inveterate rights over their spaces. It follows that we should not think about the territorial landscape of the time as singular and monolithic, but as plural and multiform. To put it simply, we should write the history of 'territories', not 'territory' in late medieval Europe. The third and final pointer is that the foundational notion which held a territory and its maker together was not sovereignty, but jurisdiction. This means that power over space was not understood as exclusive and self-contained, but as layered and distributed. Jurisdictions could overlap and communities coexist; we should therefore expect territories, too, to overlap and coexist within the same society.

Taking its cue from these pointers, the rest of this essay will survey different processes of territory-making in late medieval Italy. In keeping with the jurists, territory-making could be defined as the ensemble of actions and interactions through which a community built a space to call its own, one over which it could unequivocally claim its jurisdictional rights. Specifically, the essay's aim will be to expand the focus of the analysis horizontally, by means of looking at territories made by actors other than the state, while still retaining a sense of verticality - a basic grasp of the hierarchical

8 Specifically for the relationships between iurisdictio and territorium in these writings, consider Vaccari, 'Utrum iurisdictio cohaeret territorio', alongside Quaglioni, 'Giurisdizione e territorio'.

9 I purposely borrow the expression used by Canning, 'Italian Juristic Thought'. 
relationships which tied together different forms of territorial organisation. In treating the history of territory-making as integral but not exclusive to the process of state formation, the essay seeks to achieve two goals. One is to populate our physical as well as mental maps with territories of different shapes and sizes. By surveying the full range of territory-makers found in Italy, the essay hopes to provide a more inclusive sketch of the spatial fabric of a late medieval society. The other is to investigate the place of smaller territories within larger polities, while also examining the part played in their development by the state itself. In other words, if communities were the real drivers of territorialisation, what role was left to states in these processes?

More broadly, this essay is an opportunity to examine how medieval territories have been studied in relation to medieval Italy, and to reflect on the variety of approaches, focuses and scales employed by historians of the peninsula over the last few decades. In actual fact, Italian scholars have seldom engaged directly with the concept of territory. ${ }^{10}$ Yet their work has always included a careful look at what this volume, with Stuart Elden, calls simply 'territorial practices': practices that related people and power to space. These famously include the expansion of cities into the surrounding countryside and later the creation of the so-called territorial states in the peninsula. Less known, outside of Italy at least, are studies highlighting the practices through which non-dominant bodies became territorial: from rural communes and lordships, to townships and federal associations. It is to these practices and bodies, and to their place alongside more noted processes of polity formation, that we shall now turn. Following accepted chronological spans, this survey will look in turn at an Italy of local powers (eleventh-twelfth centuries), an Italy of cities and contadi (twelfth-fourteenth centuries), and an Italy of territorial states (fourteenth-fifteenth centuries). ${ }^{11}$

\section{An Italy of local powers (eleventh-twelfth centuries)}

Decades before jurists began writing on the nature of power over space, even centuries before the polities now filling our maps were born, Italian

10 Two notable exceptions are Somaini, 'Territory, Territorialisation, Territoriality', and Luca Mannori, 'La nozione di territorio'.

11 Among others, these terminologies can be found in some remarkable overviews, including Provero, L'Italia dei poteri locali; Vitolo, L'Italia delle altre città; and Lazzarini, L'Italia degli Stati territoriali. 
society had already experienced a first wave of territorialisation. Its protagonists were not large states, but what was then the smallest and yet most fundamental unit of political and social organisation: the rural commune. People had gathered and worked together in agrarian settlements long before the eleventh and twelfth centuries, but it is only at this time that they began developing more defined organisational structures in the countryside. Historians of the peninsula have traditionally focused on the formalisation of institutional customs, including the practice of assembling heads of household in regular meetings, the procedure of electing executive officers and ad hoc committees, and later the drafting of statutes inscribing a community's ways of life. ${ }^{12}$ As time went by, these institutions came to regulate more and more facets of a settlement's affairs: from the resolution of quarrels and the collection of duties among residents to the management of common goods, local infrastructures and charitable enterprises. More recently, following Chris Wickham's work on northern Tuscany, attention has been paid to the role of social interactions in the structuring of rural communities and especially in fostering a shared sense of identity among their members. ${ }^{13}$ Examples include friendships and family ties, the bonds between patrons and clients, the negotiation of internal tensions, collective agency against external interference (notably in the case of seigneurial and then urban powers) and generally all the acts and relationships which may both divide and bring together a community of people.

While structuring their everyday activities, these developments came to give shape and substance to defined spaces within which a universitas of people could be identified. To begin with, only residents could take part in assemblies and run for office; in other words, political participation was not based on personal membership, but on territorial belonging. ${ }^{14}$ The same applied to the right of accessing common goods, such as woods and grazing lands, or facilities owned collectively by a commune, as was sometimes the case for mills and furnaces. Indeed, claiming and then policing local resources was another way in which rural communes constructed their spaces. As Riccardo Rao has demonstrated for eastern Piedmont, it was not unusual for certain communities to argue that ownership of common goods was not just a by-product of established customs but an integral

12 To name but two representative works with an institutional and legalistic focus: Schneider, Die Entstehung; Bognetti, Studi sulle origini.

13 Wickham, Community and Clientele. On these developments more broadly, see Provero, 'Forty Years of Rural History', pp. 161-164.

14 On the nexus between residential status and political participation, see Provero, 'Abitare e appartenere'. 
feature of their jurisdictional rights. ${ }^{15}$ Communia, as they put it, were liable to the iurisdictio of the territorium loci - they were a constituent part of a commune's territory. In the south, local resources were more commonly controlled by lords or simply labelled as royal assets. Yet the allocation of their rights of usage to specific communities arguably contributed, in its own way, to structure their spaces. ${ }^{16}$ Simultaneously, a number of repeated practices helped perpetuate the association between a universitas and its territorium across generations. In many areas of northern Italy, it was common to give natural children a surname based on the place in which they were born, thus linking their individual identity with the collective identification of a community with its territory. ${ }^{17}$ Similarly, the practice of attending religious services at the local church contributed to fostering a collective sense of space. It is in this period, in fact, that parishes themselves emerged as territorial districts within which residents supported a priest and paid their share of one of the first instances of a tax levied on a territorial basis: the papal tithe. ${ }^{18}$

More than anything else, however, the process of making a community's territory was driven by continuous interactions with other forms of political and social organisation, starting from rural lordships. At this stage, the range and basis of seigniorial powers varied considerably across Italy, though they were broadly built upon the same features: a fortified residence offering refuge to local dwellers and a series of estates owned directly by a lord. In addition, nobler, wealthier or simply more resourceful individuals were able to appropriate prerogatives once pertaining to royal officials, including the control of roads and water streams, or the right to administer justice in the area - all prerogatives which allowed them to extend their influence well beyond the limits of their properties. ${ }^{19}$ Still, no matter the degree of power exerted by lords over nearby areas, it seems that their presence alone was enough to spark a dialectic process through which the territories of rural communities were validated. While their outcome was similar, the interactions between lordships and communities unfolded in a variety of ways. In places where lords were especially strong, their fortified residences

15 Rao, 'Risorse collettive'.

16 Carocci, "'Metodo regressivo"'.

17 Different traditions are found in central and southern Italy, as discussed in Collavini, 'I cognomi italiani'.

18 For these developments, consider the field-defining works by Violante, Ricerche sulle istituzioni ecclesiastiche.

19 The essential references are now Cortese, L'aristocrazia toscana; Fiore, The Seigneurial Transformation; and Carocci, Lordships of Southern Italy. 
(castra) became the centre of a defined area (territorium castri) within which their power was localised (dominatus loci). This often overlapped with the spaces of one or more communities, showing, as Cinzio Violante first pointed out, that lordships and communes reinforced one another's spatial dimension..$^{20}$ Where lords were weak, on the other hand, communities were able to protect their territories from outside interference. Disperse settlements can sometimes be found acting for the first time as a single universitas precisely in order to defend their spaces from lordly intrusion. Otherwise, long-standing solidarities among residents were reactivated in an effort to stop lords from meddling with their affairs - sometimes permanently, as when communities managed to obtain a charter sanctioning their territorial immunity (franchise). ${ }^{21}$

Regardless of the direction in which the balance of power tilted, negotiating their rights with nearby lordships compelled rural communities to define spaces to which those entitlements could be unequivocally applied. The same could be said for their interactions with neighbouring universitates. These typically took the form of quarrels over the exact extent of a commune's territory - in short, border disputes. Archives are full of records documenting the investigations, trials and written testimonies produced on the occasion of territorial settlements. As Luigi Provero has convincingly argued, these texts are a clear indicator of a mature 'culture of borders': a shared understanding of how the territories of rural communities should be claimed, marked and disentangled..$^{22}$ Elements of this culture are evident in documents drawn up explicitly to record the proceedings through which a community delimited its borders. These were largely performed on the move, with a number of deputies walking from one marker to the next one and finally returning to the marker from which they started - almost tracing an invisible polygon around the community, while a notary took note of their positions and specific traits. These markers were mostly landscape features, such as memorable stones or noticeable trees, sometimes inscribed with crosses or other signs, but could also be man-made landmarks, such as crossroads, fences and even buildings. As has been widely discussed, these proceedings were partly an attempt to distinguish the territory of a commune from those of its neighbours,

20 Violante, 'La signoria territoriale'.

21 Among a myriad of other studies, a varied sample of these dynamics for the north-west of Italy can be found in the works by Guglielmotti, Comunità e territorio. Regarding the south, the interactions between lords and rural communities, and indeed rural communities in general, are relatively less studied, though we can now refer to Loré, 'Signorie locali e mondo rurale'. 22 Provero, 'Una cultura dei confini'. 
so as to ascribe its assets unequivocally to local residents and hopefully prevent future disputes. At the same time, however, they were also an act of possession: a powerful commemoration of a community's jurisdictional rights over its territory. ${ }^{23}$

\section{An Italy of cities and contadi (twelfth-fourteenth centuries)}

Between the twelfth and thirteenth centuries, a different kind of community set in motion a further wave of territorialisation. Though here we will simply use the term 'cities', contemporary records referred to them as 'communities of citizens' (universitates civium or civitates). They were arguably borne of the same factors as their rural counterparts: the growth of social interactions among residents (via the participation in religious ceremonies or civic militias, for instance), the formalisation of institutions of self-government (and with that the fostering of a collective political will) and ultimately the forging of a shared sense of identity. ${ }^{24}$ As in the case of rural communes, these developments drove cities to shape defined spaces within which their influence could be wielded, their assets exploited and their people identified. Unlike rural communes, however, cities benefitted from the existence of delineated horizons within which their territories could be constructed. They were the ancient comitatus, the area where a count exerted their authority during the Carolingian period, and the dioecesis, the ecclesiastical district headed by a bishop. Both counts and bishops used to reside in major urban centres, therefore it was only natural for cities to inherit both their spheres of action and the very terms previously employed to describe them. Twelfth- and thirteenth-century records are replete with phrases such as civitas cum comitatus or in comitatus et episcopatus, though it was not long before territorium itself made an appearance. In truth, the territories built by cities could sometimes diverge and even go beyond the spaces after which they were originally named, but the appropriation of words charged with an enduring spatial significance did certainly have

23 Similar conclusions and a consistent sample of these proceedings for northern Italy (Friuli, Piedmont and Lombardy, respectively) can be gleaned by collating Degrassi, 'Dai confini dei villaggi'; Bordone, 'I confini delle comunità'; and Della Misericordia, 'Significare il confine'.

24 The exact mix varied considerably across the peninsula, as did the contribution of different strata of Italian society (notably new-born urban patriciates versus well-established feudal aristocracies, among which were the bishops' own networks of vassals). For a discussion of the literature, see Vallerani, 'La città e le sue istituzioni'; and Coleman, 'The Italian Communes'. 
a role in framing the process through which a city created its contado (as comitatus was later translated into Italian). ${ }^{25}$

Another variable was the breadth and especially depth of the territorymaking process. Thanks to their flourishing economies, booming populations and fierce opposition to imperial interventions, the cities of Lombardy, Tuscany and eastern Veneto were generally quite successful in claiming a space which they could unquestionably call their own. The same cannot be said for the cities of Lazio and for part of the south, where the relatively limited mass of urban centres, combined with the proximity of higher powers (notably the pope and the southern kings, not to mention several long-lived lordships) posed greater challenges to the creation of contadi. This is not to say that size was a prerequisite to territory-making, as proved already by the accomplishments of rural communes. In much of Piedmont and Umbria, but also in Abruzzo and certain areas of the south, modest centres were able to take full advantage of the remoteness and sometimes mere absence of other powers to carve themselves small but well-delineated territories. It must be noted that, in general, southern centres enjoyed far less autonomy than those of the north and centre: the monarchy saw cities as part of their estates, and was even known to award them as fiefs to some of its vassals. But as recent studies have shown, that did not stop southern cities from attempting to make a territory to call their own - often by devising unique tools and techniques in close collaboration, rather than confrontation, with the kings themselves. ${ }^{26}$

The one strategy which seems to have been common across the peninsula was the adoption of rural communes as the fundamental units around which the contadi were organised. Scholars used to interpret these developments in terms of 'conquest' or outright subjugation; these days, however, it is far more common to emphasise the dialectic nature of the process. ${ }^{27}$ To begin with, a community could accept the superior authority of a city over its spaces in exchange for special rights and privileges, including fiscal exemptions or some form of immunity from the influence of local lords. The list of duties, on the other hand, was generally much longer, mainly due to the growing power imbalance between urban and rural communes. Within their territories, rural communities were expected to preserve public order,

25 Further on these terminologies, see Banti, “'Civitas" e "Commune”; and, for a case study, Francesconi, 'Diocesi, comitatus'.

26 An overall picture can be drawn by considering, for the north and centre, Chittolini, 'A Geography of the "Contadi"; and for the south, Vitolo, Città e contado.

27 One needs only to compare influential works of old, such as De Vergottini, 'Origini e sviluppo', with more recent studies, such as Chiappa Mauri, Contado e città. 
maintain roads and infrastructures, provide authorities with a portion of their products and, of course, collect all that was owed to the city by rural taxpayers. ${ }^{28}$ Conversely, other forms of territorial organisation were progressively marginalised. This was notably the case for minute settlements, such as farmsteads, hamlets and communal neighbourhoods - all aggregations filled with strong horizontal solidarities between people, but which would now need to present their requests to a city through the vertical mediation of a commune. Lords, for their part, were often deprived of their power or forced to exercise it within parameters dictated by cities, starting from the notion that their jurisdiction applied not to individuals but to territorial communities. $^{29}$

Following an initial period of pacts and negotiations around the rights and duties of the respective parties, the role of rural communes in the making of the contadi was inscribed in two complementary bodies of law. The first were local statutes: collections of customs and regulations which cities took great care to reissue in their name. In so doing, they were asserting their superior authority over these spaces, while also acknowledging the long-standing relationships between a community and its territory. The second were the statutes written by the cities themselves, whereby the territories of rural communes were elevated even further. ${ }^{3^{0}}$ Mantua's statutes, for instance, ruled that all settlements should form a 'comune et universitas' to which the city could univocally direct its demands. ${ }^{3^{1}}$ The pressure was such that sometimes, as in the case of Siena, rural dwellers were forced to declare their communities 'broken' in an effort to evade the city's requests - something which confirms, almost ex negativo, the centrality of rural communes in structuring the territorial landscape.$^{32}$ Indeed, while policies of this kind were clearly part of a strategy for territorial control, they also celebrated the spatial dimension of rural communes as the most basic and reliable form of territorial organisation. So strong was the cities' reliance on the territories made by rural communes that at times they prompted the foundation of brand new communities, as in the case of Piedmont's borghifranchi or

28 These dynamics have been closely studied in relation to Tuscany and Lombardy: Taddei, 'Comuni rurali'; Nobili, 'I contadi organizzati'.

29 For these aspects, see Milani, 'Lo sviluppo della giurisdizione'; and broadly Castagnetti, $L e$ comunità rurali.

$3^{0}$ For an overview, consider Cortonesi and Viola, Le comunità rurali e i loro statuti; alongside Chittolini and Willoweit, Statuti, città, territori.

31 Statuti bonacolsiani, p. 191.

32 Celata, 'La condizione contadina'. 
Tuscany's terre nuove ${ }^{33}$ Reasons varied - to offset lordly influence, to relocate workers to less exploited lands, or to build new settlements on the frontier with one's enemy - but they all responded to the same idea: communities were needed to control territories.

At the same time, cities put a tremendous effort into gathering and later acting on information regarding the territory to which they lay claim. As early as the twelfth century, they were already compiling lists of all the communities they had come to control. As Gian Paolo Francesconi has noted, these 'listed contadi' were often prepared in order to obtain an imperial or royal charter endorsing urban jurisdiction over such spaces, but they were also a programmatic expression of a city's overarching claim over its territory. ${ }^{34}$ As urban communes grew and tightened their hold over the countryside, their lists and censuses became more sophisticated. In Tuscany, cities regularly produced detailed ordinances designed to spread the upkeep of roads and riverbanks among their subject communities. ${ }^{35}$ Other examples include the famous estimi and catasti compiled to distribute tax burdens on a territorial basis. ${ }^{6}$ Siena employed a whole body of land surveyors (mensuratores) charged with gauging the extent of rural communes, while other cities assembled entire registers to record the precise arrangement of local boundaries. ${ }^{37}$ As well as being cognitive, most of these measures were instrumental in actively transforming a city's territory. A prime example are the inquisitiones conducted by centres looking to take stock of their assets in the countryside, including natural resources (pastures, rivers, forests) as well as customary rights (such as that of collecting duties by fords or mountain passes). While sometimes it was just a matter of appropriating assets once controlled by local lords or communities, many cities went on to establish new rules of access and even to sell portions of those assets to the highest bidder, thus showing their willingness and capacity to take direct action regarding their territories..$^{8}$

As lists were compiled and enquiries conducted, cities began subdividing their territories into new districts run by urban officials (podestà, vicari).

Panero, Comuni e borghi franchi; Pirillo, Creare comunità.

34 For this custom and the expression 'contado elencato', see Francesconi, 'Scrivere il contado', p. 520 .

35 Szabo, Comuni e politica stradale, pp. 83-89 and 125-135.

36 Pinto, 'Estimes et cadasters'.

37 Redon, Lo spazio di una città, pp. 147-149 and 154-155; Francesconi and Salvestrini, 'La scrittura del confine'.

$3^{8}$ Rao, 'Le inchieste patrimoniali'. For the fate of communia in this period, see the special issue edited by Vigueur, 'Beni comuni'. 
While many of the day-to-day responsibilities remained with rural communities, the new officials exercised tasks which derived from a city's higher claim over its territory, including enforcing urban laws and, whenever possible, preventing controversies among local communities. Some cities put them in charge of whole areas, such as a valley or mountainous plateau (Siena's Montagna, Lucca's Valdinievole); others sent them to oversee a certain number of communities, so as to spread the administrative and fiscal burden more equally. 39 In fact, the new districts were never designed to equate to a single community. They were not territories themselves, but mediums to control them - they were merely the rural extension of urban institutions. In some cities, such as Bologna and Venice, this was encoded in the practice of naming new districts after sections of the urban environment, notably neighbourhoods and gateways. ${ }^{40}$ In the south, things were complicated by the fact that, in theory at least, the responsibility of overseeing the territory of a city lay with the capitano: a royal officer appointed directly by the crown or, in the case of enfeoffed cities, by one of its vassals. But again, that did not stop southern centres from devising new districts to suit their needs, and sometimes even taking it upon themselves to nominate the captain of their territory. ${ }^{41}$ In brief, no matter their local constraints, cities across the peninsula were determined to leave their mark on the spaces around them.

\section{An Italy of territorial states (fourteenth-fifteenth centuries)}

Over the course of the fourteenth century, the political and social system built by the communes evolved in new directions. In some cases, a period of internal tensions resulted first in the progressive marginalisation of long-standing opponents (a faction, a family, a class) and later in their reintegration into the foundational structures of urban society. United, for better or worse, under the same party, lord or social group, these communes began expanding their sphere of influence outside the boundaries of their contadi. In other cases, cities were severely weakened by tensions and left to fend for themselves while other actors occupied the stage. Take Reggio, a city 'besieged', as Andrea Gamberini put it, by the aristocratic clans of

39 A more representative sample of Tuscan cases can be found in Taddei, 'L'organizzazione del territorio'.

40 Pini, Le ripartizioni territoriali; Orlando, Altre Venezie.

Corrao and D'Alessandro, 'Geografia amministrativa'. 
its countryside.$^{42}$ Of course, conflicts were far from rare in the Italy of cities. But this time, their repercussions were bound to be profound: urban institutions became more authoritarian, so as to ensure continuity of power between members of the same party or family, while the ruling classes became less accessible to other urban groups. ${ }^{43}$ More importantly, for our purposes, these developments paved the way for the creation of dominions which extended over the territories of multiple cities. While communes that managed to retain a republican profile, like Florence, were not far behind, the most striking examples of territorial expansion can be found in cities where a single lord or faction leader had risen to power. This was famously the case of the Visconti dynasty, which from humble beginnings in the Milanese countryside came to expand their influence across what is now Lombardy, Emilia (including Reggio itself) and briefly even parts of Tuscany and eastern Veneto. ${ }^{4}$

These developments were once celebrated as Italy's first steps on the path of state formation, mainly due to the new bureaucracies and tools of government created around a centre - a prince or a small oligarchy, where communal institutions survived - to rule over their new peripheries. Furthermore, these actors claimed to exercise a higher form of power over their competitors: princes sought charters granting them the title of imperial or papal vicar and later of duke, while some republican regimes justified their jurisdiction over neighbouring cities by proclaiming themselves to be hierarchically superior to other communes (civitates potentes). ${ }^{45}$ Though they were once hailed as a definite indication of the rise of 'modern states' in Italy, these developments have recently been reassessed by specialists in light of practices of the opposite sign. It is now accepted that state-like dominions were constructed not by imposing their structures to the detriment of others, but by negotiating novel forms of allegiance with older powers, including cities, lordships and all sorts of communal organisations. ${ }^{46}$ In short, new states were built not by obliterating pre-existing entities, but by reaching some sort of agreement with them. A well-known example is the type of pact through which a community bargained its rights and duties within a larger polity (deditiones, capitula). These were typically struck upon a

42 Gamberini, La città assediata.

43 Further on these developments, see Jones, The Italian City-State; and now De Matteis and Pio, Sperimentazioni digoverno.

44 Somaini, 'L'età della signoria'.

45 Chittolini, 'Dominant Cities'.

46 The origins of this reassessment can be traced to seminal works by Guarini, 'Gli stati'; and Chittolini, 'Stati padani'. 
community's subjection to a higher power, and later renegotiated whenever new circumstances challenged the existing agreement between the two: a change of rulership, for instance, or the need to introduce new legislation (for the state) or present new demands (for the community). ${ }^{47}$ In keeping with equivalent developments across Europe, the very term 'modern state' was eventually replaced by scholars of the peninsula with more descriptive terminologies, including 'composite' or 'mosaic state' (in reference to the contractual nature of their power base) as well as 'regional' or 'territorial state' (to emphasise the fact that they extended well beyond the territory of a single centre). ${ }^{48}$

Still, terminology alone should not warrant the assumption that territorial states were also territory-makers. Like the cities before them, they began by adopting pre-existing territories as the jurisdictional units upon which their authority was exerted. This was accomplished through similar strategies: the stipulation of repeated pacts between a dominant power and a subject body, the confirmation and sometimes partial revision of local statutes, the deployment of magistrates in charge of administering the ruler's justice in the whole of the dominion, and even the drafting of lists recording the units on which policies were articulated (such as registers of taxable centres or directories of all the officers stationed in the peripheries). ${ }^{49}$ Unlike the communes, however, the new republican or princely regimes did not impose a territory of their own onto the existing landscape. To put it differently, their territoriality did not apply directly to all the individuals residing within their dominions; rather, it was enforced through the mediation of territories already in existence..$^{50}$ Taxes, for instance, continued to be levied first among the residents of a rural commune and then among all the communes traditionally attached to a contado..$^{5^{1}}$ The same went for the granting of community membership, which remained an exclusive

47 Another practice which, in different shapes and fashions, can be found across Italy: O'Connell, 'Voluntary Submission'; Chittolini, 'Models of Government'; Corrao, 'Negoziare la politica'.

48 To name but two recent discussions: Ferente, 'Stato, stato regionale'; Lazzarini, 'I nome dei gatti'.

49 The relevant bibliography is simply too vast to be summarised here. In addition to the literature on capitula and deditiones referenced earlier, a good start may be, respectively, Dondarini, Varanini and Venticelli, Signori, regimi signorili; Isaacs, 'Changing Layers of Jurisdiction'; and Lazzarini, 'Scritture dello spazio', pp. 148-161.

$5^{0}$ The point has been made extensively by Varanini, 'Governi principeschi'; and now Somaini, 'The Collapse of City-States'. Based on remarkable new studies, similar conclusions could be drawn for the south: Terenzi, LAAquila nel Regno; Senatore, Una città, il Regno.

$5^{1}$ For the tension between a state's fiscal policy and the persisting prerogatives of urban communes, see especially Chittolini, “'Fiscalité d'Etat"'. 
prerogative of each commune, and also for citizenship. Significantly, the only way a prince or ruling oligarchy could turn someone into a citizen of their dominion was to make them cives of all the civitates they controlled. ${ }^{2}$

That is not to say that all Italian states were unable to fully territorialise their power. A notable case in point is the Florentine dominion, possibly the one polity in the peninsula which might deserve the appellation 'territorial state'. There, the republican regime managed to extend the organisation of the city's old contado to the entirety of its new dominion, typically by breaking down territories built by rival cities. ${ }^{53}$ In other cases, such as Mantua, a dynasty inherited the established relationships between a city and the communities of its countryside, and was later able to sustain them using similar devices, starting from the custom of demanding oaths of fealty. ${ }^{54}$ Yet neither of these strategies turned the Florentine and Mantuan regimes into territory-makers: both were still operating within the conceptual as well as physical frameworks developed by urban communes - something exemplified by the use of words such as districtus and comitatus in descriptions of their dominions. Equally, what has been said above about the frequency with which new states relied upon older territories to exert their authority should not conceal the fact that certain regimes were at least claiming to possess a territory of their own, though not always with much success. An example much quoted by scholars is that of Gian Galeazzo, the first Visconti able to call himself duke of Milan. In line with similar tendencies in other parts of Europe, he tried to foster a close association between the princely family and the region to which they laid claim. In 1397, having failed to obtain the title of 'kings of the Lombards', he ordered the forging of an imperial charter making him duke of the whole of Lombardy (dux Lombardiae). ${ }^{55}$ Gian Galeazzo died a few years later; to his post-mortem chagrin, the chroniclers recording the event never mentioned the title, opting instead to present a 'catalogue' of all the cities he had come to control. ${ }^{6}$ He left behind an enduring legacy as well as a dynastic claim of legitimacy to much of the region, but certainly not a territory worthy of the name.

Nonetheless, it would be erroneous to assume that new territories were ultimately not made in this period. Worse still, it would be nothing less than falling into the territorial trap: just because states were not at the forefront

$5^{2}$ An illustrative example of these 'global citizenships' has been recently analysed by Covini,

'La patente perfetta'.

53 Connel and Zorzi, Lo Stato territoriale fiorentino.

54 Lazzarini, Il linguaggio del territorio.

55 Black, 'The Emergence of the Duchy'.

$5^{6}$ For this custom and the expression 'catalogue of cities', see Ricci, 'Cataloghi di città'. 
of a new wave of territorialisation does not mean that society as a whole failed to become more territorial. On this occasion, instead of rural or urban communes, change was driven by communities which sat right between them in the spatial hierarchy of the time. The first were townships: urban settlements which did not hold the status of a city but were still able to extend their jurisdiction over the surrounding countryside. Beyond actual size, their lesser status was generally due to their lacking one of the defining features of a civitas (a bishop and/or an encircling wall) or simply caused by the proximity a more established centre. ${ }^{57}$ The second were rural federations: consortia uniting the communes of the same valley, lakeshore or tableland in an effort to advance their common interests. While these were especially common in the Alps, recent studies have shown that comparable associations could be found also in the south. ${ }^{5}$ Both townships and federations had long existed alongside rural and urban communes, and some had already surpassed the latter as the chief form of territorial organisation in their area. Two noted examples are the federal universitas of Frignano, located in the Apennines south of Reggio and Modena, and the villenuove which arose in Piedmont outside the sphere of influence of nearby cities. ${ }^{59}$ In most cases, though, urban communes were able to marginalise or simply thwart the establishment of alternative forms of territorial organisation, so as to consolidate rural communes as their sole interlocutors in the countryside.

Things changed rather drastically as soon as the two-way dialogue between a city and its contado became part of the larger conversation initiated by a prince or republican oligarchy around the region. In an effort to curb the influence of subject cities and secure the loyalty of other bodies within their dominion, the new regimes pursued an opposing set of policies. They created new jurisdictional districts to fit the territories of townships and federations, often by stationing a representative of the state in the locality where the wider community used to assemble. They gave them privileges of separation, in the form of charters sanctioning their autonomy from the contado to which they once belonged (or were supposed to belong, in the case of cities which never managed truly to control them). Finally, they entitled them to exercise both rights and duties once restricted to the civitates, such as the collection of taxes among rural communes or the

57 Further on these centres and their categorisation, see Folin, 'Sui criteri di classificazione'; and broadly Svalduz, L'ambizione di essere città.

$5^{8}$ For an overview, consider Della Misericordia, 'La comunità sovralocale', alongside Senatore, 'Distrettuazioni intermedie'.

59 Santini, I comuni di valle; Guglielmotti, 'Territori senza città'. 
upkeep of military fortifications. ${ }^{60}$ In essence, the new regimes raised the territories of townships and federations to the status once enjoyed by the contadi alone: as the spaces through which their territoriality was mediated. In so doing, they coupled independent traditions of self-governance with new public responsibilities, thus legitimising from above territorial practices originating from below. In this sense, by elevating them among the units around which their dominions were organised, the new regimes were once again observing the role of communities as the most accomplished territory-makers of the time.

Overall, this survey confirms the initial indications found in the works of medieval jurists, as well as the broader methodology inspired by them. First, communities made territories far more often than states in this period. They did so by combining a variety of territorial practices. Some were nothing but the sort of social relationships and cultural activities which may foster a collective sense of space: living, working, praying, and generally doing things together within the same locality. Others were conscious strategies for territorial control: appropriating assets, marking boundaries, fighting disputes, drawing districts, commemorating possession, compiling lists, making and confirming bodies of law, and even hampering alternative forms of territorial organisation. In essence, territory-making was driven as much by interactions between people as by political interventions; as befits communities more than states, it was a social as much as an institutional practice. There is no question that many of these strategies were advocated and put in place by specific segments within those communities: wealthy landowners, artisans using natural resources in their work and groups who could generally profit from a firmer hold over the surrounding spaces. The fact remains that their actions were bound to shape more consistent territories for the entirety of their respective universitates.

Second, the territorial landscape of late medieval Italy cannot be reduced to a single form of territorial organisation, and certainly not to states alone. Different communities built different territories. Though they were never as vast as those of modern nations, they could range in size from the locality associated with a single settlement, through a valley or mountainous plateau, to the area headed by a town or city. As a rule, the more they expanded,

6o Many of these dynamics were first highlighted by Chittolini, Città, comunità e feudi. For a recent case study, I take the liberty of referring to Zenobi, 'Nascita di un territorio'. 
the less cohesive they became; the looser the links between a community and its spaces, the harder it was to tell them apart. The presence of other territories - or of powers menacing their territories - was also conducive to more defined spaces. Regardless of whether they were bitter or benign, some form of interaction was arguably behind each and every stage of territory-making: between rural communes, between communes and lords, between cities, between cities and higher powers (the pope, the emperor, the southern kings), between cities and princes or republican oligarchies, and finally between the new regimes and new intermediate communities (townships and federations). In brief, the politics of territory-making were fundamentally interactive.

Finally, these interactions were both vertical and horizontal. Much like the communities which made them, territories could exist alongside each other but also overlap. In keeping with the notion that jurisdictional rights were distributed rather than centralised, all territories could find a place in the spatial hierarchy of a late medieval society. At first glance, one could be forgiven for thinking that the territorial landscape of the time became progressively more uniform and simplified, as fewer polities took control of larger spaces. But as we have seen, such a reading would be, at best, superficial. As the period unfolded, more and more territories were made and came to supersede one another, yet only a handful of them were ever truly erased. States themselves shaped their spatial dimension not by imposing one exclusive territory in place of those which already existed, but by accepting them as the fundamental units around which society was organised. The larger they got, the more mediated their territoriality became. Despite what certain maps may suggest, their footprint on the spatial fabric of the peninsula was a shallow one.

\section{Bibliography}

\section{Primary sources}

Statuti bonacolsiani, ed. by Ettore Dezza, Anna Maria Lorenzoni and Mario Vaini (Mantova: Arcari, 2002).

\section{Secondary sources}

Agnew, John, 'The Territorial Trap: The Geographical Assumptions of International Relations Theory', Review of International Political Economy 1, no. 1 (1994), 53-80. 
Banti, Ottavio, “Civitas" e "Commune" nelle fonti italiane dei secoli XI e XII', in Forme di potere e struttura sociale in Italia nel Medioevo, ed. by Gabriella Rossetti (Bologna: Il Mulino, 1977), pp. 217-232.

Black, Jane, 'The Emergence of the Duchy of Milan: Language and the Territorial State', Reti medievali 14, no. 1 (2013), 197-210.

Bognetti, Gianpiero, Studi sulle origini del comune rurale, con speciali osservazioni pei territorii milanese e comasco (Pavia: Pubblicazioni della Regia Università di Pavia, 1926).

Bordone, Renato, 'I confini delle comunità. Incertezza territoriale e assetto insediativo tra Medioevo ed Età moderna in Piemonte', in Città e territori nell'Italia del Medioevo. Studi in onore di Gabriella Rossetti, ed. by Giovanna Petti Balbi, Giovanni Vitolo and Giorgio Chittolini (Napoli: Liguori, 2007), pp. $53-73$.

Canning, Joseph P., 'The Corporation in the Political Thought of the Italian Jurists of the Thirteenth and Fourteenth Centuries', History of Political Thought 1, no. 1 (1980), 9-32.

Canning, Joseph P., 'Italian Juristic Thought and the Realities of Power in the Middle Ages', in Politisches Denken und die Wirklichkeit der Macht im Mittelalter, ed. by Joseph Canning and Otto G. Oexle (Göttingen: Vandenhoeck \& Ruprecht, 1998), pp. 229-239.

Carocci, Sandro, Lordships of Southern Italy: Rural Societies, Aristocratic Powers and Monarchy in the $12^{\text {th }}$ and $13^{\text {th }}$ Centuries (Roma: Viella, 2018).

Carocci, Sandro, "Metodo regressivo" e possessi collettivi: i "demani” del Mezzogiorno, sec. XII-XVIII', in Écritures de l'espace social. Mélanges d'histoire médiévales offerta à Monique Bourin, ed. by Didier Boisseuil, Pierre Chastang, Laurent Feller and Joseph Morsel (Paris: Éditions de la Sorbonne, 2010), pp. 541-555.

Castagnetti, Andrea, Le comunità rurali dalla soggezione signorile alla giurisdizione del comune cittadino (Verona: LUE, 1983).

Celata, Giuseppe, 'La condizione contadina in una Signoria e in un comune rurale autonomo fra il "Duecento" e il “Trecento", Rivista di storia dell'agricoltura 19, no. 1 (1979), 73-103; 19, no. 3 (1979), 139-162.

Cortese, Maria Elena, L'aristocrazia toscana. Sette secoli, VI-XII (Spoleto: CISAM, 2017).

Chiappa Mauri, Luisa, ed., Contado e città in dialogo. Comuni urbani e comunità rurali nella Lombardia medievale (Milano: Cisalpino, 2003).

Chittolini, Giorgio, Città, comunità e feudi negli stati dell'Italia centro-settentrionale: secoli XIV-XVI (Milano: Unicopli, 1996).

Chittolini, Giorgio, 'Dominant Cities: Florence, Genoa, Venice, Milan, and Their Territories in the Fifteenth Century', in The Medici: Citizens and Masters, ed. 
by Robert Black and John E. Law (Cambridge, MA: Harvard University Press, 2015), pp. 13-26.

Chittolini, Giorgio, “Fiscalité d'État” et prérogatives urbaines dans le duché de Milan à la fin du Moyen Âge', in L'impôt au Moyen Âge: l'impôt public et le prélèvement seigneurial, fin $X I I^{e}$-début XVI $I^{e}$ siècle, ed. by Philippe Contamine, Jean Kerhervé and Albert Rigaudière, 3 vols (Paris: Institut de la gestion publique et du développement économique, 2002), vol. 1, pp. 147-176.

Chittolini, Giorgio, 'A Geography of the "Contadi" in Communal Italy', in Portraits of Medieval and Renaissance Living: Essays in Honor of David Herlihy, ed. by Samuel K. Cohn and Steven A. Epstein (Ann Arbor: University of Michigan Press, 1996), pp. 417-438.

Chittolini, Giorgio, 'Models of Government "from Below" in Fifteenth-Century Lombardy. The "Capitoli di Dedizione" to Francesco Sforza, 1447-1450', in Empowering Interactions: Political Cultures and the Emergence of the State in Europe, 1300-19oo, ed. by Wim Blockmans, Daniel Schläppi and André Holenstein (London: Routledge, 2009), pp. 51-63.

Chittolini, Giorgio, 'Stati padani, "Stati del Rinascimento": problemi di ricerca', in Persistenze feudali e autonomie comunitative in statipadani fra Cinque e Seicento, ed. by Giovanni Tocci (Bologna: CLUEB, 1988), pp. 9-29.

Chittolini, Giorgio, and Dietmar Willoweit, eds, Statuti, città, territori in Italia e Germania tra Medioevo ed età moderna (Bologna: Il Mulino, 1991).

Coleman, Edward, 'The Italian Communes. Recent Work and Current Trends', Journal of Medieval History 25, no. 4 (1999), 373-397.

Collavini, Simone, 'I cognomi italiani nel medioevo: un bilancio storiografico', in L'Italia dei cognomi. L'antroponimia italiana nel quadro mediterraneo, ed. by Andrea Addobbati, Roberto Bizzocchi and Andrea Gregorio (Pisa: Pisa University Press, 2012), pp. 59-74.

Connel, William J., and Andrea Zorzi, eds, Lo Stato territoriale fiorentino, secoli $X I V-X V$ : ricerche, linguaggi, confronti (Pisa: Pacini, 2002).

Corrao, Pietro, 'Negoziare la politica. I "capitula impetrata" delle comunità del regno siciliano nel XV secolo', in Forme della comunicazione politica in Europa nei secoli XV-XVIII. Suppliche, gravamina, lettere (Bologna: Il Mulino, 2004), pp. 119-136.

Corrao, Pietro, and Vincenzo D’Alessandro, 'Geografia amministrativa e potere sul territorio nella Sicilia tardomedievale, secoli XIII-XIV', in L'organizzazione del territorio in Italia e Germania, secoli XIII-XIV, ed. by Giorgio Chittolini and Dietmar Willoweit (Bologna: Il Mulino, 1994), pp. 395-444.

Cortonesi, Alfio, and Federica Viola, eds, Le comunità rurali e i loro statuti, secoli XII-XV (Roma: Gangemi, 2006)

Costa, Paolo, Iurisdictio: semantica del potere politico nella pubblicistica medievale, 1100-1433 (Milano: Giuffrè, 1969). 
Covini, Nadia, 'La patente perfetta. I privilegi accordati ai Simonetta dagli Sforza', in Cittadinanza e mestieri. Radicamento urbano e integrazione cittadina nell'età delle signorie, ed. by Beatrice Del Bo (Roma: Viella, 2014), pp. 179-2o6.

Degrassi, Donata, 'Dai confini dei villaggi ai confini politici. L'area friulana nel tardo medioevo', Reti medievali 7, no. 1 (2006), 1-21.

Della Misericordia, Massimo, 'La comunità sovralocale. Università di valle, di lago e di pieve nell'organizzazione politica del territorio nella Lombardia dei secoli XIV-XVI', in Lo spazio politico locale in età medievale, moderna e contemporanea, ed. by Renato Bordone, Paola Guglielmotti, Sandro Lombardini and Angelo Torre (Roma: Viella, 2006), pp. 99-111.

Della Misericordia, Massimo, 'Significare il confine. I simboli della delimitazione nelle testimonianze documentarie fra medioevo ed età moderna in Valtellina e nelle Alpi centrali', Notiziario dell'Istituto archeologico valtellinese 9 (2011), 93-106.

De Matteis, Maria C., and Bernardo Pio, eds, Sperimentazioni digoverno nell'Italia centrosettentrionale nel processo storico dal primo comune alla signoria (Bologna: Bononia University Press, 2011).

De Vergottini, Giovanni, 'Origini e sviluppo storico della comitatinanza', Studi senesi 43 (1929), 347-484.

Dondarini, Rolando, Gianmaria Varanini and Maria Venticelli, eds, Signori, regimi signorili e statuti nel tardo medioevo (Bologna: Pàtron, 2003).

Elden, Stuart, The Birth of Territory (Chicago: University of Chicago Press, 2013).

Ertman, Thomas, Birth of the Leviathan: Building States and Regimes in Medieval and Early Modern Europe (Cambridge: Cambridge University Press, 1997).

Ferente, Serena, 'Stato, stato regionale e storia d'Italia', in L'Italia come storia. Primato, decadenza, eccezione, ed. by Francesco Benigno and E. Igor Mineo (Roma: Viella, 2020), pp. 85-104.

Fiore, Alessio, The Seigneurial Transformation: Power Structures and Political Communication in the Countryside of Central and Northern Italy, 1080-1130 (Oxford: Oxford University Press).

Folin, Marco, 'Sui criteri di classificazione degli insediamenti urbani nell'Italia centro-settentrionale (secoli XIV-XVIII), Storia urbana 92, no. 2 (2002), 5-23.

Francesconi, Giampaolo, 'Diocesi, comitatus, districtus. La formazione e l'organizzazione di uno spazio cittadino (secoli XII-XIV)', in Giampaolo Francesconi, Districtus Civitatis Pistorii. Strutture e trasformazioni del potere in un contado toscano, secoli XI-XIV (Pistoia: Società pistoiese di storia patria, 2007), pp. 33-74.

Francesconi, Giampaolo, 'Scrivere il contado. I linguaggi della costruzione territoriale cittadina nell'Italia centrale', Mélanges de l'École Française de Rome 123, no. 2 (2011), 499-529. 
Francesconi, Giampaolo, and Francesco Salvestrini, 'La scrittura del confine nell'Italia comunale. Modelli e funzioni', in Frontiers in the Middle Ages, ed. by Outi Merisalo (Louvain-la-Neuve: Fédération Internationale des Instituts d'Ètudes Médiévales, 2006), pp. 197-221.

Gamberini, Andrea, La città assediata. Poteri e identità politiche a Reggio in età Viscontea (Roma: Viella, 2003).

Guarini Fasano, Elena, 'Gli stati dell'Italia centro-settentrionale tra quattro e cinquecento: continuità e trasformazioni', Società e storia 21 (1983), pp. 617-639.

Guglielmotti, Paola, Comunità e territorio. Villaggi del Piemonte medievale (Roma: Viella, 2001).

Guglielmotti, Paola, 'Territori senza città. Riorganizzazioni duecentesche del paesaggio politico nel Piemonte meridionale', Quaderni storici 3o, no. 3 (1995), 766-798.

Isaacs, Ann K., 'Changing Layers of Jurisdiction: Northern and Central Italian States in the Late Middle Ages and Early Modern Times', in Communities in European History: Representations, Jurisdictions, Conflicts, ed. by Juan Pan-Montojo and Frederik Pedersen (Pisa: Pisa University Press, 2007), pp. 133-150.

Johnston, Ron, 'Out of the "Moribund Backwater": Territory and Territoriality in Political Geography', Political Geography 20, no. 1 (2001), 677-693.

Jones, Philip, The Italian City-State: From Commune to Signoria (Oxford: Clarendon Press, 1997).

Khan, Daniel E., 'Territory and Boundaries', in The Oxford Handbook of the History of International Law, ed. by Bardo Fassbender and Anne Peters (Oxford: Oxford University Press, 2012), pp. 225-249.

Lazzarini, Isabella, Il linguaggio del territorio fra principe e comunità. Il giuramento di fedeltà a Federico Gonzaga (Mantova, 1479) (Firenze: Firenze University Press, 2009).

Lazzarini, Isabella, 'I nomi dei gatti. Concetti, modelli e interpretazioni nella storiografia politica e istituzionale d'Italia (a proposito di interpretazioni nella storiografia politica e istituzionale)', Archivio Storico Italiano 658, no. 4 (2018), 689-735.

Lazzarini, Isabella, 'La conquista di Pisa nel quadro del sistema territoriale italiano: la testimonianza delle cronache', in Firenze e Pisa dopo il 1406. La creazione di un nuovo spazio regionale, ed. by Sergio Tognetti (Firenze: Olschki, 2010), pp. 65-83.

Lazzarini, Isabella, L'Italia degli Stati territoriali (Roma: Laterza, 2003).

Lazzarini, Isabella, 'Scritture dello spazio e linguaggi del territorio nell'Italia tre-quattrocensca. Prime riflessioni sulle fonti pubbliche tardomedievali', Bullettino dell'Istituto storico italiano 113 (2011), 137-207.

Loré, Vito, 'Signorie locali e mondo rurale', in Nascita di un regno. Poteri signorili, istituzioni feudali e strutture sociali nel Mezzogiorno normanno (1130-1194), ed. by Raffaele Licinio and Francesco Violante (Bari: Adda, 2008), pp. 207-237. 
Mannori, Luca, 'La nozione di territorio fra antico e nuovo regime. Qualche appunto per uno studio sui modelli tipologici', in Organizzazione del potere e territorio. Contributi per una lettura storica della spazialità, ed. by Luigi Blanco (Milano: Angeli, 2008), pp. 23-44.

Milani, Giuliano, 'Lo sviluppo della giurisdizione nei comuni italiani del secolo XII', in Praxis der Gerichtsbarkeit in Europäischen Städten des Spätmittelalters, ed. by Franz-Josef Arlinghaus, Ingrid Baumgärtner, Vincenzo Colli, Susanne Lepsius and Thomas Wetzsteinal (Frankfurt am Main: Klostermann, 2006), pp. 21-45.

Najemy, John M., 'Stato, comune e “universitas"', Annali dell'Istituto Storico ItaloGermanico in Trento 20 (1994), 245-263.

Nobili, Paolo G., 'I contadi organizzati. Amministrazione e territorialità dei "comuni rurali" in quattro distretti lombardi (1210-1250 circa)', Reti medievali 14, no. 1 (2013), 81-130.

O'Connell, Monique, 'Voluntary Submission and the Ideology of Venetian Empire', I Tatti Studies in the Italian Renaissance 20, no. 1 (2017), 9-39.

Orlando, Ermanno, Altre Venezie. Il dogado veneziano nei secoli XIII e XIV (giurisdizione, territorio, giustizia e amministrazione (Venezia: Istituto Veneto di Scienze, Lettere ed Arti, 2008).

Panero, Francesco, Comuni e borghi franchi nel Piemonte medievale (Bologna: CLUEB, 1988).

Perrin, John W., 'Azo, Roman Law, and Sovereign European States', Studia Gratiana 15 (1972), 88-191.

Pini, Antonio I., Le ripartizioni territoriali urbane di Bologna medievale. Quartiere, contrada, borgo, morello e quartirolo (Bologna: Quaderni culturali bolognesi, 1977).

Pinto, Giuliano, 'Estimes et cadasters Toscana antérieurs au cadastre de Florence de 1427', in De L'estime au cadastre en Europe. Le Moyen Âge, ed. by Albert Rigaudière (Paris: Comité pour l'histoire économique et financière de la France, 2006), pp. 343-361.

Pirillo, Paolo, Creare comunità. Firenze e i centri di nuova fondazione della Toscana medievale (Roma: Viella, 2007).

Provero, Luigi, 'Abitare e appartenere: percorsi dell'identità comunitaria nei villaggi piemontesi dei secoli XII-XIII', in Paesaggi, comunità, villaggi medievali, ed. by Paola Galetti (Spoleto: CISAM, 2012), pp. 309-325.

Provero, Luigi, 'Forty Years of Rural History for the Italian Middle Ages', in The Rural History of Medieval European Societies: Trends and Perspectives, ed. by Isabel Alfonso (Turnout: Brepols, 2007), pp. 141-172.

Provero, Luigi, L'Italia dei poteri locali: secoli X-XII (Roma: Carocci, 1998).

Provero, Luigi, 'Una cultura dei confini. Liti, inchieste e testimonianze nel Piemonte del Duecento', Reti medievali 7, no. 1 (2006), pp. 1-19. 
Quaglioni, Diego, 'Giurisdizione e territorio in una "quaestio” di Bartolo da Sassoferrato', Archivio Scialoja-Bolla 2, no. 1 (2004), 1-16.

Rao, Riccardo, 'Le inchieste patrimoniali nei comuni dell'Italia settentrionale, XII-XIV secolo', in Quand gouverner c'est enquêter. Les pratiques politiques de l'enquête princière (Occident, XIII ${ }^{e}$-XIV $V^{e}$ siècles), ed. by Thierry Pécout (Paris: De Boccard, 2010), pp. 285-296.

Rao, Riccardo, 'Risorse collettive e tensioni giurisdizionali nella pianura vercellese e novarese, XII-XIII secolo', Quaderni storici 120, no. 3 (2005), 753-776.

Redon, Odile, Lo spazio di una città. Siena e la Toscana meridionale, secoli XIII-XIV (Roma: Viella, 1999).

Ricci, Gaspare, 'Cataloghi di città, stereotipi etnici e gerarchie urbane nell'Italia di antico regime', Storia urbana 18, no. 1 (1982), 3-33.

Sack, Robert D., Human Territoriality: Its Theory and History (Cambridge: Cambridge University Press, 1986).

Santini, Giovanni, I comuni di valle nel Medioevo. La costituzione federale del Frignano: dall'origine all'autonomia politica (Milano: Giuffrè, 196o).

Schneider, Fedor, Die Entstehung von Burg und Landgemeinde in Italien. Studien zur historischen Geographie, Verfassungs- und Sozialgeschichte (Berlin: Rothschild, 1924).

Senatore, Francesco, 'Distrettuazioni intermedie e federazioni rurali nel Regno di Napoli (Sessa, Cava, Giffoni)', in I centri minori italiani nel tardo medioevo: cambiamento sociale, crescita economica, processi di ristrutturazione: secoli $X I I I-X V I$, ed. by Federico Lattanzio and Gianmaria Varanini (Firenze: Firenze University Press, 2008), pp. 341-370.

Senatore, Francesco, Una città, il Regno: istituzioni e società a Capua nel XV secolo (Roma: Istituto storico italiano per il Medio Evo, 2018).

Shah, Nisha, 'The Territorial Trap of the Territorial Trap: Global Transformation and the Problem of the State', International Political Sociology 6 (2012), 57-76.

Somaini, Francesco, 'The Collapse of City-States and the Role of Urban Centres in the New Political Geography of Renaissance Italy', in The Italian Renaissance State, ed. by Andrea Gamberini and Isabella Lazzarini (Cambridge: Cambridge University Press, 2012), pp. 239-26o.

Somaini, Francesco, 'L'età della signoria e del principato. Processi costitutivi, dinamiche politiche e strutture istituzionali dello Stato visconteo-sforzesco', in La grande storia di Milano. Dall'età dei Comuni all'unità d'Italia (Torino: UTET, 2010), vol. 1, pp. 681-786.

Somaini, Francesco, 'Territory, Territorialisation, Territoriality: Problems of Definition and Historical Interpretation', Plurimondi 10 (2012), 19-47.

Strayer, Joseph, On the Medieval Origins of the Modern State (Princeton: Princeton University Press, 1970). 
Svalduz, Elena, ed., L'ambizione di essere città. Piccoli, grandi centri nell'Italia rinascimentale (Venezia: Istituto veneto di scienze, lettere ed arti, 2004).

Szabo, Thomas, Comuni e politica stradale in Toscana e in Italia nel Medioevo (Bologna: CLUEB, 1992).

Taddei, Gabriele, 'Comuni rurali e centri minori dell'Italia centrale tra XII e XIV sec', Mélanges de l'École Française de Rome 123, no. 2 (2011), 319-334.

Taddei, Gabriele, 'Lorganizzazione del territorio nella Toscana comunale, secc. XII-XIV', in Studi in onore di Sorgio Gensini, ed. by Franco Ciappi and Oretta Muzzi (Firenze: Polistampa, 2012), pp. 105-146.

Terenzi, Pierluigi, L’Aquila nel Regno: I rapporti politici fra città e monarchia nel Mezzogiorno tardomedievale (Bologna: il Mulino, 2015).

Vaccari, Pietro, 'Utrum iurisdictio cohaeret territorio". La dottrina di Bartolo', in Bartolo da Sassoferrato: Studi e documenti per il VI centenario, 2 vols (Milano: Giuffré, 1966), vol. 2, pp. 735-753.

Vallerani, Massimo, 'La città e le sue istituzioni. Ceti dirigenti, oligarchia e politica nella medievistica italiana del Novecento', Annali dell'Istituto storico italogermanico in Trento 20 (1994), 165-230.

Varanini, Gianmaria, 'Governi principeschi e modello cittadino di organizzazione del territorio nell'Italia del Quattrocento', in Principi e città alla fine del medioevo, ed. by Sergio Gensini (Pisa: Pacini, 1996), pp. 95-127.

Vigueur, Jean-Claude M., ed., 'Beni comuni nell'Italia comunale: fonti e studi', Mélanges de l'École Française de Rome 99, no. 2 (1987), 553-728.

Violante, Cinzio, 'La signoria territoriale come quadro delle strutture organizzative del contado nella Lombardia del XII secolo', in Histoire comparée de l'administration, $I V^{e}$-XVIII siècles, ed. by Werner Paravicini and Karl F. Werner (München: Artemis, 1980), pp. 333-344.

Violante, Cinzio, Ricerche sulle istituzioni ecclesiastiche dell'Italia centro-settentrionale nel Medioevo (Palermo: Accademia nazionale di scienze, lettere e arti, 1986).

Vitolo, Giovanni, L'Italia delle altre città. Un'immagine del Mezzogiorno medievale (Napoli: Liguori, 2015).

Vitolo, Giovanni, ed., Città e contado nel Mezzogiorno tra medioevo ed età moderna (Salerno: Laveglia, 2005).

Wickham, Chris, Community and Clientele in Twelfth-Century Tuscany: The Origins of the Rural Commune in the Plain of Lucca (Oxford: Clarendon Press, 1998).

Zenobi, Luca, 'Nascita di un territorio. La vicenda del monte di Brianza tra Trecento e Quattrocento', Quaderni storici 144, no. 3 (2013), 813-857. 


\section{About the author}

Luca Zenobi is a Research Fellow at Trinity College, Cambridge. His work explores the spatial dimension of political and social life, with a focus on late medieval Italy. He has published on the territorial organisation of factions and family militias, and - more recently - the experience of exile and migration. 



\title{
3. Clerical and Ecclesiastical Ideas of Territory in the Late Medieval Low Countries
}

\author{
Bram van den Hoven van Genderen*
}

\begin{abstract}
Stuart Elden's The Birth of Territory relies heavily on political theorists and lexical analysis; this chapter argues that the Church and clerics had an important impact Elden overlooked. Late medieval parishes and bishoprics had contiguous borders, fiscal and administrative procedures and powers, their own jurisdiction, and their own hierarchy. A bishop had, in a sense, his own territory. The chapter first discusses general ideas of geography and the specific Christian geography of two important mid-fifteenth-century clerics: (the later) Pope Pius II and Cardinal Nicholas of Cusa. It then highlights the importance of parishes and bishoprics as typical structural elements of ecclesiastical 'territories'. Finally, it provides detailed analysis of the territorial features of the creation of new bishoprics in the Low Countries in 1559.
\end{abstract}

Keywords: ecclesiastical territory; parish; bishopric; christianitas; new bishoprics of 1559

Susan Reynolds has warned scholars about the danger of attributing too easily the same meaning and interpretation to similar words in different periods - words such as 'community', 'college', or 'university'. Her most famous

* In this article I do not pretend to present an exhaustive or systematic overview of the literature. Thanks again to my friend Martin Yates for the correcting of the text. Only after finishing this article I got hold of a copy of Florian Mazel's excellent 2016 book L'évêque et le territoire, otherwise unavailable in libraries of the Low Countries. He addresses some of the topics of my article, stressing the importance of visitations, fiscal registers, inventories, and other administrative tools, resulting in an ecclesiastical idea and use of territory. I was able to refer to this book in some of the footnotes, but due to a lack of space could not discuss his ideas extensively in the corpus of the text.

Damen, M. and K. Overlaet (eds.), Constructing and Representing Territory in Late Medieval and Early Modern Europe. Amsterdam: Amsterdam University Press, 2022 DOI 10.5117/9789463726139_CHO3 
example was, of course, the history of the vague construct 'feudalism'. 'The use of concepts, keywords, or Grundbegriffe is always tricky, especially when they seem to suggest a solid basis for research or provide a clear notion of the temporal and spatial development of a certain phenomenon or idea. In a way, the political geographer Stuart Elden, in his search for the idea of 'territory', shows the perils of such a narrow approach. In the clear overview he presents in his book The Birth of Territory (2013) and even more so in his article 'How Should We Do the History of Territory?' (2013), he ends up concluding that important concepts such as 'space, the territory, and the population', as used by Foucault, 'emerged, at least in a recognisably modern sense, at a similar historical juncture'. ${ }^{2}$ Although he clearly states that he did not write a history of territory 'in the sense that territory is an ahistorical category which has been understood and practiced in different ways at different times', he nevertheless uses a historical order and chronology, divided into time periods, to suggest development, maybe even progress, especially in his use of physical denominators such as 'The Birth'. ${ }^{3}$ By concentrating on the ideas of 'the secular political theorists of temporal power' and 'the lack of conceptual tools' in the pre-modern period, he employs a teleological method that brings with it the imminent danger of constructing a circular argument. ${ }^{4}$ First, define your ideas, your concept of territory, in a modern sense, or at least in the way Foucault saw them from the seventeenth century onwards, and then search for them in the course of history, finding them, of course, for the first time in a full-blown sense in the seventeenth century. 5 An example can show the dangers of such an approach, based only on the writings of 'grand theorists'. One of

\footnotetext{
1 Reynolds, Fiefs and Vassals; Reynolds, Kingdoms and Communities, p. xliv: 'When words such as universitas, collegium, communia, or communitas occur in medieval sources in contexts that seem to suggest something like what a modern lawyer means by a corporate group (though legal definitions are less simple than historians of medieval political thought sometimes imply), that does not mean that anyone in the Middle Ages, even academic lawyers, had anything like the modern legal concept in their minds.'

2 Elden, The Birth; Elden, 'How Should We Do the History of Territory?', pp. 11-12. See also the inspiration he derived from the German tradition of Begriffsgeschichte, as mentioned on p. 15. For a short overview of Elden's ideas see the introduction of Damen and Overlaet in this volume. For an earlier concept of population and its uses, at least to me quite recognisable: Biller, The Measure of Multitude, e.g. pp. 385-419, admitting some doubts in comparison to the modern concept of demography.

3 Elden, 'How Should We Do the History of Territory?', p. 15.

4 Ibid., p. 16.

5 See ibid., p. 17: 'To control territory requires the subjugation of the people; to govern the population requires command of the land.'
} 
the most crucial concepts of the Later Middle Ages is the commune bonum, the 'common good' or the 'commonwealth'. Looking at philosophical or theological works one usually comes to the conclusion that this original Aristotelian concept was first reintroduced by John of Salisbury in the 1150s, but really became important through its systematic implementation by Thomas Aquinas a century later. However, in a charter for the Flemish town of Aire-sur-la-Lys, from 1093-1111, such a principle is already given pride of place. ${ }^{6}$ The history of this political and social concept is older by a century and a half than otherwise assumed, by looking at documents and historical practice instead of merely consulting philosophical works. Another warning is Seb Falk's recent statement in his book on medieval science:

The measure of medieval ideas should never be how closely do they match our superior modern ways?', but rather 'how important were they in their time?', and 'what impact did they have?' [...] Progress there undoubtedly has been, but it has not been a series of 'Eureka' moments by great men. ${ }^{7}$

Of course, we ought to take the latter's theories into consideration, but we should not stop there.

\section{Clerical ideas}

From all this it becomes clear that Elden gives pride of place and primacy to political theory. ${ }^{8}$ The way in which he utilises the ideas of Foucault is of interest. The latter, in Elden's words, notifies 'four registers - economic, strategic, legal and technical - [which] taken together, are crucial in addressing the political and historical specificities of territory'. ${ }^{9}$ In his reading of Foucault, he does not use or comment on the role of religion, however

6 Stein, Boele and Blockmans, 'Whose Community?', pp. 149-151: 'ad honorem et utilitatem totius ville', with more examples in the following pages. For many of its practical implications: Rawcliffe, Urban Bodies. For much of the scholastic theory: Kempshall, Common Good.

$7 \quad$ Falk, The Light Ages, p. 9.

8 He himself notes that another tradition existed: Roman law, not based on Greek political thought. He mentions writers like Bartolus, who are clear on the relation between territorium and jurisdiction. 'But, surprisingly, their work seems to have no discernible impact in political theory for some time.' Quote from Elden, 'How Should We Do the History of Territory?', p. 16. For more detail, see Elden, The Birth, pp. 218-228.

9 Elden, 'How Should We Do the History of Territory?', p. 7. 
(as Foucault did). ${ }^{10}$ In this volume, which concentrates on the fluidity and multiplicity of the concept of territory before the modern period and likewise on the political practices of lay rulers, an attempt to investigate (possibly converging) clerical ideas and practices could have added value. ${ }^{11}$ I will show how the Church and its institutions employed all kinds of territorial concepts and practices usually associated with lay rulers and their emerging states, often before the latter. Contiguous borders as well as fiscal, administrative, and legal theories and practices can all be found in the ecclesiastical sources, along with hierarchical ordering, abstract concepts, and the application of population numbers. All of these clerical contributions to the evolution of the idea of what a territory might be are just as much stepping stones in the development of 'the birth of territories' as those Elden describes, but are left out by him altogether, however undeservedly. ${ }^{12}$

This task is highly complex. Due to a lack of research on the subject, it is not possible to provide more than an initial and limited introduction. ${ }^{13}$ I will mainly concentrate on an area with which I am familiar: the Low Countries in the Later Middle Ages and the beginnings of the early modern period. ${ }^{14}$ I will start, however, with a discussion of some of the general ideas

10 Religion plays, however, a not unimportant role in Foucault's work. Among studies concentrating on power and religion in the work of Foucault: Strenski, 'Religion, Power, and Final Foucault'; Carette, Foucault and Religion, esp. pp. 129-141, with this on p. 136: '[...] Christianity in particular creates "forms of subjection" by developing "new power relations"'; and especially Holland, “'Truth as Force"'. Characteristically, religion does not feature much in Elden's Foucault: The Birth of Power, see, however, pp. 25-27 and 96-97.

11 See also the general remarks on the approaches to 'territory' of Damen and Overlaet in the introduction to this volume.

12 See, for instance, the lucid remarks of Schmidt, 'Neugliederung', pp. 107-111: 'Die hierarische Struktur der Kirche verteilte Kompetenzen, legte Befehlsgewalten und Partizipationen fest. Zuständigkeiten waren auf Räume bezogen. Ihre Gliederung musste stabil sein, weil nur so das Ideal eines brüderlichen Einvernehmen zwischen den Leitern der Raumeinheiten gewährleistet sein könnte. [...] Das vierte Laterankonzil von 1215 verfügte daher folgerichtig die Bindung jedes Gläubigen an eine Pfarrei, schützte den Bestand der Bistümer und Kirchenprovinzen vor Veränderungen, selbst wenn damit Anachronismen im Kauf genommen werden mussten, legte einen Instanzweg von den kleinen zu den grösseren Raumeinheiten fest und stabilisierte damit eine räumlichen Gefüge, das Papst Innozenz III. und die Konzilsvater als Voraussetzung für die gute Ordnung der res publica ansahen, als die Kirche neben anderen Termini bezeichnet wurde' (p. 107).

13 See, however, the articles of Schmidt and the concluding quote of Mazel at the end of this chapter, and more generally his book L'évêque et le territoire.

14 Following here Goetz, 'Discourses on Purity', p. 116: 'As far as I see, research on the Christian Middle Ages has not yet reached the stage that would allow me to simply provide a summarising survey. Consequently, my analysis had to draw more or less directly on the sources, which, in a brief paper, can only be done on the basis of some examples. I shall restrict my remarks to the 
of geography, and the more specific Christian geography, of two important mid-fifteenth-century clerics: (the later) Pope Pius II and Cardinal Nicholas of Cusa. After presenting a sketch of the broad idea of 'Christian territory', I will highlight the importance of two concrete entities - parishes and bishoprics - which are two of the typical structural elements of ecclesiastical 'territories'. Finally, a more detailed analysis will be given of 'practices', namely of the territorial features of the creation of new bishoprics in the Low Countries in 1559.

Structural elements and general ideas will concern us mostly, hereafter. Instead of merely focusing on structures and on jurisdictions, we can, however, also look at the way clerics identified themselves or were identified by others. In the papal administration, the largest bureaucracy at the time, and also in the ordinances of universities, students or clerics were often denominated by their diocese, as was, of course, the general rule for a cleric: they were first and foremost clericus Traiectensis or clericus $N$. for another diocese. Sometimes a region, the town, or a denomination like presbyter or notary was added. The system was simple to use, fairly trustworthy, and easy recognisable across all of Christendom, although silly mistakes and misunderstandings were certainly possible, such as curial clerks in Rome labelling Denmark "in Africa" or placing the (Lower Saxony) bishopric of Hildesheim in Bavaria in an overview of Christian bishoprics. ${ }^{15} \mathrm{~A}$ very elaborate example of such an identification is the following, taken from the diary of an early-sixteenth-century cleric, who lived for decades in Rome and who presented himself as 'Cornelius de Fine filius quondam Joannis de Fine natione Alemannus inferius ducatus Brabantiae et patria Bergensis supra Somam non procul ab Antverpia emporio famoso. ${ }^{16}$ A description containing an impressive amount of detail! He mentions his father, his nation, the Duchy of Brabant, his hometown, Bergen op Zoom, and by way of further explanation its situation not far from the famous market of Antwerp. Usually the diocese is, however, the foremost denominator, although here it is superseded by a reference to a nation, a duchy, and a

earlier Middle Ages with which I am more familiar. The second problem, however, is of really existential significance and refers to the state of sources: Christianity does not know specific commandments on ritual purity and, consequently, it hardly knows any coherent discourses on purity.'

15 Tewes, 'Das Spätmittelalterliche Papsttum', p. 6o8. The register was a new, up-to-date copy of the Provinciale Romanum.

16 Quoted in Schuchard and Schulz, Thomas Giese, p. 88, with many other examples of clerics denominated by their diocese or their town of origin. 
hometown, maybe under the influence of a decades-long stay in the Rome of the High Renaissance.

It goes without saying that many medieval political thinkers were clerics, too. Apart from that, we can distinguish two strands of clerical thinking about territory, and territorial ideas and practices: on the one hand, there is a shared idea of Christian space, and on the other hand, the particular construction and formation of ecclesiastical territory. In its widest sense, clerical ideas knew no limits. For Augustine, the true Church could be identified with the trans-spatial and trans-temporal City of God. ${ }^{17}$ This unworldly concept is neatly epitomised by Cardinal Nicholas of Cusa in his reform proposal for the Church (1459):

Since, however, the church of God is the mystical body of Christ, rightly likened by the apostle to the human body, in which, in the life-giving Spirit, all members are united, so that they might live, just as all members of Christ are given life in the whole body of the church by the Spirit of Christ, to whom all the faithful in this world adhere though faith. ${ }^{18}$

Cusa himself hardly uses the term 'Europe' in his work. According to Tilman Borsche, in Cusa's mind Europe was not so much a geographical entity 'as a spiritual community'. ${ }^{19}$ Christians lived under all kinds of different, sometimes overlapping, jurisdictions. 'The bonding element in this multiplicity and diversity, creating unity, is the verdict, the law, and the power of the general (catholic) Church.' In Cusa's words, it was 'the unity of the faithful which we call the Church'. ${ }^{20}$

Cusa, however, presents an open view of the world and its history here. Although he contrasts Christian truth with non-Christian errors, he nevertheless claims that all religions basically venerate one God, the Christian God, the famous una religio in rituum varietate. ${ }^{21}$ It was not the differences,

17 Oakley, Mortgage of the Past, p. 202.

18 Quoted from the translation by Watanabe and Izbicki, 'A General Reform', p. 191. For Cusa and his work, see the latest sketch by Schwaetzer, 'Nikolaus von Kues', with references to authors such as Erich Meuthen, the Acta Cusana, and the Opera omnia.

19 Borsche, 'Die verborgene Kirche', p. 51: 'als vielmehr eine geistige Gemeinschaft'.

20 Ibid., p. 52: 'Das verbindende, einheitsstiftende Band dieser Vielfalt ist das Wort, das Gesetz und die Macht der allgemeinen (katholischen) Kirche'; in Cusa's words: 'unitas fidelium, quam nos ecclesiam dicimus'.

21 Gebel, Nikolaus von Kues, pp. 134-135. Prophets were sent to all nations, which venerate the same God under different names. For the continuity of the idea, that all other religions were, as sects, derivative of the Christian religion: Akbari, Idols in the East, especially chap. 5; Tolan, 'Conquest and Its Justifications', pp. 32-40; Tolan, Saracens, pp. 40-57 and 69-134. 
but the connections and the similarities that mattered. Christ was the King of Kings, standing at the apex of a hierarchy. After Him came the Christian king, who 'ruled according to natural law, the laws of both testaments, and the true faith'. ${ }^{22}$ He was followed by the sultan, the king of the Mohammedan sect, and the king of the Tatars. In Gebel's words:

This 'graduatio' idea is also the cornerstone of Nicholas' idea of the Church. In its widest sense the Church is formed by all creatures of sense, by people and rational minds, all connected to Christ, their head, albeit in different steps. All people have, however, a share in this 'ratio', although in different degrees. ${ }^{23}$

Ratio, the acknowledgement of the Christian truth, and through it the law and the power of the Church, delineate the world and its territories in this broad view.

Aeneas Silvius Piccolomini (1405-1464) is less open-minded but just as interesting. One of the most intriguing characters of the fifteenth century, he was born into a noble family, received an excellent university education, and was prolific as a humanist writer of letters, treatises, poems, histories, commentaries-cum-memoirs, and a mix of historical-geographical narratives. He became a secretary and diplomat, and was active at the Council of Basel (1432-1449) and at the court of Emperor Frederick III (r. 1440-1493), before pursuing a real clerical career, becoming a bishop first, a cardinal later, and finally Pope Pius II (1458-1464). ${ }^{24}$

The life of Pius (like that of Cusa) revolved around the struggle between the conciliar movement and the pope, and around the imminent danger posed by the Turks, especially after the fall of Constantinople in 1453. This last threat was one of the defining elements of Pius's 'cosmographical' work. In 1461 he composed his work $A$ sia. ${ }^{25}$ In it he claims to give an up-to-date

22 Gebel, Nikolaus von Kues, p. 160.

23 Ibid., p. 180: 'Grundlegend ist der "graduatio"-Gedanke auch für Nikolaus' Kirchenbegriff. Die Kirche im weitesten Sinne besteht für ihn aus allen vernüftigen Kreaturen, aus Menschen und rationalen Geistern, die mit Christus, ihrem Haupt, auf verschiedenen Stufen verbunden sind. Alle Menschen haben aber, wenn auch in verschiedenem Grade, Anteil an der "ratio".' 24 The latest biography I am aware of is Reinhardt, Pius II. On the political problems of the curia and the conciliar movement, see O'Brien, Commentaries. See also the introduction to Reject Aeneas, pp. 1-57, and the introduction by Von Martels in Enea Silvio, pp. 25-102; furthermore, the introduction of Nancy Bisaha in Piccolomini, Europe, with all the literature mentioned in these works.

25 I will refrain from a more general overview of the cosmographical and cartographic ideas. See, for instance, in general, Cosgrove, Apollo's Eye. Central here is Oschema, Bildervon Europa, 
history of a part of Asia, however he pays no attention to the role of the Mongols. It is more of a summary, a humanist recapitulation of ancient geographical knowledge, although Pius is certainly not a simple copyist of antique sources. His main targets were the Turks, cast as the barbarous Scythians of old, without 'any redeeming virtues'. His purpose was to launch a new crusade against the Turks. ${ }^{26}$ Pius saw the non-European world from the perspective of the different, consecutive world empires. Once there had been a universal Church, but now it had shrunk due to the expansion of 'sects' like Islam into Europe. The result was a Europe which had at its core the values of Christian unity and the culture of the liberal arts and classical rhetoric. His ultimate goal was Christian unity and unification, to be brought about by the reintegration of the orthodox churches and the conversion of Muslims, resulting in a general peace. ${ }^{27}$

Three years earlier, while still a cardinal, he had written De Europa (1458). Although this book was meant to record 'the most memorable deeds accomplished among the Europeans and the islanders who are counted as Christian during the reign of Emperor Frederick III', it also contains geographical descriptions. It gives a unique view of Europe's topography by a cleric. His impressive tour starts in Hungary, Valachia (Wallachia), and Greece, and continues through Austria, Poland, Saxony, Scandinavia, Frisia, Holland, Utrecht, Ghent, France, and England, ending up with a lot of pages dedicated to Italy ${ }^{28}$ Bisaha suggests the text can be interpreted, with the Ottoman advance in mind, as

for instance, pp. 209-218. Moreover, see Harvey, The Hereford World Map, and Baumgärtner and Kugler, Europa im Weltbild. For more particular ideas about the frontiers, the end of the world and time, see Schmieder, 'Edges of the World', with its literature in note 2, and Von den Brincken, Fines Terrae. See also Von den Brincken, 'Descriptio Terrarum', for cartographic representations in Germany.

26 For this work, see especially Meserve, 'From Samarkand', pp. 17-18, 22, 24-25 (quote), and 31; Casella, 'Pio II tra geografia e storia', esp. pp. 43-46, 50-63, 66-72. For more in general, see Gebel, Nikolaus von Kues; the introduction by Nancy Bisaha in Piccolomini, Europa, pp. 10 and 35; Meserve, Empires of Islam, pp. 79-80, 96-104, 113-116, and 220-222. For the complaint against the barbarian character of the Turks, see Bisaha, Creating East and West, pp. 43-93, for eschatological elements, see pp. 139-161; the best recent work on the planned crusades against the Turks is: Weber, Lutter contre les Turcs.

27 Gebel, Nikolaus von Kues, pp. 12, 16-18, 32, 35, 39, 43, 45, 48-66; Oschema, Bilder von Europa, pp. 299-310.

28 The quote is from the Introduction to Piccolomini, Europe. For the work itself, the idea of Europe, and Piccolomini's intentions and sources, see especially the Introduction to this translation by Nancy Bisaha, pp. 3-5, 10-35. For Aeneas and the description of Germany, see Tewes, 'Zwischen Universalismus', pp. 54-56. Further, with attention to other works like Aeneas's De Boemia and De Germania, see Voigt, Italienische Berichte, pp. 127-153, and Baldi, 'Enea Silvio Piccolomini', esp. 
an exhortation to Christians to view themselves as part of a cultural, religious, and geographic collective, even as it acknowledges the diversity among its peoples. [...] What Western Christians most urgently needed to do was unite strongly enough (and long enough) to defend their common boundaries - a strikingly modern message. ${ }^{29}$

Both authors were also theorists of power, however, be it imperial, conciliar, or papal in character. Cusa even saw a crucial role for consent and underlined the importance of a correct elective procedure..$^{30}$ Their ideas on the Christian world (or Europe), and its relation to other parts of the globe show, nonetheless, a framework or notion of territory that is completely different from the secular concepts used by Elden..$^{31}$ Instead of sovereignty over a specific territory, it has to do with an idea of Christian unity. Both of them draw upon, and toy with, concepts of borders and boundaries under threat, although there is certainly a notion of superiority and a feeling of 'us versus them' in the work of Pius. The latter becomes clear when we consider Pius's use of the classics and his use of the civilised/barbarian dichotomy.

Apart from these rather fluid abstractions of a Christian world and the boundaries of a Christian Europe, the world, both physically as well as mentally, could also be divided, in a practical sense, into a societas christiana and one composed of the 'others', that is, non-Christians. This conception

pp. 667-678, with a quote from Denis de Rougemont on p. 619: 'Dans sa Cosmographie générale, il le décrit comme un ensemble humain et historique, non plus seulement géographique, dont il détaille les conditions ecclésiastiques et politiques, économiques et sociales, nous dirons aujourd'hui: culturelle au sens large.'

29 Piccolomini, Europe, pp. 15-16, and 31-35 (with her earlier suggestion that Europe in combination with Asia 'helped shape an ideology of cultural unity and superiority to the East'). See also Baldi, 'Enea Silvio Piccolomini', pp. 672-674, and this passage on p. 673: 'L'Europa [...] si identifica chiaramento con la Christianatà: la Christianità è in Europa, e si potrebbe dire, solo in Europa, tanto che in I confini religiosi coincidono ormai con quelli europei.' For the idea of Europe, and Cusa's place in it, see Karageorgos, 'Der Begriff Europa'.

30 On the ideas of Piccolomini (mainly in some of his letters and in his Commentaries), see Schmidinger, Romana regia potestas, pp. 16-24 ('Rahmen für eine saekularisierte Idee des Imperium staatsrechtlich-politischer Prägung'); O'Brien, Commentaries, esp. pp. 88-98 and 156-188, and this passage on p. 181, for example: 'Here, it is not the papacy's right to temporal rule that Pius is defending specifically. Instead it is a much broader claim to ecclesiastical rule: priests make excellent princes - better ones, in fact, than do laymen.' For Nicholas of Cusa, see Watanabe, Political Ideas, especially chap. 4; Moritz, 'Concordantia als normatives Prinzip'; Oakley, The Watershed, pp. 200-204.

31 For Cusa as a sponsor or creator of maps ('Cusanus-type') and his relation to the Eichstätt Map of 1491, see Möller, 'Cusanus als Geograph'. Further, see Von den Brincken, 'Descriptio Terrarum', pp. 25-28. 
formed the basis of the ecclesiastical administrative division of the world, with Christian dioceses under an acting bishop, on the one hand, and, on the other, the so-called in partibus infidelium bishoprics, those territories or dioceses that had been catholic Christian once, but were now in the hands of unbelievers, especially Islam. Time was not crucial here: once a territory was Christian it remained a Christian territory forever. The idea of Christian versus non-Christian was all prevailing once again, just as there was a clear boundary between regions with their separate beliefs.

Additionally, aside from this larger administrative geographical distinction, a similar idea, based on a concept of natio, divided the later European Church proper. Just as the medieval universities divided their students into categories like the natio anglicana, so late medieval prelates thought and worked with concepts such as the Gallican, the English, or the German Church. The Reform Council of Constance (1414-1418) divided the clerical participants into four (later five) nations in an effort to avoid a misrepresentation in votes caused by a surplus of Italians present..$^{22}$ Although these types of nations are usually, in a somewhat loose and malleable form, connected to royal power, exemplified in the several concordats between popes and kings in the fifteenth century (like the concordat with the German nation in 1448), they might also imply a communitarian feeling and the fate of all the clerics in a certain region. An example of this is Aeneas Silvius's tractate Germania, directed against a complaint of his learned German friend Martin Mair about the exploitation of the German Church and nation by the Curia.33

32 There is an abundance of literature on the complicated concept of natio; see, for instance, with many bibliographical references, recently Krah, "Natio", nicht Nation?' For the role played by 'nations' at universities, see, for example, Kibre, Nations. From the many recent discussions of the Council of Constance, see Swanson, 'Gens secundum cognationem'; an older treatment in Finke, 'Nation'. For the relation to modernist approaches, see Hirschi, 'Humanistische Nationskonstrukt'. For the connection between the nation at the university and at the councils, see the older treatment in Hay, Europe, pp. 75-83, and the recent Hirschi, Origins of Nationalism, pp. 78-88. For the different clerical views and divisions, see Oschema, Bilder von Europa, pp. 367-39o. One of the oldests maps (1357) records the division between the English and the Picardian nation at the University of Paris: Van der Krogt, 'Lokale kaarten', pp. 31-32.

33 For the difficulties in ranging nations and dioceses for research, see Tewes, Römische Kurie, pp. 6-18; for the difficulties in grasping the extent and organisation of the Church, see Schmidt, 'Raumkonzepte', pp. 99-105, and Tewes, 'Das spätmittelalterliche Papsttum', pp. 605-6o9. In general, for the Roman idea of the christianitas, see Schmidt, 'Raumkonzepte', pp. 105-120, and Tewes, 'Zwischen Universalismus', esp. pp. 46-47, and for borders p. 43, note 31. See also Mazel, L'évêque et le territoire, pp. 359-363. For Martin Mair and the epistolar reply of Piccolomini, see Piccolomini, Deutschland; Watanabe, 'Imperial Reform'. I could not obtain a copy of Claudia Märtl's recent article on Piccolomini and Mair. 


\section{Ecclesiastical territory}

With parishes and bishoprics, we tread on more solid ground, although the concept of frontier and boundary becomes clearer only in time. With the advent of a more modern geography and mapping, and its combination with the formation of states, we have become used to thinking in clear lines from A to B, separating different territories by boundaries. ${ }^{34}$ Ronnie Ellenblum presents a different picture of Crusader Palestine, containing centres and core settlements such as castles, with their influence and effectiveness fading and dissolving into more vague, disputed borderlands without any clear demarcations, natural features notwithstanding. ${ }^{35}$ The same is true for the ways these lands are held, sometimes in fief, sometimes as an allodium, and anything in-between, without the necessity to assemble them all in a contiguous territory, often with multiple rights by more than one person at the same time, again without the necessity to be constricted to one, well-defined area.

A similar background can be seen in the development of parishes and their territories. For a long time, parishes and their origins were presented, with a cartographic mentality, as contiguous territories clearly delimited by boundaries. ${ }^{36}$ From a clerical viewpoint, however, the parish (parochia) was originally formed not by space but by the faithful who dwelled together once in a while for services in a building or a location. ${ }^{37}$ Only growing pressure, from the need to raise tithes and other income for the priests or their institutions, and other legal incentives from bishops and dignitaries, and the integration of cemeteries and houses into the surroundings of the church building, resulted in a growing 'territorialisation' of the parish,

34 See Ellenblum, 'Were There Borders?', pp. 105-109 and 118; for the problems associated with the concept of frontier, in general, see the lucid introduction of Abulafia, 'Seven Types of Ambiguity', esp. pp. 1-6, 10-16 (for political frontiers). Furthermore, see Aydoğan, 'Changing Perceptions', p. 30: 'Geographers and political scientists consider frontiers and boundaries as belonging to distinct categories: Frontiers are zones evolving organically between states or societies; boundaries, on the other hand, are state-defined artificial lines of separation. Although this definition of "frontier" is of considerable importance for modern conceptualizations, it cannot be easily applied to premodern frontiers.'

35 Ellenblum. 'Were There Borders?', pp. 109-117.

36 A good example is the work of Michel Aubrun, La paroisse, with a ninth-century example from the Corrèze on pp. 199-200; see also p. 204. For an older overview of ecclesiastical organisation and canon law, see Feine, Kirchliche Rechtsgeschichte, pp. 402-427. For all the problems and regulations regarding Eigenkirche, see Wood, Proprietary Church.

37 Lauwers, 'Paroisse'. 
which historians newly interpret as a special spatial entity. ${ }^{38}$ In southern France this evolution transpired mainly from the end of the ninth to the twelfth centuries, sometimes earlier in the tenth century and elsewhere more than a century later. ${ }^{39}$ This can be observed occuring in other places, too, exhibiting regional differences and accents. Generally speaking, a web of interlocking, contiguous parishes with fixed boundaries and territories covered all of Europe in the Later Middle Ages. ${ }^{40}$

In parts of the Prince-Bishopric of Utrecht earlier domanial structures influenced the formation and the territory of parishes, while pre-existing archdeaconries were another formative factor. The reclamation of peatbogs and other lands, with their man-made or natural features such as ditches and watercourses, was a final element in the determination of boundaries and territories. ${ }^{41} \mathrm{~A}$ recent reconstruction of the parochial structure in Frisia led to the remarkable conclusion that the tenth and eleventh centuries showed a spectacular growth in the number of parishes, often all equally spaced and integrated into older structures, probably a planned development under the direction of the bishops and their administrators. ${ }^{42}$ According to

$3^{8}$ I am not delving here into lexicographic problems such as the difference between space and territory nor in mental spatial images and the flood of literature on this topic over the last couple of decades.

39 For the parish in general, see the excellent Iogna-Prat, La Maison Dieu, pp. 176-182, 229-249, 294-306. For this territorialisation and its cartographic expression especially: Hautefeuille, 'La cartographie de la paroisse', and Hautefeuille, 'La délimitation'. For the crucial input from the material world: Zadora-Rio, 'L'historiographie des paroisses', and in connection with burial places and churchyards: Zadora-Rio, 'The Making of Churchyard and Parish Territories'. For the somewhat different development in England: Blair, 'Recherches récentes', and Blair, The Church in Anglo-Saxon Society, pp. 368-504, esp. pp. 369-370 and 422-425. Fundamentally, see Lauwers, 'Paroisse', passim; Lauwers, Naissance, pp. 24-30, 49-54, 85-88 and 137-151. For the later situation in the German Empire, see the work of Enno Bünz, e.g. his 'Pfarreien und Pfarrgemeinden', esp. pp. 30-39 underlining all the differences between the parishes. For different types of churches: Janssen, 'Differenzierung der Pfarrorganisation'.

40 See Schmidt, 'Neugliederung', p. 107, for the importance of the Fourth Lateran Council of 1215 here.

41 Dekker, Kromme Rijngebied, pp. 279-361, esp. pp. 333-347 (boundaries identical with the reclamations).

42 De Langen and Mol, 'Church Foundation', with a recapitulation on pp. 49-52, using archaeology, GIS mapping, and an extensive historical documentation. See also their footnotes 1, 9, and 98 for references to the other literature on the formation of parishes in most of the Low Countries. Elisabeth Zadora-Rio coordinated a similar project for the Touraine. I was unable to get a copy of her edited volume, however. For an extensive review and interesting responses and debate, see Noizet, Rodier and Zadora-Rio, 'Débat', esp. pp. 7-11 and 18-21. A preliminary reconstruction of similar developments in Holland, again with an important role for the bishop and a growing territorialisation since the middle of the tenth century, is De Langen and Mol, 
Kuys, parochial boundaries (often) coincided with the territories of secular jurisdictions in the northern Low Countries, in general. ${ }^{43}$ Inside towns, the boundaries between parishes could be very explicit. In Utrecht, for example, we can follow them from street to street, sometimes even mentioning specific houses as a limit, like '[...] unto the cornerhouse called The Coffin opposite the house The Dappled Horse'. ${ }^{44}$ Fiscal registers like the Hofstedengeld of c. 1397 from Gouda (Holland) make use of a similar system, describing street by street the owners of taxable houses. In the register of 1405 , from the same town, levies for the militia run for 37 districts from certain houses in a street to other particular houses. On a lower administrative level, clerical and secular authorities drew upon the same idea of delimitation of territory with its fiscalisation and jurisdiction. ${ }^{45}$

The boundaries between villages and thereby frequently also between lordships and principalities were expressed in manifold ways, often by using the boundaries between parishes; they probably even did originate in them partly. ${ }^{46}$ These boundaries between parishes were fairly strict and well known because each man had to know where he ought to confess and where he was expected to be married and, later, to be buried. In one of a series of border disputes between the county of Holland and the Prince-Bishopric of Utrecht, spies from Holland referred to parishes and their boundaries as demarcations between these principalities in $1525,15^{26}$, and 1527 . They also used roads as points of reference, just as the location of censual lands and lease lands. Ditches and trenches were searched for, just as was the location of a fortified house, certain bushes and trees, and a mill. Other points of reference were the Cathedral Tower miles away and an important boundary sign, the so-called blauwe zerk, probably a bluish-black hardstone. (This was hidden under water in a ditch, something which made the reconnoitring party open sluices during the night, under constant threat from a loudly

'Kerk, macht en ruimte', esp. pp. 267-268 and 271-272, more extensively dealt with in De Langen and Mol, 'Church, Landscape and Power'.

43 Muller, De indeeling van het bisdom, pp. 107-120, esp. pp. 116-119: for Frisia a complete overlap; elsewhere not automatically; however, see Kuys, Kerkelijke organisatie, p. 44; Robinson, Beneficed Clergy, p. 2. See, however, Leturq, 'Territoires agraires' for the too simple equilisation of parishes and agrarian structures.

44 Muller, De indeeling van het bisdom, p. 255-256: '[...] teghen over het Vleyshuys ende enighe huysen voerby tot het hoeckhuys genaemt de Doodkist, teghens over het Bontepeert [...]". For two important French towns, see Comte and Grélois, 'La formation'. For Tours, see Noizet, 'De l'église au territoire'.

45 Het Goudse hofstedengeldregister, pp. lxxv-lxxxii, 1-13 and 27-29.

46 A complication being a situation of dual lordship or the division of a parish between two principalities, for example, Maastricht or Wegberg in Germany. 
barking watchdog whom they unsuccessfully tried to pacify with bread.) Other markers included the Leeuwenpaal (Lion's Post) of 1356 and a whole range of piles and posts. ${ }^{47}$ The Hollanders also made good use of maps; the oldest one dated from 1472 although some of them had been newly made to argue their case. They also talked to several priests, researched foundation charters in churches, checked memorial registers, tried to pick the memory of the 'oldest and richest man' in the area, and asked other men 'to which church they belonged' (ter kercke hoerden). Parochial boundaries were clearly conclusive here and they show us how much they were integrated into a more general idea of territory.

In addition, parishes gave an organisational structure to the work of couriers and messengers of bishops, archdeacons, ecclesiastical judges, the estates, and lords. Not only did the collectors of papal and other clerical subsidies use parishes and their territories as defining elements in their fiscal administration, but secular lords did the same. Cartularies and the administration of leases and lands, etc., were likewise organised by parish, just as much in clerical as in secular organisations. ${ }^{48}$

Apart from parishes, other ecclesiastical entities were relevant to the life of medieval Christians. Archdeaconries, often divided into several deaneries, were formed out of a number of parishes. ${ }^{49}$ Their boundaries were usually based on those of the parishes, although new parishes sometimes crystallised within a pre-existing archdeaconry, constricted or delimited by its boundaries. Part of the ecclesiastical jurisdiction of bishops had been delegated to the incumbents of these archdeaconries and their dependent deaneries. In the bishopric of Utrecht this entailed a large part of the supervision of the clergy, but also the correction of laypeople who broke canonical rules. Examples include bigamy, sexual delinquency, gambling, and debt litigation, but the ban on working on Sundays and feast days was most often mentioned in the juridical registers. ${ }^{50}$

47 These and the following examples from Zestiende-eeuwsche wandelingen, pp. 15-20, 22-23, 25-27, 35-37, 46-54, 57-58. For the maps: Enklaar, 'Oudste kaarten'; Groeneveld, 'Oostgrens van het Gooi'; Van der Krogt, 'Lokale kaarten', no. 7, pp. 34-35.

48 Muller, De indeeling van het bisdom, pp. 5-39, 259-263, 323-326; Bronnen voor de geschiedenis, pp. 12-20, 52-55, 146-151; Van den Hoven van Genderen, 'Registers', pp. 179-184. See also Mazel, L'évêque et le territoire, pp. 338-343.

49 Dekker, 'De vorming van aartsdiakonaten'; Bijsterveld, Laverend, pp. 35-46 with the literature cited there; De Moreau, Histoire de l'Église, pp. 91-102; Lambrecht, Parochiale synode, pp. 192-204, 210-219, 255-259; Kuys, Kerkelijke organisatie, pp. 128-149; Mazel, L'évêque et le territoire, pp. 308-315. $5^{0}$ See esp. Van Moolenbroek, 'Zeeuwen in verzet'; Bijsterveld, Laverend, pp. 39-40; Lambrecht, Parochiale synode, pp. 255-259. 
The diocese was the ecclesiastical organisational system on a higher level. Just as the parish was based on the congregation of a certain number of souls, so the bishopric grew out of the aggregate of a certain number of parishes, encompassing all kinds of other inheritances and influences like the Roman civitas or the pagus. ${ }^{51}$ Just like parishes and archdeaconries, bishoprics became gradually territorialised. In England, and probably in France, too, this process had ended in the twelfth century. $5^{2}$ The same holds true for the Low Countries, where the borders of the bishopric of Utrecht were mainly and roughly formed by the (old) courses of the Meuse and Waal/Rhine rivers. Due to the presence of extended and unreclaimed peatbogs, the boundaries between the bishoprics of Utrecht and Münster were less well defined at that time. ${ }^{53}$ Where borders were not determined by the geography, as in the eastern part of Zeeuws-Vlaanderen, dikes played a part. Parishes were 'traded' here between the bishops of Utrecht and Tournai to solve their boundary disputes, just after the middle of the thirteenth century, at a time when several Utrecht ecclesiastical organisations tried to reorder or to rescind their Fernbesitz, their far-off landed properties and rights, in Flanders or elsewhere. ${ }^{54}$ As was the case with parishes, deaneries, and archdeaconries (although enclaves certainly existed), the bishoprics had a fixed, finally contiguous territory. In it their bishops were responsible for the welfare and the correct functioning of their clergy, just as much as for the souls of the faithful. Preaching and exhortation were one part of

$5^{1}$ Iogna-Prat, La Maison Dieu, pp. 48-62, 83-98, 205-220, 249-257, 405-422; Claeys-Bouuaert, 'Évêques', pp. 570-571; Feine, Kirchliche Rechtsgeschichte, pp. 35-46, 54-56, 97-100, 125-127, 182-205, 213-218; Rapp, Holy Bishops; Patzold, Episcopus; Haarländer, Vitae episcoporum.

52 Swanson, Church \& Society, pp. 1-6, rural deaneries often 'coterminous with hundreds and wapentakes'. For France, see the brief remark in Mazel, Féodalités, pp. 363-364. See also Iogna-Prat, La Maison Dieu, pp. 216-220, 310, and Klueting, Klueting and Schmidt, Bistümer und Bistumsgrenzen. For an in-depth view, see Mazel, L'évêque et le territoire, pp. 221-227, 233-235, 237-244, 256-264 and 271-274.

53 Kuys, Kerkelijke organisatie, pp. 30-31. An example from a completely different region: Schmidt, 'Neugliederung', p. 115. For a map of the archbishopric of Cologne: Burkhardt, Mit Stab und Schwert, pp. 638-639; detailed information in Janssen, Das Erzbistum Köln, pp. 31-52, and map 3 and 4 . For the borders of the bishopric of Liège: Bijsterveld, Laverend, map 1.1 and pp. 27-28. Rivers and watercourses are in part formative here. For the other dioceses of the Low Countries this is sometimes harder to assess. See the map in Dierickx, De oprichting, p. 348. The river Schelde was decisive in the boundaries between Cambrai and Tournai, just as elsewhere the Scarpe and other watercourses like the brook La Chaudière influenced the formation of other boundaries. Landed property, and especially the dotation with domains and rights, and the interplay with the older civitates, pagi and younger principalities were prime moving factors probably too. See the discussion by J. Deharveng in De Moreau, Histoire de l'Église, pp. 31-45.

54 Van den Hoven van Genderen, “'Utrechtse Vlamingen”', pp. 154-160. 
their task; administration and jurisdiction, the application of the rules of canon law for all the inhabitants of the bishopric, were another part of it. ${ }^{55}$

\section{The new bishoprics of 1559}

Bishopric and parish borders usually remained fairly stable for centuries, sometimes even up to the present. ${ }^{6}$ The Low Countries are one of the important exceptions to this rule. ${ }^{57}$ When Philip II (r. 1555-1598) forced all involved parties to accept the creation of new bishoprics in 1559 , it completely reshuffled the older ecclesiastical division. It is therefore interesting to investigate why these new bishoprics were deemed necessary and whether new organisational principles were drawn upon for this new division.

The effort of kings and princes to control (or better regain control of) the clergy in their lands was an important political factor from the twelfth century onwards. This resulted in a lot of debates and conflicts, and in the development of new theories on the extent of royal and ecclesiastical authority. Robert Swanson characterises the situation for England as 'two laws, one kingdom', without, however, any suggestion of a constant tension between church and realm..$^{58}$ In general, there were two main points of conflict which traditionally had a territorial character, namely taxation and jurisdiction. Another general trend was to limit papal influence and intermingling, chiefly by following the notion of ecclesia gallicana or anglicana, under which bishops and clergy mainly collaborated with or were subservient to

55 Patzold, Episcopus; Haarländer, Vitae episcoporum; Van Rhijn, Shepherds of the Lord. See also Schmidt, 'Neugliederung', pp. 107-113. Some monasteries, clerics, or orders were exempted by a papal privilege, just as some cases were reserved for the judgement of the pope, but in general almost everybody was in some way subjected to episcopal supervision. In general, see Mazel, L'évêque et le territoire, pp. 318-335. Earlier in his book Mazel discussed enclaves and exemptions. 56 For many changes of earlier boundaries in France (and in the German Empire through the creation of Magdeburg, Bamberg, and the eastern bishoprics): Mazel, L'évêque et le territoire, pp. 182-215, 274-285, and 356-359, and Klueting, Klueting and Schmidt, Bistümer und Bistumsgrenzen, esp. Schmidt, 'Neugliederung', pp. 108-114, for the continuity of the boundaries of dioceses after 1215 .

57 Of course, there were other exceptions. Somewhat comparable with Utrecht, and also motivated by a concern to combat heresy, is the south of France in the beginning of the fourteenth century: Schmidt, 'Neugliederung'. During the Henrician reorganisation of 1540-1542 several 'cathedrals of the New Foundation' were established in England, with the use of some of the largest dissolved monasteries like Peterborough. The size of Philip's changes in 1559, with three new archbishoprics, each with new bishoprics, is on another level, and has also a different background than the English example.

$5^{8}$ Swanson, Church \& Society, pp. 140-19o. 
the king. Concordats with the pope were one of the ways to lessen strains and disputes and to achieve greater royal control over churches and clerics. ${ }^{59}$

One of the earliest attempts in the Low Countries to change the ecclesiastical status quo dates to the government of Duke Jan III of Brabant (r. 1312-1355) in the 1330s. Since the Duchy of Brabant was divided between the two dioceses of Liège and Cambrai, he tried to get permission for the creation of a separate Brabantian bishopric. He claimed, amongst others, that the two bishoprics were too large to be managed effectively, and that the rites differed in both dioceses. ${ }^{60}$ The count of Holland seems to have had similar plans for the creation of his own bishopric in the beginning of the fifteenth century. ${ }^{61}$ Less questionable than the count's initiative were the plans of Charles the Bold (1467) and especially those of Maximilian of Habsburg (1483) to split the diocese of Liège in order to create new bishoprics in, for example, Leuven and Namur. Maximilian underpinned his case by recalling the vastness of the bishopric of Liège, its wealth, the two languages spoken there, and the fact that it covered multiple principalities. ${ }^{62}$

The plans of Charles V carried more weight, however. They had their origin in the beginning of the 1520 s and were finally formulated in a plan presented to the pope in 1525 . At that time Charles was not yet lord of the north-eastern parts of the Low Countries. Six new bishoprics were proposed: in Leiden (Holland), Middelburg (Zeeland), Brussels (Brabant; Cambrai would keep its francophone parts), Ghent (added in 1530 for the Flemish parts of Cambrai), Bruges (the Flemish territories of Tournai), and Ypres (the Flemish territories of Thérouanne). ${ }^{6} 3$ The plan was suddenly, and rather unexpectedly, dropped in 1530.

The impetus for the decisive plan for the creation of new bishoprics in 1559 came from Franciscus Sonnius (1507-1576), a former professor of theology

59 From the classic expositions of Joseph Strayer and Walter Ullmann over biographies as Jean Favier's Philippe le Bel and Enguerran de Marigny, and the whole literature on the Western Schism and the conciliar movement. More recent work often highlights, and problematises, the cooperation of clerics with the state; see, for example, Barralis et al., Église et État, Église ou État? For political thought, see the last two volumes of Oakley's magnum opus.

60 Fairon, 'Un projet de démembrement', esp. pp. 147-157; Dierickx, De oprichting, pp. 27-28; Dierickx, Documents, vol. 1, pp. 59-71. Compare with Schmidt, 'Neugliederung', p. 114 for the argument of a 'zu große Ausdehnung' of a bishopric, and the concern for the care of souls.

61 Dierickx, De oprichting, p. 29, contrary to Jongkees, Staat en kerk, p. 16.

62 Dierickx, De oprichting, pp. 30-31.

63 Dierickx, Documents, vol. 1, pp. 76-96; Dierickx, De oprichting, pp. 32-37. For a summary of Dierickx and the history behind the new dioceses, see Weis, 'Hierarchie'. For the contemporary plans of Cardinal Wolsey, see Swanson, Church \& Society, p. 2. 
and rector of the University of Leuven, cathedral canon in Utrecht, and inquisitor in Holland, Utrecht, and Guelders (1545-1557). Sonnius attended the Council of Trent two times as one of the representatives of the bishop of Cambrai. During the sessions of $155^{1-155^{2}}$ he devised a kind of masterplan for the division of older bishoprics and the creation of new ones. ${ }^{64}$ His main motive was to impede the growth of Protestantism in the Low Countries; his main objective was the creation of smaller dioceses, all under the aegis of the Habsburgs, with resident bishops, graduated in law or theology, and a cathedral clergy which was vitalised by the obligatory admission of a set of likewise trained new canons, who would also act as papal and episcopal inquisitors. A new system of remuneration would stimulate the residence of the clergy of these new cathedrals and its active participation in choir services. ${ }^{65}$ All in all, this was intended to result in a more active and effective defence of Catholicism. At the council Sonnius asked several prelates for information and discussed his ideas with them, with some of the cardinals present. He was also well aware that his plan, if supported, would be presented to the pope and his cardinals. ${ }^{6}$

In his plan Sonnius proposed to create eleven or twelve new bishoprics, and two new church provinces with their archbishops at the apex. This was all to be at the cost of the existing provinces of Cologne and Rheims, and the dioceses of Cologne, Utrecht, Liège, Cambrai, Tournai, and Thérouanne (and less so Arras), all of which would lose large tracts of their territories and many subjects. Cologne would be compensated for its losses by the creation of a new diocese with its cathedral in Roermond, covering the area from Nijmegen southwards into Limbourg. This diocese would become a new suffragan of Cologne. The other bishops would receive annuities as compensation, as well as the landed properties of some important monasteries. Even better, with their reduced sizes, the affected dioceses would be able to improve the care of the souls of all their inhabitants, and who could complain about that? ${ }^{67}$

64 Dierickx (De oprichting, pp. 37-38; Documents, vol. 1, p. 151) still believed that the author was another inquisitor, Ruard Tapper. Since then, Postma has convincingly shown that the old attribution of the plan to Sonnius was correct indeed: Postma, 'Nieuw licht op een oude zaak', and Postma, Viglius van Aytta, pp. 83-85. The text of the plan is edited in Dierickx, Documents, vol. 1, pp. 107-151.

65 Dierickx, Documents, vol. 1, p. 145: 'ut saltem plurima oppida simul cum suis territoriis habeant unum episcopum unumque collegium doctorum virorum ad defensionem animarum suarum contra rapacissimos lupos undequaque irruentes'. On p. 127: half of the income of the canons would come from attendance fees for choir services.

66 Ibid., p. 112: 'Sanctissimus Dominus noster Julius et qui cum eo sunt Cardinales [...]".

67 Ibid., pp. 142-144. Compare with Schmidt, 'Neugliederung', pp. 114-118 and 120-122. 
Sonnius justified all these changes by recalling that no part of the Christian world was more populous than the Low Countries, dotted as these were with towns, castles, and villages, rich in trade and crafts - with the exception, however, of an adequate number of bishops. ${ }^{68}$ Furthermore, some of these bishoprics were situated partly outside the dominions of Charles V, with nefarious consequences due to the ever-ongoing wars of kings and princes. Sonnius noted that the bishopric of Utrecht contained no less than 2,080 parishes and circa 200 walled towns. He tried to devise its partition into five or six bishoprics, taking account of former principalities and existing regions, natural frontiers, and distances, but also of an idea of population density. He argued to the pope and his cardinals that Utrecht itself was more or less comparable to Augsburg, in population and circumference. Other towns like Amsterdam, Delft, or Gouda were much larger than Trent (c. 7,000 inhabitants); a number of others were comparable or (much) smaller. ${ }^{69}$ The town of Den Bosch was easily four times as large as Trent, and contained a school with over 1,00o pupils, maybe even double that number. ${ }^{70}$ More curious in our eyes was his justification for the creation of a bishopric in Zeeland, with its seat in Middelburg: this island was situated in the ocean, where the air is unhealthier and the smell of the sea is more repulsive to outsiders'. For that reason, it was more expedient if the inhabitants got their own bishop, a native of their region who could better stand the odour. ${ }^{71}$ Sometimes Sonnius used distances between towns (a two-day trip) or existing regions and borders, at other times he 'draws a straight line' to demarcate territories..$^{2}$ The word territorium itself is rarely used in this proposal, although Sonnius writes that the regions mentioned (like Holland) will have one bishop, who together with his clergy will take care of several towns and the surrounding

68 Dierickx, Documents, vol. 1, p. 108: 'nulla pars orbis Christiani aut populosior sit, aut frequentior oppidis, castris, pagis, negotiationibus, divitiis, nobilitate [...]".

69 Ibid., pp. 109-113, with this on p. 112: "habent perspectissimam magnitudinem et qualitatem huius civitatis Tridentinae'.

70 Ibid., p. 132. Sonnius himself was born in Zon, in the vicinity of Den Bosch where he had been a pupil himself. In his study of Sonnius and all the criticism voiced against him, Goossens gives the average number of parishioners in these new dioceses as 150,000: Goossens, Franciscus Sonnius in de pamfletten, p. 47.

71 Ibid., p. 115: 'Et quia haec insula est in Oceano, ubi est aer insalubrior et odor maris exteris hominibus inconveniens, ideo expediret eos habere proprium episcopum ex ea regione assumptum, illiusque aeris bene patientem.' Sonnius might refer to the smell of drying and rotting plants or grounds during ebb.

72 Ibid., p. 113: 'usque ad rectam lineam trahendam a Munickhuysen prope Airnhem ad medium locum inter Amersfoert et Harderwijck [...]'. For distances, also p. 132; for a straight line, p. 133. 
'territories' under their authority. ${ }^{73}$ While the word 'territory' means the geographical zone of urban jurisdiction here, it is clear that the new bishoprics can be interpreted likewise as a type of territory, as dioceses with all of the earlier described criteria of borders, jurisdiction, fiscality, population, and conceptual coherence. ${ }^{74}$ For the design of the other dioceses, Sonnius used the same criteria, although he was less elaborate for Flanders. The rest of his plan was devoted to a project for an endowment of all these new bishoprics, mainly by the incorporation of (parts of) some of the grand old monasteries. The great advantage of this type of endowment for the emperor would be the huge reduction of costs; its political consequences were severely underestimated, but that is another story.

Sonnius's plan gained momentum the moment it got into the hands of Viglius of Aytta, president of the Secret or Privy Council, one of the most influential councillors and politicians in the Low Countries, and a close collaborator of Regent Mary of Hungary and Granvelle, the future cardinal and archbishop of Malines. ${ }^{75}$ From 1558 onwards Sonnius worked in Rome as a representative of Philip II, the new overlord of the Low Countries, to secure papal consent and support for the new bishoprics. Partly due to changing political circumstances, the pope finally solemnly promulgated the creation of the bishoprics on 12 May 1559. Sonnius had received an extensive instruction for the reorganisation, signed by Philip himself, and presented the pope and his cardinals with all kinds of documents and several maps, decorated with coloured ribbons to indicate the new dioceses. A committee of several cardinals had approved the plans beforehand.$^{6}$ In the end, fourteen new bishoprics and three new provinces (Cambrai was added) were created.

On the advice of the committee of cardinals, Sonnius had added an explanation and justification to the decision of the committee. He stressed all the expenses the king had incurred with the Inquisition and with the creation of these new bishoprics. He mentioned that all their territories were part of the Low Countries. In another document the author clearly differentiated

73 Ibid., p. 145 .

74 See also Schmidt, 'Einleitung', p. 12: ‘[... er blieb wirksam und förderte eine räumlich struktierte Kompetenzdefinition, welche sich auch als Präfiguration moderner Staatlichkeit erweisen konnte. Vor allem verknüpften die Bistümer die Beziehungen der Menschen innerhalb konkret erfahrbarer Kontakte des Alltagslebens mit einer umfassenden Großorganisation, deren Wirkung den Horizont des Einzelnen überschritt, ihn an eine idealiter die Menschheit umfassende Kirche und Christenheit anband. [...]'.

75 Postma, Viglius van Aytta, pp. 84-86.

76 Dierickx, De oprichting, pp. 45-59; Dierickx, Documents, vol. 1, pp. 171-174, 178-207; Postma, Viglius van Aytta, pp. 168-172; the advice of the Committee of Seven Cardinals is edited by Jansen, 'Het advies', pp. 3-22; the papal bull by Brom and Hensen in Romeinsche bronnen, pp. 69-74. 


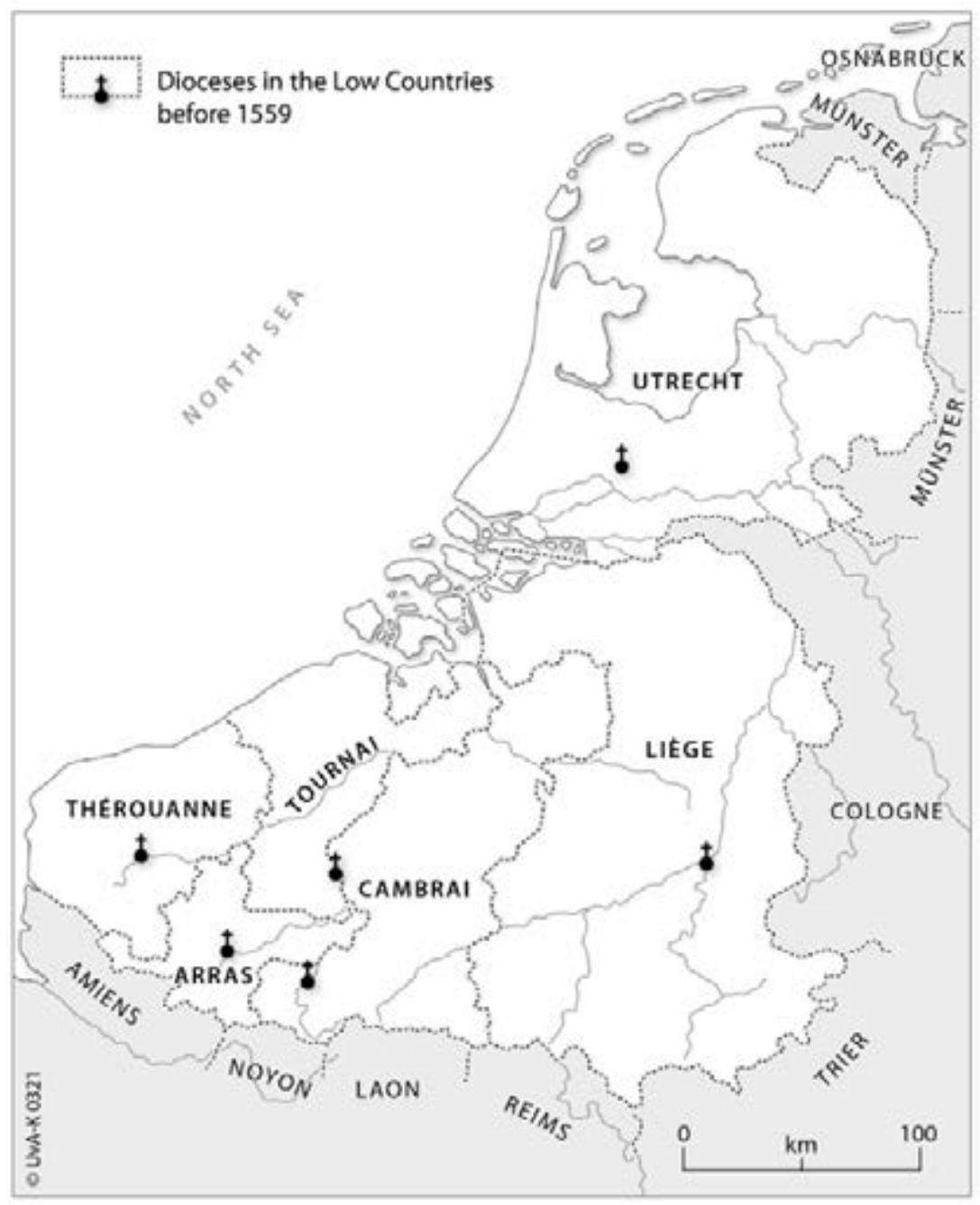

Fig. 3.1. Map of the dioceses in the Low Countries before 1559. Source: UvA-Kaartenmakers, on the basis of a design by Hans Erens. WikiCommons Low Countries Medieval Dioceses.

between Flemish-speaking lands and dioceses and francophone ones. ${ }^{77}$ In still another one the magnitude of the dioceses was given with their length and breadth (for example, 69 Italian miles by 40 miles for Utrecht), and the number of their towns. ${ }^{78}$ In the final bull all these elements return, the diocesani linguae idiomate, the boundaries of Philip's dominions (intra 


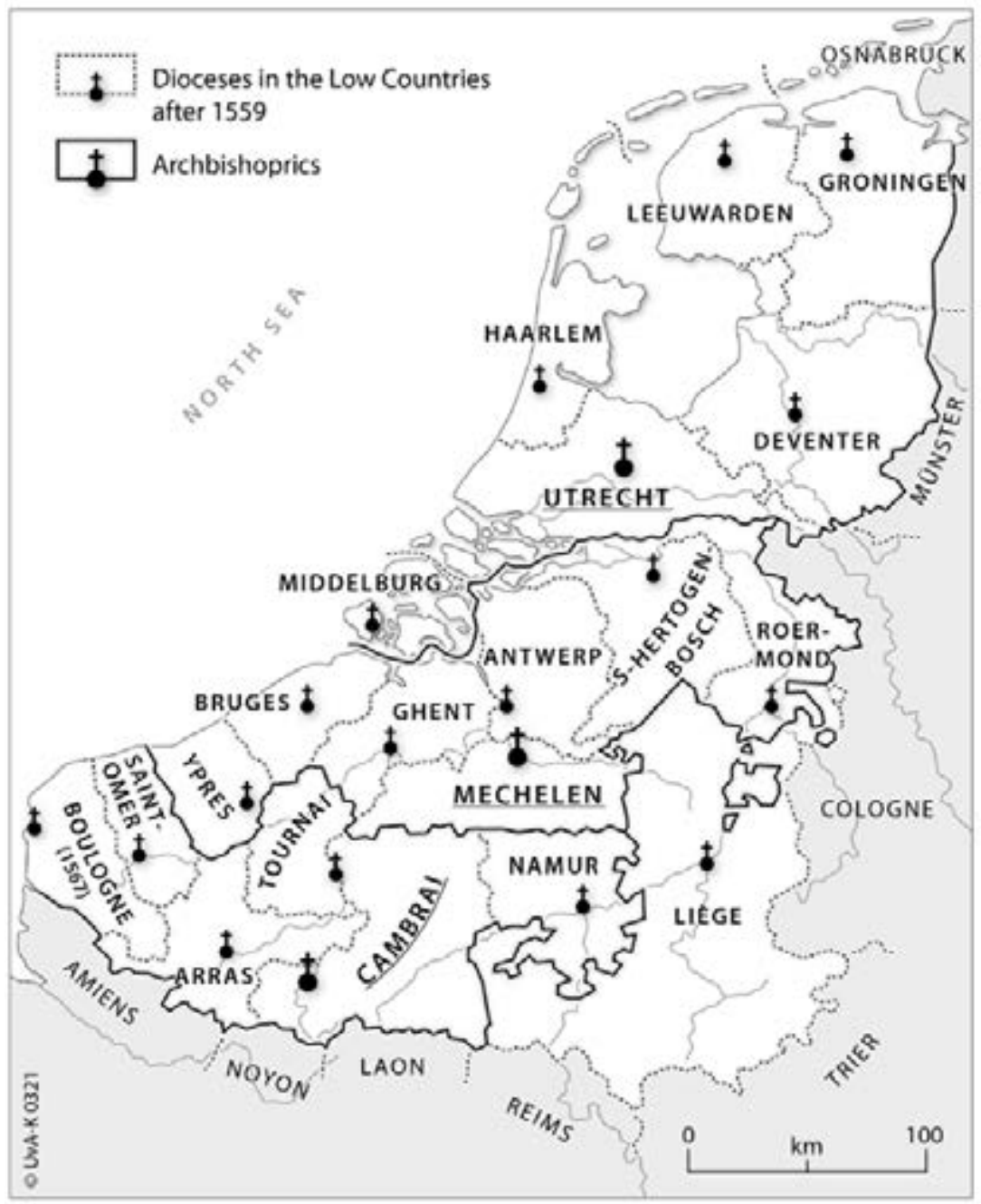

Fig. 3.2. Map of the (arch)dioceses in the Low Countries after 1559. Source: UvA-Kaartenmakers, on the basis of a design by Hans Erens. WikiCommons Super Universas Dioceses.

fines Philippi regis), natural frontiers like the river Waal (=Rhine), and the dimensions and towns of each diocese..$^{79}$ In response to the proposal of Sonnius, the pope had ordered a committee of five (which consisted, among others, of Granvelle, Viglius, and, later, Sonnius) definitively to settle the territories of the new dioceses and their endowments. Almost all dioceses were described by an enumeration of oppida et villagia sive pagos, although 
for Saint-Omer and Ypres the churches and parishes of each town, in their respective deaneries, were listed. Both systems were probably identical, so that a village coincided with its parish. ${ }^{80}$

All in all, most elements and motivations in these plans were not new. For instance, the wish to let a diocese correspond with (a part of) a principality can already be found in reform proposals for Flanders circa 1300. Another example concerns the idea of natural borders, and the wish for smaller dioceses with a reformed, learned, and resident clergy. The criterion of language to separate bishoprics is equally important. However, this principle had already been drawn upon after the Battle of the Golden Spurs of 1302, when the Flemish supplicated the pope to remove the Walsce (francophone) bishops and to create new bishoprics. ${ }^{81}$ More important than mere politics here was canon law, which required that each parish priest be able to preach and converse in the native language (idioma). Border maps were at least a century and a half old or more. However, the combination of population density, distances, natural borders (or just straight lines), language as a demarcation, political unity, and the correspondence between ecclesiastical and political unity, plus the new purpose of defence against heresy, was a potent one. According to the geographer Herman van der Haegen, it was even a first attempt to create a new spatial, rational, administrative, and hierarchical division of the Low Countries. ${ }^{82}$ North of the 'great rivers' we find the northern Low Countries with Utrecht as archbishopric; south of it a 'Flemish space' for the non-francophone southern Low Countries (with Malines), and furthermore the francophone southern Low Countries minus the independent Liège (with Cambrai). ${ }^{8_{3}}$ The new dioceses reinforced existing identities; for Van der Haegen it was the start of a tripartite division of the Low Countries, and the first acknowledgement of the Flemish-speaking Low Countries as a unified spatial and ecclesiastical entity. ${ }^{84}$

8o Dierickx, Documents, vol. 1, pp. 223-224 and 266-302. For the endowment, see pp. 506-526. Compare with Schmidt, 'Neugliederung', pp. 114-116 and 122-124.

81 Dierickx, De oprichting, pp. 26-27. In the decision of the Committee of the Seven Cardinals in 1558 or 1559 for instance: 'Postremo quia diversitas idiomatum est inter Remenses et plerasque ecclesias per Flandriam erigendas, atque tanta distantia, ut novem dierum itinere opus sit, priusquam Remensis ecclesiam adeatur [...]'. On language as a decisive factor, see also: Schmidt, 'Raumkonzepte', pp. 121-124, although he mentions canonical objections.

82 Van der Haegen, De eerste Vlaamse ruimte, p. 34

83 Ibid., pp. 42-48 and 52-56.

84 Ibid., pp. 57-61. Van der Haegen's grand concept is, however, liable to critique in its discussion of the historical dimension of modern terms. 


\section{Conclusion}

Parishes grew out of the need to take care of the souls of people. The scale of this care was, just as much in the Later Medieval period as in the early modern one, described as a particular number of 'souls': a curate had to take care of a certain number of souls or his parish numbered a stated number of souls. The parishes, or more correctly for the earliest period, their parish churches, formed the basis of dioceses. A diocese consisted of a number of parishes. Usually, the boundaries of parishes determined the boundaries of dioceses. From the Later Middle Ages onwards we have a system in which people identified themselves with their parishes. ${ }^{85}$ They also carried all kinds of fiscal and monetary obligations, in the form of the upkeep of the church building, the remuneration of the clergy, and the payment of tithes and taxes to bishops, cathedrals, archdeacons, and so on. Legally, they were subjected to a whole hierarchy, from their own parish priest to the archdeacon, bishop, archbishop, and finally to the pope and his auditors and penitentiaries. These clerical leaders made elaborate use of canon law, expressed in diocesan statutes, in edicts, and in all kinds of verdicts. Finally, there was a clear idea of boundaries and contiguous territories, albeit with disputes and their resulting adjustments. Distances and population density mattered, too. Finally, the vernacular language was another formative factor. With Dominique Iogna-Prat, we can succinctly summarise the Church as an 'institution totale'. ${ }^{86}$

All in all, we have all the criteria and conceptual tools here that Elden stipulated: territory, economy, law, population, identity, and even, in a way, sovereignty and supremacy, not just as vague ideas, not only in practices, but clearly delineated and integrated into a complete ecclesiastical structure and mindset. ${ }^{87}$ One wonders why Elden chose to concentrate on 'political technology', and looked for it only in the theorists of temporal power and the great names of Western political

85 For instance: Duffy, Stripping of the Altars, pp. 131-154; Duffy, Voices of Morebath; Bogaers, Aards, betrokken en zelfbewust, pp. 179-346 and 371-492.

86 Iogna-Prat, La Maison Dieu, p. 309, in a preliminary conclusion under the heading 'une première territorialité chrétienne', describing the end of a development between c. 800 and c. 1040, with l'emergence de l'Église comme “institution totale”, comme "corps" destiné à inclure l'ensemble de la société'.

87 See also Schmidt, 'Neugliederung', p. 107: 'Die verfaßte Kirche imitierte das römische Imperium und präfigurierte damit den neuzeitlichen Staat. Die hierarchische Struktur der Kirche verteilte Kompetenzen, legte befehlsgewalten und Partizipationen fest. Zuständigkeiten waren auf Räume bezogen', and pp. 108-113. 
thought. ${ }^{88}$ Is it because they won the game in the end? Is it because the modern mind rejects the idea of a clerical birth of some of these ideas and of the important role clerics played in the development of an alternative idea of ecclesiastical territory? ${ }^{89}$ More broadly, Francis Oakley has shown in his trilogy how much of the Western character of political theory originates in the way clerical ideas and positions were integrated in the debate on power and responsibility, and were used to formulate new theories. $9^{9}$

The word 'territory' may have been used rarely by medieval writers with the exception of legists like Bartoldus - but the concept certainly was well known, at least in the matter of ecclesiastical organisation and the structure of the church and its faithful. The concept of a territory definitely existed in the minds of the late medieval clergy, first and foremost of ecclesiastical territory. It also means that elements of this concept were used in debates, in conflicts, and in modes of thinking. ${ }^{11}$ It even influenced theorists of temporal power and respublica as, for example, the fourteenth-century cleric and legal expert Philip of Leyden. He used Justinian's maxim but then with the pope instead of the emperor as 'the living law on earth', the lex animata in terrenis..$^{92}$ How exactly clerical ideas and concepts of ecclesiastical territories like parishes and bishoprics influenced the development of secular notions and practices is still a question that has to be delved into more deeply. The conclusion of Florian Mazel's book on bishops and territory neatly summarises some options here:

Concerning the concept of territory, the Church showed the State the way to proceed in a double way: on the one hand it provided the men and the administrative framework, indispensable for two practices which can be considered as the main instruments of power of the Later Middle Ages: the inquiry and direct taxes. On the other hand, it provided the State, in a more general sense, with a concept of spatial control, construed in

88 Elden, The Birth, pp. 6, 8, and 15-18.

89 Mazel, L'évêque et le territoire, pp. 290-306 and 365-376.

90 Oakley, The Watershed, pp. ix-xv. See in his books the references to, for instance, ecclesiastical jurisdiction, dominium, and spiritual vs. temporal authority.

91 For one of the possible approaches to get a better grip on forms of pre-modern innovation, see the conclusion of Stefan Burkhardt on twelfth-century Mainz: “Stupentes"', pp. 174-175.

92 Timmer, Profeet, p. 107; Leupen, Philip of Leyden, pp. 188-197; the quote comes from a disputatio of Jan van Borssele $\left(1365^{\dagger}\right)$, professor of law in Paris and a canon of St. Saviour in Utrecht: see Philippus de Leyden, De cura reipublicae, pp. 123-125. 
a territorial way, and not as an aspect of lordship. A concept that was more connected to practices of sovereignty than it pertained to a feudal rationale. ${ }^{93}$

\section{Bibliography}

\section{Primary sources}

Bronnen voor de geschiedenis der kerkelijke rechtspraak in het bisdom Utrecht in de middeleeuwen, vol. 6, ed. by J.G.C. Joosting ('s-Gravenhage: Martinus Nijhoff, 1919).

Dierickx, M., ed., Documents inédits sur l'érection des nouveaux diocèses aux Pays-Bas (1521-1570), 3 vols (Bruxelles: Académie Royale de Belgique, 1960-1962).

Het Goudse hofstedengeldregister van ca. 1397 en andere bronnen voor de vroege stadsontwikkeling van Gouda, ed. by K. Goudriaan, B.J. Ibelings and J.C. Visser (Hilversum: Uitgeverij Verloren, 2000).

Enea Silvio Piccolomini - Pius II (1405-1464): een humanistisch paus op de bres voor Europa. Bloemlezing uit zijn brieven en Gedenkschriften, trans. by Michel Goldsteen, introduction and notes by Zweder von Martels and Michel Goldsteen (Hilversum: Uitgeverij Verloren, 2011).

Fairon, Émile, ed., 'Un projet de démembrement du diocèse de Liége proposé par les Brabançons en 1332 et 1336', Bulletin de la Commission royale d'Histoire 78 (1909), 142-192.

Jansen, A., ed., 'Het advies der commissie van zeven kardinalen omtrent het voorstel van Philips II ter regeling van de bisschoppelijke hierarchie in de Nederlanden', Archief voor de geschiedenis van het Aartsbisdom Utrecht 9 (1881), 1-22.

Philippus de Leyden, De cura reipublicae et sorte principantis, ed. by P.C. Molhuysen ('s-Gravenhage: Martinus Nijhoff, 1915).

Piccolomini, Aeneas Sylvius, Europe (c. 1400-1458), trans. by Robert Brown; intr. and ann. by Nancy Bisaha (Washington, DC: Catholic University of America Press, 2013). Piccolomini, Enea Silvio, Deutschland. Der Brieftraktat an Martin Mayer und Jacob Wimpfelings 'Antworten und Einwendungen gegen Enea Silvio', trans. by Adolf Schmidt (Köln/Graz: Böhlau Verlag, 1962).

93 Mazel, L'évêque et le territoire, p. 373: 'En matière territoriale, l'Église ouvrit donc doublement le chemin à l'État: d'une part en mettant à sa disposition les hommes et le cadre administratif indispensables à la mise en œuvre des deux pratiques qui apparaissent aujourd'hui comme les principaux instruments de l'essor de sa puissance au cours du second Moyen Âge, l'enquête et la fiscalité directe ; d'autre part et de manière plus générale en lui offrant un modèle de domination spatiale d'ordre territorial et non seigneurial, qui relevait d'une logique de souverainité et non d'une logique féodale.' 
Reject Aeneas, Accept Pius. Selected Letters of Aeneas Sylvius Piccolomini (Pope Pius II), trans. by Gerald Christianson, Thomas M. Izbicki, and Philip Krey (Washington, DC: Catholic University of America Press, 2006).

Romeinsche bronnen voor den kerkelijk-staatkundigen toestand der Nederlanden

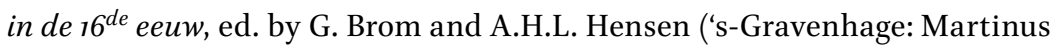
Nijhoff, 1922).

Schuchard, Christiane, and Knut Schulze, ed., Thomas Giese aus Lübeck und sein römisches Notizbuch der Jahre 1507 bis 1526 (Lübeck: Schmidt-Römhild, 2003).

Zestiende-eeuwsche wandelingen door Nederland. Zwerftochten van Pieter Aelmanszoon, secretaris van Naarden, 1525-1527, ed. by D.Th. Enklaar (Hilversum: De Kroon, 1934).

\section{Secondary sources}

Abulafia, David, 'Introduction: Seven Types of Ambiguity, c. 1100-c. 1500', in Medieval Frontiers: Concepts and Practices, ed. by David Abulafia and Nora Berend (Aldershot: Ashgate, 2002), pp. 1-34.

Akbari, Suzanne Conklin, Idols in the East. European Representations of Islam and the Orient, 1100-1450 (Ithaca, NY: Cornell University Press, 2009).

Aubrun, Michel, La paroisse en France des origines au $X V^{e}$ siècle (Paris: Picard, 1986). Aydoğan, Zeynep, 'Changing Perceptions along the Frontiers: The Moving Frontier with Rum in Late Medieval Anatolian Frontier Narratives', in Living in the Ottoman Realm: Empire and Identity, $13^{\text {th }}$ to $20^{\text {th }}$ Centuries, ed. by Christine Isom-Verhaaren and Kent F. Schull (Bloomington: Indiana University Press, 2016), pp. 29-41.

Baldi, Barbara, 'Enea Silvio Piccolomini e il De Europa: umanesimo, religione e politica', Archivio Storico Italiano 161 (2003), 619-683.

Barralis, Christine, et al., eds, Église et État, Église ou État? Les clercs et la genèse de l'État moderne (Rome: Publications de la Sorbonne/École française de Rome, 2014).

Baumgärtner, Ingrid, and Hartmut Kugler, eds, Europa im Weltbild des Mittelalters: kartographische Konzepten (Berlin: Akademie Verlag, 2008).

Bijsterveld, A.J.A., Laverend tussen kerk en wereld. De pastoors in Noord-Brabant 1400-1570 (Amsterdam: VU Uitgeverij, 1993).

Biller, Peter, The Measure of Multitude. Population in Medieval Thought (Oxford: Oxford University Press, 200o).

Bisaha, Nancy, Creating East and West. Renaissance Humanists and the Ottoman Turks (Philadephia: University of Pennsylvania Press, 2004).

Blair, John, 'Les recherches récentes sur la formation des paroisses en Angleterre: similitudes et différences avec la France', Médiévales 49 (La paroisse. Genèse d'une forme territoriale) (2005), 33-44. 
Blair, John, The Church in Anglo-Saxon Society (Oxford: Oxford University Press, 2005).

Bogaers, Llewellyn, Aards, betrokken en zelfbewust. De verwevenheid van cultuur en religie in katholiek Utrecht, 1300-16oo (Utrecht: Levend Verleden, 2008).

Borsche, Tilman, 'Die verborgene Kirche (ecclesia occulta) als verbindende Kraft Europas nach Nikolaus von Kues: De concordantia catholica', in Nikolaus von Kues: Die Großregion als Denk- und Lebensraum, ed. by Harald Schwaetzer and Marie-Anne Vannier (Münster: Aschendorff Verlag, 2019), pp. 49-59.

Bünz, Enno, 'Pfarreien und Pfarrgemeinden im spätmittelalterlichen Deutschland', in Pfarreien in der Vormoderne. Identität und Kultur im Niederkichenwesen Europas, ed. by Michele C. Ferrari and Beat Kümin (Wiesbaden: Harrssowitz Verlag, 2017), pp. 25-59.

Bünz, Enno, and Gerhard Fouquet, eds, Die Pfarrei im späten Mittelalter (Ostfildern: Thorbecke, 2013).

Burkhardt, Stefan, Mit Stab und Schwert. Bilder, Träger und Funktionen erzbischöflicher Herrschaft zur Zeit Kaiser Friedrich Barbarossa. Die Erzbistümer Köln und Mainz im Vergleich (Ostfildern: Thorbecke, 2008).

Burkhardt, Stefan, “Stupentes ob inauditam novitatem”. Das "Neue” im Mainzer Erzstift des 12. Jahrhunderts. Zur Anwendung von Innovationstheorien auf das Mittelalter', VSWG: Vierteljahrschrift für Sozial- und Wirtschaftsgeschichte 97 (2010), 160-175.

Carette, Jeremy R., Foucault and Religion: Spiritual Corporality and Political Spirituality (New York: Routledge, 200o).

Casella, Nicola, 'Pio II tra geografia e storia: La "Cosmographia”, Archivio della Società Romana di Storia Patria 95 (1972), 35-112.

Claeys-Bouüaert, F., 'Évèques', Dictionnaire de droit canonique, 7 vols (Paris: Librairie Letouzey, 1935-1965), vol. 5 [1953], pp. 569-589.

Comte, François, and Emmanuel Grélois, 'La formation des paroisse urbaines: les exemples d'Angers et de Clermont ( $\mathrm{X}^{\mathrm{e}}$-XIII ${ }^{\mathrm{e}}$ siècles)', Médiévales 49 (La paroisse. Genèse d'une forme territoriale) (2005), 57-72.

Cosgrove, Denis E., Apollo's Eye: A Cartographic Genealogy of the Earth in the Western Imagination (Baltimore: Johns Hopkins University Press, 2001).

Dekker, C., 'De vorming van aartsdiakonaten in het diocees Utrecht in de tweede helft van de 11 e en het eerste kwart van de $12{ }^{\mathrm{e}}$ eeuw', KNAG Geografisch tijdschrift, nieuwe reeks 11 (1977), 339-36o.

Dekker, C., Het Kromme Rijngebied in de Middeleeuwen. Een institutioneelgeografische studie (Zutphen: Walburg Pers, 1983).

De Langen, G., and J.A. Mol, 'Church Foundation and Parish Formation in Frisia in the Tenth and Eleventh Cenruries: A Planned Development?', The Medieval Low Countries 4 (2017), 1-55. 
De Langen, Gilles J., and Johannes A. Mol, 'Church, Landscape, and Power in "Holland" West Frisia up to the Middle of the Eleventh Century: The Bishop, the Count, and the Development of the Parish System in Frisia between Vlie and Zonnemare', The Medieval Low Countries 7 (2020), 9-48.

De Langen, Gilles de, and Hans Mol, 'Kerk, macht en ruimte in Holland tot het midden van de $11^{\text {de }}$ eeuw. De uitbouw van het parochiewezen tussen Maas en Vlie', Holland Historisch Tijdschrift 50 (2018), 264-273.

De Moreau, E., Histoire de l'Église en Belgique, tome complémentaire I, texte, circonscriptions ecclésiastiques (Bruxelles: L'Édition Universelle, 1948).

Dierickx, M., De oprichting der nieuwe bisdommen in de Nederlanden onder Filips II 1559-1570 (Antwerpen en Utrecht: Standaard en Spectrum, 1950).

Duffy, Eamon, The Stripping of the Altars. Traditional Religion in England, c. 140o-c. 1580 (New Haven/London: Yale University Press, 1992).

Duffy, Eamon, The Voices of Morebath. Reformation and Rebellion in an English Village (New Haven/London: Yale University Press, 2001).

Elden, Stuart, The Birth of Territory (Chicago: University of Chicago Press, 2013).

Elden, Stuart, Foucault: The Birth of Power (Cambridge: Polity Press, 2017).

Elden, Stuart, 'How Should We Do the History of Territory?', Territory, Politics, Governance 1, no. 1 (2013), 5-20.

Ellenblum, Ronnie, 'Were There Borders and Borderlines in the Middle Ages? The Example of the Latin Kingdom of Jerusalem', in Medieval Frontiers: Concepts and Practices, ed. by David Abulafia and Nora Berend (Aldershot: Ashgate, 2002), pp. 105-119.

Enklaar, D.Th., 'De oudste kaarten van het Gooiland en zijn grensgebieden', Nederlandsch Archievenblad 39 (1931/1932), 185-205.

Esch, Arnold, Landschaften der Frührenaissance. AufAusflug mit Pius II (München: Verlag C.H. Beck, 2008).

Falk, Seb, The Light Ages. A MedievalJourney of Discovery (London: Penguin Random House, 2020).

Favier, Jean, Un roi de marbre (= Philippe le Bel (1978) and Enguerran de Marigny (1963)) (Villeneuve d'Asq: Fayard, 2005).

Feine, Hans Erich, Kirchliche Rechtsgeschichte. Die Katholische Kirche (Köln/Wien: Böhlau Verlag, 1972).

Finke, Heinrich, 'Die Nation in den spätmittelalterlichen allgemeinen Konzilien', Historisches Jahrbuch 57 (1937), 323-338.

Gebel, Doris, Nikolaus von Kues und Enea Silvio Piccolomini. Bilder der außereuropäischen Welt als Spiegelung europäischer Sozialverhältnisse im 15. Jahrhundert, PhD thesis, Hamburg 1977.

Goetz, Hans-Werner, 'Discourses on Purity in Western Christianity in the Early and High Middle Ages', in Discourses of Purity in Transcultural Perspective 
(300-16oo), ed. by Stefan Kock, Nikolas Jaspert and Matthias Bley (Boston/ Leiden: Brill, 2015), pp. 116-150.

Goossens, Th., Franciscus Sonnius in de pamfletten. Bijdragen tot zijne biografie ('s-Hertogenbosch: G. Mosmans, 1917).

Groeneveld, Jaap, 'De oostgrens van het Gooi. De geschiedenis van de verschillende grensvakken', Historische Kring Eemnes 28 (2006), 115-131.

Haarländer, Stephanie, Vitae episcoporum: eine Quellengattung zwischen Hagiographie und Historiographie, untersucht an Lebensbeschreibungen von Bischöfen des Regnum Teutonicum im Zeitalter der Ottonen und Salier (Stuttgart: Hiersemann, 2000).

Halfond, Gregory, 'Review: Florian Mazel, L'évêque et le territoire', Church History 87 (2018), 189-191.

Harvey, P.D.A., ed., The Hereford World Map: Medieval World Maps and Their Context (London: The British Library, 2006).

Hautefeuille, Florent, 'La cartographie de la paroisse et ses difficultés de réalisation', in Aux origines de la paroisse rurale en Gaule méridionale (IV $V^{e} I X^{e}$ siècles), ed. by Christine Delaplace (Paris: Éditions Errances, 2003), pp. 24-32.

Hautefeuille, Florent, 'La délimitation des territoires paroissiaux dans les pays de moyenne Garonne ( $\mathrm{X}^{\mathrm{e}}-\mathrm{XV}^{\mathrm{e}}$ siècles)', Médiévales 49 (La paroisse. Genèse d'une forme territoriale) (2005), 73-88.

Hay, Denys, Europe: The Emergence of an Idea (Edinburgh: Edinburgh University Press, 1957).

Hirschi, Caspar, 'Das humanistische Nationskonstrukt vor dem Hintergrund modernistischer Nationalismustheorien', Historisches Jahrbuch 122 (2002), 46-66.

Hirschi, Caspar, The Origins of Nationalism. An Alternative History from Ancient Rome to Early Modern Germany (Cambridge: Cambridge University Press, 2012).

Holland, Nancy J., “'Truth as Force”: Michel Foucault on Religion, State Power, and the Law', Journal of Law and Religion 18 (2002-2003), 79-97.

Iogna-Prat, Dominique, La Maison Dieu. Une histoire monumentale de l'Église au Moyen Âge (Paris: Seuil, 2006).

Janssen, Wilhelm, Das Erzbistum Köln im späten Mittelalter 1191-1515 (Köln: J.P. Bachem Verlag, 1995).

Janssen, Wilhelm 'Die Differenzierung der Pfarrorganisation in der spätmittelalterlichen Erzdiözese Köln. Bemerkungen zum Verhältnis von "capella dotata”, "capella curata" und "ecclesia parochialis", Rheinische Vierteljahrsblätter 55 (1991), 58-83.

Jongkees, A.G., Staat en kerk in Holland en Zeeland onder de Bourgondische hertogen 1425-1477 (Groningen en Batavia: Wolters, 1942).

Karageorgos, Basileios, 'Der Begriff Europa im Hoch- und Spätmittelalter', Deutsches Archiv für Erforschung des Mittelalters 48 (1992), 137-164. 
Kempshall, M.S., The Common Good in Late Medieval Political Thought (Oxford: Clarendon Press, 1999).

Kibre, Pearl, The Nations in the Mediaeval Universities (Cambridge, MA: Mediaeval Academy of America, 1948).

Klueting, Edeltraut, Harm Klueting and Hans-Joachim Schmidt, eds, Bistümer und Bistumsgrenzen vom frühen Mittelalter bis zur Gegenwart (Rome: Herder, 2006).

Krah, Adelheid, “'Natio”, nicht Nation?', Francia. Forschungen zur westeuropäischen Geschichte 45 (2018), 241-262.

Kuys, Jan, Kerkelijke organisatie in het middeleeuwse bisdom Utrecht (Nijmegen: Valkhof Pers, 2004).

Lambrecht, D., De parochiale synode in het oude bisdom Doornik gesitueerd in de Europese ontwikkeling ${ }_{11}{ }^{\text {de }}$ eeuw-1559 (Brussel: Verhandelingen van de Koninklijke Academie voor Wetenschappen, Letteren en Schone Kunsten van België, 1984).

Lauwers, Michel, Naissance du cimetière. Lieux sacrés et terre des morts dans l'Occident médiéval (Paris: Aubier, 2005).

Lauwers, Michel, 'Paroisse, paroissiens et territoire. Remarques sur parochia dans les textes latins du Moyen Âge', Médiévales 49 (La paroisse. Genèse d'une forme territoriale) (2005), 11-32.

Leturq, Samuel, 'Territoires agraires et limites paroissiales', Médiévales 49 (La paroisse. Genèse d'une forme territoriale) (2005), 89-103.

Leupen, Piet, Philip of Leyden. A Fourteenth Century Jurist (The Hague and Zwolle: Leiden University Press and Tjeenk Willink, 1981).

Mazel, Florian, Féodalités 880-118o (Paris: Belin, 2010).

Mazel, Florian, L'évêque et le territoire. L'invention médiévale de l'espace ( $V^{e}-X I I I^{e}$ siècle) (Paris: Seuil, 2016).

Meserve, Margaret, Empires of Islam in Renaissance Historical Thought (Cambridge, MA: Harvard University Press, 2008).

Meserve, Margaret, 'From Samarkand to Scythia: Reinventions of Asia in Renaissance Geography and Political Thought', in Pius II, 'el piu expeditivo pontefice': Selected Studies on Aeneas Silvius Piccolomini (1405-1464), ed. by Zweder R.W.M. von Martels and Arjo Vanderjagt (Boston/Leiden: Brill, 2003), pp. 13-40.

Möller, Steffen, 'Nicolaus Cusanus als Geograph', in Das europäische Erbe im Denken des Nikolaus von Kues. Geistesgeschichte als Geistesgegenwart, ed. by Harald Schwaetzer and Kirstin Zeyer (Münster: Aschendorff Verlag, 2008), pp. 215-227.

Moolenbroek, J.J. van, 'Zeeuwen in verzet tegen hun kerkelijke rechters. Een enquête in het jaar 1505', Tijdschrift voor Geschiedenis 100 (1987), 507-532.

Moritz, Arne, 'Concordantia als normatives Prinzip der Herrschaft über Freie und Gleiche. Nikolaus von Kues innerhalb der Geschichte der europäischen Demokratie', in Das europäische Erbe im Denken des Nikolaus von Kues. Geistesgeschichte 
als Geistesgegenwart, ed. by Harald Schwaetzer and Kirstin Zeyer (Münster: Aschendorff Verlag, 2008), pp. 257-282.

Muller Hzn., S., De indeeling van het bisdom ('s-Gravenhage: Martinus Nijhoff, 19o6). Nikolaus von Kues: Die Großregion als Denk- und Lebensraum, ed. by Harald Schwaetzer and Marie-Anne Vannier (Münster: Aschendorff Verlag, 2019).

Noizet, Hélène, 'De l'église au territoire: les paroisses à Tours (XI ${ }^{\mathrm{e}}-\mathrm{XIII}{ }^{\mathrm{e}}$ siècles)', Médiévales 49 (La paroisse. Genèse d'une forme territoriale) (2005), 45-56.

Noizet, Hélène, Xavier Rodier and Elisabeth Zadora-Rio, 'Débat à propos Des paroisses de Touraine aux communes d'Indre-et-Loire. La formation des territoires: une lecture critique d'Hélène Noizet, avec les réponses des auteurs de l'ouvrage', Les petits cahiers d'Anatole 23 (2013), 2-26, http://citeres.univ-tours.fr/doc/lat/ pecada/pecada_23.pdf.

Oakley, Francis, The Mortgage of the Past: Reshaping the Ancient Political Inheritance (1050-1300) (New Haven/London: Yale University Press, 2012).

Oakley, Francis, The Watershed of Modern Politics: Law, Virtue, Kingship, and Consent (1300-1650) (New Haven/London: Yale University Press, 2015).

O'Brien, Emily, The Commentaries of Pope Pius II (1458-1464) and the Crisis of the Fifteenth-Century Papacy (Toronto: University of Toronto Press, 2015).

Oschema, Klaus, Bildervon Europa im Mittelalter (Ostfildern:Jan Thorbecke Verlag, 2013).

Patzold, Steffen, Episcopus. Wissen über Bischöfe im Frankenreich des späten 8. bis frühen 10. Jahrhunderts (Ostfildern: Jan Thorbecke Verlag, 2008).

Postma, Folkert, 'Nieuw licht op een oude zaak: de oprichting van de nieuwe bisdommen in 1559', Tijdschrift voor Geschiedenis 103 (1990), 10-27.

Postma, Folkert, Viglius van Aytta. De jaren met Granvelle 1549-1564 (Zutphen: Walburg Pers, 2000).

Rapp, Claudia, Holy Bishops in Late Antiquity: The Nature of Christian Leadership in an Age of Transition (Berkeley: University of California Press, 2005).

Rawcliffe, Carole, Urban Bodies: Communal Health in Late Medieval English Towns and Cities (Woodbridge: The Boydell Press, 2013).

Reinhardt, Volker, Pius II. Piccolomini. Der Papst, mit dem die Renaissance begann. Eine Biographie (München: Verlag C.H. Beck, 2013).

Reynolds, Susan, Fiefs and Vassals: The Medieval Evidence Reinterpreted (Oxford: Oxford University Press, 1994).

Reynolds, Susan, Kingdoms and Communities in Western Europe, 9oo-130o, $2^{\text {nd }}$ ed. (Oxford: Clarendon Press, 1997).

Robinson, David, Beneficed Clergy in Cleveland and the East Riding, 1306-1340 (York: St. Anthony's Press, 1970).

Schmidinger, Heinrich, Romana regia potestas. Staats- und Reichsdenken bei Engelbert von Admont und Enea Silvio Piccolomini (Basel/Stuttgart: Helbing \& Lichtenhahn, 1978). 
Schmidt, Hans-Joachim, 'Einleitung', in Bistümer und Bistumsgrenzen vom frühen Mittelalter bis zur Gegenwart, ed. by Edeltraut Klueting, Harm Klueting and Hans-Joachim Schmidt (Rome: Herder, 2006), pp. 9-12.

Schmidt, Hans-Joachim, 'Neugliederung der Bistümer und Kirchenprovinzen in Südfrankreich und in Aragón zu Beginn des 14. Jahrhunderts', in Bistümer und Bistumsgrenzen vom frühen Mittelalter bis zur Gegenwart, ed. by Edeltraut Klueting, Harm Klueting and Hans-Joachim Schmidt (Rome: Herder, 2006), pp. 107-125.

Schmidt, Hans-Joachim, 'Raumkonzepte und geographische Ordnung kirchlicher Institutionen im 13. Jahrhundert', in Raumerfassung und Raumbewußtsein im späten Mittelalter, ed. by Peter Moraw (Stuttgart: Thorbecke Verlag, 2002), pp. 87-125.

Schmieder, Felicitas, 'Edges of the World - Edges of Time', in The Edges of the Medieval World, ed. by Gerhard Jaritz and Juhan Kreem (Budapest/New York: Central European University Press, 2009), pp. 4-20.

Schwaetzer, Harald, 'Nikolaus von Kues - ein Mentor für Europa', in Nikolaus von Kues: Die Großregion als Denk- und Lebensraum, ed. by Harald Schwaetzer and Marie-Anne Vannier (Münster: Aschendorff Verlag, 2019), pp. 11-40.

Stein, Robert, Anita Boele and Wim Blockmans, 'Whose Community? The Origin and Development of the Concept of Bonum Commune in Flanders, Brabant and Holland (Twelfth-Fifteenth Century)', in De Bono Communi: The Discourse and Practice of the Common Good in the European City $\left(13^{\text {th }}-16^{\text {th }}\right.$ Century), ed. by Elodie Lecuppre-Desjardin and Anne-Laure Van Bruaene (Turnhout: Brepols, 2010), pp. 149-169.

Strenski, Ivan, 'Religion, Power, and Final Foucault', Journal of the American Academy of Religion 66 (1998), 345-367.

Swanson, R.N., Church \& Society in Late Medieval England (Oxford: Blackwell, 1993). Swanson, Robert, 'Gens secundum cognationem et collectionem ab alia distincta? Thomas Polton, Two Englands, and the Challenge of Medieval Nationhood', in Das Konstanzer Konzil als europäischer Ereignis: Begegnungen, Medien, Rituale, ed. by Gabriela Signori and Birgit Studt (Ostfildern: Thorbecke, 2014), pp. 57-87.

Tewes, Götz-Rüdiger, 'Das spätmittelalterliche Papsttum und die Problematik der Raumerfassung', in Raum und Raumvorstellungen im Mittelalter, ed. by Jan A. Aertsen and Andreas Speer (Berlin/New York: Walter de Gruyter, 1998), pp. 6o3-612.

Tewes, Götz-Rüdiger, Die römische Kurie und die europäischen Länder am Vorabend der Reformation (Tübingen: Max Niemeyer Verlag, 2001).

Tewes, Götz-Rüdinger, 'Zwischen Universalismus und Partikularismus: Zum Raumbewußtsein an der päpstlichen Kurie des Spätmittelalters', in Raumerfassung und Raumbewußtsein im späten Mittelalter, ed. by Peter Moraw (Stuttgart: Thorbecke, 2002), pp. 31-85. 
Timmer, Rijk, Profeet in eigen land. Philips van Leiden en het publiek belang (Hilversum: Verloren, 2008).

Tolan, John, 'Conquest and Its Justifications: Jihad, Crusade, Reconquista', in Europe and the Islamic World: A History, ed. by John Tolan, Gilles Veinstein and Henry Laurens (Princeton: Princeton University Press, 2013), pp. 27-48.

Tolan, John V., Saracens: Islam in the Medieval European Imagination (New York: Columbia University Press, 2002).

Van den Hoven van Genderen, Bram, Het kapittel-generaal en de staten van het Nedersticht in de $15^{e}$ eeuw (Zutphen: Walburg Pers, 1987).

Van den Hoven van Genderen, Bram, 'Registers en rekeningen: een voorbeeld van middeleeuwse administratie en verschriftelijking', De kerk en de Nederlanden. Archieven, instellingen, samenleving, ed. by E.S.C. Erkelenz-Buttinger et al. (Hilversum: Verloren, 1997), pp. 168-188.

Van den Hoven van Genderen, Bram, “'Utrechtse Vlamingen”. De Vier Ambachten vanuit het noorden: Utrechtse lenen en tienden in de middeleeuwen', in Hulst in de Middeleeuwen en de kroniek van haar haven (Hulst: Oudheidkundige Kring "De Vier Ambachten", 2017), pp. 139-185.

Van der Haegen, Herman, De eerste Vlaamse ruimte. De kerkelijke driedeling van de Nederlanden in 1559. Een historisch-geografische analyse (Hofstade: Doorbraak, 2017).

Van der Krogt, Peter, 'Lokale kaarten van Nederland uit de late Middeleeuwen', Caert-Thresoor 27 (2008), 29-42.

Van Rhijn, Carine, Shepherds of the Lord: Priests and Episcopal Statutes in the Carolingian Period (Turnhout: Brepols, 2007).

Voigt, Klaus, Italienische Berichte aus dem spätmittelalterlichen Deutschland. Von Francesco Petrarca zu Andrea de' Franceschi (Stuttgart: Ernst Klett Verlag, 1973).

Vollmann, Benedikt Konrad, 'Aeneas Silvius Piccolomini as a Historiographer: Asia', in Pius II, 'el piu expeditivo pontefice': Selected Studies on Aeneas Silvius Piccolomini (1405-1464), ed. by Zweder R.W.M. von Martels and Arjo Vanderjagt (Boston/Leiden: Brill, 2003), pp. 41-54.

Von den Brincken, Anna-Dorothee, 'Descriptio Terrarum. Zur Repräsentation von bewohnten Raum im späteren deutschen Mittelalter', in Raumerfassung und Raumbewußtsein im späten Mittelalter, ed. by Peter Moraw (Stuttgart: Thorbecke Verlag, 2002), pp. 11-30.

Von den Brincken, Anna-Dorothee, Fines Terrae: die Enden der Erde und der vierte Kontinent aufmittelalterlichen Weltkarten (Hannover: Hahn, 1992).

Watanabe, Morichimi, 'Imperial Reform in the Mid-Fifteenth Century: Gregor Heimburg and Martin Mair', The Journal of Medieval and Renaissance Studies 9 (1979), 209-235. 
Watanabe, Morichimi, The Political Ideas of Nicholas of Cusa with Special Reference to His De Concordantia Catholica (Genève: Librairie Droz, 1963).

Watanabe, Morichimi, and Thomas M. Izbicki, 'Nicholas of Cusa, a General Reform of the Church', in Nicholas of Cusa on Christ and the Church. Essays in Memory of Chandler McCuskey Brooks for the American Cusanus Society, ed. by Gerald Christianson and Thomas M. Izbicki (Leiden/Köln: Brill, 1996), pp. 175-202.

Weber, Benjamin, Lutter contre les Turcs. Les formes nouvelles de la croisade pontificale au $X V^{e}$ siècle (Rome: École Française de Rome, 2013).

Weis, Monique, 'Die spanisch-niederländische Hierarchie und die Diözesanneuordnung in den Niederlanden unter Philipp II', in Bistümer und Bistumsgrenzen vom frühen Mittelalter bis zur Gegenwart, ed. by Edeltraut Klueting, Harm Klueting and Hans-Joachim Schmidt (Rome: Herder, 2006), pp. 158-169.

Wood, Susan, The Proprietary Church in the Medieval West (Oxford: Oxford University Press, 2006).

Zadora-Rio, Elisabeth, 'L'historiographie des paroisses rurales à l'épreuve de l'archéologie', in Aux origines de la paroisse rurale en Gaule méridionale (IVe-IXe siècles), ed. by Christine Delaplace (Paris: Éditions Errances, 2003), pp. 15-23.

Zadora-Rio, Elisabeth, 'The Making of Churchyard and Parish Territories in the Early Medieval Landscape of France and England in the $7^{\text {th }}-12^{\text {th }}$ Centuries: A Reconsideration', Mediaeval Archaeology 47 (2003), 1-19.

Zadoro-Rio, Elisabeth, 'Territoires paroissiaux et construction de l'espace vernaculaire', Médiévales 49 (La paroisse. Genèse d'une forme territoriale) (2005), 105-119.

\section{About the author}

Bram van den Hoven van Genderen is a Lecturer in Medieval History at Utrecht University. He publishes regularly on the religious, political, and social history of the Later Middle Ages, often taking Utrecht and its prince-bishopric as a starting point. 



\title{
4. Marginal Might? The Role of Lordships in the Territorial Integrity of Guelders, \\ C. 1325 -c. 1575 \\ Jim van der Meulen
}

\begin{abstract}
This chapter examines the institution of lordship in Guelders, demonstrating that the number of semi-autonomous lordships in one subregion of Guelders remained constant, or even expanded, in the period 1325-1570, and exploring the implications of their spatial position along the borders of Guelders. The sources to support this quantitative development mainly consist of feudal records from Guelders and other neighbouring polities, supplemented with various documents about lordships without princely overlords (allodia). Sixteenth-century court cases over contested boundaries will serve to illustrate how contemporaries perceived the spatial components and physical boundaries of lordships in relation to the overarching territory of Guelders. I argue that in their predominantly marginal location, lordships may have functioned as a 'buffer zone' between Guelders and neighbouring principalities.
\end{abstract}

Keywords: lordship; state formation; Guelders; Low Countries

The main line of enquiry in this volume builds on Stuart Elden's innovative conceptualisation of 'territory' in his book The Birth of Territory (2013). Specifically, the goal of Part 1 is to explore 'premodern conceptions about the link between certain spatial settings and political power. ${ }^{1}$ Elden has argued that the origin of territory as a 'political technology' should be dated back to the sixteenth and seventeenth centuries. As discussed in the 
introduction to this volume, his definition emphasises the interpretation of 'territory' as a collection of methods and techniques of top-down coercion, through which states could literally shape and communicate the physical range of their power. Thus emerged a new notion of space as a 'political category: owned, distributed, mapped, calculated, bordered and controlled'. Elden contrasts this emergence to the medieval period, which 'did not have a territorial system, and lacked an articulated concept of territory'. ${ }^{2}$ The second of these positions is, I think, more persuasive than the first. Through his impressive analysis of the trajectory of European intellectual history, Elden builds a solid argument that the territorial foundation of state power is a modern phenomenon. Less convincing, however, is his notion that the Middle Ages did not have a territorial system. In this chapter, I propose that the relationship between power and space in late medieval Europe may be interpreted as a system in its own right. Proceeding from the political-juridical institution of lordship in the Netherlandish polity of Guelders, my thesis is that there was in fact such a thing as a spatial order of governance during the late medieval period. This order of territorial integrity, as I will call it, was constructed through negotiations between the top level of the state, the meso-level of power elites, and the local level of rural communities.

'Territorial integrity' should not be interpreted in the present-day sense here. Late medieval government was not buttressed by an ideal according to which heads of state had the exclusive claim to sovereignty or to the preservation of (linear) borders demarcating the physical area of their command. ${ }^{3}$ What I mean by the term is the long-term stability of loosely defined spatial bounds of the ruler's area of jurisdiction, specifically in the countryside. Therein lies the crux of my argument: this spatial stability was the result of cooperation between royal or princely administrations whose main concerns were fiscal and military, between rural lords who largely shared these interests (only one rung down on the ladder of power), and between the residents of lordships whose main worries were of the economic kind. On the one hand, these medieval spatial concerns fit within Elden's two subcategories of territory, what he calls 'land' (the economic aspect), and 'terrain' (the military component). ${ }^{4}$ On the other hand, Elden's analysis still hinges on a top-down perspective of state-making through coercion, which is no longer supported in the most recent historiography. Even in 
the kingdom of France, late medieval government was 'an open-ended dialogue', a 'cooperative project shared between the crown and local elites'. 5 Because of this, Elden's version of medieval territory downplays important techniques relating to the negotiating of space that were implemented from the middle and bottom-up.

The analytical focus of this chapter thereby intersects, both with earlier, twentieth-century German historiography that emphasises the role of interactions between top-down and bottom-up initiatives in state formation - most prominently the work of Otto Brunner (see the Introduction to this volume by Mario Damen and Kim Overlaet) - and especially with the recent work of Alice Taylor on the kingdom of Scotland in the twelfth and thirteenth centuries. In her book The Shape of the State in Medieval Scotland, 1124-129o (2016), the latter advocates for a reconsideration of medieval states based on the notion of co-dependence between local aristocratic and central royal power. This meant, 'in traditional terms, a more limited and mediated government but [...] nonetheless a conceptually unified government'. ${ }^{6}$ In this chapter, I will argue that Taylor's conceptualisation of the medieval state seems tailor-made to fit the principality of Guelders until the very end of the Middle Ages. Rather than detracting from the spatial unity of Guelders, the lordships of this Netherlandish principality instead appear to have been fundamental building blocks of the state, in part by fulfilling an important function in maintaining its territorial integrity. This is relevant to the discussions in this volume, because it expands Elden's conceptualisation of political space as a top-down territorial project of centralisation by considering the impact of local, decentralised territorial units: lordships.

The chapter consists of three parts. The first part offers some historical context about the regional case study of Guelders, specifically about the relationship between its princely government and the institution of lordship. The second part begins by showing that lordships knew a stable existence in the principality of Guelders between the early fourteenth and later sixteenth centuries. I will explore the potential causes of this stability and its connotations for territorial integrity. My central hypothesis is that the rulers of Guelders largely outsourced the tasks of maintaining the principality's physical boundaries to decentralised, local units of authority, lordships among them. The final section briefly descends to the ground

5 Firnhaber-Baker, Violence and the State, p. 22, 183. See also: Taylor, 'Formalising Aristocratic Power', pp. 59-64; Schneider, The King's Bench, pp. 1-5.

6 Taylor, The Shape of the State, p. 446. 


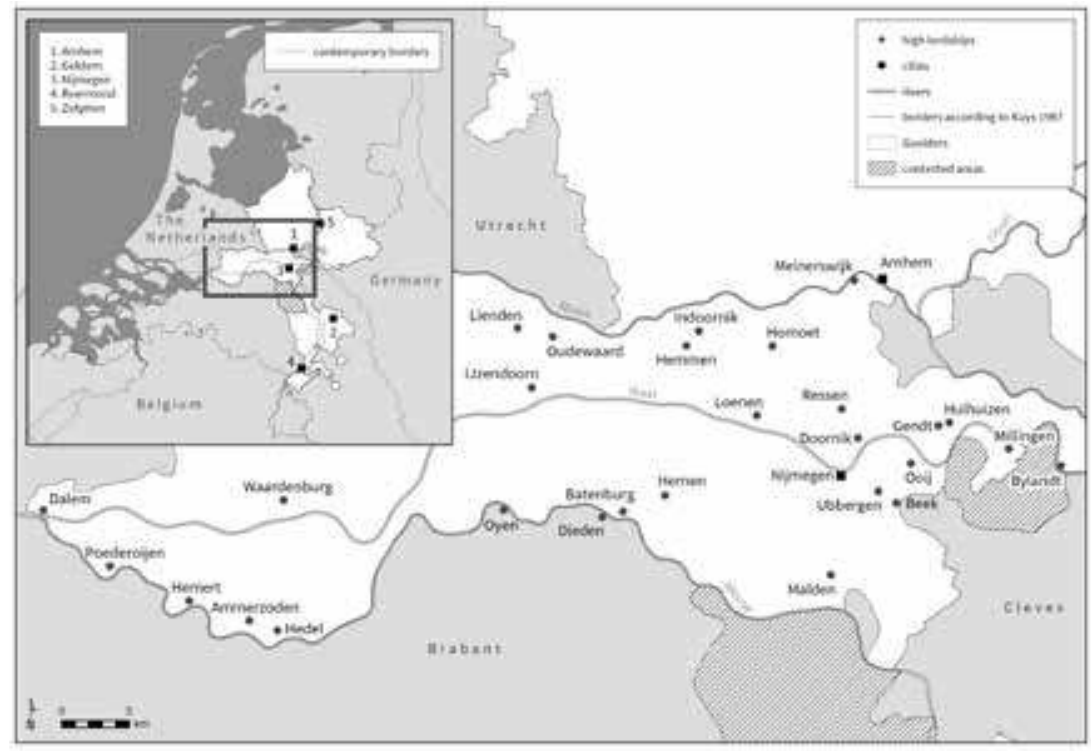

Fig. 4.1. The Duchy of Guelders, with the high lordships of the Nijmegen Quarter (fourteenthsixteenth centuries). Source: Hans Blomme, Ghent University. The borders between the shires are based on Kuys, De Ambtman.

level of spatial negotiations within some of these lordships in the sixteenth century. The scrupulously measured and coercive limitations of space that apply to the present-day historian prevent me from exploring this topic more fully in this chapter. I have nevertheless chosen to include it, because the evidence both illustrates how local subjects' interactions with space followed a seigneurial 'grid', and how princely law courts began to act as mediator in these interactions.

\section{Land(s) of Guelders}

In his late-sixteenth-century Description of All the Low Countries, the Florentine historian Lodovico Guicciardini referred to the shape of the duchy of Guelders as 'so odd and so disunited [...] that it is no wonder the writers sometimes disagree over it'. ${ }^{7}$ Indeed, much like the Holy Roman Empire from which its princes ultimately held their authority, the principality

7 'la forma sua è tanto stravagante, \& tanto disgregata dal Reno, il quale appunto col suo Bicorne per il mezzo la divide, che non è maraviglia, se talvolta gli scrittori l'uno con l'altro non si accordano': Guicciardini, Descrittione, p. 238. 
of Guelders was a 'composite state', consisting of different subregions accumulated over the course of several centuries. A modern reconstruction of the medieval territory of Guelders demonstrates the odd, squiggly shape of the polity, patched together from originally separate jurisdictions, and wedged in tightly between various neighbouring principalities (Fig. 4.1). The county (after 1339, the duchy) of Guelders stemmed from a power base first expanded by the counts of Wassenberg from around 1100 onwards. The initial patrimonial lands of these soon-to-be counts of Guelders consisted of a collection of Carolingian counties spread out around the various corners of what would become the polity's four administrative quarters (Kwartieren) in the fifteenth century. Through the accumulation of claims to land and jurisdiction, the county of Guelders had reached a more or less fixed physical form by the early fourteenth century, structured along 'shires' (ambten) that were later subsumed into the overarching division into four quarters. ${ }^{8}$

As Guicciardini and his contemporaries disagreed over its physical shape, so present-day historians have debated whether medieval Guelders should be considered a 'state'. Rooted in Max Weber's dictum that modern states have 'the monopoly of legitimate physical violence within a particular territory', over Charles Tilly's emphasis on states' centralised fiscal-military apparatus (see the Introduction to this volume), most of these historians are hesitant to apply the state label to Guelders. By most reckonings, late medieval Guelders lacked strong princes, had a backward fiscal system, and experienced a general paucity of centralised institutions. ${ }^{9}$ However, Aart Noordzij has shown that the inhabitants of Guelders did acquire a sense of territorial unison, even a certain geographical identity, between the twelfth and sixteenth centuries. Supporting the recent revisionism of the older view that states emerge through top-down coercion, it was in fact the Estates assemblies of Guelders that pushed territorial issues such as the stability of borders, the appointment of indigenous princely officers, and the integrity of the ducal (agrarian) domain. This underlines the importance of interactions between local and central levels of government

8 Noordzij, Gelre, pp. 106-108, 112, 130-131. Apart from some losses (for instance, of the shire of Liemers to the county of Cleves around the end of the fourteenth century) and temporary acquisitions (mainly the land of Cuijk, between 1400 and 1473), the outer territorial bounds of Guelders remained more or less stable during the research period. See also Böck, Herzöge und Konflikt, pp. 273-276, 318-324.

9 Weber, 'Politics as a Vocation', p. 38; Tilly, Coercion; Noordzij, Gelre, pp. 28-30; Noordzij, 'The Wars of the Lord of Bronkhorst', pp. 91-93; Van Schaïk, 'Taxation, Public Finances and the State-Making Process', pp. 266-271. 
in shaping the state. ${ }^{10}$ The aristocracy played a prominent role in Guelders in this regard.

In fact, the interests of seigneurial lords were more of a factor in the political assemblies of Guelders than in other principalities of the Low Countries. In that sense, the principality seems an outlier compared to regions such as Flanders, Brabant, and Holland, where cities are usually deemed to have been the dominant political force. That said, this seeming exceptionalism is partly a consequence of the fact that Guelders has not been studied as extensively as these other regions. Guelders had politically potent urban centres just like other parts of the Low Countries. A recent monograph on the urban finances of Arnhem and Zutphen, for example, suggests that these cities had a strong bargaining position in their dealings with the dukes of Guelders. ${ }^{11}$ The four administrative quarters of Guelders also supplied the grid lines for the Estates meetings. So, the 'capital' cities of these quarters (Nijmegen, Zutphen, Arnhem, Roermond) exerted the main impetus behind assemblies within their own hinterlands and behind the so-called 'land days' (landdagen). However, the difference between Guelders and other Netherlandish polities seems to have been that the lay aristocracy of the countryside was particularly powerful in the former. For instance, unlike in other Low Countries principalities such as Flanders and Brabant, the clergy was not represented at the political assemblies of Guelders. In this, the political structure of Guelders resembled the county of Holland. Wherein it differed from Holland was that its nobility was further subdivided into the knighthood (ridderschap) and the lords-banneret (bannerheren). And, although members of the Knighthood were essentially armigerous men of established noble lineage, they often possessed lordships. ${ }^{12}$ Meanwhile, each of the lords-banneret held at least one lordship with 'high justice' or 'high jurisdiction', which partly defined their membership of this Estate. ${ }^{13}$ The result was the relative political dominance of the seigneurial aristocracy of Guelders.

10 For the revisionism, see above. Noordzij, Gelre, pp. 123-124, 249-261; Taylor, The Shape of the State, pp. $438-455$.

11 See the conclusion in Bosch, Stedelijke macht. See also Stein, Magnanimous Dukes, p. 14.

12 For instance, an overview of the Ridderschap of Nijmegen in 1570 explicitly identifies several of its members as holding lordships that did not belong to the banneret category (e.g. Balgoy, Hernen, Ressen, Doornik, Loenen, Hemmen, Meinserswijk, Doddendaal, Poederoijen): GA, Hof van Gelre en Zutphen, no. 1592, f. 117r-120r.

13 Denessen, 'De Gelderse bannerheren', pp. 33-34; Maris, 'De lijst van bannerheerlijkheden', pp. 144-145. 
In late medieval Guelders, lordships were first and foremost units of political and juridical authority over people. Yet, just like larger units, such as kingdoms, duchies, and counties, the jurisdiction over local subjects also had a spatial dimension, albeit a dynamic one. ${ }^{14}$ The political landscape of rural Guelders formed a patchwork that consisted, on the one hand, of such lordships - where the local lord exercised (parts of) governmental authority over a physical area of jurisdiction and its inhabitants - and, on the other hand, of shires (ambten) - where princely officers ('sheriffs', or ambtmannen) took a similar role. ${ }^{15}$ So the lordships of Guelders enjoyed a degree of political independence from the princely administration, but as lords generally had personal and formal ties to the prince, one could argue that their position was essentially not that different from that of the sheriffs: in both cases, the central level of government operated through the mediation of a local agent. ${ }^{16}$ That said, some lords were clearly more independent from princely control than others. In fact, the already-mentioned lordships with high jurisdiction had their own criminal court, vested with the power to collect all local fines and to mete out corporal (and capital) punishment. ${ }^{17}$ This separated them from the other kind of lordship commonly found in Guelders: the so-called 'day-to-day' lordship (dagelijkse heerlijkheid). Here, the local lord could only lay claim to modest fines, not exceeding 3 s per infraction. Court sessions in these day-to-day lordships also had a more ad hoc character. ${ }^{18}$ In practice, the dividing line between these day-to-day lordships and shires was very vague indeed.

Yet high lordships in particular could still pose potential risks to the principality's territorial integrity - that is, from the Weberian perspective of the state monopoly on licit violence, which is still a dominant position in the historiography on late medieval state formation, in the Low Countries as elsewhere. ${ }^{19}$ According to more recent works, however, the relationship

14 Wickham, 'Defining the seigneurie since the War', pp. 44-48; Johnson, 'The Tree and the Rod', pp. 36-37.

15 Martens van Sevenhoven, 'Schets van de geschiedenis der burgerlijke gemeenten in Gelderland', pp. 4-7.

16 Again, this is a very similar situation to that in medieval Scotland, where the political system at the local level consisted of a combination of lordships and 'sheriffdoms': Taylor, The Shape of the State, pp. 454-455.

17 Kuys, De Ambtman in het Kwartier van Nijmegen, pp. 203-204; Damen, 'Heren met banieren', pp. 145-148; Buylaert, Eeuwen van ambitie, p. 66; Janse, Ridderschap in Holland, pp. 152-155.

18 Kuys, 'Dagelijkse heerlijkheden in de Bommeler- en Tielerwaard', pp. 1, 9-16; Janse, Ridderschap in Holland, pp. 146-152.

19 Gunn, Grummet and Cools, War, State and Society, p. 163. 
between these lordships and the princely government may have been one of mutualism rather than opposition. ${ }^{20}$

To address this question, the upcoming analysis will focus on these lordships with high justice. Some of these lordships even had their own separate legislature, in the form of 'land constitutions' (landbrieven). One such document that survives for the lordship of Ammerzoden in 1471 reveals that, in the case of manslaughter (dootslach), the seigneurial law court was licensed to execute criminals ('so sal die mensche sijn lijff bescudt ende quijt hebben'). ${ }^{21}$ Moreover, these pieces of independent legislation meant that the physical areas to which they pertained were perceived (and functioned as) their own legal units. And these 'lands' were delineated in space, even though the records are vague in specifying their boundaries. ${ }^{22}$ Moreover, the lord's court edifice and his fortified residence, often a castle, were buildings people in the countryside passed by in their daily lives, as opposed to the more distant princely structures. Accordingly, local people will have first and foremost associated these seigneurial buildings with justice and power. ${ }^{23}$

Perhaps for this reason, the exact location of law courts was an issue of some concern to these local lords. So, in 1548 a seigneurial officer named Joost van Zweten testified before one of the appellate courts of the Nijmegen Quarter, in the town of Tiel, that he had moved the court bench (die banck) of the parish of Zoelen 'across the water, where it currently stands, on the border ['t gesceyt] between the two day-to-day lordships, [...] where it had stood of old'. ${ }^{24}$ The document does not make entirely clear why the appellate court required this testimony of Van Zweten, but it appears some doubt had arisen over the bench's rightful spot. This confusion probably stemmed from the parish of Zoelen's legal fragmentation between two lordships, whose lords had been squabbling over juridical claims since at least $1487 \cdot{ }^{25}$ As we shall see, such concerns over the spatial integrity of lordships mirrored, and perhaps supported, overarching territorial concerns of the princely government of Guelders.

\footnotetext{
20 Taylor, The Shape of the State, see above.

21 Van Veen, 'Landrechten van Ammerzoden', p. 601.

22 On 'lands' as separate legal and spatial units, see Brunner, Land und Herrschaft, pp. 182-183. See also Croenen, 'Regions, Principalities and Regional Identity', p. 144.

23 See also Lefebvre, Production of Space, pp. 38-41.

24 'over dat water, daer se nu staet, in 't gesceyt van beyde dagelixe heerlicheyden Wilms van Rossum ende Adriaens van Buerens erffgenamen, soe die banck daer van alts plach to staen': GAA, Huis Zoelen, no. 202 (charter of 22 June 1548).

25 GAA, Huis Zoelen, nos 201, 298, 314.
} 


\section{Lordships as territorial buffers}

To assess the relationship between high lordships and territorial integrity in Guelders, the first step is to reconstruct the quantitative development of these decentralised, or local, institutions. The analysis hinges on three overviews (c. 1325, c. 1475, c. 1570) of the number of high lordships in one of the four quarters of Guelders, namely Nijmegen. This method of using cross-sections was pioneered by Christine Carpenter in her 1992 study of the Warwickshire gentry, and has since been successfully used for other regions. ${ }^{26}$ The restriction to only one administrative district is to keep the survey feasible over the long period between the early fourteenth century and the late sixteenth century. With the highest number of lordships of any of the principality's subregions, the Nijmegen Quarter is well suited to serve as the subject of such a quantitative survey. Furthermore, this area is interesting from the perspective of political space, because it bordered on several neighbouring principalities (Holland, Utrecht, Brabant, Cleves). The records consist of documents of infeudation, both in the form of loose charters, and as collected in ledgers by the 'Feudal Chamber' (Leenkamer) of the princes of Guelders. ${ }^{27}$ To ensure - as much as possible - that the lordships in question effectively belonged to the physical land area (terra) of Guelders, the analysis proceeds regressively from an overview of 1569 . This document contains 'all the high lordships located within the principality of Guelders' (my emphasis). ${ }^{28}$ The princely administration deemed these lordships to be a physical part of Guelders. This marks a useful contrast with the earlier ducal records, which only offer an insight into those lordships held in fief from the princes of Guelders.

From this survey, we learn that the Nijmegen Quarter counted a total of 27 high lordships that were all held by somebody other than the prince of Guelders at some point during the period under discussion. In other words: either the prince of Guelders gave these high jurisdictions out in fief, or some other prince was the overlord, or they were allods that did not have an overlord. What is especially interesting is that the number of these high lordships remained stable between 1325 and 1570 . There is even evidence of a slight increase after 1500 (Table 4.1). Thus, even accounting for the

26 Carpenter, Locality and Polity; Damen and Jansen, 'Adel in meervoud', p. 534.

27 The key documents are Van Doorninck, Het Oudste Leenactenboek (c. 1325); GA, Leenkamer, no. 115-16 (c. 1475); Maris, 'De lijst van bannerheerlijkheden' (c. 1570).

28 'Alle die baenneriën ende hooge heerlicheyden, gelegen in den Furstendomme Gelre ende Zutphen': Maris, 'De lijst van bannerheerlijkheden', p. 143. 
potential paucity of the earlier source material, it is clear that lordship was not a waning institution in Guelders. In fact, it apparently went through something like an Indian summer at the end of the Middle Ages. A slight increase between 1475 and 1570 derives from a cluster of newly granted high jurisdictions around the first decade of the sixteenth century. At that time, Duke Karel van Egmond (r. 1492-1538) created high lordships to reward his loyal supporters with expanded juridical powers. ${ }^{29}$ He needed these supporters because his reign was marked by an almost continuous struggle with the dukes of Burgundy and their Habsburg successors, who strove to incorporate Guelders into their large collection of Netherlandish principalities.

This bartering of local seigneurial areas of jurisdiction by the central administration of Guelders underlines the notion that political space was a dynamic construction in the medieval period. Based on the literature of state formation in Guelders, one might attribute the data of Figure 4.2 to the continuous financial and political difficulties of its relatively weak princes. $3^{30}$ By that rationale, the princely administration of Guelders was forced to forego ambitions of centralisation, having instead to accept the undesirable persistence of these independent zones of power within its territory as collateral damage. Consider how this differed from what happened in fifteenth-century Brabant under the overlordship of the Valois dukes of Burgundy (see the chapter by Arend Elias Oostindiër and Rombert Stapel in this volume). Indeed, the slow expansion of centralised governmental institutions in Guelders from the late fifteenth century onwards is often seen as a consequence of the brief period of Burgundian overlordship (1473-1477) - the process has even been referred to as 'Burgundisation'. ${ }^{11}$ However, consider also that territorial integrity was not necessarily a matter of concern for the princes of Guelders alone. The importance of maintaining a measure of physical continuity grew across the political levels between the fourteenth and sixteenth centuries, and in this regard Guelders was not so different from, for example, Brabant. Admittedly, in their political negotiations, the ruling elites of the various towns, lordships, and shires

29 For instance, Duke Karel granted Hendrick van Gendt the lordship of Gendt as a reward for his loyal service ('om syns mennichvoldigen trouwen dienst begiffticht ind versien hebben mitter heirlicheyt, stat ind kerspell van Ghent'): GAA, Leenkamer van Gelre en Zutphen, no. 12, f. 10or.

30 See note 9 .

31 Groustra-Werdekker, 'Bourgondisering van het hertogdom Gelre'. Again, there are similarities with the case of medieval Scotland, where governmental institutionalisation has often been deemed a consequence of 'Anglicisation': Taylor, The Shape of the State, pp. 19, 446-447, 449. 
of Guelders primarily pushed their own privileges and interests. But they continuously connected these interests to a concern for the principality in general. ${ }^{32}$ By the late fifteenth century and certainly in the sixteenth century, chronicles and histories about the mythical past and origins of Guelders contributed to the sense of community among its inhabitants. ${ }^{33}$ In the sixteenth century, political songs about Guelders even began to refer to a collective 'nature' (Art) of its people, which suggests that the non-literate masses could also be instilled with such a notion. ${ }^{34}$

The emphasis on territorial integrity was not simply empty rhetoric. The various power groups in Guelders showed a keen concern for spatial stability, both insisting that the princes maintained the borders, and negotiating the boundaries among themselves. At times, these negotiations concerned the staking of physical border poles (palen). But at other times, instead of border poles, the different stakeholders focused on the specific lordships and urban jurisdictions that would form the territory's outer bounds. ${ }^{35}$ This is indicative of a contemporary perception of political space wherein lordships functioned like buffer zones, or at least as a legal-institutional basis for spatial negotiations.

As such, lordships could contribute to the territorial integrity of a principality, if only indirectly. For instance, we have already seen that the Estates insisted that all local officials should come from Guelders. But the same trend was mirrored at the level of high lordships. So, the previously mentioned landbrief of Ammerzoden of 1471 stipulated that 'whoever is or will be chosen as an alderman of the lordship, he must be propertied within the same lordship'. And we find a similar bylaw in the legislation of the lordship of Nederhemert in $1487 \cdot \cdot^{36}$ If these jurisdictions formed constitutive parts of the overarching principality, these measures of spatial containment instituted by local governments can be seen as examples of lower-level territorial maintenance.

Yet were these high lordships part of any principality, or were they rather independent territorial units? It is in this regard that the Nijmegen Quarter of Guelders is particularly interesting. When assessing the physical distribution

\footnotetext{
32 Noordzij, Gelre, pp. 258, 151-154.

33 Anderson, Imagined Communities, pp. 5-7.

34 Van 't Hooft, Honderd Jaar Geldersche geschiedenis, p. 176 (for a negative characterisation), 197 (for a positive characterisation).

35 Noordzij, 'De landvrede van 1377', pp. 44-47.

36 'so wie scepen in der heerlicheit [van Amersoyen] gekoren wordt of wesen sal, die sal gegoet sijn bynnen derselver heerlicheit': Van Veen, 'Landrechten van Ammerzoden', p. 599 (bylaw no. 16); GA, Hof van Gelre en Zutphen, no. 4346, f. 313r (bylaw no. 16; copy of 1569).
} 
of high lordships in this area, what catches the eye is that these jurisdictions are largely located towards the outer bounds of the polity, especially along the borders with Brabant and Cleves (Fig. 4.1). ${ }^{37}$ One explanation for this is that semi-independent jurisdictions like these could more easily persist at the territorial margins. In that view, the process of territorial formation is envisioned as a more or less linear accumulation of hitherto independent areas proceeding from certain core regions of power. Lordships were simply able to persevere in the power vacuums between the territorial projects of adjacent princes. ${ }^{38}$ This 'snow shovel' explanation makes sense, but it hides some of the complexity of spatial politics. One of these obscured elements is the potentially mutualistic relationship between neighbouring princely administrations and the marginal lordships. ${ }^{39}$ Rather than passive remnants of a 'pre-territorial age', these high jurisdictions may have been convenient territorial insulation material. The spatial distribution along the margins of Guelders, Cleves, Holland, and Brabant would then be the result of a multisided political tug-of-war between adjoining princes and these local lords. Paradoxically, therefore, these marginal jurisdictions simultaneously belonged to, and were independent from, princely territories.

At the same time, the territorial integrity of the adjoining principalities partly depended upon these lordships. This was certainly the case from the perspective of the dukes of Guelders: around half of the high seigneurial jurisdictions in the Nijmegen Quarter were not even held from their feudal court. At least seven of them were feudally bound to the prince of Cleves, for example (Table 4.1). However, the lords who held these 'foreign' lordships were nevertheless granted access to the Estates assemblies. ${ }^{40}$ This means that they were politically embedded in Guelders. Furthermore, the lords-banneret formed a separate Estate in Guelders, and the very inclusion into this category stemmed from these lords' relative independence from the prince..$^{41}$

37 Note that modern maps like this one are slightly misleading in that they suggest the static nature of borders. These borders need to be taken with a large pinch of salt.

38 Moorman van Kappen, 'Proeven van locale wetgeving', pp. 140-141.

39 This explanation also ignores some of the location factors that determined where lordships arose in the first place. I am currently working on an article that explores this aspect in fuller detail.

40 See the examples of Hemmen (1566), Lienden and Oudewaard (1556), Loenen $(1544,1574)$ : Van Gent, Landdagen en andere landelijke bijeenkomsten, nos 35, 206, 339, 258. For a counterexample: Maris, 'De lijst van bannerheerlijkheden', pp. 148-149 (the lord of Homoet).

41 Denessen, 'De Gelderse bannerheren', pp. 33-34. 
In fact, the noble holders of high lordships in this region often owed allegiance to several neighbouring princes, reinforcing the idea that they acted like territorial buffers. For instance, for most of the fourteenth century, the lords of Hedel in Guelders also held the high lordship of Cranendonck in Brabant. ${ }^{42}$ Of course, such an arrangement could become problematic when lords had to choose a side during a military conflict between their two overlords. ${ }^{43}$ Then again, lords sometimes allied themselves with their overlord's enemy without having feudal ties to the latter. The lord of Ammerzoden, for example, switched to the side of the duchess of Brabant while she was at war with Guelders in 1386 . Unsurprisingly, these double-crosses evoked powerful reactions from the rightful prince. In this case, the duke of Guelders besieged and conquered the castle of Ammerzoden, imprisoned the lord, and claimed the castle and the lordship for himself. ${ }^{44}$

This phenomenon of super-regional or 'border nobility' was widespread in the late medieval Low Countries - although these nobles' degree of political autonomy varied from case to case. The princes of Guelders were especially wont to undermine the independence of lordships with military fortifications. They did so through the Germanic ius aperturae, which obliged the lord to 'open' his castle to the ducal troops even if the lordship itself had no feudal ties to Guelders. Some historians interpret this as a 'deliberate stronghold policy' with regards to military terrain. ${ }^{45}$ Whether a conscious policy or not, it made sense to outsource territorial maintenance in some degree to the level of the local lordship. Doing so allowed the princely administration to save on legal and military costs by relying on the self-interest of lords for border protection. This is illustrated by the case of the high lordship of Hulhuizen, located on the boundary between Cleves and Guelders. When the count of Cleves granted the lordship to Otto van Bellinchaven in 1369, he insisted that the newly instated lord 'would maintain the old border poles of the lordship'. ${ }^{46}$ Therefore, the persistence of this 'marginal might' may have supported the territorial integrity of Guelders as well as its neighbours. Lords or local administrators protected economic and political boundaries pertaining to their own areas of jurisdiction, which

42 Van Doorninck and Van Veen, Acten, pp. 207-208. See also: Van der Meulen, 'Vassalage and Authority', p. 89 .

43 Burgers and Damen, 'Feudal Obligation', p. 789.

44 Kuys, 'De heerlijkheid Ammersoyen en zijn heren', p. 126.

45 On 'border nobility': Croenen, 'Regions, Principalities and Regional Identity', p. 144; Van Doornmalen, De Herlaars, pp. 351-353; Kalkwiek, De hertog en zijn burchten, pp. 50-54.

46 'onse palen end voerpalen halden also als si van alds geleghen siin': Graswinckel, 'Hulhuizen', p. 12 . 
ensured territorial continuity in general. As such, the lordship became an intermediate link in a chain connecting local spatial politics to the level of the principality.

Table 4.1. High lordships in the Nijmegen Quarter, c. 1325-1570

\begin{tabular}{|c|c|c|c|c|c|}
\hline Lordship & Overlord & High jurisdiction since & c. 1325 & c. 1475 & c. 1570 \\
\hline Ammerzoden & Guelders & 1351 & - & $x$ & $x$ \\
\hline $\begin{array}{l}\text { Batenburg } \\
\text { (with Horssen and } \\
\text { Leur }>1534 \text { ) }\end{array}$ & H.R. Empire & 1349 & - & $x$ & (Prince) \\
\hline Beek & Cleves & 1324 & - & $x$ & $x$ \\
\hline Bylandt & Cleves & 1305 & $x$ & $x$ & $x$ \\
\hline Dalem & Holland/Guelders & 1505 & - & - & $x$ \\
\hline Dieden & $\begin{array}{l}\text { (Brabant) Guelders } \\
>1361\end{array}$ & 1361 & $x$ & (Prince) & (1559) \\
\hline Doornik & Guelders & 1507 & - & - & $x$ \\
\hline Gendt & Guelders & 1506 & - & - & $x$ \\
\hline Hedel & Guelders & 1342 & $x$ & $x$ & $x$ \\
\hline Hemert & Guelders/Holland & 1310 (?) & $x$ & $x$ & $x$ \\
\hline Hemmen & H.R. Empire & 1361 (?) & - & (1454) & $x$ \\
\hline Hernen & Guelders & 1390 & $?$ & $x$ & $\mathrm{x}$ \\
\hline Homoet & $\begin{array}{l}\text { (Oosterhout) allodium } \\
<1569\end{array}$ & 1362 (?) & - & $x$ & $x$ \\
\hline Hulhuizen & Cleves & 1316 & $x$ & $x$ & $x$ \\
\hline IJzendoorn & Guelders & 1345 (half) & - & $x$ & $x$ \\
\hline Indoornik & Cleves & 1471 & - & $x$ & $x$ \\
\hline Lienden & Utrecht/Elten & 1327 & $x$ & $x$ & (Prince) \\
\hline Loenen & Cleves & 1410 & $x$ & $(1441)$ & $x$ \\
\hline Malden & Cleves & 1436 (?) & $x$ & $x$ & $x$ \\
\hline Meinerswijk & Hemmen/Rosande & $<1569$ & - & - & $x$ \\
\hline Millingen & Cleves & $<1569$ & - & $x$ & (Prince) \\
\hline Ooij & Guelders & 1331 (?) & $x$ & $x$ & $x$ \\
\hline $\begin{array}{l}\text { Oudewaard } \\
\text { (with Ter Lede) }\end{array}$ & Utrecht/Guelders & 1328 & $x$ & $x$ & (1541) \\
\hline Oyen & $\begin{array}{l}\text { (Brabant) Guelders } \\
>1361\end{array}$ & 1361 & $x$ & (Prince) & (1559) \\
\hline Poederoijen & Guelders & 1395 & - & $x$ & $x$ \\
\hline Ressen & $\begin{array}{l}\text { (Cleves) } \\
\text { Guelders > } 1385\end{array}$ & 1367 & - & $?$ & $x$ \\
\hline Ubbergen & (Cuijk) Guelders > 1530 & 1424 (?) & - & $x$ & $\mathrm{x}$ \\
\hline Waardenburg & Guelders & 1481 & $x$ & $x$ & $x$ \\
\hline Total: 28 & & & 11 & 20 & 23 \\
\hline
\end{tabular}




\section{Territory from below}

Stuart Elden traces the development of territory as a political technology to the sixteenth century. However, his focus on intellectual history and top-down state coercion hides the role of bottom-up initiatives that connected power to place. In approaching spatial politics, it is important not to overlook the complexity of interactions between the level of princes, lords, and local residents. ${ }^{47}$ Let me illustrate this by ending with a ground-level view of spatial negotiations, in which the central state administration was arguably more a passenger than a driver.

To begin with, late medieval evidence suggests that the lordship's physical area of jurisdiction was a legal reality independent from dynastic unions among noble lords. So, although the powerful lords of Bergh held both the lordship of Millingen and the neighbouring lordship of Bylandt in 1462 , their local officers still had to maintain the border poles (uterste pelinghe) and other elements of demarcation, such as trees and streams, between the two jurisdictions. ${ }^{48}$ The relationship between lords and their tenants was also reciprocal, which meant that the latter could invoke certain customary rights and privileges, even against their own lord or prince. These initiatives usually pertained to property claims or local residents' attempts to shirk fiscal obligations ('land' issues, in Elden's terminology).

But these negotiations over space had implications for the emergence of territory as a political technology. The reason is that the ducal law courts of Guelders increasingly took the role of supreme arbitrator in local conflicts over space. Through this mediation in local spatial negotiations, the princely administration was able to partly absorb areas outside its core region of power into the larger territorial schema. This is especially apparent from the many civil suits relating to spatial issues brought before the court of Guelders after the duchy had been incorporated in the Habsburg Low Countries in 1543. In addition to implicitly presenting its own authority as supreme, the court began to use maps to bolster claims to property rights. Thus, the princely administration made local societies more 'legible', thereby furthering the agenda of the state.

47 See especially De Keyzer, Jongepier and Soens, 'Consuming Maps and Producing Space', pp. 233-235.

48 AHB, Heerlijkheid Bylandt, no. 4947. 
Yet we should be careful not to overstate the top-down nature of this process. ${ }^{49}$ In 1544, a local tenant named Walraven Smit challenged the lord of Ooij in civil court over the location of a piece of meadowland (weert) in the former's possession. The lord of Ooij alleged that this meadow lay within the jurisdiction of his own lordship, but Smit asserted that it belonged to the neighbouring lordship of Gendt..$^{0}$ To help resolve the dispute, the court officers drew up a schematic map of the area in question (Fig. 4.2). The spatial consensus between the two parties, whose signatures can still be seen in the upper-left corner of the map, went on record in this form. It is only one among dozens of examples from the same period ${ }^{11}$ These cases underline how the production of space, and the role of cartographic techniques in that production, was negotiated between various sociopolitical parties, including the administrators and inhabitants of local lordships. At the same time, the resultant spatial consensus became a matter of record during the sixteenth century. These findings do not refute Elden's thesis, nor his timeline, about the rise of territory as a political technology. However, they suggest that the (unintended) consequences of local negotiations should be taken into account when analysing this transition at the end of the medieval period.

\section{Concluding remarks}

In sum, the territorial integrity of late medieval Guelders was a product of spatial negotiations between neighbouring princes, between lords who were somewhat caught in the middle but who could profit from the liminal spatial position of their jurisdictions, and, finally, between local inhabitants of these jurisdictions. Records from the princely administration of Guelders and elsewhere reveal stability in the number of lordships with high jurisdiction in the Nijmegen Quarter between the early fourteenth century and the later sixteenth century. During this same period, the physical area of power of the princes of Guelders was also relatively stable. As it turned out, the high lordships in Nijmegen's hinterland were largely located along the margins of Guelders and its neighbouring principalities of Brabant, Cleves, and Holland.

49 Scott, Seeing Like a State; De Keyzer, Jongepier and Soens, 'Consuming Maps and Producing Space', pp. 210-212, 233-235.

$5^{\circ}$ GAA, Hof van Gelre en Zutphen, no. 1270. See also Van der Meulen, 'Grillige landschappen', pp. 138-141.

51 Most of these are collected in the 'Civiele procesdossiers' and the 'Verbalen en informatien' of the Court of Guelders: GAA, Hof van Gelre en Zutphen, no. 1270 (for the period 1544-1611), nos 4907-5018 (1543-1600). 


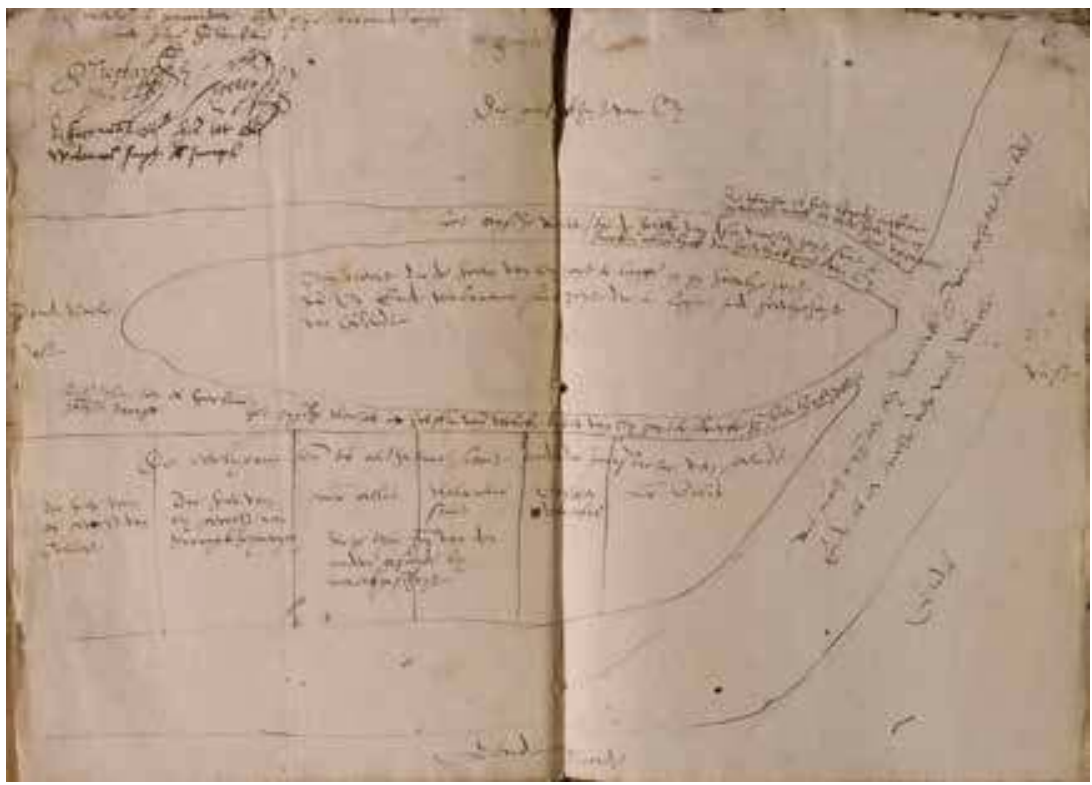

Fig. 4.2. Sixteenth-century 'map' of the border area between the lordships of Ooij and Gendt (1544). Source: GAA, Hof van Gelre en Zutphen, no. 1270.

Semi-independent jurisdictions like these lordships may have persisted in liminal areas in particular, because they indirectly facilitated continuity in the territorial status quo. The reason would be that the administrators of lordships were obliged to maintain local border poles and other forms of demarcation, thereby securing the spatial boundaries on a local level. Whenever such jurisdictions bordered on neighbouring principalities, territorial integrity was effectively outsourced to these local governments. Although it is hard to offer decisive proof, it is a distinct possibility that this became part of the raison d'être of high lordships, at least from the perspective of princely administrations. Even more so, because, in practice, these juridical enclaves did not pose a large military and legal threat to ducal authority.

In that sense, as a 'state', late medieval Guelders shared much common ground with the medieval kingdom of the Scots, as recently examined by Alice Taylor in The Shape of the State in Medieval Scotland, 1124-129o (2016). In both polities, the ruling administration and the rural aristocracy depended on each other to maintain and exercise their power. Much like the kings of Scotland, the princes of Guelders had to rely on intermediaries (sheriffs, but also lords) to ensure that governance was enacted at the local level within their territories. While this version of the medieval state differed from well-known examples of centralised governments, such as England 
and, to a lesser extent, the Burgundian principalities of the late medieval Low Countries, it is very much the question which of the two versions was more common in Europe in the Middle Ages. This question is relevant to the discussion of the link between pre-modern spatial settings and political power, as it challenges the idea that political space should be conceived in terms of 'centre' and 'margins', or 'top-down' and 'bottom-up', at all.

\section{Bibliography}

\section{Primary sources}

Archival sources

Arnhem, Gelders Archief (GAA).

Hof van Gelre en Zutphen, nos 1270, 4346.

Huis Zoelen, nos 200, 201, 202, 298, 314.

Leenkamer van Gelre en Zutphen, no. 12.

's-Heerenberg, Archief Huis Bergh (AHB).

Heerlijkheid Bylandt, no. 4947.

\section{Edited sources}

Guicciardini, Lodovico, Descrittione di M. Lodovico Guicciardini, patritio fiorentino, di tutti i Paesi Bassi, altrimenti detti Germania Inferiore. Con tutte le carte di geographia del paese, \& col ritratto naturale di molte terre principali (Antwerp, $1581)$.

Nijhoff, I., ed., Gedenkwaardigheden uit de geschiedenis van Gelderland, door onuitgegeven oorkonden, 8 vols (Arnhem, 1830-1875).

Van Doorninck, P., ed., Het Oudste Leenactenboekvan Gelre, 1326 (Haarlem: Gebroeders van Brederode, 1898).

Van Doorninck., P.N., and J.S. van Veen, eds, Acten betreffende Gelre en Zutphen, 1107-1415. Naar de drie handschrchriften: A Dat alste register en I oldste register te Arnhem, zoomede B no. 22 te Dusseldorp (Haarlem: Gebrs. van Brederode, 1908).

Van Gent, M., ed., Landdagen en andere landelijke bijeenkomsten van Staten en steden in Gelre en Zutphen 1423-1584, http://resources.huygens.knaw.nl/.

Van 't Hooft, B., Honderd jaar Geldersche geschiedenis in historieliederen (Arnhem, 1948).

Van Veen, J., ed., 'Landrechten van Ammerzoden', Vereeniging tot Uitgave der Bronnen van het Oude Vaderlandsche Recht. Verslagen en Mededeelingen 4 (1903), 595-612. 


\section{Secondary sources}

Anderson, Benedict, Imagined Communities: Reflections on the Origin and Spread of Nationalism, rev. ed. (London/New York: Verso, 2006).

Bavel, Bas van, Transitie en Continuïteit. De Bezitsverhoudingen en de Plattelandseconomie in het Westelijke Gedeelte van het Gelderse Rivierengebied, ca. 130o-ca. 1570 (Hilversum: Verloren, 1999).

Böck, Matthias, Herzöge und Konflikt. Das spätmittelalterliche Herzogtum Geldern im Spannungsfeld von Dynastie, ständischen Kräften und territorialer Konkurrenz (1339-1543) (Geldern: Historischer Verein für Geldern und Umgegend, 2013).

Bosch, Rudolf, Stedelijke macht tussen overvloed en stagnatie. Stadsfinanciën, staatsvorming en economie in het hertogdom Gelre, ca. 1350-1550 (Hilversum: Verloren, 2019).

Brunner, Otto, Land und Herrschaft. Grundfragen der territorialen Verfassungsgeschichte Österreichs im Mittelalter (Darmstadt: Wissenschaftliche Buchgesellschaft, 1970).

Burgers, Jan, and Mario Damen, 'Feudal Obligation or Paid Service? The Recruitment of Princely Armies in the Late Medieval Low Countries', The English Historical Review 133, no. 563 (2018), 777-805.

Buylaert, Frederik, Eeuwen van ambitie. De adel in laatmiddeleeuws Vlaanderen (Brussels: Peeters, 2010).

Buylaert, Frederik, "The Late Medieval "Crisis of the Nobility" Reconsidered: The Case of Flanders', Journal of Social History 45 (2012), 1117-1134.

Carpenter, Christine, Locality and Polity: A Study of Warwickshire Landed Society, 1401-1499 (Cambridge: Cambridge University Press, 1992).

Croenen, Godfried, 'Regions, Principalities and Regional Identity in the Low Countries: The Case of the Nobility', in Regional Landscapes, Reality and Imagination in Late Medieval and Early Modern Europe, ed. by Peter Ainsworth and Tom Scott (Berlin: P. Lang, 2000), pp. 139-154.

Damen, Mario, 'Heren met banieren. De baanrotsen van Brabant in de vijftiende eeuw', in Bourgondië voorbij. De Nederlanden 1250-1650. Liber alumnorum Wim Blockmans, ed. by Mario Damen and Louis Sicking (Hilversum: Verloren, 2010), pp. 139-158.

Damen, Mario, and Antheun Jansen, 'Adel in meervoud: methodologische beschouwingen over comparatief adelsonderzoek in de Bourgondische Nederlanden', Bijdragen en Mededelingen Betreffende de Geschiedenis der Nederlanden 123 (2008), 517-540.

De Keyzer, Maïka, Iason Jongepier and Tim Soens, 'Consuming Maps and Producing Space: Explaining Regional Variations in the Reception and Agency of 
Mapmaking in the Low Countries during the Medieval and Early Modern Periods', Continuity and Change 29 (2014), 209-240.

Denessen, Henny, 'De Gelderse bannerheren in de vijftiende eeuw', Virtus:Journal of Nobility Studies 20 (2013), 11-37.

Elden, Stuart, The Birth of Territory (Chicago/London: University of Chicago Press, 2013).

Elden, Stuart, 'Land, Terrain, Territory', Progress in Human Geography 34, no. 6 (2010), 799-817.

Elden, Stuart, Terror and Territory: The Spatial Extent of Sovereignty (Minneapolis/ London: University of Minnesota Press, 2009).

Firnhaber-Baker, Justine. Violence and the State in Languedoc, 1250-1400 (Cambridge: Cambridge University Press, 2014).

Graswinckel, Dirk, 'Hulhuizen', Bijdragen en Mededelingen van de Vereniging Gelre 27 (1927), 1-29.

Groustra-Werdekker, Aafje, 'Bourgondisering van het hertogdom Gelre vóór het Tractaat van Venlo, 1473-1543', Publications du Centre Européen d'Etudes Bourguignonnes 36 (1996), 89-103.

Gunn, Steven, David Grummet and Hans Cools, War, State and Society in England and the Netherlands, 1477-1559 (Oxford: Oxford University Press, 2007).

Janse, Antheun, Ridderschap in Holland. Portret van een Adellijke Elite in de Late Middeleeuwen (Hilversum: Verloren, 2001).

Johnson, Tom, 'The Tree and the Rod: Jurisdiction in Late Medieval England', Past \& Present 237 (2017), 13-51.

Lefebvre, Henri, The Production of Space, trans. by Donald Nicholson-Smith (Oxford: Blackwell, 1991).

Ligthart, Jaap, 'Involvement of the Guelders Estates in the Alienation of Ducal Domains (1423-1473)', in Publieke Financiën in de Lage Landen (1300-180o), ed. by Jaco Zuijderduijn and Dries Raeymaekers (Maastricht: Shaker Publishing, 2015), pp. 49-68.

Ligthart, Jaap, 'Verpanding van domeingoederen in het Kwartier van Arnhem door Arnold van Gelre (1423-1473)', Bijdragen en Mededelingen van de Vereniging Gelre 105 (2013), 51-80.

Kalkwiek, Klaas, De hertog en zijn burchten. Kastelen in de Gelderse geschiedenis tot 1543 (Zaltbommel, 1976).

Kuys, Jan, 'Dagelijkse heerlijkheden in de Bommeler- en Tielerwaard tot omstreeks het midden van de zeventiende eeuw', Bijdragen en Mededelingen van de Vereniging Gelre 70 (1979), 1-35.

Kuys, Jan, De Ambtman in het Kwartier van Nijmegen (ca. 1250-1543) (Nijmegen: Gerard Noodt Instituut, 1987). 
Kuys, Jan, 'De heerlijkheid Ammersoyen en zijn heren in de middeleeuwen', in Ammersoyen. Bijdragen tot de geschiedenis van het kasteel, de heerlijkheid en de heren van Ammersoyen, ed. by Dirk Buurman (Zutphen: Walburg Pers, 1986), pp. 119-135.

Maris, Adriana, 'De lijst van bannerheerlijkheden en andere hoge heerlijkheden in Gelre en Zutphen van 1569', Bijdragen en Mededelingen van de Vereniging Gelre 68 (1974-1975), 143-159.

Martens van Sevenhoven, A.H., 'Schets van de geschiedenis der burgerlijke gemeenten in Gelderland vóór de invoering der Gemeentewet van 1851', Bijdragen en Medeedelingen Gelre 24 (1921), 1-50.

Moorman van Kappen, Olav, 'Proeven van locale wetgeving door de heren van Ammersoyen in de $_{15} 5^{\mathrm{e}}$ en $16^{\mathrm{e}}$ eeuw: de Ammersoyense landbrieven van 1471 en 1548', in Ammersoyen. Bijdragen tot de geschiedenis van het kasteel, de heerlijkheid en de heren van Ammersoyen, ed. by Dirk Buurman (Zutphen: Walburg Pers, 1986), pp. 136-159.

Nijsten, Gerard, Het Hofvan Gelre. Cultuur ten tijde van de Hertogen uit het Gulikse en Egmondse Huis (1371-1473) (Kampen: Vbk Media, 1992).

Nobel, Arjan, Besturen op het Hollandse Platteland. Cromstrijen, 1550-1770 (Zutphen: Walburg Pers, 2012).

Noordzij, Aart, 'De landvrede van 1377: de betekenis van grenzen binnen een Gelders verbond', in Gelderland Grensland. 2000 Jaar Verdeeld en Verbonden, ed. by Dolly Verhoeven et al. (Nijmegen: Vantilt, 2016), pp. 40-49.

Noordzij, Aart, Gelre. Dynastie, Land en Identiteit in de Late Middeleeuwen (Hilversum: Verloren, 2008).

Noordzij, Aart, 'The Wars of the Lord of Bronkhorst: Territory, Lordship, and the Proliferation of Violence in Fourteenth-Century Guelders', The Medieval Low Countries 1 (2014), 61-93.

Prins, Maarten, 'Heren van Holland: het bezit van Hollandse heerlijkheden onder adel en patriciaat (1500-1795)', Virtus: Journal of Nobility Studies 22 (2015), 37-62.

Reynolds, Susan, 'The Historiography of the Medieval State', in Companion to Historiography, ed. by Michael Bentley (London: Routledge, 1997), pp. 109-129.

Schneider, Zoe, The King's Bench: Bailiwick Magistrates and Local Governance in Normandy, 1670-1740 (Suffolk: Boydell \& Brewer, 2008).

Scott, James, Seeing Like a State: How Certain Schemes to Improve the Human Condition Have Failed (New Haven/London: Yale University Press, 1998).

Stein, Robert, Magnanimous Dukes and Rising States: The Unification of the Burgundian Netherlands, 1380-1480 (Oxford: Oxford University Press, 2017).

Struick, Jules, Gelre en Habsburg, 1492-1528 (Gouda: Quint, 1960). 
Taylor, Alice, 'Formalising Aristocratic Power in Royal Acta in Late Twelfth- and Early Thirteenth-Century France and Scotland', Transactions of the Royal Historical Society 28 (2018), 33-64.

Taylor, Alice, The Shape of the State in Medieval Scotland, 1124-129o (Oxford: Oxford University Press, 2016).

Tilly, Charles, Coercion, Capital, and European States, A.D. 990-199o (Cambridge, MA: Basil Blackwell, 1990).

Van der Meulen, Jim, 'Grillige landschappen, grillige heerschappen. De veranderlijke natuur en de ruimtelijke afbakening van heerlijkheden in het Gelderse rivierengebied ( $15^{\mathrm{e}}$ en $16^{\mathrm{e}}$ eeuw)', Bijdragen en Mededelingen: Historisch Jaarboek voor Gelderland 111 (2020), 125-145.

Van der Meulen, Jim, 'Vassalage and Authority: The Knightly Estate of FourteenthCentury Brabant', The Medieval Low Countries 3 (2016), 61-95.

Van Doornmalen, Alois, De Herlaars in het Midden-Nederlands Rivierengebied (ca. 1075-1400) (Hilversum: Verloren, 2018).

Van Schaïk, Remi, 'Taxation, Public Finances and the State-Making Process in the Late Middle Ages: The Case of the Duchy of Guelders', Journal of Medieval History 19 (1993), 251-271.

Van Steensel, Arie, 'Beyond the Crisis of the Nobility: Recent Historiography on the Nobility in the Medieval Low Countries II', History Compass 12 (2014), 273-286. Weber, Max, 'Politics as a Vocation', in Max Weber, The Vocation Lectures, ed. by David Owen and Tracy Strong, trans. by Rodney Livingstone (Indianapolis: Hackett Publishing, 2004), pp. 32-94.

Wickham, Chris, 'Defining the seigneurie since the War', in Pour une anthropologie du prélévement seigneurial dans les campagnes médiévales (Xle-XIV siècles): Réalités et représentations paysannes. Colloque tenu à Medina del Campo du 31 mai au 3juin 2000, ed. by Monique Bourin and Pascual Martínez Sopena (Paris: Publications de la Sorbonne, 2004), pp. 43-50.

Zmora, Hillay, Monarchy, Aristocracy and the State in Europe, 1300-180o (London/ New York: Routledge, 2001).

Zuijderduijn, Jaco, 'On the Home Court Advantage: Participation of Locals and Non-residents in a Village Law Court in Sixteenth-Century Holland', Continuity and Change 29 (2014), 19-48.

\section{About the author}

Jim van der Meulen is working as a Postdoctoral Researcher in a comparative team project about lordship and state formation in late medieval Europe, where his focus is on the principality of Guelders, 1300-16oo. 


\section{Part 2}

The Construction of Territory 



\title{
5. Demographic Shifts and the Politics of Taxation in the Making of Fifteenth- Century Brabant
}

\author{
Arend Elias Oostindiër and Rombert Stapel
}

\begin{abstract}
In 1437, the Burgundian Duke Philip the Good introduced hearth counts in the Duchy of Brabant, engineering a complete overhaul of the existing fiscal system. Hearth or household counts offered a rational and uniform determinant for allocating each locality a share in the general taxes. This curbed opportunities to negotiate rebates, reducing the bargaining power of the duke's subjects in this key principality in the Burgundian composite monarchy and one of the most densely populated regions in Europe.

In this paper we use new GIS-reconstructions of village-level boundaries and novel spatial techniques to map the fiscal capacity of the contributing localities before $(1383 / 1386)$ and after $(1436-1442)$ the reform. By combining this to written sources of the negotiations, we show how the duke was able to exploit the hearth censuses as a tool of power for mastering the political space.
\end{abstract}

Keywords: Brabant; human geography; historical GIS; hearth counts; fiscal history

\section{Introduction}

Prior to developments in cartography and land surveying, administration formed the primary instrument for the representation and mastery of space. ${ }^{1}$ This is especially true in a fiscal context. Of the full spectrum of

1 Regarding the role of administration in the development of government in medieval France and its mastery of space (maîtrise de l'espace): Dauphant, Royaume des quatre rivières.

Damen, M. and K. Overlaet (eds.), Constructing and Representing Territory in Late Medieval and Early Modern Europe. Amsterdam: Amsterdam University Press, 2022 DOI 10.5117/9789463726139_CHO5 
fiscal resources available to pre-modern rulers, direct taxation in particular requires an active and often repetitious acknowledgement that a subject (be it a person, household, institution, or a community), willingly or not, belongs to a political entity that exerts a form of 'tax sovereignty', which can be actively consolidated through administration. ${ }^{2}$ Both taxation and administration are therefore strongly related to the development of the concept of territory, understood in this volume as the relationship between people, power, and space. ${ }^{3}$ This point is stressed even more by the fact that direct taxation always - at least in a medieval context - was the result of a negotiation process between a sovereign and representatives of his subjects. Such negotiations between political stakeholders legitimised the tax sovereignty of a ruler, shaped the act of taxation itself (who is being taxed, when, and how much), established administrative practices, and contributed to the development of institutions through which these negotiations could take place. As such, fiscal politics can have a layered effect on the evolution of fledgling territories into coherent relational spaces.

In this article we will study how reforms in the fiscal practices in the Duchy of Brabant - one of the key principalities of the Low Countries helped its new Burgundian rulers to control this space. Particular focus goes out to the role of knowledge of the socio-economic and demographic composition and relations of the territory as a tool of power during this process, especially in the negotiations on direct taxes. It is set against the backdrop of one of the most ambitious political projects in late medieval Europe, the unification of the Low Countries under Burgundian, later Habsburg, rule. As the Burgundian dukes expanded their influence in the Low Countries from the late fourteenth century onwards, slowly building towards their composite monarchy, they not only gained control over some of the most populous territories in Europe, they also inherited, in Robert Stein's words, bankrupt dynasties. ${ }^{4}$ Improving the revenue flow, both in terms of maximisation and of reliability, was an immediate priority. Whereas previous dynasties in the Low Countries (like elsewhere in Europe) had relied strongly on revenues from domains, coinage, and indirect taxation, by the end of the fifteenth century, revenues from direct taxation - always subject to negotiation and previously reserved for specific occasions only

2 For the concept of 'tax sovereignty': Bonney, 'Introduction', pp. 3-4. Although direct taxation can also be applied in a local context, this paper will focus on the so-called 'general taxes' levied by territorial princes on the entire population subject to their sovereignty.

3 See the introduction of this volume, and Elden, The Birth, pp. 10-11.

4 Stein, Magnanimous Dukes, chap. 4. 
- had become the most important (and steady) source of income for the Burgundian dukes. ${ }^{5}$ This increased emphasis on direct taxation followed from a strategy of the fifteenth-century Burgundian dukes that focused on professionalisation of the (financial) administrative apparatus and creating a more equitable repartition of the taxes. ${ }^{6}$ A cornerstone of this strategy was the introduction of hearth counts, inspired by the French fouage, as a rational and uniform determinant for the repartition of taxes in all parts of the Burgundian composite monarchy.7 From the duke's perspective, the hearth counts - despite being a costly affair ${ }^{8}$ - offered an opportunity to increase the regularity of income from taxes, to improve the revenues, and to expedite his negotiations with the Estates in his individual principalities that preceded each round of taxes. The counts were a significant step in the direction of creating fiscal equity, in which every subject (in this case, towns and villages) contributed to its economic rather than its political weight. This meant that opportunities to negotiate rebates were curbed, reducing the bargaining power of the duke's subjects. ${ }^{9}$

In the Duchy of Brabant, this transformation was set in motion by Duke Philip the Good's introduction of hearth counts as a basis for taxation, in 1437. ${ }^{10}$ Whereas a previous attempt to repartition Brabantine taxes using objective economic data, in 1374, had failed to set a longstanding precedent, ${ }^{11}$ the hearth count system remained in place during the entire Burgundian and much of the Habsburg period. ${ }^{12}$ It seems that the duchy was an important testing ground for fiscal innovations by the Burgundian dukes. Brabant was not only one of the first territories in the Low Countries where the Burgundians introduced regular - yearly - aids, ${ }^{13}$ it was also, apart from an extraordinary taxation in the Kennemerland in the County of Holland

5 On taxation as an instrument of state formation, see Stein, Magnanimous Dukes, chap. 8.

6 Blockmans, 'Low Countries', pp. 281-284.

7 Like the fouage, the hearths in the Low Countries - in a fiscal sense - are usually equalled to households and/or (especially in the earlier censuses) to houses, and much less often to physical fireplaces, as was the case in seventeenth-century England. Arnould, Relevés de feux, pp. 17-21.

8 For instance, the Brabantine hearth count of $15^{2} 6$ had cost 26,601 florins: Cuvelier, Dénombrements de foyers, p. ccliv.

9 Blockmans, 'Low Countries', p. 285.

10 On the organisation of hearth counts, see the introduction by Cuvelier, Dénombrements de foyers.

11 Moureaux-Van Neck, 'L'aide brabançonne', p. 271; Cuvelier, Dénombrements de foyers, pp. xcv-xcvi.

12 Regarding the decline of hearth count-based taxes in the sixteenth century: Arnould, Dénombrements de foyers, pp. 11-20.

13 Stein, Magnanimous Dukes, p. 235. 
in $1426,{ }^{14}$ the first territory in which the Burgundian dukes successfully negotiated an overhaul of the fiscal system based on demographic surveys (mirroring existing examples in Hainaut, France, and Burgundy itself). ${ }^{15}$

Most importantly, because of the existence of the incidental report of 1374, it is also one of the few territories for which sources allow us to study the per capita effects of the fiscal reform on a village-by-village basis. In our analysis we will compare two rounds of taxes that were levied according to the traditional taxation system $(1383 / 1386)^{16}$, with the first round that was levied on the basis of Philip the Good's reform (1436-1442). Subsequently, we will approximate the contributions per capita for each of the hundreds of localities addressed in the tax, using the adult count of 1374 and hearth count of $1437 / 1438$. This analysis is paired with a new GIS reconstruction of the village-level boundaries in the medieval Duchy of Brabant (Fig. 5.1), which is used to demarcate geographically the unaggregated hearth counts and fiscal capacity of the contributing communities before and after the tax reform. ${ }^{17}$

To our knowledge, such a detailed spatial approach has not been applied before to an area of this extent. ${ }^{18}$ It provides an opportunity to juxtapose the negotiating positions of individual members of the Estates with the actual results of the reform. In that way, it becomes possible to assess the level of knowledge concerning the Brabantine territory possessed by the individual negotiating parties at the onset of the negotiations. The GIS reconstructions allow us, as historians, accurately to map how uneven demographic developments in Brabant, one of the most densely populated areas in Europe, led to an unbalanced distribution of the fiscal burdens which is particularly eye-catching prior to the Burgundian rule. Rather than focusing on this information in itself, we exploit this knowledge as a hermeneutic tool, to

14 This will be briefly addressed below.

15 Hearth (or house) counts were introduced in Brabant in 1437 and subsequently in Burgundiancontrolled territories of Limbourg in 1445, in Artois, Boulonnais, Flanders (partially), Namur, and Picardy in 1469, in Liège in 1470, Luxembourg in 1473, and Holland in 1494 (apart from the aforementioned experiment in 1426). Only in some territories, like Brabant, the hearth counts remained in use for a longer period. Hearth counts had already been in existence in Hainaut since 1365, and in Burgundy since 1357 (with an early example dating back to 1285). In Guelders the basis for taxation were counts of the heads of household, which included an estimation of their wealth. In Stavelot-Malmédy the earliest hearth count has been recorded in 1524 .

16 The aid of 1386 is sometimes wrongly dated 1385 : Uyttebrouck, 'Inventaire des comptes généraux', p. 124, note 39 .

17 Stapel, 'Historical Atlas'. The GIS dataset is available at https://hdl.handle.net/10622/ PGFYTM.

18 A recent paper using GIS to present late medieval fiscal sources from Southern Italy is primarily technical in nature: Carrion et al., 'From Historical Documents to GIS'. 


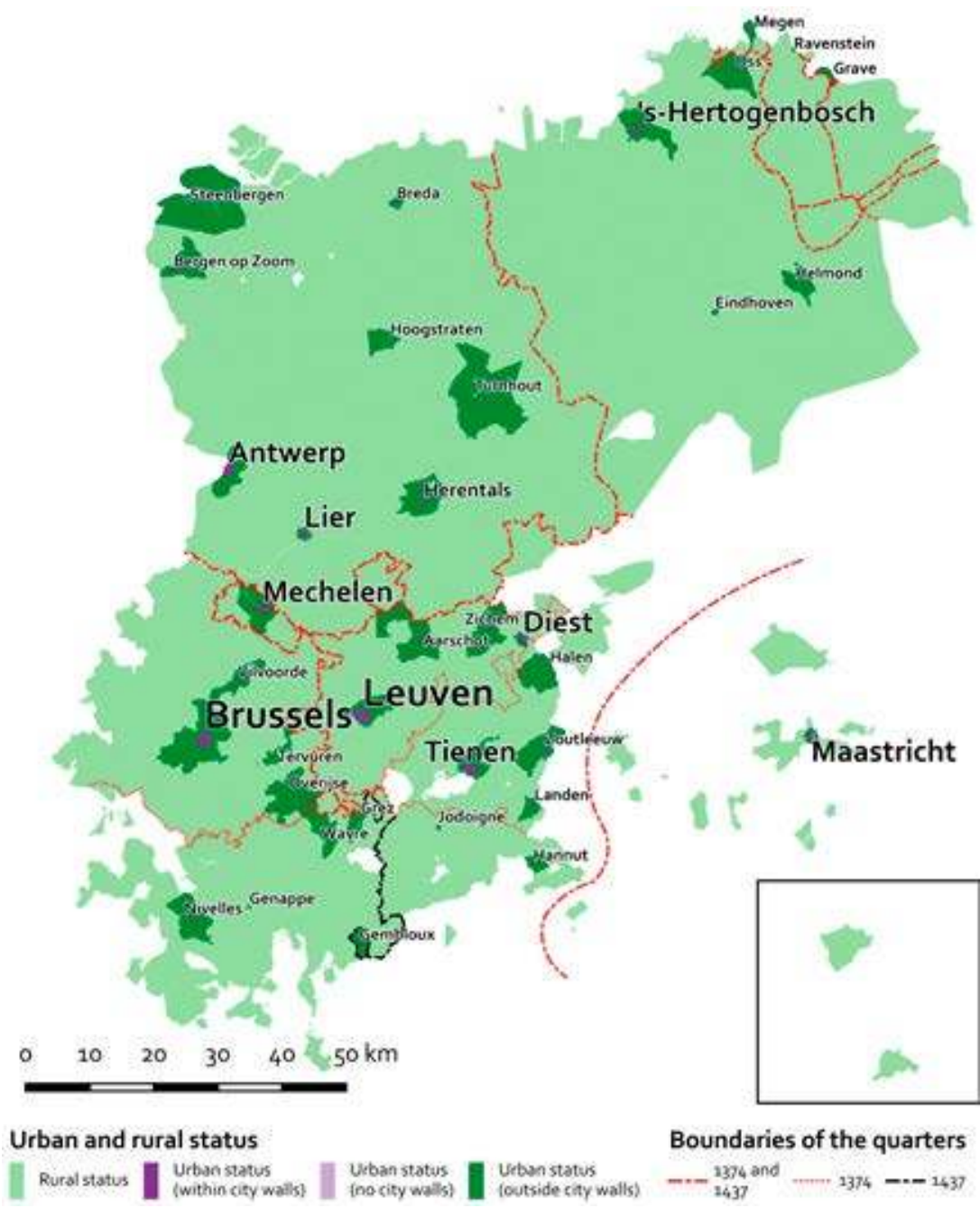

Fig. 5.1. Urban and rural status of the Duchy of Brabant. The inlay (with identical scale) shows the Brabantine enclaves of Lommersum and Kerpen (near Cologne). The introduction of the hearth counts was accompanied by a reorganisation of the six, later four, main quarters. In 1374 these were Brussels, Leuven, Tienen, Antwerp, Walloon Brabant (or Nivelles), and 's-Hertogenbosch. After 1437, Walloon Brabant was split between Leuven and Brussels, whereas Tienen became part of the quarter of Leuven. Maastricht and other condominiums with the Prince-Bishopric of Liège, as well as areas in the northeast, were administered separately from the quarters. ${ }^{19}$

test to what extent those involved in the fiscal negotiations were aware of the demographic weight and wealth of the different corners of the duchy, and able to utilise this information to their advantage. 


\section{Traditional organisation of the taxes}

In moments at which territorial princes like the dukes of Brabant were in financial need, they could ask their subjects for incidental aids or subsidies. These were called beden, in Dutch, or aides, in French..$^{20}$ The dukes requested specific sums of money for specific purposes. In some situations, the socalled cas féodaux, their subjects were obliged to participate in the aids: in the event of an accolade, princely marriage, or as ransom should the prince be taken captive. ${ }^{21}$ In other cases, for instance, when ducal debt had to be salvaged or when the dukes waged an expensive war, the Brabanters could not be forced to support the dukes financially. Each time the dukes requested an aid, it had to be approved by the Estates, the representative organ of prelates, nobles, and towns. ${ }^{22}$ In return for the aids, they were able to negotiate concessions from the dukes. Rather than negotiating individual concessions or tax rebates, the Estates used this financial power to force the dukes to comply with their inauguration charters (Blijde Inkomsten, or 'Joyous Entries'). That way, the aids functioned as a system of checks and balances which allowed the Estates to rescind violations by the duke of specific articles, for example, concerning the alienation of domains. ${ }^{23}$

Once an aid was granted, the burden of the tax was divided among the (many hundreds of) contributors via a graduated repartition system. The traditional repartition of the aid seems somewhat arbitrary; it is not clear whether (or to what degree) it was based on demographic, economic, or political relations. It was divided into three equal parts. ${ }^{24}$ The first part was paid for by the 'prelates', a group of around 45 religious institutions. ${ }^{25}$ Although the composition of the list of contributing institutions changed little from the fourteenth century onwards, the reasons why some institutions

20 For an overview of the Brabantine subsidies between 1356-1430, see Moureaux-Van Neck, 'Un aspect'; and Moureaux-Van Neck, 'L'aide brabançonne'. For a comparative view of fiscal policies in pre-modern Europe, see the contributions in Bonney, The Rise.

21 Moureaux-Van Neck, 'Un aspect', p. 65.

22 On the Estates as an institutionalised platform of deliberation, see Damen, 'Nobility in the Estates'.

23 Vrancken, Blijde Inkomsten, p. 72; see, for example, Stein, Magnanimous Dukes. For negotiations in the fourteenth century: Avonds, Land en instellingen; Moureaux-Van Neck, 'Un aspect'; for the fifteenth century: Vrancken, Blijde Inkomsten.

24 Moureaux-Van Neck, 'Un aspect'.

25 The group consisted of the oldest male and female institutions of regular clergy with possessions in the duchy. It excluded secular clergy, more recent religious orders such as the Carthusians or mendicants, as well as a handful of abbeys, such as La Ramée and Gembloux: Damen, 'Prelaten, edelen en steden', pp. 43-47; Van Uytven, 'Wereldlijke overheid', pp. 82-90, 99-106. 
were included and others excluded are unknown. ${ }^{26}$ The second group of contributors consisted of the seven major Brabantine towns: Leuven, Brussels, Antwerp, 's-Hertogenbosch, Tienen, Nivelles, and Zoutleeuw. The third group consisted of villages in the countryside and the smaller towns. For each of the three groups, a sub-repartition existed that was immutable, which meant that it was unable to adapt to demographic and economic dynamism. Leuven and Brussels, for example, both paid one-third of the urban share, and the other towns paid a fraction: Antwerp one-ninth, 's-Hertogenbosch one-twelfth, Tienen one-fifteenth, Nivelles one-eighteenth, Zoutleeuw one-forty-fifth. ${ }^{27}$

Between 1356 and 1430, the organisation of aids was firmly controlled by the Estates: they voted on the aids, they co-decided on the ends for which the profits would be spent, and they supervised the collection of the aids. ${ }^{28}$ Only in four cases did they deviate from the traditional repartition. In 1356 , the shares were adjusted, and as a result the towns paid half of the aid instead of one-third. ${ }^{29}$ In 1374 they counted all adult individuals in the duchy whose wealth reached a particular threshold, and taxed towns and villages accordingly (without further differentiating between poor and rich localities).$^{30}$ This case was exceptional: the Estates allowed not a single representative of the duke in the receiving committee of the aid. ${ }^{31}$ Moreover, they negotiated a reassurance that future aids would be repartitioned again according to the traditional tax.$^{32}$ This explains why there is no evidence that the results of the 1374 adult count were used - either by the Estates or the duke - to gain insight into the socio-economic constitution of the territory in subsequent years..$^{33}$ In 1394 the Estates repartitioned the aid on the basis

26 Van Uytven, 'Wereldlijke overheid', p. 105.

27 Within a town or village, the subsidy could be further repartitioned according to the wealth of individuals or households: Blockmans, 'Low Countries', p. 285; Korvezee, 'Belastingen', pp. 99-100. 28 Uyttebrouck, Gouvernement, vol. 1, pp. 530-535. The reign of Antoon (r. 1406-1415) was an exception, during which the duke had more control over the aids.

29 The countryside paid its regular share of one-third; the prelates only one-sixth. Moureaux-Van Neck, 'Un aspect', p. 73, note 1.

30 Moureaux-Van Neck, 'Un aspect', p. 76 .

31 See the table concerning the organisation of aids in Uyttebrouck, Gouvernement, vol. 1, pp. 530-535.

32 In 1356 , the Estates expressed that they would make a different repartition 'only this time' ('ista vice'); in 1374, the duke was forced to confirm that 'hereafter [...] all usual customs and taxations remain in place that have applied to aids in Brabant in the old days' ('vortaen bliven staende in alzulk ghewoenliker costumen ende taxatien als men van ouds in Brabant van beeden ende van dienste geuseert ende gewoenlec heeft gheweest te doene'): Moureaux-Van Neck, 'Un aspect', p. 73, note 1 .

33 The only exception is the 'riders tax' (glaviegeld) in the quarter of 's-Hertogenbosch in 1387, which was repartitioned using the 1374 adult count: Cuvelier, 'Le fouage', pp. 546-547; Van 
of a poll tax, taxing individual Brabanters on the basis of the value of their possessions. ${ }^{34}$ In 1428 they took the level of control over the aid a number of steps further: the Estates collected and spent the profits of the aid, and not a penny reached the duke himself. Also, led by Leuven, Brussels, and Antwerp, the Estates forced Duke Philip of St-Pol to abstain from his right to ask for aids in the future, even for the 'legitimate' cas féodaux, and forbade the duke from alienating any more of his domains - a policy that generated short-term profits, but destroyed the basis of ducal income - except with the approval of the three Estates. ${ }^{35}$

For the aid of 1428, the Estates decided to charge the parts of the duchy most affected by a declining economy, most notably the quarters of Leuven, Tienen, and Walloon Brabant, according to a form of capitation. ${ }^{6}$ The other localities, mainly in the quarters of Brussels, Antwerp, and 's-Hertogenbosch, were taxed according to the traditional repartition. ${ }^{37}$ Although the administrators realised that they could not estimate the result of this procedure, they did not prepare themselves for the eventual deficit, nor was the procedure supported by a thorough analysis of the socio-economic structure of the duchy. The experiment proved a financial disaster for the Brabantine administration. In 1428, Leuven contributed 3,174 crowns instead of the 13,888 crowns it would have contributed, according to the old repartition. Similar decreases occurred in the contributions of other towns. As a result, only a fraction of the requested sum could be collected..$^{8}$

A constant which runs through the aids prior to the hearth counts is that no central authority possessed the territorial knowledge or expertise reliably to estimate the real fiscal balance in the duchy; something that, as the example of France has made clear, was a major element in the mastery of the territory. ${ }^{39}$ Attempts to experiment with adult counts or capitation, such as in 1374 and 1428 , were crudely executed and, to the extent these experiments led to the creation of socio-economic data, their results failed to become part of an institutional memory. Thus, the adjustments of the traditional tax repartition retained an ad hoc character, leading to chaos in the fiscal administration and a loss of income.

Asseldonk, 'De Meierij', p. 496.

34 Moureaux-Van Neck, 'Un aspect', p. 77.

35 Vrancken, Blijde Inkomsten, pp. 298-299.

36 Moureaux-Van Neck, 'Un aspect', pp. 75-79; Kauch, 'Ladministration', pp. 168-172.

37 Except for Vilvoorde, Overijse, and Tervuren in the quarter of Brussels, and Steenbergen and the villages under Cleves in the quarter of Antwerp: Moureaux-Van Neck, 'Un aspect', p. 77.

38 Moureaux-Van Neck, 'Un aspect', p. 78.

39 Dauphant, Royaume des quatre rivières, chap. 2 (especially Section II). 


\section{Shifts in population geography}

The mounting challenges associated with the traditional repartition schemes fell at a time of significant changes in the population geography of the duchy. ${ }^{4^{0}}$ Years of uneven demographic - and assumedly economic - growth in the various Brabantine towns and regions were altering the socio-economic constitution of Brabant and put a strain on the contributionto-population ratios in the various parts of the duchy.

It is not straightforward to document these demographic shifts. Whereas Brabantine population estimates based on hearth and other counts are widely available for over a century, ${ }^{41}$ most analyses feature aggregate values such as totals for the entire territory, specific quarters only, or urban and rural divisions. ${ }^{42}$ This is not sufficient if we want to compare the outcomes of the repartition systems for specific political actors in the negotiation process. Any imbalances that may have existed in the traditional taxation system (in terms of the contribution-to-population ratio), or the effects of the new repartition, were not limited to one quarter versus another, or towns versus countryside. Rather, the old taxation system was marred by a myriad of local imbalances. When reconstructing the demography of the duchy, it is therefore essential to retain a local differentiation in order to make meaningful assessments of the effects of the fiscal reform.

Using our GIS reconstruction, it is possible to link data collected from the various hearth counts and aids to the maps. This requires combining different types of sources, taken at various moments in time, under different conditions, and each with different geographical extents. To counter any problems that may occur, the data need to be specially prepared. These preparations, described in the Appendix, allow for valid comparisons of the unaggregated hearth counts and aids through time. By contrasting the results of the adult count in 1374 with the number of hearths or houses taxed in $1437 / 1438$, the shifts in the geographical distribution of the population

40 Referring to the part of the duchy that coincided with the nineteenth-century Belgian provinces of Antwerp and Brussels: Klep, Bevolking en arbeid, chap. 1.

41 Cuvelier, Dénombrements de foyers; Cosemans, Bevolking van Brabant; Klep, Bevolking en arbeid; Paul Klep continued to publish on the subject: Klep, 'Regional Disparities'; Klep, 'Long-term Developments'.

42 An exception is the work by Norman Pounds: Pounds, 'Population and Settlement'; Pounds and Roome, 'Population Density'. Paul Klep made extensive use of the unaggregated counts, but was not able to publish the data in that form. 

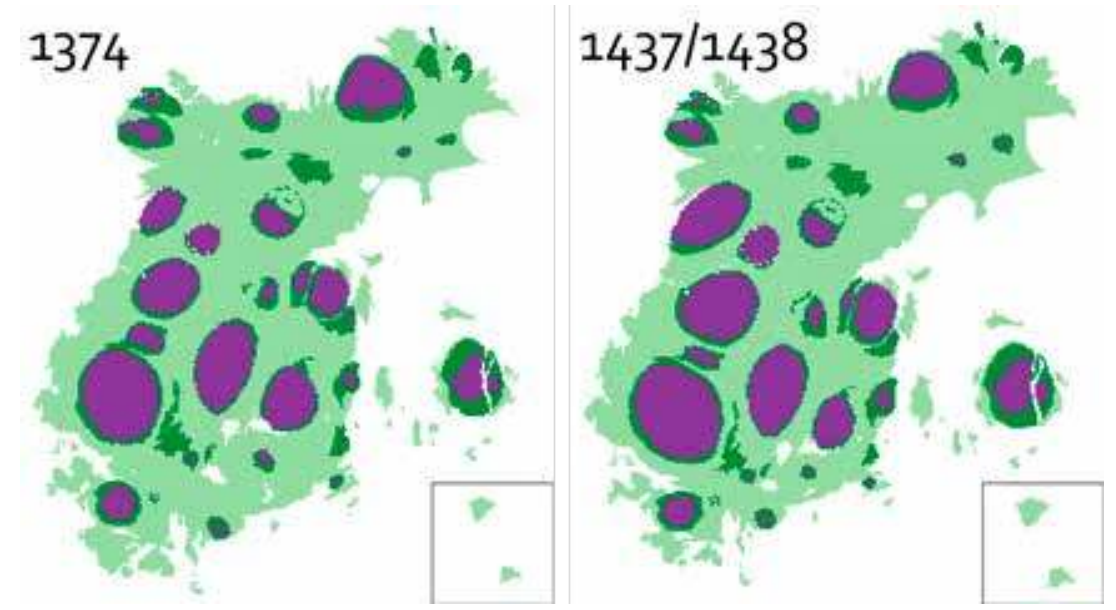

Figs 5.2a-b. Cartogram maps of the Duchy of Brabant, by share of the census. The cartograms consist of a number of hexagons, each hexagon more or less representing an equal share in the count. Missing values are interpolated. ${ }^{43}$

within the duchy become evident (Figs 5.2a-b and 5.3). First of all, the variability between communities was quite high. Most eye-catching, however, is the strong decline of Walloon Brabant's share in the census, in favour of the Campine area in the north-east (Fig. 5.3). The rural communities of Walloon Brabant had experienced economic stagnation due to the decline of industries and low grain prices. ${ }^{44}$ The growing importance of Antwerp, meanwhile, in terms of population size, can also be clearly observed (Figs $5.2 \mathrm{a}-\mathrm{b}) .{ }^{45}$ Other urban centres witnessed rather mixed, but much more modest, changes. Brussels increased its share slightly, Leuven remained

43 Localised and computed certainty values to accompany these maps are currently being prepared to appear in a separate publication. As it stands, a small selection of areas for which there are few (nearby) counts are quite speculative. To some extent this affects Mechelen (included only in counts of 1544 and 1800 ), but especially Maastricht (which is based solely on the population in 1800 , interpolated using growth rates of nearest neighbours which are quite far removed), is a key example.

44 Van Uytven, 'Dichte bevolking'.

45 Note that our estimation of the number of regularly taxed households within the town of Antwerp in 1374 is 1,131 households, which is much lower than the 1,6oo previously estimated by Van Gerven. Whereas we have used the corresponding ratios of the count of 1437 to separate Antwerp and the surrounding villages from each other (counted together in 1374), Van Gerven based his estimate on a mid-fourteenth-century report that highlights Antwerp's fiscal contributions in comparison to the surrounding villages, which in our view likely overestimates the town's share in the population. This means that the growth of Antwerp during the late fourteenth and fifteenth centuries was even more pronounced: Van Gerven, 'Antwerpen', p. 910. 


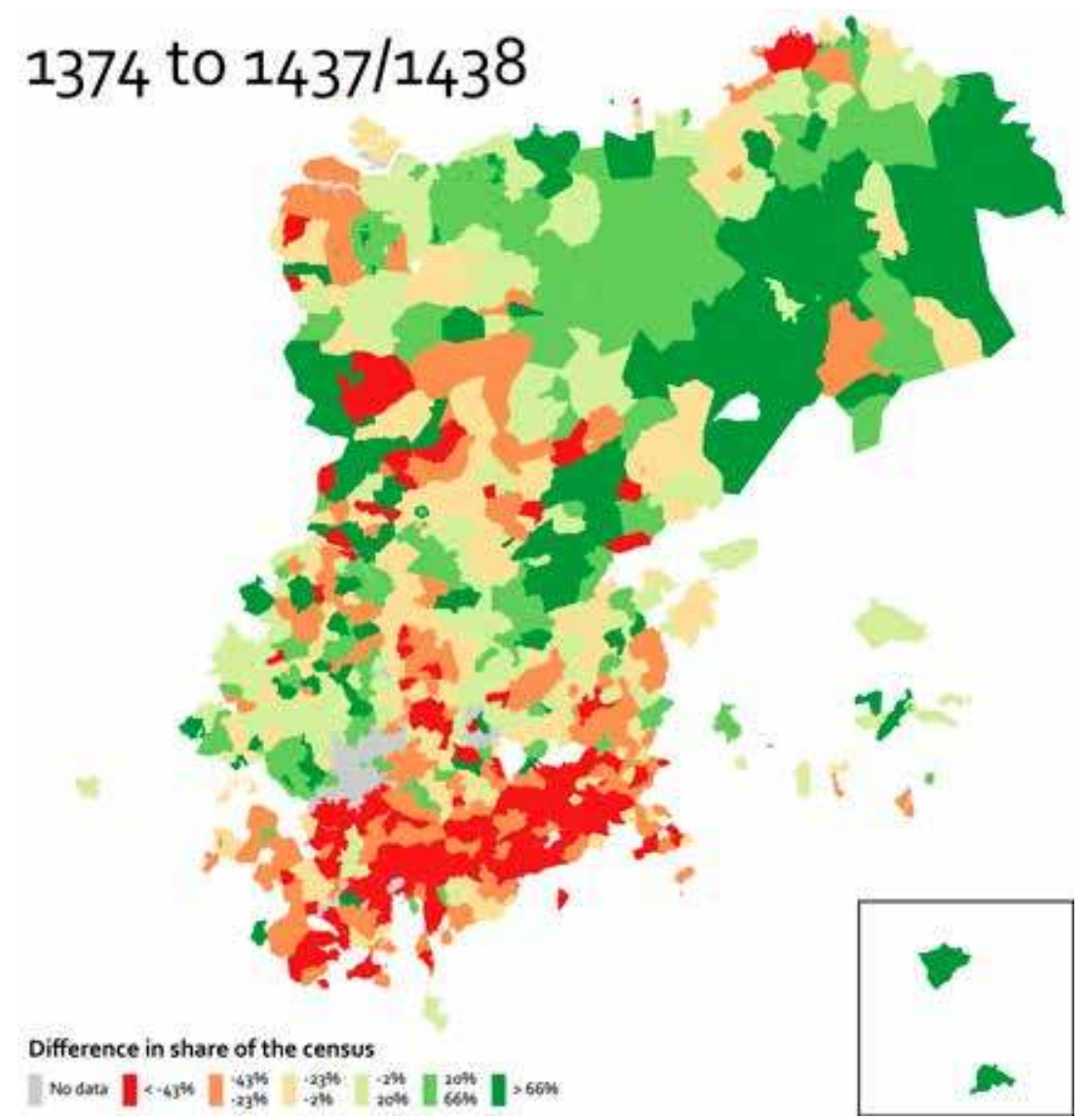

Fig. 5.3. Difference in a community's share of the census between 1374 and 1437/1438. Missing values are interpolated.

the same, and 's-Hertogenbosch was confronted with a small drop in its share (which either reflects a population decrease or a failure to match the growth rates reached elsewhere in the duchy).

\section{Introduction of the hearth count system}

The changes in the population geography and imbalances associated with the contribution-to-population ratio had the potential to undermine the long-term effectiveness of the fiscal system. It is unclear to what extent the Estates, which had been overseeing the aids thus far, or the ducal administration were aware of this. We may assume that at the very least the fiasco of 1428 prepared those in charge to accept the need for reform. 
Most importantly, though, the Estates were soon confronted with a new duke, Philip the Good (r. 1430-1467), who was familiar with alternative repartition systems. Under his reign, the power balance between the duke and the Estates shifted dramatically.

On 9 May 1433, Philip asked the Estates for an aid to pay for his Joyous Entry, which had taken place three years before. ${ }^{46}$ Theoretically, Joyous Entries did not belong to the cas féodaux, but in practice the Estates had paid for the Entries of Philip's predecessors. ${ }^{47}$ For the levy of this aid, the Estates set out to innovate the outdated repartition. They did so in consultation with representatives of the duke. In 1436, they discussed the matter in at least ten meetings, but they did not reach consensus on what should be the basis of the reform. ${ }^{48}$ The major towns, in particular, feared that the tax reform would have a negative impact on them: on 13 January 1436, a day before the Estates would vote for the subsidy, Leuven sent a delegation to the duke's chancellor and seneschal, to urge them to make sure that 'the town would receive a reformation of its tax that would be reasonable'. ${ }^{49}$ Finally, on 14 January 1436 , after more than 20 meetings over the course of two and a half years, the Estates formally decided to grant the duke a sum of 300,000 riders, ${ }^{\circ}$ before having agreed on the basis of the new repartition. Moreover, they were not unanimous, which was unprecedented: 's-Hertogenbosch, which had distanced itself from the other three major towns during the politically turbulent decade that preceded, persisted in its opposition to the aid..$^{1}$

The question of the basis for the new repartition seems to have paralysed the Estates, but Philip tried to speed up their deliberation process. On 17 February 1436 he instructed his receiver-general to collect the aid according to the repartition that was still being developed, and announced

46 Leuven, SA, inv. no. 5055, fol. 98 r.

47 Vrancken, Blijde Inkomsten, p. 299; Uyttebrouck, Gouvernement, vol. 1, p. 532.

48 Kauch, 'Ladministration'. As this catalogue of meetings is based on the travel expenses of Leuven city delegates, it is unclear how often the Estates convened to discuss the matter in towns other than Leuven.

49 'Omme hen te bidden dat de stat ter redelicheide reformatie van haeren taxse mochte comen': Leuven, SA, inv. no. 506o, fol. 59 .

$5^{0}$ Riders, or philippusrijders, were the signature gold coins of a new uniform monetary system introduced in the Burgundian territories in 1434.

$5^{1}$ Leuven, SA, inv. no. $5^{063}$, fol. 86r. The dates of these meetings are attested in the Leuven city accounts. See also the catalogue of Kauch, 'Ladministration', pp. 216-226. 's-Hertogenbosch was the only town that continued to support Duke Jan IV whereas the others united against his government; during the last years of his reign, it attended significantly less meetings of the Estates, and could therefore exert less influence on the duchy's government. See Vrancken, Blijde Inkomsten, pp. 250-253. 
that the collection would start at the Feast of All Saints (1 November) and be finished by Christmas. The aid should be paid in six yearly terms from 1436 onwards. ${ }^{2}$ With this announcement, Philip posed a clear deadline to the negotiations over the new repartition. However, in the fall of 1436 , the Estates and the ducal representatives had not yet found agreement, and the Brabantine localities were taxed somewhat arbitrarily; the basis for this taxation remains unclear. At Christmas, the town and bailiwick of 's-Hertogenbosch had still not collected a penny, and on 2 January 1437 Philip sent his receiver there to force them to pay. ${ }^{53}$ Philip's receiver did not succeed in collecting the funds from 's-Hertogenbosch, so around 15 May 1437 he sent a delegation to the town to convince the magistrates of 's-Hertogenbosch to comply. Philip's representatives consisted of delegates not only from the major towns of Leuven, Brussels, and Antwerp, but also from Tienen and Zoutleeuw, and the two major seigniorial towns of Diest and Breda. ${ }^{54}$ However, 's-Hertogenbosch did not yield.

Furthermore, the duke seized the initiative and set out to introduce hearth counts in Brabant. Hearth counts had already been in use for some time in neighbouring principalities, France (the fouage), and most notably the Duchy of Burgundy itself. ${ }^{55}$ Like in France, but in contrast to later examples (such as seventeenth-century England), in the medieval Low Countries the 'hearth' was usually equated with a household rather than indicative of a physical fireplace (of which especially wealthy households could have many).$^{6}$ Prior to the first Brabantine hearth count, Philip the Good had initiated hearth counts in Burgundy on no fewer than six separate occasions, mainly to finance his war efforts. ${ }^{57}$ In 1426 , as retribution for their defiance of Philip the Good, the villages in Holland's Kennemerland were forced to pay a yearly sum for each hearth or house..$^{8}$ Building on these experiences, in the summer of 1437, Philip installed two committees in Brabant, one charged with the preparation of the census, and the other with the hearth

55 Henneman, 'France'; Lot, 'L'état des paroisses'; Arnould, Dénombrements de foyers; Van Schaïk, Belasting, bevolking en bezit (formally speaking counts of the heads of households); Bos-Rops, Graven op zoek, pp. 191-193; Garnier, La recherche. For the Holy Roman Empire, see Vogeler, 'Tax accounting'.

56 Henneman, 'France', p. 115; Cuvelier, Dénombrements de foyers, p. ciii, note 3; Goose, 'How Accurately'.

57 Beck, Archéologie d'un document, pp. 46-47.

$5^{8}$ The hearth tax in Kennemerland continued until 1456, but it is unclear whether the hearth census on which it was based was updated after 1426. Bos-Rops, Graven op zoek, pp. 191-193. 
count itself. ${ }^{59}$ Significantly, the towns were not represented in either of these committees, but they consisted of commissioners close to the duke. Philip appointed as representatives his councillors and other important officials such as his receiver-general, Peter van der Eiken; the nobility was represented by high-ranking nobles, such as Jan van Wezemaal and Jan van Rotselaar, who were both councillor-chamberlains of the duke. ${ }^{60}$ The prelates, who would have had limited invested interests in the execution of the hearth count since their shares in the aid were determined using an independent repartition system, were only represented in the procedural committee. This arrangement was unprecedented: the towns had been in charge of all preceding censuses, and they had always managed to let the dukes confirm that censuses were exceptional, one-time measures. However, now the duke took control, with the explicit purpose of a structural tax reform: from 1437 onwards, hearth counts would form the sole basis for taxation in Brabant. ${ }^{61}$

Nevertheless, the towns tried to be involved in the process. When the committee counted the hearths in Brussels, on 7 September 1437, a delegate from its rival town of Leuven, Willem Lombard, was present to assist in the inspection; likewise delegates from Brussels were present when the hearths of Leuven were being counted. ${ }^{62}$ Initially, the Brussels authorities hindered the count. ${ }^{63}$ They only allowed the committee to proceed with the census when they had received a written warrant, stating that the inhabitants of Brussels would not be obliged to pay individually for the aid, but that the aid would be paid from the communal funds of the town. ${ }^{64}$

By 10 December 1437, the census had been carried out in all the towns and villages of the duchy, but the quarter and the town of 's-Hertogenbosch still refused to cooperate. While the remainder of the Estates proceeded with

59 Cuvelier, Dénombrements de foyers, pp. ci-cii; Brussels, ARA, CC, inv. no. 15.722, second term, extraordinary expenses, fols $38 \mathrm{v}-41 \mathrm{v}$.

60 Damen, 'Prelaten, edelen en steden', p. 133 (nrs 573 and 574).

61 Cuvelier, Dénombrements de foyers, pp. ci-cii.

62 Leuven and Brussels were known to compete for the most prominent place in the Brabantine urban hierarchy. Whereas the military and fiscal hierarchy between towns was not fixed, politically Leuven remained at the top of the urban hierarchy throughout the fifteenth century: Damen, 'Political Ranking', pp. 161, 169-170; Cuvelier, Dénombrements de foyers, p. cii, cii, note 2; Leuven, SA, inv. no. 5064 , fol. $17 \mathrm{v}$.

63 Cuvelier, Dénombrements de foyers, p. ciii.

64 'That the inhabitants will not be burdened, but that this aid, now as well as in the future, will be paid for with the common goods of the town of Brussels, like it had always been accustomed' ('Dat die ingesetene [...] onghelast sullen bliven, [...] maar dat men de selve beden nu, ende in toecommende tiden, gelden, uytreycken ende betaelen sal, van den ghemeynen goede der stadt van Bruessele, voirsz. alsoemen tot hier toe ghewoenlick heeft gheweest te doen'): Ansems, Luyster ende glorie, vol. 2, p. 107. 
discussions (in January, February, March, and June 1438) on how the census could be used in a new repartition system, 's-Hertogenbosch was headed on a collision course with the duke. ${ }^{65}$ Philip did not accept their resistance, and sent his seneschal, Jan van Nassau, to the town to claim the money by force. The duke imposed a high fine of 1,00o riders on its citizens to cover any expenses that Jan van Nassau had incurred doing this. ${ }^{66}$ Moreover, in order to replace the money he did not receive from 's-Hertogenbosch, Philip sold some annuities on the ducal domains. ${ }^{67}$ This caused unrest among the Estates, as this outcome was precisely the financial action they had tried to prevent under his predecessor, Philip of St-Pol. In an open letter, the duke announced that he had taken notice of the Estates' attempts to reverse the situation. Word had reached him that in some of the major towns (the letter does not specify which ones) new magistrates had been sworn in, at St. John's Mass 1438 (24 June), and that their regular oath of office had been extended with the stipulation that they should do everything within their power to make sure the domains would be rebought immediately. The letter stated, however, that the duke would surrender the annuities only if 's-Hertogenbosch agreed to pay its share in the aid. ${ }^{68}$ Moreover, Philip announced the addition of an extra seventh term to the aid. The payments of each term were lowered from 50,000 to 44,00o riders, so that the total sum of the aid would amount to 308,000 riders, instead of the initial 300,000 riders. ${ }^{69}$ The protests of 's-Hertogenbosch delayed the hearth census more than a full year. On 5 January 1439 , the deputies handed over their final results to the meeting of the Estates, thereby finally concluding a tax reform that had been initiated three years before..$^{0}$

65 Brussels, ARA, CC, inv. no. 15.722, third term, fols 38v-41v.

66 Cuvelier, Dénombrements de foyers, p. cvii, note 2.

67 The duke announced his refusal to rebuy the annuities in an open letter, that provided no further specifications: it speaks of 'certain annuities' (zekere renten). Brussels, ARA, CC, inv. no. 15.722, third term, fol. 1 (=Cuvelier, Dénombrements de foyers, pp. 39-40, no. 9).

68 Brussels, ARA, CC, inv. no. 15.722, third term, fol. $1 v$ (=Cuvelier, Dénombrements de foyers, p. 40, no. 9).

69 Brussels, ARA, CC, inv. no. 15.722, third term, fol. $1 v$ (=Cuvelier, Dénombrements de foyers, p. 38 , no. 9).

70 Cuvelier, Dénombrements de foyers, pp. cvii-cix. 


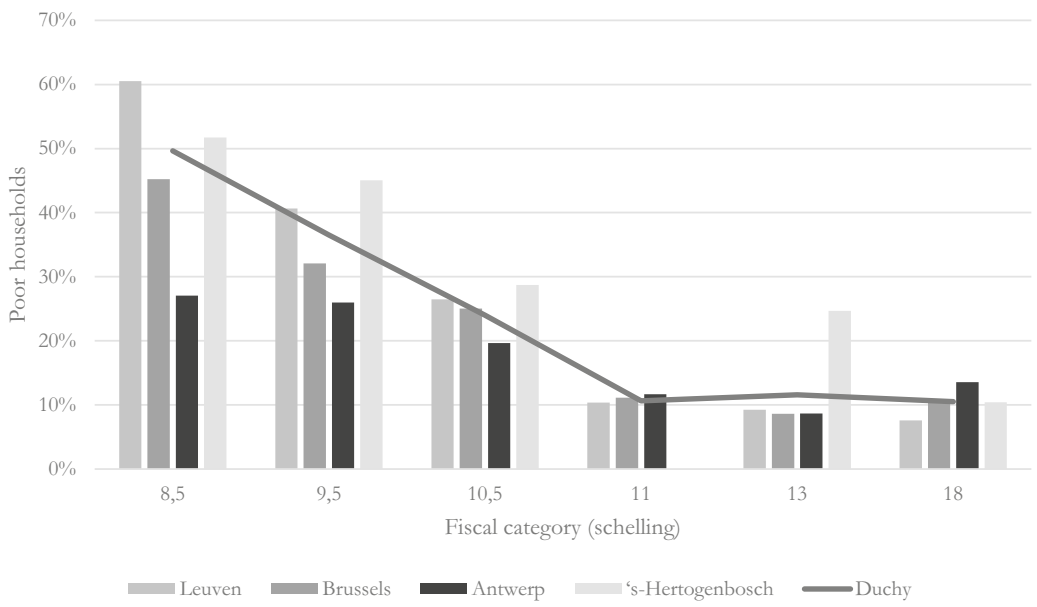

Fig. 5.4. Percentage of poor households per fiscal category for each of the four quarters of the Duchy of Brabant (1437/1438). Fiscal category: schelling or $1 / 4$ philippusrijder per contributing hearth. The data are aggregated using the new administrative classification of 1437/1438.

\section{Interpreting the results of the fiscal reform}

The tax reform greatly changed the repartition of the aids among the different communities. Whereas some of them witnessed an increase in their share, others were more positively impacted. The towns of Leuven and Brussels and the town and quarter of 's-Hertogenbosch were the most afraid that the reform would have a negative impact on them, but before the census had been carried out, they could only guess how it would affect them. The question is whether we can identify the communities that benefitted and that were disadvantaged by the reform.

First, we will have to determine how the burden of the aid was distributed among the communities. The repartition was not only dependent on the number of hearths (or households) counted in each community, but also the contribution per hearth, which could vary from place to place. Such detailed conditions of the repartition were decided upon in July 1438 , based on the preliminary results of the hearth count. ${ }^{71}$ It is hard to fathom exactly how the contributions per hearth, placed in six categories, were settled and to

71 Ibid., pp. civ-cv. It was determined that a tenth of the households in the towns would be subtracted from the count, as well as a fifth of the rural households, on the basis of them being too poor to contribute. The remaining number of hearths or households in each community would be multiplied with a coefficient applied to that specific community: either $8.5,9.5$, or 10.5 schelling per rural hearth, or 11, 13, or 18 per urban hearth. 

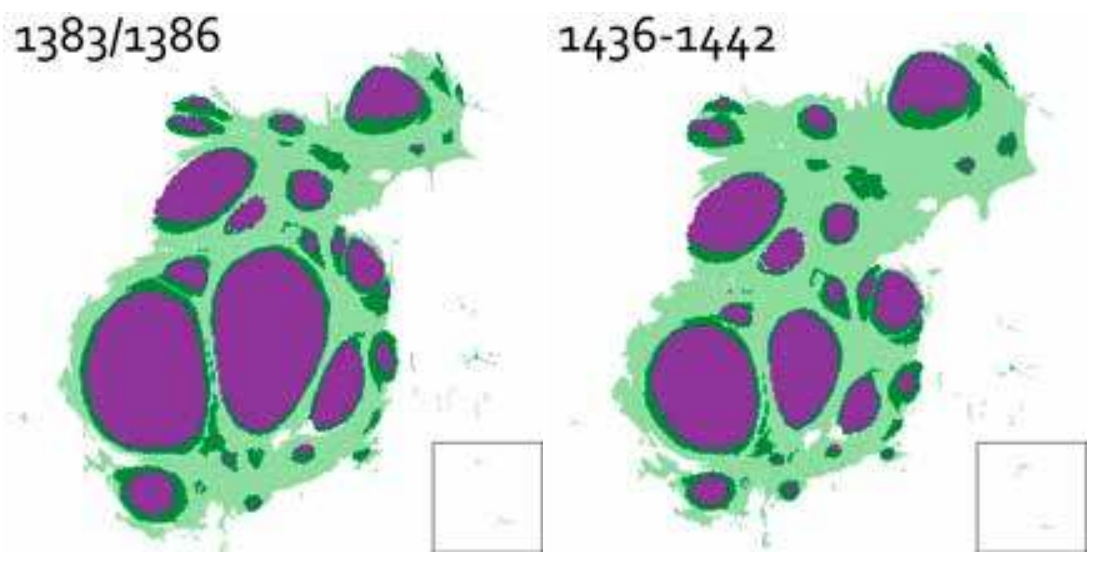

Figs 5.5a-b. Cartogram maps of the Duchy of Brabant, by share of the aid.

what degree this process was sensitive to haggling and particularism. A guiding figure, however, was made available in the form of the number of poor households - collected as part of the new hearth count..$^{72}$ This figure had no direct influence on the contribution per hearth or on the repartition as a whole, and was solely intended to inform the Brabantine administration of the socio-economic constitution of individual communities. This information would have been completely lacking - or anecdotal at best - prior to $1437 / 1438$ and exemplifies the mastery of the space by the Burgundian administration..$^{73}$ Although the figure was purely informative, the percentage of poor households does correlate with the separate categories (Fig. 5.4).

At this point, it should be emphasised that by July 1438 the hearth count in the quarter of's-Hertogenbosch had not yet commenced. Since the stipulated proceeds for the duchy as a whole were fixed at 300,000 riders, and no hearths were counted yet in 's-Hertogenbosch, a curious situation arose. Whereas the contributions per hearth were agreed upon for all communities in the quarters of Brussels, Leuven, and Antwerp, hence fixing the share of the aid for three-quarters of the duchy, the coefficients for 's-Hertogenbosch were still pending. This was not particularly beneficial for's-Hertogenbosch. In each fiscal category, the average percentage of poor households in the

72 Like the hearth count in general, administrating the number of 'fiscal poor' followed the procedure common in the Duchy of Burgundy: Dubois, 'Population et fiscalité', p. 548; Regarding the 'fiscal poor' in hearths counts: Blockmans and Prevenier, 'Poverty in Flanders and Brabant'.

73 For instance, in the adult count of 1374 , the number of (fiscal) poor adults was estimated at an immutable one-third - irrespective of local circumstances: Cuvelier, Dénombrements de foyers, pp. lxxxvi-lxxxvii. 
Table 5.1. Summary of differences in the share of the aids of $1383 / 1386$ and 1436-1442, relative to the share of the censuses of 1374 and 1437/1438, respectively. The data are aggregated using the administrative classification of $1383 / 1386$

\begin{tabular}{lllllll}
\hline Quarter & $\begin{array}{l}\text { Fourteen } \\
\text { towns } \\
\text { (total) }\end{array}$ & $\begin{array}{l}\text { Other } \\
\text { (total) }\end{array}$ & $\begin{array}{l}\text { Fourteen } \\
\text { towns } \\
\text { (ducal) }\end{array}$ & $\begin{array}{l}\text { Fourteen } \\
\text { towns } \\
\text { (seign.) }\end{array}$ & $\begin{array}{l}\text { Other } \\
\text { (ducal) }\end{array}$ & $\begin{array}{l}\text { Other } \\
\text { (seign.) }\end{array}$ \\
\hline Brussels & $-39 \%$ & $58 \%$ & $-39 \%$ & & $58 \%$ & $48 \%$ \\
Leuven & $-35 \%$ & $52 \%$ & $-60 \%$ & $2 \%$ & $52 \%$ & $21 \%$ \\
Tienen & $-39 \%$ & $15 \%$ & $-39 \%$ & & $15 \%$ & $64 \%$ \\
Antwerp & $-36 \%$ & $45 \%$ & $-36 \%$ & & $45 \%$ & $60 \%$ \\
Walloon Brabant & $-23 \%$ & $-3 \%$ & $-23 \%$ & & $-3 \%$ & $48 \%$ \\
's-Hertogenbosch & $50 \%$ & $19 \%$ & $50 \%$ & & $19 \%$ & $40 \%$ \\
\hline TOTAL & $-31 \%$ & $\mathbf{2 5 \%}$ & $\mathbf{- 3 6 \%}$ & $\mathbf{2 \%}$ & $\mathbf{2 5 \%}$ & $\mathbf{4 7 \%}$ \\
\hline
\end{tabular}

quarter of 's-Hertogenbosch was consistently higher than average (Fig. 5.4). In other words, the percentage of poor households, being relatively high in comparison to other non-Walloon regions of the duchy, was less influential on the contribution than elsewhere in the duchy. The protracted challenges by 's-Hertogenbosch against the hearth count were not only effectively thwarted - in the end they resulted in a higher share in the contribution to the duke as well.

The differences before and after the fiscal reform can be visualised when the method applied to the population geography is also applied to the aids of $1383 / 1386$ and 1436-1442 (see Appendix, Table 5.3). The cartograms, which ignore the share of the designated religious institutions which contributed $32 \%$ and $16 \%$ of the respective aids, highlight the consequences of the fiscal reform by Philip the Good (Figs $5 \cdot 5 \mathrm{a}-\mathrm{b}$ ). If we compare the distribution of the aid of $1383 / 1386$ (Fig. 5.5 a) with the distribution of the population in 1374 (Fig. 5.2a), the incongruent nature of the aid prior to Philip the Good's reform, heavily biased towards Leuven and Brussels, cannot be ignored.

In order fully to compare the fourteenth-century situation to the distribution of the aid after the reform and recognise how communities benefitted differently, it is necessary to mitigate any effects of population growth between the two designated aids. The importance of this is underlined by the example of the town of Antwerp. In contrast to the neighbouring major towns of Leuven and Brussels, Antwerp's share in the aid increased substantively. Our model estimates that the town of Antwerp more than doubled in size during this period as well. Since under the new fiscal system 


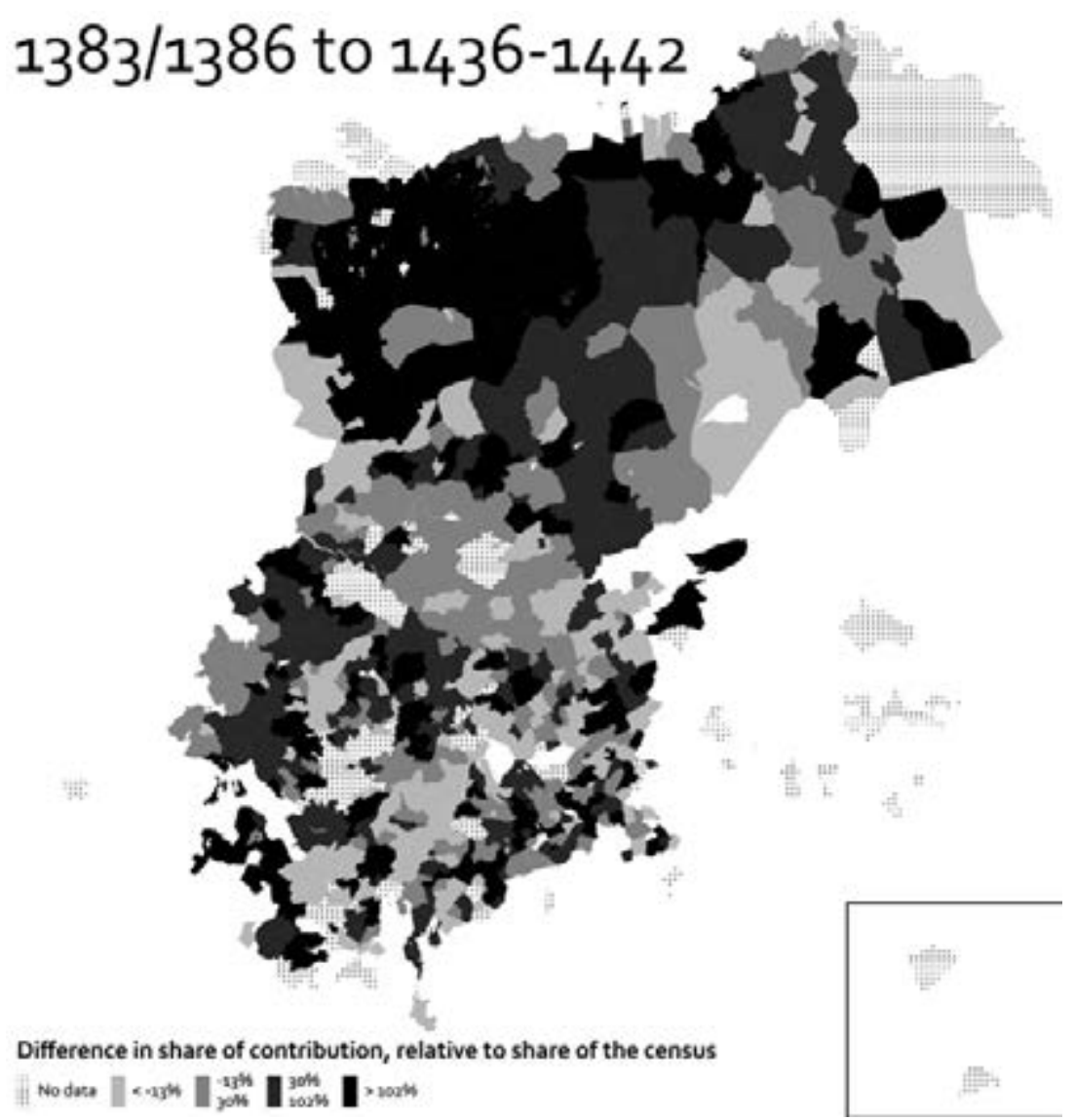

Fig. 5.6. Difference in the share in the aids of $1383 / 1386$ and $1436-1442$, relative to the share of the censuses of 1374 and 1437/1438, respectively.

the number of households directly influences the contribution to the aid, an increase in Antwerp's share can be expected and does not reflect any positive impacts Antwerp may have experienced from the reform. In order to counter this, we have chosen, for each community, to divide the relative share of the aids of $1383 / 1386$ and $1436-1442$ by the relative share in the censuses of 1374 and 1437/1438 (Table 5.1 and Fig. 5.6; more detailed data are included in the Appendix, Table 5.4). It is the closest we can come to identify the shifts in taxes paid per capita (or household) before and after the reform. 


\section{The mastery of space}

A number of striking observations can be made from these data. The major towns of Leuven, Brussels, and Antwerp, which had initially been among the fiercest critics of the hearth counts and were, extraordinarily, kept from the executing committees, actually encountered some of the strongest reductions of the per capita share (see Appendix, Table 5.4). Of the four capitals of the quarters, only 's-Hertogenbosch had its per capita burden raised substantially - by $50 \%$. The prelates, who, unlike the towns, were involved in the planning of the repartition system, could claim a dramatic reduction in their share in the aid. Traditionally, the prelates had collectively contributed one-third of the aids, but as a result of the new repartition system their share lowered incrementally to $16 \%$ in $1436-1442,12 \%$ in 1451 , and $4 \%$ in $1473 .^{74}$ This should not unequivocally be interpreted as a good result. We know that religious institutions in Brabant were increasingly supposed to contribute to the local repartitions and were confronted with mortmain legislation and direct (ducal) taxes, all of which may well have nullified any accomplishments in the aids. ${ }^{75}$

It is also noteworthy that some of the worst hit rural areas were those under seigniorial jurisdictions. ${ }^{76}$ These areas formed a significant part of the territory (Fig. 5.7) and had traditionally contributed not only to the duke, but also to their local lords. For this reason, under the traditional system, their contributions had been rather limited relative to their fiscal capacity. ${ }^{77}$ This time around, some of the highest-ranking nobles in the duchy, such as Jan van Nassau of Breda and Jan van Glimes of Bergen op Zoom - chamberlains-councillor to the duke - were not seeking rebates or tax exemptions, but actively cooperated with the duke to introduce a taxation system that would take a step towards fiscal equity and hit their own local territories particularly hard.

These results show a profound mismatch with the negotiation positions of members of the Estates on the reform. Only the resistance of the town

74 Brussels, ARA, CC, inv. no. 15.722; Van Uytven, 'Wereldlijke overheid', p. 104.

75 Van Asseldonk, 'De Meierij', pp. 597-598; An overview of the types of taxes paid for by the clergy in Brabant: Van Uytven, 'Wereldlijke overheid'. Regarding increasingly stringent mortmain legislation, see also Adriaenssen, 'Een aanslag'. In 1441, Philip the Good issued a new tax on all Brabantine churches, at least those in the Prince-Bishopric of Liège: Berthels, 'Notice sur les limites', p. 382.

76 See 5.11 . The changes in the per capita burden show peaks in La Hulpe (125\% versus $23 \%$ in nearby ducal areas) and Nivelles (121\% versus $-36 \%$ ) in Walloon Brabant, as well as in Merchtem ( $97 \%$ versus $33 \%)$ in the quarter of Brussels.

77 Van Uytven, 'Diest, Aarschot en Zichem', p. 188. 
and quarter of 's-Hertogenbosch ran parallel with the actual effects of the new repartition. It may be a coincidence, but only in 's-Hertogenbosch was evidence found that the results of the adult count of 1374 were reapplied in subsequent, regional, repartitions. ${ }^{78}$ All this indicates that, prior to the hearth counts, the members of the Estates lacked the expertise and the knowledge to make reliable estimations of how the demographic and economic developments of different areas within the duchy related to each other, and how this would affect a new, equitable, tax repartition. There was no centralised, institutional memory that could strengthen the negotiating position of the Estates towards the duke, for instance, of the results of the previous territory-wide count carried out in 1374. Insofar as the positions in the negotiations can be explained, such as for the high-ranking nobility whose fate had long been intertwined with the Burgundian party, very different motives can be put forward.

Philip the Good took advantage of this lack of knowledge among the Estates as well as of their internal division by seizing full control over the tax reform - including its administration. By doing so, he not only ensured a more stable form of income, he also significantly strengthened his control over the territory. Traditional spheres of administration of the territory (domains and justice), were insufficient means to monitor and map the territory. Fiscality, however, enabled rulers not only to map their territory in greater detail, but also to take control over the administrative process, because the central administration could arbitrate between local powers that were internally divided. ${ }^{79}$

In the hands of a capable central administration, the information that Philip the Good had collected, not only the number of hearths, but also a first quantifiable indicator for the level of poverty in every corner of the duchy, did not just lead to the creation of a geographic overview. On the one hand, this knowledge could be exploited by the duke (for instance, in negotiations with the Estates) as a new administrative technology to strengthen his power base. On the other hand, the hearth counts legitimised the duke's exertion of tax sovereignty and bonded subjects to the sovereign, especially in previously seigniorial areas, slowly reducing the number of tax-exempt individuals or communities. This legitimisation process was further consolidated by an effective fiscal administration associated with the hearth counts, epitomised by the lists of communities in the hearth censuses. As such, the hearth counts transformed the territory itself into 


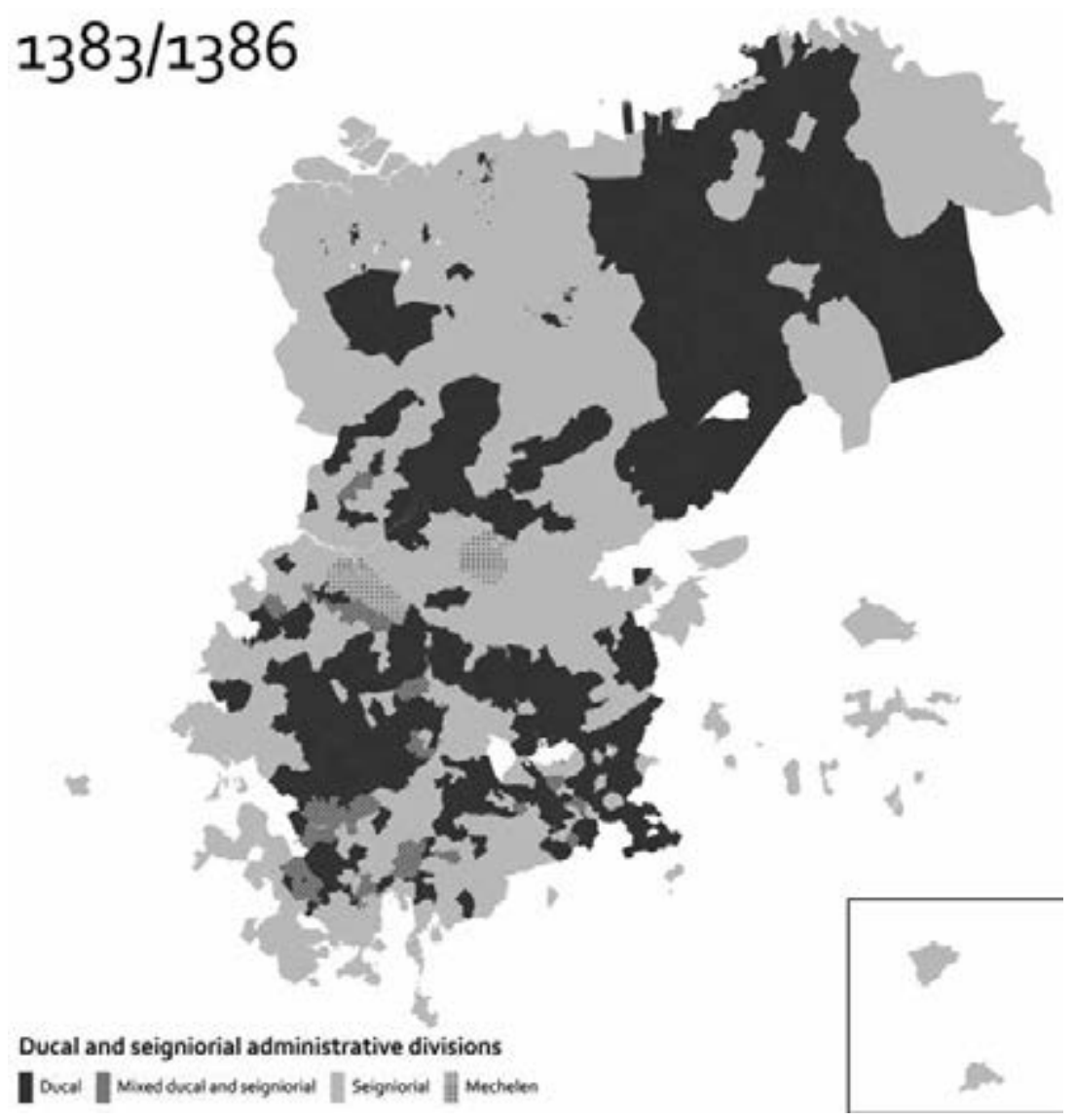

Fig. 5.7. Ducal and seigniorial administrative divisions, based on the $1383 / 1386$ aid report.

a political space that the duke could govern more efficiently through his administration. ${ }^{80}$ It was a strong deviation from the ad hoc and unbalanced nature of the traditional fiscal system, and it left the Estates sidelined in the administrative process. For the Burgundian administration, the hearth counts were a newly acquired knowledge that could be exploited to achieve the structural ambitions of the dynasty, namely the creation of a composite monarchy. ${ }^{81}$

8o Administration does not just represent the territory, but, as cartography, it is actively used as a tool in this transformative process. See Elden, 'Land, Terrain, Territory', p. 8og, and Dauphant, Royaume des quatre rivières, chap. 2.

81 Regarding these (ultimately unsuccessful) ambitions, see Stein, Magnanimous Dukes; Lecuppre-Desjardin, Le royaume inachevé. 


\section{Conclusion}

As a technology of measuring and quantifying space, the hearth counts became an important instrument of government for Duke Philip the Good. Not only was he able to develop an overview of the territory, he was also able to exploit this new knowledge. As a result of the tax reform, the tax revenues stabilised in the course of the fifteenth century. Moreover, the reform strengthened the duke's power base: he no longer had to make major concessions to his subjects or place himself under their financial guardianship, as his predecessors, Philip of St-Pol and Jan IV, had been obliged to do. As such, the hearth counts were not only full-scale administrative representations of territory that could be used as a governmental technology, but also instrumental in the production of the Brabantine territory as a political space.

The fiscal reforms introduced by Duke Philip the Good significantly impacted the way taxes were levied in the duchy, as well as the extent to which many communities could exert a certain level of independence within the territory. As soon as Brussels, Leuven, and Antwerp realised they would financially benefit from the new partition system, their initial opposition slackened; paving the way for Philip the Good to pursue a divideand-conquer strategy towards the parties still resisting the reform. With hindsight, the prolonged opposition by 's-Hertogenbosch had not benefitted their cause. In July 1438 , before a single hearth was counted in the quarter, the procedures for the hearth count and repartition were already being established. This meant that's-Hertogenbosch, with relatively high numbers of poor households, did not benefit from reduced rates for poverty-stricken communities as much as did the other quarters. Moreover, the fact that the town of 's-Hertogenbosch, which had witnessed - in contrast to the three other major towns in this period - a negative population trend between 1374 and 1438 and which was, by 1438 , less than half the size of, for instance, Brussels, was equally appraised with Brussels, Leuven, and Antwerp, added to their list of worries.

Seigniorial town and village communities, meanwhile, saw any autonomy they might have within the duchy reduced very effectively. The hearth count-based fiscal system had therefore both a uniformising and centralising effect on the territory, creating a more level playing field, led by a centralised administration. It created the opportunity for the Burgundian dukes to master the Brabantine space. First and foremost, though, it was a great administrative feat by Philip the Good which appears to have been considered worth repeating by the Burgundian administration. In 
1440, Philip the Good and his advisor Guillebert de Lannoy had already discussed plans to expand the hearth count - in secrecy, without revealing its fiscal intentions - to all Burgundian-controlled localities. ${ }^{82}$ Although these plans did not immediately materialise, its sheer costs likely being a factor, ${ }^{83}$ they were indeed followed up by Philip's son and successor, Charles the Bold, as part of a new series of fiscal reforms. Charles instigated a massive hearth count campaign around 1469 in Picardy, Boulonnais, Artois, Flanders, Hainaut, Brabant, Namur, Guelders, Liège, Limbourg, and Luxembourg. ${ }^{84}$

In the end, the hearth counts of 1469 did not lead to the intended uniform fiscal system in the Burgundian Low Countries, with most territories sticking to their specific fiscal procedures. An unfortunate timing and steadfast opposition to the censuses by the Estates in various principalities were the key factors for this lack of success. ${ }^{85}$ Yet, the hearth counts did have a lasting effect on fiscal policies in the Low Countries. The revenues from direct taxation were raised substantially during the reigns of Philip the Good and Charles the Bold and the concept of using rational socio-economic and/or demographic approaches to repartition direct taxation, exploiting the advantages of fiscal equity among the taxpayers, reappears in various shapes and sizes in the medieval and early modern Low Countries. ${ }^{86}$ In Holland, a county that had withstood attempts by Charles the Bold to introduce hearth counts, household censuses as a basis for fiscal repartitions were successfully implemented in 1494 and 1514, well after Charles's death, accompanied by two of the most elaborate socio-economic surveys of the late medieval Low Countries. ${ }^{87}$ Like the data collected on poverty in the 1437 Brabantine hearth count, the majority of the variables covered by these Hollandish surveys had no direct effect on the outcome of the repartition. Yet, the (in this case, Habsburg) administration considered it to be worthwhile to invest time and money in broadening its knowledge of the territory. Such considerations undoubtedly built on experiences gained by previous administrations, by

82 Arnould, Relevés de feux, p. 39. See also Stein, Magnanimous Dukes, p. 241.

83 See note 8.

84 Arnould, Relevés de feux, pp. 39-41.

85 Blockmans, 'Low Countries', pp. 285-286.

86 Ibid.; Stein, Magnanimous Dukes, pp. 237-239.

87 These surveys, especially the one conducted in 1514, covered a wide range of topics well beyond rudimentary demographics. These included the main sources of income for villagers, land ownership, rent values, etc. With references to literature: Stapel, 'Holland rond 150o'; Van Zanden, 'Taking the Measure'. 
trial and error, that such knowledge was an effective tool for controlling a political space.

\section{Appendix}

\section{Calculation of the shares in the population and the aids}

This chapter is accompanied by two open-access datasets:

- Rombert Stapel, 'Hearth and Population Censuses for the Duchy of Brabant (1374-180o)' (IISH Data Collection, 2020), http://hdl.handle. net/10622/YGRTHJ.

- Arend Elias Oostindiër and Rombert Stapel, 'Fiscal Repartitions for the Duchy of Brabant (1383-1572)' (IISH Data Collection, 2020), http://hdl. handle.net/10622/WGEKRX.

The methodological approach that led to these datasets is driven by two objectives: first, to make it possible to analyse the effects of the fiscal reform at a local level; second, to overcome obstacles that hinder sensible comparisons between places, between places in different periods, and between varying types of censuses or aids. Apart from creating the historical GIS itself, our methodology consists of five phases: (1) linking each figure in the count to a specific (number of) area(s); (2) disaggregating figures for joint areas using known ratios in other counts ${ }^{88}$ or the size of the underlying areas, which is essential to create consistent spatiotemporal data series; (3) converting the units of each count (hearths, houses, adults) into consistent values across time; (4) interpolating missing values; and (5) visualising the data, using both the conventional GIS map and a hexagon-based cartogram, in which each hexagon represents an equal proportion of the count. ${ }^{89}$

While we focus in this chapter on the period up to the fiscal reforms associated with the aid of 1436-1442, our data have a much wider temporal scope. The core of the dataset consists of eight more or less complete house, hearth, or population counts $(1374,1437 / 1438,1464,1472,1496,1526$, and,

88 This is actually quite a substantive procedure, which was by and large automated using a specially prepared script. Information on the individual steps of the procedure is stored with each data point, in order to support replicability and provide insight into the computations. 89 These cartograms were created using the open-source software ScapeToad:Andrieu, Kaiser, and Ourednik, ScapeToad, version 1.1. 
for comparison, 1795/180o), as well as several counts with a more limited geographic scope $(1468,1492$, and 1544$) \cdot{ }^{90}$ Using the GIS to our advantage, it is possible to define precisely the towns and villages of the duchy that featured in all eight counts: referred to as the 'consistent space' in Table 5.2. By dividing the number of counted units of a particular village by the total number of the consistent space, it is possible to create a coherent data series of the relative share of that village within the duchy as a whole. This data series is independent of the type of count and thus consistent through time, while it also avoids arduous discussions regarding the relationship between hearth counts and population size. ${ }^{91}$ As a last step, we have interpolated missing values by using the average growth rates of the relative share of the ten nearest recorded localities.

Table 5.2. Summary of counted and computed units

\begin{tabular}{|c|c|c|c|c|c|c|c|c|c|c|c|}
\hline & $\underset{m}{\stackrel{N}{m}}$ & 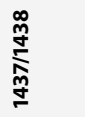 & 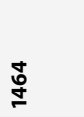 & 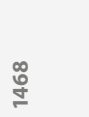 & $\underset{2}{N}$ & 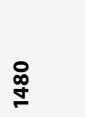 & ฐั & ஓ̊ & ֻั & ঋn & 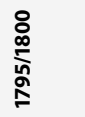 \\
\hline Type of unit & TA & $\mathrm{Ho}^{92}$ & Ho & Ho & Ho & Ho & THo & Ho & $\mathrm{He}$ & Ho & $\mathbf{P}$ \\
\hline Total counted units & 130,409 & 93,108 & 91,550 & 632 & 84,816 & 85,862 & 22,061 & 74,877 & 104,595 & 5,091 & 876,512 \\
\hline $\mathbf{n}=$ & 956 & 963 & 954 & 15 & 951 & 950 & 591 & 945 & 958 & 11 & 1,133 \\
\hline Consistent space & 126,666 & 89,800 & 89,003 & & 82,789 & 83,951 & & 73,285 & 101,893 & & 729,329 \\
\hline $\mathbf{n}=$ & 902 & 902 & 902 & & 902 & 902 & & 902 & 902 & & 902 \\
\hline $\begin{array}{l}\text { Interpolated } \\
\text { results }{ }^{93}\end{array}$ & 153,244 & 112,099 & 111,289 & 108,585 & 106,019 & 106,363 & 53,979 & 85,679 & 119,635 & 115,797 & 862,579 \\
\hline $\mathbf{n}=$ & 1,104 & 1,104 & 1,104 & 1,104 & 1,104 & 1,104 & 1,104 & 1,104 & 1,104 & 1,104 & 1,104 \\
\hline
\end{tabular}

Type of unit: TA: Taxed adult, including a fixed third added to every adult to represent lower-taxed individuals. Ho: Inhabited house(hold). THo: Taxed house(hold). He: Inhabited hearth. P: Individual. Convents and noble houses are usually counted as one unit, but prior to 1526 it is not always clear

90 Stapel, 'Hearth and Population Censuses'.

91 Endless discussions on coefficients for household sizes have not led to a clear consensus: Blockmans et al., 'Tussen crisis en welvaart', pp. 42-43; Stabel, Dwarfs among Giants, p. 19ff.; De Brouwer, 'Het belang van de kommunikantencijfers'; Van der Woude, Het Noorderkwartier, vol. 1, pp. 72-73; Laslett and Wall, Household and Family; Stapel, 'Holland rond 150o', p. 182; Arnould, Relevés de feux, pp. 6o-61.

92 The contemporary sources actually use 'houses' and 'hearths' interchangeably, at least in 1437/1438: Cuvelier, Dénombrements de foyers, p. ciii, note 3.

93 This is the area that features on the maps in this publication, which covers all villages and towns most commonly associated with the Duchy of Brabant, as well as the Lordship of Mechelen, and Megen, Ravenstein, Gemert, Boxmeer, and Cuijk. 

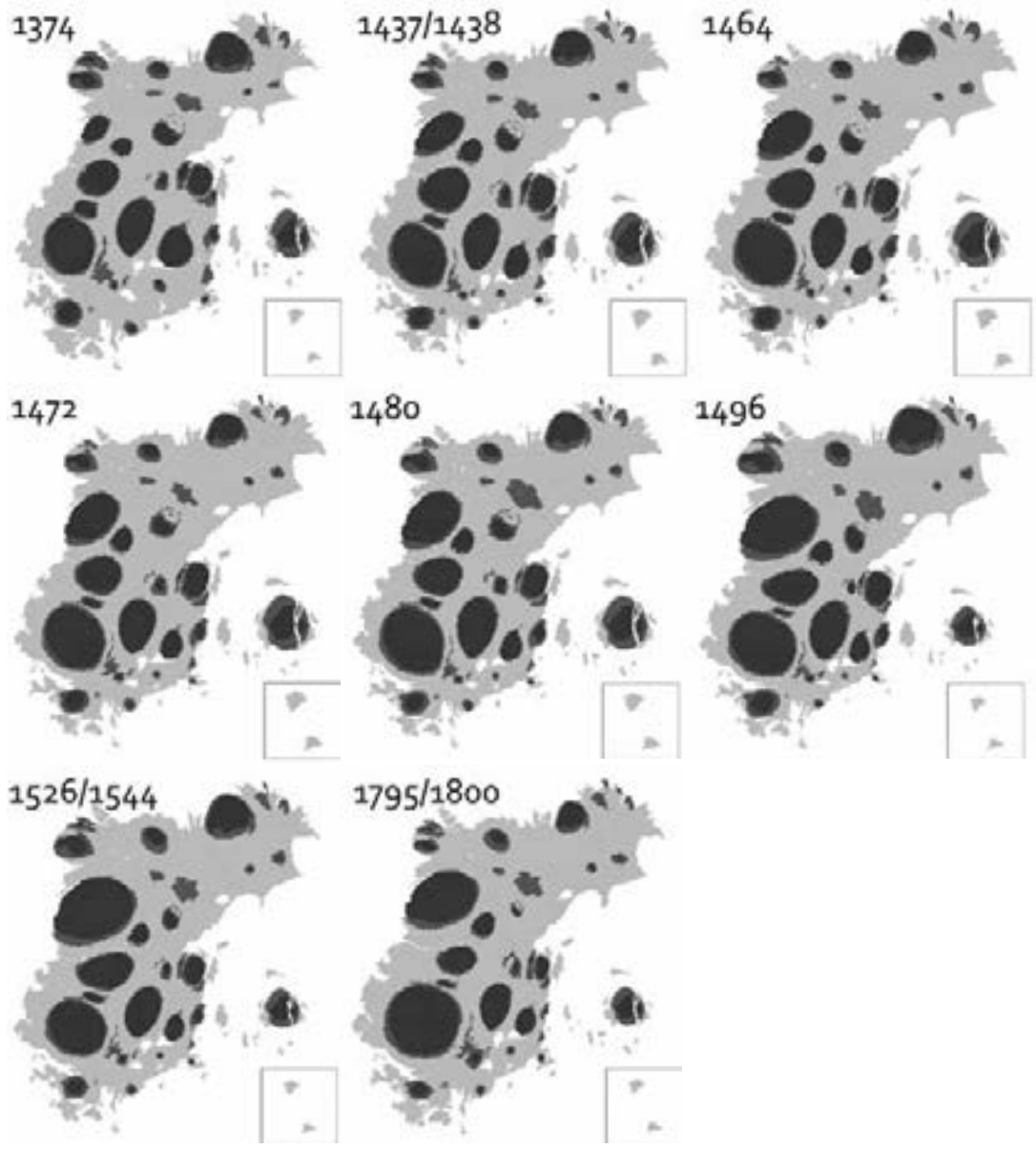

Figs 5.8a-h. Cartogram maps of the Duchy of Brabant, by share of the census. See also Figs 5.2a-b.

whether they were included or not. The interpolated results for the partial counts $(1468,1492$, and 1544) can be quite unpredictable and should be applied in analyses with caution. ${ }^{94}$

The same method can be applied to the aids of $1383 / 1386$ and $1436-1442$ (Table 5.3). ${ }^{95}$ Unlike hearth or population censuses, it makes little sense to

94 Sources: Cuvelier, Dénombrements de foyers; Verbeemen, 'Demografische evolutie'; Vrielinck, Territoriale indeling; Centraal Bureau voor Statistiek and NIWI-KNAW, 'Population Census 1795'; Maastricht, RHCL, 03.01 Frans Archief, 1794-1814, inv. nrs 1030a-1062g; Wasserfall, Annuaire; Dorsch, Statistique; Cavenne, Statistique.

95 Oostindiër and Stapel, 'Fiscal Repartitions'. 
interpolate the data for communities that were not supposed to contribute to the duke, hence this step is skipped. Our dataset also includes the ' $100^{\text {th }}$ penny' levied by the Duke of Alva in 1569-1572, a tax on real estate..$^{6}$ This ' $100^{\text {th }}$ penny' is linked to the other subsidies for other researchers to benefit from, but simultaneously stresses the mutable nature of Brabantine taxations in, for instance, geographical terms. Above all, it marks the turbulent development Antwerp and its hinterland went through during the sixteenth century.

Table 5.3. Summary of the aids in $1383 / 1386$ and $1436-1442$, as well as the $100^{\text {th }}$ penny of 1569-1572

\begin{tabular}{|c|c|c|c|}
\hline & $\begin{array}{l}\stackrel{0}{\infty} \\
\stackrel{\infty}{m} \\
\stackrel{m}{m} \\
\stackrel{\infty}{m}\end{array}$ & 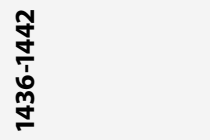 & 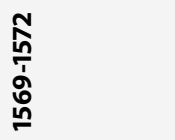 \\
\hline Type of unit & Oude schild & Philippusrijder & Gouden reaal \\
\hline Total counted units & 125,378 & 231,544 & 294,175 \\
\hline $\mathbf{n}=$ & 1,010 & 961 & 971 \\
\hline Fine gold equivalent (troy mark) & 2,139 & 3,403 & 6,338 \\
\hline Consistent space & 123,691 & 229,714 & 278,135 \\
\hline$n=$ & 946 & 946 & 946 \\
\hline
\end{tabular}
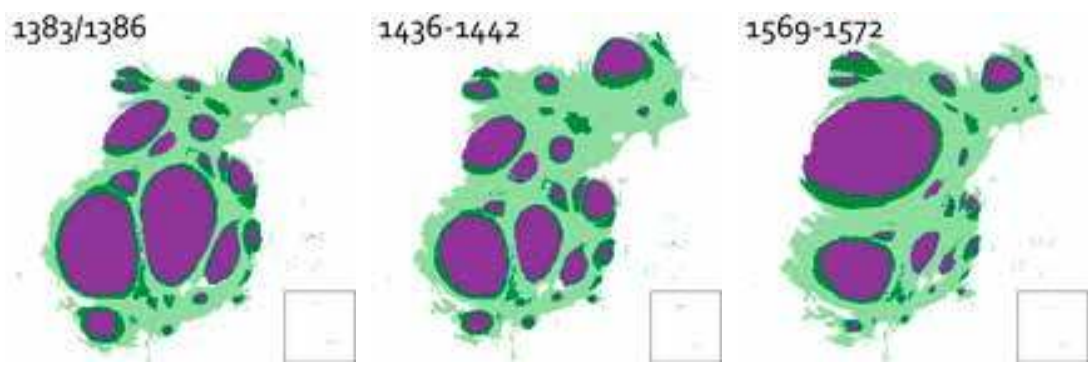

Figs 5.9a-c. Cartogram maps of the Duchy of Brabant, by share of the aid. The Lordship of Mechelen is excluded.

96 Similar to the range of other hearth and population censuses we collected, these data, originally compiled by Peter Stabel and Filip Vermeylen but digitised and linked to GIS geometries by us, will be made available for future use. 


\begin{tabular}{|c|c|c|c|}
\hline & 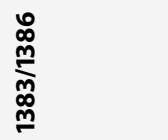 & 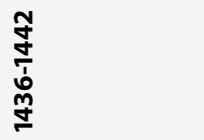 & 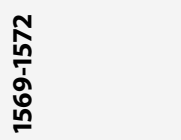 \\
\hline Type of unit & Oude schild & Philippusrijder & Gouden reaal \\
\hline Fine gold equivalent (troy mark) & 2,110 & 3,376 & 5,992 \\
\hline
\end{tabular}

Note that the consistent space mentioned in this table is different to the consistent space of the censuses (Table 5.2) and that these figures only include the aids directly linked to Brabantine communities, and not those linked to institutions, prelates, or other individuals. ${ }^{97}$

97 Sources: Brussels, ARA, CC, inv. no. 15.716; Brussels, ARA, CC, inv. no. 15.722; Cuvelier, Dénombrements de foyers; Stabel and Vermeylen, Fiscale vermogen; The fine gold equivalents were calculated using the Coin Production of the Low Countries dataset: Zuijderduijn, Stapel and Lucassen, 'Coin Production'. The calculations are based on records 'CA_2288' (1356), 'CA_109' (1434-1435), and 'CA_1099' (1569). The data can be queried here: https://coins.iisg.amsterdam/ coins/. 
Summary of shares of the aids

Table 5.4. Differences in the share of the aids of $1383 / 1386$ and 1436-1442, aggregated using the administrative classification of 1383/1386

\begin{tabular}{|c|c|c|c|c|c|c|}
\hline Quarter & Bailiwick & $\begin{array}{l}\text { Share in aid } \\
(1383 / 1386)\end{array}$ & $\begin{array}{l}\text { Share in } \\
\text { aid (1436- } \\
1442)\end{array}$ & $\begin{array}{l}\text { Differ- } \\
\text { ence in } \\
\text { share }\end{array}$ & $\begin{array}{l}\text { Difference } \\
\text { in fine gold } \\
\text { equivalent }\end{array}$ & $\begin{array}{l}\text { Difference } \\
\text { relative to } \\
\text { share in } \\
\text { census }\end{array}$ \\
\hline \multirow[t]{7}{*}{ Large towns } & $\begin{array}{l}\text { Leuven / } \\
\text { Louvain }\end{array}$ & $16.2 \%$ & $6.3 \%$ & $-61 \%$ & $-38 \%$ & $-60 \%$ \\
\hline & $\begin{array}{l}\text { Brussel / } \\
\text { Bruxelles }\end{array}$ & $16.2 \%$ & $10.8 \%$ & $-33 \%$ & $7 \%$ & $-43 \%$ \\
\hline & $\begin{array}{l}\text { Antwerpen / } \\
\text { Anvers }\end{array}$ & $5.4 \% 98$ & $6.1 \%$ & $12 \%$ & $79 \%$ & $-57 \%$ \\
\hline & $\begin{array}{l}\text { 's-Hertogenbosch / } \\
\text { Bois-le-Duc }\end{array}$ & $4.0 \%$ & $5.1 \%$ & $26 \%$ & $101 \%$ & $50 \%$ \\
\hline & Tienen / Tirlemont & $3.2 \%$ & $1.7 \%$ & $-47 \%$ & $-15 \%$ & $-14 \%$ \\
\hline & Nijvel / Nivelles & $2.7 \%$ & $1.4 \%$ & $-47 \%$ & $-16 \%$ & $-38 \%$ \\
\hline & $\begin{array}{l}\text { Zoutleeuw } \\
\text { / Léau }\end{array}$ & $1.1 \%$ & $0.9 \%$ & $-19 \%$ & $29 \%$ & $-51 \%$ \\
\hline \multirow[t]{7}{*}{ Small towns } & $\begin{array}{l}\text { Vilvoorde / } \\
\text { Vilvorde }\end{array}$ & $1.5 \%$ & $0.7 \%$ & $-53 \%$ & $-25 \%$ & $-30 \%$ \\
\hline & Lier / Lierre & $1.5 \%$ & $2.0 \%$ & $36 \%$ & $117 \%$ & $-1 \%$ \\
\hline & Herentals & $1.5 \%$ & $1.2 \%$ & $-16 \%$ & $34 \%$ & $-7 \%$ \\
\hline & $\begin{array}{l}\text { Geldenaken / } \\
\text { Jodoigne }\end{array}$ & $0.6 \%$ & $0.3 \%$ & $-50 \%$ & $-20 \%$ & $5 \%$ \\
\hline & Diest (seigniorial) & $1.9 \%$ & $2.8 \%$ & $45 \%$ & $133 \%$ & $11 \%$ \\
\hline & $\begin{array}{l}\text { Aarschot / } \\
\text { Aerschot } \\
\text { (seigniorial) }\end{array}$ & $1.8 \%$ & $2.1 \%$ & $18 \%$ & $89 \%$ & $-13 \%$ \\
\hline & $\begin{array}{l}\text { Zichem } \\
\text { (seigniorial) }\end{array}$ & $1.5 \%$ & $1.5 \%$ & $5 \%$ & $69 \%$ & $11 \%$ \\
\hline \multirow{4}{*}{$\begin{array}{l}\text { Brussels } \\
\text { (villages) }\end{array}$} & Kampenhout & $0.5 \%$ & $0.6 \%$ & $39 \%$ & $123 \%$ & $91 \%$ \\
\hline & $\begin{array}{l}\text { Kampenhout } \\
\text { (seigniorial) }\end{array}$ & $0.3 \%$ & $0.6 \%$ & $98 \%$ & $216 \%$ & $83 \%$ \\
\hline & $\begin{array}{l}\text { Kapelle-op-den- } \\
\text { Bos }\end{array}$ & $0.1 \%$ & $0.1 \%$ & $67 \%$ & $167 \%$ & $148 \%$ \\
\hline & $\begin{array}{l}\text { Kapelle-op-den- } \\
\text { Bos (seigniorial) }\end{array}$ & $0.1 \%$ & $0.2 \%$ & $143 \%$ & $289 \%$ & $133 \%$ \\
\hline
\end{tabular}

98 Antwerp's intended contribution was met by the other towns in 1383, whereas Antwerp is left out of the account of 1386 altogether. The figure in this table represents Antwerp's intended contribution to the aids of 1383 and 1386 . 


\begin{tabular}{|c|c|c|c|c|c|c|}
\hline Quarter & Bailiwick & $\begin{array}{l}\text { Share in aid } \\
(1383 / 1386)\end{array}$ & $\begin{array}{l}\text { Share in } \\
\text { aid (1436- } \\
1442)\end{array}$ & $\begin{array}{l}\text { Differ- } \\
\text { ence in } \\
\text { share }\end{array}$ & $\begin{array}{l}\text { Difference } \\
\text { in fine gold } \\
\text { equivalent }\end{array}$ & $\begin{array}{l}\text { Difference } \\
\text { relative to } \\
\text { share in } \\
\text { census }\end{array}$ \\
\hline & Merchtem & $0.8 \%$ & $0.9 \%$ & $14 \%$ & $82 \%$ & $33 \%$ \\
\hline & $\begin{array}{l}\text { Merchtem } \\
\text { (seigniorial) }\end{array}$ & $0.7 \%$ & $1.5 \%$ & $122 \%$ & $256 \%$ & $97 \%$ \\
\hline & Sint-Genesius-Rode & $0.6 \%$ & $1.3 \%$ & $108 \%$ & $233 \%$ & $79 \%$ \\
\hline & $\begin{array}{l}\text { Sint-Genesius- } \\
\text { Rode (seigniorial) }\end{array}$ & $0.3 \%$ & $0.4 \%$ & $77 \%$ & $183 \%$ & $20 \%$ \\
\hline & Vilvoorde & $1.2 \%$ & $1.4 \%$ & $14 \%$ & $82 \%$ & $47 \%$ \\
\hline & Asse & $0.8 \%$ & $0.7 \%$ & $-8 \%$ & $46 \%$ & $-4 \%$ \\
\hline & Gaasbeek & $0.8 \%$ & $1.4 \%$ & $66 \%$ & $166 \%$ & $48 \%$ \\
\hline \multirow{3}{*}{$\begin{array}{l}\text { Leuven } \\
\text { (villages) }\end{array}$} & Herent & $0.5 \%$ & $0.5 \%$ & $-1 \%$ & $59 \%$ & $48 \%$ \\
\hline & Lubbeek & $0.4 \%$ & $0.7 \%$ & $65 \%$ & $164 \%$ & $114 \%$ \\
\hline & $\begin{array}{l}\text { Lubbeek } \\
\text { (seigniorial) }\end{array}$ & $0.9 \%$ & $1.2 \%$ & $30 \%$ & $108 \%$ & $21 \%$ \\
\hline \multirow{4}{*}{$\begin{array}{l}\text { Tienen } \\
\text { (villages) }\end{array}$} & Tienen & $1.5 \%$ & $1.2 \%$ & $-22 \%$ & $25 \%$ & $16 \%$ \\
\hline & Halen & $1.3 \%$ & $1.4 \%$ & $2 \%$ & $62 \%$ & $25 \%$ \\
\hline & Kumtich & $1.1 \%$ & $0.8 \%$ & $-23 \%$ & $23 \%$ & $-15 \%$ \\
\hline & $\begin{array}{l}\text { Quarter Tienen } \\
\text { (seigniorial) }\end{array}$ & $1.4 \%$ & $1.7 \%$ & $20 \%$ & $92 \%$ & $64 \%$ \\
\hline \multirow{5}{*}{$\begin{array}{l}\text { Antwerp } \\
\text { (villages) }\end{array}$} & Kontich & $0.2 \%$ & $0.3 \%$ & $4 \%$ & $66 \%$ & $3 \%$ \\
\hline & Waterland & $0.3 \%$ & $0.7 \%$ & $127 \%$ & $263 \%$ & $89 \%$ \\
\hline & Herentals & $1.6 \%$ & $2.1 \%$ & $28 \%$ & $105 \%$ & $46 \%$ \\
\hline & Zandhoven & $1.0 \%$ & $1.1 \%$ & $12 \%$ & $79 \%$ & $58 \%$ \\
\hline & $\begin{array}{l}\text { Quarter Antwerp } \\
\text { (seigniorial) }\end{array}$ & $9.3 \%$ & $17.0 \%$ & $82 \%$ & $191 \%$ & $60 \%$ \\
\hline \multirow{12}{*}{$\begin{array}{l}\text { Walloon } \\
\text { Brabant } \\
\text { (villages) }\end{array}$} & Nivelles & $0.2 \%$ & $0.1 \%$ & $-66 \%$ & $-46 \%$ & $-36 \%$ \\
\hline & $\begin{array}{l}\text { Nivelles } \\
\text { (seigniorial) }\end{array}$ & $0.9 \%$ & $1.3 \%$ & $36 \%$ & $117 \%$ & $121 \%$ \\
\hline & Genappe & $0.6 \%$ & $0.2 \%$ & $-60 \%$ & $-36 \%$ & $-46 \%$ \\
\hline & $\begin{array}{l}\text { Genappe } \\
\text { (seigniorial) }\end{array}$ & $1.0 \%$ & $0.7 \%$ & $-24 \%$ & $21 \%$ & $27 \%$ \\
\hline & La Hulpe & $0.4 \%$ & $0.3 \%$ & $-37 \%$ & $1 \%$ & $23 \%$ \\
\hline & $\begin{array}{l}\text { La Hulpe } \\
\text { (seigniorial) }\end{array}$ & $0.2 \%$ & $0.3 \%$ & $20 \%$ & $93 \%$ & $125 \%$ \\
\hline & Mont-Saint-Guibert & $0.9 \%$ & $0.6 \%$ & $-34 \%$ & $5 \%$ & $10 \%$ \\
\hline & $\begin{array}{l}\text { Mont-Saint-Guib- } \\
\text { ert (seigniorial) }\end{array}$ & $1.7 \%$ & $1.0 \%$ & $-44 \%$ & $-10 \%$ & $-7 \%$ \\
\hline & Grez & $0.6 \%$ & $0.3 \%$ & $-56 \%$ & $-29 \%$ & $-52 \%$ \\
\hline & Hannut & $0.5 \%$ & $0.3 \%$ & $-36 \%$ & $2 \%$ & $-4 \%$ \\
\hline & Jodoigne & $0.8 \%$ & $0.6 \%$ & $-27 \%$ & $17 \%$ & $64 \%$ \\
\hline & $\begin{array}{l}\text { Jodoigne } \\
\text { (seigniorial) }\end{array}$ & $1.3 \%$ & $0.9 \%$ & $-32 \%$ & $9 \%$ & $49 \%$ \\
\hline
\end{tabular}




\begin{tabular}{|c|c|c|c|c|c|c|}
\hline Quarter & Bailiwick & $\begin{array}{l}\text { Share in aid } \\
(1383 / 1386)\end{array}$ & $\begin{array}{l}\text { Share in } \\
\text { aid (1436- } \\
1442)\end{array}$ & $\begin{array}{l}\text { Differ- } \\
\text { ence in } \\
\text { share }\end{array}$ & $\begin{array}{l}\text { Difference } \\
\text { in fine gold } \\
\text { equivalent }\end{array}$ & $\begin{array}{l}\text { Difference } \\
\text { relative to } \\
\text { share in } \\
\text { census }\end{array}$ \\
\hline \multirow{5}{*}{$\begin{array}{l}\text { 's-Her- } \\
\text { togenbosch } \\
\text { (villages) }\end{array}$} & Maasland & $1.4 \%$ & $1.6 \%$ & $15 \%$ & $84 \%$ & $27 \%$ \\
\hline & Peelland & $1.8 \%$ & $3.8 \%$ & $116 \%$ & $245 \%$ & $28 \%$ \\
\hline & Oisterwijk & $1.2 \%$ & $2.7 \%$ & $120 \%$ & $252 \%$ & $71 \%$ \\
\hline & Kempenland & $1.4 \%$ & $2.6 \%$ & $86 \%$ & $197 \%$ & $-22 \%$ \\
\hline & $\begin{array}{l}\text { Quarter's- } \\
\text { Hertogenbosch } \\
\text { (seigniorial) }\end{array}$ & $1.6 \%$ & $3.0 \%$ & $86 \%$ & $198 \%$ & $40 \%$ \\
\hline SUBTOTAL & & $101.4 \%$ & $100.9 \%$ & $0 \%$ & $59 \%$ & $-20 \%$ \\
\hline \multicolumn{2}{|c|}{$\begin{array}{l}\text { Contributing religious } \\
\text { institutions }\end{array}$} & $48.4 \%$ & $18.5 \%$ & $-62 \%$ & $-39 \%$ & \\
\hline TOTAL & & $149.8 \%$ & $119.4 \%$ & $-20 \%$ & $27 \%$ & \\
\hline
\end{tabular}

The percentages refer to the 'consistent space' mentioned in Table 5.2, hence the total exceeds $100 \%$.

\section{Bibliography}

\section{Primary sources}

'Brussels, ARA, CC, inv. no. 15.716' (Brussels), Algemeen Rijksarchief, Chambre des Comptes, inv. no. $15 \cdot 716$.

'Brussels, ARA, CC, inv. no. 15.722' (Brussels), Algemeen Rijksarchief, Chambre des Comptes, inv. no. $15 \cdot 722$.

'Leuven, SA, inv. no. 5055' (Leuven), Stadsarchief, inv. no. 5055 .

'Leuven, SA, inv. no. 5060' (Leuven), Stadsarchief, inv. no. 5060.

'Leuven, SA, inv. no. 5063' (Leuven), Stadsarchief, inv. no. 5063.

'Leuven, SA, inv. no. 5064' (Leuven), Stadsarchief, inv. no. 5064.

'Maastricht, RHCL, 03.01 Frans Archief, 1794-1814, inv. nos 1030a-1062g' (Maastricht), Regionaal Historisch Centrum Limburg, 03.01 Frans Archief, 1794-1814, inv. nos 1030a-1062g.

\section{Secondary sources}

Adriaenssen, Leo, 'Een aanslag op de calculerende clerus. De amortisatie van de geestelijke goederen in stad en meierij van 's-Hertogenbosch', Noordbrabants Historisch Jaarboek 15 (1998), 81-117.

Andrieu, Dominique, Christian Kaiser and André Ourednik, ScapeToad, version 1.1 (2008), http://scapetoad.choros.place/. 
Ansems, J.B., Den luyster ende glorie van het hertoghdom van Brabant, her-stelt door de genealogique beschryvinghe van desselfs souveryne princen, ende door het ontdecken van den schat der privilegien, ordonnantien, ende soo rechts, en staetkundige, als oeconomique reglementen der stadt Brussel, 3 vols (Brussel, 1699).

Arnould, Maurice-Aurélien, Les dénombrements de foyers dans le Comté de Hainaut (XIV -XVI siècle) (Brussels: Paleis der Academiën, 1956).

Arnould, Maurice-Aurélien, Les relevés de feux (Turnhout: Brepols, 1976).

Avonds, Piet, Brabant tijdens de regering van Hertog Jan III (1312-1356): land en instellingen (Brussel: Paleis der Academiën, 1991).

Beck, Patrice, Archéologie d'un document d'archives. Approche codicologique et diplomatique des cherches des feux bourguignonnes (1285-1543) (Publications de l'École nationale des chartes, 2006).

Berthels, Charles, 'Notice sur les limites de l'ancien diocèse de Liége, depuis la Meuse (Hollande) jusqu’à la Dyle (Belgique), précédée de quelques considérations générales sur la géographie ecclésiastique de la Belgique ancienne', Revue d'histoire et d'archéologie 1 (1859), 290-318, 368-394.

Blockmans, Wim, 'The Low Countries in the Middle Ages', in The Rise of the Fiscal State in Europe c. 1200-1815, ed. by Richard Bonney (Oxford: Oxford University Press, 1999), pp. 281-308.

Blockmans, Wim, and Walter Prevenier, 'Poverty in Flanders and Brabant from the Fourteenth to the Mid-Sixteenth Century: Sources and Problems', in Acta Historiae Neerlandicae: Studies on the History of the Netherlands X, ed. by Ivo Schöffer (Dordrecht, 1978), pp. 20-57.

Blockmans, Wim, Gerard Pieters, Walter Prevenier and Remi van Schaïk, 'Tussen crisis en welvaart: sociale veranderingen 1300-1500', in Algemene Geschiedenis der Nederlanden, ed. by Dick Blok, 15 vols (Haarlem: Fibula-Van Dishoeck, 1977-1983), vol. 4, pp. 42-86.

Bonney, Richard, 'Introduction', in The Rise of the Fiscal State in Europe c. 1200-1815, ed. by Richard Bonney (Oxford: Oxford University Press, 1999), pp. 1-17.

Bonney, Richard, ed., The Rise of the Fiscal State in Europe c. 1200-1815 (Oxford: Oxford University Press, 1999).

Bos-Rops, Yvonne, Graven op zoek naar geld. De inkomsten van de graven van Holland en Zeeland, 1389-1433 (Hilversum: Verloren, 1993).

Carrion, Daniela, Frederica Migliaccio, Guido Minini and Cynthia Zambrano, 'From Historical Documents to GIS: A Spatial Database for Medieval Fiscal Data in Southern Italy', Historical Methods: AJournal of Quantitative and Interdisciplinary History 49, no.1 (2016), 1-10.

Cavenne, François-Alexandr, Statistique du département de la Meuse-Inférieure (Maastricht, 1802). 
Centraal Bureau voor Statistiek and NIWI-KNAW, 'Population Census of the Netherlands, 1795: General Population in the Batavian Republic' (Data Archiving and Networked Services, 1998), https://doi.org/10.17026/dans-zge-xbkf.

Cosemans, Alex, De bevolking van Brabant in de XVII en XVIII eeuw (Brussels, 1939).

Cuvelier, Joseph, 'Le fouage brabançon de 1374', Bulletin de la Commission royale d'Histoire. Académie royale de Belgique 76, no. 1 (1907), 537-547.

Cuvelier, Joseph, Les dénombrements de foyers en Brabant (XIV -XVI siècle) (Brussels: Kiessling \& Imbreghts, 1912).

Damen, Mario, 'Prelaten, edelen en steden. De samenstelling van de Staten van Brabant in de vijftiende eeuw', Handelingen van de Koninklijke Commissie voor Geschiedenis 182 (2016), 5-274.

Damen, Mario, 'The Nobility in the Estates of Brabant in the Late Middle Ages', in Political Representation Communities, Ideas and Institutions in Europe (c. 1200-c. 169o), ed. by Mario Damen, Jelle Haemers and Alastair Mann (Leiden/Boston: Brill, 2018), pp. 161-181.

Damen, Mario, 'The Political Ranking and Hierarchy of the Towns in the Late Medieval Duchy of Brabant', Anuario de Estudios Medievales 48, no. 1 (2018), 149-177.

Dauphant, Léonard, Le royaume des quatre rivières: l'espace politique français (1380-1515) (Champ Vallon: Seyssel, 2012).

De Brouwer, Jozef, 'Het belang van de kommunikantencijfers en de verhouding ervan tot de bevolking', Handelingen van de Koninklijke Zuidnederlandse Maatschappij voor Taal- en Letterkunde en Geschiedenis 17 (1963), 67-80.

Dorsch, Anton Joseph, Statistique du département de la Roer (Cologne: Oedenkoven \& Thiriart, 1804).

Dubois, Henri, 'Population et fiscalité en Bourgogne à la fin du Moyen Âge', Comptes rendus des séances de l'Académie des Inscriptions et Belles-Lettres 128, no. 4 (1984), 540-555.

Elden, Stuart, The Birth of Territory (Chicago: University of Chicago Press, 2013).

Elden, Stuart, 'Land, Terrain, Territory', Progress in Human Geography 34, no. 6 (2010), 799-817.

Garnier, Joseph, La recherche des feux en Bourgogne aux XIV et $X V^{e}$ siècles (Dijon: Lamarche, 1876).

Goose, Nigel, 'How Accurately Do the Hearth Tax Returns Reflect Wealth? A Discussion of Some Urban Evidence', Local Population Studies 67 (2001), 44-63.

Henneman, John Bell, Jnr, 'France in the Middle Ages', in The Rise of the Fiscal State in Europe c. 1200-1815, ed. by Richard Bonney (Oxford: Oxford University Press, 1999), pp. 101-122.

Kauch, Pierre, 'Ladministration et le contrôle des finances du duché de Brabant (1404-1467)', PhD thesis, Université libre de Bruxelles, 1933. 
Klep, Paul, Bevolking en arbeid in transformatie: een onderzoek naar de ontwikkelingen in Brabant, 1700-19oo (Nijmegen: Socialistiese Uitgeverij Nijmegen, 1981).

Klep, Paul, 'Long-term Developments in the Urban Sector of the Netherlands (1350-1870)', in Le réseau urbain en Belgique dans une perspective historique: (1350-1850). Une approche statistique et dynamique (Bruxelles: Crédit Communal de Belgique, 1992), pp. 201-242.

Klep, Paul, 'Regional Disparities in Brabantine Urbanisation before and after the Industrial Revolution (1374-1970): Some Aspects of Measurement and Explanation', in Disparities in Economic Development since the Industrial Revolution, ed. by Paul Bairoch and Maurice Lévy-Leboyer (London/Basingstoke: Macmillan, 1981), pp. 259-269.

Korvezee, Betsy, 'Belastingen in Noord-Brabant vóór 1648', Varia Historica Brabantica 4 (1975), 97-163.

Laslett, Peter, and Richard Wall, Household and Family in Past Times (Cambridge: Cambridge University Press, 1972).

Lecuppre-Desjardin, Élodie, Le royaume inachevé des ducs de Bourgogne $\left(X I V^{e}-X V^{e}\right.$ siècles) (Paris: Belin, 2016).

Lot, Ferdinand, 'Létat des paroisses et des feux de 1328', Bibliothèque de l'École des chartes 90 (1929), 51-107, 256-315.

Moureaux-Van Neck, Anne, 'Laide brabançonne de 1374', in Hommage au professeur Paul Bonenfant (1899-1965). Études d'histoire médiévale dédiées à sa mémoire par les anciens éleves de son séminaire à l'Université Libre de Bruxelles, ed. by Georges Despy, Maurice-Aurélien Arnould and Mina Martens (Bruxelles: Universa, 1965), pp. 267-283.

Moureaux-Van Neck, Anne, 'Un aspect de l'histoire financière du Brabant au Moyen Âge. Les aides accordées aux ducs entre 1356 et 1430', Annales de la Société royale d'Archéologie de Bruxelles 51 (1966), 65-94.

Oostindiër, Arend Elias, and Rombert Stapel, 'Fiscal Repartitions for the Duchy of Brabant (1383-1572)' (IISH Data Collection, 2020), http://hdl.handle.net/10622/ WGEKRX.

Pounds, Norman J.G., 'Population and Settlement in the Low Countries and Northern France in the Later Middle Ages', Revue belge de philologie et d'histoire 49, no. 2 (1971), 369-402.

Pounds, Norman J.G., and Charles C. Roome, 'Population Density in Fifteenth Century France and the Low Countries', Annals of the Association of American Geographers 61, no. 1 (1971), 116-130.

Stabel, Peter, Dwarfs among Giants: The Flemish Urban Network in the Late Middle Ages (Leuven: Garant, 1997). 
Stabel, Peter, and Filip Vermeylen, Het fiscale vermogen in Brabant, Vlaanderen en de heerlijkheid Mechelen. De Honderdste Penning van de hertog van Alva (1569-1572) (Bruxelles: Académie Royale de Belgique, 1997).

Stapel, Rombert, 'Hearth and Population Censuses for the Duchy of Brabant (1374180o)' (IISH Data Collection, 2020), http://hdl.handle.net/10622/YGRTHJ.

Stapel, Rombert, 'Historical Atlas of the Low Countries (1350-180o)', under review. Stapel, Rombert, 'Holland rond 1500: een geografische verkenning van de Enqueste (1494) en Informacie (1514)', Holland: historisch tijdschrift 49, no. 4 (2017), 177-184. Stein, Robert, Magnanimous Dukes and Rising States: The Unification of the Burgundian Netherlands, 1380-1480 (New York: Oxford University Press, 2017).

Uyttebrouck, André, 'Inventaire des comptes généraux du duché de Brabant antérieurs à l'avènement de Philippe le Bon (1342-1430)', in Recherches sur l'histoire des finances publiques en Belgique, ed. by Maurice-Aurélien Arnould et al., Acta Historica Bruxellensia, 3 (Bruxelles: Institut d'histoire de l'Université Libre de Bruxelles, 1974), 101-130.

Uyttebrouck, André, Le gouvernement du duché de Brabant au bas Moyen Âge (1355-1430) (Bruxelles: Éditions de l'Université de Bruxelles, 1975).

Van Asseldonk, Martien, 'De Meierij van 's-Hertogenbosch. De evolutie van plaatselijk bestuur, bestuurlijke indeling en dorpsgrenzen, circa 1200-1832', PhD thesis, Tilburg University, 2002.

Van der Ree-Scholtens, Gineke, De grensgebieden in het Noordoosten van Brabant ca. 1200-1795. Institutionele en juridische aspecten (Assen/Maastricht:Van Gorcum, 1993). Van der Woude, Ad, Het Noorderkwartier. Een regionaal historisch onderzoek in de demografische en economische geschiedenis van westelijk Nederland van de late middeleeuwen tot het begin van de negentiende eeuw, 3 vols (Wageningen: Afdeling Agrarische Geschiedenis, Landbouwhogeschool, 1972).

Van Gerven, Jan, 'Antwerpen in de veertiende eeuw. Kleine stad zonder toekomst of opkomend handelscentrum?', Revue belge de philologie et d'histoire 76, no. 4 (1998), 907-938.

Van Schaïk, Remi, Belasting, bevolking en bezit in Gelre en Zutphen (1350-1550) (Hilversum: Verloren, 1987).

Van Uytven, Raymond, 'Diest, Aarschot en Zichem: de Demersteden en hun heren vóór het einde van de zestiende eeuw', in De heerlijke stad. 8 e Colloquium 'De Brabantse Stad', Bergen op Zoom, 2 en 3 oktober 1987, ed. by Th. Bosman, Jos Coopmans and Trix Jacobs (Assen: Van Gorcum, 1988), pp. 183-192.

Van Uytven, Raymond, 'Een dichte bevolking in ogenschijnlijke welstand', in Geschiedenis van Brabant: van het hertogdom tot heden, ed. by Raymond van Uytven, Andries van den Abeele and Jan van Oudheusden, $2^{\text {nd }}$ ed. (Zwolle/ Leuven: Waanders/Davidsfonds, 2008), pp. 234-241. 
Van Uytven, Raymond, 'Wereldlijke overheid en reguliere geestelijkheid in Brabant tijdens de Late Middeleeuwen', in Sources de l'histoire religieuse de la Belgique: Moyen Âge et temps modernes. Actes du colloque de Bruxelles, 3o nov.-2 déc. 1967 (Ie et IIe sections) (Louvain: Publications universitaires, 1968), pp. 48-134.

Van Zanden, J.L., 'Taking the Measure of the Early Modern Economy: Historical National Accounts for Holland in 1510/14', European Review of Economic History 6, no. 2 (2002), 131-163.

Verbeemen, Jozef, 'De demografische evolutie van Mechelen (1370-180o)', Handelingen van de Koninklijke Kring voor Oudheidkunde, Letteren en Kunst van Mechelen 58 (1953), 135-179.

Vogeler, Georg, 'Tax Accounting in the Late Medieval German Territorial States', Accounting, Business and Financial History 15, no. 3 (2005), 235-254.

Vrancken, Valerie, De Blijde Inkomsten van de Brabantse hertogen. Macht, opstand en privileges in de vijftiende eeuw (Brussels: Academic and Scientific Publishers, 2018).

Vrielinck, Sven, De territoriale indeling van België (1795-1963). Bestuursgeografisch en statistisch repertorium van de gemeenten en de supracommunale eenheden (administratief en gerechtelijk): met de officiële uitslagen van de algemene volkstellingen (Leuven: Universitaire Pers Leuven, 2000).

Wasserfall, Peter, Annuaire historique et statistique consacre au département de la Roer (1799).

Zuijderduijn, Jaco, Rombert Stapel and Jan Lucassen, 'Coin Production in the Low Countries: Fourteenth Century to the Present', Tijdschrift voor Sociale en Economische Geschiedenis 15, nos 2/3 (2018), 69-88.

\section{About the authors}

Arend Elias Oostindiër is a PhD candidate at the University of Amsterdam, working on constructions and representations of territory in the late medieval Duchy of Brabant.

Rombert Stapel is a Postdoctoral Researcher at the International Institute of Social History in Amsterdam. He specialises in historical GIS and digital humanities and currently studies the interplay between landscape, economics, and demography in the medieval and early modern Low Countries.

Damen, M. and K. Overlaet (eds.), Constructing and Representing Territory in Late Medieval and Early Modern Europe. Amsterdam: Amsterdam University Press, 2022 DOI 10.5117/9789463726139_CHo6 


\title{
6. From Knights Errant to Disloyal Soldiers? The Criminalisation of Foreign Military Service in the Late Medieval Meuse and Rhine Regions, 1250-1550
}

Sander Govaerts

\begin{abstract}
This chapter examines the territorial implications of a new legal concept - 'foreign military service'. It focuses on the river basins of the Meuse and Rhine, some of Europe's most important recruiting grounds. As paying wages to combatants gradually become the norm, it was easier for rulers to recruit soldiers outside their own lands, which gave the soldiers more independence. Both princes and city councils tried to mitigate this freedom by reinterpreting existing laws. The prohibition against fighting a lord to whom one owned loyalty was now expanded to include all unauthorised military service outside one's home jurisdiction. Legally, a soldier's geographical origin became more important than all other ties of loyalty. The new laws provided a basis for all subsequent legislation on 'foreign military service'.
\end{abstract}

Keywords: soldiers; migration; military recruitment; laws of war; feudal relations

\section{Introduction}

Central to all chapters in this volume is the idea - inspired by Stuart Elden that researchers can avoid an ahistorical approach to the concept of territory by analysing the techniques that states and other political actors actually used to link people and power to space(s). One particularly well-known example is the growing importance of cartography during the Late Middle Ages and early modern period, a development that was closely connected to 


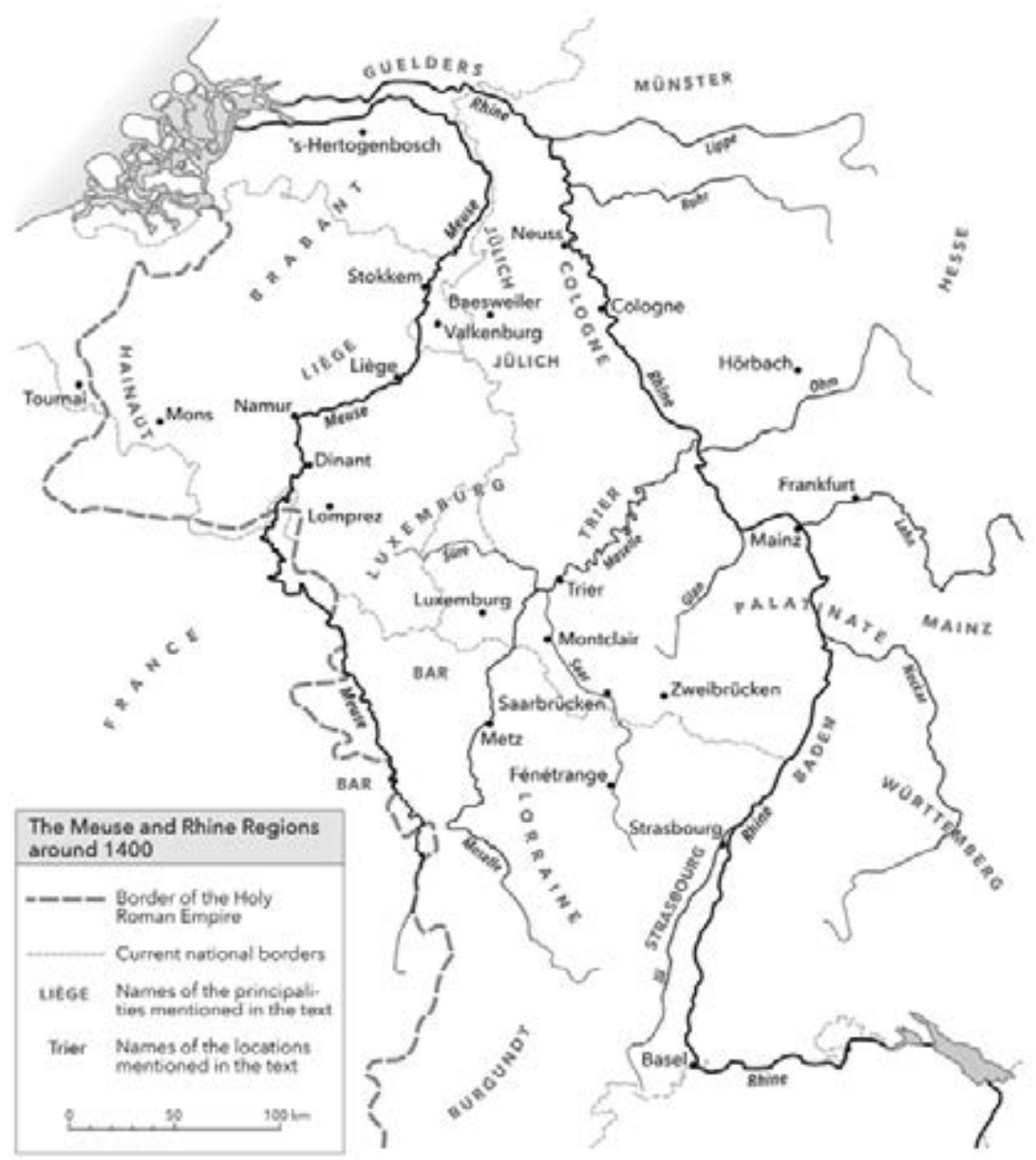

Fig. 6.1. The Meuse and Rhine regions, 1400-1600.

military control over land ('terrain'). ${ }^{1}$ The question to what extent historical armed forces also tried to regulate migration has received far less attention, even though the human aspects of territory formation are a key element in Michel Foucault's interpretation of territory (the turning of 'people' into 'populations'). ${ }^{2}$ This article takes a logical next step, and considers attempts to control the movements of one particular social group, namely soldiers, as a territorial practice. It will more specifically study the possible medieval origins of the concept of 'foreign military service', which refers to the practice of enlisting in the army of a potentate outside the territory

1 Elden, 'Land, Terrain, Territory', pp. 801-807.

2 Elden, 'How Should We Do the History of Territory?' 
where one was born or lived (fremde Kriegsdienste, vreemde krijgsdienst, service militaire à l'étranger).

Whereas several studies comment on prohibitions against fighting in 'foreign' armies during the (early) modern period, few attempts have been made to see similar medieval regulations in a 'territorial' light ${ }^{3}$ Instead, recent research tends to emphasise the 'international' or even 'mercenary' outlook of medieval combatants. ${ }^{4}$ To be sure, the exact meaning of the word 'mercenary' in a historical context is very much open to interpretation, although most researchers acknowledge that it includes an element of being primarily motivated by material gain, and having little or no attachment to the cause they were fighting for. ${ }^{5}$

It should be noted that medieval societies had no particular word for 'mercenary'. ${ }^{6}$ The word 'soldier' (soudoyer, Soldener, soudener, souldoyer, soudenair) was a common and generic term to refer to combatants receiving wages, regardless of their individual motivations or geographical origins. The absence of unambiguous distinctions between different kinds of soldiers might explain why medieval societies were unfamiliar with the concept of 'foreign military service'. The Tractatus de bello de represaliis et de duello (1360), for instance, an authoritative legal text on the medieval law of arms, discusses subjects such as the right to start a war, and whether combatants were entitled to wages, but does not mention anything remotely similar to seventeenth- or eighteenth-century laws on 'foreign military service'.7

In order to determine whether the concept of 'foreign military service' can be traced back to the Middle Ages and study its development as a territorial practice, this article will first explain the importance of focusing on the Meuse and Rhine regions. It will then examine the main characteristics of paid military service in these same regions within the context of the medieval law of arms, before analysing princes' and cities' initial (fourteenthand early-fifteenth-century) attempts to use their power over specific spaces to limit soldiers' mobility. The final section will study the actual implementation of 'foreign military service' as a legal concept in the late fifteenth and early sixteenth centuries. The conclusion returns to the main

3 See, however, Nicholson, 'International Mobility'.

4 Lower, 'European Mercenaries'; Pépin, Lainé and Boutoulle, Routiers et mercenaires.

5 DeVries, 'Medieval Mercenaries', pp. 44-45.

6 The term condotierri is often translated as 'mercenary soldiers' or 'mercenary captains', but given that it derives from the Italian word condotta ('contract'), 'contractors' or 'soldiers' might be far more close to its original meaning. Caferro, 'Condottieri', pp. 417-419.

7 Legnano, Tractatus de bello, pp. 112-123, 254-268. 
argument and explains the importance of these findings for future research on territory formation and military service in the pre-modern period.

\section{The Meuse and Rhine regions in 1250-1550}

This study does not adopt a political framework, but rather studies the territorial aspects of military service in the late medieval Meuse and Rhine regions, or the river basins of the Meuse and Rhine. Studies on late medieval military service generally focus on strong central governments, such as the kingdoms of England and France. ${ }^{8}$ However, as this chapter will demonstrate, the Meuse and Rhine regions also provide an excellent context to examine attempts to control soldiers' movements, because of their political fragmentation and function as some of Europe's most important recruiting grounds. The period under scrutiny ranges from the second half of the thirteenth century, when paid military service became standard practice, to $155^{\circ}$, at which point the concept of foreign military service had become firmly established.

Theoretically, most of the Meuse and Rhine regions were part of the Holy Roman Empire since the disintegration of Lothair's empire in the ninth century. Around 1250, however, imperial power had become relatively weak except in Swabia and the bishoprics of Strasbourg, Mainz, and Trier. The majority of the duchies, counties, prince-bishoprics, imperial cities, free cities, and lordships in these regions can therefore be considered as more or less independent entities. Still, the rising power of the kings of France and later also the dukes of Burgundy caused increasing unease. Notably examples include Henry (III) of Bar's recognition of Philip IV as his overlord for the part of his county lying west of the river Meuse in 1301 (Bar non-mouvant), the French siege of Metz in 1444, and Charles the Bold's aggressive campaigning against Liège, Guelders, Neuss, the Swiss Confederacy, and Lorraine in the 1460s and 1470s. ${ }^{9}$

The weakening of imperial authority went hand in hand with, and was indeed partially caused by, the sizeable community of nobles that made the Meuse and Rhine regions their home. Werner Paravicini has rightfully called the lands between the Meuse and the (Lower) Rhine a core area of

8 Baker, Lambert and Simpkin, Military Communities; Pépin, Lainé and Boutoulle, Routiers et mercenaires.

9 Aimond, Les relations; Jappe Alberts, Overzicht; Leukel, Das Reichsheer 
chivalric culture. ${ }^{10}$ This group of noblemen was in fact so important that one herald, the king of the Ruwieren, who was also the highest-ranking herald in the Empire, was the designated specialist for this specific (heraldic) area. ${ }^{11}$ The lack of a strong central government offered these nobles ample opportunity to pursue martial exploits. Contemporaries such as Lodewijk van Velthem, Jean le Bel, and Jean Froissart depict them as very warlike, but also greedy, and sometimes downright cruel. ${ }^{12}$ During the fourteenth century, a well-documented period, they fought in the Hundred Years' War, in northern Italy, and in crusades to Granada, Prussia-Lithuania, Hungary, Scandinavia, Gallipoli, and North Africa. Most also participated in numerous local feuds and wars, and many of their family members joined the Teutonic Order. ${ }^{13}$

The martial reputation of noblemen from the Meuse and Rhine brought them both prestige and material benefits. From the twelfth to the fifteenth centuries it was common for strong rulers such as the kings of England and France, and powerful dukes and counts such as those of Brabant, Flanders, and Holland, to grant fief rents to create ties of loyalty, and encourage nobles to provide military aid when needed. Imperial and free cities, such as Cologne, Metz, Strasbourg, and Frankfurt, typically secured alliances by granting noblemen the status of outburgher (Aussenbürgher). Members of the city council also intermarried with noble families living in the surrounding area. ${ }^{14}$ By maintaining multiple ties of loyalty even knights bachelor and squires could assert some degree of independence. Most importantly, however, these fief rents played a key role in the transition of a military recruitment system solely based on feudal obligations to one built on contracts and wages. ${ }^{15}$ As late as the sixteenth century Philip II of Spain granted numerous pensions to secure the loyalty of high-ranking noblemen in the Holy Roman Empire and to obtain access to the troops they could raise. ${ }^{16}$

Changes within noble lifestyles during the Late Middle Ages also exerted a major influence on aristocrats' military activities. In the late

10 Paravicini, 'Ritterliches Rheinland', pp. 239-242.

11 Van Anrooij, Spiegel, pp. 67-77.

12 Froissart, Oeuvres, vol. 13, p. 277; Le Bel, Chronique de Jehan le Bel, vol. 2, p. 238; Luce, Jeanne d'Arc à Domrémy, pp. lxii-lxiii; Van Velthem, Lodewijk Van Velthem's voortzetting van den Spiegel historiael, vol. 2, p. 221-222 (part 5 , book 3 , v. 3540-3567).

13 Govaerts, “'Mannen van Wapenen”', pp. 321-323; Paravicini, 'Ritterliches Rheinland'.

14 Marchal, 'Pfahlburger, bourgeois forains, buitenpoorters, burgeois du roi'; Wübbeke, Das

Militärwesen, pp. 38-52.

15 Burgers and Damen, 'Feudal Obligation', pp. 791-798; Lyon, 'The Fief-Rente'.

16 Edelmayer, Söldner und Pensionäre. 
fourteenth and early fifteenth centuries chivalric travel and crusading were increasingly replaced by grand tours and unarmed pilgrimages. ${ }^{17}$ The herald Claes Heynen zoon, king of the Ruwieren, wrote a series of poems in the last decades of the fourteenth century, in which he praised the chivalric deeds of noblemen of the Meuse and Rhine regions. He did so, however, at a time in which the majority of his subjects were no longer among the living. His poems might thus have glorified behaviour that had become uncommon. ${ }^{18}$

Monarchs, dukes, bishops, counts, and cities for their part actively tried to reduce violence within the Meuse and Rhine regions by promoting socalled Landfriede from the twelfth century onwards. These agreements, which also involved knights and squires, sought to solve conflicts among their members in a peaceful manner, and also led to the taking of military action against those who broke the public peace. The object was certainly not to deny noblemen their right to use force, but to repress its unlawful use. ${ }^{19}$ Nevertheless, high-ranking nobles continued to engage in feuding well into the sixteenth century. Götz von Berlichingen and Franz von Sickingen are two particularly well-known examples. The spread of Landfriede demonstrates that the establishment of a formal ban on foreign military service has to be seen in the context of more general attempts to limit the prevalence of unsanctioned violence. ${ }^{20}$

\section{Military labour and the medieval law of arms}

Given the presence of large groups of noblemen, who were relatively autonomous and well known for their martial exploits, it comes as no surprise that soldier recruitment across political boundaries in the late medieval Meuse and Rhine regions mostly involved horsemen. Before the rise of the Swiss Reisläufer and German Landsknechten in the late fifteenth century, foot soldiers were normally raised from among the local population (often members of shooting guilds). Mounted soldiers were typically organised in 'lances' (Gleven, glaives, lansen), consisting of a heavily armoured horseman, a man-at-arms, and his retinue. ${ }^{21}$ 
These men-at-arms often maintained ties of loyalty to multiple lords and cities. The granting of fief rents by rulers in effect proved to be a doubleedged sword: while it allowed princes to create ties of loyalty with noblemen living outside the lands they controlled, it also gave their own fief holders more independence, because their income no longer depended solely on land ownership. The expansion of a monetary economy during the twelfth and thirteenth centuries meant that wages became an increasingly important motivation to provide military service, and that soldiers could enter the service of multiple lords.

This complexity is reflected in military contracts. On 24 June 1297, for instance, Warnier de Dave, a knight from the county of Namur, agreed to serve Guy de Dampierre, count of Flanders and margrave of Namur, in his campaign against the king of France only if he did not have to enter the lands of the bishop of Liège, the count of Hainaut, the duke of Brabant, and the lord of Valkenburg. Members of his retinue - he brought three other knights and 21 squires - who were not fief holders of these lords, were free to enter these lands. ${ }^{22}$ Similarly, on 3 September 1348 Jehan de la Piere, Nikelos Kese from Saarbrücken, and Simon Xelkin from Montclair (Mettlach) agreed to serve the city of Metz against Bouquart de Fénétrange. None would serve against the duke of Lorraine and the count of Saarbrücken, and each horseman added the name of one other lord to the contract, against whom he would not fight either. ${ }^{23}$

Such arrangements were not limited to horsemen living nobly, but also to other high-status soldiers. The contract specifying the conditions under which Johan von Troy became master gunner of Strasbourg in 1370, for example, stipulates that he would remain neutral during any (future) conflicts between the city and one of his other lords (Duke Rupert of Bavaria; Margrave Rudolf of Baden; Count John and Simon Wecker of ZweibrückenBitsch; Count John of Salm, the duke of Lorraine; and Lord Huwart Röppe). Still, Johan promised that in such a case he would teach his 'art' to one citizen chosen by the city council. ${ }^{24}$

One can consider the military service of these soldiers as a kind of 'labour', which required a formal agreement on its conditions, limits, and payments (such as English indentures or Italian condotta). The word 'labour' (arbeyd, arbeyt), which was also used in the context of chivalric romance to denote the making of an effort or experiencing trouble which causes suffering and 


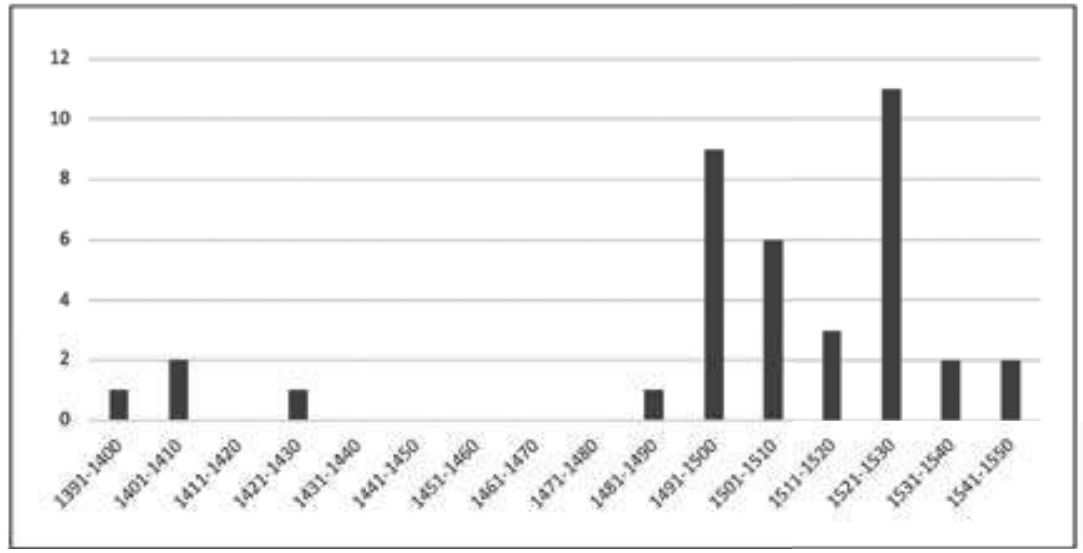

Fig. 6.2. Overview of people prosecuted for foreign service in the Bailiwick of 's-Hertogenbosch, 1393-1550. Source: ARB, 1107 Rekeningen Hoogschout 's-Hertogenbosch, inv. nr 2797, 12990, 12991, 12995, 12996.

pain, appears regularly in military contracts in the more specific meaning of 'work'. ${ }^{25}$ If medieval men-at-arms can be considered as 'labourers' they were certainly one of the most prestigious kinds, for they offered their service from a position of relative strength. Sometimes soldiers even bonded over shared frustrations against their employer(s). In 1394 former soldiers in the service of Cologne started a feud against the city, claiming that the city council had treated them unjustly. ${ }^{26}$

The negotiating of such particular duties and exceptions between (urban as well as noble) rulers and their soldiers has to be seen in the context of the medieval 'law of arms'. ${ }^{27}$ According to Christine de Pisan's Livre des faits d'armes et de chevalerie (1410), someone could fight for anyone or any cause, and accept pay for his service, providing only that it was a just war'. ${ }^{28}$ It is worth noting that this section is not included in the earlier fourteenth-century works of Honoré Bovet or John of Legnano on which the legal part of Pisan's book is based. Its addition might therefore indicate that contemporaries increasingly perceived military service across political boundaries or outside one's own region as problematic.

One of the most important implications of this law of arms, which was recognised throughout Christian Europe, was that a soldier could not fight 
his own lord. Even captains of military companies, men who possessed many of the characteristics traditionally attributed to mercenaries, generally respected this taboo. There were loopholes, however. A soldier could, for instance, engage in a conflict against his own lord if he did not enter his lord's lands or fight him directly. His participation could also be allowed if his lord was not the main antagonist of his paymaster, but only an ally. ${ }^{29}$ Despite these exceptions, the political fragmentation of the Meuse and Rhine could lead to difficult dilemmas. In 1395, for example, Archbishop Conrad of Mainz contracted fourteen men-at-arms to provide military service, and had to agree that if they became the enemy of one of their own lords because of him, he would not make peace with that lord before he had made sure that their fiefs would be returned to them..$^{30}$

The uncertainty about which side a nobleman might choose in the event of a conflict also had direct repercussions for the defence of a ruler's territory. In the fourteenth-century Prince-Bishopric of Liège the Estates stipulated that all castellans had to be 'native' ('du pays'). After the unification of the county of Loon with the prince-bishopric in 1361, the castellans of Stokkem, a town that guarded a strategic passageway in the Meuse, also had to swear their oath of loyalty before the councillors of Liège. In this way, the city council wanted to make sure that the castellans did not just safeguard the interests of the bishop, but their interests as well. This was an understandable precaution given that the relationship between the bishops of Liège and their own subjects regularly deteriorated into open war. ${ }^{31}$

\section{Controlling military labour}

Soldiers' employers - rulers, noblemen, and city councils - did not respond to the weakening of traditional ties of loyalty by simply reasserting existing military obligations, feudal or otherwise, but tried to develop new forms of control by using the existing law of arms as a starting point. This means that soldiers' mobility primarily became a problem when it could be interpreted as treason. A French remission letter from 1445 provides a good example. It concerns a man from Tournai, a member of one of the city's archery guilds, who had joined soldiers from Luxemburg to fight against Metz. They

30 StA Wü, MIB 12 fol. $290 v$ (02), in Die Regesten der Mainzer Erzbischöfe (http://www.ingrossaturbuecher.de/id/source/3954).

31 Deprez, 'La politique castrale', pp. 525-526. 
changed their allegiance, however, and fought against the French royal army in 1444. The document clearly specifies that this constituted a crime of lèse-majesté. The archer in question was held prisoner by the prévôt of Tournai, the king's representative in the city, at the time mercy was granted, which means that territorial control was an essential condition for bringing offenders to justice..$^{2}$

Other sources confirm this impression. The fiscal accounts of the high bailiffs of 's-Hertogenbosch, the officials charged with maintaining law and order in the northern part of the Duchy of Brabant, the Meijerij (Bailiwick), have been preserved in an almost complete series from 1368 onwards, and include 39 cases of people prosecuted for joining an enemy or foreign army from 1393 to $1550.0^{33}$ None of the fiscal accounts uses the specific expression 'foreign military service'. Offenders are punished because they joined 'the enemy', 'Guelders', and 'the French army', or fought against their 'ruler' or 'natural prince'. Thirty-five of these indeed concern soldiers or unpaid servants who had fought against the duke of Brabant. The four exceptions concern two men who participated in the war between the count of Holland and Lord Jan van Arkel (1401-1412), and pursued this conflict within the high bailiff's jurisdiction, and two men who had fought in Frisia against the duke of Saxony in 1497 and 1502-1503. Duke Albrecht of Saxony was a close ally of the Habsburgs, which means that their actions could also be interpreted as enemy service.

These fiscal accounts indicate that enemy service became a major problem in the last decades of the fifteenth and early sixteenth centuries, during the revolts against Maximilian in the Low Countries (1483-1492) and the wars between Charles V and Francis I (1521-1530; 1536-1538). It should be stressed, however, that attempts to prohibit 'foreign military service' had been made as early as the late fourteenth century. In 1396 Duchess Joan of Brabant forbade both her fief holders and other subjects to join the military expedition of Count Albrecht of Holland to Frisia. ${ }^{34}$ Six years later the high bailiff of 's-Hertogenbosch sent messengers to proclaim in churches that it was forbidden to join either side in the conflict between the count of Holland and the lord of Arkel. Given the limited number of people (two) prosecuted for violating these prohibitions, enforcement of these orders seems to have

32 Tuetey, Les écorcheurs, pp. 393-394.

33 Brussels, Algemeen Rijksarchief (ARB), 1107 Rekeningen Hoogschout 's-Hertogenbosch, inv. nr 2797, 12990, 12991, 12995, 12996 (transcript Henk Beijers Archiefcollectie, http://www. henkbeijersarchiefcollectie.nl).

34 Janse, Grenzen aan de macht, p. 263. 
been difficult, or perhaps it was not a priority ${ }^{35}$ Revealing in this regard is the charter granted to the crossbowmens' guild of 's-Hertogenbosch of 1453. It stipulates that its members could not enrol in anyone's service or leave the city for more than three days without permission from the city's councillors and the guild's masters. Offenders risked exclusion from the guild. ${ }^{6}$

City councils were even more anxious that they would be held responsible for the actions of their citizens. When Duke William of Jülich, an outburgher of the city of Cologne, asked its councillors for military aid in late June or early July 1371, they informed him that they would not send help because other signatories of the Landfriede were involved in the conflict. Still, they did permit citizens who were fief holders of the duke to join his army. In the fall of 1371, shortly after a combined force of Guelders and Jülich defeated a Brabant invasion army at the Battle of Baesweiler, the councillors had to answer allegations of Duchess Joan of Brabant that citizens of Cologne had fought against her husband and brought their captives and booty to the city. The councillors countered her claim by saying that they had indeed allowed individual citizens to join the army of the duke of Jülich, but sent letters ordering them to return as soon as they realised that the Brabant army carried the imperial banner. They admitted, nevertheless, that five or six of their citizens might have participated in the battle, because the letters did not reach them in time. The city council also requested the duchess not to take retaliatory measures against its citizens and their belongings (an appeal that proved unsuccessful). 37

The precarious position of Cologne was not unique. Many cities in the Holy Roman Empire enacted laws during the fourteenth and fifteenth centuries, which prohibited citizens from taking part in conflicts, especially feuds, without the councillors' permission. Offenders could be punished by loss of citizenship, banishment, and fines. ${ }^{38}$ City councils thus used their territorial control to limit the movements of their citizens. In the case of Cologne, the social bias of the councillors exacerbated existing tensions within the city and caused an open battle between the city's guilds and its patricians (the Weberschlacht). While the city council had simply asked the knight Johan Scherfgin to release his prisoner, they arrested Henken vom Turne, a member of the weavers' guild, for participating in

ARB, 1107 Rekeningen Hoogschout 's-Hertogenbosch, inv. nr 2818, 44.1.2.3; 12991, 74.2.3.10;

36 Reintges, Ursprung und Wesen, 357 .

37 Ennen and Eckertz, Quellen, vol. 4, pp. 619-624, 650, 660; Rotthoff-Kraus, Die politische Rolle, pp. 265-28o.

38 His, Das Strafrecht, p. 67. 
the battle and bringing booty back to the city, and sentenced him to be executed. A complicating factor in this case is that Johan might have lost his citizenship at the time of the battle because he started a feud against the city. 39

In practice, most conflicts about 'foreign military service' still concerned soldiers who had broken specific ties of loyalty or the 'laws of war' more generally. In 1397, for example, Margrave Bernard of Baden asked the city council of Strasbourg to release two soldiers from their service, because they had enlisted without his consent. He called them his Eigenleute ('bondsmen'), and claimed that they had long been in disfavour, and had sworn not to serve another lord without his permission. ${ }^{40}$ In 1430, by contrast, it was the city council that sent a formal complaint to Emperor Sigismund of Austria regarding the margrave's unlawful actions. These included the stealing of warhorses before a feud had been declared, and the imprisonment of one of their soldiers, who had, not coincidently, earlier served the margrave. ${ }^{41}$

The punishments to which offenders were actually sentenced could be surprisingly lenient. In 1404 King Rupert of the Palatinate accused a certain Heinrich Kemerer, whom he held prisoner at that time, of breaking his oath of fealty. The list of offences included two examples of military service: Heinrich had fought alongside the cities against Rupert's father (probably the conflict between the Süddeutscher Städtebund and the Löwenbund in the 1380s), even though his father and ancestors had always supported the dukes of the Palatinate, and had recruited soldiers for the duke of Orléans. Rupert's son Louis was married to Blanche of England at that time, which made this enemy service. Nevertheless, Heinrich's name still appears in later charters issued by the king, so it is likely that Rupert granted him mercy. This would be in line with his father's policy: when Rupert (II), elector palatine, took Heinrich prisoner in his war against the cities, he simply made him swear loyalty. ${ }^{2}$

The fact that in the early fifteenth century geographical origin in itself was not a sufficient reason to allow or prohibit military enlistment can be illustrated by a passage from the chronicle of Jean de Stavelot. According to this narrative the nobleman Jean de Beauraing wanted to organise a

Militzer, Ursachen und Folgen, pp. 174-177, 276-277.

40 RIplus Regg. Baden 1,1 nr 1760-1761, in Regesta Imperii Online; Wiegand et al., Urkundenbuch, vol. 5.2 , p. 693 .

41 RIplus Regg. Baden 1,1 nr 4301, in Regesta Imperii Online.

42 Regg. Pfalzgrafen 2 nr 3495, in Regesta Imperii Online. 
raid in 1425 , and asked the inhabitants of Lomprez - a fortress located in the Duchy of Luxemburg - whether anyone wished to accompany him. Three men agreed, but when they understood that they would be invading the Prince-Bishopric of Liège, two declined to go any further. One of them, named Gerart Belle-Jambe, explained that they had sworn fidelity to Everard de la Marck, lord of Lomprez and one of the most powerful noblemen in Liège, and afterwards went to warn the citizens of Dinant of the imminent enemy attack. ${ }^{43}$

\section{The development of foreign military service}

While these sources make clear that both rulers and city councils made efforts to control the movement of soldiers and used their power over specific spaces to this end, they provide no indication that they sought to prohibit 'foreign military service' as such. The focus lay on soldiers who joined an enemy force, disregarded their ties of loyalty, and compromised their community's neutrality. This point is also reflected in the memoirs of Olivier de la Marche. In his description of the Burgundian campaign against Luxemburg in 1443, he singles out one man in particular: a certain Jehan de la Plume who was a soldier in Metz and had a wife there, but left his home to join his sovereign lord by birth (souverain seigneur de nativité). De la Marche's description does not suggest that there was anything unusual or negative about De la Plume's moving from the Duchy of Burgundy to the city of Metz, but rather depicts him as an example of loyalty and bravery. ${ }^{44}$ The dukes of Burgundy in fact founded the Order of the Golden Fleece to attach higher-ranking nobles, who often had landed possessions in several principalities, closer to their ruler. The so-called bandes d'ordonnance, the first permanent military units in the Meuse and Rhine regions, might have served a similar function.

Soldiers' ties of allegiance to multiple potentates, their freedom of action to choose another employer, only became a major problem in the last decades of the fifteenth century, as a result of the large-scale recruitment of foot soldiers combined with the political turmoil following the death of Charles the Bold, and Louis IX's threat to the newly created Burgundian-Habsburg composite state. Emperor Maximilian was especially concerned about 
imperial subjects enlisting in the French army. ${ }^{45} \mathrm{~A}$ fiscal account from Hainaut, dating to 1489 , mentions the execution of a French soldier on the market square in Mons. The man in question was born in Hainaut, and had lived there for several years, but had 'denaturalised' himself ('en soy desnaturant') by becoming French nine or ten years earlier. He had also acted against the loyalty he owed to his sovereign, and betrayed his 'natural lord and prince' ('prince et seigneur naturel') by raiding the lands of Hainaut, committing arson, and guiding other soldiers to do the same. ${ }^{6}$

The use of the expression 'natural lord' or 'natural prince' means that someone was expected to privilege his relationship with a specific lord above all others. Its use was in itself not new, for it had already appeared in Froissart's chronicle and Christine de Pisan's book on chivalry. ${ }^{47}$ It adopted a new meaning in the political context of the late fifteenth and early sixteenth centuries, however, and paved the way for a new concept: that of foreign military service. By executing the aforementioned soldier from Hainaut, the Habsburgs made known that all people who were born or living in the principalities they controlled owned them loyalty regardless of whether they had sworn an actual oath in the context of a military contract, a feudal relationship, or membership in a shooting guild. This extension might have become necessary because of the increasing importance of paid infantrymen from the Empire (Landsknechten) in European warfare.

The expression 'fremde Kriegsdienste' first appears in an imperial decree dated 4 March 1521, during another war with France (an earlier decree, from 1512, already used the term 'fremde Dienste'). The prohibitions it contains would be repeated and further refined in subsequent years. ${ }^{48}$ By $155^{1}$ the concept of foreign military service had become firmly established in imperial edicts. It now included those who accepted military service outside the Empire and/or fought against the emperor. The imperial government considered unauthorised foreign military service as a breach of the pubic peace, and associated offenders with other 'criminal' migrants, namely discharged soldiers and vagabonds. ${ }^{49}$ The publication of these laws should also be seen in the context of significant social unrest and rebellions, notably the Bundshuh movement (1493-1517) and the German Peasants' War (15241526). Other princes within the Empire, the Swiss Confederacy, and imperial

46 Deloffre, 'Guerres et brigandages', p. 472.

47 Pizan, The Book of Deeds, pp. 150-151; Froissart, Oeuvres, vol. 13, p. 270.

48 Baumann, Das Söldnerwesen, pp. 73-84; May, Der Kurfürst, vol. 2, pp. 373-374; Solleder, 'Reichsverbote'.

49 Behr, 'Garden und Vergardung'. 
cities published their own proclamations, which could sometimes go against imperial interests. Martin Tann from Hörbach, for instance, was arrested in 1545 , because he had disregarded the landgrave of Hessen's prohibition regarding enlistment in the army of Henry VIII, who fought with Emperor Charles V against the king of France..$^{0}$

As argued before, the actual punishment of offenders differed according to their social status and the general political context: Count Emich (VIII) von Leiningen, who remained in French service despite an explicit imperial ban, saw all his belongings confiscated in 1512-1514, but managed to get most of them back after returning to imperial service. Sebastian Vogelsberger, on the other hand, a captain of non-noble origin who tried to recruit soldiers for French service in the Empire, was executed in $1548 . .^{11}$ The Urfehden made before officials of the duke of Wurttemberg in 1520-1550 indicate that soldiers convicted of joining a foreign army, the French in most cases, simply had to swear that they would never enlist in a foreign army again without prior consent. Some were also forbidden to carry arms without permission, or had to provide guarantors for their good behaviour. This might be related to the duke's anti-imperial stance at that time (he joined the Schmalkaldic League in 1536$) \cdot 5^{2}$

The high bailiffs of 's-Hertogenbosch by contrast executed offenders in 13 of 39 cases, but many of these soldiers were also charged with other crimes, such as deserting from the imperial forces and pillaging. It is noteworthy, nevertheless, that all executions date to the 1498-1550 period, meaning that punishments did become harsher over time. Enforcing restrictions on the movement of soldiers seems in fact to have been very difficult, despite the introduction of passports in the last decades of the fifteenth century. ${ }^{53}$ When the landgrave of Hessen granted pensions in 1536 and 1539 to two armed servants, a captain and a horseman respectively, to secure their services in event of a conflict, he specified that they could not take up service with another ruler without his permission. ${ }^{54}$

At first glance, the introduction of the concept of fremde Kriegsdienste had thus relatively little effect. The main emphasis still lay on the prosecution of those who had joined an enemy army or broke personal bonds of loyalty. In fact, military service across political boundaries became more common in

50 Regesten der Landgrafen von Hessen, $\mathrm{nr} 15255$.

$5^{1}$ Baumann, Das Söldnerwesen, pp. 82-83; Solleder, 'Reichsverbote', pp. 327-333.

$5^{2}$ Landesarchiv Baden-Württemberg, Hauptstaatsarchiv Stuttgart, A 44 Urfehden, nr 111, 137-140, 643, 947, 2456, 2581, 2585, 2839, 3181, 4687, 4727.

53 Groebner, Der Schein der Person, pp. 124-130.

54 Regesten der Landgrafen von Hessen, nr 15462, 15493. 
the Meuse and Rhine regions during the late sixteenth and early seventeenth centuries. The long-term effects of this new legal concept should not be underestimated, however. It meant that soldiers could now be prosecuted simply because they joined an armed force not in the service of the potentate who controlled the lands where they were born and/or had been living in. In this way, the laws introduced by the Habsburgs in the early sixteenth century provided a basis for all subsequent laws on foreign military service, and paved the way for nineteenth-century national armies.

\section{Conclusion}

Soldiers' autonomy in choosing their own paymaster became restricted long before the introduction of conscription and national armies. While fighting for several lords was still an integral part of a chivalric way of life in the fourteenth-century Meuse and Rhine regions, by the 1550 s it had turned into a criminal act. A soldier's connection to a specific space by birth or residence gradually became more important than other ties of loyalty, and could even be enforced violently. In this way, the establishment of a formal ban on foreign military service can be considered as a medieval territorial practice, in which both princes and cities played an important part.

The spread of a monetary economy during the High Middle Ages, which brought about a transition from feudal to contractual armies, gave combatants initially more independence towards their lords. In order to curtail perceived excesses resulting from this development, in terms of the supply of manpower and the maintenance of public order, both princes and cities experimented with new form of control. The existing law of arms, which stipulated that someone could not fight against a lord to whom he owned fealty, served as a legal basis. As a result of these new policies, the notion of having a 'natural lord' or 'natural prince' slowly evolved into a formal claim on someone's loyalty based on geographical origin rather than personal bonds.

The Habsburg government introduced 'foreign military service' as a legal concept in the early sixteenth century in order to control the movements of their subjects in the context of major political disorder (rebellions, peasant revolts) and ongoing conflicts with the French monarchy. The large-scale recruitment of paid infantry (Landsknechten) might have been a further stimulus, because it increased the number of itinerant soldiers, and mostly 
involved men of non-noble backgrounds who did not maintain feudal ties with their employers.

While the practical enforcement of new laws on foreign military service still left much to be desired, at least from the point of view of rulers and cities, their long-term consequences were still very significant. Governments, both princely and urban, expressed an intention to control the movement of soldiers by linking people to spaces, to the specific lands they controlled, as early as the fourteenth and fifteenth centuries. Even more remarkable is that these policies were not introduced in strong centralised governments but rather in the politically fragmented Meuse and Rhine regions. It draws attention to the importance of the periphery in the construction of territories.

\section{Bibliography}

\section{Primary sources}

De la Marche, Olivier, Mémoires d'Olivier de la Marche, maître d' hotel, capitaine des gardes de Charles le Téméraire, ed. by Henri Beaune and Jules d'Arbaumont, 4 vols (Paris: Librairie Renouard, 1883-1888).

De Saint Genois, Jules Baron, Inventaire analytique des chartes des comtes de Flandre, 3 vols (Ghent, 1843-1846).

De Stavelot, Jean, Chronique de Jean de Stavelot, ed. by Ad Borgnet (Brussels: M. Hayez, 1861).

Ennen, Leonard, and Gottfried Eckertz, eds, Quellen zur Geschichte der Stadt Köln, 6 vols (Cologne, 1860-1879).

Froissart, Jean, Oeuvres de Froissart. Chroniques, ed. by Kervyn de Lettenhove, 26 vols (Brussels, 1867-1877).

Le Bel, Jehan, Chronique de Jehan le Bel, ed. by J. Viard and E. Déprez, 2 vols (Paris: Société de l' histoire de France, 1904-1905).

Legnano, John of, Tractatus de bello de represaliis et de duello, ed. by Thomas Erskine Holland (Oxford: Oxford University Press, 1917).

Pizan, Christine de, The Book of Deeds of Arms and of Chivalry, trans. by Sumner Willard and ed. by Charity Cannon Willard (University Park: Pennsylvania State University Press, 2003).

Van Velthem, Lodewijk, Lodewijk Van Velthem's voortzetting van den Spiegel historiael (1248-1316), ed. by Herman vander Linden, Willem de Vreese, Paul de Keyser and Adolphe van Loey, 3 vols (Brussels: Académie Royale de Belgique; Commission Royale d' Histoire, 1906-1938). 
Wiegand, Wilhelm, et al., eds, Urkundenbuch der Stadt Strassburg, 7 vols (Strasbourg, 1879-1900).

\section{Secondary sources}

Aimond, Charles, Les relations de la France et du Verdunois de 1270 à $155^{2}$ (Paris, 1910). Andermann, Kurt, 'Götz von Berlichingen und Franz von Sickingen: ZeitgenossenAltersgenossen-Standesgenossen', Zeitschrift für die Geschichte des Oberrheins 165 (2017), 141-161.

Baker, Gary P., Craig L. Lambert and David Simpkin, eds, Military Communities in Late Medieval England: Essays in Honour of Andrew Ayton (Woodbridge: Boydell Press, 2018).

Baumann, Reinhard, Das Söldnerwesen im 16. Jahrhundert im bayerischen und süddeutschen Beispiel. Eine gesellschaftsgeschichtliche Untersuchung (München: Stadtarchiv München, 1978).

Behr, Hans-Joachim, 'Garden und Vergardung. Das Problem der herrenlosen Landsknechte im 16. Jahrhundert', Westfälische Zeitschrift 145 (1995), 41-72.

Burgers, Jan, and Mario Damen, 'Feudal Obligation or Paid Service? The Recruitment of Princely Armies in the Late Medieval Low Countries', The English Historical Review 133 , no. 563 (2018), 777-805.

Buschmann, Arno, 'Der Rheinische Bund von 1254-1257. Landfriede, Städte, Fürsten und Reichsverfassung im 13. Jahrhundert', in Kommunale Bündnisse Oberitaliens und Oberdeutschlands im Vergleich, ed. by Helmut Maurer (Sigmaringen: Thorbecke, 1987), pp. 167-212.

Caferro, William, 'Condottieri', in The Oxford Encyclopedia of Medieval Warfare and Military Technology, ed. by Clifford J. Rogers, 3 vols (New York: Oxford University Press, 2010), vol. 1, pp. 416-419.

Deloffre, Guy, 'Guerres et brigandages au XV' siècle en Hainaut, Pays d'Avesnes, Thiérache et Ardennes', Mémoires de la Société Archéologique et Historique de l'Arrondissement d'Avesnes (Nord) 29 (1985), 263-514.

Deprez, René, 'La politique castrale dans la principauté épiscopale de Liège du $\mathrm{X}^{\mathrm{e}}$ au XIV siècle.', Le Moyen Âge 65 (1959), 501-538.

DeVries, Kelly R., 'Medieval Mercenaries: Methodology, Definitions and Problems', in Mercenaries and Paid Men: The Mercenary Identity in the Middle Ages, ed. By John France (Leiden/Boston: Brill, 2008), pp. 43-6o.

Edelmayer, Friedrich, Söldner und Pensionäre. Das Netzwerk Philipps II. im Heiligen Römischen Reich (Wien: Verlag für Geschichte und Politik; München: Oldenbourg Verlag, 2002).

Elden, Stuart, 'How Should We Do the History of Territory?', Territory, Politics, Governance 1, no. 1 (2013), 5-20. 
Elden, Stuart, 'Land, Terrain, Territory', Progress in Human Geography 34, no. 6 (2010), 799-817.

Gaier, Claude, 'Analysis of the Military Forces in the Principality of Liège and the County of Looz from the Twelfth to the Fifteenth Century', Studies in Medieval and Renaissance History 2 (1965), 207-261.

Govaerts, Sander, “Mannen van Wapenen”: The Baesweiler Campaign and the Military Labour Market of the County of Loon in the Fourteenth Century', Viator Medieval and Renaissance Studies 47, no. (2016), 297-342.

Groebner, Valentin, Der Schein der Person. Steckbrief, Ausweis und Kontrolle im Mittelalter (München: C.H. Beck, 2004).

His, Rudolf, Das Strafrecht des deutschen Mittelalters, 2 vols (Leipzig, 1920-1935). Janse, Antheun, Grenzen aan de macht. De Friese oorlog van de graven van Holland omstreeks 1400 (The Hague: Hollandse Historische Reeks, 1993).

Jappe, Alberts Wybe, Overzicht van de geschiedenis van de Nederrijnse territoria tussen Maas en Rijn, ca. 80o-1500, 2 vols (Assen: Van Gorcum, 1979-1982).

Keen, Maurice, The Laws of War in the Late Middle Ages (London: Routledge \& Kegan Paul, 1965).

Leukel, Patrick, 'All welt wil auf sein wider Burgund'. Das Reichsheer im Neusser Krieg 1474/75 (Paderborn: Ferdinand Schöningh, 2019).

Lindgren, Uta, 'Kölner Fehden als Problem von Verwaltung und Verfassung', Jahrbuch des Kölnischen Geschichtvereins 54 (1983), 1-134.

Lower, Michael T.R., 'New Wars, Old Wars, and Medieval Wars: European Mercenaries as State Actors in Europe and North Africa, ca. 1100-1500', Mediterranean Studies 25 (2017), 33-52.

Luce, Siméon, Jeanne d'Arc à Domrémy: recherches critiques sur les origines de la mission de la Pucelle, accompagnées de pieces justificatives (Paris, 1886).

Lyon, Bryce D., 'The Fief-Rente in the Low Countries: An Evaluation', Revue belge de philologie et d'histoire 32, nos 2-3 (1954), 422-465.

Marchal, Guy Paul, 'Pfahlburger, bourgeois forains, buitenpoorters, burgeois du roi: Aspekte einer zweideutigen Rechtsstellung', in Neubürger im späten Mittelalter. Migration und Austausch in der Städtelandschaft des Alten Reiches (1250-1550), ed. by Roland Gerber, Barbara Studer and Rainer Christoph Schwinges (Berlin: Duncker \& Humblot, 2002), pp. 333-367.

May, Jakob, Der Kurfürst, Cardinal und Erzbischof Albrecht IIvon Mainz und Magdeburg, Administrator des Bisthums Halberstadt, Markgrafvon Brandenburg und seine Zeit, 2 vols (München, 1865).

Mellard, Sébastien, 'Les mercenaires au service de la cité de Metz au XIV e siècle (Edition du MS 930 de la bibliothèque municipale de Metz et commentaire)', MA thesis, Université de Metz-Paul Verlaine, 2008. 
Militzer, Klaus, Ursachen und Folgen der innerstädtischen Auseinandersetzungen in Köln in der zweiten Hälfte des 14. Jahrhunderts (Cologne: H. Wamper, 1980).

Nicholson, Helen, 'International Mobility versus the Needs of the Realm: The Templars and Hospitallers in the British Isles in the Thirteenth and Fourteenth Centuries', in International Mobility in the Military Orders (Twelfth to Fifteenth Centuries): Travelling on Christ's Business, ed. by Jochen Burgtorf and Helen Nicholson (Cardiff: University of Wales Press, 2006), pp. 87-101.

Paravicini, Werner, 'Ritterliches Rheinland', in Noblesse: Studien zum adeligen Leben im spätmittelalterlichen Europa (Ostfildern: Thorbecke, 2012), pp. 217-250.

Paravicini, Werner, 'Von der Heidenfahrt zur Kavalierstour. Über Motive und Formen adligen Reisens im späten Mittelalter', in Noblesse: Studien zum adeligen Leben im spätmittelalterlichen Europa (Ostfildern: Thorbecke, 2012), pp. 131-170.

Pépin, Guilhem, Françoise Lainé and Frédéric Boutoulle, eds, Routiers et mercenaires pendant la guerre de Cent Ans. Hommage à Jonathan Sumption (Pessac: Ausonius, 2016).

Reintges, Theo, Ursprung und Wesen der spätmittelalterlichen Schützengilden (Bonn: Ludwig Röhrscheid Verlag, 1963).

Rotthoff-Kraus, Claudia, Die politische Rolle der Landfriedenseinungen zwischen Maas und Rhein in der zweiten Hälfte des 14. Jahrhunderts (Aachen: Verlag des Aachener Geschichtvereins, 1990).

Solleder, Fridolin, 'Reichsverbote fremden Kriegsdienstes, fremder Werbung und Rüstung unter Maximilian I', Zeitschrift für Bayerische Landesgeschichte 18 (1955), 315-351.

Tuetey A., Les écorcheurs sous Charles VII. Episodes de l'histoire militaire de la France au $X V^{e}$ siècle (Montbéliard, 1874).

Van Anrooij, Wim, Spiegel van ridderschap. Heraut Gelre en zijn ereredes (Amsterdam: Prometheus, 1990).

Wübbeke, Brigitte Maria, Das Militärwesen der Stadt Köln im 15. Jahrhundert (Stuttgart: Franz Steiner Verlag, 1991).

\section{Digital sources}

Die Regesten der Mainzer Erzbischöfe (http://www.ingrossaturbuecher.de).

Landesarchiv Baden-Württemberg, Hauptstaatsarchiv Stuttgart (https://www2. landesarchiv-bw.de).

Regesta Imperii Online (www.regesta-imperii.de).

Regesten der Landgrafen von Hessen (https://www.lagis-hessen.de). 


\section{About the author}

Sander Govaerts is a Postdoctoral Researcher at Utrecht University. He specialises in the military and environmental history of pre-modern Europe. 


\title{
7. Conquest, Cartography and the Development of Linear Frontiers during Henry VIII's Invasion of France in $1544-1546$
}

\author{
Neil Murphy
}

\begin{abstract}
When Henry VIII captured Boulogne in 1544, he did not seek to rule the Boulonnais territory as the rightful king of France but instead annexed these lands to the English crown. His move to justify his actions by right of conquest rather than through dynastic succession led to the development of precisely mapped linear borders. The geometric maps of the Boulonnais produced in the mid-1540s visually represented the ideology of the right of conquest. Henry's efforts to obtain a geometrically measured border of his lands in the Boulonnais facilitated the development of linear boundaries by moving away from the less precise 'feudal' definitions of sovereignty, whereby different rulers could have settlements in the same territory, towards one based around precisely mapped linear borders.
\end{abstract}

Keywords: Henry VIII, cartography, England, France, warfare

In the summer of 1544 , Henry VIII invaded France with 36,00o soldiers, then the largest army ever sent overseas by an English ruler. ${ }^{1}$ The Tudor monarch's campaign led to the greatest expansion of English territory on the continent since the Hundred Years' War. As well as capturing the important Channel port of Boulogne, Henry VIII brought tens of thousands of acres of prime agricultural land in the surrounding region (the Boulonnais) under his rule. These lands, formerly ruled by the counts of Boulogne, were attached to Picardy in 1477 when Bertrand de la Tour d'Auvergne, the last count of Boulogne, handed them to Louis XI in exchange for Lauragais in

1 This would remain the case until the reign of William of Orange in the late seventeenth century: Childs, William III, pp. 102-103; Davies, 'English People and War', p. 2; Potter, Final Conflict, p. 312 . 
southern France. ${ }^{2}$ While the Boulonnais was incorporated into the French royal domain in 1477 , it retained enclaves of imperial rule. Henry VIII's conquest of the Boulonnais led to the removal of this medieval landholding pattern, with the Tudor monarch annexing all the terrain he conquered to the English crown, including imperial possessions (despite the fact that he had allied himself with Charles V against Francis I). Henry VIII moved away from feudal methods of sovereignty, whereby different rulers could have settlements in the same territory, to develop a territorial realm with precisely mapped linear borders. According to Jordan Branch, before the seventeenth century 'there was no discussion of delineating territorial claims or exchanges by the use of linear boundaries, mapped features, or "natural frontier" divisions', while James Akerman writes of 'the continuing strength of feudal, and hence non-territorial, claims to authority' in the sixteenth century. ${ }^{3}$ Yet an examination of Henry VIII's actions in the Boulonnais shows that the disregarding of traditional jurisdictions, which has been taken as a mark of the eighteenth century, was already coming into existence in the sixteenth. While other European rulers were employing the latest cartographical techniques to map their dominions during the sixteenth century, the pressures Henry VIII faced from the late 1530 s gave a particular impetus to this project in England and produced a remarkable series of maps depicting the frontiers of the kingdom.

The Tudor monarch based his claim to Boulogne and the Boulonnais squarely on the right of conquest rather than on his claim to the French crown, which he had used to justify his previous invasions of France (1512, 1513 , 1522-1523). By setting aside a claim founded on a right to rule the French people and asserting instead one that was focused on land won by force, Henry could remove any obligations he had to the native population and distribute their lands as he saw fit. The conquered lands, which had been almost entirely depopulated during the war of 1544-1546, were surveyed and leased out to English settlers. Advances in cartography underpinned this process of territorialisation, with Henry VIII harnessing technological developments in mapping to expand his realm. While Henry VIII made use of maps for the 1512 Gascon campaign, his earliest military expedition, it was the wars of his final years - and particularly the conquest and colonisation of Boulogne - which really drove forward developments in cartography as a tool of English expansion. Maps were used extensively during both the military conquest of Boulogne and the peace negotiations which led to the 
Treaty of Camp (which brought an end to the Anglo-French war in June 1546) and the subsequent delimitation of the Boulonnais.

Henry's map-makers drew on recent developments in cartography to give a precise definition to the lands their master had conquered. In particular, English military engineers employed the latest geometric methods in mapmaking to survey the region and provide a linear border with France. This link between violence and territorialisation was highlighted by Henri Lefebvre, who saw sovereignty as 'a space established and constituted by violence'. ${ }^{4}$ Cartography played a central role for Henry VIII in the Boulonnais in two key ways. First, the maps the Tudor monarch's military engineers produced underpinned his conquest of the land. Second, these maps were used to shape the conquered terrain into a new English territory in France. As Stuart Elden observes, 'territory is more than merely land, and goes beyond terrain, but is a rendering of the emergent concept of "space" as a political category: owned, distributed, mapped, calculated, bordered and controlled'. 5 We see all these processes at work when we examine Henry VIII's use of maps in France in the 1540 s.

This chapter begins with an examination of the role that maps played in Henry's conquest of Boulogne in 1544, considering in particular the interplay between violence and cartography. The second part of the chapter moves on to consider how maps underpinned both the negotiations which led to the development of peace in 1546 and the creation of a new English territory in the Boulonnais. I utilise the maps and plans produced by Henry VIII's military engineers as well as the written records (including letters, surveys and texts of treaties) attached to them. Maps were typically accompanied with a written commentary or annotated with comments explaining what the maps showed and how they were to be used. This combination of image and text was itself representative of developments in mapping, because as Kimmi Katajala observes in her study of early modern mapping 'the relationship between the described object and the sign in the map changed significantly during the sixteenth century'. ${ }^{6}$ Medieval maps often had no explanation of the content because symbols for towns or mountains were taken to be self-evident, whereas the introduction of features such as scale required additional description. A new language to describe bounded political spaces was emerging from the Late Middle Ages, with the words employed - such as 'frontier' - often having strong military connotations. 
When mapping the Boulonnais, the English favoured the word 'limits' when describing their new border with France. While Daniel Power notes that the term limites became 'the preferred Enlightenment term for political borders precisely because it was less militaristic than frontière' - in early modern England the term was used to describe a defined boundary which was often militarised and designed to guard the peripheries of the kingdom against invasion. ${ }^{7}$ This is precisely what Henry VIII sought to do with his geometrically mapped borders of the lands he had conquered in the Boulonnais, which were delimited by a ring of the most advanced fortifications in the realm - a process which corresponds to Lefebvre's ideas about 'dominated space'. ${ }^{8}$

\section{Cartography and conquest}

The rediscovery of ancient texts in early Renaissance Europe highlighted the long tradition of rulers using maps for military purposes, with the first print publication of Ptolemy's Geographica (1475) especially encouraging advances in cartography - developments which soon became tied to concerns about the security of the kingdom. ${ }^{9}$ Certainly, the outbreak of war with France in 1543 led to considerable advances in the use of English cartography, particularly because Henry VIII used maps to monitor the actions of English soldiers fighting in France. After beginning to destroy the Boulonnais in 1543, Sir John Wallop and his troops joined Charles V's soldiers at the siege of Landrecies. Wallop sent Henry maps showing the progress of the siege, which the English monarch returned with comments regarding the strategy they should employ to take the town. ${ }^{10}$ Yet it was the Tudor monarch's sieges of Boulogne and Montreuil in the summer of 1544 which really placed maps at the centre of the offensive operations of the English army. ${ }^{11}$ While Henry returned to England shortly after the capture of Boulogne in September 1544, the military engineers Sir Richard Lee and John Rogers produced a series

7 Power, 'Frontiers', pp. 6-7. See also: Febvre, Histoire à part entiére, pp. 208-211; Sahlins, 'Natural Frontiers Revisited'; Abulafia, 'Introduction'.

8 Lefebvre, Production of Space, p. 164.

9 Dalché, 'The Reception of Ptolemy's Geography'; Mundy, Mapping of New Spain, pp. 3-8.

10 State Papers [hereafter StP], vol. 11, p. 527. For these maps, see BL Cotton MS Augustus I.i, nos $49,5^{\circ}$.

11 Vasari, Lives of the Painters, vol. 2, p. 348; Pouncey, 'Girolamo da Treviso'; Harvey, Maps in Tudor England, pp. 27-28. 
of maps and plans which allowed Henry VIII to monitor developments in the Boulonnais, especially the fortification of the region.

The production of maps and plans was an important means for early modern rulers to extend the gaze of the state. Cartography was coming to play a key role in the expansion of state power during the sixteenth century. Sixteenth-century works on statecraft such as those by Castiglione and Machiavelli discussed the value of maps for rulers, as did the English writer Thomas Elyot in his Boke Named the Governour (1531). ${ }^{12}$ Rulers across Europe in first half of the sixteenth century - from Portugal to Norway - started to employ maps for military and administrative purposes. ${ }^{13}$ Maps were of particular help in aiding rulers to be absent and understand the development of their borders. As Geoffrey Parker has observed, Louis XIV's maps and models of Vauban's frontier fortifications meant that 'the king could visualise the defences of his kingdom without leaving his palace.. ${ }^{14}$ Over a century earlier, the English military engineers Richard Lee and John Rogers produced a series of maps and models showing Henry VIII the fortifications they were constructing to secure his frontiers in France. The production of these maps allowed Henry to take a guiding hand in the design and development of the fortifications. ${ }^{15}$ In November 1544, John Rogers and Sir Thomas Palmer brought plats of the fortifications at Boulogne to the English monarch, which were then taken back across the Channel with Henry's comments appended to them. ${ }^{16}$ As well as overhauling Boulogne's defences, Rogers prepared new fortifications throughout the Boulonnais to secure the region and make it ready for development. In April 1546, Rogers made a geometric plan of the fortified harbour he planned to build at Ambleteuse (which the English renamed New Haven) ${ }^{17}$ Henry VIII returned Rogers's

12 Sanford, Maps and Memory, p. 18; Barber, 'Maps at Court', p. 30.

13 Katajala, 'Maps, Borders and State-building', p. 73.

14 Parker, Global Crisis, p. 627.

15 For the plan of the fortifications Sir Anthony Knyvet was to bring to Henry VIII, see TNA SP 1/193, fol. $78 \mathrm{v}$ (Letters and Papers [hereafter $L P$ ], vol. 19, pt 2, no. 385). For Henry's opinions on the design of these fortifications, see TNA SP 1/193, fols $28 \mathrm{r}-3$ or, 32r-32v, 69v-7or ( LP, vol. 19, pt 2, nos 352, 353, 383). For Lee and Rogers's plans of the fortifications at Boulogne during this period, see also TNA SP $1 / 216$, fols $137 \mathrm{v}-138 \mathrm{r}, 139 \mathrm{r}(L P$, vol. 21 , pt 1, nos 565,566$)$.

$16 L P$, vol. 19, pt 2, no. 591; TNA SP 1/195, fol. 61r ( $L P$, vol. 19, pt 2, no. 592). Lee and Rogers also made plans of the fortifications at Boulogne in April 1546: TNA SP 2/216, fol. 137v, SP 1/217, fol. $114 \mathrm{r}(L P$, vol. 21, pt 1, 565, 686). For Henry's comments on the maps and plans for the fortifications at Boulogne, see also: TNA SP 1/215, fols 35v, $87 \mathrm{r}$ ( $L P$, vol. 21, pt 1, nos 356, 394).

17 For Rogers and the construction of the fortifications at New Haven/Ambleteuse, see Shelby, John Rogers, pp. 76-82. 
plans the following month with his comments attached. ${ }^{18}$ The English wanted to develop fortified harbours in the Boulonnais to safeguard the coast and bring soldiers and supplies into the region. In 1546, both John Rogers and Edward Seymour championed the construction of a fortified harbour at Cap Gris-Nez (which the English called Blackness), sending Henry geometric plans of the intended fortifications. ${ }^{19}$

As well as using maps to monitor the development of fortifications in the Boulonnais, Henry VIII had his officials prepare maps showing the strongholds the French were constructing on the edges of his conquest. John Rogers made detailed plans showing the development of the French fort at Outreau in $1545-1546 .{ }^{20}$ This fort was of particular concern to Henry because it threatened his control of Boulogne's harbour. As well as showing the positions of French king's forts and soldiers, the maps also depicted features in the landscape which held military significance. A map made in the 1540 s, showing the fortifications and heights of buildings and bulwarks in towns and villages surrounding the Calais Pale, also depicted features such as churches and woods. ${ }^{21}$ It was important to know the location of woods because Henry VIII's soldiers systematically cleared them of their inhabitants during the conquest of the Boulonnais, while churches could be fortified and thus had to be either garrisoned or destroyed. Moreover, as armies during this period used features in the landscape - both natural, such as hills and woods, and man-made, such as church steeples - for the purpose of navigation, it was important that distances were represented accurately on maps of conflict zones.

These maps also reveal the impact which the English military strategy had on the Boulonnais. John Rogers's 1546 map of the English lands in France shows the high level of devastation the war had caused to the region. In contrast to the houses of the English villages of the Calais Pale, which are shown as intact and thus inhabited, those in the Boulonnais are without roofs, highlighting the fact that they were destroyed in the war. The maps John Rogers produced of the development New Haven highlight the imposition of English rule over the region. In the first plan (made in April 1546), Rogers shows the church and the 32 houses which comprised the village of Ambleteuse. By the time of the fourth plan, the church and existing village

18 The National Archives, Kew, London, State Papers [hereafter TNA SP] 1/217, fol. 114r ( $L P$, vol. 21, pt 1, no. 686).

19 TNA SP 1/221, fol. 42r ( $L P$, vol. 21, pt 1, no. 1159).

20 TNA SP 1/203, fol. 206r ( $L P$, vol. 20, pt 1, no. 1192); TNA SP 1/213, fol. 24 r ( $L P$, vol. 21 , pt 1, no. 18);

$L P$, vol. 21, pt 1, no. 19; BL Augustus I.ii, nos 53, 77; Barber, 'Maps at Court', 37.

21 West Sussex Record Office PHA/3878. 
had been obliterated and a large pentagonal fortified town introduced in its place. The plans show that the settlement was comprised of a series of bastions and towers, with defensive concerns being paramount. Inside this space there were houses, a square and geometrically designed streets based around the river and the harbour. Rogers's drawings also highlight other advantages beyond trade in settling areas which lay on the coast or along rivers. In particular, Rogers marked the high tide of the river Liane on his maps. This was important because Henry demanded control over the land covered by the high tide on the French side of the river Liane, which included valuable pastures. The English used maps to construct a territory which encompassed the bulk of the fertile lowlands of the Basse-Boulonnais in contrast to the less fertile uplands of the Haut-Boulonnais which remained under French control. While the French wanted the river Liane to be held in common, the English insisted on having exclusive control of the river. ${ }^{22}$ Both the French and the English were seeking to have control of the river and mills it powered, as well as giving control of the harbour. ${ }^{23}$ By depicting features such as harbours, rivers, woods and meadows, Rogers's maps also highlighted the economic value of the land the English monarch had conquered, with Henry's principal military and diplomatic representatives in France using these documents to highlight the fertility of the lands they had brought under his rule. ${ }^{24}$ The maps also reflect the wider socio-economic developments occurring in sixteenth-century England, which Henry hoped to harness to achieve his political aims. In particular, the development of agrarian capitalism was fundamental to English actions in the Boulonnais because Henry VIII sought to achieve his territorial ambitions in France by conquering lands and then depopulating them so that they could be resettled by English commercial farmers who sold their goods to the colonists. To this end, the Boulonnais was divided into two new counties (the county of Boulogne and the county of New Haven), each of which was based around a central town which was to provide a market for the settler. As Henri Lefebvre noted, this combination of violence to control a space and the exploitation of economic resources of that space was fundamental to the development of the territorial state. ${ }^{25}$

22 StP, vol. 11, pp. 167-168, 171, 177.

23 StP, vol. 11, p. 170; TNA SP 1/223, fols 89 r-89v ( $L P$, vol. 21, pt 1, no. 1444).

24 StP, vol. 11, p. 168; TNA SP 1/220, fol. 92 (LP, vol. 21, pt 1, no. 1055); BL Cotton MS Augustus I.ii., no. 82 .

25 Lefebvre, Production of Space, pp. 117-118. 


\section{Maps, treaties and peacemaking}

Maps played a central role in the peace talks regarding the Boulonnais, with Henry VIII using these documents to remain at the centre of the discussions. Maps were more effective than written descriptions in showing the English monarch the proposed limits of his new lands. In May 1546, Henry's representatives at the negotiations informed their master that they had the terms of the treaty (the 'capitulations') 'framed as a platt [i.e. a plan or map] for your better instruction', so that he could see the proposed territorial settlement and highlight any changes he wished to make. ${ }^{26}$ While the use of cartography was undoubtedly a product of developments in technology, it also required an impetus from kings who recognised the value of cartography to the construction of territorial realms. Certainly, Henry VIII was a leading advocate of the emerging belief that maps possessed a scientific authority. The prominent use of maps in the peace negotiations of $1545-1546$ reflected a conviction on both sides of the negotiating table that they were objective documents which gave an accurate view of the terrain. ${ }^{27}$ There was a wider emergence in Europe of a belief in scientific rationalism and that the world could be mapped accurately by means of geometric approaches to mapmaking - a view which drew on resurgent ideas about maps put forward by people such as Euclid. The addition of scale to English maps in the late 1530 s encouraged trust in the scientific accuracy of maps. The first scale maps in England were made by the Italian engineers Henry VIII employed to fortify key ports in the late 1530 s against a feared French invasion, while the military engineers Richard Lee, John Rogers and Thomas Petit produced scale maps of English holdings in France. ${ }^{28}$ The production of scale maps in the 1540 s was underpinned by advances in surveying methods and technology, with the greater degree of mathematical precision provided by the introduction

26 StP, vol. 11, pp. 171-172. See also TNA SP 1/218, fol. 102r ( $L P$, vol. 21, pt 1, no. 818); StP, vol. 11. 141. Maps were used during the peace negotiations from 1545: StP, vol. 10, p. 80o. The French also produced maps during the treaty negotiations, with Sir William Paget remarking to Sir William Petre that 'Montluc brought a plat with hym of Bullonoys, the fayrest that ever I saw, one of them, and best sett fruth': StP, vol. 11, p. 167. For French mapping, see Dauphant, 'Entre la liste et le terrain'; Dauphant, Royaume des quatres rivières, pp. 176-179; Pelletier, 'Representations of Territory'; Buisseret, 'French Cartography'.

27 Biggs, 'State on the Map', p. 379; Branch, Cartographic State, pp. 6, 51-52; Harley, 'Tudor Cartography', pp. 27-28.

28 See also the map of Guînes made in 1541 to the scale of one 1:50: BL Cotton Augustus I Supplement 2. Rogers was then mason at Guînes castle: Shelby, John Rogers, p. 5. For these developments, see Merriman, 'Italian Military Engineers', pp. 58, 6o; Barber, 'Maps at Court', pp. 32, 35, 38; Harvey, Maps in Tudor England, pp. 31, 36. 
of scale increasing confidence in the accuracy of maps. ${ }^{29}$ While Henry VIII returned to England soon after the fall of Boulogne, Rogers's scale maps helped to compensate for his absence from the Boulonnais by providing him with detailed information about his new lands. The increased accuracy of Rogers's maps allowed the French landscape to be represented with a precision absent from the maps produced before the 1540 s.

Geometric maps were believed to reveal aspects of the landscape which would otherwise remain hidden or be difficult to perceive through words alone. Certainly, the maps Rogers made of the Boulonnais during the peace negotiations of 1546 revealed problems that were not immediately apparent in the text of the peace treaty which brought an end to the war. As soon as the English and French commissioners agreed that the river Liane was to form the western boundary of Henry's lands in the Boulonnais, John Rogers prepared a map of the region showing the proposed settlement, which he brought to the Tudor monarch. In the text of the treaty, the Liane seemed to offer a clear and definite border between English and French lands. ${ }^{30}$ Yet Rogers's map revealed problems to the English monarch which were not evident on the ground. In particular, Henry - fearing the French would alter the river as means to cripple Boulogne - observed that it was essential for his lands to cover both banks of the river Liane so that the French 'neither doo ne attempte any thing in the sayd ryver, wherby the same may be turned any other waye from thaccustumed way by which it nowe renneth into the haven'. ${ }^{3}$ Moreover, custom dictated that when a river used to divide lands under different jurisdictions altered its course then the border itself changed. Accordingly, a ruler stood to gain territory by reorientating the course of a river. It was for this reason that Hugo Grotius (who while writing 70 years after the Treaty of Camp reflected the same concerns Henry VIII had about the river Liane in the 1540s) stated that a ruler could hold sovereignty over a river provided that he held land on both banks. ${ }^{32}$ In 1546, Henry insisted on having lands on the left bank of the river Liane (i.e. on the French side) so that he could maintain control over the border with France and ensure its stability. 33

John Rogers prepared a map representing the English king's territorial demands on which a dotted red line indicates the river Liane's high-water

31 Ibid., p. 174. See also ibid., p. 177; Rymer, Foedera, vol. 15, pp. 96-97; LP, vol. 21, pt 1, no. 1014; TNA SP $68 / 15$, fol. 62r.

32 Grotius, Law of War and Peace, pp. 108, 112-114. 
mark. If contemporaneous with the production of the map, this can be considered as one of the earliest examples of the cartographic representation of a national boundary with a dotted line. ${ }^{34}$ In his study of the maps of the Bourbon monarchs, David Buisseret noted that the moment when boundaries began to be depicted on maps through dotted lines 'is of some importance, for it bears on the passage from frontier-regions to linear boundaries, and the ability to fix a boundary on a map [...] marks a certain stage in the administrative sophistication of a state. ${ }^{35}$ Such a strict definition of territory was not typical of England's other land borders during this period. The ill-defined nature of the Calais Pale created persistent disputes with the French which had continued right through to the 1540 s. $^{36}$ Indeed, the precise delimitation of the boundaries of the Boulonnais may have been influenced by a desire to avoid the difficulties that arose from having such a fluid land border with France along the Calais Pale. Furthermore, it became customary to use a dotted line to represent national boundaries in north-eastern France in the second half of the sixteenth century. In Gerardus Mercator's map of Europe published at Duisburg in 1564, there is a dotted line dividing Artois and Picardy. This is the only use of a dotted line on the map and it is widely seen as the earliest use of a dotted line to depict a national boundary on a map. Likewise, in Abraham Ortelius's Theatrum Orbis Terrarum (1570) the only place which has a fixed border marked with a dashed line is the area around Calais. ${ }^{37}$ Whereas maps had tended to use natural features in the landscape such as mountains or rivers to highlight boundaries, from the middle of the sixteenth century abstract dotted lines came to represent the limits of territorial states. ${ }^{38}$ Rather than just give the river Liane as the border between England and France, Henry's engineers used the latest surveying techniques to produce a map with a dotted line to give a precise representation of the new border. When Henry's engineers delimited the eastern frontier of these new lands - where there was no river of other obvious natural frontier - an abstract line was also drawn across the lands overriding existing jurisdictions.

Henry VIII used maps to resolve other problems arising from the imprecise description of the river Liane given in the text of the Treaty of Camp, so that he could have a clearly defined border with France. He appointed a

36 Grummitt, Calais Garrison, pp. 5, 6o; Grummitt, 'Early Tudor Policy', pp. 184-185; Dillon, 'Calais and the Pale'.

37 Biggs, 'State on the Map', p. 393; Buisseret, 'Cartographic Definition', p. 72.

38 Katajala, 'Maps, Borders and State-building', p. 74. 
commission to produce a map of the river Liane, instructing Richard Lee (who led the party) that 'of thintent of making of this plat, you shall not nede to give any notice to thother side' 39 The English monarch probably wanted to ascertain which of the six branches of the river Liane should be taken as its head - and thus the boundary of his territory - before meeting the French. This was an important consideration because Henry stood to gain or lose territory depending on which branch of the Liane was taken as its source. The heated discussions which occurred between the English and French commissioners regarding the head of the river Liane reminds us that despite claims about the apparent scientific objectivity of maps, they were political documents which reflected the concerns and ambitions of those who produced them. Both sides used maps to substantiate their claims about which branch of the river they believed to be the longest. The English surveyors searched for the branch 'which is moost for His Majesties advauntage' and produced a map as evidence of their claim, which the French disputed and produced maps of their own to argue to the contrary..$^{40}$ The key issue behind the denials and shifting of positions was the allocation of territory. In particular, the French were then seeking to prevent the village of Brunembert coming under Henry's control. ${ }^{41}$

In addition to the commission appointed to settle the limits of the Liane, a further Anglo-French delegation was appointed to agree on the border running from the head of the river Liane to Guines. ${ }^{42}$ As with the frontier along the Liane, this was to be a linear border with no enclaves of French rule or disputed territories. Henry used maps to show where he wanted his eastern frontier with France to be located. ${ }^{43}$ If the French were not willing to hand over the villages held within this line, the English monarch was prepared to use violence to achieve his aims. ${ }^{44}$ Henry wanted to create coherent linear borders with no pockets of French control and he used maps to help achieve this aim. After studying one of these maps, Henry declared that 'where they clayme three villages lying between the hed of the sayd ryver and Guisnez, for that, as they saye, they have as yet the possession of the same, ye shal declare unto them, that their possession (if any such be) hath been and is but precaria possession [i.e. that they were occupying

StP, vol. 11, pp. 15-16.

40 Ibid., p. 182; TNA SP 1/223, fols 43 r-43v ( $L P$, vol. 21, pt 1, no. 1427); TNA SP 1/225, fol. 94r ( $L P$, vol. 21, pt 2, no. 189).

41 StP, vol. 11, p. 285.

$42 L P$, vol. 21, pt 1, no. 1427.

43 StP, vol. 11, p. 141.

44 Ibid., p. 191. 
these places without permission of their owner, Henry VIII]' ${ }^{45}$ It was not simply that Henry wanted to accumulate as many possessions as possible; he wanted to ensure that his lands were defined with coherent borders. As well as noting - through the study of maps - that the French held a number of villages which formed an enclave into his lands between the river Liane and Guînes, Henry also observed that his soldiers 'had possession of somme of their [French] townes asfarre as Tyrwan [Thérouanne], be nevertheles pleased nowe to departe with the same agayn, they cannot by any reason styk with Us at so smal tryfle as thies three villages, thatteigneng wherof may be to our pale an occasion of somme unquietnes, and to them no commodtie'..$^{46}$ The French villages which Henry held towards Thérouanne were of little economic or strategic worth and they would be difficult to hold, particularly because they projected out from his main body of lands. Overall, Henry wanted to move away from a situation whereby different villages in the same region owed loyalty to various rulers (a state of affairs which existed in the Boulonnais prior to his invasion of 1544). Instead, Henry delimited the terrain by a line drawn on a map and claimed sovereignty over all the land that lay behind it, creating a new English territory in France.

The maps which Henry VIII's military engineers produced of the Boulonnais in the mid-1540s visually represented the ideology of the right of conquest, with the mapping of the Boulonnais playing a complementary role to the actions of Henry's soldiers in bringing this region under English rule. These maps were first and foremost documents produced for military purposes. Indeed, the emergence of geography as a science in early modern Europe was closely linked to war (and it continues to be closely connected to war - in the words of Yves Lacoste: 'la géographie ça sert d'abord à faire la guerre') ${ }^{47}$ Certainly the development of geometrical mapping during the sixteenth century considerably aided the English military strategy in the Boulonnais. This was the first major English conflict where maps played a central role in both the progress of the war and the making of the peace (with the war producing developments in geometric mapping). It should come as no surprise that a conflict on this scale - and in which military engineers played a prominent role - drove forward cartographic techniques. While the development of linear frontiers is typically seen as a product of the later seventeenth century, Henry VIII sought to achieve this in the 
Boulonnais. Previous efforts to define the boundaries of the English Pale in France had typically been rudimentary. During an attempt to trace the boundaries of the Calais Pale in December 1541, it was noted how in the early 145 os Sir Thomas Fynderne, Lieutenant of Guînes, had 'caused a post to be set up hangning from the same by a Cheyne [i.e. chain] a sword. Where upon these words were graven, no man be so hardy to take me awaye, for this ys the right pale between Ingland and Fraunce. ${ }^{48}$ Henry VIII's efforts in the 1540 s to move away from such rough-and-ready methods of defining frontiers to obtain a geometrically measured border of his lands in the Boulonnais facilitated the development of linear borders by moving away from the less precise definitions of jurisdiction which had existed on the edges of the kingdom.

Maps also played a key role in creating territorial realms in the sixteenth century particular in the form of constructions of national ethnic identity. 49 As Megan Cassidy-Welch argues, 'collective national identities are forged at least in part through the appropriation of physical space, while the acts of historicising that appropriation (through writing, marking the landscape, claiming commonality) themselves spatialise (proto)nationalistic indicators of belonging and possession'. $5^{\circ}$ Certainly, Henry VIII's maps represent the development of a territorial realm in which the ruler gave increasing attention to the peripheries of the realm by developing linear frontiers defended by a ring of fortifications. The construction of linear borders was important because while England was an island state it had land borders with France, Scotland and Gaelic Ireland, all of which came to be increasingly defined by cartography in the second half of the sixteenth century.

In sum, Henry VIII's conquest of the Boulonnais led to a redrawing of the border with France, behind which the English monarch was the sole political and religious authority. Henry was constructing an imperial form of monarchy whereby his political authority as king of England was to be imposed without limitation throughout all his lands. Historians have located the territorial consequences of Henry VIII's vision of an integrated imperial monarchy and royal ecclesiastical supremacy in terms of England's relationship with its neighbours in Britain and Ireland. Graham Nicholson has argued that the right of conquest which Henry VIII established over Ireland, Scotland and Wales merged with declarations about England's historic independence from papal authority in the $1530 \mathrm{~s}$ 
to form the basis of the claim that Rex est imperator in regno suo, which in turn reignited the English monarchy's imperial ambitions to conquer land from its island neighbours. ${ }^{51}$ Yet this also manifested itself in the nature of Henry VIII's rule in France. There were to be no overlapping jurisdictions in the English lands in France and he was to rule a precisely defined territory. All those who lived within these borders were to acknowledge Henry's authority - and his authority alone. Maps of English settlements and fortifications - like the towns, villages and forts themselves - created these territories and confirmed the imposition of the English monarchy's authority over them. In this way, Henry VIII's actions in the Boulonnais are a clear illustration of the increasingly important role which cartography came to play in the development of monarchical power in early modern Europe..$^{2}$

\section{Bibliography}

\section{Archives}

British Library, London

Cotton MS Augustus I.i

Cotton MS Augustus I.ii

Cotton MS Augustus I Supplement 2

The National Archives, Kew, UK

SP $1 / 168,189,190,193,195,197,203,213,215,216,217,218,220,221,223,225 ; 68 / 15$

West Sussex Record Office

$\mathrm{PHA} / 3878$

\section{Printed sources}

Abulafia, D., 'Seven Types of Ambiguity, c. 1100-c. 1500', in Medieval Frontiers: Concepts and Practices, ed. by David Abulafia and Nora Berend (Aldershot: Ashgate, 2002), pp. 1-34.

Akerman, James R., 'The Structuring of Political Territory in Early Printed Atlases', Imago Mundi 47, no. 1 (1995), 138-154.

51 Nicholson, 'Act of Appeals', p. 24. For the ideology of Henry VIII's imperial monarchy, see also Robertson, 'Empire and Union'.

$5^{2}$ On this point, see Day, Conquest, p. 31 . 
Barber, P., 'England I: Pageantry, Defense and Government Maps at Court to 1550', in Monarchs, Ministers, and Maps: The Emergence of Cartography as a Tool of Government in Early Modern Europe, ed. by D. Buisseret (Chicago: University of Chicago Press, 1992), pp. 26-56.

Biggs, M., 'Putting the State on the Map: Cartography, Territory, and European State Formation', Comparative Studies in Society and History 41 (1999), 374-405.

Branch, J., The Cartographic State: Maps, Territory and the Origins of Sovereignty (Cambridge: Cambridge University Press, 2014).

Buisseret, D., 'The Cartographic Definition of France's Eastern Boundary in the Early Seventeenth Century', Imago Mundi 36 (1984), 72-80.

Buisseret, D., 'French Cartography: The ingénieurs du roi, 1500-1650', in The History of Cartography, Volume 3: Cartography in the European Renaissance, Part 1, ed. by David Woodward (Chicago: University of Chicago Press, 2007), pp. 1504-1521.

Cassidy-Welch, M., 'Space and Place in Medieval Contexts', Parergon (2010), 1-12.

Childs, J., The British Army of William III, 1689-1702 (Manchester: Manchester University Press, 1987).

Dalché, P.G., 'The Reception of Ptolemy's Geography (End of the Fourteenth to Beginning of the Sixteenth Century)', in The History of Cartography, Volume 3: Cartography in the European Renaissance, Part 1, ed. by David Woodward (Chicago: University of Chicago Press, 2007), pp. 285-364.

Dauphant, L., 'Entre la liste et le terrain, la carte dans les négociations de paix au $\mathrm{XV}^{\mathrm{e}}$ siècle (Dauphiné et Savoie, France et Bourgogne)', Cartes \& Géomatique 228 (2016), 11-21.

Dauphant, Léonard, Le royaume des quatre rivières: l'espace politique français (1380-1515) (Champ Vallon: Seyssel, 2012).

Davies, C.S.L., 'The English People and War in the Early Sixteenth Century', in Britain and the Netherlands, Volume 6: War and Society, ed. by A.C. Duke and C.A. Tamse (The Hague: Nijhoff, 1977), pp. 1-18.

Day, D., Conquest: How Societies Overwhelm Others (Oxford: Oxford University Press, 2008).

Dillon, H.A., 'Calais and the Pale', Archeologia 53 (1892), 289-388.

Elden, S., 'Land, Terrain, Territory', Progress in Human Geography 34, no. 6 (2010), 799-817.

Febvre, L., Pour une histoire à part entiére (Paris: École Pratique des Hautes Études, 1962).

Grotius, H., On the Law of War and Peace, ed. by S.C. Neff (Cambridge: Cambridge University Press, 2012)

Grummitt, D., The Calais Garrison: War and Military Service in England, 1436 -1558 (Woodbridge: Boydell, 2008). 
Grummitt, D., “For the Surety of the Towne and Marches”: Early Tudor Policy towards Calais, 1485-1509', Nottingham Medieval Studies 44 (2000), 184-203.

Harley, J.B., 'Deconstructing the Map', Cartographica 26 (1989), 1-20.

Harley, J.B., 'Meaning and Ambiguity in Tudor Cartography', in English Map Making 1500-1650, ed. by S. Tyacke (London: British Library, 1983), pp. 22-45.

Harvey, P.D.A., Maps in Tudor England (London: British Library, 1993).

Kamen, H., Philip II (New Haven: Yale University Press, 1997).

Katajala, K., 'Maps, Borders and State-building', in Physical and Cultural Space in Pre-Industrial Europe: Methodological Approaches to Spatiality, ed. by Marko Lamberg, Marko Hakanen and Janne Haikari (Lund: Nordic Academic Press, 2011), pp. 58-91.

Lacoste, Y., La géographie ça sert d'abord à faire la guerre (Paris: Maspero, 1976).

Lefebvre, H., The Production of Space, trans. by Donald Nicholson-Smith (London: Wiley-Blackwell, 1991).

Letters and Papers, Foreign and Domestic, of the Reign of Henry VIII, ed. by J.S. Brewer, J. Gardiner and R.H. Brodie, 21 vols (London: HMSO, 1862-1932).

Lettres de Louis XI, roi de France, ed. by J. Vaesen, B. de Mandrot and É. Charavay, 11 vols (Paris: Société de la Histoire de France, 1883-1909).

Merriman, M., 'Italian Military Engineers in Britain in the 1540s', in English Map Making 1500-165o, ed. by S. Tyacke (London: British Library, 1983), pp. 57-67.

Mundy, B.E., The Mapping of New Spain: Indigenous Cartography and the Maps of the Relaciones Geograficas (Chicago: University of Chicago Press, 2000).

Mundy, B.E., 'Mapping the Aztec Capital: The 1524 Nuremberg Map of Tenochtitlan, Its Sources and Meanings', Imago Mundi 50 (1998), 11-33.

Nicholson, G., 'The Act of Appeals and the English Reformation', in Law and Government under the Tudors, ed. by C. Cross, D. Loades and J.J. Scarisbrick (Cambridge, 1988), pp. 19-30.

Parker, G., Global Crisis: War, Climate and Catastrophe in the Seventeenth Century (New Haven: Yale University Press, 2014).

Pelletier, M., 'Representations of Territory by Painters, Engineers, and Land Surveyors in France during the Renaissance', in The History of Cartography, Volume 3: Cartography in the European Renaissance, Part 1, ed. by David Woodward (Chicago: University of Chicago Press, 2007), pp. 1522-1537

Potter, D., Henry VIII and Francis I: The Final Conflict, 1540-47 (Leiden: Brill, 2011). Pouncey, P., 'Girolamo da Treviso in the Service of Henry VIII', Burlington Magazine 95 (1953), 208-111.

Power, D., 'Frontiers: Terms, Concepts, and the Historians of Medieval and Early Modern Europe', in Frontiers in Question: The Eurasian Borderlands, 700-1700, ed. by Daniel Power and Naomi Standen (London: Macmillan Education, 1999), pp. 1-12. 
Robertson, J., 'Empire and Union: Two Concepts of the Early Modern European Political Order', in John Robertson, A Union for Empire: Political Thought and the British Union of 1707 (Cambridge: Cambridge University Press, 1995), pp. 3-36.

Rymer, T., Foedera, conventiones, literae, et cujuscunque generis acta publica, 20 vols (London: Tonson, 1704-35).

Sahlins, P., 'Natural Frontiers Revisited: France's Boundaries since the Seventeenth Century', American Historical Review 95 (1990), 1435-1443.

Sanford, R.L., Maps and Memory in Early Modern England (London: Palgrave, 2002). Shelby, L.R., John Rogers: Tudor Military Engineer (Oxford: Clarendon, 1967).

Smith, D.K., The Cartographic Imagination in Early Modern England: Re-Writing the World in Marlowe, Spencer, Raleigh and Marvell (Farnham: Ashgate, 2008).

State Papers Published under the Authority of His Majesty's Commission: King Henry VIII, 11 vols (London: HMSO, 1830-1852).

Unger, R.W., Ships on Maps: Pictures of Power in Renaissance Europe (London: Palgrave, 2010).

Vasari, G., The Lives of the Painters, Sculptors \& Architects, trans. by A.B. Hinds, 4 vols (New York: Dutton, 1927).

\section{About the author}

Neil Murphy is Professor of Medieval and Early Modern History at Northumbria University and has published three monographs. His interests lie principally in the history of north-western Europe.

Damen, M. and K. Overlaet (eds.), Constructing and Representing Territory in Late Medieval and Early Modern Europe. Amsterdam: Amsterdam University Press, 2022 DOI 10.5117/9789463726139_CH08 


\title{
8. From Multiple Residences to One Capital? Court Itinerance during the Regencies of Margaret of Austria and Mary of Hungary in the Low Countries (c. 1507-1555)
}

Yannick De Meulder

\begin{abstract}
Historians of the Low Countries have often maintained that, following the itinerance of the fifteenth-century dukes of Burgundy, Margaret of Austria and Mary of Hungary's sojourns in Mechelen and Brussels established these as 'capital cities'. Drawing on analyses of their itineraries, this chapter argues that the governesses travelled to maintain control over the principalities of the Low Countries and actively partook in the construction of the 'Burgundian territory'. Frequent visits to Burgundian palaces in cities like Brussels and Ghent bolstered the image of continuity from the devout, civic-minded Burgundian dukes to the new Habsburg rulers. Margaret of Austria's later tendency to remain in Mechelen - a cultural rather than a political centre - thus indicates declining influence over policy and a focus on constructing her own territory.
\end{abstract}

Keywords: Margaret of Austria; Mary of Hungary; composite state; Low Countries; Burgundian-Habsburg dynasty

\section{Introduction}

In January 1531, Emperor Charles V (r. 1515-1555) returned to the Low Countries after an absence of ten years. It was a sad occasion: Charles returned to put affairs in order after the death of his aunt, Margaret of Austria (r. 1507-1530), who had acted as his representative or 'governess' in the Low Countries, in his absence. Not only did Charles return to appoint a new representative, but he also wanted to thoroughly reform central government in the Low Countries. The emperor restructured central government by putting three new advisory councils in place, named the 'collateral councils' (collaterale 
raden). He appointed his sister, Mary of Hungary (r. 1530-1555) as the new governess and she would preside over these councils in his absence. Meetings of the collateral councils would take place in the Coudenberg Palace in the city of Brussels. ${ }^{1}$ The Coudenberg was an ancient ducal palace, which had been renovated by one of the most illustrious Burgundian dukes of the fifteenth century, Philip the Good (r. 1419-1467). This renovation, and the fact that Philip started to reside there more often, even staying in the palace permanently in the last two years of his life, convinced the Belgian historian Henri Pirenne (1862-1935) that Brussels 'started to resemble a capital [of the Kingdom of Belgium]' in the fifteenth century. Brussels then became a true capital city in the sixteenth century, when Charles $V$ established his collateral Councils there. ${ }^{2}$ Pirenne, like many of his contemporaries, held the view that this concentration of political power in one capital city was a stage in the successful evolution towards a nation state The capital city had now become the neutral administrative centre of the national 'territory', defined by Stuart Elden as 'a bounded space ruled by the same group of people, with fixed boundaries and internal sovereignty'.3

This teleological view of the development of capital cities, as the political centres of territories that would later become nation states, has obviously faced a lot of criticism over the years. London and Paris, for instance, were often seen as the medieval prototypes of modern capital cities, combining royal presence, political institutions, and economic growth. The development of these cities as capital cities in the Middle Ages was viewed as evidence for the modernity of the French and English kingdoms. It has been pointed out, however, that the palace of Westminster in London did not really become 'the permanent base of royal government' until at least the start of the Hundred Years' War in $1337 .{ }^{4}$ Similarly, Paris never was the king's permanent place of residence throughout the Ancien Régime, not even in the Middle Ages. This, in fact, was a broader European phenomenon: kings often alternated between several residences and princely residence rarely coincided with the administrative centre of the state. ${ }^{5}$

In the late medieval Low Countries, a similar pattern emerged, despite centralising efforts by the dukes of Burgundy, which by the end of the fifteenth century ruled most of the principalities of the Low Countries in

1 Janssens, 'Vorstelijk hof (15e eeuw-1794)', p. 164; Vermeir, 'Les gouverneurs-généraux', pp. 23-24.

2 Pirenne, 'Van het begin der XIVe eeuw', p. 361.

3 Boucheron, et al., 'Formes d'émergence', pp. 14, 16-17, 68; Elden, The Birth, p. 18.

4 Ormrod, 'Competing Capitals?', pp. 75-76.

5 Paravicini and Le Gall, 'Conclusions', p. 336. 
personal union. Several institutions of central government were established in central places, starting with the chambre des comptes of the county of Flanders in Lille, an institution responsible for auditing all the accounts in the county. ${ }^{6}$ The Burgundians founded similar auditing chambers in their principalities throughout the fifteenth century, and by 1447 there were four of them, in Lille in Flanders, Brussels in Brabant, The Hague in Holland, and Dijon in Burgundy, forming an integrated auditing system. Under the guise of cost efficiency and rationalisation, the Burgundian duke Charles the Bold (r. 1467-1477) tried to centralise the auditing chambers of Brussels, Lille, and The Hague into a single institution in the city of Mechelen, where he also founded a 'parliament' or central judicial council, but these institutions did not survive the turmoil following the duke's unexpected demise on the battlefield in $1477^{7}$

The Burgundian drive towards centralisation of the political institutions also coincided with a preference of the dukes of Burgundy for longer residences in the largest cities of the Low Countries where institutions of central government were located. Scholarly research by Werner Paravicini has determined that the residences visited most were located in either the county of Flanders or the Duchy of Brabant, in a 'Burgundian residence group'. ${ }^{8}$ However, the Burgundians were the lord, count, or duke in each of the principalities of the Low Countries separately, so there was no such thing as one 'sovereign territory of the Low Countries'. Personal presence in each of the principalities of the Low Countries was necessary to retain control over the union, as each of the principalities had its own political organisation and central institutions and remained, in essence, separate territories in the sense that each of the principalities of the Low Countries had its own political, jurisdictional, and socio-economic realities linking its people and its power to its 'land'. ${ }^{9}$ Therefore, the Burgundian duke never settled permanently in one of his many residences, as itinerance itself remained a mode of government in the medieval Low Countries. ${ }^{10}$

Because the prince's territories in the Low Countries were as diverse as they were many, it was also impossible to identify one 'capital city' in the Low Countries that represented the prince's authority over all his territories. The term 'capital city' existed during Burgundian rule over the Low Countries,

6 Clauzel, 'Le roi, le prince et la ville', p. 42.

7 Stein, De hertog en zijn staten, pp. 219-221.

8 Paravicini, 'Die Residenzen der Herzöge von Burgund', p. 249.

9 In the introduction of this book, territories are defined as 'political, jurisdictional, and/or socio-economic constructions which linked people and power to space'.

10 Boucheron, et al., 'Formes d'émergence', pp. 48-49. 
to be sure, but contemporaries might not have used this term to describe the city in which either their prince or his central institutions were located. The Estates of Brabant, for instance, recognised four hoofdsteden or 'capital cities' in 1426, by which they meant the largest cities of the duchy, which represented territorial subdivisions (kwartieren) during Estates meetings. ${ }^{11}$ These were Antwerp, Brussels, 's-Hertogenbosch, and Leuven, and of these four, only Brussels housed institutions of central government by the start of the fifteenth century, and only Brussels and Leuven contained important princely residences, the ones in Leuven already being left aside by the dukes of Brabant in favour of those in Brussels by the end of the fourteenth century. ${ }^{12}$ All of these territories, and the cities that represented these territories, had to be visited by the prince of the Low Countries at least once during his reign, which is why the dukes of Burgundy remained itinerant. In other words, the personal presence of the prince in most of his lands was crucial to construct a 'Burgundian territory of the Low Countries', over which the Burgundian dynasty had a legitimate authority.

Historians have maintained that this changed in the sixteenth century. Wim Blockmans, for instance, asserted that 'in the long term, one can observe the tendency to concentrate the [princely] residences in the Low Countries in centrally located, relatively peaceful, large cities where the main central institutions also had their seats'. By the start of the sixteenth century, Blockmans concluded, 'the tendency towards the concentration [of state power] into a single permanent capital reflects the consolidation of the central state in the Low Countries'. According to the historian, this first happened between 1474 and 1530 in Mechelen, the city where Charles the Bold first tried to establish his new central institutions. ${ }^{13}$

Therefore, many historians conclude that Mechelen became the first 'capital city of the Low Countries' in the beginning of the sixteenth century. ${ }^{14}$ The evidence for this seems abundant. In 1504, the highest court of appeals in the Low Countries was re-established in Mechelen and between 1507 and 1530 the palace of Savoy in the city became the favourite residence of the governess of the Low Countries, Margaret of Austria, who acted as a representative for the Burgundian-Habsburg dynasty on two occasions, between 1507 and 1515 and again between 1518 and her death in 1530 . According to Walter Prevenier Mechelen in this period was 'the centre of a

Augustyn, 'Staten van Brabant', p. 104.

Uyttebrouck, 'Les résidences des ducs de Brabant', p. 196.

Blockmans, 'Court and City', p. 77.

Buylaert, 'From Periphery to Centre and Back Again', p. 610. 
network in which the political function dominated, [where] the monarch often stayed [...], and [where] the most important central, administrative, financial and judicial institutions were present, so that a constant dialogue between monarch and top officials was possible.. ${ }^{15}$ As we have seen, both the representative of the monarch and his central institutions moved to Brussels after Margaret's death in 1530. It seems that by the end of the Middle Ages, the monarch or his representative in the Low Countries gave up the effort to actively construct a 'Burgundian territory of the Low Countries' by constant travel through the different principalities in the region. The presence of the monarch or his representative in one capital city, Mechelen and, later, Brussels, was enough to establish authority over the territory.

\section{The Low Countries in female hands (1507-1555)}

This model of Burgundian centralisation of power culminating in the establishment of one capital city of the Low Countries that represented his power in early sixteenth century ignores the political reality of the sixteenth-century Low Countries, however. By the sixteenth century, the 'Burgundian territory in the Low Countries' had become part of a larger whole. After the marriage between Philip the Fair, the duke of Burgundy (r. 1494-1506), and Juana of Castile (r. 1504-1555), heiress to the throne of the Spanish kingdoms of Castile and Aragon, the Burgundian dynasty became inextricably linked to the Spanish monarchy. Philip and Juana's eldest son, Charles, became the universal heir to both the Spanish kingdoms and the Burgundian territories, united what has been called a 'composite state' in literature. A 'composite state' is a political construction in which one 'monarch' or 'sovereign' rules several territories that were not necessarily geographically close to one another and that retained their own political institutions and customs. ${ }^{16}$ At the head of a composite monarchy was an itinerant monarch, a ruler whose personal presence in all of the territories of the union was required (at least once) to establish and maintain control over them. As the monarch could never hope to be everywhere at once, royal absenteeism was part and parcel of rulership in composite states. To resolve this problem, the monarch appointed governors, viceroys, or 
Table 8.1. Cities most frequented by Margaret of Austria in percentages of her two regencies (presence above $1 \%$ of the regency).

\begin{tabular}{lll}
\hline $\begin{array}{l}\text { Cities frequented by } \\
\text { Margaret of Austria }\end{array}$ & $\begin{array}{l}\text { First regency } \\
\text { (1507-1515) }\end{array}$ & $\begin{array}{l}\text { Second regency } \\
\text { (1518-1530) }\end{array}$ \\
\hline Brussels & $37.20 \%$ & $23.24 \%$ \\
Mechelen & $26.26 \%$ & $48.80 \%$ \\
Unknown & $8.67 \%$ & $8.15 \%$ \\
Ghent & $7.07 \%$ & $5.61 \%$ \\
Antwerp & $4.08 \%$ & $3.49 \%$ \\
's-Hertogenbosch & $3.32 \%$ & $/$ \\
The Hague & $2.21 \%$ & $1.80 \%$ \\
Lille & $1.63 \%$ & $/$ \\
Leuven & $1.45 \%$ & $/$ \\
Bruges & $1.45 \%$ & $2.22 \%$ \\
Breda & $1.00 \%$ & $/$ \\
Hoogstraten & $/$ & $1.27 \%$ \\
\hline
\end{tabular}

Source: Based on Bruchet and Lancien, L'itinéraire de Marguerite d'Autriche.

lieutenant-generals, assisted by native councillors, to represent him in his absence, to help him determine policy, and to give the native elites a forum to air their grievances. ${ }^{17}$ Philip the Fair did a similar thing in the Low Countries when he went to Spain to claim the throne of Castile, installing a regency council in his Burgundian territories to rule in his absence. His unexpected death in 1506 put an early end to this experiment, however. Charles, Philip's heir, was only six years old when his father died, and therefore the composite monarchy forged by the marriage between his parents was divided again.

That division did not last long, however. When Charles's father, Philip, died, his maternal grandfather, Ferdinand of Aragon (r. 1479-1516), seized control over Castile, but when Ferdinand died in 1516, Charles inherited both Spanish kingdoms. ${ }^{18}$ Charles left for Spain in 1517 to enforce his claims in Aragon and Castile, but before his departure he appointed a regency council to rule in his absence, just like his father had done. Later, Charles also appointed his aunt Margaret of Austria as governess of the Low Countries. Margaret had already fulfilled a similar role between 1507 and 1515 during Charles's minority, because Charles's official guardian and the regent of the Low Countries, his grandfather, Maximilian of Habsburg, had been busy with his Austrian lands and with his duties as emperor of the Holy Roman 


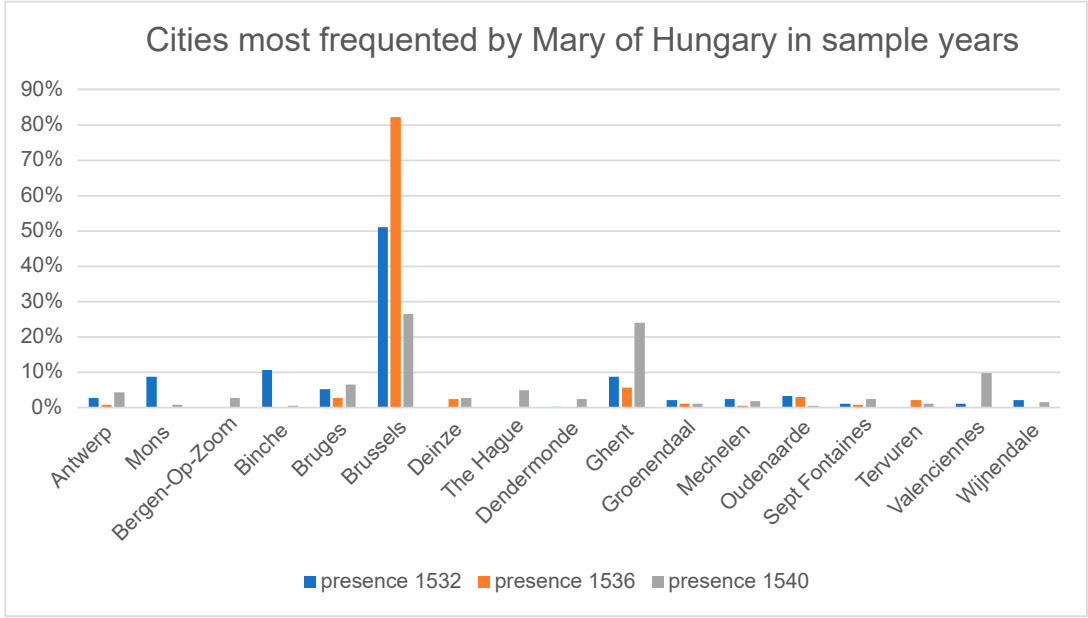

Fig. 8.1. Cities most frequented by Mary of Hungary in percentages of sample years based on the accounts of her treasurer. Includes only cities visited more than $1 \%$ of the year.

Empire. ${ }^{19}$ When in 1519 Maximilian died as well, Charles also inherited the Habsburg lands in Austria. Finally, in 1520 Charles was elected emperor of the Holy Roman Empire as Charles V and the Burgundian-Habsburg composite monarchy took its final form. That meant that the principalities in the Low Countries, from this point until the end of the sixteenth century, would be ruled by representatives of their sovereign prince, rather than by that prince himself, as he would only occasionally visit his territories in the Low Countries. After the death of Margaret of Austria in 1530, Charles codified this representative mode of government when he appointed his sister Mary of Hungary as the new governess. ${ }^{20}$ The interests of the Low Countries now became, as Koenigsberger put it, 'subordinate to Charles's all-European interests and aims. ${ }^{21}$

If we are to believe the centralisation-model proposed by Prevenier and Blockmans, the presence of these governesses, as the monarch's representatives, and the institutions of central government in the capital cities of Mechelen and later in Brussels were enough to represent BurgundianHabsburg power and authority in all the Burgundian-Habsburg territories in the Low Countries, even though the Burgundian-Habsburg monarch was mostly absent from these territories. However, according to J.H. Elliott, who first theorized about 'composite monarchies', the departure of the 
monarch and his court entailed the loss of capital status for the principal city of the territory that was brought into the union. ${ }^{22}$ In addition, the new sedentary mode of government proposed in the centralisation-model, is in stark contrast with the Burgundian itinerant mode of government, in which the personal presence of the ruler in all Burgundian territories was a prerequisite to be able to retain control and to construct the idea of a joint 'Burgundian territory'. Finally, it seems obvious that representatives of the monarchs in composite monarchies could never replace the monarch entirely. This begs the question if and how the governesses, as representatives of an absent Burgundian-Habsburg monarch, were able to maintain the relationship between the monarch and his territories in the Low Countries and how they used the (capital) cities of the Low Countries to do so.

\section{Favourite residences}

To be able to answer this question, I will delve deeper in the itineraries of the governesses during their regencies. For Margaret of Austria, this is relatively easy, since a detailed itinerary of the governess throughout her life has been published. ${ }^{23}$ By using data from this publication, an overview of the governess's residence patterns during both her regencies could be compiled. No such publication exists for the regency of Mary of Hungary, but the location of the governess can be derived from the daily expenses in the account books of her treasurer, which are preserved between 1531 and 1540 . Because of the wealth of information in these account books, the analysis had to be limited to three randomly selected sample years, 1531-1532, 1535-1536, and 1539-1540. ${ }^{24}$ Insights from these sources will provide a better overview of the presence of the governesses in the cities of the Low Countries and the strategy they used to represent the power of the dynasty in the Burgundian territories in the Low Countries.

Table 8.1 shows the locations Margaret of Austria frequented most during both of her regencies separately, which provides some interesting details about her mobility. Contrary to what Blockmans and Prevenier have suggested, the governess preferred Brussels as a residence over Mechelen between 1507 and 1515. She spent $37.2 \%$ of that period in Brussels, compared to only $26.2 \%$ of

22 Elliott, 'A Europe of Composite Monarchies', p. 55.

23 Bruchet and Lancien, L'itinéraire de Marguerite d'Autriche gouvernante des Pays-Bas.

24 These accounts are preserved in the Archives Départementales du Nord in Lille, see nrs B3355, B3358 and B3362. 
the same period in Mechelen. During Margaret's second regency (1518-1530), the situation reversed. Mechelen was frequented for $48.8 \%$ of that regency, while the governess stayed in Brussels for $23.24 \%$ of the time. The table also suggests that Margaret frequently visited other cities during both of her regencies as well, such as Ghent and Bruges in Flanders and even The Hague in Holland. The cities that were visited the most were the largest centres of the principalities, which had urban princely residences. Some of them, like The Hague and Lille, also contained institutions of central government.

Contrary to her predecessor, Mary of Hungary almost never visited Mechelen, as is indicated by Figure 8.1. This analysis of her whereabouts, in three sample years of her regency, shows Mary's overwhelming preference for long residences in Brussels. In 1536, for instance, Mary stayed in Brussels for $81 \%$ of the year, making it her favourite city by far. Similar patterns in 1531 and 1540 confirm this preference for Brussels. She too retained a certain mobility, though, visiting some of the same large centres as did Margaret. Figure 8.1 also clearly shows how Mary of Hungary's favourite pastime, hunting, affected her travel pattern. She frequently visited hunting lodges and monasteries in the Sonian Forest in the Duchy of Brabant, like Tervuren or the monasteries of Groenendaal and Sept Fontaines. The Sonian Forest, of course, was a favourite Burgundian hunting site, conveniently located near one of their favourite Brabantine residences, Brussels. ${ }^{25}$

Except for Mary of Hungary's stops for hunting purposes, and aside from the preference of the governesses for longer stays in Mechelen and Brussels, the data generally indicate that both governesses retained a certain degree of mobility, most often visiting the largest cities of the Low Countries with political and economic importance, particularly in the Duchy of Brabant. The cities of the Low Countries were prosperous places of capital accumulation, capital the Burgundian-Habsburg dynasty needed to fund their numerous wars and other endeavours. This gave the cities the bargaining power to continue to resist the penetration of consolidated states, which made the full integration of the Low Countries in a consolidated state by coercion very difficult. ${ }^{26}$ Negotiations about capital extraction by the prince in person or by his replacement, the governess, were a key aspect of gaining access to the capital accumulated by the cities. This bargaining between cities and a prince in need of money was also very much a face-to-face affair in the Low Countries. The elites of the Low Countries, especially those of the 
county of Flanders, expected to be governed by their natural prince, after all. In his absence, his representative, preferably a member of his family, would do, however. ${ }^{27}$

The preference of the governesses for frequent stops in Brabantine cities must therefore be seen as a consequence of the economic centre of gravity of the Low Countries fully shifting from the county of Flanders to the Duchy of Brabant in the sixteenth century. Brabant contained several cities with thriving luxury industries and a large centre of commerce, Antwerp. ${ }^{28}$ The economic prosperity of Brabant clearly contributed to the principality's overall importance in the Burgundian-Habsburg composite state as an interesting location for capital extraction, which was reflected in the frequent presence of the governesses.

A city like Brussels, in the most prosperous principality of Brabant, was the ideal location for frequent and long residences to negotiate with Brabantine representatives, since it contained a large palace on the Coudenberg to accommodate the princely household and was located in the heart of Brabant not far from the commercial centre of Antwerp. ${ }^{29}$ Antwerp itself was not visited that frequently by either governess: presumably because representatives from Antwerp, located in the same principality as Brussels, could easily come to this city to negotiate. The fact that the Low Countries contained multiple prosperous centres in which bargaining for capital extraction was necessary probably also explains the governesses' urban preference, which was not shared by their princely contemporaries. The kings of France, for instance, preferred their chateaux in the countryside for longer residences and only occasionally visited Paris, the largest French political and commercial centre..$^{30}$

Still, neither Mechelen nor Brussels could be the permanent residence of the governesses, since the cities did not fully represent the monarch's authority and separate territories, in the sense of constructions with their own political customs, continued to exist in the sixteenth-century Low Countries. Representatives from the county of Flanders, for instance, would not come to Brabant for tax negotiations, as is clear from a passage in the account book of the receiver general of 1536 . The account book shows that Mary of Hungary demanded the representatives of the Estates of Flanders

27 Vermeir, 'Les gouverneurs-généraux', p. 21.

28 Van Uytven, 'De triomf van Antwerpen en de grote steden', pp. 243-252; Blondé and Limberger,

'De gebroken welvaart', pp. 307-320.

29 Van Uytven, 'De triomf van Antwerpen en de grote steden', pp. 241-245.

3o Paravicini and Le Gall, 'Conclusions', pp. 336-338. 
come to Brussels in June of that year to negotiate about the taxes needed for Charles V's war with France. They instead organised their own Estate meeting in the Flemish city of Ghent, without the governess present..$^{31}$ This situation got out of hand in 1537 when Ghent refused to pay the taxes. In 1539 the city rebelled openly after Mary tried collecting the taxes anyway. It took a punitive expedition by Charles V himself in 1540 to put things back in order. ${ }^{32}$ This example shows two things. First, Mary of Hungary, as the representative of the monarchy could not stay in the Coudenberg Palace in Brussels permanently, even though it was her favorite residence. Her visits to some principalities were vital to make them fall in line: the Flemish representatives would not come to Brabant for tax negotiations and if the governess herself was not present, she would not be included in the decisions made in the county. Seconldy, the example also shows that if all else failed, only the personal presence of the monarch himself could resolve the situation.

In fact, the personal presence of the monarch himself remained important for the principalities of the Low Countries in general. After the Ghent affair was resolved in 1540, delegates from Holland and Zeeland were sent to Emperor Charles $\mathrm{V}$ to invite him to come to visit their principalities, indicating that elites of the separate principalities of the Low Countries themselves apparently also demanded the presence of their natural prince within the borders of their territories and Charles obliged. ${ }^{33} \mathrm{He}$ visited the Low Countries thirteen times between 1530 and 1555, making tours through some of the principalities almost every time, indicating that he observed the Burgundian tradition of government through itinerance in the Low Countries and understood the importance of that tradition for the Low Countries. ${ }^{34}$ The residence patterns of the governesses suggests that they would have partaken in this tradition in the absence of the natural prince of the Low Countries, who ruled over a vast composite state and could not be everywhere at once. The Ghent example illustrates that the situation could get severely out of hand when the governess did not take her representative task seriously by neglecting her travel duties even in the face of important

31 Accounts of Henri Stercke, Archives départementales du Nord, nr B2392, folio 368 recto and folio 385 verso.

32 Kerkhoff, 'Maria van Hongarije en haar hof (1505-1558)', pp. 216, 219.

33 Ibid., pp. 19-21.

34 Charles V stayed in the Low Countries more frequently during his sister's regency, than Maximilian of Austria did during the regency of Margaret of Austria. See Gachard, Collection des voyages des souverains des Pays-Bas. 


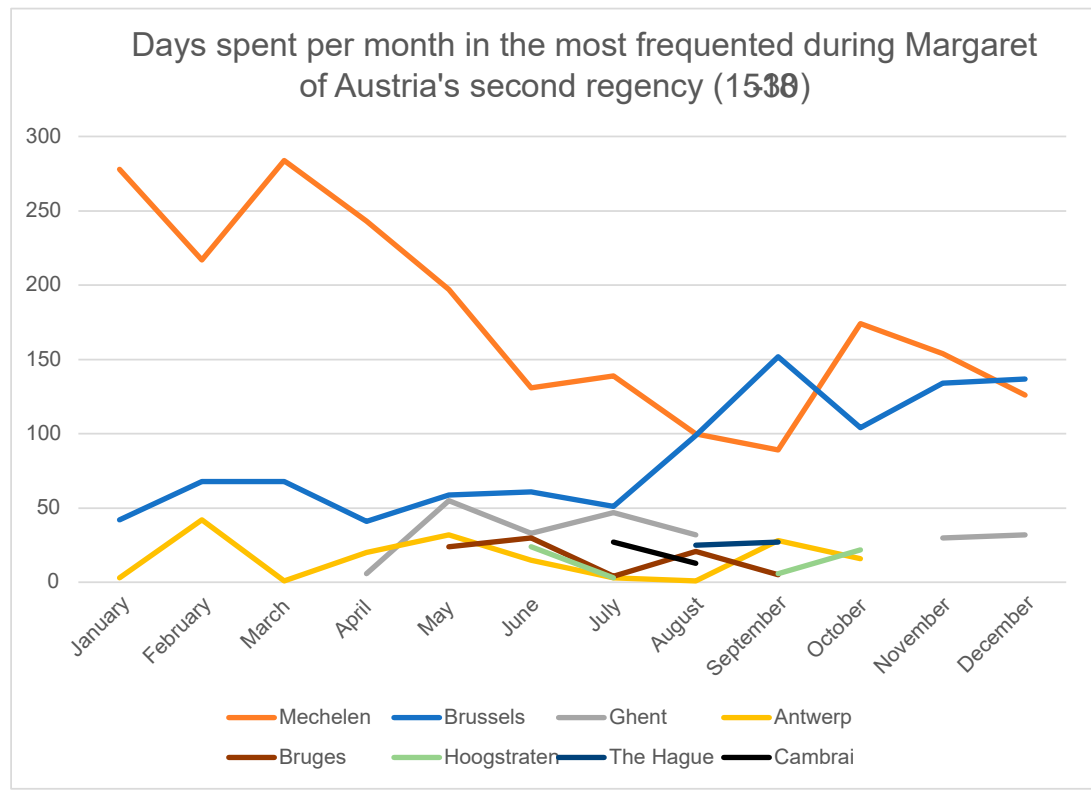

Fig. 8.2. Days spent per month in the most frequented cities during Margaret of Austria's second regency (1518-1530). Includes only cities visited more than $1 \%$ of her regency. Source: Based on Bruchet and Lancien, L'itinéraire de Marguerite d'Autriche.

tax negotiations. Then, only the personal presence of the monarch himself could repair the relationship between his territory and himself.

\section{Legitimising power}

The person of the 'monarch' or 'natural prince' was thus vital to maintain the relationship between the Burgundian-Habsburg dynasty and the Burgundian territory in the Low Countries for political reasons. The travel pattern of the governesses shows that they had to represent the person of the prince during important negotiations with elites about things like taxes. However, this representative role went even further, as the governesses also played a vital role in tying the dynasty to its territory, by partaking in important ceremonies like Joyous Entries. After being appointed as the representative of her father, Maximilian, in the Low Countries in 1507, Margaret of Austria travelled through the region to perform entries in his name and in the name of the future emperor, Charles V. Her chronicler, Jean Lemaire des Belges, describes how she travelled through the Low Countries accompanied by a retinue of nobles and other dignitaries, to swear to uphold the privileges of the different principalities and cities of the Low Countries in their respective 
political centres, like Leuven, Brussels, Mons and Arras. It is striking that neither Maximilian, nor Charles, whom Margaret represented, seem to have accompanied her on these voyages. Taking the young Crown Prince Charles with her would have been easy enough for Margaret, after all, since the boy was in her care in Mechelen. ${ }^{35}$ It was, however, the governess herself who legitimised the authority of the Burgundian-Habsburg dynasty in the Low Countries, literally taking the place of the monarch in swearing to uphold the privileges of its cities. In Ghent, for instance, Lemaire des Belges specifically mentions that Margaret 'swore the oaths the counts of Flanders used to swear' ${ }^{6}{ }^{6}$

Apparently, becoming the alter ego of the natural prince during these ceremonies was possible for the governesses even though they were women. According to the chronicle, Margaret was indeed accepted as a replacement for both Maximilian and Charles: After the ceremony in which the governess swore her oath to the Ghentois, she rode to the town hall, where a large crowd of citizens was waiting to swear their own oaths to the future governess, which they, according to Lemaire, had 'since time immemorial not done with such prompt fervour or with such thrilled faces'. ${ }^{37}$ That acceptance is not as remarkable as it might seem. In fact, sixteenth-century noblewomen were often able to reframe their subordinate role by taking up public political functions in service of their family. Women like the queen of France, Catherine de Médicis (r. 1533-1589), who served her husband and son as queen-regent on several occasions, are prime examples of this. ${ }^{3}$ Examples in which a fully capable and healthy king formally delegated part of his power in a certain territory to a female member of his family also exist. Maria of Castile (r. 1416-1458), for instance, replaced her husband, the king of Aragon, as lieutenant-general of Catalunya when he went to war in Sicily. ${ }^{39}$ In fact, there was even precedent for a similar arrangement in the Burgundian Low Countries: when Duke Philip the Good travelled, he often delegated his powers to his spouse. ${ }^{40}$ Similarly, Emperor Maximilian and later Emperor Charles V delegated their power in the Low Countries to the governesses Margaret of Austria and Mary of Hungary. In fact, there is evidence to suggest that he used the Aragonese tradition as an inspiration

The itinerary of Charles V shows that he stayed in Mechelen almost the whole year in 1507 .

See Gachard, Collection des voyages des souverains des Pays-Bas.

36 Stecher, Oeuvres de Jean Lemaire des Belges, vol. 4, pp. 477-483, 501.

37 Ibid., 501-502.

$3^{8}$ Crawford, 'Catherine de Médicis', p. 654.

39 Earenfight, 'Without the Persona of the Prince', p. 3.

40 Vermeir, 'Les gouverneurs-généraux', p. 20. 
for his overhaul of the government structures of the Low Countries and for the codification of the position of the 'governess of the Low Countries' in $1531{ }^{41}$ Thus, as governesses, Margaret of Austria and Mary of Hungary were expected to take up the duties of the 'natural prince' they represented, and these duties clearly included travel.

There is evidence to suggest that the governesses did not only occasionally travelled to attend political negotiations or important ceremonies, but that they frequently visited certain places throughout their regencies even when there were no ceremonies or political negotiations to attend. Figure 8.2 illustrates this for the governess Margaret of Austria. Even though she resided most often in Mechelen during her second regency (1518-1530), she visited important cities like Bruges, Lille, and The Hague mostly in the spring and summer months, exhibiting a clear cyclical travel pattern. Anne-Laure Van Bruane has demonstrated how the Habsburg dynasty closely orchestrated their princely appearances in the public sphere to shape dynastic, territorial, and local identities..$^{42}$ Therefore, this continued itinerance by the governesses to large urban centres in the Low Countries must be interpreted as a part of the Burgundian-Habsburg public image building.

Frequent travel by the prince, or in this case his representative, tied the dynasty to the Low Countries and helped construct the idea of a 'Burgundian territory of the Low Countries' within the Burgundian-Habsburg composite state. Reshaping the dynasty's image was particularly important during the first half of the sixteenth century. During the last decades of the fifteenth century, the Low Countries had known nothing but turmoil, largely instigated by conflicts between civic particularism and centralising efforts by Burgundian-Habsburg princes which had made them unpopular. In particular, the dispute between Maximilian of Habsburg and the Flemish cities about the regency of the future Philip the Fair and the subsequent Flemish Uprising of 1488 must have still been fresh in the memories of the urban elites. ${ }^{43}$ It is therefore no surprise that when the dust settled, it was precisely the 'Burgundian myth of able and devout rulers' that served as a point of reference for the two parties. ${ }^{44}$

When viewed in this light, the places to which the governesses travelled frequently and where they resided for longer periods are significant. For instance, besides the obvious advantages of Brussels as an administrative 
centre, with its central location, and the Coudenberg as a particularly well-equipped palace for princely use, the palace in Brussels also had a strong connection with the dukes of Burgundy, for whom the urban elites were nostalgic: Philip the Good and Charles the Bold. ${ }^{45}$ These dukes had substantially renovated the palace, regularly resided there, and used it for large ceremonies of political importance. ${ }^{46}$ Therefore, the Coudenberg Palace itself became an important material relic of these dukes and it was filled to the brim with references to the period of Burgundian splendour in the form of tapestries, paintings, glassworks, sculptures, and gold and silver objects. ${ }^{47}$ The Prinsenhof in Bruges and the Hof ten Walle in Ghent, both residences rebuilt and frequently visited by the Burgundians, must have had similar connotations. ${ }^{8}$ More importantly, these palaces were in the principality of Flanders, where the civil war of the final decades of the fifteenth century had been especially scarring. That the governesses, as representatives of the Burgundian-Habsburg dynasty stayed in Ghent and Bruges relatively frequently is therefore not a coincidence. This was a way to reconcile with the Flemish elites and to re-establish Burgundian-Habsburg authority in Flanders.

One could thus say that the governesses, as representatives of the ruling Burgundian-Habsburg dynasty, used regular journeys to these ancestral palaces in the same way they might have used pilgrimages: to tie the dynasty to the land. ${ }^{49}$ In regularly visiting these palaces, the governesses showed that they descended from the natural Burgundian princes so fondly remembered by the elites of the Low Countries. This not only granted them legitimacy as representatives of the Burgundian-Habsburg monarch, but also reconnected the dynasty they represented with the Low Countries. It reconstructed the idea of the Burgundian territory of the Low Countries within the context of the Burgundian-Habsburg composite state.

\section{Margaret of Austria and Mechelen}

The final question that must be asked is where Margaret of Austria's frequent and long stays in Mechelen fit in all this. When he left for Spain in 1517, an

46 Smolar-Meynart, 'De grands travaux dans un contexte politique difficile (1452-1459)'; Arnade, 'State, and Public Ritual', p. 300.

47 Kerkhoff, 'Maria van Hongarije en haar hof (1505-1558)', pp. 135-136.

48 De Jonge, 'Bourgondische residenties in het graafschap Vlaanderen', pp. 93-95.

49 Duerloo, 'Archducal Piety and Habsburg Power', p. 279. 
emancipated Charles $\mathrm{V}$ had only reluctantly reappointed his aunt Margaret to his regency council in the Low Countries, so the relationship between Margaret and her nephew Charles was not ideal. In addition, Margaret had earned the resentment of the aristocracy of the Low Countries, who felt they did not get the rewards they deserved. They decided to petition the emperor directly to air their grievances and Charles was willing to listen. This was the great weakness of the representational system: patronage remained firmly in the hands of the monarch himself and those who felt slighted could go over the governess's head to get what they thought they deserved. If the monarch sided with those who felt slighted, there was little the governess could do to remedy the situation and to restore her image..$^{50}$ Moreover, from the 1520 s onwards, Charles repeatedly tried to restrict Margaret's political powers, since he felt she acted to independently from both his own wishes and those of the aristocracy of the Low Countries. To this end, he transferred his aunt's former financial responsibilities to important nobles and the governess only retained a supervisory role as head of most of the councils of state, although she could still exert some influence on politics through her household, some members of which were active in the central councils of the Low Countries. In addition, Margaret retained her representative function in diplomatic affairs. ${ }^{51}$ Most likely due to this loss of formal power and her increasing unpopularity with the nobles, prolonged presences in the administrative centre of the Low Countries - Brussels - had become unnecessary and perhaps even unwanted. This waning of her formal power coincides with Margaret's more frequent and longer stops in Mechelen, where she seemed to have retreated to her own 'palace of Savoy'.

But why, then, did the governess retreat to Mechelen and not another residence with a more important Burgundian or ancestral pedigree? First, due to her loss of formal power, it might not have been as important to increase her symbolic capital as the representative of the BurgundianHabsburg dynasty by travelling to the most important ancestral palaces. In addition, the palace of Savoy in Mechelen was more modern, smaller, and probably more comfortable than the large Coudenberg in Brussels..$^{2}$ Finally, the city and the seigneury surrounding Mechelen had, since the High Middle Ages, been independent from the Duchy of Brabant. In 1520 it became Margaret's personal enclave in Brabant, when she received the seigneury from Charles. Margaret then started to turn Mechelen into a 
cultural and artistic centre. ${ }^{53}$ This stimulation of the arts in Mechelen was already set in motion by Margaret of York, duchess-dowager of Burgundy, one of Margaret of Austria's role models. Between the death of her husband, Charles the Bold, in 1477, and her own death in 1503, the duchess-dowager held a subtle influence over the politics of the Low Countries from her residence in the city of Mechelen, which she held as part of her dowry. ${ }^{4}$ The city and seigneury of Mechelen, and its reference to the powerful woman Margaret of York, was thus the perfect place for Margaret of Austria to start concentrating on projecting her own prestige as a renaissance princess and to start working on more traditionally 'female' ways of exerting power, like the patronage of the arts. .5

Mary of Hungary did not have the same connection to Mechelen as her predecessor and did not come there often. During her earliest childhood, Mary and her siblings had indeed stayed in Mechelen, but Mary was whisked off to the Empire when she was only eight years old to receive her education from her grandfather Maximilian and to prepare her for her marriage to the king of Hungary and Bohemia. ${ }^{6}$ In addition, the political situation in the Low Countries had changed after 1531, which made ruling through informal contacts within the household increasingly difficult. Therefore Mary, who still needed to retain influence over government as her brother's representative, had to stay in the administrative centre of Brussels more and longer than her predecessor. And yet, towards the end of her regency, Mary also started art collections in her newly built palaces in Binche and Mariemont. After 1550, she even moved a large part of her predecessor's library from Mechelen to these palaces, not only to show the French king the artistic splendour of the Burgundian-Habsburg dynasty, but undoubtably also to underline her own prestige as a woman in charge, just like her predecessor Margaret had done in Mechelen.57

\section{Conclusion}

The analysis of the itineraries of the governesses Margaret of Austria and Mary of Hungary has yielded some interesting insights into the development

53 Eichberger, 'A Cultural Center in the Southern Netherlands'; Quinsonas, Materiaux pour servir à l'histoire de Marguerite d'Autriche, vol. 3, pp. 267-274.

54 Blockmans, 'Margareta van York de subtiele invloed van een hertogin', p. 47.

56 Kerkhoff, 'Maria van Hongarije en haar hof (1505-1558)', pp. 130-132.

57 Ibid., p. 180. 
of the relationship between the Burgundian-Habsburg dynasty and their territories in the Low Countries in the early sixteenth century. First, it is important to note that in that period, the 'Burgundian territory in the Low Countries' had become part of a 'composite state', in which the monarch had authority over several other territories. Since the monarch was often not present himself, he needed representatives to be able to retain control over territories from which he was absent. In the Low Countries, these representatives were preferably members of the monarch's family since the elites of many of the principalities of the Low Countries would not accept anyone else as a ruler.

In the early sixteenth century the representatives were the governesses Margaret of Austria and Mary of Hungary. Even though they were women, it was expected that they would take up the role of the 'natural prince' as his alter ego. This included travelling to the largest cities of the different principalities of the Low Countries to negotiate with elites about things like capital extraction. The governesses Margaret of Austria and Mary of Hungary clearly had preferences for longer residences in some cities of the Low Countries, especially in the Duchy of Brabant, but to a lesser extent also those in the county of Flanders, two of the most prosperous and therefore politically influential principalities of the Low Countries.

Travelling to and residing in these principalities was not only important to govern, but also part of the reconstruction of the idea of the 'Burgundian territory in the Low Countries' in the context of the Burgundian-Habsburg composite state. By the sixteenth century, the members of the Burgundian dynasty were remembered in the Low Countries as devout rulers who understood civic sensibilities and the early Habsburgs very much wanted to be associated with that memory. To do this, they not only actively took part in (civic) ceremonies, but they also travelled to and resided in Burgundian palaces. Like the ancient French royal castles in the Île de France, the most impressive residences of the Burgundian dukes had become important lieux de mémoire by the turn of the sixteenth century. ${ }^{8}$ One residence stood out above all the rest in this regard: the Coudenberg Palace in Brussels. By the sixteenth century, that palace had become a symbol of the Burgundian dynasty and therefore the Burgundian claim over the principalities of the Low Countries. Staying in the palace thus reinforced the image of the Habsburgs as a continuation of the Burgundian line and their claim over the 'Burgundian territory in the Low Countries'. 
Finally, the fact that Margaret of Austria increasingly retreated to Mechelen from 1520 onwards is tied to her loss of formal political power, not to the increasing importance of the city as a 'capital city'. In Mechelen the ageing governess started to concentrate more on exerting her influence through her own household, less frequently visiting the political centres of the Low Countries where her presence was not appreciated. By now, the seigneury of Mechelen had decidedly become one Margaret's own territories, which she used to build her own image as a renaissance princess, this time using one of her female ancestors, Margaret of York, as a role model.

Even if the governesses might have been less mobile than their Burgundian predecessors, personal interaction between the natural prince of the Low Countries or his representatives and his territory remained a vital part of government and of the construction of territory in the Low Countries. Without denying the importance of at least Brussels as an administrative centre of government, the idea that 'one capital city of the Low Countries' existed in the sixteenth century that combined the permanent presence of the monarch with institutions of central government and therefore represented the authority of that monarch over his territory in the Low Countries must be revised, because the 'Burgundian territory' in the Low Countries remained under construction in the early sixteenth century. The itinerance of the governesses Margaret of Austria and Mary of Hungary to the princely residences in largest and most prosperous cities of the Low Countries shows that both the governesses and these cities played a crucial role in the construction of that Burgundian territory as part of the Burgundian-Habsburg composite state. How this evolved further in the later sixteenth century and what other consequences this continued itinerance might have had for the cities of the Low Countries is a subject for further research.

\section{Bibliography}

\section{Primary sources}

Accounts of Henri Stercke, Archives départementales du Nord, nr B2392.

Accounts of Jean de Gyn, Archives départementales du Nord, nrs. B3355, B3358 and $\mathrm{B}_{3362 .}$

Bruchet, M., and E. Lancien. L'itinéraire de Marguerite d'Autriche gouvernante des Pays-Bas (Lille: Imprimerie L. Danel, 1934). 
Gachard, M., Collection des voyages des souverains des Pays-Bas. Tom. 2, Itinéraire de Charles-Quint de 1506 à 1531. Journal des voyages de Charles-Quint, de 1514 à 1551 par Jean de Vandenesse (Brussels: F. Hayez, 1874).

Quinsonas, E., le Comte de. Materiaux pour servir à l'histoire de Marguerite d'Autriche, duchesse de Savoie, regente des Pays-Bas, 3 vols (Parijs: Delaroque Frères, 1860).

Stecher, J., Oeuvres de Jean Lemaire de Belges, 4 vols (Leuven: Imprimerie Lefever Frères et Soeur, 1891).

\section{Secondary sources}

Arnade, P., 'State, and Public Ritual in the Late-Medieval Burgundian Netherlands', Comparative Studies in Society and History 39, no. 2 (1997), 300-318.

Attreed, L., 'Gender, Patronage, and Diplomacy in the Early Career of Margaret of Austria (1480-1530)', Mediterranean Studies 20, no. 1 (2012), 3-27.

Augustyn, B., 'Staten van Brabant', in De gewestelijke en lokale overheidsinstellingen in Brabant en Mechelen tot 1795, ed. by R. van Uytven, C. Bruneel, H. Coppens and B. Augustyn (Brussel: Algemeen Rijksarchief, 2000), pp. 97-134.

Blockmans, W., 'Court and City, a Tense Relation in the Burgundian Netherlands', in Städtisches Bürgertum und Hofgesellschaft. Kulturen Intergrativer und Konkurierender Beziehungen in Residenz- und Hauptstädten vom 14. Bis ins 19. Jahrhundert, ed. by J. Hirschbiegel, W. Paravicini and J. Wettlaufer (Ostfildern: Jan Thorbecke Verlag, 2012), pp. 71-79.

Blockmans, W., 'Margareta van York de subtiele invloed van een hertogin', in Dames met klasse. Margareta van York. Margareta van Oostenrijk., ed. by Dagmar Eichberger (Leuven: Davidsfonds, 2005), pp. 43-48.

Blondé, B., and M. Limberger, 'De gebroken welvaart', in Geschiedenis van Brabant. Van het hertogdom tot heden, ed. by R. van Uytven, C. Bruneel, A.M. Koldeweij, A.W.F.M. van de Sande and J.A.F.M. van Oudheusden (Leuven: Waanders Uitgevers/Davidsfonds, 2008), pp. 307-330.

Boucheron, P., D. Menjot and P. Monnet, 'Formes d'émergence, d'affirmation et de déclin des capitales: Rapport introductif'. Paper presented at the Les villes capitales au Moyen Âge, XXXVI ${ }^{\mathrm{e}}$ Congrès de la SHMES, Istanbul, 2005.

Bove, B., 'Habiter la ville. Paris et la noblesse de cour au XIV siècle.' Université de Paris 1 - Panthéon Sorbonne, 2018.

Buylaert, F., 'From Periphery to Centre and Back Again: Elite Transformations in Mechelen (Fourteenth to Sixteenth Centuries)', Urban History 47, no. 4 (2019), 610-631. Clauzel, D., 'Le roi, le prince et la ville: L'enjeu des réformes financières à lille à la fin du moyen âge', in Finances et financiers des princes et des villes à l'époque bourguignonne, ed. by J.M. Cauchies (Turnhout: Brepols, 2004), pp. 41-62. 
Crawford, K., 'Catherine de Médicis and the Performance of Political Motherhood', The Sixteenth Century Journal 31, no. 3 (2000), 643-673.

Damen, M., 'The Town as a Stage? Urban Space and Tournaments in Late Medieval Brussels', Urban History 43, no. 1 (2016), 47-71.

De Jonge, K., 'Bourgondische residenties in het graafschap Vlaanderen' Handelingen der Maatschappij voor Geschiedenis en Oudheidkunde te Gent 54, no. 29 (2000), 93-134.

De Jonge, K., 'De voornaamste residenties in Mechelen. Het hof van Kamerijk en het hof van Savoyen', in Dames met klasse. Margareta van York-Margareta van Oostenrijk, ed. by Dagmar Eichberger (Leuven: Davidsfonds, 2005), pp. 56-66.

Duerloo, L., 'Archducal Piety and Habsburg Power', in Albert \& Isabella 1598-1621, ed. by W. Thomas and L. Duerloo (Turnhout: Brepols, 1998), pp. 267-279.

Earenfight, T., 'Without the Persona of the Prince: Kings, Queens and the Idea of Monarchy in Late Medieval Europe', Gender \& History 19, no. 1 (2007), 1-21.

Eichberger, Dagmar, 'A Cultural Center in the Southern Netherlands: The Court of Margaret of Austria (1480-1530) in Mechelen', in Princes and Princely Culture, 1450-1650, ed. by M. Gosman, A. Macdonald and A. Vanderjagt, 2 vols (Leiden/ Boston: Brill, 2003), vol. 1, pp. 239-258.

Elden, S. The Birth of Territory (Chicago: University of Chicago Press, 2013).

Elliott, J.H., 'A Europe of Composite Monarchies', Past \& Present 137 (1992), 48-71.

Gorter-van Royen, L.V.G., 'De regentessen van Karel V in de Nederlanden. Beeld en werkelijkheid', Tijdschrift voor Geschiedenis 110 (1997), 169-197.

Gorter-van Royen, L.V.G., Maria van Hongarije, regentes der Nederlanden. Een politieke analyse op basis van haar regentschapsordonnanties en correspondentie met Karel V(Hilversum: Verloren, 1995).

Haemers, J., De strijd om het regentschap over Filips de Schone. Opstand, facties en geweld in Brugge, Gent en Ieper (1482-1488) (Gent: Academia Press, 2014).

Janssens, P., 'Vorstelijk hof (15 eeuw-1794)', in De centrale overheidsinstellingen van de Habsburgse Nederlanden (1482-1795), ed. by E. Aerts, M. Baelde, H. Coppens, H. De Schepper, H. Soly, A.K.L. Thijs and K. Van Honacker (Brussel: Algemeen Rijksarchief, 1994), pp. 163-171.

Kerkhoff, J., Maria van Hongarije en haar hof (1505-1558). Tot plichtsbetrachting uitverkoren (Hilversum: Verloren, 2008).

Koenigsberger, H.G., Monarchies, States Generals and Parliaments: The Netherlands in the Fifteenth and Sixteenth Centuries (Cambridge: Cambridge University Press, 2001).

Ormrod, W.M., 'Competing Capitals? York and London in the Fourteenth Century', in Courts and Regions in Medieval Europe, ed. by S. Rees Jones, R. Marks and A.J. Minnis (Woodbridge: York Medieval Press, 200o), pp. 75-98. 
Paravicini, W., 'Die Residenzen der Herzöge von Burgund, 1363-1477', in Fürstlichen Residenze im spätmittelalterlichen Europa, ed. by W. Paravicini and H. Patze. Vorträge un Forschungen (Sigmaringen: Jan Thorbecke Verlag, 1991), pp. 207-250.

Paravicini, W., and J.M. Le Gall, 'Conclusions: Paris, la cour et la ville', in Paris, ville de cour $\left(X I I I^{e}-X V I I{ }^{e}\right.$ siècle), ed. by B. Bove, M. Gaude-Ferrague and C. Michon (Rennes: Presses universitaires de Rennes, 2017), pp. 333-358.

Parker, G., Emperor: A New Life of Charles V(New Haven/London: Yale University Press, 2019).

Pirenne, H., 'Van het begin der XIV eeuw tot den dood van Karel den Stoute', trans. by R. Delbecq. In Geschiedenis van België (Gent: Samenwerkende maatschappij volksdrukkerij, 1932).

Prevenier, W., 'Mechelen rond 1500. Een kosmopolitische biotoop voor elites en non-conformisten', in Dames met klasse. Margareta van York - Margareta van Oostenrijk, ed. by Dagmar Eichberger (Leuven: Davidsfonds, 2005), pp. 31-41.

Smolar-Meynart, A., 'De grands travaux dans un contexte politique difficile (1452-1459). La Aula Magna du palais de Philippe le Bon édifiée par la ville de Bruxelles', in Mélanges offerts à Claire Dickstein-Bernard, ed. by P. Bonenfant and P. Cockshaw (Brussels: Annales de la Société royale d'Archéologie de Bruxelles, 1999), pp. 377-397.

Stein, R., De hertog en zijn staten: De eenwording van de Bourgondische Nederlanden, ca. 1380-148o (Hilversum: Verloren, 2014).

Tilly, C., 'Entanglements of European Cities and States', in Cities and the Rise of States in Europe, A.D. 1000 to 1800 , ed. by C. Tilly and W. Blockmans (Boulder/ San Francisco/Oxford: Westview Press, 1989), pp. 1-27.

Uyttebrouck, A., 'Les résidences des ducs de Brabant 1355-1430', in Fürstliche Residenzen im spätmittelalterlichen Europa, ed. by W. Paravicini and H. Patze (Sigmaringen: Jan Thorbecke Verlag, 1991), pp. 189-205.

Van Bruane, A.-L., 'The Habsburg Theatre State: Court, City and the Performance of Identity in the Early Modern Southern Low Countries', in Networks, Regions and Nations: Shaping Identities in the Low Countries, 1300-1650, ed. by R. Stein and J. Pollmann (Leiden/Boston: Brill, 2010), pp. 132-149.

Van Uytven, R., 'De triomf van Antwerpen en de grote steden', in Geschiedenis van Brabant. Van het hertogdom tot heden, ed. by R. van Uytven, C. Bruneel, A.M. Koldeweij, A.W.F.M. van de Sande and J.A.F.M. van Oudheusden (Leuven: Davidsfonds, 2008), pp. 241-252.

Vermeir, R., 'Les gouverneurs-généraux aux Pays-Bas habsbourgeois', in A la place du roi: Vice-rois, gouverneurs et ambassadeurs dans les monarchies françaises et espagnoles (XVI ${ }^{e}$-XVIII $I^{e}$ siècles), ed. by D. Aznar, G. Hanotin and N.F. May (Madrid: Casa de Velázquez, 2014), pp. 17-33. 


\section{About the author}

Yannick De Meulder is a PhD candidate at the Centre for Urban History of the University of Antwerp. His main interest is in the social and economic relationships between cities and courts in the early modern Low Countries. 



\section{Part 3}

\section{The Representation of Territory}

Damen, M. and K. Overlaet (eds.), Constructing and Representing Territory in Late Medieval and Early Modern Europe. Amsterdam: Amsterdam University Press, 2022 DOI 10.5117/9789463726139_CHO9 


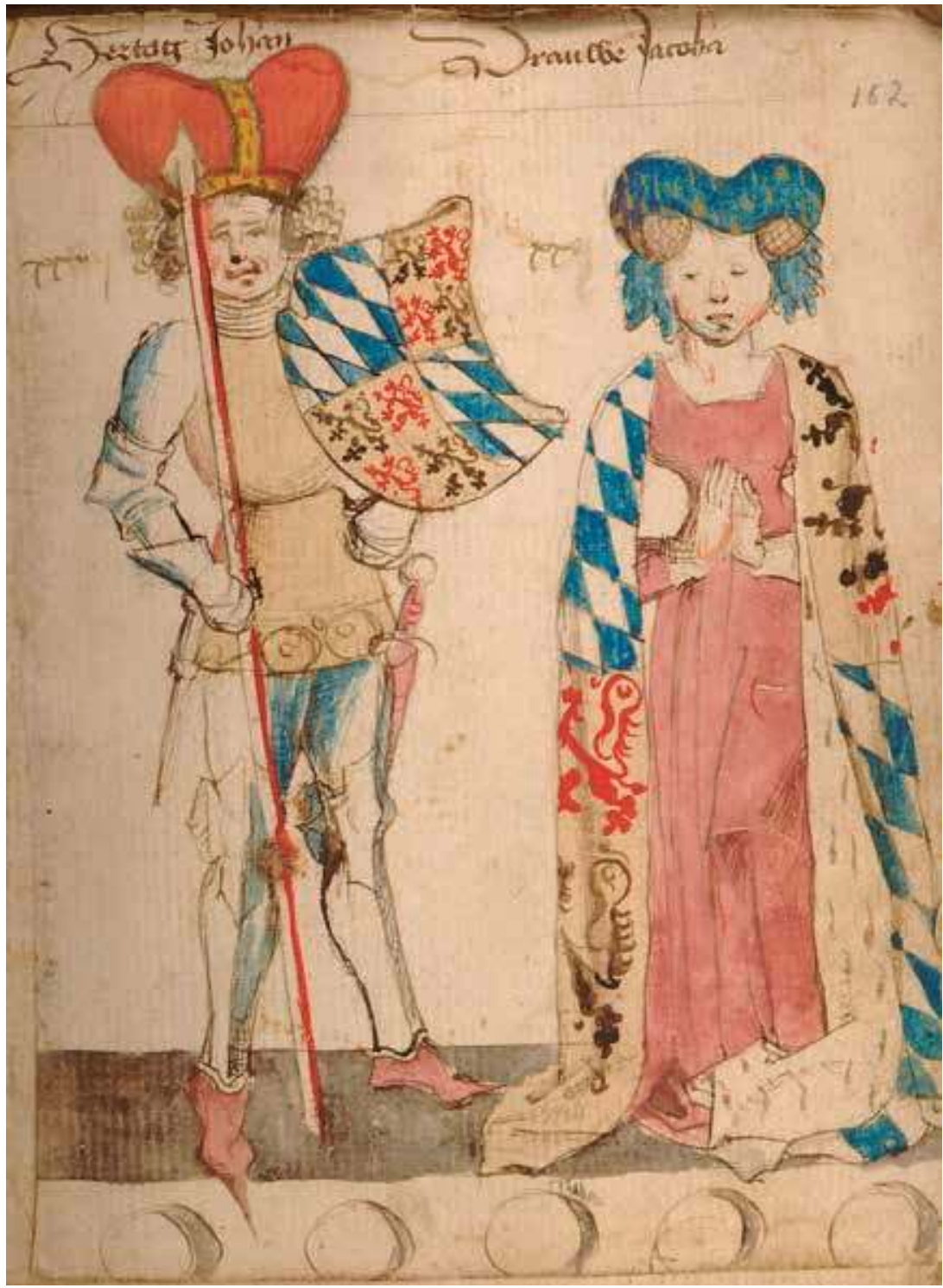

Fig. 9.1. Jan of Bavaria, uncle of Willem VI, and Jacoba of Bavaria. Taken from the series of the counts of Holland and Zeeland which the herald Hendrik van Heessel painted after the series in the chapel of the Binnenhof. Note the coat of arms as an identifier and the arms (lance and dagger) held by Jan. Source: Hendrik van Heessel, Wapenboek, B 89420 fol. 162r, Collectie Stad Antwerpen, Erfgoedbibliotheek Hendrik Conscience. Photograph via Flandrica.be, provided under a CC BY-NC 2.0 license. 


\title{
9. Heraldry and Territory: Coats of Arms and the Representation and Construction of Authority in Space
}

\author{
Mario Damen and Marcus Meer
}

\begin{abstract}
In this chapter we analyse coats of arms as a powerful and versatile tool of late medieval communication. We explore how territorial titles and claims of kings, princes, nobles, and urban elites alike were translated into heraldic signs and communicated to socially diverse audiences. The ubiquity of territorial heraldry is demonstrated in manuscript sources, including armorials, chronicles, illuminations and account books, as well as for visual and material sources such as heraldically decorated objects such as banners, painted walls, and stained glass in town halls, churches, and noble palaces. We examine the interplay of heraldry and territory in its textual, visual, material, and performative dimensions in order to show how heraldic communication was used to represent and (re)construct complex territorial structures in the Late Middle Ages.
\end{abstract}

Keywords: armorials; chronicles; material culture; Holy Roman Empire; Burgundian Low Countries

In January 1470, Jehan Hennequart, painter and valet to Charles the Bold, duke of Burgundy (r. 1467-1477), carved two figures destined for the chapel of the ducal residence in The Hague. The first figure represented Charles's father, the late Philip the Good (r. 1419-1467), and the second represented the late Willem VI, count of Holland (r. 1404-1417). Both men were shown 'ready to fight on the battlefield': Philip was armed with a battle axe and a dagger while Willem carried a lance (Fig. 9.1). They must have been easily recognisable to late medieval observers, since each held a shield painted with his coat of arms. But the painter also added several other heraldic signs which conveyed yet more information: next to Philip the Good, Hennequart painted

1 We would like to thank Wim van Anrooij, Elmar Hofman, and Werner Paravicini for their comments on an earlier version of this chapter. 
a small panel quartering the coats of arms of the duke's grandparents, juxtaposed with a larger panel comprising the seventeen coats of arms of Philip the Good's duchies, counties, and lordships. ${ }^{2}$ This latter arrangement was, notably, not an exact heraldic survey of all Burgundian lands and lordships. Rather, it was a visual shorthand, summarising the extensive patchwork of principalities under ducal rule, not all of which resulted from 'natural' inheritance. ${ }^{3}$

Like so many late medieval kings and princes, the dukes of Burgundy were keen to keep alive the memory of their forebears. They constantly commissioned tombs, stained glass, and statues or figurines of their predecessors in chapels and churches in towns like Lille, Ghent, Brussels, Mons, and The Hague. They also created a monumental burial place dedicated to their dynasty at the Carthusian monastery of Champmol near Dijon. ${ }^{4}$ It was crucial for the dukes to underline their genealogical connection to their predecessors in this way, since so many claims of legitimacy in the Middle Ages rested on the natural line of succession by means of which the dynasty had acquired its possessions. ${ }^{5}$ However, in the case of the burial chapel in The Hague, the heraldically portrayed succession was not at all 'natural'. The four heraldic quarters of Philip the Good, representing his four grandparents, indicated a clear line to the house of Bavaria, the former rulers of the county of Holland. Philip's mother was Margaret of Bavaria, daughter of Duke Albert (r. 1358-1404) and sister of Count Willem VI. But despite this apparently unambiguous genealogical descent, the incorporation of the county of Holland and that of Zeeland into the Burgundian composite state in 1433 was the result of political manipulation, intrigues, and warfare. None of these struggles are remembered in the princely chapel. Here, Philip the Good used coats of arms to connect his dynasty firmly and unequivocally to the principalities it had gained in the past.

As this example would suggest, and as we will argue in the remainder of this chapter, heraldry was extremely useful for the communication of princely claims to territory. Of course, a princely chapel was a highly exclusive space with restricted access, so the audience of this specific heraldic configuration was likely rather limited socially. But how did

2 Greve, Comptes de l'argentier, no. 2140: 'prest pour combatre et faire le champ d'armes'. See also Van Egmond, 'Opgetekend', pp. 43-44.

3 Stein, 'Seventeen'.

4 Lindquist, Agency.

5 Holladay, Genealogy; Andenna and Melville, Idoneität-Genealogie - Legitimation. 
heraldry relate to the construction and representation of territory in the Middle Ages more generally? To answer this question, it is essential to understand 'territory' not as a given, but as the outcome of a rather complex process. Stuart Elden characterises territory as the political notion of space, a 'political technology' even. In Elden's view, territory is more than simply a bounded or enclosed area: it includes both the politico-economic connotation (land) and the politico-strategic connotation (terrain), but at the same time it involves the management of space through a variety of policies and techniques. To analyse the notion of territory in any historical setting, it is therefore important to look at territorial practices - 'practices that relate politics or power to place' - and representations of territory in concert. ${ }^{6}$ In this chapter, we will argue that heraldry was an important part of such practices in late medieval Europe. Territorial titles and claims of kings, princes, nobles, and urban elites alike were translated into and communicated by means of heraldry in a wide range of media (e.g. seals, manuscripts, tombs, gates, etc.). Over time, the signs themselves obtained territorial connotations and began to represent territories or claims to space, just as their material expressions were consciously placed in spaces to reflect or establish claims to authority over territories. In short, just as coats of arms were represented in space, they came to represent space, adding meaning(s) to both the direct physical environment in which they were placed and the larger territorial space they symbolised. ${ }^{7}$

This chapter focuses primarily, but not exclusively, on cities and principalities situated in the Burgundian Low Countries and the Holy Roman Empire. In these politically fragmented areas, urban influence was relatively strong, with princely and imperial authority being contested continuously. ${ }^{8}$ We will study the interplay of heraldry and territory in various media to analyse how coats of arms were used to represent and (re)construct authority in complex territorial structures. Starting with the heraldic signs themselves, this chapter will show that coats of arms acquired noticeably territorial associations over the course of the Middle Ages. These associations were represented and reinforced in manuscripts, for example: armorials compiled and structured coats of arms in relation

6 Elden, The Birth, pp. 10-18; Elden, 'How Should We Do the History of Territory?', pp. 14-15.

7 We are indebted here to Henry Lefebvre's triad of spatial practices, representations of space and spaces of representation; see Lefebvre, Production of Space, pp. 31-33.

8 Reynolds, Kingdoms and Commmunities, esp. pp. xxii-lxiii; Dumolyn and Haemers, 'Urban Rebellion'; Johanek, 'Free Towns'. 
to space, whilst narrative sources such as chronicles, too, related coats of arms to territorial entities. The same territorial dimension of heraldry found its expression in material culture. Painted walls, carved stones, and stained glass in noble palaces, churches, and town halls, for instance, show how extensive arrangements of heraldic signs evoked notions of territory, demarcating dedicated spaces or representing diverse territorial structures. Such displays were not necessarily permanent in nature, but were also created specifically for temporary occasions such as Joyous Entries. This ephemeral side to the relation of heraldry in territory is best seen in conflicts prompted by heraldic displays meant to establish claims to authority. Thus, this chapter also highlights the performative character of heraldic communication, suggesting that awareness of such signs and their territorial implications existed throughout all layers of late medieval society.

\section{What's in a shield? Coats of arms and territories}

There is no lack of interest in the territorial dimensions of coats of arms on the part of established heraldists. ${ }^{9}$ On the one hand, this interest can be linked to astonishing modern continuities: many coats of arms still in use today are territorial in nature, identifying districts, regions, and even states on official flags and government documents, or embellishing local products and tourist merchandise. On the other hand, this interest is the result of a contradiction that requires explanation: the territorial perception of heraldry seems to defy the oft-repeated opinion that coats of arms 'proper' emerged in the twelfth century as, first and foremost, steady and soon hereditary personal identifiers of fighting noblemen, before they were also adopted by non-noble persons such as townsmen and even peasants, just as corporate bodies (e.g. monasteries, cities, guilds) began to create heraldic signs for themselves. ${ }^{10}$ However, as scholarship on the place of heraldry in medieval society stresses, any coat of arms was a highly polyvalent sign, far

9 Sutter, 'Landeswappen'; Adam-Even, 'Armoiries territoriales'; Hye, 'Programmatische Polit-Heraldik'.

10 For important additions to the narrative set out in the 'textbooks' cited below, n. 76 , see also Hablot, 'Entre pratique militaire'; Nieus, 'L'invention'; Pinoteau, Les armoiries non nobles. 


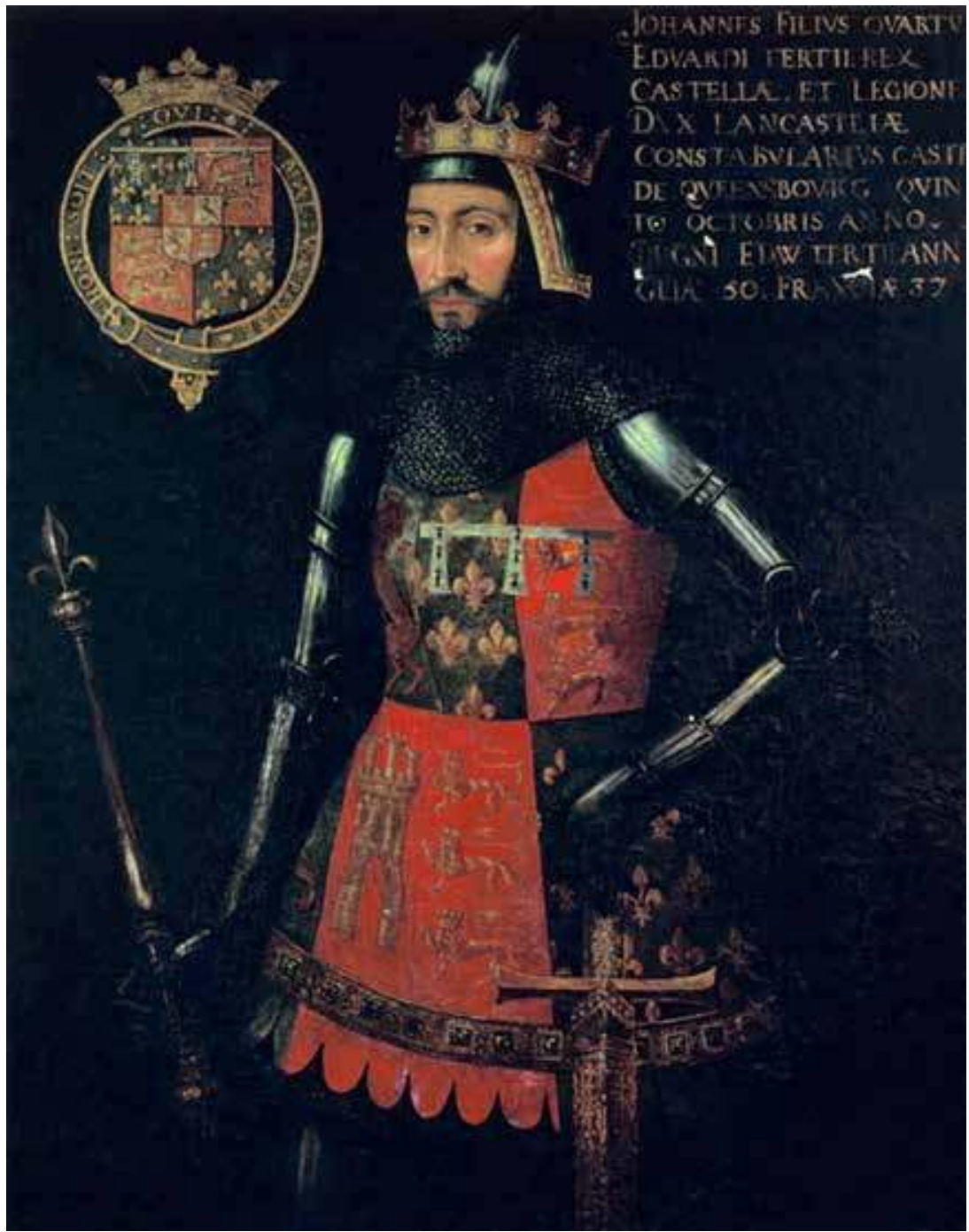

Fig. 9.2. Late-sixteenth-century painting of John of Gaunt, showing the English royal arms with the label of a third son and an inescutcheon of pretence with the arms of Castile and Leon. Source: Public domain material, printed in Armitage-Smith, John of Gaunt, p. 100.

from restricted to a unidimensional role as the visible marker of a person and their dynasty or an institution and its continuity. ${ }^{11}$

As heraldic scholar Paul Adam-Even suggested, there were territorial dimensions to coats of arms as well, potentially even before they became the

11 Hablot, 'Heraldic Imagery'; Paravicini, ‘Gruppe und Person'. For more recent studies from the perspective of cultural history, see also below, n. 77 . 
shared visual inheritance of medieval dynasties. According to Adam-Even, initially twelfth- and thirteenth-century lords had their bannerets and vassals, who were tied to their land, display their lordly heraldry, often on banners, on the battlefield, so that these symbols became firmly associated with the fiefs that provided - literally - the ground for these feudal bonds. As a result, arms gradually became associated with the land and eventually remained unchanged even when the lord in control of a fief changed. The new lord often adopted the arms of his fief and its land, combining them with his inherited arms or abandoning his accustomed arms altogether in favour of the territorial arms. ${ }^{12}$

The most frequent simultaneous transmission of arms and territories appeared in the context of inheritance. Many lords chose to visualise the inheritance of another significant possession by adopting the arms associated with the new land's former lord. This approach resulted in often complex combinations of multiple coats of arms in a single shield, since the new owners were usually keen to show the full extent of their possessions by means of heraldry. ${ }^{13}$ This 'marshalling' of two or more coats of arms resulted in the famous arms of the Kingdom of Castile and Leon, for example. When Ferdinand III (r. 1217-1252) inherited the two formerly independent kingdoms in 1230, he united them both politically and heraldically. ${ }^{14}$ The royal arms of Castile and Leon also illustrate the importance of women for heraldic and territorial inheritance: once John of Gaunt, duke of Lancaster (r. 1362-1399), married his second wife, Constance, daughter of King Peter I of Castile and Leon (r. 1350-1369), in 1371, he felt entitled to claim the kingdom of Castile and Leon, combining his own arms with the royal arms of Castile and Leon by adding an inescutcheon of pretence to his coat of arms (Fig. 9.2). ${ }^{15}$ As this example shows, heraldry was a shared phenomenon of late medieval culture which enabled kings and princes across Europe to combine representations of their territories even when separated by long distances. Heiresses played a key role in this process, since they passed on their entire patrimony - lands, titles, and arms - to their husbands, who often chose to show this appropriation by combining their wives' heraldry with their own. ${ }^{16}$

Adam-Even, 'Armoiries territoriales', pp. 81-85.

13 Coss, 'Knighthood, Heraldry and Social Exclusion', p. 6o. See International Congress of Genealogical and Heraldic Sciences, Les combinaisons.

14 Menéndez Pidal de Navascués, 'El nacimiento'; Woodcock and Robinson, The Oxford Guide, p. 26.

15 Goodman, John of Gaunt, pp. 134-136.

16 Chassel, 'Le nom et les armes'; Nassiet, 'Nom et blason'. 


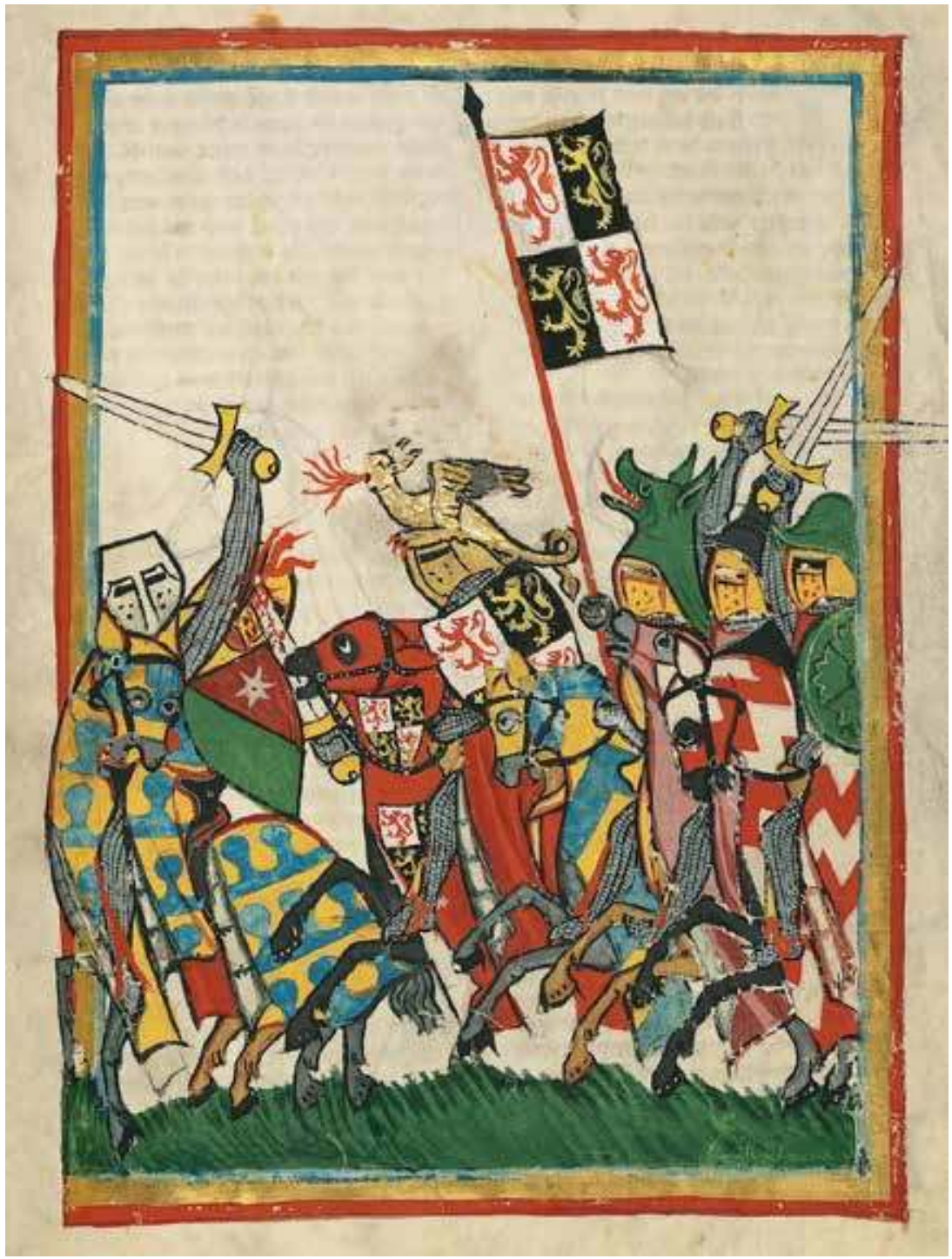

Fig. 9.3. Jan I of Brabant with the quartered coat of arms of Brabant and Limbourg in the Codex Manesse (c. 1300-1340). Source: Universitätsbibliothek Heidelberg, Cod. Pal. germ. 848, fol. 18r. Public domain material, provided by Universitätsbibliothek Heidelberg.

If a land-holding lineage died out, their fiefs reverted to the ruler, who was authorised to grant these to a new vassal (or new vassals). Repeatedly, this acquisition of land by investiture was accompanied by the acquisition of the coat of arms of the now extinct family. ${ }^{17}$ In this context of investiture, 
banners and the coats of arms they displayed were highly significant. In the Holy Roman Empire, banners provided the symbolic means of princely investiture, indicating the prince's ability to summon his vassals for war. ${ }^{18}$ Although their iconography usually predated the advent of heraldry and was thus not necessarily heraldic in appearance, throughout the Late Middle Ages the arms of noble dynasties became more frequently displayed on banners and thus associated with the transferred territory. ${ }^{19} \mathrm{Of}$ course, banners also served as a 'visual focus for troops' morale and cohesion' in battle. ${ }^{20}$ Precisely because banners were thus at the heart of warfare as the raison d'être of feudal relations, they and the arms they showed must have come to be seen as more abstract symbols for such ties as well.

Warfare itself was a common way of acquiring land and its associated arms in medieval Europe. In 1288, Jan I, duke of Brabant (r. 1267-1294), conquered the Duchy of Limbourg after the Battle of Woeringen. On a well-known miniature from the Manesse codex (c. 1300-1340, see Fig. 9.3), he is depicted carrying a banner with the quartered arms of Brabant and Limbourg. Interestingly, it was only his son Jan II who would bear this quartered coat of arms with the heraldic lions of Brabant and Limbourg from 1298 onwards, as seals of Jan I and Jan II show. However, more than a century later, in 1415, the chronicler Henne van Merchtenen wrote that Jan I, 'who won the rich land of Limbourg [...] in the manner of a brave prince', personally quartered his coat of arms after he 'destroyed the castle of Woeringen'. This 'predating' of the unity of Brabant and Limbourg, implied by their heraldic unification, served as a seemingly historically grounded claim to the duchy, presented to both the wider public and princely competitors as an argument against any challenge to the allegedly long-established rights of the duke. ${ }^{21}$

The ruler's subjects, particularly those in towns, were sometimes themselves keen to ensure an appropriate heraldic representation of 'their' territory in their ruler's coat of arms, as in the case of the Burgundian composite state. On the succession of Philip the Good to the ducal throne of Brabant in 1430, the Estates of the duchy made the prince promise to 'adopt the titles and arms of Lotharingia, Brabant, Limbourg, and of margrave of the Holy Roman Empire, as was appropriate. ${ }^{22}$ Subsequently,

18 Schramm, 'Fahnen', esp. pp. 650-651. See also Ailes, Royal Arms, pp. 24-25.

19 Seyler, Geschichte der Heraldik, p. 281; Gritzner, 'Heraldik', p. 72; Damen, 'Heren met banieren'.

20 Jones, “What Banner Thine?”, p. 106. See also Crouch, Tournament, pp. 75-76; Contamine, La noblesse, pp. 82-83.

21 Van Anrooij, 'Duitse lof', p. 132; Avonds, Koning Artur, pp. 73-76.

22 Vrancken, Blijde Inkomsten, p. 313: 'Item geloven wij hen dat wij aennemen soelen den titel ende wapenen van Lothrijck, van Brabant, van Lymborch ende marcgreve des heilichs rijcs also 
Philip quartered his arms of Burgundy with the golden lion on a black field (Brabant), and the red lion on a silver field (Limbourg). However, although Philip the Good acquired more principalities in the 1430s, Holland and Zeeland for example, he did not change his coat of arms again. The same applies to Charles the Bold, who maintained his father's arms even after he had acquired another two duchies. Perhaps the dukes did not want to divide their personal coat of arms into smaller parts for reasons of visibility and recognizability. ${ }^{23}$

The most mundane procedure to express the link between heraldry and territory was the purchase of land and the use of the associated arms. Thus, the Leuchtenberg landgraves Louis (r. 1463-1487) and Frederick (r. 1463-1486) sold the county of Hals in 1486 alongside the coat of arms that had once belonged to the long extinct counts of Hals. ${ }^{24}$ Just how matter of course this practice must have been is further demonstrated by legal provisions that created explicit exceptions: when Duke Albert of Mecklenburg (r. 1348-1379) had purchased the county of Schwerin from Count Nicholas of Schwerin and Tecklenburg, the charter emphasised that the count and his son preserved their right 'to use the arms of the county of Schwerin as before.. 25

\section{Territories in armorials and chronicles}

One place in which such connections between coats of arms and territories were created, preserved and reinforced, visually and textually, are manuscripts. A prime example for the heraldic wealth of these sources is the late-fourteenth-century Chronicle of the Ninety-Five Austrian Lordships. Written for the house of Habsburg, the chronicler combined a history of Austria with extensive heraldic displays when setting out the succession of legendary predecessors of the land's former rulers, all the way back to Abraham. In this effort, the text also implies an association of heraldry with Austria's territory. Initially, the chronicle describes and depicts 'how often the land's arms have changed' as new houses established their rule. Eventually, however, the various arms of Austrian rulers of

dat behoirt.'

23 Stroo, De celebratie, p. 107.

24 Hefner, Altbayerische Heraldik, p. 111; Brunner, Die Grafen von Hals, p. 55, n. 12.

25 Lisch, 'Urkunde', p. 202: 'Vortmer so moghen de vorbenomeden greuen bruken der wapene der greueschop van Zwerin na alse vore.' See also Hauptmann, Wappenrecht, p. 427. 


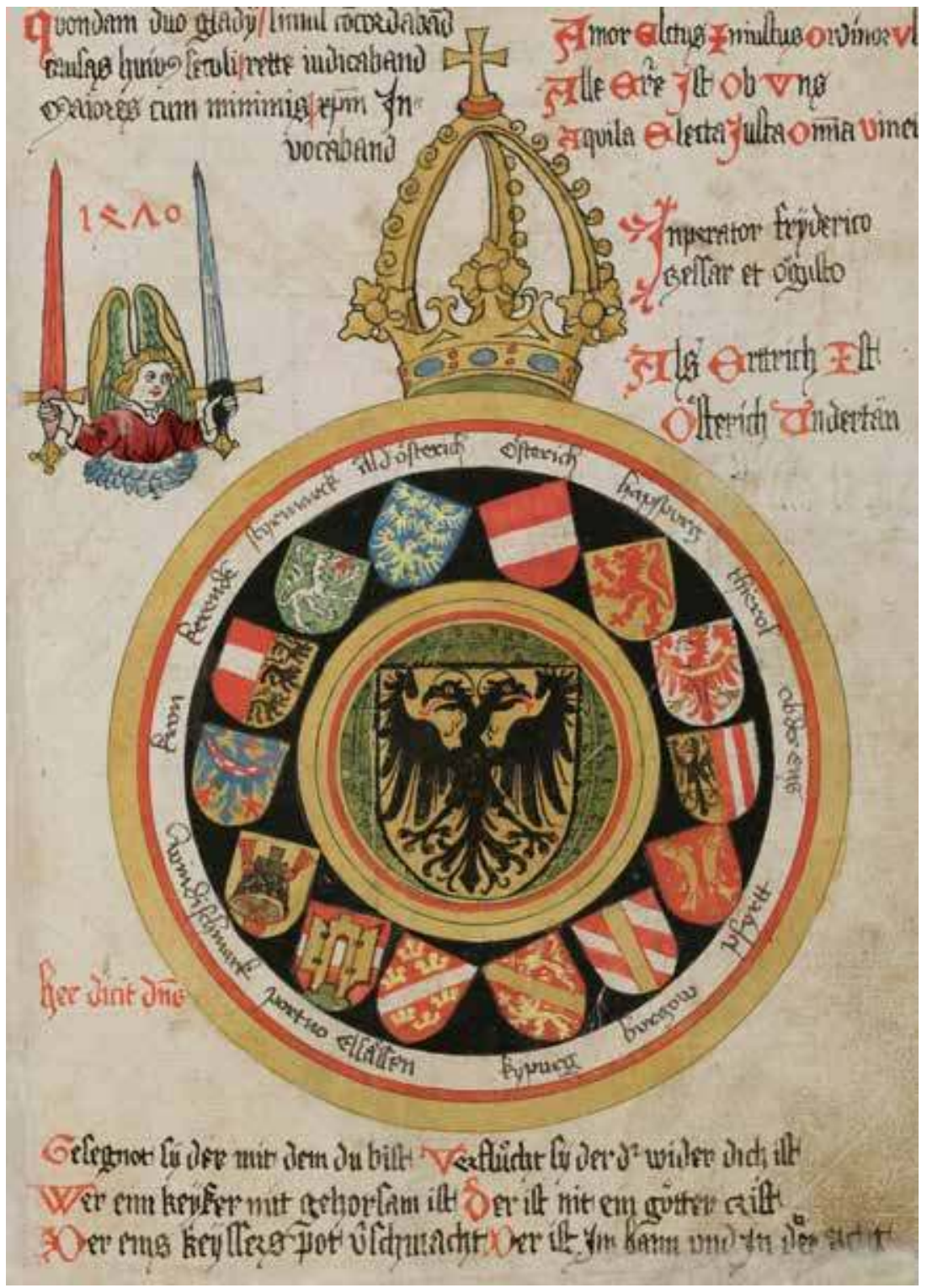

Fig. 9.4. Illumination dedicated to Emperor Frederick III, showing the arms of Habsburgian territories around a shield of the imperial arms in the centre of the folio, in the fifteenth-century Haggenberg armorial. Source: St Gall, Stiftsbibliothek, Cod. Sang. 1084, p. 40. Photograph via e-codices, provided under a CC BY-NC 4.0 license. 
old were replaced with the arms of the house of Habsburg, whose shield, the chronicler's efforts seem to suggest, was to become the ultimate sign of the Austrian lands. ${ }^{26}$

The Habsburg arms later found their way into a conspicuous heraldic arrangement in the so-called Haggenberg armorial (c. 1488), which pays homage to Emperor Frederick III (r. 1440-1493) with a splendorous heraldic illumination (Fig. 9.4). Unlike other depictions of the imperial arms accompanied by the Reichsquaternionen ${ }^{27}$ - a heraldic representation of the Holy Roman Empire's structure - the illumination in the Haggenberg armorial focuses on the various possessions of the house of Habsburg, represented by their arms grouped in a circle around Frederick and the imperial arms. ${ }^{28}$ These circular heraldic representations later received a larger audience when they were incorporated in panels featuring Charles V (r. 1506-1555), made for the town hall of Mechelen in 1517-1518 by Jan van Battel, and again after his coronation as emperor in 1519. In these configurations the coats of arms surrounding the figure of Charles represented his Spanish territories, which he had formally acquired upon his coronation after the death of his grandfather Ferdinand II of Aragon (r. 1479-1516). ${ }^{29}$

Medieval armorials were a frequent place for the visual demonstration of such possessions. As most recently Elmar Hofman's doctoral thesis shows, these manuscripts were far from simple collections of coats of arms, but instead carefully curated to serve very different purposes, one of which was to 'map' the territories of a region or indeed the world at large, compiling both real and attributed coats of arms with territorial associations. ${ }^{30}$ The structure of armorials is often based on the so-called marches d'armes, territorial units going back to the times of Charlemagne, according to a tournament treatise by the French writer Antoine de La Sale (c. 1385-c. 1460). La Sale states that this ruler was the founder of the two original marches d'armes, 'who in arms and tournaments are called' Ruyers and Poyers, separated by the river Rhine. Later, other emperors and kings, La Sale claimed, created new marches within and outside their territories. For the

26 Seemüller, Chronik, pp. 24-25: 'Nu chüm ich besunderleich auf das edel land ze Österreich, wie lang des sey, das der erst mensch ist chömen in daz lande, [...] und wie offt sich des landes wappen haben vercheret.' See also Hagemann, Geschichtsfiktion, esp. p. 157.

27 On the Reichsquaternionen, see also below, p. 263.

28 Gull, 'Haggenberg', p. 4; Stiftsbibliothek, St Gall, Cod. Sang. 1084, p. 48. On similarly concentric heraldic arrangements, see Kremb, 'Wappentafeln', esp. pp. 14-20. See also Hofman, 'Armorials', chap. 6.2.1.3.

29 Kruip, 'Jan van Battel', pp. 121-123.

30 Hofman, 'Armorials'. See also Hiltmann, 'Potentialities'; Huthwelker, 'Ordnung'. 


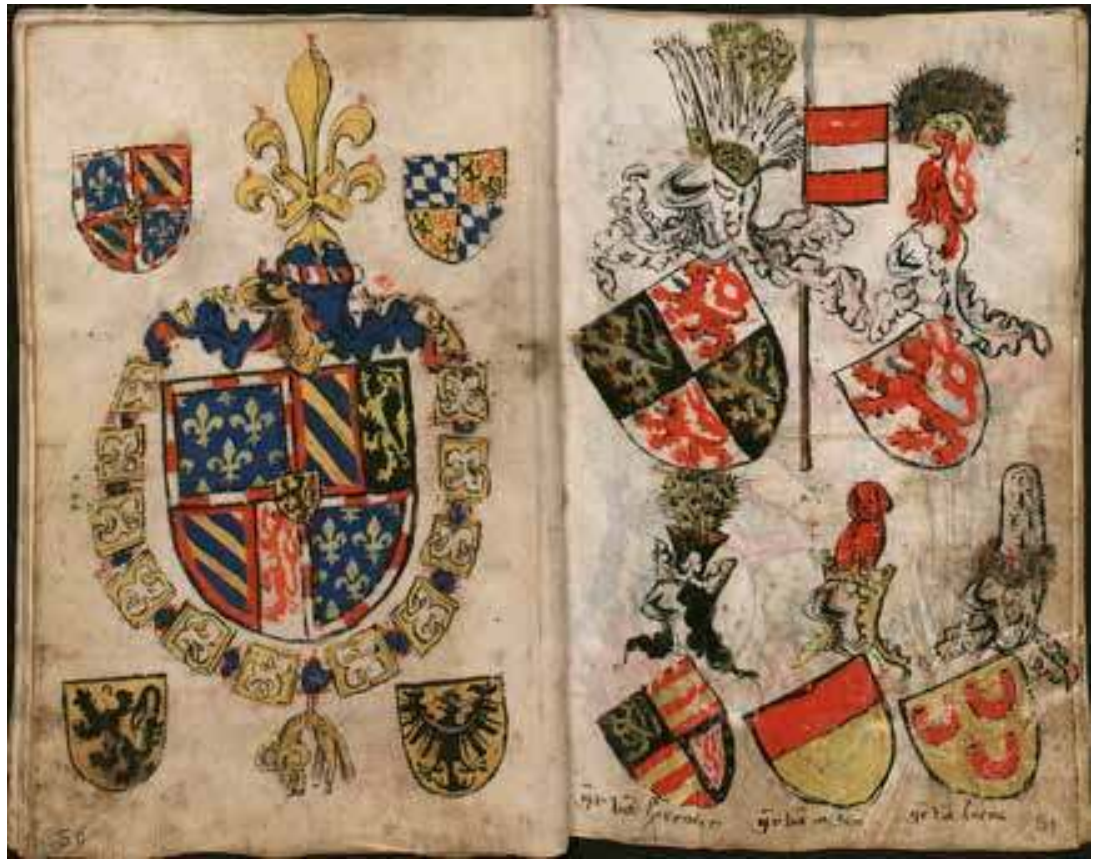

Fig. 9.5. First pages of the marche of Brabant in the Bergshammar armorial. Source: Riksarkivet, Täby, SE/RA/720085/Z.

Empire, he specifically mentioned the alienation of several basses marches on the other side of the Rhine, 'which would be called at tournaments Brabanters, Hainauters, Liegois, Ardenois, Hesbaeyois [...] rather than Poyers'. The French king supposedly also divided the Poyers into three marches: Poyers, Aquitains, and the Champagnois, with several provinces et pays each. Further fragmentation occurred when brothers and children of the king were given duchies and counties, which eventually lead to the creation of another nine marches. ${ }^{31}$

The question whether the term marche d'armes was at all territorial in semantic scope is difficult to answer: even specialists like Michel Pastoureau and Michel Popoff admit that the term is difficult to define. They are of the opinion that a marche d'armes is at the same time a geographical entity (a specific region such as a county, a duchy, or a kingdom) and a feudal entity (a group of fiefs) without any clear boundaries but rather dependent on a variety of rights, homages, and pretensions. ${ }^{32}$ Of course, there is an

31 Lefèvre, Antoine de La Sale, pp. 300-301; Huizinga, 'Ruyers en Poyers', pp. 536-538; Van Anrooij, 'King of Arms', pp. 113-114.

32 Pastoureau and Popoff, L'armorial, pp. 7-8. See also Hiltmann, 'Potentialities', p. 184. 
important disclaimer to be added: the compilers of these armorials were not primarily interested in an exact historical reconstruction of specific marches d'armes. Instead, they created these 'collections' to offer their patron and the courtly audience an overview of the coats of arms used in that marche during a certain period. What is more, they seldom used the word marche in their manuscripts.

Hofman argues that most armorials are characterised by a straightforward representation of principalities rather than a strictly applied survey of marches d'armes in their heraldic sense. ${ }^{33}$ However, our analysis of five armorials compiled between 1280 and 1450 shows that the heraldic representation of the marches d'armes located in the Low Countries underwent changes in their territorial 'framing' (Table 9.1). The politically and economically important principalities of Brabant and Flanders, for example, are integrated in all five armorials, followed by Guelders and Holland. The latter are sometimes combined with Hainaut and/or Zeeland, thus reflecting the personal union of these principalities. In the fifteenth century, Flanders and Brabant became the heart of the Burgundian composite state, and this emerging union is clearly visible in the earlier armorials. That being said, the marches as represented in these armorials are clearly based on personal ties and not on 'land'. The possession of lordships seems to have been the guiding principle of the composition of the marches. The sum of the coats of arms represented the principality as a territory that was constructed on the basis of noble lordships. It was partly a heraldic embodiment of noble space and partly a reflection of the actual possessors of the lordships.

A closer look at the first coat of arms of all these marches, each representing the person supposed to be its leader, shows an interesting change. In the Wijnbergen armorial from c. 1280 , the coats of arms of the counts and dukes are not portrayed as larger than those of bannerets, nobles, and other knights. In this instance, these princes were no more than primi inter pares. This impression is in sharp contrast to the Bellenville and Gelre armorials, both composed in the second half of the fourteenth century. Here, the ducal and comital coats of arms are depicted four times the size of their vassals' shields. In the Bergshammer armorial, made around the middle of the fifteenth century, the composition was yet again different. The arms of Philip the Good (the duke of Brabant) introduce the first page of the marche of Brabant, suggesting that this prince was of a higher rank than his predecessors as duke of Brabant and 
testifying to the changing position of the prince vis-à-vis the nobility (Fig. 9.5).

Table 9.1. Number of coats of arms of different principalities of the Low Countries in armorials ${ }^{34}$

\begin{tabular}{|c|c|c|c|c|c|}
\hline & $\begin{array}{l}\text { Wijnbergen } \\
\text { (c. 1280) }\end{array}$ & $\begin{array}{l}\text { Bellenville } \\
\text { (c. 1380-1390) }\end{array}$ & $\begin{array}{l}\text { Gelre } \\
\text { (c. 1390-1400) }\end{array}$ & $\begin{array}{l}\text { Bergshammer } \\
\text { (c. 1449-1456) }\end{array}$ & $\begin{array}{l}\text { Lyncenich } \\
\text { (c. 1440-1445) }\end{array}$ \\
\hline Artois & 63 & & & 146 & 153 \\
\hline Brabant & 35 & 89 & 102 & 207 & 180 \\
\hline Bourgogne & 86 & & & 68 & 75 \\
\hline Gelre & & 137 & 102 & 116 & 81 \\
\hline Hainaut & 27 & & & 85 & 86 \\
\hline Holland & & & & 89 & 123 \\
\hline $\begin{array}{l}\text { Holland-Zeeland- } \\
\text { Hainaut }\end{array}$ & & 145 & 117 & & \\
\hline Limbourg & & & 9 & 12 & 12 \\
\hline Luxembourg & & & & 39 & 40 \\
\hline Liège & & 22 & 12 & & \\
\hline Namur & & & & 24 & 24 \\
\hline Ponthieu & & & & 39 & \\
\hline Vermandois & 46 & & & 70 & \\
\hline Utrecht & & 46 & 27 & 32 & 31 \\
\hline Flanders & 25 & 83 & 87 & 98 & 126 \\
\hline Zeeland & & & & 31 & 37 \\
\hline
\end{tabular}

Similar to princely chroniclers and heralds using coats of arms to depict the numerous territories of the Burgundian composite state, urban writers, too, explicitly linked their city's heraldic sign to the municipal territory. Firm in the belief that his hometown had been founded as a Roman colony, the Augsburg chronicler Hector Mülich (d. 1490) began his history of the city thus: 'Drusus, a Roman, was the stepson of Emperor Octavian. He built a wall for the city of Augsburg, and he gave it its shield of arms.' ${ }^{35}$ The city's

34 Wijnbergen is still in private ownership. Mario Damen was able to consult it and would like to thank the owners for their permission to do so. For an older 'edition' of the armorial, see Adam-Even and Jéquier, 'L'armorial Wijnbergen'; Bellenville: Pastoureau and Popoff, L'armorial; Gelre: Koninklijke Bibliotheek, Brussels, ms. 15652-56, https://uurl.kbr.be/1733715; Bergshammer: Riksarkivet, Täby, SE/RA/720085/Z, https://sok.riksarkivet.se/bildvisning/Rooo1216_oooo1; Raneke, Berghammarvapenboken; Lyncenich: Koninklijke Bibliotheek, Brussels, ms. II 6567, https://uurl.kbr.be/1734449; Clemmensen, 'The Lyncenich Armorial'.

35 Die Chroniken der schwäbischen Städte, p. 1: 'Item Drusus, ain Römer, was kaiser [...], der ließ dise stat Augspurg ummauren und gab ir das wappen.' 
walls, symbolising Augsburg's urban identity as a community distinct from the rural countryside, were closely linked to the municipal arms as another foundational element of Augsburg's history. The same was achieved visually in a depiction of Augsburg's skyline in Hartmann Schedel's Liber chronicarum (1493), which shows the Augsburg arms above a town gate. ${ }^{36}$ In fact, this chronicle features a considerable number of woodcuts of other late medieval cities (e.g. Cologne, Nuremberg, Metz, Nicea, Padua) which are conspicuously identified by a prominent display of municipal heraldry on their distinctive fortifications. ${ }^{37}$ In chronicles written in the county of Holland in the last decades of the fifteenth century, even the city walls and towers of Troy were adorned with the coat of arms of the counts of Holland, which was supposedly the same as that of their Trojan 'predecessors'. Princes and nobles loved to entertain the idea that they descended from ancient heroes like Hector, whose son Francus was supposed to be the mythical progenitor of the Franks. ${ }^{38}$ Heraldry in manuscripts thus allowed both cities and princes to boast about the ancient roots of their territory and/or their family, connecting their most visible signs to a mythical past.

\section{Material culture}

These textual reference and artistic depictions are representative of the role heraldry played in representing territory in everyday life-how coats of arms 'signed' spaces, as Laurent Hablot puts it. ${ }^{99}$ As Schedel's Liber accurately depicts, coats of arms often featured on the fortifications of pre-modern towns. That the gates of Augsburg, for example, were painted with the municipal arms follows from expenses recorded by the city in $1396{ }^{40}$ Here, they marked the urban territory and put a 'stamp' on the urban defence system; even in an urban context coats of arms thus remained closely connected to the military sphere. But the presence of coats of arms on these sites of urban defence also reinforced the territorial connotations of the signs themselves. After all, town gates provided the central liminal threshold of the fortifications which circumscribed and established an urban space its

36 Bayerische Staatsbibliothek, Munich, Rar. 287, fol. 92r.

37 See also Kreuer, Imago civitatis.

38 Keesman, De eindeloze stad, pp. 181-197, 543-550.

39 Hablot, “'Ubi armae ibi princeps"', esp. pp. 44-45.

40 Kah, Die wahrhaft königliche Stadt, p. 227. For other examples, see also Meer, 'Cities, Citizens, and Their Signs', chap. 4.4.1. 


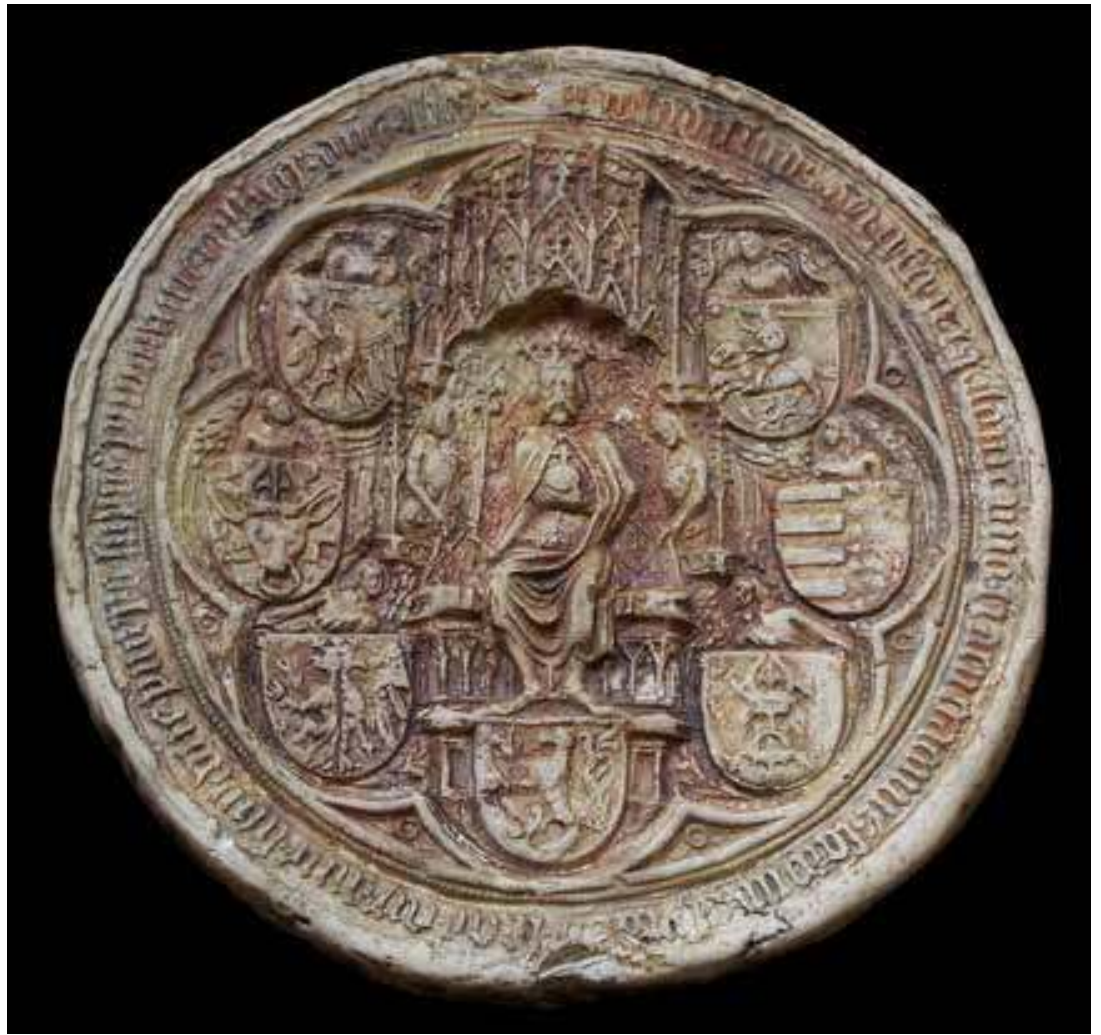

Fig. 9.6. Royal seal of Władysław II Jagiełło (1386), with coats of arms of the Kingdom of Poland's territories set around the figure of the king. Source: Photograph by Jan Mehlich provided under a CC BY-SA 3.0 license via Wikimedia Commons.

inhabitants perceived as fundamentally different from the outside world. ${ }^{41}$ This significance of the urban fortifications also explains why so many municipal coats of arms incorporated these symbols of urban autonomy into their iconography.

Furthermore, like their princely counterparts, towns were able to show off the extent of their own, communal possessions by means of heraldry displayed on urban architecture. Just as the dukes of Burgundy combined the different coats of arms of their possessions in a single shield, the town of Erfurt showed off its purchased extramural possessions by adding their corresponding coats of arms to its shield. ${ }^{42}$ This quite complex arrangement of quarterings testified to the increasingly extensive possessions of the

41 Creighton and Higham, Medieval Town Walls, p. 32; Kühtreiber, 'Town Wall'.

42 Hermann, 'Das Wappen', pp. 59-63. 
urban community and was proudly displayed outside the late medieval town hall, where the town's municipal arms are framed by the coats of arms of the hamlets of Kapellendorf, Vippach, Vieselbach, and Vargula. ${ }^{43}$ These stone carvings closely resemble the four quarters displayed by noblemen in similar iconographic settings meant to evoke at least four ancestors as 'proof' of their nobility, ${ }^{44}$ but with a much more distinct territorial implication.

Of course, emperors, kings, and princes were equally keen to represent their possessions by means of heraldic communication, as not least the example discussed in the introduction has shown. The territorial structure of the Burgundian-Habsburg composite state was visible to a wider audience in a range of different media, notably the stained-glass windows the duke installed in his palaces and residences, or donated to churches and monasteries. The financial accounts of the Burgundian and Habsburg princes reveal that they donated at least 150 stained-glass windows to churches and convents in the Low Countries between 1419 and 1519.45 The initiative of donating stained-glass windows was never exclusively a princely matter, but depended on the material needs of the churches and how they could communicate these needs to the ruler. ${ }^{46}$ In 1454-1455, for example, Duke Philip the Good donated a window to the church of St Nicholas in Amsterdam. Since a new choir was built in exactly those years, it is most likely that the church wardens had approached the duke for a material contribution. The window depicted seventeen coats of arms: four personal, quartering Philip the Good's four grandparents, and thirteen coats of arms reflecting the titles of the duke, most of them territorial, others less so. ${ }^{47}$ Although it is important to remember that such extensive heraldic representations were only possible when the duke had a relatively large window at his disposal, similar displays existed in the churches in Brussels, Ghent, Lille, and Dordrecht. In this way, the duke publicly displayed his devotion and contributed to the maintenance and splendour of the building, whilst appealing directly to the loyalty of the citizens and reminding them of the composite state of which they were part.

The kings of the Jagiellonian dynasty, who ruled large parts of Eastern Europe, were equally concerned with the heraldic representation of their territories, again especially after their death. ${ }^{48}$ The pedestal of the canopied 
tomb of Władysław II Jagiełło (r. 1377-1434) in Cracow’s Wawel Cathedral is occupied by the four shields of the lands united by his crown, namely Lithuania, Poland, Greater Poland, and Wieluń and Dobrzyń (Fig. 9.6). ${ }^{49}$ Wladyslaw II had inherited the Grand Duchy of Lithuania from his father in 1377 and gained the crown of Poland through his marriage with the heiress Jadwiga; the lands of Wielun and Dobrzyn were integrated after the Battle of Grunwald of 1410 as separate entities within the kingdom.

Other masters of such territorial representations by means of heraldry were antagonists of the Jagiellonians, namely members of the house of Habsburg. They often relied on the sheer number of territories represented by their coats of arms to inspire awe in passers-by. $5^{\circ} \mathrm{A}$ painter in the employ of Emperor Maximilian I (r. 1486-1519), Jörg Kölderer, explicitly noted that he had been charged with 'painting on parchment all the lands of his majesty, that is shields, helmets, and crests'.$^{1}$ Among Maximilian's precursors was Rudolf IV, duke of Austria (r. 1358-1365), who, like the Polish king, heraldically showed off the territorial reach of his rule over Carinthia, Styria, Habsburg, Mark, Carniola, Pordenone, Burgau, Kyburg, and Rapperswil on a magnificent seal..$^{2}$ His grandnephew Frederick III, as German emperor, followed in Rudolf's footsteps: vast territorial possessions were implied by a 'wall of arms' part of the chapel of the Habsburgs' castle in Wiener Neustadt, Austria. Erected about 1453, the wall was adorned with stone carvings representing a total of 107 arms, taken from the aforementioned Chronicle of the Ninety-Five Lordships. Apart from the fourteen coats of arms of the house of Habsburg's actual Austrian principalities, the wall showed the (attributed) arms of the legendary kingdoms which had supposedly existed on the Austrian soil in time out of memory. ${ }^{53}$ In this way, this material display, too, presented the Habsburgian possessions as rooted in the past, hence legitimizing the rule of the dynasty over these lands.

A similarly extensive (and similarly cryptic) heraldic representation of the house of Habsburg's territorial domination was inspired by such architectural landmarks, namely the monumental Triumphal Arch designed for and partly by Emperor Maximilian. ${ }^{54}$ It seems that this arrangement was

Ibid., 348-349; Fischinger, 'Grabdenkmäler', p. 137.

Eisenbeiss, 'Wappen und Bilder', pp. 103-110; Pálffy, 'Heraldische Repräsentation'.

$5^{1}$ Schönherr, 'Urkunden', p. xxviii: 'Ich sol kn. mjt. auf pergamen malen alle landt, die ir mjt. zuegehorn, schilt vnd helm vnd helmklainat.'

52 Sauter, Fürstliche Herrschaftsrepräsentation, p. 204.

53 Schwarz, 'Die Wiener Neustädter Wappenwand'; Schauerte, 'Heraldische Fiktion'; Boeheim 'Burg', pp. 44-52.

54 Eisenbeiss, 'Wappen und Bilder', p. 101; Coreth, 'Dynastisch-politische Ideen', pp. 92-105. 
never meant to be executed in any form other than woodcut prints, possibly intended to be reproducible wherever the emperor happened to travel. ${ }^{55}$ The arch must have been meant to serve as an ad hoc piece of Habsburgian self-aggrandisement which offered a plethora of dynastic and imperial symbolism - not least in the form of heraldry - to any audience, regardless of whether they were able to recognise individual coats of arms, or whether they were simply awestruck by its sheer size. Certainly, the makers of the arch drew on a long tradition of similarly short-lived decorations meant to convey notions of the vast and widespread possession of the dynasty by means of heraldry, especially during Joyous Entries in the towns of the Habsburg composite state..$^{6}$

\section{Heraldic performances and contested territories}

Joyous Entries point to a less permanent and more ephemeral, performative side to the representation of territory through heraldry, which was deeply involved in representing, establishing, and challenging claims to territorial possessions. Towns and cities - the 'public spheres' of the Late Middle Ages ${ }^{57}$ - proved particularly prominent stages for this kind of ritual which served the delicate double function of acknowledging the entering ruler's legal authority whilst preserving and sometimes even extending the city's privileges and liberties..$^{8}$ Urban governments and institutions, notably guilds, were in charge of such displays and certainly up to the challenge, as the creation of elaborate heraldic programmes shows. ${ }^{59}$ In the Burgundian Low Countries, like elsewhere, gates, streets, and numerous tableaux vivants were adorned with coats of arms of ruler, town, and principality, ready to be seen by the visitors and urban crowds alike; not only were urban writers and painters expected to 'speak' the 'language' of heraldry, but this sign system was also aimed at a relatively large and apparently heraldically knowledgeable urban audience, not least for the communication of territorial messages.

During the entry of Maximilian of Austria in Antwerp in January 1478, for example, the guilds had set up 'a tree with seventeen branches with shields of the seventeen lands which our princess [Mary of Burgundy, Maximilian's 
bride] had inherited from her father, Duke Charles'. Apparently, in the eyes of Antwerp's citizens their polity now transcended the borders of both city and the Duchy of Brabant. What is more, in another tableau they connected the heraldry of the Duchy of Brabant to biblical imagery: beneath the throne of God the four Evangelists featured, with Mark shown as 'a golden lion with a shield quartered with the four lions of these lands', that is the quartered arms of Brabant and Limbourg, which were part of the arms of Mary of Burgundy (r. 1477-1482, see above). ${ }^{60}$

When Maximilian came to Nuremberg in 1489, the townspeople's embrace of his rule was equally territorial in nature. Children lined the streets, 'each holding a pennon which depicted, on the one side, an eagle with one head and Austria [Habsburg] in the centre, and on the other side a shield of his lands, of which he has $24{ }^{\prime 61}$ The same had happened at his father Frederick III's quite similar reception in 1471, when children from local Nuremberg schools greeted the emperor with 'a pennon painted with the emperor's lands in each of their hands' ${ }^{62}$ Territorial heraldry also embellished the canopies under which the cherished guests were led through the streets of the city, usually borne by the most influential urban representatives: when King Sigismund of Luxembourg (r. 1411-1437) entered Speyer in 1414, a canopy 'of a yellow colour and with a black eagle' also showed 'the arms of the Empire, Hungary, and the prince-electors' on its fringes. ${ }^{63}$ Reminiscent of the Holy Roman Empire's 'constitutional' elements expressed in the Reichsquaternionen ${ }^{64}$ this arrangement of multiple heraldic signs closely resembled the ensemble of Habsburg territories represented on pennons in Nuremberg. Once again, the composite character of the Habsburg state was communicated both ways - from town to ruler and from ruler to town - showing that both parties were acutely aware of the specific territorial configuration of which they were part.

60 Damen and Overlaet, 'Weg van de staat', nos 19 and 21.

61 Die Chroniken der fränkischen Städte, p. 499: 'Die schulerlein trug ieder ein panerlein gemalt: auf der ainen seiten ein adler mit einem kopf und Östereich in der mitt, auf der andern seiten ein wopen von seinem land eins, der er 24 hot.'

62 Ibid., p. 458: 'Item als kaiser Friderich zu Nermberg ein rait [...] anno 1471 [...] was bestelt von allen schulern ir iedem ein panerlein in sein hant der lant des kaisers wappen daran gemalt.' 63 Janssen, Frankfurts Reichscorrespondenz, vol. 1, no. 465: 'Auch was daz duch, darunder er zu Spire inging, xvi fusze lang und xii breit, und was das duch zu Mencze bynnen eim tage gemachet und gemalet von geler farbe und ein schwarcz adeler darynne, und die umbhenge zweier fusze breit und lappen zweier fusze lang und breit, die waren mit des richs und Ungern und der kurfursten wappen.' On canopies depicting the 'political family' of the Holy Roman Empire by means of heraldry, see also Schenk, Zeremoniell und Politik, p. 461.

64 Schubert, 'Die Quaternionen'. 
Parallel to such coordinated representations of territorial possessions, on the level of the individual sign in relation to the surrounding space, heraldry was also involved in the communication of concrete claims to power over the city. When towns in the Holy Roman Empire were conquered by 'predatory' princes, frequently the conqueror removed the arms of his predecessor from symbolic sites of urban self-government, notably the town hall and the marketplace. ${ }^{65}$ After Louis IX of Bavaria (r. 1450-1479) had conquered the imperial city of Donauwörth in 1458 , for example, the duke not only replaced the members of the town council with men more faithful to the new lord, but also substituted the symbols of imperial sovereignty with those of ducal rule: 'The arms of the Empire were struck down from all gates and from the town hall, and [instead] the arms of Bavaria were painted there. ${ }^{66}$

Charles the Bold was another expert in such heraldically communicated territorial claims. During his military exploits, the objects of his territorial ambition were often conspicuously marked by means of heraldry, as a Swiss chronicler knew all too well: 'The reason why the duke of Burgundy always carries a large number of flags and signs with him [...] is that so whenever cities or lands are conquered [...] numerous Burgundian banners can be erected and unfurled so that they scare and frighten the people, as happened in Ghent, Liège, Dinant, and other great cities. ${ }^{67}$ These three towns had rebelled against the duke's authority, and apart from material punishments (the closing of a town gate, the demolition of the town walls), they had to face the clear and daily visible heraldic submission to his rule, too. ${ }^{68}$ In April 1474, the council of Cologne similarly complained about the 'putting up of arms' ('upslayn der wapen') by Charles's men, and shortly afterwards, in June, Pope Sixtus IV himself admonished the duke to cease

65 Meer, 'Cities, Citizens, and Their Signs', chap. 5.2.2.

66 Die Chroniken der schwäbischen Städte, p. 140: 'Also rait hertzog Ludwig hinein mit 400 edlen und wolt sunst niemand hinein lassen. Also ward des reichs wappen an allen toren und am rathaus herab gehawen und das [vom] Bairland hinan gemalt.'

67 Schilling, Berner Chronik, vol. 1, p. 386: 'Warumb ouch der herzog von Burgunnen so vil panern und zeichen alweg bi im gehebt und mit im gefúrt hat, [...] das semlichs darumb beschechen [...], wann [...] stett oder lande mit dem swert gewunnen und under sich gebracht [...] von stunt an vil panern von Burgunnen ufgericht und usgestossen [...], damit sie das gemein volk zů schrecken und vorchten bringen möchten, als dann zů Jent, Lúttich, Dynant und in andern großen stetten ouch beschechen ist.' For Swiss examples, see Sieber-Lehmann, Spätmittelalterlicher Nationalismus, pp. 49-54.

68 Boone, 'Destroying'. 
'affixing your arms to the castles and places of the said diocese [of Cologne] or hanging your banner therefrom. 69

Such heraldically staked claims to authority or even possession of territory were not always left unchallenged. After Charles the Bold had ordered a herald to distribute his personal coat of arms in Cologne, the townspeople rejected this visible claim to their city with an attack on the very same heraldry: 'The common men gathered in all places where the duke's letters and arms had been put up, hurled faeces and other muck at them, ripped them off and dragged them through the dirt, shaming the proud prince [...] as much as possible. ${ }^{70}$ Similarly, if conquered towns were, eventually, reconquered, the restoration of the heraldic status quo ante was an important measure. After the aforementioned town of Donauwörth was recaptured by imperial forces in 1459, the heraldic changes imposed by Louis IX were reversed, rejecting the territorial claims of the duke and restoring of imperial sovereignty over Donauwörth: 'People removed the arms of Bavaria from all gates and the town square, and once again painted the arms of the Empire there. ${ }^{71}$ The same was the case when cities overthrew disagreeable lords themselves, as was the fate of the de facto rulers of Florence, the Medici family, and their coats of arms in 1527: 'Not only were their arms displayed in holy places removed, but in fact all arms of that noble family, whether they were hung on the doors of private families or inside some public building, were torn apart or set on fire. ${ }^{72}$ Thus, coats of arms were not only displayed in space, but were seen as powerful symbols that shaped space, hence influencing the way territory was perceived by a large audience.

69 Historisches Archiv, Cologne, B. 20, no. 30, fol. 110v; Ulrich, Acten zum Neusser Kriege, p. 9 : 'Nulle partium assistas nec tuos assistere permittas neque tua arma castris et locis dicte ecclesie affigi aut tua vexilla ex eisdem extendi.'

70 Bayerische Staatsbibliothek, Munich, Cgm. 895, fol. 329r: 'Zudem lueff der gemain Man von allen orten do des Hertzoge brief, wappen vnnd Mandaten angeschlagen waren zu, warffen mit koth vnnd aller on sauberkait zu denselben, Rissen die herab, Drattens Inn das kot vnd schmäheten den stoltzen fůrsten vnnd Iren Bischoff auff das höhist.'

71 Die Chroniken der schwäbischen Städte, p. 151: '[D]o hat man das wappen des Pairlands an allen thoren und an dem platz abgethaun und des reichs wappen wider dahin gemalt.'

72 Segni, Storie fiorentine, vol. 3, pp. 253-254: 'Nè pur l'arme loro poste ne'luoghi sagri furono messe giù, ma tutte le arme di quella Casa, che a usci di private famiglie, o dentro in alcum luogo fosino state appicate, andarono o a fuoco o in pezzi.' We are grateful to Luca Zenobi (Cambridge) for his help with this translation. 


\section{Conclusion}

This chapter has shown that, in the Late Middle Ages, heraldry served important communicative purposes in relation to territory by representing, reinforcing, and constructing claims to authority in space. Individual coats of arms first gained territorial associations in the context of warfare: placed on banners, they became associated with the land of the fief that mustered the troops, and as fiefs moved through inheritance (often through [heraldic] heiresses), investiture, sale, or conquest, so too did the coats of arms associated with the land. Princes, noblemen, and cities chose to combine their established coat of arms with the arms of newly acquired possessions, thus creating a complex visual shorthand for the entirety of territories in their possession. This approach was particularly useful for composite states such as the Burgundian Low Countries, though of course it also lent itself well to ambitious princes who wished to lay claim to lands by appropriating their coat of arms, as Edward III of England had done, ${ }^{73}$ to name another famous example. Heraldry was a capable and space-efficient solution to the problem of communicating the nature of territory to a large audience; it allowed the conveyance of a spatial claim tied to a coat of arms just as it allowed for the compact representation of complex territorial configurations by combining multiple arms in a single shield.

Sometimes such heraldic representations also had to satisfy the desires and ambitions of the local and regional elites and other powerbrokers who had to accept claims to territory or required integration into the new composite state. ${ }^{74} \mathrm{~A}$ wide range of media was available to serve these purposes. Manuscripts such as armorials and chronicles curated these complex territorial structures (real and imagined) and thus allowed the tracing of their historical development over time, just as the appearance of heraldic seals reflected such changes. Architecture, from palaces and churches to town halls, displayed heraldic representations of territories as well, and the same was the case for tombs and monuments. Finally, there also was a performative dimension to the representation of territory by means of heraldry. Joyous Entries saw the display of territorial arms and heraldic arrangements of various possessions. Likewise, similar to individual signs used to demarcate urban spaces displayed on town gates, coats of arms were put on display (or destroyed) to stake (or reject) new claims to authority over space, as in the case of Charles the Bold's campaigns. 
If we want to write a history of territory in the late medieval period which looks at territory 'not simply as an object' but as 'a process, made and remade, shaped and shaping, active and reactive', as Elden highlights, ${ }^{75}$ then the role of visual communication in general and heraldry in particular emerges as a key component to study. In this sense, this chapter echoes important methodological developments in the discipline of heraldry, which is currently moving away from 'traditional' approaches to coats of arms, focused on their connoisseurial appreciation and antiquarian uses as identifiers of their bearers, ${ }^{76}$ towards approaches inspired by cultural history. ${ }^{77}$ From this perspective, heraldic signs emerge as a versatile and ubiquitous phenomenon of late medieval visual culture. They were deeply involved in the representation, negotiation, and construction of social and political structures - not least with regard to the communication of authority in space and thus the creation of territory.

\section{Bibliography}

\section{Primary sources}

Adam-Even, Paul, and Léon Jéquier, eds., 'Un armorial français du 13e siècle: L'armorial Wijnbergen', in Archives héraldiques suisses 65/68 (1951/1954), pp. 49-62, 101-11.

Bayerische Staatsbibliothek, Munich, Cgm. 895 .

Bayerische Staatsbibliothek, Munich, Rar. 287.

Clemmensen, Steen, ed., 'The Lyncenich Armorial' (2016), http://www.armorial. $\mathrm{dk} /$ french/Lyncenich.pdf.

Die Chroniken der fränkischen Städte Bd. 5: Nürnberg, Die Chroniken der deutschen Städte vom 14. bis ins 16. Jahrhundert, 11 (Leipzig: S. Hirzel, 1874).

Die Chroniken der schwäbischen Städte Bd. 3: Augsburg, Die Chroniken der deutschen

Städte vom 14. bis ins 16. Jahrhundert, 22 (Leipzig: S. Hirzel, 1892).

Greve, Anke, Comptes de l'argentier de Charles le Téméraire, Duc de Bourgogne:

Année 1469. Le registre CC1924 des Archives générales du Royaume, Bruxelles

(Paris: Boccard, 2002), vol. 2.

Historisches Archiv, Cologne, B. 20, no. 30. 
Janssen, Johannes, ed., Frankfurts Reichscorrespondenz nebst andern verwandten Aktenstücken [...], 3 vols (Freiburg [Breisgau], 1863).

Koninklijke Bibliotheek, Brussels, ms. II 6567, https://uurl.kbr.be/1734449

Koninklijke Bibliotheek, Brussels, ms. 15652-56, https://uurl.kbr.be/1733715.

Lisch, Georg Christian Friedrich, ed., 'Urkunde über den Kauf der Grafschaft Schwerin am 7. December 1358, zur Erinnerung an die vor fünfhundert Jahren vollbrachte Wiedererwerbung der Grafschaft durch die Herzoge von Mecklenburg', in Jahrbücher des Vereins für Mecklenburgische Geschichte und Altertumskunde 24 (1859), 197-211.

Pastoureau, Michel, and Michel Popoff, L'armorial Bellenville (Lathuile: Éd. du Gui, 2004).

Raneke, Jan, Bergshammarvapenboken: En medeltidsheraldisk studie, 2 vols. (Lund: AV-Centralen I, 1975).

Riksarkivet, Täby, SE/RA/720085/Z, https://sok.riksarkivet.se/bildvisning/ Rooo1216_oooo1.

Schilling, Diebold, Die Berner Chronik des Diebold Schilling, 1468-1484, ed. by Gustav Tobler, 2 vols (Bern: K.J. Wyss, 1897-1901).

Schönherr, David, ed., 'Urkunden und Regesten aus dem k. k. Statthalterei-Archiv in Innsbruck', in Jahrbuch der Kunsthistorischen Sammlungen des Allerhöchsten Kaiserhauses 2, no. 2 (1884), 1-173.

Seemüller, Joseph, ed., Österreichische Chronikvon den 95 Herrschaften, Monumenta Germaniae Historica: Deutsche Chroniken 6 (Hanover, 1909).

Segni, Bernardo, Storie fiorentine [...] dall'anno MDXXVII al MDLV, ed. by Andrea di Lorenzo Cavalcanti, 3 vols (Florence, 1835).

Stiftsbibliothek, St Gall, Cod. Sang. 1084, https://www.e-codices.ch/de/list/one/ csg/1084.

Ulrich, Adolf, ed., Acten zum Neusser Kriege, 1472-1475 (Cologne, 1889).

\section{Secondary sources}

Adam-Even, Paul, 'Armoiries territoriales et armoiries de famille au Moyen-Âge, principalement en France', in Recueil du VIIe congrès international des sciences généalogique et héraldique, ed. by Joan Karel Hendrik de Roo van Alderwerelt (The Hague, 1964), pp. 81-93.

Ailes, Adrian, The Origins of the Royal Arms of England: Their Development to 1199 (Reading: Graduate Centre for Medieval Studies, Reading University, 1982).

Andenna, Cristina, and Gert Melville, eds, Idoneität - Genealogie - Legitimation: Begründung und Akzeptanz von dynastischer Herrschaft im Mittelalter (Cologne: Böhlau, 2015). 
Avonds, Piet, Koning Artur in Brabant (12 ${ }^{\text {de }}-14^{\text {de }}$ eeuw): Studies over riddercultuur en vorstenideologie (Brussels: Koninklijke Vlaamse Academie van België voor Wetenschappen en Kunsten, 1999).

Boeheim, Ferdinand Carl, 'Die Burg zu Wiener Neustadt und ihre Denkwürdigkeiten', Beiträge zur Landeskunde Österreichs unter der Enns 4 (1834), 1-83.

Boone, Marc, 'Destroying and Reconstructing the City: The Inculcation and Arrogation of Princely Power in the Burgundian-Habsburg Netherlands $\left(14^{\text {th }}-16^{\text {th }}\right.$ centuries)', in The Propagation of Power in the Medieval West: Selected Proceedings of the Internationaal Conference, Groningen, 20-23 November 1997, ed. by M. Gosman, A. Vanderjagt and J. Veenstra (Groningen: Egbert Forsten, 1996), pp. 1-33. Brunner, Luitpold, Die Grafen von Hals: Ein Beitrag zur Geschichte Bayerns (Augsburg: F. C. Kremer, 1857).

Chassel, Jean-Luc, 'Le nom et les armes: La matrilinéarité dans la parenté aristocratique du second Moyen Âge', Droit et cultures: Revue internationale interdisciplinaire 64 (2012), 117-148.

Contamine, Philippe, La noblesse au royaume de France de Philippe le Bel à Louis XII: Essai de synthèse (Paris: Presses universitaires de France, 1997).

Coreth, Anna, 'Dynastisch-politische Ideen Kaiser Maximilians I. (Zwei Studien)', Mitteilungen des österreichischen Staatsarchivs 3 (1950), 81-105.

Coss, Peter R., 'Knighthood, Heraldry and Social Exclusion in Edwardian England', in Heraldry, Pageantry, and Social Display in Medieval England, ed. by Peter R. Coss and Maurice Keen (Woodbridge: Boydell Press, 2002), pp. 39-68.

Creighton, Oliver Hamilton, and Robert A. Higham, Medieval Town Walls: An Archaeology and Social History of Urban Defence (Stroud: Tempus, 2005).

Crouch, David, Tournament (London: Hambledon and Continuum, 2005).

Damen, Mario, 'Heraldiek en politiek. Bourgondische glazen in de Oude kerk van Amsterdam', Amstelodamum: Maandblad voor de kennis van Amsterdam 92, no. 6 (2005), 3-16.

Damen, Mario, 'Heren met banieren: De baanrotsen van Brabant in de vijftiende eeuw', in Bourgondiëvoorbij: De Nederlanden 1250-1650: Liber alumnorum Wim Blockmans, ed. by Mario Damen and Louis Sicking (Hilversum: Verloren, 2010), pp. 139-158.

Damen, Mario, 'Vorstelijke vensters: Glasraamschenkingen als instrument van devotie, memorie en representatie (1419-1519)', Jaarboek voor middeleeuwse geschiedenis 8 (2005), 140-200.

Damen, Mario, and Kim Overlaet, 'Weg van de staat: Laatmiddeleeuwse Blijde Intredes in de Nederlanden op het snijvlak van sociale, culturele en politieke geschiedenis', BMGN: Low Countries Historical Review 134, no. 2 (2019), 3-44.

Dumolyn, Jan, and Jelle Haemers, 'Patterns of Urban Rebellion in Medieval Flanders', Journal of Medieval History 31, no. 4 (2005), 369-393. 
Eisenbeiss, Anja, 'Wappen und Bilder im Diskurs - Das Beispiel der Habsburger', Das Mittelalter 11 (2006), 98-120.

Elden, Stuart, The Birth of Territory (Chicago/London: University of Chicago Press, 2013).

Elden, Stuart, 'How Should We Do the History of Territory?', Territory, Politics, Governance 1, no. 1 (2013), 5-20.

Feger, Otto, ed., Ulrich Richental: Das Konzil zu Konstanz: Faksimile (Starnberg: Keller, 1964).

Fischinger, Andrzej, 'Grabdenkmäler der Könige aus der Dynastie der Jagiellonen im Dom auf dem Wawel in Krakau', in Polen im Zeitalter der Jagiellonen 1386-1572: Ausstellung auf der Schallaburg vom 8. Mai bis 2. November 1986, ed. by Gottfried Stangler and Franciszek Stolot (Vienna: Amt der niederösterreichischen Landesregierung, 1986), pp. 137-158.

Fox-Davies, Arthur Charles, A Complete Guide to Heraldry (London, Edinburgh: T.C. \& E.C. Jack, 1909).

Goodman, Anthony, John of Gaunt: The Exercise of Princely Power in FourteenthCentury Europe (Abingdon: Routledge, 2016).

Gritzner, Erich, 'Heraldik', in Sphragistik - Heraldik - Deutsche Münzgeschichte, ed. by Theodor Ilgen, Erich Gritzner, and Ferdinand Friedensburg, $2^{\text {nd }}$ ed. (Leipzig/ Berlin: B.G. Teubner, 1912).

Gull, Ferdinand, 'Das Wappenbuch des Abtes Ulrich Rösch von St. Gallen, genannt Codex. Haggenberg', Schweizer Archiv für Heraldik 10 (1896), 1-6.

Hablot, Laurent, 'Entre pratique militaire et symbolique du pouvoir, l'écu armorié au XII ${ }^{\mathrm{e}}$ siècle', in Estudos de heráldica medieval, ed. by Maria de Lurdes Rosa and Miguel Metelo de Seixas (Lisbon: Instituto de Estudos Medievais, 2012), pp. 143-165.

Hablot, Laurent, 'Heraldic Imagery, Definition, and Principles', in The Routledge Companion to Medieval Iconography, ed. by Colum P. Hourihane (London: Routledge, 2017), pp. 386-398.

Hablot, Laurent, and Torsten Hiltmann, eds, Heraldic Artists and Painters in the Middle Ages and Early Modern Times (Ostfildern: Thorbecke, 2017).

Hablot, Laurent. "Ubi armae ibi princeps": Medieval Emblematics as the Real Presence of the Prince', in Absentee Authority across Medieval Europe, ed. by Frédérique Lachaud and Michael A. Penman (Woodbridge: Boydell \& Brewer, 2017), pp. 37-55.

Hagemann, Christoph J., Geschichtsfiktion im Dienste territorialer Macht:Die Chronik von den 95 Herrschaften des Leopold von Wien (Heidelberg: Universitätsbibliothek Heidelberg, 2017).

Harding, Elizabeth, and Michael Hecht, 'Ahnenproben als soziale Phänomene des Spätmittelalters und der Frühen Neuzeit: Eine Einführung', in Die Ahnenprobe 
in der Vormoderne: Selektion, Initiation, Repräsentation, ed. by Elizabeth Harding and Michael Hecht (Münster: Rhema, 2011), pp. 9-84.

Hartmann, Heiko, 'Heraldry', in Handbook of Medieval Studies: Terms - Methods - Trends, ed. by Albrecht Classen (Berlin, New York: De Gruyter, 2010), vol. 1, pp. 619-624.

Hauptmann, Felix, Das Wappenrecht: Historische und dogmatische Darstellung der im Wappenwesen geltenden Rechtssätze: Ein Beitrag zum deutschen Privatrecht (Bonn: P. Hauptmann, 1896).

Hefner, Otto Titan von, Altbayerische Heraldik: Unter Zugrundelegung eines neuen allgemeinen Systems der wissenschaftlichen Heraldik (Munich: Heraldisches Institut, 1869).

Hermann, Karl, 'Das Wappen und die Siegel der Stadt Erfurt', Mitteilungen des Vereins für Geschichte und Altertumskunde von Erfurt 1 (1865), 1-126.

Hiltmann, Torsten, 'Potentialities and Limitations of Medieval Armorials as Historical Sources: The Representation of Hierarchy and Princely Rank in Late Medieval Collections of Arms in France and Germany', in Princely Rank in Late Medieval Europe: Trodden Paths and Promising Avenues, ed. by Thorsten Huthwelker, Jörg Peltzer and Maximilian Wemhöner (Ostfildern: Thorbecke, 2011), pp. 157-198.

Hofman, Elmar, 'Armorials in Medieval Manuscripts: Collections of Coats of Arms as Means of Communication and Historical Sources in France and the Holy Roman Empire (13 ${ }^{\text {th }}$-early $16^{\text {th }}$ centuries)', PhD thesis, Münster University, 2019. Holladay, Joan A., Genealogy and the Politics of Representation in the High and Late Middle Ages (Cambridge: Cambridge University Press, 2019).

Howell, Martha C., 'The Spaces of Late Medieval Urbanity', in Shaping Urban Identity in Late Medieval Europe, ed. by Marc Boone and Peter Stabel (Leuven: Garant, 200o), pp. 3-19.

Huizinga, Johan, 'Ruyers und Poyers', in Wirtschaft und Kultur: Festschrift zum 70. Geburtstag von Alfons Dopsch (Baden; Leipzig: R.M. Rohrer, 1938), pp. 535-546. Huthwelker, Thorsten, 'Ordnungen in spätmittelalterlichen Wappenrollen', in Bild - Macht - UnOrdnung: Visuelle Repräsentationen zwischen Stabilität und Konflikt, ed. by Anna-Maria Blank, Vera Isaiasz and Nadine Lehmann (Frankfurt/ New York: Campus, 2011), pp. 111-134.

Hye, Franz-Heinz, 'Programmatische Polit-Heraldik: Landeswappen, Einheitswappen, Anspruchswappen', in Bericht über den 19. österreichischen Historikertag, ed. by Lorenz Mikoletzky (Vienna: Verband Österreichischer Historiker und Geschichtsvereine, 1993), pp. 395-402.

International Congress of Genealogical and Heraldic Sciences, ed., Les combinaisons d'armoiries par les personnes privées: Les brisures de bâtardise (Canterbury: Family History, 1995). 
Johanek, Peter, 'Imperial and Free Towns of the Holy Roman Empire: City-States in Pre-Modern Germany?', in A Comparative Study of Thirty City-State Cultures: An Investigation, ed. by Mogens Herman Hansen (Copenhagen: Kongelige Danske Videnskabernes Selskab, 200o), pp. 295-319.

Jones, Robert, “What Banner Thine?": The Banner as a Symbol of Identification, Status and Authority on the Battlefield', The Haskins Society Journal 15 (2004), 101-109.

Kah, Daniela, Die wahrhaft königliche Stadt: Das Reich in den Reichsstädten Augsburg, Nürnberg und Lübeck im Späten Mittelalter (Leiden: Brill, 2018).

Keesman, Wilma, De eindeloze stad: Troje en Trojaanse oorsprongsmythen in de (laat)middeleeuwse en vroegmoderne Nederlanden (Hilversum: Verloren, 2017).

Kremb, Jens, 'Die runden Wappentafeln der Zünfte und die Quadratur des (Wappen-) Kreises' (2017), https://doi.org/10.11588/artdok.00005015.

Kreuer, Werner, Imago civitatis: Stadtbildsprache des Spätmittelalters: Essener Bearbeitung der authentischen Stadtansichten aus der Schedelschen Weltchronik von 1493 mit 32 Vollfaksimilierungen des Originals der Diözesan- und Dombibliothek Köln (Essen: Institut für Geographie der Universität Essen, 1993).

Kruip, Marjolijn, 'Jan van Battel (1477-1557), (heraldisch) schilder in Mechelen: Kunstenaar, werken en nieuwe vondsten', Handelingen van de Koninklijke Kring voor Oudheidkunde, Letteren en Kunst van Mechelen 119 (2015), 105-138.

Kuczynski, Stefan Krzysztof, 'Les armoiries territoriales polonaises au Moyen Âge', in Staaten, Wappen, Dynastien: XVIII. Internationaler Kongreßfür Genealogie und Heraldik in Innsbruck vom 5. bis 9. September 1988, ed. by Franz-Heinz Hye (Innsbruck: Stadtmagistrat Innsbruck, 1988), pp. 337-350.

Kühtreiber, Thomas, 'The Town Wall: Sign of Communication and Demarcation (the Example of Hainburg, Lower Austria)', Medium Aevum Quotidianum 47 (2003), 50-68.

Lefebvre, Henri, The Production of Space, trans. by Donald Nicholson-Smith (London: Basil Blackwell, 1991).

Lefèvre, Sylvie, Antoine de La Sale: La fabrique de l'oeuvre et de l'écrivain, suivi de l'édition critique du Traité des anciens et des nouveaux tournois (Genoa: Droz, 2006).

Liddy, Christian D., 'Bill Casting and Political Communication: A Public Sphere in Late Medieval English Towns?', in La gobernanza de la ciudad Europea en la Edad Media, ed. by Jesús Ángel Solórzano Telechea and Beatriz Arizaga Bolumburu (Logroño: Instituto de Estudios Riojanos, 2011), pp. 447-462.

Lindquist, Sherry C.M., Agency, Visuality and Society at the Chartreuse de Champmol (London: Routledge, 2017).

Lüken, Sven, 'Kaiser Maximilian I. und seine Ehrenpforte', Zeitschrift für Kunstgeschichte 61, no. 4 (1998), 449-490. 
Marks, Richard, Stained Glass in England during the Middle Ages (Toronto/London: University of Toronto Press, 1993).

Meer, Marcus, 'Cities, Citizens, and Their Signs: Heraldic Communication and Urban Visual Culture in Late Medieval England and Germany', unpublished PhD thesis, University of Durham, 2019.

Menéndez Pidal de Navascués, Faustino, 'El nacimiento de las armas de Leon y de Castilla', Revista Hidalguía 21 (1973), 385-408.

Michael, Michael, 'The Little Land of England is Preferred before the Great Kingdom of France: The Quartering of the Royal Arms by Edward III', in Studies in Medieval Art and Architecture Presented to Peter Lasko, ed. by Thomas Alexander Heslop and David Buckton (Stroud: Alan Sutton, 1994), pp. 113-126.

Monnet, Pierre, 'Die Stadt, ein Ort der politischen Öffentlichkeit im Spätmittelalter?', in Politische Öffentlichkeit im Spätmittelalter, ed. by Martin Kintzinger (Ostfildern: Thorbecke, 2011), pp. 329-359.

Nassiet, Michel, 'Nom et blason: Un discours de la filiation et de l'alliance (XIV XVIII' siècle)', L'Homme 34 (1994), 5-30.

Nieus, Jean-François, 'Linvention des armoiries en contexte: Haute aristocratie, identités familiales et culture chevaleresque entre France et Angleterre, 1100116o', Journal des savants (2017), 93-155.

Pálffy, Géza, 'Heraldische Repräsentation der Jagiellonen und der Habsburger: Die Wappen des königlichen Oratoriums im Prager Veitsdom im mitteleuropäischen Kontext', Historie - Otázky - Problémy 7, no. 2 (2015), 176-19o.

Paravicini, Werner, 'Gruppe und Person: Repräsentation durch Wappen im späteren Mittelalter', in Die Repräsentation der Gruppen: Texte - Bilder - Objekte, ed. by Otto Gerhard Oexle and Andrea von Hülsen-Esch (Göttingen: Vandenhoeck \& Ruprecht, 1998), pp. 327-390.

Pinoteau, Hervé, Michel Pastoureau, and Michel Popoff, eds., Les armoiries non nobles en Europe: XIIIe-XVIIe s.: IIIe Colloque international d'héraldique, Montmorency, 19-23 septembre 1983 (Paris: Léopard d'Or, 1986).

Raßloff, Steffen, 'Historisches Stadtwappen am Rathaus: Symbol des “Landes Erfurt", Erfurt-Web (2012), http://www.erfurt-web.de/Stadtwappen_Rathaus_Erfurt.

Reynolds, Susan, Kingdoms and Communities in Western Europe, 90o-130o, $2^{\text {nd }} \mathrm{ed}$. (Oxford: Clarendon Press, 1997).

Rietstap, Johannes B., Handboek der wapenkunde (Gouda: Van Goor, 1857).

Robertson, Fiona, and Peter N. Lindfield, 'Introduction: Speaking of Arms', in Semy-de-lys: Speaking of Arms, 1400-2016, ed. by Fiona Robertson and Peter N. Lindfield (2016), pp. 1-6, https://heraldics2014.files.wordpress.com/2015/12/ introduction1.pdf.

Sauter, Alexander, Fürstliche Herrschaftsrepräsentation: Die Habsburger im 14. Jahrhundert (Ostfildern: Thorbecke, 2003). 
Schauerte, Thomas, 'Heraldische Fiktion als genealogisches Argument: Anmerkungen zur Wiener Neustädter Wappenwand Friedrichs III. und zu ihrer Nachwirkung bei Maximilian', in Erzählen und Episteme: Literatur im 16. Jahrhundert, ed. by Tobias Bulang et al. (Tübingen: M. Niemeyer, 2011), pp. 345-364.

Schenk, Gerrit Jasper, Zeremoniell und Politik: Herrschereinzüge im spätmittelalterlichen Reich (Cologne: Böhlau, 2003).

Schramm, Percy Ernst, 'Beiträge zur Geschichte der Fahnen und ihre Verwandten: Fahne, Banner, Wimpel, Feldzeichen', in Herrschaftszeichen und Staatssymbolik: Beiträge zu ihrer Geschichte vom dritten bis zum sechzehnten Jahrhundert, ed. by Percy Ernst Schramm (Munich: Monumenta Germaniae Historica, 1955), vol. 2, pp. 643-673.

Schubert, Ernst, 'Die Quaternionen: Entstehung, Sinngehalt und Folgen einer spätmittelalterlichen Deutung der Reichsverfassung', Zeitschrift für historische Forschung 20 (1993), 1-63.

Schwarz, Jörg, 'Die Wiener Neustädter Wappenwand', in Neue alte Sachlichkeit: Studienbuch Materialität des Mittelalters, ed. by Romedio Schmitz-Esser and Jan Keupp (Ostfildern: Thorbecke, 2015), pp. 141-162.

Seyler, Gustav A., Geschichte der Heraldik (Wappenwesen, Wappenkunst, Wappenwissenschaft) (Neustadt an der Aisch: Bauer \& Raspe, 1970).

Sieber-Lehmann, Claudius, Spätmittelalterlicher Nationalismus: Die Burgunderkriege am Oberrhein und in der Eidgenossenschaft (Göttingen: Vandenhoeck \& Ruprecht, 1995).

Small, Graeme, 'Local Elites and "National" Mythologies in the Burgundian Dominions in the Fifteenth Century', in Building the Past/Konstruktion der eigenen Vergangenheit, ed. by Rudolf Suntrup and Jan R. Veenstra (Frankfurt [am Main]: Peter Lang, 2006), pp. 229-245.

Stein, Robert. 'Seventeen: The Multiplicity of a Unit in the Low Countries', in The Ideology of Burgundy: The Promotion of National Consciousness, 1364-1565, ed. by D'Arcy Jonathan Dacre Boulton and Jan Veenstra. (Leiden: Brill, 2006), pp. 223-285.

Stroo, Cyriel, De celebratie van de macht: presentatieminiaturen en aanverwante voorstellingen in handschriften van Filips de Goede (1419-1467) en Karel de Stoute (467-1477) (Brussel: KVABWK, 2002).

Sutter, Berthold, 'Landeswappen und Landesbewusstsein: Die Landeswappen als Symbol territorialer Selbständigkeit', Zeitschrift des Historischen Vereins für Steiermark 93 and 94 (2002 and 2003), 57-147 and 47-81.

Turner, Hilary L., Town Defences in England and Wales: An Architectural and Documentary Study, AD 9oo-150o (Hamden: Archon Books, 1971).

Vale, Malcolm, War and Chivalry: Warfare and Aristocratic Culture in England, France and Burgundy at the End of the Middle Ages (London: Duckworth 1981). 
Van Anrooij, Wim, 'Duitse lof voor een Brabantse hertog. De ererede op Jan I', Queeste 10 (2003), 127-145.

Van Anrooij, Wim, 'King of Arms of the Ruwieren: A Special Function in the German Empire', in The Herald in Late Medieval Europe, ed. by Katie Stevenson (Suffolk: Boydell \& Brewer, 2009), pp. 111-132.

Vanden Bemden, Yvette, 'Le vitrail sous les ducs de Bourgogne et les Habsbourg dans les ancien Pays-Bas', in Liber Amicorum Raphaël de Smedt, ed. by J. Vander Auwera (Leuven: Peeters, 2001), pp. 19-46.

Van Egmond, Anne-Maria J., 'Opgetekend: materiële representatie aan het Haagse hof 1345-1425', PhD thesis, University of Amsterdam, 2019.

Vrancken, Valerie, De Blijde Inkomsten van de Brabantse hertogen: Macht, opstand en privileges in de vijftiende eeuw (Brussels: Academic and Scientific Publishers, 2018).

Woodcock, Thomas, and John Martin Robinson, The Oxford Guide to Heraldry (Oxford: Oxford University Press, 1990).

\section{About the authors}

Mario Damen is a Senior Lecturer at the University of Amsterdam. He has published widely on the social and political history of the late medieval Low Countries and is the PI of the research project 'Imagining a Territory: Constructions and Representations of Late Medieval Brabant', financed by the Dutch Research Council (NWO).

Marcus Meer is a Research Fellow at the German Historical Institute London (GHIL). His focus is on communication and visual culture in the towns and cities of late medieval Europe. 


\title{
10. The Territorial Perception of the Duchy of Brabant in Historiography and Vernacular Literature in the Late Middle Ages
}

\author{
Bram Caers and Robert Stein
}

\begin{abstract}
The medieval Duchy of Brabant was composed of several geographical and territorial elements. This composite structure was generally known, but is not entirely reflected in Brabantine historiography. Canonical texts, both in Latin and in the vernaculars, were structured along the lines of the ducal dynasty, and generally emphasised the indissoluble relationship between the dukes and a more or less well-defined territory. This contribution traces the development of the triangular relation between dynasty, title, and territory in narrative texts. In looking for traces of the multifaceted composition of the duchy, it confronts canonical historiography with vernacular epic literature, showing that high nobility looked for a way to integrate its own ancestry into the dominant narrative of the ducal genealogies.
\end{abstract}

Keywords: Duchy of Brabant; historiography; genealogy; Duchy of Lower Lotharingia; Grimbergsche oorlog

In an address to the Estates of Brabant in 1398, Philip the Bold, duke of Burgundy and count-consort of Flanders (r. 1384-1404), tried to lay claim to the inheritance of his 76 -year-old kinswoman Johanna (r. 1355-1406), the childless duchess of Brabant. ${ }^{1}$ Burgundian claims to Brabant were 
substantial, but there were others coveting the duchy, making the possibility of inheritance along female lines a crucial factor in the discussion, as Philip's claims relied on two female links in the genealogical chain. In his address, Philip the Bold showed himself to be well aware not only of the female succession, but also of the composite character of the Duchy of Brabant:

La duchié de Brabant fu composée de plusieurs baronnies ou seigneuris particuliers, c'est assavoir de la conté de Louvaing et des terres de Bruxelles et marquisat d'Anvers, èsquelles femmes succèdent. ${ }^{2}$

The duke of Burgundy referred to the main constituent elements of the duchy, being the old counties of Brussels and Leuven on the one hand, and the margraviate of Antwerp on the other. Quite like Philip, modern scholars have stressed the fragmentation of the Duchy of Brabant, as a sometimes inconsistent collection of several territories. The duke's address invites us to nuance the deconstruction of the concept of 'territory' in the work of Stuart Elden. While such a deconstruction may bear fruit for an analysis of the usage of territorial concepts specifically, Philip seems to refer mainly to the geographical extent of the Duchy of Brabant. Along these lines, we use the term 'territory' for a geographical space, enclosed within known (albeit changing) frontiers and with a political and historical significance. Our analysis of territory is not primarily related to geography, but to historiography and literature, and stresses the interplay between territory and dynasty, in that noble titles theoretically fuel claims to territories, and that these claims are voiced, legitimised, and strengthened in literary texts. As such, our usage of the term 'territory' sides with what Elden has called 'territoriality'.

Whereas the duke of Burgundy referred to only three elements, the fragmentation was much more complex below this superstructure, as is reflected in the survival of several banneret lordships and the coexistence of different urban jurisdictions. ${ }^{4}$ Modern scholars acknowledge that over the centuries, the territory of the duchy was expanded by generations of princes, in conflicts with vassals and ambitious neighbours. Nevertheless, the perceived union of Brabant is an image that persists strongly in

sister, Margaret of Brabant (1324-1380), who had married the late count of Flanders, Louis of Male (1330-1384).

2 Trans.: 'The duchy of Brabant is composed of multiple banneret lordships and seigneuries with female successions, notably the county of Leuven, the lands of Brussels and the margraviate of Antwerp'; Froissart, Oeuvres, vol. 13, pp. 342-345.

3 Elden, 'Land, Terrain, Territory'.

4 See, for example, Damen, 'Prelaten, edelen en steden', pp. 52-53; Damen, 'Heren met banieren'. 
narrative sources of the Late Middle Ages, and especially in the genre of historiography. In these narrative texts, there is a firm linkage between 'territory', understood as an enclosed geographical space with political and historical significance, and 'dynasty', in that a princely title nearly always referred to a more or less specific territory, and that both title and territory were ideally passed down through generations of a dynasty. The triad of dynasty, title, and territory were part of a cultural construction in historiographical and literary texts, that could confirm or challenge existing political realities at the time of writing. Examples such as Jan van Boendale's Brabantsche yeesten (first half of the fourteenth century), Hennen van Merchtenen's Cornike van Brabant (1415) or the 1498 prose chronicle Alder excellenste cronyke van Brabant all significantly deal with the genealogy of the dukes, but also with the continuity of a princely title that referred to a more or less well-defined territory. 5 They show that in the Late Middle Ages, the duchy was an object of recognition and love for its inhabitants - or at least for those who were aware of its history. For a historically informed audience, the territory of Brabant and the dynasty were mutually binding elements in their emotional recognition, and formed the two pillars of the Brabantine 'imagined community'. 6 The ducal court and the urban elites actively promoted this image through literature and historiography, and this patronage seems to have been followed to a certain extent also by others engaged in literary patronage, albeit infusing it with their own interests. Indeed, outside the ducal court, noble patrons seem to have cherished the ambition to intertwine their own glorious history with that of the dukes. ${ }^{8}$ In line with the growing attention paid to regional and local history in the Late Middle Ages, we aim to show that the noble families of Brabant aspired to have their own ancestral histories written into the dominant narrative of the ducal dynasty. By confronting the evolution of historiography with literary material that holds the middle ground between historiography and fiction, we will argue that there was room for a more diverse understanding of the history of the territory of Brabant. We will discuss the traditions with

5 Van Anrooij, 'De literaire ambities'; Tigelaar, Brabants historie ontvouwd.

6 For the tension between written historiography and broader knowledge: Caers and Overlaet, 'Brabo en de Grimbergse Oorlog in Antwerpen'; Stein, Politiek en historiografie. The concept of the 'imagined community' is Benedict Anderson's.

7 Boendale, who wrote his Brabantsche yeesten for the Antwerp alderman Willem Bornecolve, is just one example; see Sleiderink, De stem van de meester, pp. 118-122.

8 Sleiderink, “'Une si belle histoire”', pp. 556-557; Sleiderink, De stem van de meester, for the literary patronage under subsequent dukes; Caers, 'Een "buchelin inn flemische”', for the genre of epic literature specifically. 
regard to the dynasty, the ducal titles, and the territory identified in the canonical historiography of Brabant and will address these from a multifocal perspective found in an important historical epic that reflects the point of view of one of the local bannerets, the so-called Grimbergsche oorlog.

\section{Historiography in Brabant}

Traditionally, the genre of medieval historiography was highly structured by continuity of princely blood. Central to many chronicles is the idea that the noble status of a dynasty was passed along bloodlines and could be ennobled further through the ages. In these cases, the legitimacy of a prince rested on his ancestors, represented in genealogies in a linear sense: A genuit B, B genuit C, and so on. ${ }^{9}$ Exclusive succession along a male line of descent - agnatic - was seen as ideal, but was sometimes impossible. History is littered with examples of erratic successions. Either the lineage continued along female (cognatic) lines, was broken, or dynastic succession was impossible, as in the case of (prince-)bishops and popes.

Ideally, the founding father of a dynasty was associated with a certain territory, which provided a basis for the claims of supposed descendants, at the time in which the chronicles were written. This linear image is often represented in historiography and genealogy, across the Low Countries, and lends itself also to iconographical use. ${ }^{10}$ In Flanders, according to the Liber Floridus (1112-1115), the ancestors of the counts laid claim to uninhabited lands somewhere in the eighth century. ${ }^{11}$ In Holland, the Chronicon Egmondanum (1269-1272) voices the oldest claims of the present lineage of counts to the territory of Holland, as well as the highly contested region of Frisia. ${ }^{12}$ In this way, most principalities in the Low Countries boasted historiographical and genealogical texts that looked for distant links between princely authority and territory, legitimising the power of contemporaneous princes.

Scholars studying Brabantine historiography have devoted considerable attention to its emphasis on the dynastic lines: the supposed continuity of the ducal dynasty into Carolingian and even Trojan times. ${ }^{13}$ There has been much less debate on the continuity of territory associated with this

10 See, for example, the foldout genealogy included in the Alder exellenste cronyke van Brabant, discussed extensively by Tigelaar, Brabants historie ontvouwd.

11 Carasso-Kok, 'Het Woud zonder genade'.

12 Burgers, 'Geschiedschrijving in Holland tot omstreeks 1300', pp. 104-117.

13 Keesman, De oneindige stad, passim. 
title, and the form that claims to this territory took in the course of the centuries. Also, while the fragmented nature of the duchy is widely agreed upon, the attention paid to signals of this fragmentation in historiography is scant. Speaking mainly in general terms, historians have analysed the tension between ducal concerns and the concerns of a mainly urban elite in historiography and literature, but have only recently started looking for specific traces of the territorial fragmentation of the duchy in the texts under scrutiny. ${ }^{14}$ These studies have shown that a need for a more local narrative existed mainly in peripheral areas, such as 's-Hertogenbosch, or in localities that had a complex geographical situation in the duchy as well as in the historiography of Brabant, such as Mechelen. ${ }^{15}$

The roots of Brabantine historiography most probably lie in a dynastic crisis after the demise of Hendrik III of Brabant (r. 1248-1261) in 1261. Hendrik IV (r. 1261-1267), his firstborn son, was deemed unfit to rule the duchy, and authority in practice passed to his mother, Aleidis of Burgundy, widow of Hendrik III, until Jan I (r. 1267-1294), the secondborn, came of age and became duke of Brabant in 1267. This controversial succession may have triggered a number of Latin genealogies written around 1268, which trace the roots of the ducal dynasty back to the Carolingians and the Trojan king Priamus (see Fig. 10.1). ${ }^{16}$ These magnanimous ancestors helped to legitimise Jan's position.

There are three genealogies: a long and short version of the Genealogia Karoli Magni successorumque eius ducum Brabantie, heredum Francie, the Genealogia ducum Brabantiae amplicata and the Genealogia ducum Brabantiae metrica. In 1294, an anonymous author, probably working on the basis of these genealogies, completed the Chronica de origine ducum Brabantiae, which laid the groundwork for Jan van Boendale's Brabantsche yeesten, the first vernacular chronicle of the duchy, written in the first half of the fourteenth century. This text would become the backbone of both vernacular and Latin historiography in the duchy for centuries to come. ${ }^{17}$ Boendale's work was not only continued in verse in the 1430 s, but would also form the basis of the printed prose chronicle Alder excellenste cronyke, which continued to dominate the historiography of the duchy through the sixteenth century and beyond.

14 See, for example, Sleiderink, De stem van de meester, pp. 118-122 and elsewhere. For a recent overview, see Caers, Demets and Van Gassen, Urban History Writing.

15 See Van Os, Kroniek van Petervan Os, and Caers, Vertekend verleden.

16 The epic text Sone de Nansay, probably commissioned by Aleidis, is illustrative of the discussions in the duchy concerning the succession after Hendrik III. See Sleiderink, De stem van de meester, pp. 69-75. On Troy, see specifically Keesman, De eindeloze stad.

17 Van Anrooij, 'De literaire ambities', pp. 291-292. 


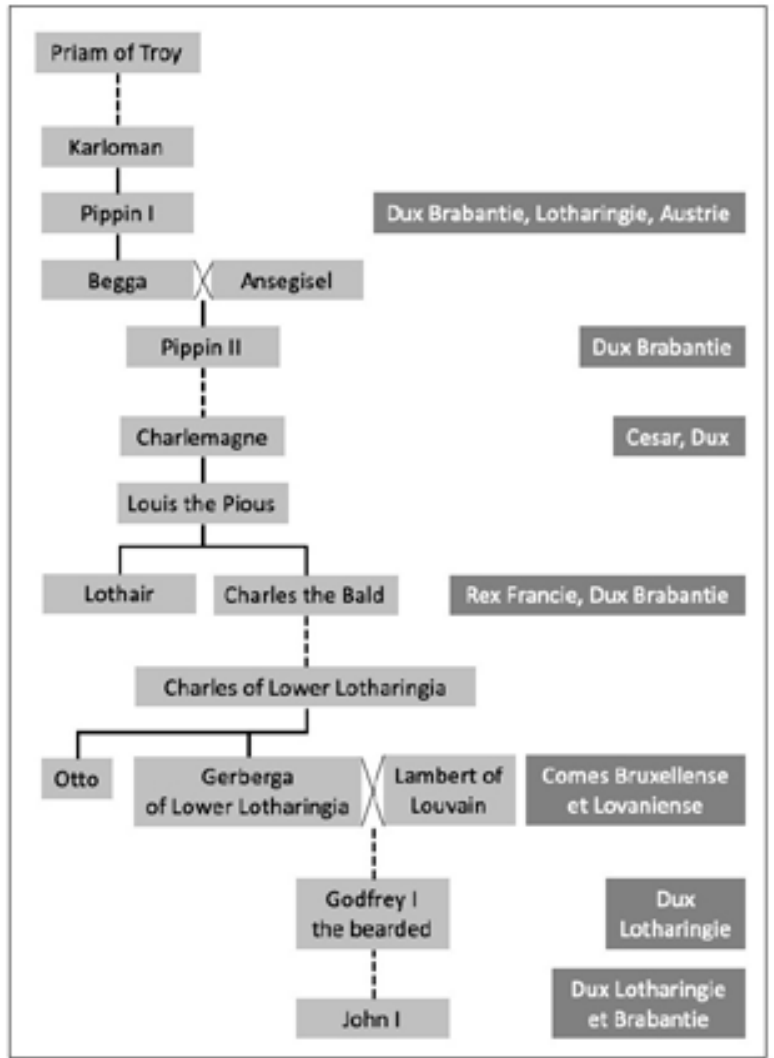

Fig. 10.1. Line of descent in Brabantine genealogies.

In the genealogies, the ancestry of the dukes is traced back through Charlemagne, to his illustrious sixth-century forefather Karloman. The ideal agnatic line of succession was broken on two occasions by the intervention of a cognatic link. In the seventh century, Pippin I's firstborn daughter, Begga, married Ansegisel, producing a son, Pippin II (of Herstal), whose descendants would form the Carolingian dynasty. Further down the line, there was another rupture, where the title passed from Charles, duke of Lower Lotharingia, to Gerberga, whose descendants would become the counts of Leuven and Brussels.

Dynastic lines mattered to medieval chroniclers, but most important to them was the nature of the titles held by subsequent ancestors and the territories to which these titles theoretically laid claim (see Table 10.1). The oldest dukes were interchangeably called 'dux Austrie', 'dux Brabantie' or 'dux Lotharingie'. Despite the different titles, all three essentially denote the same dignity. In the Genealogia Karoli Magni successorumque eius ducum 
Table 10.1. Titles used in the genealogies

\begin{tabular}{lll}
\hline & Text title & $\begin{array}{l}\text { Indication of title of the } \\
\text { first-mentioned prince }\end{array}$ \\
\hline 1A & $\begin{array}{l}\text { Genealogia Karoli Magni successorumque eius } \\
\text { ducum Brabantie. Short version }\end{array}$ & Dux Austrie inferioris \\
1B $\quad \begin{array}{l}\text { Genealogia Karoli Magni successorumque eius } \\
\text { ducum Brabantie. Long version }\end{array}$ & Dux Brabantie \\
2 & $\begin{array}{l}\text { Genealogie ducum Brabantiae ampliata } \\
\text { Genealogia ducum Brabantiae metrica } \\
\text { Brabantscheyeesten }\end{array}$ & $\begin{array}{l}\text { Dux Lotharingie et Brabantie } \\
\text { Dux Lotharingie et Brabantie } \\
\text { Hertoghe van Lotrike }\end{array}$ \\
\hline
\end{tabular}

Brabantie, heredum Francie, the founding father of the dynasty, Pippin I, is called 'Dux Brabantie, que tunc Austria vocabatur' ('duke of Brabant, which was called Austrasia at the time'). Elsewhere, it is written that Lothair was 'Dux Austrie, que ab ipso Lothario mutato nomine est vocata Lotharingia' ('duke of Austrasia, which after this Lothair changed its name and was called Lotharingia'). ${ }^{18}$

From a territorial perspective, there is an important element in the genealogy that later historiographers did not fail to stress. The first princes in the ducal lineage possessed titles such as 'dux Lotharingie' or 'dux Austrie', as did Charlemagne for example, whose full title in the short version of the Genealogia Karoli Magni succesorumque eius ducum Brabantie begins: 'Karolus imperator, rex et dux Austrie'. However, there was an important rupture in the succession of Charles of Lotharingia, who suffered a defeat against the usurper Hugues Capet, which caused the collapse of the glorious Brabantine dynasty, effectively shrinking the territory it laid claim to, to the counties of Leuven and Brussels. The title of 'duke of Lower Lotharingia' passed to the house of Ardennes-Namur - at least according to the simplified version, related in Brabantine historiography. ${ }^{19}$ Sole heir of the dynasty, Gerberga of Lower Lotharingia, married Lambert, count of Leuven and Brussels, laying the base of the later Duchy of Brabant. It would take a few generations before Godfried I of Brabant (r. 1095-1139) would regain the title of duke of Lower Lotharingia, in 1106, or as one of the Genealogiae has it: 'in quo stirps Karoli restituta est in gradum pristinum, scilicet ducatum Lotharingie' ('in him the Carolingian lineage was restored to its old position,

18 For a discussion of both territories, also in a geographical sense, see Gaillard, 'L'héritage austrasien'.

19 Historically speaking, the developments are of course much more complex. We restrict ourselves here to the perception in historiography. 


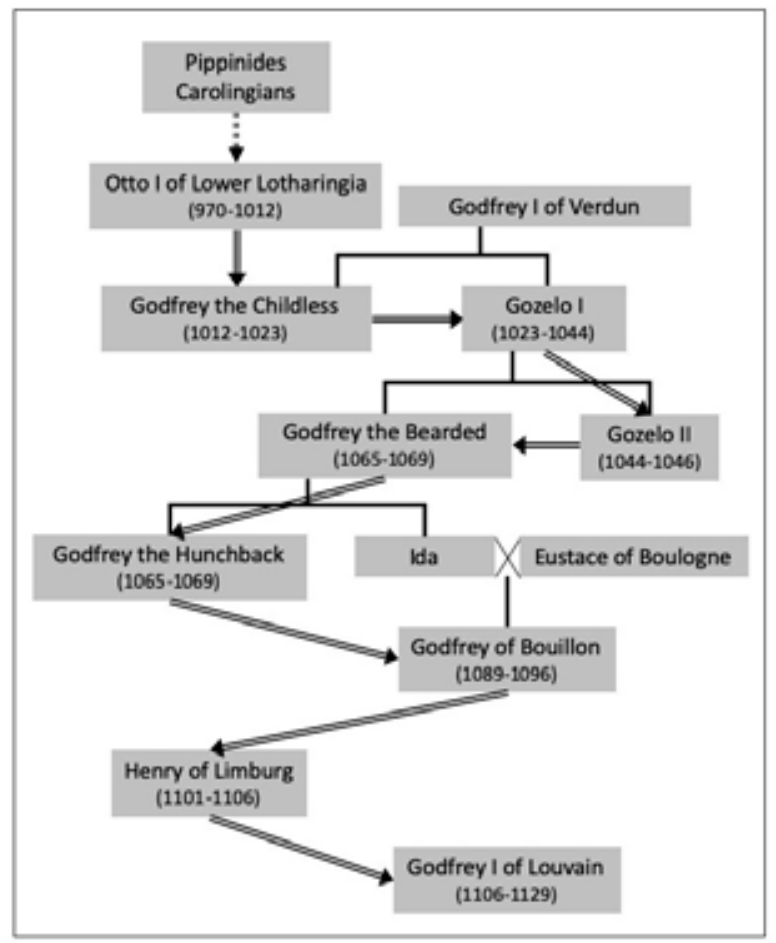

Fig. 10.2. Dukes of Lower Lotharingia (970-1129), according to Brabantine historiographical tradition.

namely the Duchy of Lotharingia'). ${ }^{20}$ The acquisition of the Lotharingian title by the house of Leuven-Brussels is confirmed in modern scholarship, which stresses that the title also implied the acquisition of the margraviate of Antwerp. ${ }^{21}$

It is interesting to see that Brabantine historiography 'filled in the blanks', so to speak, between Charles of Lower Lotharingia and Godfried I of Brabant, by relating a short version of how the title of Lower Lotharingia passed to the house of Ardennes, which gave them the opportunity to incorporate into their histories not only the impressive feats of Godefroi of Bouillon, but also the life of Saint Ida, his mother (see Fig. 10.2). This confirms that in the Late Middle Ages, chroniclers were not only interested in the continuity of the dynasty, but also in the historical development of the title of 'dux Lotharingie' and the territorial claims to the entirety of Lower Lotharingia that came with it.

20 Genealogiae, p. 389.

21 Bonenfant and Bonenfant-Feytmans, 'Du duché de Basse-Lotharingie au duché de Brabant'; Guilardian, 'Les ducs de Brabant, héritiers des ducs de Lotharingie'. 


\section{The territory}

The claim to the title of duke of Lower Lotharingia, and indeed the territorial claims that the title implied, were legitimised and perceived as historically just, at least in the canonical historiography. Not only did the ancestors of the dukes in bygone days carry the title of Lower Lotharingia, they were also born and bred in the territory, making their roots and their claims as firm as can be. In the vernacular, Jan van Boendale formulated this as follows, explicitly claiming the land 'tlant' of Lotharingia for 'Brabant', to be understood here as the ducal dynasty:

Oec heeft van Brabant tlant
Van Lothrike altoes gheweest
Dat vorste, alsoe men leest,
Ende daer die princen hier te voren
Van beghinne uut sijn gheboren,
Ende daer si ooc te wonen plaghen
[...]
Dus mach men, bi vele saken,
Merken ende verstaen, claerlike,
Dat die gherechte name van Lothrike
Den hertoghen van Brabant
toebehoert. ${ }^{22}$

Oec heeft van Brabant tlant

Dat vorste, alsoe men leest,

Ende daer die princen hier te voren

Ende daer si ooc te wonen plaghen

$[\cdots]$

Merken ende verstaen, claerlike,

Dat die gherechte name van Lothrike

Den hertoghen van Brabant

toebehoert. ${ }^{22}$
The land of Lower Lotharingia has always belonged to [the dynasty of] Brabant. Its first princes were born there and they have always lived in Lotharingia, [...] so it is fair to say that the title belongs to the dukes of Brabant.

Having developed over centuries, without being a recognisable political unit, one could ask what 'Lower Lotharingia', in terms of actual land, meant to the minds of people in the Late Middle Ages. The genealogies assert that the dukes of Lower Lotharingia ruled over a vast land between the rivers Scheldt and Rhine - 'terra scilicet iacentis inter Scaldam er Renum. ${ }^{23}$ This demarcation can be traced back to the subsequent divisions of the Carolingian Empire, which stipulated that Lower Lotharingia lay between the Scheldt to the west, the Rhine to the east, and the petty river of Vinxtbach to the south, which had been serving as a frontier since Roman times. ${ }^{24}$ While unsubstantiated by contemporary political reality, this idea of a land confined between the great rivers would survive the ages and would, for example, resonate in the Burgundian claim to a separate kingdom between France and the Empire. Through its association with a title that was passed on over generations, the space became a territorial image. As a historical 
ideal, Lotharingia was used through the ages to legitimise territorial as well as dynastic claims, by the Brabantine dukes and by the Burgundians after them. ${ }^{25}$

It is no surprise to see that historiographers in medieval Brabant tried to mould the idea of Lower Lotharingia into the contemporary territorial reality of the duchy, including the ambition of expansive dukes such as Jan I (r. 1267-1294). His eastbound campaigns, culminating in the Battle of Woeringen (1288) and the definitive acquisition of the Duchy of Limburg, stimulated historiographers to continue to include the eastward side of Lotharingia in their description of the Duchy of Brabant. From c. 1300 onwards, they referred most often not to the Rhine, but rather to the river Meuse as the eastern frontier, tuning their historiography to the actual situation. To the north, the new acquisition of the title of duke of Lower Lotharingia by Godfried I meant that he could add the margraviate of Antwerp to his possessions, stretching eastward from its capital on the river Scheldt. ${ }^{26}$ It became uncontested as a constitutive part of the Duchy of Brabant in the Late Middle Ages. ${ }^{27}$ It is surprising how little Jan van Boendale has to say about the territorial implications of the acquisition of the title of duke of Lower Lotharingia, in his discussion of the conflict with Hendrik of Limburg, another contestant for the old title:
Ende [Godfried I] dede [Hendrik And [Godfried of Brabant] of Limburg] selke scande,
Dat hi Godevaerde, ten selven tide,
Moeste laten die westside
Van der Masen, al tenen male.
Dus wijde Godevaert sine pale,
Ende vercreech Lothrike met allen,
Dat sinen vorders was ontvallen. ${ }^{28}$

While the acquisition of the margraviate is implicitly referred to by stating that the duke was able to push his frontier eastward to the river Meuse, it is surprising that Boendale, himself a city clerk in Antwerp, did not take the opportunity to stress the role of the margraviate more explicitly. The fact

26 Steurs, 'Brabant groeit naar macht', pp. 65-66.

27 The fact that the town of Antwerp and some of the neighbouring villages passed into Flemish hands for half a century during the Brabantine War of Succession (1356-1357) is perceived as a historical anomaly in Brabantine sources.

28 Boendale, Brabantsche yeesten, book III, ll. 34-40. 
that the river Meuse, and not the river Rhine, was now the border of the duchy, is a difference that Boendale referred to elsewhere, in a discussion of the ducal title:

Sint wonnen sijt [the dukes of Brabant], met ghewelt, Tusschen den Rijn ende der Scelt Ende hieldent oec met eeren;<smiles>[AlH2]</smiles>

Van dese lande, is ons bekant, Scriven die hertoghen van Brabant, Dat si heren sijn al gheheel; Nochtan en ist maer een deel Dat sijs houden heden daghe. Maer om dat wilen hoer maghe Gheweldighe heren daer in saten, Is hem die name noch ghelaten. ${ }^{29}$
The dukes conquered and honourably held the land between the Rhine and the Scheldt. Their titles claim to hold this land entirely, but they rule only over part of it. They were allowed to hold on to the title because of the greatness of their ancestors.

In other words: Boendale is well aware that the dukes of his time could not realistically lay claim to the entirety of Lower Lotharingia, and held the title in effect as a remembrance of the greatness of their ancestors. In later historiographical texts, this difference would serve as a starting point for explaining the actual geography of the Duchy of Brabant on the one hand, and the ideal territory of Lower Lotharingia on the other. For example, in the narrative of Brabon, a legendary origin myth that first appeared in the second quarter of the fourteenth century, the original territory is referred to as being enclosed within Cambrai on the river Scheldt, and Nijmegen on the river Rhine..$^{30}$ Over a century later, the compiler of the Alder excellenste cronyke van Brabant handily refers to the actual situation as 'Clein Lothrijk, vander Masen nederweert totter Scelt' ('Small Lotharingia, from the Meuse down to the Scheldt'), and when discussing the reign of Godfried I, he similarly attests that his lands stretched 'vander Masen totter Schelt'. ${ }^{31}$

While there are discussions as to the natural limits of the duchy, both in its daily political sense and in its ideal, Lotharingian sense, it is interesting

29 Ibid., book 1, ll. 173-186. Trans.: 'The dukes conquered and honourably held the land between the Rhine and the Scheldt. Their titles claim to hold this land entirely, but they rule only over part of it. They were allowed to hold on to the title because of the greatness of their ancestors.'

30 Keesman, De eindeloze stad, p. 325.

31 Alder excellenste cronyke van Brabant, fols N5v, L3v; and see also Hir. 
to see how most chroniclers looked at the duchy as a single territory under a single ruler, with a single line in history related to a single title. Even Boendale, who wrote his chronicle in Antwerp, failed to do justice to the history of 'his' margraviate within the body of the duchy. Still, when Philip the Bold addressed the Estates of Brabant, he showed himself to be well aware of its composite character. The reality, indeed, was far more complex, and while the canonical historiographies do not fully reflect the fragmented nature of the duchy, some other vernacular texts do.

\section{Grimbergsche oorlog}

A narrative that attempts to combine both the acquisition of the title of duke of Lotharingia, and the new ascent to power of the line of counts of Leuven after Hugues Capet, is the so-called Grimbergsche oorlog (War of Grimbergen), an epic tale in rhymed couplets. Written in the first half of the fourteenth century (roughly contemporary to Boendale's Brabantsche yeesten), this text deals with the events of a mid-twelfth-century conflict between the dukes of Brabant and Lotharingia on the one hand, and the lords of Grimbergen on the other. It is important to note that the direct descendants of the Grimbergen party, the noble house of Berthout, were among the highest nobility in the Duchy of Brabant, often in close proximity to the court, while at the same time wielding power over part of the city of Mechelen, an independent enclave in the duchy. $3^{2}$ In its bare essence, the Grimbergsche oorlog relates how the lords of Grimbergen, in contrast to other important banneret lords in the region of Brabant, failed to bend their knee and pay homage to the duke of Brabant, who had only recently reacquired this title along with the dignitary title of duke of Lotharingia. 33 The conflict escalated into an open war, ending with the destruction of the castle of Grimbergen and the victory of the dukes.

The text of the Grimbergsche oorlog features dozens of noble characters who must have been well known to the fourteenth-century audience,

32 See for an exhaustive study on the Berthout family: Croenen, Familie en macht. Some of the family members are known to have been patrons of literature; see Sleiderink, "Une si belle histoire"', p. 553 .

33 The conflict was only very scarcely described in the Auctarium Affligemense (c. 1148-c. 1164), a compendium of annals recorded in the Brabantine monastery of Affligem, near Brussels. The full Latin passage has been edited along with the entire Auctarium affligemense in the Monumenta Germaniae Historia, Scriptores, band 6, p. 404. The description of the Auctarium here is partly based on Caers and Overlaet, 'Brabo en de Grimbergse Oorlog in Antwerpen'. 
often including full heraldic description of their arms. ${ }^{34}$ While the core of this narrative is historical, the events have been fictionalised to such an extent that the complete story should be seen as siding more with contemporaneous epic literature, than with historiography, albeit incorporating factual elements such as the heraldic information. ${ }^{35}$ The patronage and initial reception of this text are still subject of debate, but it is evident that the text in part justifies the claims of the Grimbergen party, or at the very least paints a rather more positive picture than Boendale, who explicitly doubts their noble intentions..$^{36}$ The Grimbergsche oorlog introduces readers into courtly debates on the Grimbergen side, gaining insight into their motives in standing up to the dukes of Brabant: pacifists and warmongers alike get a chance to voice their opinions. In this way, the narrative invites the audience to ponder the limits of ducal power in Brabant, and the balance between princely ambition and that of the high nobility circling his court. ${ }^{37}$

In terms of the depiction of territory and the link between the duchy and the dynasty, it is interesting to see how the authors of the Grimbergsche oorlog looked for a careful synthesis of the canonical view of Brabantine historiography and their ambition to rectify the overly negative portrayal of the Grimbergen party. The epic opens with a long passage that places this twelfth-century history in line with canonical genealogy of the dukes. In the first few verses, the Grimbergsche oorlog relates the elevation of the dukes of Brabant from their lower state of counts of Leuven, introducing this event as the catalyst of the conflict that will be the centre of the narrative. In the passage that follows, the lords of Grimbergen are described as powerful noblemen, quite in the way the banneret lords served the duke in reality:

34 On the heraldry in the Grimbergsche oorlog, and its implications for dating the narrative, see Haverals, 'Heraldisch vakmanschap', who counted no less than 98 detailed heraldic descriptions.

35 The text sits well with the epics of revolt in the genre of the chanson de geste, where rebellious vassals stand up against their overlord Charlemagne. On the specificity of vernacular literature in Brabant, see Caers, 'Een "buchelin inn flemische”', pp. 241-244, and Sleiderink, “'Une si belle histoire"'.

$3^{6}$ For the debate on initial reception, see Croenen, 'Het dubbele auteurschap', Appelmans, 'De "Grimbergsche oorlog"', and Sleiderink, “Une si belle histoire”, pp. 556-557, as well as Sleiderink, De stem van de meester, pp. 112-113. We lean towards the opinion of Sleiderink, who places the patronage in the context of the Berthout family, who were the direct descendants of the house of Grimbergen. Croenen convincingly showed that the text was written by two authors with distinct profiles. The passage in Boendale's Brabantsche yeesten (book IV, 1l. 221-223) is short. 37 Sleiderink, “'Une si belle histoire”', pp. 556-557. 
In't oirloghe, als ic verstae,

Dat tusschen den hertoghe

Godevaerde

Was endoic den heren waerde

Van Grimberghen, die sekerlike

Machtich waren ende rijcke

Van grote lande in dien tyde,

Dat omtrent hem wide ende side

Met sconen beempden was

gheleghen.

Sy hadden menighen coenen deghen,

Die Grimbergen hoirden toe,

Dair sy den hertoghe doe

Met oirloghden, alse ic u sal

Segghen, om dat hy woude van al

Grimberghen overheere wesen,

Ghelijc ghy hier sult horen lesen ${ }^{38}$
In the war between Duke

Godfried and the lords of

Grimbergen, who were cer-

tainly powerful and wealthy,

in riches and land, stretching

widely around them in beautiful pastures, [the lords] commanded many brave men among their vassals, with whom they fought the duke, who wanted to be sovereign over Grimbergen, as you will hear told.

The rest of the lengthy introduction is a crash course in Brabantine historiography, taking the audience along the canonical line of genealogy. The descendants of the Trojans, who settled in the region, are said to have claimed a territory 'tusschen der Masen en den Scelt' ('between Meuse and Scheldt') (l. 106) or 'tusschen der Scelt ende Haspeguwe' ('between Scheldt and Hesbaye') (l. 119), handily comprising the recently acquired Duchy of Limburg, which played an important role in the Brabantine claims to the title of Lower Lotharingia. In the following few hundred lines, the author relates how the title and territory of Lotharingia were subsequently transferred to the house of the Ardennes. The house of Brabant was left with the county of Leuven and Brussels, 'dair luttel dorpen hoirden toe' ('with only a few villages') (l. 293). It is in this fall from grace, and indeed in this reduction of power and territory, that the author of the Grimbergsche oorlog places the origin of the feudal conflict in the twelfth century: the noble houses that in bygone years had sworn fealty to the duke of Lotharingia - not only the house of Grimbergen, but also those of Edingen (Enghien), Gaasbeek, and Horn, all banneret lordships still present in the fourteenth century and therefore recognisable to the audience - now went their own ways. When Godfried I of Brabant was restored to the power of his forebears, his claims to their former territory were met with doubt among the important houses 
in the duchy. His bold ambition to subjugate the houses of Brabant closes the introduction to the Grimbergsche oorlog:

Tot dat op Her Godevart quam,

Die stout was als d'onvervaerde, Ende die men hiet metten Baerde.

Hoort ende swiget overal

Wat ic u voort seggen sal

Hoe hi ten hertochrike quam weder,

Dat lange gelegen hadde ter neder,

Van Lothrike ende van Brabant;

Al gader ginc't al schoon te hant ${ }^{39}$
Until the ascent of the brave Godfried the Bearded. Listen to what I will tell you, about the rise of the duchy [i.e. dignity] of Lotharingia and Brabant, which had long been subdued.

In this introduction as well as throughout the description of the conflict that follows, the Brabantine party is repeatedly referred to as the 'Lotharingians', endorsing the claims of the dukes. It takes a little while before the audience is properly introduced to the Grimbergen side, but this passage firmly links their power not only to their vast territories and their material wealth, but also to the vassals under their banners or the nobles supporting their claims - Vianden, Artois, Hainaut, Breda, and several others, often introduced with full mention of their arms. ${ }^{40}$ These noble supporters, to the minds of the medieval audience, were connected to the lands they commanded, in terms of the number of knights and footmen that could be levied from them. On the Brabantine side, the most important bannerets are introduced in the same way. The idea conveyed to the audience is that in terms of real territory as well as feudal support, the lords of Grimbergen at least equalled the duke of Brabant, who in fact only exerted real power over the old counties of Leuven and Brussels, while relying on the feudal support of vassals elsewhere. At the same time, the power of the duke, too, is shown to be divided between several nobles in his support. More than contemporary historiographical texts, the Grimbergsche oorlog therefore provides insight into the motivations of the rebellious vassals, and into the multifaceted composition of ducal power. In part, the text exempts the house of Grimbergen from its historical uprising. The dukes, on the other hand, were depicted as having history on their side, even if they were greatly reduced in importance when compared to their forebears. Both parties are 
presented as having claims that are legitimate to a certain extent, and the audience is left to form its own opinion.

\section{Conclusion}

As the canonical origin myths in the Duchy of Brabant mainly focused on the dynasty of the dukes, and the territory of Brabant and Lotharingia, one could wonder how the lower nobility dealt with this dominant narrative. Historiography had to balance out the historical claims to territory and power of the dukes on the one hand, and the hierarchy of power with its most important vassals on the other. In the canonical view of the history of Brabant, which went back to Latin genealogies written in the thirteenth century, the stress is on the unity of the titles and the dynastic lines tracing the ancestry of the dukes to illustrious forefathers. The territorial implication of this inheritance lies mainly in the title of Lower Lotharingia, which was passed down through the generations, only to get lost in the early eleventh century. When the line of the dukes regained the title in the twelfth century, under Godfried I of Brabant, subsequent dukes of Brabant actively sought to restore the power and glory of their ancestors. This battle was fought not only on the fields of Brabant and neighbouring principalities, but also in ink. Historiographers tied to the court legitimised the territorial claims of the dukes by tracing their lineage through the shrouds of time, and by continuously stressing that the position of duke of Lower Lotharingia entitled the dukes to a territory situated between the rivers Rhine (or Meuse) and Scheldt. In canonical historiography, the all-encompassing narrative of dynastic succession and territorial claims left little room to do justice to the daily reality of the Duchy of Brabant as an essentially fragmented region, composed of several more or less equal parts, in which power and territory was shared among the high nobility, the Estates, and the duke. But the complexity was known, for example, by Philip the Good, and was reflected in narrative sources outside canonical historiography. The Grimbergsche oorlog conveys the message that Brabant was fragmented, both in terms of its territory as well as in terms of the balance of power. Its audience in the fourteenth century was invited to ponder the limits of ducal power, and the way in which lesser nobles were able to exert power in their own right within the unity of the Duchy of Brabant. In this way, the epic ties in with the contemporary reality in the duchy. It is perhaps no coincidence that the scions of the Grimbergen dynasty, the house of Berthout, ruled over the independent city of Mechelen while at the same time playing an important role at the Brabantine court. 
These high noblemen, as well as other bannerets in the Duchy of Brabant, will have been keen to tie their own ancestry and history in with the dominant historiographical narrative in the duchy. While more or less entirely fictional, the Grimbergsche oorlog was set into prose in the fifteenth century and incorporated into historiographical texts, signalling the need of late and post-medieval audiences for a more local take on historiography, which could counterbalance the primacy of the holistic perspective.

\section{Bibliography}

\section{Primary sources}

Alder excellenste cronyke van Brabant. Transcription included in Jaap Tigelaar, Brabants historie ontvouwd (Hilversum: Verloren, 2006), https://www.dbnl.org. Boendale, Jan van [Jan de Klerk, d'Anvers], Brabantsche yeesten [Les gestes des ducs de Brabant], ed. by Jan Frans Willems and Jan Hendrik Bormans (Brussel: Koninklijke Commissie voor Geschiedenis, 1843), https://www.dbnl.org.

Froissart, Jean, Oeuvres de Froissart. Chroniques, ed. by Kervyn de Lettenhove, 26 vols (Brussels, 1867-1877).

Genealogiae ducum Brabantiae, ed. by J. Heller, in Monumenta Germaniae Historia, Scriptores, vol. 25 (Hannover: Hahn, 1880), pp. 385-413, http://www.dmgh.de.

Grimbergsche oorlog, ed. by Philip Blommaert and Constant Philippe Serrure (Ghent: Annoot-Braeckman, 1854), https://www.dbnl.org.

Van Merchtenen, Hennen, Cornicke van Brabant, ed. by Guido Gezelle (Ghent: Siffer, 1896), https://www.dbnl.org.

Van Os, Peter, Kroniek van Petervan Os, ed. by Anne-Marie Van Lith-Droogleever Fortuijn et al. (The Hague: Instituut voor Nederlandse Geschiedenis, 1997).

\section{Secondary sources}

Anderson, Benedict, Imagined Communities: Reflections on the Origin and Spread of Nationalism (London: Verso, 1983).

Appelmans, Janick, 'De “Grimbergsche Oorlog”: een curieuze en een boeiende tekst', De Donjon 4-6 (2002-2004).

Avonds, Piet, Brabant tijdens de regering van Hertog Jan III (1312-1356): land en instellingen (Brussel: Paleis der Academiën, 1991).

Bijker, Sjoerd, 'The Functions of the Late Medieval Brabantine Legend of Brabon', in Networks, Regions and Nations: Shaping Identities in the Low Countries, 1300-1650, ed. by Robert Stein and Judith Pollmann (Leiden: Brill, 2010), pp. 91-109. 
Bijsterveld, Arnoud-Jan, and David Guilardian, 'De vorming van het hertogdom (8431106)', in Geschiedenis van Brabant. Van hertogdom tot heden, ed. by Raymond van Uytven (Zwolle/Leuven: Waanders/Davidsfonds, 2004), pp. 41-63.

Bonenfant, Paul, and Anne-Marie Bonenfant-Feytmans, 'Du duché de BasseLotharingie au duché de Brabant', Revue belge de philologie et d'histoire 44 (1969), 1129-1165.

Burgers, Jan, 'Geschiedschrijving in Holland tot omstreeks 130o', Jaarboek voor Middeleeuwse Geschiedenis 3 (2000), 92-130.

Caers, Bram, 'Een "buchelin inn flemische”: over ontstaan en verspreiding van de ridderepiek in de Nederlanden (ca. 1150-1450)', Tijdschrift voor Nederlandse taal- en letterkunde 127 (2011), 223-251; 128 (2012), 389.

Caers, Bram, Vertekend verleden. Geschiedenis herschrijven in vroegmodern Mechelen (1500-1650) (Hilversum: Verloren, 2020).

Caers, Bram, and Kim Overlaet, 'Brabo en de Grimbergse Oorlog in Antwerpen (13 januari 1478). De stedelijke toe-eigening van regionale historiografie en orale tradities in het laatmiddeleeuwse Brabant', Belgisch Tijdschrift voor Filologie en Geschiedenis 97, no. 4 (2019), 21-44.

Caers, Bram, Lisa Demets and Tineke Van Gassen, eds, Urban History Writing in Northwest Europe (15 ${ }^{\text {th }}-16^{\text {th }}$ centuries) (Turnhout: Brepols, 2019).

Carasso-Kok, Marijke, 'Het Woud zonder genade', Bijdragen en Mededelingen betreffende de Geschiedenis der Nederlanden 107 (1992), 241-263.

Croenen, Godfried, Familie en macht. De familie Berthout en de Brabantse adel (Leuven: Peeters, 2003).

Croenen, Godfried, 'Het dubbele auteurschap van de "Grimbergsche oorlog"', in Maar er is meer: avontuurlijk lezen in de epiek van de Lage Landen: studies voor JozefD. Janssens, ed. by Remco Sleiderink, Veerle Uyttersprot and Bart Besamusca (Leuven/Amsterdam: Davidsfonds/Amsterdam University Press, 2005), pp. 131-151.

Damen, Mario, 'Heren met banieren. De baanrotsen van Brabant in de vijftiende eeuw', in Bourgondië voorbij: De Nederlanden 1250-1650: Liber alumnorum Wim Blockmans, ed. by Mario Damen and Louis Sicking (Hilversum: Verloren, 2010), pp. 139-158.

Damen, Mario, 'Prelaten, edelen en steden. De samenstelling van de Staten van Brabant in de vijftiende eeuw', Handelingen van de Koninklijke Commissie voor Geschiedenis 182 (2016), 5-274.

Elden, Stuart, 'Land, Terrain, Territory', Progress in Human Geography 34, no. 6 (2010), 799-817.

Gaillard, Michèle, 'L'héritage austrasien', in La Lotharingie en question. Identités, oppositions, integration, ed. by Michel Margue and Hérold Pettiau (Luxemburg: Section historique de l'Institut G.-D. de Luxembourg, 2018), pp. 375-389. 
Guilardian, David, 'Les ducs de Brabant, héritiers des ducs de Lotharingie', in La Lotharingie en question. Identités, oppositions, integration, ed. by M. Margue and H. Pettiau (Luxemburg: Section historique de l'Institut G.-D. de Luxembourg, 2018), 475-488. Haverals, Wouter, 'Heraldisch vakmanschap in "De Grimbergsche oorlog”', Queeste 23 (2016), 22-36.

Hazebrouck-Souche, Véronique, Spiritualité, sainteté et patriotisme. Glorification du Brabant dans l'oeuvre hagiographique de Jean Gielemans (1427-1487) (Turnhout: Brepols, 2007).

Houthuys, Astrid, Middeleeuws kladwerk: de autograafvan de Brabantsche yeesten, boek VI (vijftiende eeuw) (Hilversum: Verloren, 2009).

Keesman, Wilma, De eindeloze stad. Troje en Trojaanse oorsprongsmythen in de (laat)middeleeuwse en vroegmoderne Nederlanden (Hilversum: Verloren, 2017).

Meisen, Karl, 'Niederland und Oberland', Rheinische Vierteljahrsblätter 15-16 (19501951), 417-464.

Melville, Gert., 'Vorfahren und Vorgänger. Spätmittelalterliche Genealogien als dynastische Legitimation zur Herrschaft', in Die Familie als sozialer und historischer Verband. Untersuchungen zum Spätmittelalter und zur frühen Neuzeit, ed. by Peter-Johannes Schuler (Sigmaringen: Thorbecke, 1987), pp. 204-309.

Sleiderink, Remco, De stem van de meester: de hertogen van Brabant en hun rol in het literaire leven (1106-1430) (Amsterdam: Prometheus, 2003).

Sleiderink, Remco, “Une si belle histoire de nos propres seigneurs”: la noblesse brabançonne et la littérature en néerlandais (première moitié du XIV siècle)', in Les librairies aristocratiques dans les anciens Pays-Bas au Moyen Âge: actes de la journée d'étude internationale organisée à Bruxelles (Palais des Académies), le 20 octobre 2006, ed. by An Faems and Colette Van Coolput-Storms (special issue of Le Moyen Âge 113 (2007)), pp. 549-567.

Stein, Robert, Politiek en historiografie. Het ontstaansmilieu van Brabantse kronieken in de eerste helft van de vijftiende eeuw (Leuven: Peeters, 1994).

Stein, Robert, 'Recht und Territorium. Die lotharingischen Ambitionen Philipps des Guten', Zeitschrift für historische Forschung 25 (1997), 374-386.

Steurs, Willy, 'Brabant groeit naar macht', in Geschiedenis van Brabant. Van hertogdom tot heden, ed. by Raymond van Uytven (Zwolle/Leuven: Waanders/ Davidsfonds, 2004), pp. 65-73.

Tigelaar, Jaap, Brabants historie ontvouwd. Die alder excellenste cronyke van Brabant en het Brabantse geschiedbeeld anno 1500 (Hilversum: Verloren, 2006).

Uyttebrouck, André, Le gouvernement du duché de Brabant au bas Moyen Âge (1355-1430) (Bruxelles: Éditions de l'Université de Bruxelles, 1975).

Van Anrooij, Wim, 'De literaire ambities van Hennen van Merchtenen', Tijdschrift voor Nederlandse taal- en letterkunde 109 (1993), 291-314. 
Van Eeckenrode, Marie, and Véronique Flammang, 'Le jardinet de Hainaut: essai de typologie et clés d'interprétation (XIV ${ }^{\mathrm{e}}$ XVIII ${ }^{\mathrm{e}}$ siècles). Mises en scène d'un comté lors des inaugurations princières en Hainaut', Bulletin de la Commission royale d'Histoire 177 (2011), 45-80.

Van Tol, D., 'De Orde van de Hollandsche Tuin. De oudste ridderorde van Holland (1387-1418)', De Nederlandsche Leeuw 114 (1997), 6-34.

Van Uytven, Raymond, De geschiedenis van Mechelen: van heerlijkheid tot stadsgewest (Tielt: Lannoo, 1991).

\section{About the Authors}

Bram Caers is a Postdoctoral Researcher (NWO-Veni) at Leiden University and specialises in medieval and early modern Dutch literature and early modern manuscripts. He has published on epic literature, urban historiography and early modern rhetorician's manuscripts. He is currently studying subversive manuscripts presenting an alternative memory of the Dutch Revolt in the Habsburg Low Countries.

Robert Stein is Senior University Lecturer in History at Leiden University, specialising in the medieval political and cultural history of the Burgundian Netherlands. At present he is working on the 'culture of accountability' - the development of a shared administrative culture - in the Late Middle Ages and early modern period. 


\title{
11. Imagining Flanders: The (De)construction of a Regional Identity in Fifteenth-Century Flanders
}

\author{
Lisa Demets
}

\begin{abstract}
This chapter examines the construction of collective historical identities in late medieval Flemish towns in the early fifteenth century. The Burgundian dukes and the Flemish elites tried to shape and 'control' representations of their principality, but in literary, pictorial, and historiographical sources the focus on the Flemish count gradually gave way to a focus on the largest Flemish cities. Analysing the Imago Flandriae, a Latin prophecy on the Hundred Years' War, and the Flandria Generosa C, a Latin chronicle of Flanders, I argue that these literary sources illustrate the new influence of major Flemish towns in new regional institutions, such as the Four Members of Flanders, and on regional politics under Burgundian rule.
\end{abstract}

Keywords: chronicles; Flanders; cities; ideology; elites

\section{Introduction}

Medievalists have been occupied with the cultural and social aspects of 'national', or, better, 'regional' identity for decades. ${ }^{1}$ Some scholars argued that already as early as the twelfth century, around 1111, something like

1 Guenée, Histoire et culture historique; Werner, 'Les nations et le sentiment national'. There are numerous publications on 'national identities' in the Low Countries, in particular for the county of Flanders and the duchy of Brabant: De Ridder, 'Dynastiek en nationaal gevoel'; Verbruggen, 'Het nationaal gevoel'; Stein, 'Nationale identiteiten'. In a volume on national identities combining research on identities in Flanders, Brabant, Friesland and Guelders, Robert Stein and Judith Pollmann argued how the concept of 'nationalism' can (carefully) be applied to some medieval principalities. Stein, 'Introduction', p. 5. However, following Walter Prevenier,

Damen, M. and K. Overlaet (eds.), Constructing and Representing Territory in Late Medieval and Early Modern Europe. Amsterdam: Amsterdam University Press, 2022 DOI 10.5117/9789463726139_CH11 
a 'Flemish identity' emerged in a poem by Petrus Pictor, a canon of the Church of Our Lady at Saint-Omer and a contemporary of the more famous writers Lambert of Saint-Omer, his colleague, and the comital secretary Galbert of Bruges. ${ }^{2}$ Indeed, in his De Laude Flandriae, Pictor pledged his love for the county of Flanders. Rather than a song of praise for the territory and land of Flanders, the poem was first and foremost a homage to the glory of the Flemish counts. ${ }^{3}$ Although Pictor frequently used the word terra to refer to the county, his eulogy focused exclusively on the comital dynasty, and not on Flemish towns, villages, borders, or landmarks. A just interpretation of this alleged early expression of 'Flemish identity' requires an analysis of the specific context in which De Laude Flandriae was written. Remarkably enough, the canon had been banished from his beloved county when he wrote his piece. Petrus Pictor was clearly more aware of his 'Flemish identity' while forced to be living abroad. It seems that expressions of 'regional identities' became particularly relevant when a person left his home region - an important consideration scholars should keep in mind when studying medieval representations of territorial and feudal affiliations. As Robert Stein has stated: 'It is especially in confrontations with strangers that we are forced to define ourselves. ${ }^{4}$ For instance, in trading networks within the county of Flanders, between the largest Flemish cities, such as Ghent, Bruges, and Ypres, merchants would be addressed by their specific individual hometown. In contrast, while trading abroad, they are referred to universally as 'Flemings'.5 Examples of a 'Flemish identity' used within the context of the county are rather scarce until the late medieval period.

Although there are various possible ways to approach or define 'identity', I will refer to both individual and collective identities in this contribution as 'plural', 'composite', or 'multilayered' identities, shaped by several political, social, and cultural factors, but, more importantly, unstable and fluctuating over time. Issues of identity, belonging, and integration are recurrent in contemporary political discourses today. Belonging to a 'nation' nowadays does not merely begin or end with obtaining an official juridical status (citizenship) or with a financial obligation (paying taxes). Discourses of shared 'standards', 'behaviour', 'culture', and, of course, 'language' are

Wim Blockmans and Marc Boone, I prefer to use the more neutral concept of 'regional identities' for fifteenth-century Flanders, see Blockmans, 'Regionale Identität'.

2 Verbruggen, 'Het nationaal gevoel', p. 3; Van Acker, 'Petrus Pictor'.

3 Petrus Pictor, De Laude Flandriae, p. 132: 'Flandria diva, paris reges magnos comitesque'

('Divine Flanders, you gave birth to great kings and counts').

4 Stein, 'Introduction', p. 6.

5 Pajic, 'Flemish Rebels'. 
omnipresent in identity politics today. ${ }^{6}$ The layered meanings of such concepts are still subject of debate, in particular when applied to earlier historical periods. First and foremost, it is not clear if the term 'identity', which refers primarily to an individual attitude, can easily be applied to a group. The question of whether there are 'shared' or 'collective' identities is central not only to sociological or historical research, but also to social and political movements, both in the present and in the past. In this contribution, I will address how regional identities are related to territorial spaces in the late medieval county of Flanders. Doing so, I will focus on the construction of Flemish identities in the late medieval Flemish towns under the rule of the Burgundian dukes. Territory is a geographical concept which contains a political denotation. In contrast to Elden, I will approach the representation of a territory, in this case a principality, from a bottom-up perspective. ${ }^{7}$ First, not only the prince and his court are trying to shape and 'control' terrains and lands, but citizens, and, in particular, local or urban elites, as well. ${ }^{8}$ Second, ideological representations of territories were equally important to take into account apart from 'political technologies' such as measurements and borders. ${ }^{9}$ How did city dwellers in the county of Flanders identify with Flanders as a principality in the Late Middle Ages? I will illustrate how the focus on the prince, still central in the poem of Petrus Pictor, gradually shifted to a greater prominence of the largest Flemish cities in various representations of the county. Scrutinising this development, I will turn to literary, pictorial, and historiographical sources (such as a fifteenth-century prophecy and a Flemish chronicle) to offer a holistic approach to the cultural, social, and political factors influencing these changing representational strategies.

\section{Belonging to a region: The case of Flanders under Burgundian rule (1384-1482)}

For many years, regional identity was at the centre of the historical research on Burgundian 'state formation' and its processes of 'centralisation'. The question of whether there emerged a supra- or interregional identity between the

6 Anthias, 'Identity and Belonging'; Anthias, 'Where Do I Belong?'

7 I follow Stuart Elden's call for a more 'historical' and fluid approach to the concept of 'territory'. Elden, 'Land, Terrain, Territory', p. 810.

8 See the contribution of Jim van der Meulen in this volume for another bottom-up approach focusing on local lordships in the duchy of Guelders.

9 Elden, 'Land, Terrain, Territory', p. 811. 
different principalities of the Low Countries in the fifteenth and sixteenth centuries has been addressed by scholars such as Robert Stein and Judith Pollman..$^{10}$ Following Wim Blockmans, Robert Stein among others saw a shared supra-regional identity in the Low Countries in the late fifteenth century, resulting in the request for a common 'Great Privilege' from Mary of Burgundy in 1477. Nevertheless, Elodie Lecuppre-Desjardin highlighted the regional aspects and discourses in the Great Privilege of Mary of Burgundy, and the necessity for other regional charters and urban privileges. ${ }^{11}$ Amongst other towns in the Low Countries, Ghent and Bruges were both granted individual urban privileges. ${ }^{12}$

Surprisingly, Stein, Blockmans, and Lecuppre-Desjardin took the regional identity of each principality as a self-evident point of departure for their research. In fact, regional identity was not at all 'obvious' nor 'completed' at the beginning of the Burgundian dukes' rule over the different principalities in the Low Countries. By combining top-down and bottom-up approaches, Marc Boone argued that most principalities in the Low Countries developed a sort of 'regional identity' through the princely dynasty, central institutions, and fiscal policy of the Burgundian dukes. ${ }^{13}$ The Burgundian dukes were heavily influenced by the French royal ideology of absolute sovereign power, which then found expression in central institutions such as regional and supra-regional courts of justice and regional chambers of accounts. Furthermore, the state-making process of the Burgundian dukes was also a cultural one, as exemplified by the cultural splendours of the Burgundian court. ${ }^{14}$ In this regard, Boone pointed to 'the Burgundian appropriation of the collective memory of the principalities of the Low Countries' through a deliberate policy of gradually integrating historiographical traditions. ${ }^{15}$ This is true, at least, for the duchy of Brabant and the county of Hainaut, where historiographical projects were initiated by Philip the Good around 1440. ${ }^{16}$ There are very few examples of Flemish chronicles related directly to the Burgundian dynasty, let alone evidence that any were commissioned

\footnotetext{
10 Stein, 'Introduction'.

11 Lecuppre-Desjardin, Le royaume inachevé, p. 280.

12 Haemers, For the Common Good, pp. 166, 231.

13 Boone, 'Flemish and Brabantine Identity'.

14 Brown, 'Bruges and the Burgundian "Theatre-State"'; Van Bruaene, 'The Habsburg Theatre State'. The cultural splendour of the Burgundian dukes was, of course, central in the work of Johan Huizinga: Huizinga and Van der Lem, Herfsttij der Middeleeuwen.

15 Boone, 'Flemish and Brabantine Identity'.

16 Stein, Politiek en historiografie; Lecuppre-Desjardin, La ville des cérémonies; Small, 'Les Chroniques de Hainaut'.
} 
by the dukes themselves. However, as Robert Stein and Graeme Small illustrated, this historiographical campaign in Brabant and Hainaut was heavily embedded, if not initiated, by local urban and noble elites. ${ }^{17}$

Examples for the nearby duchy of Brabant are more common. Moreover, such a multilayered Brabantine identity might have preceded the rule of the Burgundian dukes. In Brabant, this 'regional' focus was imposed by the Brabantine dukes, but emerged in dialogue with towns and nobility. First, as mentioned, there are the early examples of a regional historiographical tradition with a strong connection to the local elites and towns (such as the thirteenth-century Rymkronyk by Jan van Heelu or Jan van Boendale's Brabantsche yeesten in the fourteenth century). Second, and perhaps more importantly, there is the constitutional tradition of charters issued by the Brabantine dukes. Since the middle of the thirteenth century, the Brabantine dukes issued a testament at the end of their rule in order to smooth the succession..$^{18}$ This resulted in the tradition of institutional charters for the whole Brabantine territory (such as the Charter of Kortenberg of 1312 and the Blijde Inkomsten or the 'Joyous Entry' charters) in the fourteenth century and afterwards. A similar tradition of charters issued for the entire county was, by contrast, absent in Flanders.

For Flanders, examples earlier than the late fourteenth century are rather scarce. Local particularism was relatively high and remained important in the county of Flanders. Various factors impeded a sense of regionalism in the county. First, the region itself is a composite from a feudal point of view, divided between the kingdom of France (Royal Flanders, west of the river Scheldt) and the Holy Roman Empire (Imperial Flanders, east of the river Scheldt). Second, there is the evident language issue. A linguistic 'border' divided the county of Flanders into a francophone south and a Dutch-speaking north. This linguistic border was not only territorial, but also social, as was the case for most principalities in the Netherlands. The Flemish counts, often firmly tied to the French court, were francophone, as was most of the higher nobility. Furthermore, in some of the 'Dutch-speaking' towns, such as Ypres, a patrician elite represented in the benches of aldermen spoke almost exclusively French. ${ }^{19}$ This language issue became problematic only during the early rule of the Burgundian dukes in 1404. This is especially interesting for the present study as the language question was politically attached to a regional identity when French-speaking 'foreigners' occupied 
positions in central institutions ('Flamans flamengans, nés de Flandre'). ${ }^{20}$ In Brabant, stipulations demanding a 'Brabantine origin' for ducal councillors had existed since $1356 .{ }^{21}$

Urban identity was perhaps more straightforward in the county of Flanders due to the exceptional commercial and political position of its towns: roughly one-third of the total population in the county of Flanders consisted of city dwellers. ${ }^{22}$ Although many urban inhabitants never acquired the status of citizen and its associated rights, 'official' city dwellers had a clear judicial status ('burghership'), which provided legal protection and economic privileges. Such a judicial position is absent on the regional level. This is the case for most territories in the Middle Ages, apart from England, where in the thirteenth century denisation (by the king) and naturalisation (by parliament) formed a sort of national judicial statute. ${ }^{23}$ Remarkably, these rights were exclusively granted to foreigners, often merchants. In the Bruges Poortersboeken (lists of new burghers) of the early fifteenth century, a new regulation was written down each time a female citizen acquired burghership: if she should marry someone from outside the county of Flanders ('lands Vlaenderen'), she would lose her citizenship. ${ }^{24}$ As female burghers could transfer their legal status to their husbands in some Flemish cities such as Bruges and Ghent, this new statute would limit citizenship exclusively to inhabitants of the county of Flanders, an indirect proof of a 'regional' identity.

Scholars have mainly focused on the role of the princely dynasty as the unifying factor in the county of Flanders. ${ }^{25}$ Medieval territories were not nations but 'principalities', bound together by the figure of a prince, his blood relatives, and his dynasty. As mentioned above, it was the Flemish dynasty, and, in particular, its representatives through marriages with the

20 Lecuppre-Desjardin, Le royaume inachevé, pp. 322-326.

21 In December 1355, the duchy was inherited by a female ruler, Johanna van Brabant. The concerns on 'foreign ducal advisors' were related to the fear for her husband Wenceslas of Luxemburg appointing his own councillors in the ducal council. Vrancken, Blijde Inkomsten, p. 298.

22 Boone, 'Flemish and Brabantine Identity', p. 180.

23 Lambert and Ormrod, 'Denization'.

24 E.g. Bruges, City Archives, 130 (Poortersboeken), eerste poortersboek (1418-1434), folio 4r ${ }^{\circ}$ (3 februari 1419): 'Kateline Fransoys Donckers dochter geboren van Ghent cochte haer poorterscip upten darden dach van sporkele bi Janne den Ram, in dezer condicien waerd dat zoe hier naer ener man trauwede van buten lands van Vlaendere gheboren dat haer danne haer poorterscip te gheenre bate commen zoude' ('Kateline Fransoys, Doncker's daughter, born in Ghent, bought her burghership through Janne den Ram, on the third day of February, on the condition that if she would marry a man born outside Flanders, she would lose her burghership'). Thanks to Leen Bervoets and Elisa Bonduel for this suggestion.

25 De Ridder, 'Dynastiek en nationaal gevoel'; Stein, 'Nationale identiteiten'. 
royal houses of England and France, that were praised in Petrus Pictor's twelfth-century De Laude Flandriae. In the late medieval period, the figure of the unifying prince remained important. Elodie Lecuppre-Desjardin stated that Burgundian state formation was solely related to the person of the duke, 'a contractual prince', not to a territorial identity. ${ }^{26}$ From the late fourteenth century onwards, regionalism became more and more tied to the Flemish towns. On the one hand, this can indirectly be related to shifts in literary practices. More and more city dwellers and lower lay elites were engaged in writing administrative, literary, and historiographical sources. Regional chronicles are exceptionally interesting in this regard. Often based on early or high medieval dynastic genealogies, regional chronicles shifted their focus from a given princely dynasty to the actual history of the principality and its largest towns. ${ }^{27}$ For the county of Flanders, regional history writing became entangled with urban history writing from the late fourteenth and early fifteenth centuries onwards. ${ }^{28}$ Various city dwellers were engaged in the rewriting of regional chronicles in the fifteenth century.

On the other hand, a new political situation in the late fourteenth and early fifteenth centuries stimulated this trend as well: the institutionalisation of the Four Members of Flanders, a representative council with deputies from the three largest Flemish towns, Ghent, Bruges, and Ypres, and the wealthy rural district around Bruges, the Franc of Bruges.$^{29}$ Although these three cities frequently gathered to negotiate with or without the Flemish counts earlier in the fourteenth century, the Four Members gained importance under the rule of the first Burgundian duke, Philip the Bold, and Margaret of Male, heiress to the counts of Flanders. ${ }^{30}$ This was related to the duke's frequent absences from Flanders. Moreover, Philip the Bold stimulated such central organisation of the county. The evolution of the Four Members into an actual representative institution influenced literary culture and historiography. The political position of the towns as representatives of the county needed legitimisation, and called for an ideological programme on who constituted the county of Flanders: the towns or the count.

26 Lecuppre-Desjardin, Le royaume inachevé, pp. 339-344.

27 Van Houts, Local and Regional Chronicles, pp. 20-24.

28 On the issue of urban chronicles in the Low Countries, see Lecuppre-Desjardin, La ville des cérémonies, pp. 68-75; Stein, 'Selbstverständnis oder Identität?'; Van Bruaene, 'Lécriture de la mémoire'; and, recently, the contributions to Caers, Demets and Van Gassen, Urban History Writing.

29 Prevenier, 'Het Brugse Vrije'.

30 Ibid. 
The arrival of the Burgundian dukes stimulated an interest in regional history writing in the commercial towns, in particular, in Bruges. This emergent (Flemish) 'identity' was, however, not dependent on the territory of Flanders as a whole, but rather on the unity between the largest Flemish towns. Regionalism, perhaps as much as particularism, emerged as an answer to the centralising politics of the Burgundian dukes. ${ }^{31}$ Central to this article are two representative case studies: the Imago Flandriae and the origin myth in the Flandria Generosa C, both written by or in the circle of Lubert Hautscilt, abbot of Eeckhout abbey in Bruges and advisor to the Burgundian dukes in the early fifteenth century. Both literary documents are illuminating examples of the 'composite' or 'multilayered' regional identity that emerged under early Burgundian rule in the Flemish cities.

\section{Regional history writing in the county of Flanders: The Flandria Generosa tradition}

The Flandria Generosa chronicles are generally considered the most important regional chronicle group in the county of Flanders. In the late twelfth century, a Benedictine monk from the Saint Bertin abbey in Saint-Omer wrote a short genealogy of the Flemish counts in Latin: the Flandria Generosa A. ${ }^{32}$ Over time, medieval writers translated, rewrote, and expanded the original text into an embellished chronicle. One manuscript of the Ancienne Chronique de Flandre, a rewritten French version of the genealogy, was probably commissioned by Robert of Bethune (d. 1322), or his father Guy of Dampierre (d. 1305). ${ }^{33}$ However, most Flandria Generosa texts and manuscripts cannot directly be related to the comital house. Important for this contribution is another rewritten branch of the complex Flandria Generosa chronicle group. In the aftermath of the Flemish coast uprising in 1323-1328, a Cistercian monk of Clairmarais abbey near Saint-Omer, Bernard of Ypres, revised and continued the original Benedictine genealogy. Later, the so-called Flandria Generosa $\mathrm{C}$ or Catalogus et Cronica Principum et Comitum Flandriae was founded upon this Clairmarais continuation. In the course of the fifteenth century, the Latin text was translated into Middle Dutch,

32 Kelders, 'De Flandria Generosa'. This genealogy was based on older genealogies, such as the one incorporated in the Liber Floridus of Lambert of Saint-Omer.

33 Moeglin, 'Une première histoire nationale'. 
and this eventually resulted in the first Middle Dutch prose chronicle of Flanders, the Excellente Cronike van Vlaenderen. ${ }^{34}$

The Flandria Generosa chronicles go through a profound change from the moment of the county's incorporation into the Burgundian realm, when the chronicle was appropriated by the Flemish cities. The Catalogus narrates Flemish history from the mythical origin of the county until the first years of the rule of the Burgundian duke Philip the Good. Due to the lack of original manuscripts, scholars have dated the Catalogus text to quite different periods, from the middle of the fourteenth century in Lille to the court of Duke Philip the Good in $1430 .{ }^{35}$ Recently, I argued that the Catalogus or Flandria Generosa C was written in the Eeckhout abbey of Bruges in the early fifteenth century - probably at the end of the reign of John the Fearless around 1411 - under the patronage of the notable abbot Lubert Hautscilt (abbot from 1393 until his death in 1417). ${ }^{6}$ Hautscilt was a writer himself, an astrologian, but also a cultural and literary patron. ${ }^{37} \mathrm{He}$ founded a religious confraternity in the Eeckhout abbey, the so-called fratres ad succurendum. John Duke of Berry, the elder brother of the Burgundian duke Philip the Bold, was a member, but there were numerous Bruges city dwellers who also belonged to this elite club, including various Bruges burgomasters and the Gruuthuse poet and rederijker ('rhetorician') Jan van Hulst. The composite identity of a figure like Lubert Hautscilt, who had important connections to the Burgundian court and religious societies in Flanders as well as political networks in Bruges, can be retraced in the discourse of the Catalogus.

The Flandria Generosa C is a Flemish chronicle, in its scope and outlook, structured by the succession of the Flemish counts. The author and his intended public shared a particular interest in the history of Bruges. Several additions were made to the original Clairmarais continuation, revealing a Bruges perspective.$^{38}$ For instance, the continuation describes the Revolt of Ghent (1379-1385) and ends with the Bruges factional war and rebellion against Duke John the Fearless at the beginning of the fifteenth century.

34 On the Excellente Cronike van Vlaenderen: Demets, 'The Late Medieval Manuscript Transmission'; Demets, Onvoltooid verleden.

35 Kelders, 'De kronieken van Vlaanderen', pp. 348-349; Lecuppre-Desjardin, La ville des cérémonies, pp. 68-75; Moeglin, 'Les ducs de Bourgogne'.

36 As I argued in my PhD dissertation. See further: Demets, 'De Flandria Generosa C'.

37 On Lubert Hautscilt, see Smeyers, 'Lubert Hautscilt'.

38 Such as the foundation of Damme in the twelfth century, the Bruges Moerlemaye or revolt at the end of the thirteenth century and the introduction of Jan Breydel as captain of the rebels during the Good Friday revolt on 18 May 1302. 
This focus on Bruges can be explained by the network of the author's patron, Lubert Hautscilt. The abbot was not only a prominent figure in the Burgundian context, but he also had a firm political base in his hometown, Bruges. Hautscilt was involved in the yearly renewal (i.e. election) of the benches of aldermen in 1411 and 1413, after the factional conflict in Bruges. Furthermore, Eeckhout abbey served as a meeting place for various urban events.

Besides the obvious Flemish and more implicit urban content, the Catalogus can also be interpreted as a 'Burgundian' chronicle. Although the text only fragmentarily deals with the history of Flanders under Burgundian rule, the appearance of the mythological forestier Liederik of Buc, the son of a Burgundian prince from Dijon, undoubtedly served to display a proBurgundian propaganda message..$^{39}$ More importantly, the inclusion of his legendary progenitor of the Burgundian dukes fits into the ideological programme of Hautscilt in his role as councillor to Philip the Bold and John the Fearless. The abbot worked as a diplomat during the Hundred Years' War, during which he also became an intimate friend of Duke John of Berry. ${ }^{40}$ This combination of Flemish, Burgundian, and urban narrative elements not only relates to early-fifteenth-century politics, but, as I will argue, also to the contemporary need to legitimise a new political and institutional role of the Flemish urban elite in the county of Flanders, and in the wider Burgundian realm. ${ }^{41}$ This discourse is particularly notable in the new Flemish origin myth introduced in the chronicle.

\section{Imagining a territory through its towns: The origin myth of Liederik de Buc and Brugstoc in the Flandria Generosa $\mathrm{C}$ and the Imago Flandriae of Lubert Hautscilt}

At the beginning of the fifteenth century, the county of Flanders had barely recovered from the Revolt of Ghent (1379-1385). The ongoing troubles linked

39 The new origin myth in the Catalogus has been analysed by many scholars: Kelders, 'Laverend tussen de hof der historie en de warande der literatuur'; Lambert, 'Oorsprongsmythen'; Keesman, De eindeloze stad, pp. 487-498.

40 Smeyers, 'Lubert Hautscilt'.

41 The urban view is central in this contribution. In the article by Bram Caers and Robert Stein in this volume, we see how noble families had their own ancestral histories written into the dominant narrative of the ducal dynasty in the duchy of Brabant. Similar conclusions on noble history writing can be made for the county of Flanders. See Buylaert, 'Memory'; Buylaert et al., 'Politics'. 
to the Hundred Years' War culminated during the reign of John the Fearless (1404-1419), particularly after the murder of Louis of Orléans in 1407. In Bruges, a civil war emerged, initiated by the Burgundian duke, which lasted from 1407 until around $1411 .{ }^{42}$ Around this turbulent political period, the Catalogus was written at Eeckhout abbey. The first case I want to address in this contribution is the new origin myth written in the Flandria Generosa $\mathrm{C}$ or Catalogus. This myth introduced a descendant of a Burgundian line of princes, Liederic de Buc, as the first ruler of the county of Flanders. Of course, this suggestion that the Flemish dynasty was originally 'Burgundian' primarily served to legitimise Burgundian rule in the county. Several details in the new origin myth point to the conflict of the Hundred Years' War, such as the banishment of Liederik's father and mother from France after a dispute with the eldest son of the French king and Liederik's short affair with an English princess. However, more specifically, the origin myth has an underlying hope for a peace treaty: Liederik eventually marries a French princess and reconciles with the French king. Of course, it is not exceptional for origin myths to refer to contemporary political problems. ${ }^{43}$ It would appear that the political situation at the beginning of the fifteenth century called for a new origin of the county of Flanders referring to contemporary Burgundian politics, as did the position of the major towns in this new political reality.

Scholars have overlooked the obviously 'urban' and, more specifically, Bruges-related elements in the new origin myth. For instance, Bruges is described as a flourishing harbour with established commercial connections to England. When Liederik was forced to flee England after his affair with the princess, the Catalogus writes how he sailed from Dover to Bruges ('Brugstoc'), where he stayed with a friendly local innkeeper or broker. ${ }^{44}$ The innkeeper recognised Liederik as the lost prince and informed him about his mother, still locked away in the castle of Lillebuc by the giant Finard. The innkeeper accompanied Liederik to Lille where Liederik slayed the giant. Afterwards, Liederik was asked by the people of Flanders to become their ruler. The Catalogus clearly and rather boldly describes how the city of Bruges was an attractive and wealthy harbour prior to the foundation of the comital house. The Catalogus also mentions how the new Flemish ruler, Liederik de Buc, founded a castrum on the Burg in Bruges and a small chapel which would eventually become Saint Donatian's Church. These 
details seem random at first sight, but they have a clear territorial political implication from the perspective of political 'areas' within the town: the Burg in Bruges was the oldest part of the town associated with comital power (as represented by the castrum and later the town hall), whereas the market square held the burghers' political symbols such as the Belfry. The harbour can be seen as a symbol referring to these commercial urban networks in Bruges. Moreover, according to the myth, these networks existed well before the princely castrum founded by Liederik de Buc. ${ }^{45}$ The exact age or foundation of Bruges was probably left deliberately vague, suggesting that the cities in the county of Flanders were older than history itself. In short, the new origin myth not only highlighted the Burgundian descent of the comital house, but also argued how the cities in the county of Flanders were much older than the first Burgundian forestier of Flanders. ${ }^{46}$

This could be one of the reasons why the myth of Liederik de Buc was never adopted by the Burgundian court historiographers and remained in the collective memory of urban society, in particular, the inhabitants of Bruges. ${ }^{47}$ This seems strange at first, with regard to the position of Lubert Hautscilt as a ducal advisor. Still, the seemingly innocent role of the Bruges innkeeper could refer to an urban intended audience of the Flandria Generosa $\mathrm{C}$ and the wider urban networks of Lubert Hautscilt. In this regard, it is interesting to look at the Hautscilt family's position in Bruges, as they were themselves innkeepers and brokers with Hanseatic roots, and had been active in Bruges from the beginning of the fourteenth century. ${ }^{48}$ The link with the Bruges brokers and innkeepers in the origin myth also leads us to a new cultural and political organisation that emerged in the $1390 \mathrm{~s}$ in Bruges, an organisation led by a forestier: the urban jousting society of the White Bear. ${ }^{49}$ Members of this elite urban society were mainly brokers and wealthy craftsmen. Furthermore, there is a clear link with Eeckhout abbey. Descriptions in the early-fifteenth-century cartulary of the abbey

45 The castrum is the oldest part of Bruges: Verhulst, The Rise of Cities, pp. 88-9o.

46 For example, the Catalogus mentions how Ghent had been founded by Julius Caesar. The Roman origin of Ghent was based on the Saint Bavo legend: Keesman, De eindeloze stad, pp. 498-499.

47 The origin myth of Liederik de Buc was given a prominent place in a tableau vivant during the Joyous Entry of Charles the Bold in 1515. Mareel, 'Jan de Scheereres'.

48 Demets, Onvoltooid verleden, pp. 78-85.

49 Brown, 'Urban Jousts'. The White Bear of Bruges was probably also a literary society as many early-fifteenth-century Bruges literary texts have been attributed to this milieu, including a number in the Gruuthuse manuscript, in particular the poem the 'Seven Gates of Bruges'. Dumolyn, 'Une idéologie urbaine "bricolée”. 
of Eeckhout show how the jousters organised meetings at the abbey. $5^{0}$ For their annual tournament each May, they assembled at the grounds of the abbey before they marched and rode to the Great Market. It follows that this new origin myth could have been used as a theme for one of the society's jousts or gatherings, perhaps in the presence of the Burgundian duke. This performative aspect is important with regard to the 'composite' urban, Flemish, and Burgundian identity emerging among these urban patrician elites in the early fifteenth century. Many of the jousters of the White Bear were members of important political families in Bruges, and represented the city in the meetings of the Four Members of Flanders. ${ }^{51}$ Perhaps, more than legitimising the Burgundian dynasty, the new origin myth links the success of the comital and 'Burgundian' dynasty to these urban elites.

Arguably, the Catalogus can be related to the networks of Lubert Hautscilt only indirectly. Nevertheless, the Eeckhout abbot was the author of a contemporary literary text, the Imago Flandriae. The Imago Flandriae is a Latin poem and image containing a prophecy on the future of Flanders. It was written by Lubert Hautscilt around 1400, and was transmitted widely and applied to many crises in Flanders such as the Eighty Years' War (1568-1648). The original prophecy was lost, but several sixteenth- and seventeenth-century printed copies have been preserved. Prophecies were written intentionally vaguely so as to be applicable to various future political events..$^{2}$ The original prophecy, however, was obviously composed in the context of the Hundred Years' War between France and England, as it warns the major cities of Flanders, or 'GYBID', that is, Ghent, Ypres, Bruges, Lille ('Insula'), and Douai, of the political and economic consequences of the war. The discourse of the prophecy in the context of the Hundred Years' War is equally omnipresent in the Flandria Generosa C, and relevant for an urban context as the largest Flemish towns depended on the English trade. Moreover, the prophecy shows striking similarities to the Properheden van den steden van Vlaendren (The properties of the towns of Flanders) written around 1380. An anonymous author, probably linked to the jousting society of the White Bear in Bruges as well, described Flanders ('dus hebben wij Vlaendren int ronde') by listing 58 Flemish towns along with a local characteristic, an eating habit, their political or social standing, or cultural markers..$^{53}$ Not coincidentally, the Properheden starts with the Four Members of Flanders 


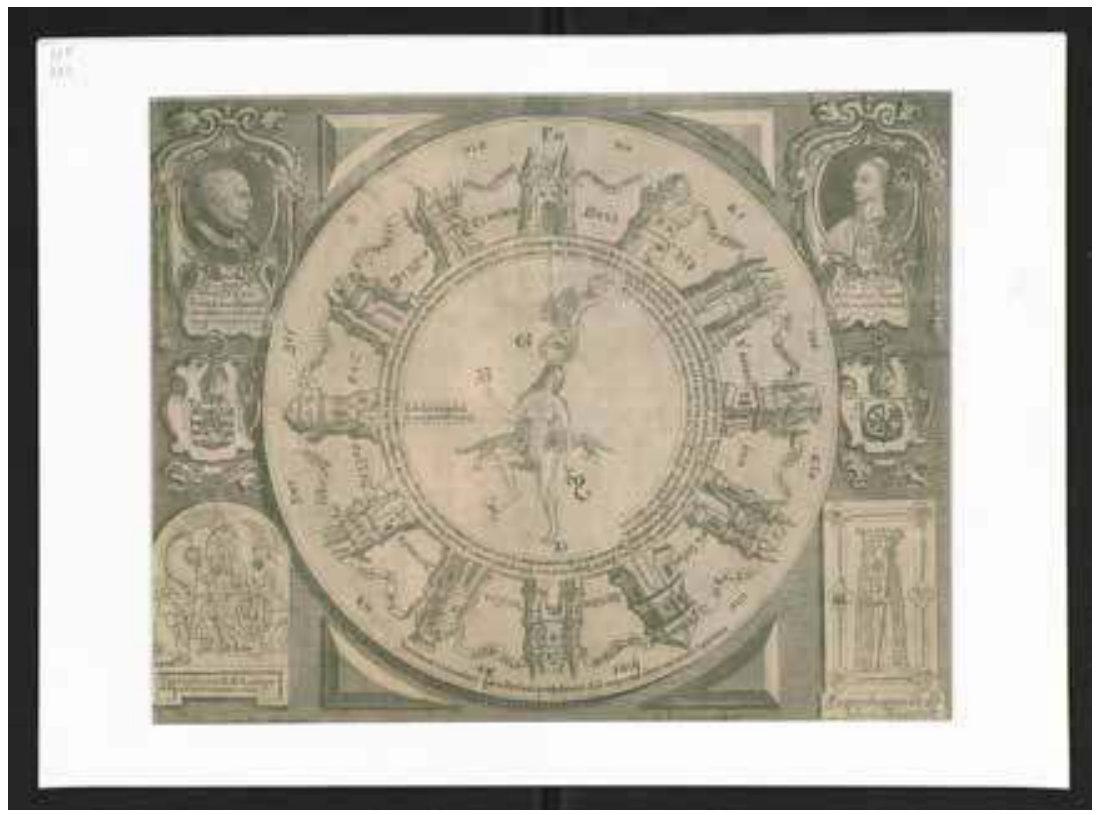

11.1. Imago Flandriae of Lubert Hautscilt by Jacob Van Oost II and Pieter De Brune (Brugge: Lucas Vanden Kerckhove, 1671). ๑ Public Library Bruges, H.F. 226.

'Heeren van Ghendt. Poerters van Brugghe. Kindre van Ypere. Darinc berders van den Vrien' ('Lords of Ghent. Burghers of Bruges. Children of Ypres. Peat fires of the Franc'). ${ }^{4}$ This hierarchy between the towns can also be detected in the Imago Flandriae.

The prophecy itself belongs to a larger pictorial and textual entity: a clarifying poem was written in a band around an allegorical representation of the county of Flanders. ${ }^{55}$ The naked woman in the middle of the image symbolises Flanders, nursing two wolves representing England and France. In this way, the Imago Flandriae bears a resemblance to the allegory of city maidens, symbolising the purity of the town and its need for protection, a recurrent political image in the late medieval and early modern Low Countries..$^{6}$ The letters surrounding the woman's body refer to the five largest Flemish towns, and were written each next to a different body part, representing the body politic of Flanders. ${ }^{57}$ Ghent is her head, Bruges her right hand, Ypres her left hand, and Douai and Lille her feet. These are not 
the only territorial aspects of the image: the woman is also enclosed by the city gates of several Flemish towns..$^{8}$ The Flemish towns are thus central in this allegorical representation of Flanders: they are the body, the head, and the limbs of the county, but equally serve as a protective hortus conclusus ('enclosed garden'). The placement of the letters referring to the five largest cities next to the image of Flanders is not random and stands in direct relation to the prophecy predicting the loss of Douai and Lille: 'Gyb fiet ex GYBID, cum deca decas ibit' ('GYB will come forth out of GYBID, when ten decades have passed'). ${ }^{59}$ Although the pictorial representation implies a hierarchy (Ghent as the head, the leading town of the Four Members), the prophecy-poem clearly describes them as a unity: GYBID dilecta ('beloved GYBID'). Strikingly, Flanders is not once mentioned in the poem, nor is the comital house or the duke. The county of Flanders is instead represented by the unity of its most important towns and protected by its gates and walls.

\section{Conclusion}

The question of whether and how urban elites of the county of Flanders identified themselves with the Flemish territory cannot be answered straightforwardly. Nevertheless, the interest in a Flemish chronicle in urban milieux increased from the moment the county was incorporated into a larger territorial entity, the Burgundian composite state. In this contribution, I discussed two literary products from the early fifteenth century: the origin myth of Liederik de Buc in a newly written regional chronicle, the Catalogus et Cronica Principum et Comitum Flandriae (or Flandria Generosa C), and a prophecy on the future of Flanders, the Imago Flandriae. These texts were produced in an elite milieu in Bruges around the figure of the abbot of Eeckhout, Lubert Hautscilt, who was connected to urban society in Bruges (through the jousting society of the White Bear) as well as to the Burgundian court. His literary texts show how the Burgundian dynasty was integrated into Flemish history, but even more that 'Flanders' was viewed as an entity constituted by its towns, in particular the largest cities of Ghent, Bruges, and Ypres. The cities were the political body of the county, represented by a naked woman in the Imago Flandriae prophecy and protected by urban features (walls and gates). The head and limbs of Flanders were composed

$5^{8}$ The towns differ according to the edition, so probably they were adapted over time. Hautscilt made a clear statement by depicting the gates wide open.

59 Hautscilt, Imago Flandriae, p. 85. 
of the five largest towns: Ghent, Bruges, Ypres, Lille, and Douai. A regional identity emerged as a call for unity between the Flemish cities. Of course, the question remains whether such a constructed 'regional identity', a political ideology, ever truly surpassed the particularising tendencies of the towns, and even the individual elite urban factions within the Flemish cities.

Around 1111, the poem of Petrus Pictor illustrated how the Flemish dynasty gave shape to expressions of the county's regional identity. In the early fifteenth century, the towns gradually claimed this representational position: by integrating their history into the origin myth of the comital house. The role of the three largest Flemish cities, introduced in the origin myth and the text of the Catalogus or Flandria Generosa $C$, was elaborated in the rewriting of the text during the fifteenth century. In the Excellente Cronike van Vlaenderen, the Middle Dutch translation and continuation of the Catalogus, the "Three Cities' appear as an institution, a prominent historical actor, as a protector of the county, and projected back through time onto the earliest history of the county. ${ }^{60}$ Similar to the representation of the Flemish towns in the Imago Flandriae, they function as a sort of defender of the balanced relationship between the prince and his subjects, appearing as a deus ex machina at times of conflict, restoring order by calling for the rightful count. Late medieval Flemish readers would link the appearance of the Three Cities with the late medieval institution, the Four Members of Flanders. Like its Middle Dutch translations and continuations, the Catalogus was not commissioned by or explicitly dedicated to the Burgundian dukes. Nevertheless, its intended audience was clearly a pro-Burgundian, Flemish and urban elite assembled in the representative institution of the Four Members of Flanders. In this way, the Catalogus as well as the Imago Flandriae legitimised the role of the towns in regional politics. The Four Members saw themselves as the true guardians of the Flemish heritage, willing to protect it against 'foreigners'. Or, as the new origin myth in the Catalogus implicitly states: Bruges was already a wealthy harbour before the arrival of the prince of Dijon.

\section{Bibliography}

\section{Primary sources}

Bruges, City Archives, 130 (Poortersboeken), Eerste Poortersboek (1418-1434). Bruges, Public Library, H.F. 226. 
Catalogus et Cronica Principum et Comitum Flandrie, ed. by J.J. de Smet, in Recueil des chroniques de Flandre - Corpus chronicorum Flandriae (Brussel: Hayez, 1837), pp. 19-257.

Hautscilt, Lubert, Imago Flandriae, ed. and trans. by Maurits Smeyers, in 'Lubert Hautscilt, abt van de Brugse Eeckhoutabdij (1393-1417). Over handschriften, planeten en de toekomst van Vlaanderen', Academiae Analecta. Mededelingen van de Koninklijke Academie voor Wetenschappen, Letteren en Schone Kunsten van België 55 (1995), 41-104.

Petrus Pictor, De Laude Flandriae, ed. and trans. by Lieven Van Acker, 'Petrus Pictor en zijn “De Laude Flandriae”, De Franse Nederlanden 8 (1983), 129-145.

De Properheden van den Steden van Vlaendren, ed. by Antoon Viaene, in 'De Properheden van den Steden van Vlaendren 1380-1400', Biekorf 77 (1977), 129-133.

\section{Secondary sources}

Anthias, Floya, 'Identity and Belonging: Conceptualisations and Political Framings', KLA Working Paper Series, Working Paper, no. 8 (2013), https://kompetenzla. uni-koeln.de/sites/fileadmin2/WP_Anthias.pdf.

Anthias, Floya, 'Where Do I Belong? Narrating Collective Identity and Translocational Positionality', Ethnicities 2 (2004), 491-514.

Blockmans, Wim, 'Regionale Identität und staatliche Integration in den Niederlanden 13.-16. Jahrhundert', in Nationale, ethnische Minderheiten und regionale Identitäten in Mittelalter und Neuzeit, ed. by Antoni Czacharowski (Torun, 1994), pp. 137-149.

Boone, Marc, 'Flemish and Brabantine Identity in Late Medieval/Early Modern Europe: Cities and Princes in the Contest for Mastering Regional Identities', Spiel 21 (2002), 178-186.

Brown, Andrew, 'Bruges and the Burgundian 'Theatre-State': Charles the Bold and Our Lady of the Snow', History: The Journal of the Historical Association 84 (1999), 573-589.

Brown, Andrew, Civic Ceremony and Religion in Medieval Bruges (ca. 1300-1520) (New York: Cambridge University Press, 2011).

Brown, Andrew, 'Urban Jousts in the Later Middle Ages: The White Bear of Bruges', Belgisch Tijdschrift voor Filologie en Geschiedenis 78 (2000), 315-330.

Buylaert, Frederik, 'Memory, Social Mobility and Historiography. Shaping Noble Identity in the Bruges Chronicle of Nicholas Despars (+1597)', Belgisch Tijdschrift voor Filologie en Geschiedenis 87 (2010), 377-408.

Buylaert, Frederik, Jelle Haemers, Tjamke Snijders and Stijn Villerius, 'Politics, Social Memory and Historiography in Sixteenth-Century Flanders: Towards a 
Research Agenda', Publications du Centre Européen d'Etudes Bourguignonnes $5^{2}$ (2012), 195-215.

Caers, Bram, Lisa Demets and Tineke Van Gassen, eds, Urban History Writing in Northwest Europe (15 ${ }^{\text {th }}-16^{\text {th }}$ Centuries) (Turnhout: Brepols, 2019).

Demets, Lisa, 'De Flandria Generosa C. Een Kroniek van Vlaanderen uit de Brugse Eeckhoutabdij aan het begin van de vijftiende eeuw', Handelingen van het Genootschap voor Geschiedenis 157 (2020), 39-71.

Demets, Lisa, 'In omni terra potestatis mei: discours, macht en legitieme autoriteit in de oorkonden van de hertogen van Brabant (1106-1248)', Revue belge de philologie et d'histoire 95 (2017), 193-218.

Demets, Lisa, 'The Late Medieval Manuscript Transmission of the "Excellente Cronike Van Vlaenderen” in Urban Flanders', The Medieval Low Countries 3 (2016), 123-173.

Demets, Lisa, Onvoltooid verleden. De handschriften van de Excellente Cronike van Vlaenderen in de laatmiddeleeuwse Vlaamse steden (Hilversum: Verloren, 2020). Demets, Lisa, and Jan Dumolyn, 'La ville comme Sainte Vierge. Un aspect de l'idéologie urbaine en Flandre médiévale (fin du XIV siècle-début du XVI ${ }^{\mathrm{e}}$ siècle)', Cahiers électroniques d'histoire textuelle du Laboratoire de Médiévistique Occidentale de Paris 9 (2016), 24-52.

Demets, Lisa, Jan Dumolyn and Els De Paermentier, 'Political Ideology and the Rewriting of History in Fifteenth-Century Flanders', BMGN: The Low Countries Historical Review 134 (2019), 73-95.

De Ridder, Paul, 'Dynastiek en nationaal gevoel in Brabant onder de regering van Hertog Jan I (1267-1294)', Handelingen van de Koninklijke Zuidnederlandse Maatschappij voor Taal- en Letterkunde 33 (1979), 73-99.

Dumolyn, Jan, De Brugse Opstand van 1436-1438 (Heule: UGA, 1997).

Dumolyn, Jan, 'Justice, Equity and the Common Good: The State Ideology of the Councillors of the Burgundian Dukes', in The Ideology of Burgundy: The Promotion of National Consciousness, 1364-1565, ed. by Jonathan Boulton and Jan Veenstra (Leiden: Brill, 2006), pp. 1-20.

Dumolyn, Jan, Staatsvorming en vorstelijke ambtenaren in het graafschap Vlaanderen (1419-1477) (Leuven: Garant, 2003).

Dumolyn, Jan, 'Une idéologie urbaine "bricolée" en Flandre médiévale: "les sept portes de Bruges" dans le manuscrit Gruuthuse (début du XV siècle)', Belgisch Tijdschrift voor Filologie en Geschiedenis 88 (2010), 1039-1084.

Dumolyn, Jan, 'Urban Ideologies in Later Medieval Flanders: Towards an Analytical Framework', in The Languages of Political Society: Western Europe, $14^{\text {th }}-17^{\text {th }}$ Century, ed. by Andrea Gamberini, Jean-Philippe Genet and Andrea Zorzi (Rome: Viella, 2011), pp. 69-96. 
Dumolyn, Jan, and Jelle Haemers, “'A Blabbermouth Can Barely Control His Tongue”: Political Poems, Songs, and Prophecies in the Low Countries (Fifteenth-Sixteenth Centuries)', in Spoken Word and Social Practice: Orality in Europe (1400-170o): Medieval and Renaissance Authors and Texts, ed. by Thomas Cohen and Lesley Twomey (Leiden: Brill, 2015), pp. 280-299.

Elden, Stuart, 'Land, Terrain, Territory', Progress in Human Geography 34, no. 6 (2010), 799-817.

Fris, Victor, 'Het Brugsche Calfvel van 1407-1411', Bulletin de l'Académie d'Archéologie de Belgique (1910), 183-274.

Guenée, Bernard, Histoire et culture historique dans l'Occident médiéval (Paris: Aubier Montaigne, 1980).

Haemers, Jelle, For the Common Good: State Power and Urban Revolts in the Reign of Mary of Burgundy (1477-1482) (Turnhout: Brepols, 2009).

Huizinga, Johan, and Anton Van der Lem. Herfsttij der Middeleeuwen: studie over levens- en gedachtenvormen der veertiende en vijftiende eeuw in Frankrijk en de Nederlanden (Leiden: Leiden University Press, 2018).

Keesman, Wilma, De eindeloze stad: Troje en Trojaanse oorsprongsmythen in de (laat)middeleeuwse en vroegmoderne Nederlanden (Hilversum: Verloren, 2017).

Kelders, Ann, 'De Flandria Generosa', in The Encyclopedia of the Medieval Chronicle, ed. by Graeme Dunphy (Leiden: Brill, 2010), pp. 621-622.

Kelders, Ann, 'De kronieken van Vlaanderen: aspecten van de laat-middeleeuwse historiografie in de Flandria Generosa C', MA thesis, Rijksuniversiteit Gent, 1989-1990.

Kelders, Ann, 'Laverend tussen de hof der historie en de warande der literatuur. Kroniekschrijving in het graafschap Vlaanderen', in Medioneerlandistiek. Een inleiding tot de Middelnederlandse letterkunde, ed. by Ria Jansen-Sieben, Jozef Janssens and Frank Willaert (Hilversum: Verloren, 200o), pp. 167-177.

Lambert, Bart, and Mark Ormrod, 'Denization: Friendly Foreigners: International Warfare, Resident Aliens and the Early History of Denization in England, c. 1250-c. 1400', The English Historical Review 130 (2015), 1-24.

Lambert, Véronique, 'Oorsprongsmythen en nationale identiteit. De forestiers van Vlaanderen', De Leiegouw 48 (2006), 189-246; 49 (2007), 97-121 and 163-181.

Lecuppre-Desjardin, Elodie, La ville des cérémonies. Essai sur la communication politique dans les anciens Pays-Bas Bourguignons (Turnhout: Brepols, 2004).

Lecuppre-Desjardin, Elodie, Le royaume inachevé des ducs de Bourgogne (XIV $V^{e} X V^{e}$ siècles) (Paris: Belin, 2016).

Mareel, Samuel, 'Jan de Scheereres triumphe ghedaen te Brugghe ter Intreye van Caerle. Teksteditie met inleiding en aantekeningen', Jaarboek de Fonteine 55 (2005), 79-143. 
Moeglin, Jean-Marie, 'Les ducs de Bourgogne et l'historiographie flamande', in Les historiographes en Europe de la fin du Moyen Âge à la révolution, ed. by Chantal Grell (Paris: Presses de l'université Paris-Sorbonne, 2006), pp. 21-36.

Moeglin, Jean-Marie, 'Une première histoire nationale flamande. L'Ancienne Chronique de Flandre (XII ${ }^{\mathrm{e}}$-XIII' ${ }^{\mathrm{e}}$ siècles)', in Liber largitorius, études d'histoire médiévale offertes à Pierre Toubert par ses élèves, ed. by Dominique Barthélemy and Jean-Marie Martin (Genève: Librairie Droz, 2003), pp. 455-476.

Nederman, Cary Joseph, and Kate Langdon Forhan, Medieval Political Theory: A Reader: The Quest for the Body Politic, 1100-140o (Londen: Routledge, 1993).

Pajic, Milan, 'Flemish Rebels in Exile: Their Perception in $14^{\text {th }}$ Century London and the Creation of New Identities', in Peuples conquérants, peuples conquis. Perception identitaires au Moyen-Âge en Europe (IX $-X V^{e}$ siècle), ed. by Tatjana Silec-Plessis and Alessandra Stazzone (Paris: AMAES, 2015), pp. 187-206.

Prevenier, Walter, 'Het Brugse Vrije als Vierde lid van Vlaanderen', in Handelingen van het XXII ${ }^{e}$ Vlaams Filologencongres (Leuven, 1957), pp. 307-311.

Prevenier, Walter, and Thérèse de Hemptinne, 'La Flandre au Moyen Âge. Un pays de trilinguisme administratif', in La langue des actes, ed. by Olivier Guyotjeannin (Paris: éditions en ligne de l'Ecole des Chartes, 2005), pp. 1-16.

Ramakers, Bart, 'Van maagden en poorten. Stadsmetaforen in historische toneelstukken', in Nederland stedenland: continü̈teit en vernieuwing, ed. by Ed Taverne, Jaap Evert Abrahamse and Judith Van den Bos (Rotterdam: naio1o, 2012), pp. 178-192.

Small, Graeme, 'Les Chroniques de Hainaut et les projets d'historiographie régionale en langue française à la cour de Bourgogne', in Les chroniques de Hainaut ou les ambitions d'un prince bourguignon, ed. by Pierre Cockshaw and Christiane Van den Bergen-Pantens (Turnhout: Brepols, 200o), pp. 17-22.

Small, Graeme, 'Local Elites and "National" Mythologies in the Burgundian Dominions in the Fifteenth Century', in Building the Past. Konstruktion der eigenen Vergangenheit, ed. by Rudolf Suntrup and Jan Veenstra (Frankfurt: Peter Lang, 2006), pp. 229-245.

Smeyers, Maurits, 'Lubert Hautscilt, abt van de Brugse Eeckhoutabdij (1393-1417). Over handschriften, planeten en de toekomst van Vlaanderen', Academiae Analecta. Mededelingen van de Koninklijke Academie voor Wetenschappen, Letteren en Schone Kunsten van België 55 (1995), 41-104.

Stein, Robert, 'Introduction', in Networks, Regions and Nations: Shaping Identities in the Low Countries, 1300-1650, ed. by Robert Stein and Judith Pollmann (Leiden: Brill, 2009), pp. 1-18.

Stein, Robert, 'Nationale identiteiten in de Late Middeleeuwen. Een verkenning', Tijdschrift voor Sociale Geschiedenis 28 (2002), 222-246. 
Stein, Robert, Politiek en historiografie. Het ontstaansmilieu van Brabantse kronieken in de eerste helft van de vijftiende eeuw (Leuven: Peeters, 1994).

Stein, Robert, 'Selbstverständnis oder Identität? Städtische Geschichtsschreibung als Quelle für die Identitätsforschung', in Memoria, communitas, civitas. Mémoire et conscience urbaines en occident à la fin du Moyen Âge, ed. by Hanno Brand, Pierre Monnet and Martial Staub (Ostfildern: Jan Thorbecke Verlag, 2003), pp. 181-202.

Van Acker, Lieven, 'Petrus Pictor en zijn "De Laude Flandriae"', De Franse Nederlanden 8 (1983), 129-145.

Van Bruaene, Anne-Laure, 'The Habsburg Theatre State: Court, City and the Performance of Identity in the Early Modern Southern Low Countries', in Networks, Regions and Nations: Shaping Identities in the Low Countries 1300-1650, ed. by Robert Stein and Judith Pollmann (Leiden: Brill, 2010), pp. 131-149.

Van Bruaene, Anne-Laure, 'L'écriture de la mémoire urbaine en Flandre et en Brabant (XIV ${ }^{\mathrm{e}}-\mathrm{XVI}^{\mathrm{e}}$ siècle)', in Villes de Flandre et d'Italie (XIII ${ }^{e}-X I^{e}$ siècles): les enseignements d'une comparaison, ed. by Elisabeth Crouzet-Pavan and Elodie Lecuppre-Desjardin (Turnhout: Brepols, 2008), pp. 149-164.

Van Houts, Elisabeth, Local and Regional Chronicles (Turnhout: Brepols, 1995).

Verbruggen, Jan-Frans, 'Het nationaal gevoel in het graafschap Vlaanderen voor en na 1302', Genootschap voor Geschied-en Oudheidkunde te Vilvoorde 8 (2002), 3-12.

Verhulst, Adriaan, The Rise of Cities in North-western Europe (Cambridge: Cambridge University Press, 1999).

Vrancken, Valerie, De Blijde Inkomsten van de Brabantse hertogen. Macht, opstand en privileges in de vijftiende eeuw (Brussels: Academic and Scientific Publishers, 2018).

Werner, Karl Ferdinand, 'Les nations et le sentiment national dans l'Europe médiévale', Revue Historique 244 (1970), 285-304.

\section{About the author}

Lisa Demets is a postdoctoral researcher at Utrecht University and Ghent University. Her main research interests are multilingualism, manuscripts, gender history, chronicle writing and the political and cultural history of the medieval Low Countries. 



\title{
12. Mapping Imagined Territory: Quaresmio's Chorographia and Later Franciscan Holy Land Maps
}

\author{
Marianne Ritsema van Eck
}

\begin{abstract}
This contribution examines pre-modern cartography as a territorial technique for representing imagined territory, linking social groups to geographical space. It suggests that pre-modern maps could project territory by means other than visualising boundaries, and that accompanying texts could play a significant role, as in the case of Friar Francesco Quaresmio's map of the Holy Land in Terrae Sanctae Elucidatio (1639). By analysing the immediate context of Quaresmio's map - a lavish book publication - I show how Quaresmio's Chorographia represents Franciscan territorial claims through an interaction between the map's visual content and its immediate textual context within the book. Like other Franciscan maps also discussed here, it employs the imagined territories of the Bible as a versatile cartographical topos for various purposes, territorial or otherwise.
\end{abstract}

Keywords: Franciscans; Holy Land; cartography; territoriality; early modern 
A map is not the territory it represents, but, if correct, it has a similar structure to the territory, which accounts for its usefulness. ${ }^{1}$ - Alfred Korzybski

Alfred Korzybski remarks this in the context of a philosophical discussion about the limitations of human perception, and he uses the terms 'map' and 'territory' metaphorically. Nonetheless, Korzybski's observation offers an excellent starting point for this chapter, since it invites us to consider how maps may operate as representations of territory and/or territorial claims. ${ }^{2}$ Moreover, Korzybski's dictum assumes that maps can either be correct or incorrect. This is a value judgement rooted in the widespread modern expectation that maps should 'accurately' show the lie of the land, so as to serve as tools for practical purposes, such as navigation or delimiting political domains. Since the 1980 s the study of historical cartography has become less concerned with recounting a development towards ever more scientific and 'better' maps. Instead, some scholars have begun to emphasise the utterly constructed and subjective qualities of maps as social and cultural artefacts that have been - and remain - deeply entangled in the politics of human power relations. ${ }^{3}$ Notwithstanding this recent historiographical development, analyses of pre-modern Franciscan Holy Land cartography are influenced by more traditional, positivistic approaches. This chapter aims to offer a new perspective on this multifarious corpus of maps connected to the Observant Franciscan establishment in the Holy Land, not only by taking into account what is represented on the maps themselves, but also considering their purpose and context of use, vital for understanding their historical significance. ${ }^{4}$ Ultimately, my analysis aims to reveal the potential of these maps as cultural and social artefacts, regardless of their purported 'realism'.

The first section of this chapter introduces Franciscan Holy Land cartography and further elucidates my methodological approach. In the second section I analyse the Holy Land map in Francesco Quaresmio's Terrae Sanctae Elucidatio (1639) and its territorial intent. My understanding of territoriality builds on definitions from behaviour studies, best represented by Sack's

1 This is a well-known dictum by Alfred Korzybski, a Polish-American independent scholar who founded the field of general semantics (a self-improvement/therapy programme). Korzybski, Science and Sanity, p. $5^{8}$.

2 Crampton, 'Maps as Social Constructions', p. 239.

3 Harley, 'The Map and the Development of the History of Cartography'; Crampton, 'Maps as Social Constructions', pp. 235-243; Jacob, 'Toward a Cultural History of Cartography', pp. 192-193; Dalché, 'Maps, Travel and Exploration', pp. 143-149, 157, 161-162.

4 Jacob, 'Toward a Cultural History of Cartography', pp. 192-194. 
well-known definition: 'the attempt by an individual or group to affect, influence, or control people, phenomena, and relationships, by delimiting and asserting control over a geographic area'. ${ }^{5}$ I see territoriality as an aspirational strategy: the assertion of a claim over a place or area (real or imagined), which does not require actual or full control of it. While Sack mostly refers to spatial strategies, this essay is primarily concerned with the cartographic representation of territorial claims. Therefore, Raffestin's theorisation of territoriality as 'mediated relationships linking individuals/ groups to space', which focuses on processes of communication and mediation, also informs my approach. ${ }^{6}$

The focus on territoriality also allows me to reflect on how Quaresmio's map projects territory, differentiating this from modern or state-centred conceptions. In this chapter territory does not necessarily point to the unproblematised 'product' territoriality, namely actual bounded and controlled space. ${ }^{7}$ While the Observant Franciscans had a clear political agenda regarding the Holy Land, they never were, nor did they aim to, be in control of the Holy Land as territorial lords or rulers. Rather I examine the maps they produced as a territorial technique for representing imagined territories, which were intended to have real-life political effects. This perspective has affinities with Elden's definition of modern territory as a space dependent on political technologies such as mapping to ensure bordering and control, yet is not the same. ${ }^{8}$ The delimitation of actual geographical borders is not at stake in the friars' maps, rather they aim to lodge the abstract idea of 'territory' in people's minds as an affective category, for which 'maps are the quintessential territorial technology' as has been cogently discussed by Leslie. ${ }^{9}$

In the final section, I discuss the same issues with regard to a sequence of Holy Land maps in Franciscan publications on the Holy Land. These maps were printed in the period 1646-1681 as part of books belonging to territorial literature of Franciscan Holy Land appropriation that flourished during this period. ${ }^{10}$ By looking beyond the often emphasised 'accuracy' of Franciscan

5 Sack, Human Territoriality, p. 19; on definitions from behaviour studies, see Somaini, 'Territory, Territorialisation, Territoriality', pp. 33-35.

6 Raffestin, 'Space, Territory, and Territoriality'; Klauser, 'Thinking through Territoriality', pp. 106114; on the distinctions between Sack's and Raffestin's arguments, see Murphy, 'Entente Territorial'. 7 It has been suggested that such a definition does not do justice to pre-modern space based on etymological concerns, see Elden, 'Land, Terrain, Territory'; yet 'bounded political spaces' can be said have existed before, during and after the emergence of modern territory, see Antonsich, 'Rethinking Territory', pp. 422-425.

8 Elden, 'Land, Terrain, Territory', pp. 8o9-810.

9 Leslie, 'Territoriality, Map-mindedness', p. 171.

10

Ritsema van Eck, The Holy Land in Observant Franciscan Texts, pp. 1-33. 
Holy Land maps, and by considering their potential as territorial projections of the Franciscan claims in the Holy Land, this essay aims to elucidate how pre-modern maps may represent territory, even if they are not concerned with measuring and delimiting actual bounded political spaces.

\section{A contextual take on Franciscan Holy Land cartography}

During the late medieval and early modern periods the Franciscans held a singular position for mediating representations of the Holy Land and Jerusalem to Western Europe. Following the fall of Acre in 1291 there were no permanently present representatives of Catholicism there until 1333, when the Mamluk authorities granted the Franciscan friars permission to establish a custodia. As the hosts and guides of all Western pilgrims, the friars could exercise an extraordinary influence on perceptions of the Holy Land in Western Europe, not least through the texts - some of which included maps - that emanated from their convent library on Mount Sion in Jerusalem. ${ }^{11}$ The friars managed to maintain this unique position as sole representatives of Catholicism in the Holy Land throughout the sixteenth and seventeenth centuries, also actively striving to deflect attempts by the Capuchins and Jesuits to settle there. ${ }^{12}$

Just before the foundation of the Franciscan custodia Terrae Sanctae, a proposed Crusade project by the Venetian scholar Marino Sanudo (1260-1338) was presented to Pope John XXII in 1321. Sanudo's Liber Secretorum Fidelium Crucis included a grid map of the Holy Land by the Genoese map-maker Piero Vesconte (active 1310-1330) that would greatly and for a long time influence Franciscan cartography (Fig. 12.1).

Sanudo's project was examined by a committee consisting of a Dominican and three Franciscans, including the prolific historian Paulinus of Venice (c. 1270-1344), who included a very similar map in his Chronologia Magna. The considerable influence of this grid map of the Holy Land is also seen in the Descriptio Terrae Sanctae (1330-1335) by Friar Giovanni di Fedanzola da Perugia. His verbal description of the Holy Land was structured around each square of this grid map. Moreover, the grid map also found its way to the Franciscan convent library in Jerusalem, as is testified by two manuscripts. ${ }^{13}$

11 Saletti, I Francescani in Terrasanta, pp. 69-130; Lemmens, Die Franziskaner auf dem Sion, pp. 37-73, 149-178; Tolan, Saint Francis and the Sultan, 258-266. For the friars' influence on textual culture specifically, see Campopiano, 'Islam, Jews and Eastern Christianity'.

12 Ritsema van Eck, The Holy Land in Observant Franciscan Texts, pp. 170-190.

13 Campopiano, 'Écrire/décrire la Terre sainte', pp. 170-178; for a reconstructed rendering of Fedanzola's grid perspective on the Holy Land, see Fedanzola, Descriptio Terrae Sanctae, plates section. 


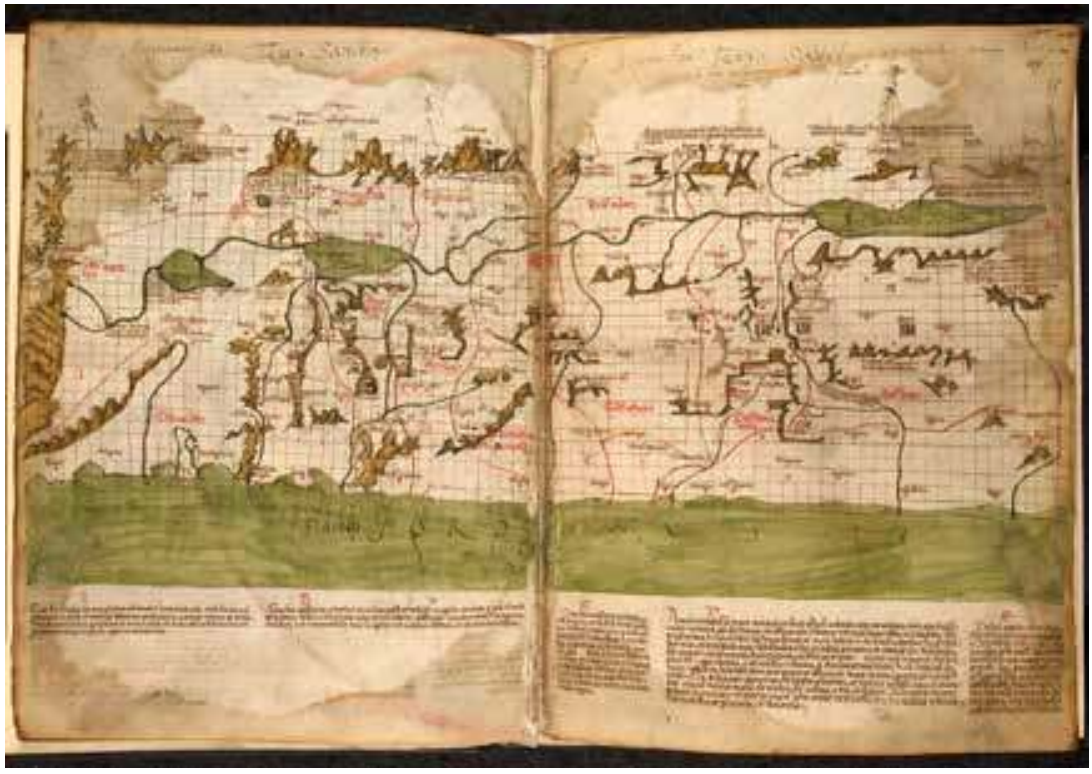

Fig. 12.1. Grid map of the Holy Land c. 1321 by Pietro Vesconte, in Marino Sanudo's Liber Secretorum Fidelium Crucis. 350 x 255 mm. Source: British Library, Add. MS 27376, ff. 188v-189. Public domain image accessible via the British Library Catalogue of Illuminated Manuscripts.

In the course of the fourteenth and fifteenth centuries other types of maps and views of Jerusalem and the Holy Land were occasionally introduced by friars associated with the Franciscan establishment there. For example, illustrated versions of Friar Niccolò da Poggibonsi's travelogue include a bird's-eye view of Jerusalem. ${ }^{14}$ Friar Paul Walther von Guglingen's Treatise on the Holy Land contains a circular Holy Land map, and his closely related travelogue includes a circular map of Hebron and its surroundings, a plan of the Ashrafiyya Madrasa in Jerusalem, and an itinerary map of Cairo. ${ }^{15}$ However, these Franciscan visualisations of the Holy Land were never as influential as Vesconte's original grid map.

During the sixteenth and seventeenth centuries derivatives of Vesconte's grid map continued to appear among the friars' Holy Land maps. In this period Franciscans affiliated to the Jerusalem convent were able to reach a wide European audience with a variety of printed maps. For example, a large wall map of Jerusalem by Friar Antonio de Angelis, printed in Rome in 1578 , was among the first maps of the Holy City with a claim to realism in the

14 Moore, 'Seeing through Text', pp. 405-409.

15 Ritsema van Eck, The Holy Land in Observant Franciscan Texts, pp. 36-51, esp. p. 48; Ritsema van Eck, 'Encounters with the Levant', pp. 163-175. 
modern sense. It influenced representations for two centuries to come. ${ }^{16}$ Friar Bernardino Amico's well-known Trattato delle Piante \& Immagini de Sacri Edifizi di Terra Santa (1609) contains a derivative of De Angelis's Jerusalem map, as well as plans and views of sacred sites based on measurements. ${ }^{17}$ The Jerusalem map in Friar Francesco Quaresmio's Terrae Sanctae Elucidatio (1639) has also attracted some scholarly attention..$^{18}$ Rehav Rubin has recently discussed a Jerusalem map by yet another Franciscan friar, Paulus Milonis, which was printed in Paris in $1687 .{ }^{19}$

Most of the maps the friars produced in this period were printed, either as independent wall maps or included in books on the Holy Land the Franciscans published in great numbers. However, Franciscan cartographic output was also expressed in material culture, defined more broadly. ${ }^{20}$ This includes - less well-known, but fascinating - fresco maps on the walls of the Franciscan establishments of Lugano (SW), Brescia (IT), and Caltagirone (IT). ${ }^{21}$ The Observant Franciscan sacro monte of San Vivaldo (Tuscany, IT) founded in 1509 also merits mention in this context. This sanctuary represents a 'New Jerusalem' by means of a topography of chapels on a hill that represent Holy Sites, which may be described as geographically accurate in a modern sense. ${ }^{22}$

It is well known that many pre-modern maps, including maps of the Holy Land, do not represent geography with the 'realism' appreciated today. Positional accuracy was not the aim of these maps; instead, they served other purposes, such as mental explorations of biblical geography. ${ }^{23}$ In this respect, the early modern Jerusalem maps by the Franciscans De Angelis, Amico, and Quaresmio (discussed above) are exceptional. They mark a turning point in Holy Land cartography in general, because they are the very first Jerusalem maps based on measurements. It is therefore not surprising that influential scholarly appraisals of Franciscan Holy Land cartography have emphasised the high level of detail, accuracy, and 'realism' in the maps of De Angelis, Amico, and Quaresmio in particular, placing these maps

\footnotetext{
16 Moldovan, 'The Lost De Angelis Map of Jerusalem'; Rubin, Image and Reality, pp. 87-99.

17 Piccirillo, 'The Role of the Franciscans', pp. 369-371, 378-38o.

18 Ibid., pp. 371-373; Rubin, Image and Reality, pp. 99-102; Rubin, 'Quaresmius's Novae Ierosolymae'.

19 Rubin, 'One City, Different Views', pp. 269-270.

20 On this textual culture, see Ritsema van Eck, The Holy Land in Observant Franciscan Texts.

21 Segre, 'New Research'; Piccirillo, 'La Raffigurazione di Gerusalemme'.

22 Cardini and Vannini, 'San Vivaldo in Valdelsa'.

23 Dalché, 'Maps, Travel and Exploration', pp. 143-153; Rubin, Image and Reality, pp. 13-15; Woodward, 'Medieval Mappaemundi', pp. 288-29o.
} 
in a narrative of progressively 'better' maps. ${ }^{24}$ In addition, these features are typically connected to the familiarity of their Franciscan composers with these landscapes, since many had lived in the Holy Land for several years. ${ }^{25}$ Michele Piccirillo (1944-2008), a friar of the custodia Terrae Sanctae himself, goes even further by seeing these historic maps as being part of a Franciscan mission to provide truthful, 'scientific' information about the Holy Land.$^{26}$ In addition, scholarly attention to the visual content of these maps has certainly improved our knowledge of pre-modern Franciscan maps of Jerusalem. ${ }^{27}$ However, all too exclusive focus on their visual content has obscured these maps' cultural/ideological significance beyond, for example, the preponderance of Christian sites represented. ${ }^{28}$

In this contribution, I aim to deepen and complicate our understanding of the 'Franciscan' aspect of Franciscan Holy Land cartography. A preponderance of Christian sites points to a general Christian, rather than a specifically Franciscan, perspective. Moreover, I argue that empirical collection of data and positional accuracy are not necessarily the defining feature of Franciscan Holy Land cartography, since in some prominent cases (Quaresmio's Holy land map) they are in fact not a feature at all.

To reveal Franciscan aspects, I take a contextual approach to the maps under discussion. Instead of seeing maps as mostly self-sufficient visual artefacts (possibly related to other maps), the scope of my analysis is broadened by approaching the maps as materially situated objects that derived at least part of their historical significance from context/location and user interaction. ${ }^{29}$ For example, a large printed wall map of Jerusalem may have had a rather different significance when hung in the library of a secular Bible scholar or a wealthy merchant, than on the wall of a Franciscan convent. This heuristic offers excellent opportunities for deepening our understanding of the 'Franciscan' quality of these maps. Apart from the Franciscan identity of the ideator of the map and the messages he manifestly

24 Zur Shalev has deconstructed this perspective with respect to Amico's Trattato. Shalev, Sacred Words and Worlds, pp. 103-139.

25 Segre, 'New Research', p. 230; Rubin, Image and Reality, p. 89.

26 Piccirillo, 'The Role of the Franciscans', pp. 379-380; Piccirillo, 'La Raffigurazione di Gerusalemme', p. 150.

27 Rubin, 'One City, Different Views'; Rubin, 'Quaresmius's Novae Ierosolymae'; Rubin, Image and Reality, pp. 87-105; Segre, 'New Research'; Piccirillo, 'The Role of the Franciscans'; Piccirillo, 'La Raffigurazione di Gerusalemme'.

28 Rubin, Image and Reality, pp. 89, 99-102; Rubin, 'Quaresmius's Novae Ierosolymae', p. 284; Segre, 'New Research', pp. 227-232.

29 Della Dora, 'Performative Atlases', pp. 243-244; Jacob, 'Toward a Cultural History of Cartography', pp. 193-194. 
aimed to project, the cultural potential of these maps as products of the Franciscan order in many ways exceeded their edges. This certainly holds for Quaresmio's Holy Land map, analysed below, which represents Franciscan territorial claims through an interaction between the map's visual content and its immediate context.

\section{Territory and territoriality in Quaresmio's Holy Land map}

Some Franciscan maps of the Holy Land are explicitly territorial, in the sense outlined in the introduction of this chapter: as mediating a claim on the regions visualised. The Holy Land map in Friar Francesco Quaresmio's Terrae Sanctae Elucidatio (1639) certainly fits into this category. The Elucidatio is a highly influential exponent of the territorial Franciscan Holy Land literature that flourished during this period, as a response to the attempts by Jesuit and Capuchin missionaries to establish themselves in the Holy Land, as well as the more general atmosphere of embittered conflict over officiating at the Holy Sites with several Eastern Christian communities in Jerusalem..$^{30}$ Apart from mostly successful litigation at the missionary Congregation of the Faith in Rome aimed at keeping the Jesuits and Capuchins out, the Observant Franciscans also tried to garner support for the view that they were the only Catholic order that had a right to be present in the Holy Land. ${ }^{31}$

Unlike the more well-known Jerusalem map in Quaresmio's Elucidatio, the Holy Land map it also contains - titled Chorographia Terrae Sanctae seu Terrae Promissionis Nova Descriptio (Fig. 12.2) - has not attracted in-depth scholarly attention. ${ }^{32}$ Quaresmio's Holy Land map can ultimately be traced back to the Sanudo-Vesconte grid map of the Holy Land (Fig. 12.1) - an artefact that was likewise produced with territorial claims in mind, as part of fourteenth-century Crusading plans (see above). Therefore a discussion of Quaresmio's seventeenth-century Chorographia may shed light on the longue durée of the friars' territorial mappings. ${ }^{33}$ Before considering what constituted the Franciscan 'territory' that Quaresmio sought to claim and how it is represented on the map, I first examine the map's immediate context in Quaresmio's Elucidatio. 


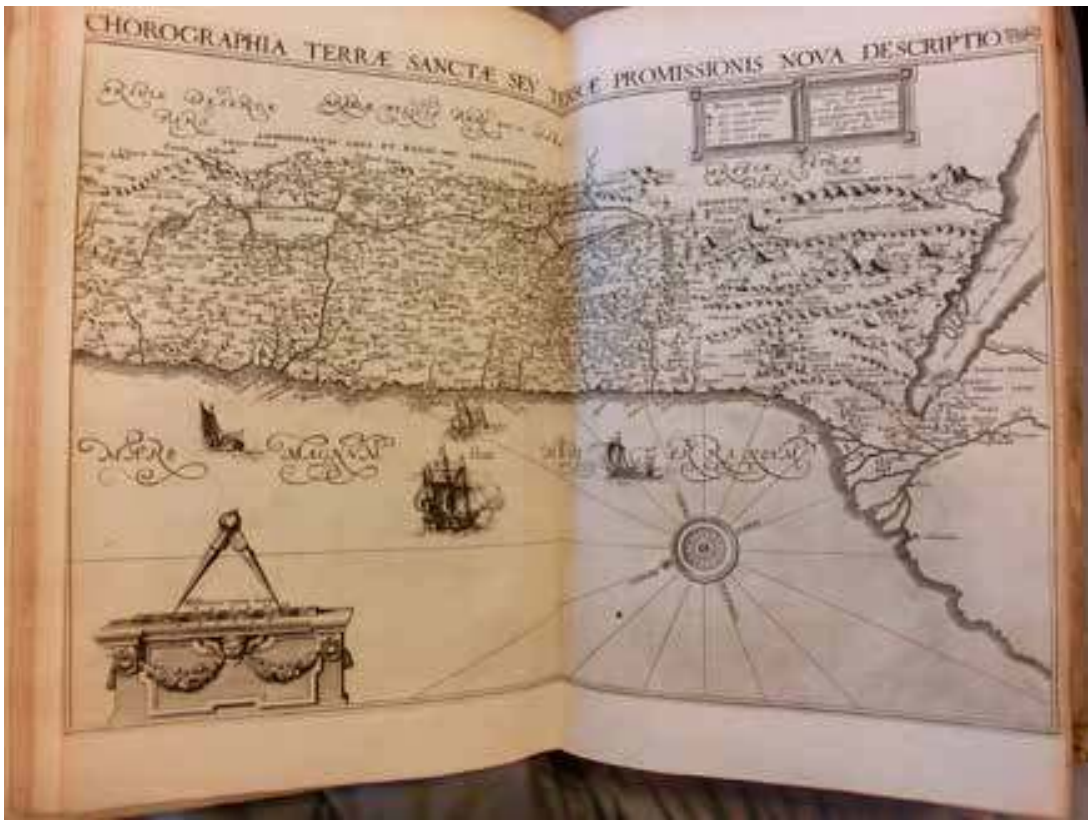

Fig. 12.2. Map of the Holy Land in Quaresmio's Terrae Sanctae Elucidatio (1639). 427 x 354 mm. Source: Leiden University Libraries, 567 A 7-8.

Like the majority of early modern maps, Quaresmio's map reached its audience in the context of a book. Too often it is forgotten that the 'meta-space' of the book and the texts it contains provide (political) meaning to such maps. ${ }^{34}$ The Elucidatio is a massive two folio volume publication filled with laborious considerations of the geographia sacra of the Holy Land. ${ }^{35}$ Its essential message is territorial, and this figures most prominently in the book's prefatory apparatus. The frontispiece and an extensive commentary explaining its visual message make clear that the Holy Land belongs to the Observant Franciscans (Fig. 12.3).

God the Father, sitting at the top, promised the Holy Land to Abraham, standing to the left, and his heirs. According to Quaresmio, St Francis is Abraham's only legitimate heir; ergo, the Holy land belongs to the Observant Franciscans by way of legacy. In his commentary on the frontispiece Quaresmio observes:

Wherefore on both sides you see the holy fathers, and their sons, to whom the ownership of that land was promised and consigned: Abraham and 


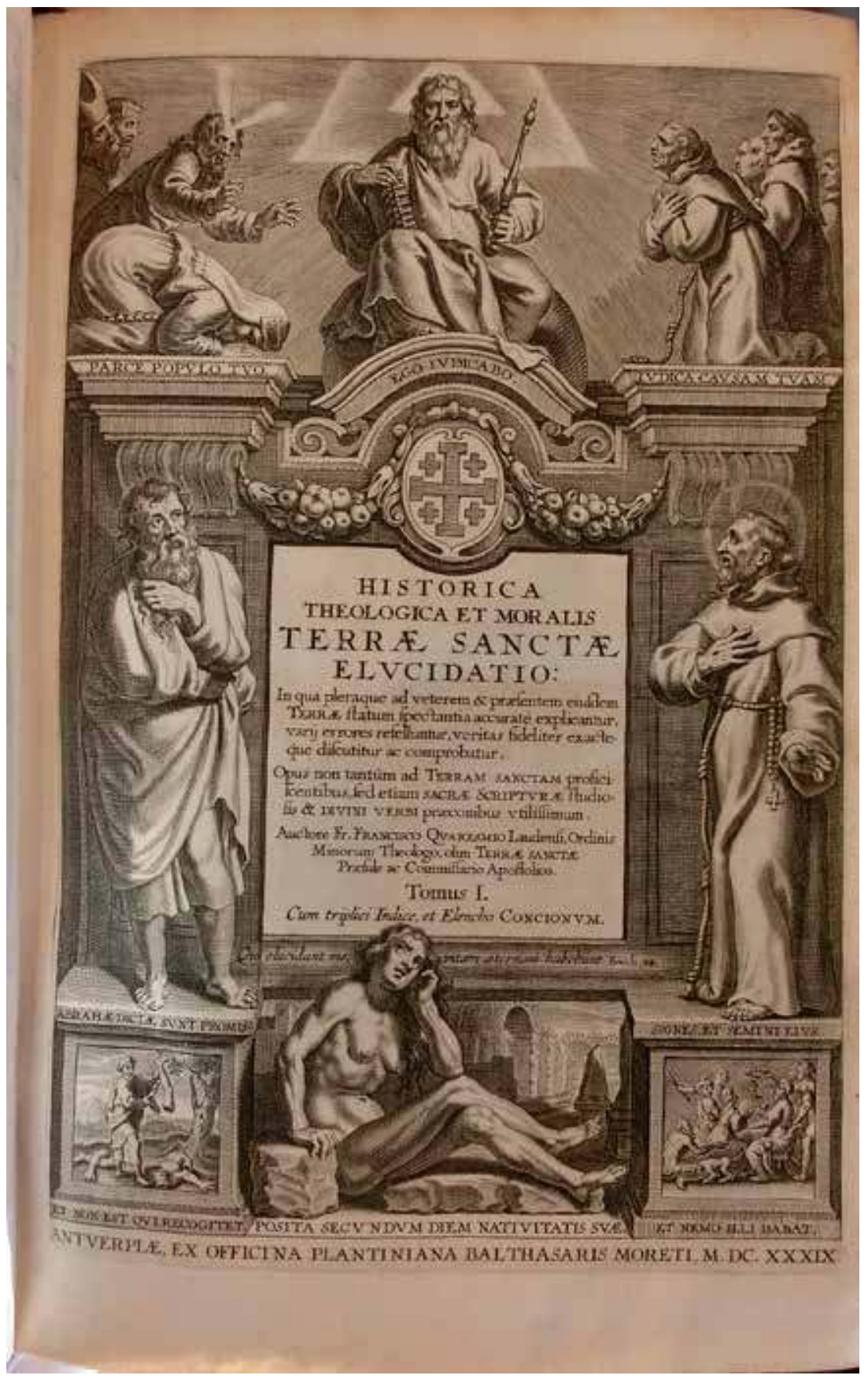

Fig. 12.3. Frontispiece of Quaresmio's Terrae Sanctae Elucidatio (1639). 224 × 352 mm. Source: Leiden University Libraries, 567 A 7-8. 
other faithful on the one side, and on the other side our seraphic father St Francis, and his friars, with hands raised and faces turned up to God, pouring out humble prayers for the salvation of that [land]. Regarding the possession of it promises were given to Abraham and his seed, that is St Francis, as is said in Galatians $3 \cdot{ }^{36}$

In the book's dedication (to Christ) Quaresmio sternly reprimands all Catholic princes for forsaking their duty to go on a Holy Land Crusade. ${ }^{37}$ The dedication to Christ testifies that Quaresmio was convinced about the correctness of his ideas (as were his superiors who approved the publication) and willing to risk offending powerful rulers. Following the approbations by Franciscan dignitaries and the printing license, the prefatory material concludes with the Holy Land map. ${ }^{38}$

The context of the Holy Land map within the book - as an interface between prefatory material and its contents proper - helps to reconstruct its meaning. Once readers get to this map, they are unlikely to perceive it as a neutral or even merely sacred cartographic representation. Instead, the map's immediate context suggests its represents Observant Franciscan property. Maps may often communicate a territorial claim, and in this case the message is accentuated further by the contextual suggestion that the Holy Land should be recovered by a Crusade as soon as possible. The contents of the two extensive volumes that follow further 'fill in' the geographical space projected by this map, with a clearly territorial outlook. Book 1 gives a description and history of the Holy Land, discussing the various nations that have possessed it and to whom it should belong now: the Observant Franciscans (at the expense of other Catholic orders and Eastern Christians). Book 2 offers editions of (papal) documents, stating the rights and privileges of the Franciscans, as well as Quaresmio's apocalyptic Crusade project. In Book 3 Quaresmio gives a theological analysis of Holy Land pilgrimage, and Volume 2 (Books 4-8) discusses various pilgrimage routes and the historicity of their Holy Sites at great length.

The map's position within Quaresmio's Eludicatio (concluding the territorial prefatory apparatus of Volume 1 and preceding the main argument of Book 1 regarding which religious group should control this space) points to its primary function as a visual locus for the book's territorial intent.

36 My translation and emphasis, the Latin word it highlights is twice possessio. Ritsema van Eck, The Holy Land in Observant Franciscan Texts, p. 198; Quaresmio, Elucidatio, vol. 1, xxvj.

37 Ritsema van Eck, The Holy Land in Observant Franciscan Texts, pp. 193-200.

$3^{8}$ The map is followed by the first chapter of Book 1. 
A possible function for the map as an aid in the study of sacred history is conceivable given Quaresmio's laborious investigations of source criticism concerning the Holy Sites in Volume 2. While the map (in Volume 1) does not explicitly represent the pilgrimage routes and sites discussed in Volume 2 of the Elucidatio, both tomes may be opened next to each other: one at the map, and the second at a discussion of a route. The massive folio tomes were destined for the libraries of literati and are clearly unfit as vade-mecums. ${ }^{39}$ The map was therefore not intended for navigation or virtual pilgrimage; Quaresmio does not provide instructions to these ends.

Having established the territorial intent of Quaremio's map, the question remains: what is the nature of the territory this map seeks to claim and how is this represented cartographically? This can be a knotty topic: theorisations of modern territory are polymorphous and state-centric thinking may lead to unrealistic conceptions of territory as unchanging, strictly bounded, controlled, and culturally homogeneous space (Agnew's 'territorial trap'). ${ }^{40}$ Moreover, projecting such modern notions on pre-modernity leads to anachronisms. Elden suggests that territory (understood as the strictly bounded and controlled spaces of modern polities) did not exist in pre-modernity, based on extensive philological investigations centred around terms like terra and territorium. ${ }^{41}$ While I agree that anachronism should be avoided, I do not believe that Elden's essentially etymological approach can provide a complete account. The word territorium may have meant various things through time, but the notion of bounded political space could be, and was, expressed in pre-modernity through other means/words, as Antonsich and others have argued. ${ }^{42}$ Any investigation of the historicity of territory should focus on the contextual meaning of primary sources, rather than the specific terms used. That said, let us (re)turn to cartographic representations, which do suggest some transformative developments.

Medieval conceptions of space centred around places, itineraries (written sequences of place names), and verbally recorded distances. ${ }^{43}$ The relative scarcity of maps before 1500 may be correlated to a more verbal/sequential (rather than visual) conceptualisation of geographical space. The vast majority of European medieval maps fall into two categories: portolan 
charts and mappaemundi. ${ }^{44}$ The first is associated with (Mediterranean) maritime navigation and the second, mappaemundi, typically served an instructive or contemplative purpose by representing the main moments and locations of Christian salvation history on a world map. ${ }^{45}$ While (early) modern maps usually represent a specific moment in time, the 'sacred space-time' of mappaemundi thus covers a broad historical span. ${ }^{46}$

Medieval maps of 'worldly' domains, like states or kingdoms, were very rare. ${ }^{47}$ This does not necessarily mean that bounded political space was nonexistent, only that little need was apparently felt to represent it cartographically. This changed during the sixteenth and seventeenth centuries, although maps and (political) territory were still not closely aligned in pre-modernity. Borders were often in flux and representing them on a map might offend a ruler (by suggesting a territorial claim). Cartographic representations of territory, as bounded space by visualising (political) boundaries on maps, remained unusual until the mid-seventeenth century. ${ }^{48}$ For later centuries, it has often been emphasised that cartography co-produced modern territory by representing boundaries as seemingly objective divides. ${ }^{49}$

In this essay, I aim to reveal how pre-modern maps could project territory by means other than delimiting geographical borders, with Quaresmio's Holy Land map as my case study. First, I demystify the apparently 'modern' appearance of the map, by briefly discussing its cartographic sources, in order to nuance existing characterisations of Franciscan Holy Land cartography as empirical and accurate. Second, I elucidate how this map operates as a territorial technique for representing imagined territory, namely by recontextualising a well-known mental locus - the timeless lands of the Bible - in a textual discussion of Franciscan Holy Land territoriality. It will become clear that the 'territory' of early modern maps was not necessarily concerned with demarcating political geographical space and that accompanying texts also had a role to play.

At first sight Quaresmio's map appears 'modern': the drafting compass and scale in the lower left corner aims to suggest it was drawn to scale (it was not). The map is also highly detailed, densely filled with towns labelled with names,

44 Harvey, 'Medieval Maps'; Woodward, 'Cartography and the Renaissance', pp. 11-12.

45 Woodward, 'Medieval Mappaemundi', pp. 286-29o; Dalché, 'Maps, Travel and Exploration',

pp. 146-149.

46 Woodward, 'Cartography and the Renaissance', pp. 16-17.

47 Harvey, 'Local and Regional Cartography'; Farish, 'Maps and the State', pp. 442-445.

48 Akerman, 'The Structuring of Political Territory', pp. 139-144.

49 Strandsbjerg, Territory, Globalization and International Relations, pp. 68-88, 121-146; Paasi, 'Political Boundaries', pp. 217-224; Elden, 'Land, Terrain, Territory', p. 809. 


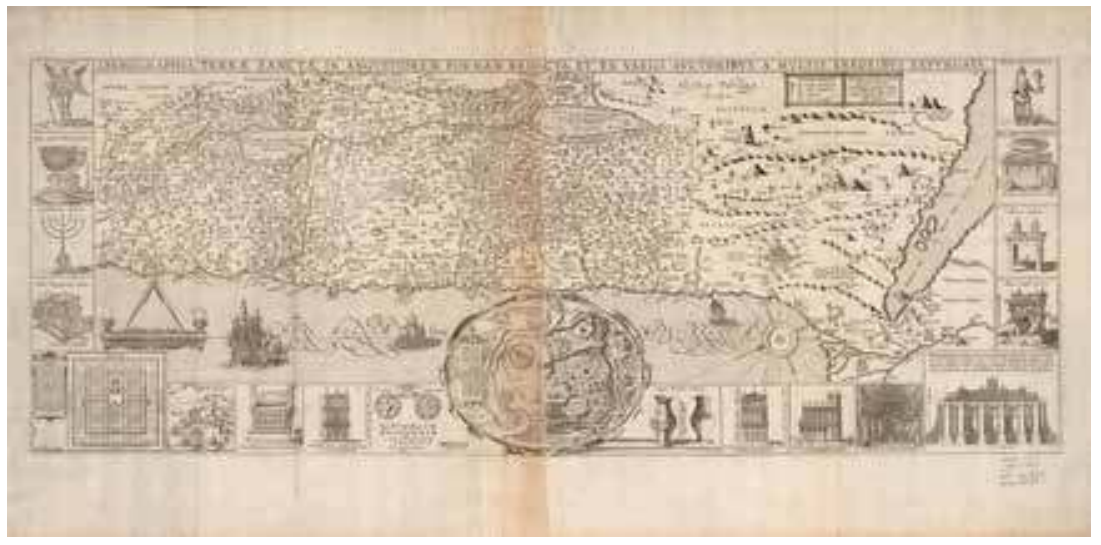

Fig. 12.4. Chorographia Terrae Sanctae in Angustiorem Formam Redacta (1632) by Jacques Tirin. 330 x $850 \mathrm{~mm}$. Source: Public domain image provided by the Stephen S. Clark Library, University of Michigan Library.

and a finely meshed network of roads and waterways. Based on this impression, one might be inclined to accept existing characterisations of Franciscan Holy Land cartography as characterised by detail and accuracy. These qualities are often said to result from Franciscans' unique position as the only Catholic order established in the Holy Land and therefore in a good position to gather first-hand knowledge and observations in situ, as well as possibly a Franciscan mission for fact-finding (see the first section above). However, all these towns, roads, rivers, and boundaries were in fact taken over from the Chorographia Terrae Sanctae published by the Jesuit scholar Jacques Tirin in $163_{2}$ (Fig. 12.4), the direct forerunner of Quaresmio's Chorographia. Tirin's map, likely engraved by Cornelis Galle, was originally prepared for Tirin's Bible commentary, the Commentarius in Vetus et Novum Testamentum (Antwerp: Nutius, 1632). It became relatively widespread through successive reprints and circulation as an independent map during the following two decades..$^{50}$

Quaresmio's map is thus not based on 'Franciscan' empirical observations in the Holy Land, but instead on a biblical map compiled by a Jesuit who did not visit the Holy Land. ${ }^{5}$ Possibly Quaresmio (resident in the Holy Land for many years) felt uneasy about relying on the expertise of a Jesuit, also given the recent competition between Jesuits and Franciscans for the missionary stage of the Holy Land.$^{52}$ This would also explain why Quaresmio

$5^{0}$ Laor and Klein, Maps of the Holy Land, p. 106.

$5^{1}$ Paquot, Mémoires, pp. 484-486. There are small variations. For example, Quaresmio charts the Israelites' route through the Red Sea (Exodus) in a slightly different way.

$5^{2}$ Ritsema van Eck, The Holy Land in Observant Franciscan Texts, pp. 171-173, 191-192. 


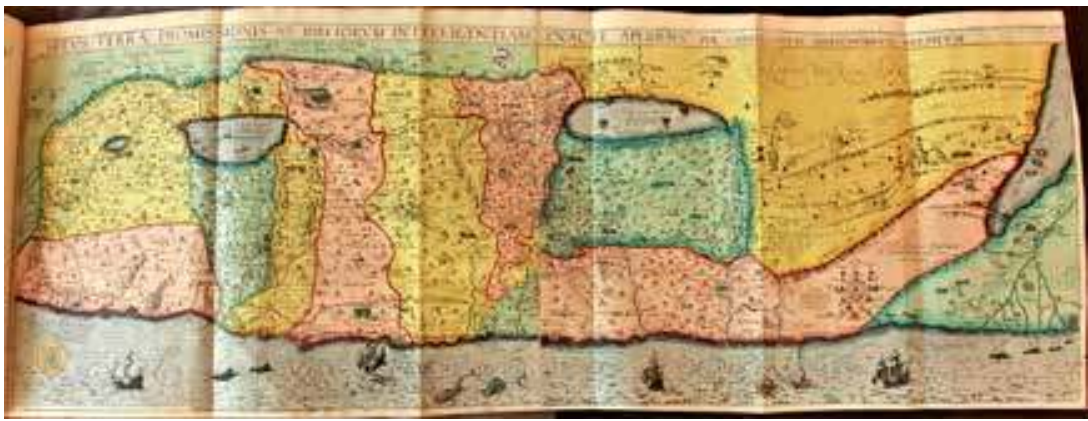

Fig. 12.5. Map of the Holy Land in Adrichem's Theatrum Terrae Sanctae (1593). $1020 \times 374 \mathrm{~mm}$. Source: Leiden University Libraries, 567 A 4.

does not mention Tirin's map or Bible commentary as a source, while his Franciscan colleague Bernardino Amico (whose map provided the example for Quaresmio's Jerusalem map) and Christiaan Adrichem (a secular priest, not affiliated to an order, who did not travel to the Holy land) are explicitly acknowledged. ${ }^{3}$ Quaresmio more than once emphasises the importance of Adrichem's Holy Land atlas for his endeavour. ${ }^{54}$ Yet although the Holy Land map in Adrichem's spectacular atlas (Fig. 12.5) is an important and influential intermediary between Vesconte's grid map and the Chorographia by Jacques Tirin, Adrichem's map is clearly not the direct source for Quaresmio's map.

In addition, despite its 'modern' appearance Quaresmio's map does not construct territory by visualising a bounded political space. The boundaries it contains do not delimit the confines of the Holy Land, rather the territories of the twelve tribes of Israel. These borders were taken directly from Tirin's map (Fig. 12.4), and ultimately derive from the medieval Sanudo-Vesconte map on which the borders between the tribes are demarcated with red lines and the names of the tribes are given in rubrics (Fig. 12.1). As in the cases of Tirin's map (part of Bible commentary) and of Adrichem's atlas (a self-proclaimed theatre of biblical history), the dotted tribal borders on Quaresmio's map may serve as an aid in the study of sacred history. This is particularly likely since Book 1 of the Elucidatio (directly following the map)

53 Adrichomius, Theatrum Terrae Sanctae. Cf. Quaresmio: 'Mecum ergo cogitans, quomodo huic tanto Praesuli ex partes satisfacerum, cum artis delineatoriae imperitus loca sancta \& ipsorum ruinas geographice delineare non possem; existimaui, melius me ei morem gesturum, si loca sancta studiosius enuclearem, \& ab aliis praetermissa adderem. Tabulas itaque pro maiori parte praetermisi, quod alij accurate illas exhibuerint, quae forte ad illius Antistitis manus non venerunt, \& inter alios, quos viderim, Christianus Adrichomius, Fr. Bernardinus Amicus Minorita, \& Ioannes Zeullardus Eques sancti Sepulchri.' Quaresmio, Elucidatio, vol. 1, p. xxxvij. 54 Ibid., vol. 1, pp. xxxiiij-xxxv. 
discusses at great length to whom the Holy Land belonged in the past and to whom it should belong now. Quaresmio explains that following the deluge in Genesis, the Canaanites, descending from Noah's son Ham, possessed it for a while, until the Jews, descendants of Noah's son Shem and pre-figuring the elect, received possession. The biblical promise to Abraham and his seed is given much prominence in the text of the Eludicatio. According to Quaresmio, this promise then extended to the twelve tribes of Israel following the Egyptian captivity, and the division of the land between the Jewish tribes is therefore also meticulously examined in the text. ${ }^{55}$

The map explicitly visualises these divisions and thus the legacy of Abraham. This is the inheritance of the Franciscan friars, as the seed and heirs of Abraham, according to Quaresmio's point of view and argument in the text. ${ }^{6}$ The places of the twelve tribes in Ezekiel's vision of the fourth temple also receive much attention in Quaresmio's discussions, thus also pointing to post-biblical times. ${ }^{57}$ Moreover, the route of the twelve tribes from Egyptian Captivity to the Promised Land (Fig. 12.6) - also taken from Tirin's map - may be read as a type of future conquest: Quaresmio's visions of the Crusade and Apocalypse described in his Elucidatio. ${ }^{8}$ By recontextualising Tirin's biblical map in his Elucidatio, Quaresmio has created a new map that may flexibly suit any era - past, present, or future. It shows the dominion of the elect at a certain point in time; its territory is biblical, yet through a conversation with the textual content of the Elucidatio it also charts the territory of the elect through time and promotes understanding of the present as well as future millennial reigns. Like a medieval mappamundi that represents different stages of salvation history on one map, Quaresmio's Chorographia may serve to accommodate both the sacred history as well as the future of the land discussed in the text.

This is not to say that Quaresmio's Holy Land map is old-fashioned or anachronistic: a clean break with the sacred space-time of medieval maps never occurred..$^{59}$ Moreover, geography remained overwhelmingly preoccupied with charting space through textual description. Even the functional purpose of Quaresmio's Chorographia is characteristic of early modern cartography: it serves as a visual interface intended to deepen understanding of the book's textual content. This is in line, for example, with the observations about the function of maps by Abraham Ortelius in

Ibid., vol. 1, pp. 140-206.

Ibid., vol. 1, pp. 51-59.

Woodward, 'Cartography and the Renaissance', p. 10. 


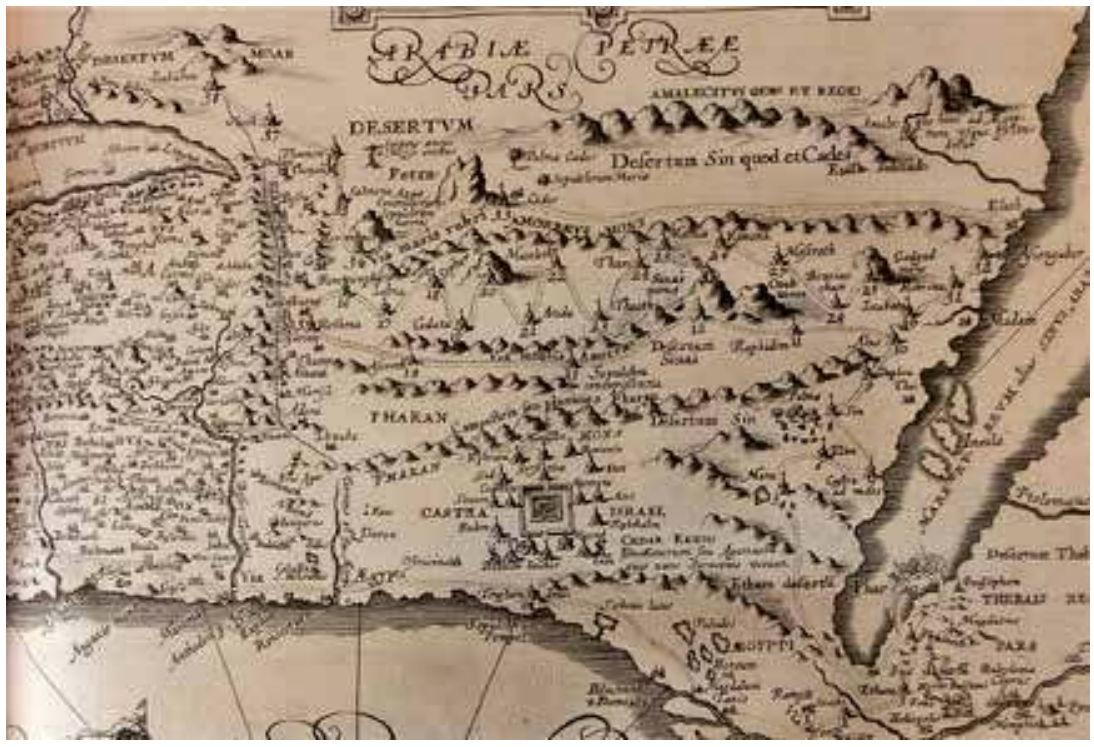

Fig. 12.6. Itinerary of the twelve tribes on their way out of Egyptian Captivity (Exodus) as represented on the map of the Holy Land in Quaresmio's Elucidatio (1639). Source: Leiden University Libraries, 567 A 7-8.

the preface to his famous 1570 atlas. ${ }^{60}$ Territory and territoriality are not visually represented on, or bounded by, Quaresmio's Holy Land map; instead, they are produced in interaction with the textual content of the Eludicatio, a crucial backdrop for the map's significance.

Quaresmio's Chorographia visualises a then well-known mental entity the biblical topography of the Twelve Tribes - rather than the bounded space of a worldly polity. The territory it represents is 'imagined' in that it portrays, not the actual terrain of the Holy Land in the 163os, but a geography created by contemporary Bible scholars like Adrichem and Tirin. The immediate context of the Chorographia (effectively copied from Tirin) - in a volume that is an extensive scholarly manifesto arguing for the unique right of the Observant Franciscans to be present and officiate in the Holy Land, as opposed to other Catholic orders - confers on the map its main potential as cultural artefact. Quaresmio uses the archetypical image of an imagined territory, which (scholarly) contemporaries would immediately recognise,

60 'And when we have acquainted ourselves somewhat with the use of these Tables or Mappes, [...], whatsoever we shall read, these Chartes being placed, as it were certaine glasses before our eyes, will be the longer kept in memory, and make the deeper impression in us: by which meanes it commeth to passe, that now we do seeme to perceive some fruit of that which we have read.' Ortelius, The Theatre of the Whole World, preface to the reader, no pagination. 
to provide a fitting visual locus for his Franciscan 'territorial' claims. ${ }^{61}$ The Observant Franciscans did not aspire to worldly control over an actual patch of land. Instead Quaresmio wished to convince contemporaries of the Franciscans' unique link to the timeless lands of the Bible as the heirs of the Abraham, as the main argument for excluding other Catholic orders. Qaresmio thus uses the Chorographia as a territorial technology, not by demarcating spatial boundaries, but by creating an associative link between his own order and the ubiquitous imagined territory of the Bible lands. ${ }^{62}$

\section{Quaresmio's Chorographia and later Franciscan Holy Land maps in books}

Since Quaresmio's Elucidatio was very influential during the decades following its publication, this raises the question of whether, how, and to what extent his map has influenced maps in later Franciscan publications on the Holy Land. The survival of relatively large numbers of Quaresmio's expensive tomes in present-day collections points to a wide audience of scholarly sacred geographers. ${ }^{63}$ At the same time, Quaresmio's fellow friars were also deeply attracted by his territorial message: many subsequent Observant Franciscan publications on the Holy Land take inspiration from the Elucidatio in this respect. ${ }^{64}$ Some of these also incorporate a Holy Land map. It remains to be determined, however, whether these maps project the Holy Land as an imagined Franciscan territory in a similar way. Studying these maps enhances our understanding of Franciscan Holy Land cartography (often characterised through large, lavish - but rare - wall maps like De Angelis's), because Franciscan Holy Land maps probably became most widely disseminated as modest fold-out maps in books.

I examine the Holy Land maps in the publications by the Franciscan friars Eugène Roger (1646), Bernardinus Surius (1650), Electus Zwinner (1661), Antonius Gonsales (1693), and Jacques Goujon (1681), applying the same contextual method as before. ${ }^{6}$ Their books form part of the broader Observant

61 The Holy Land was the most often mapped country during the sixteenth century. Woodward, 'Cartography and the Renaissance', p. 10.

62 Cf. Leslie, 'Territoriality, Map-mindedness', p. 171.

63 Shalev, 'Early Modern Geographia Sacra'.

64 Ritsema van Eck, The Holy Land in Observant Franciscan Texts, pp. 206-211.

65 These are the Holy Land maps in seventeenth-century Franciscan publications about the Holy Land which I am aware of, more may yet come to light. The early-eighteenth-century map commissioned by Francesco Caccia for his Jerusalem, sue Palaestina Nova, deserves mention in 
Franciscan literature that sought to defend the Franciscan claim on the Holy Land (excluding other Catholic orders), especially subsequent to Quaresmio's influential Elucidatio. However, unlike Quaresmio's book, the five books discussed in this section are directed at a different type of audience. Rather than aiming to impress scholars and prelates in Latin, the books by Roger, Surius, Zwinner, Gonsales, and Goujon aim to edify and entertain a wider, middle-brow, audience of pious lay readers in Dutch, French, and German. Apart from Holy Land maps, all five books under discussion also contain a variety of copperplate engravings from various sources: maps of Jerusalem and other Levantine regions, portraits of ethno-religious groups, plans and images of holy places, etc. The present discussion limits itself to the Holy Land maps.

The Holy Land map (Fig. 12.7a) in Friar Eugene Roger's La Terre Sainte ou Description Topographique Trés-Particuliere (1646; repr. 1664) is situated between the book's prefatory materials and its first chapter, like Quaresmio's Chorographia. However, Roger's map is not based on Quaresmio's (or its precursor by Tirin); it appears to be a truncated (without Egypt) and simplified version of Adrichem's map (Fig. 12.5). Following the prefatory apparatus, we find Roger's Holy Land map, plus a legend subdivided according to the twelve tribes of Israel. Book 1 of La Terre Sainte offers a topographical description, structured according to the territories of the twelve tribes, also indicated on the map by dotted boundaries. ${ }^{66}$ This, at first sight, rather unelaborate map thus functions as a structuring device within the book. It provides a visual framework for the subsequent historio-geographical descriptions, from Old Testament to present times, in twelve tribal chunks (also modelled on Adrichem's Theatrum). Roger underlines the importance of this heuristic in his preface. His aim is to provide solid information about the Holy Land while avoiding getting sidetracked (only too common in Holy Land travelogues according to him); therefore he does not traverse the limits of the Land, that is, the area of the twelve tribes. ${ }^{67}$

Roger's map does not appear to have had the same territorial intent as Quaresmio's. Roger does express sentiments of Franciscan Holy Land territoriality similar to Quaresmio's in a section about the Latins (i.e. the Franciscans), as part of the ethno-religious discourse of Book 2 (discussing various Muslim groups, and their religion, Druses, Jews, Greeks, Abyssinians,

this context, but remains outside of the scope of the present discussion. Caccia.Jerusalem, sue Palaestina Nova; Ritter, 'Die Karte des Heiligen Landes'.

66 Roger, La Terre Sainte, pp. 1-228.

67 'Neantmoins mon dessein n'estant point de sortir les limites de la Terre de Promission, [...] Ie parleray seulement de ce qui est, \& de ce qui a esté autrefois compris dans l'étenduë des douze Tribus d'Israël'. Roger, La Terre Sainte, [au lecteur]. 


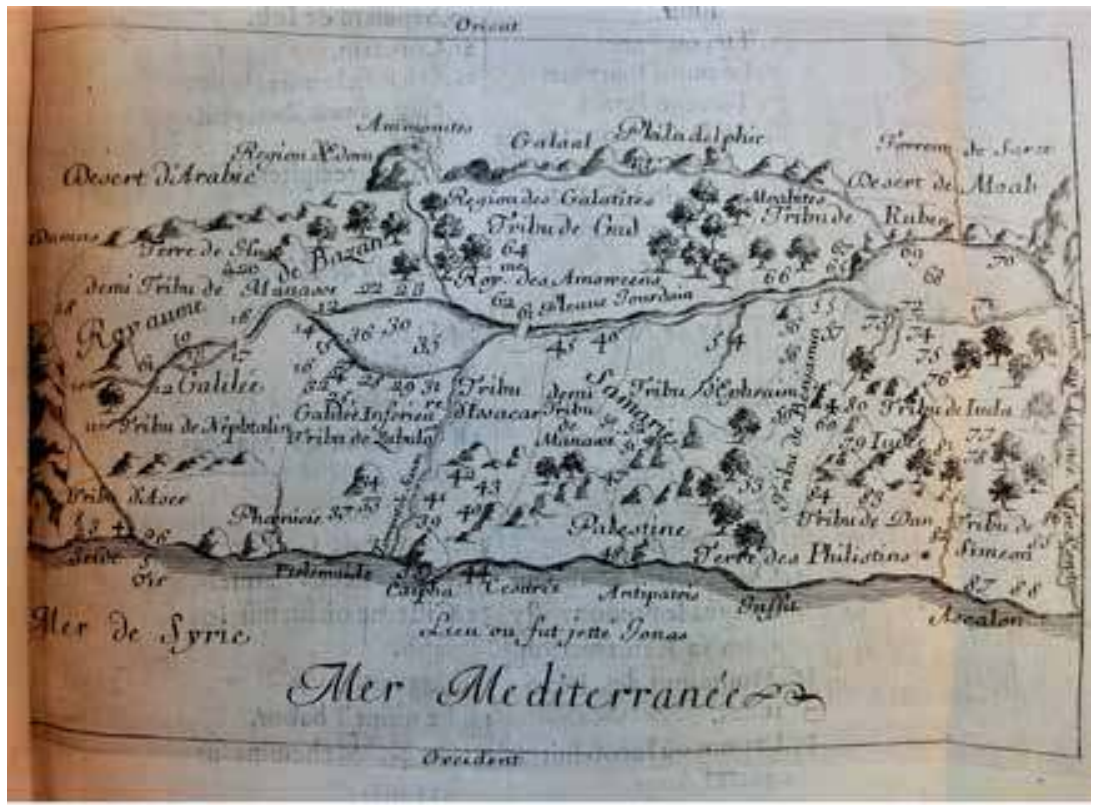

Fig. 12.7a. Map of the Holy Land in Roger's La Terre Sainte (1646). 193 x 135 mm. Source: Leiden University Libraries, 505 F 11.

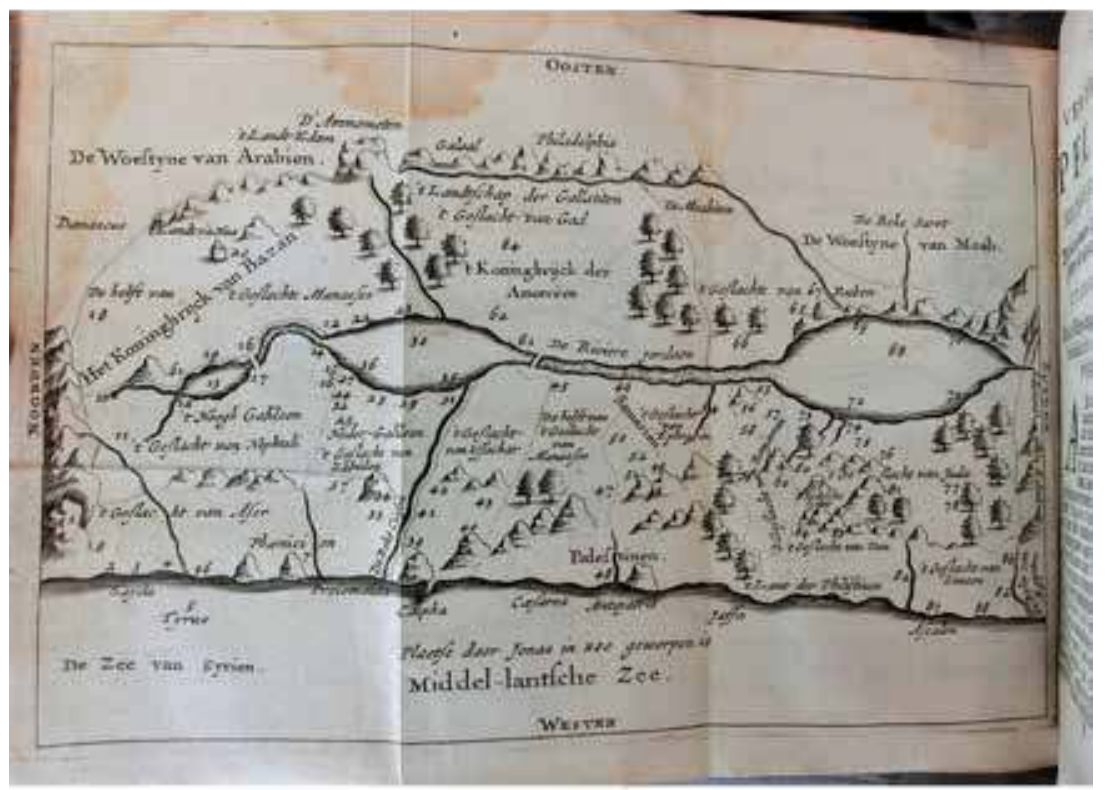

Fig. 12.7b. Map of the Holy Land in Surius's Den Godtvruchtighen Pelgrim (1665). $178 \times 248 \mathrm{~mm}$. Source: Leiden University Libraries, 717 G 28. 


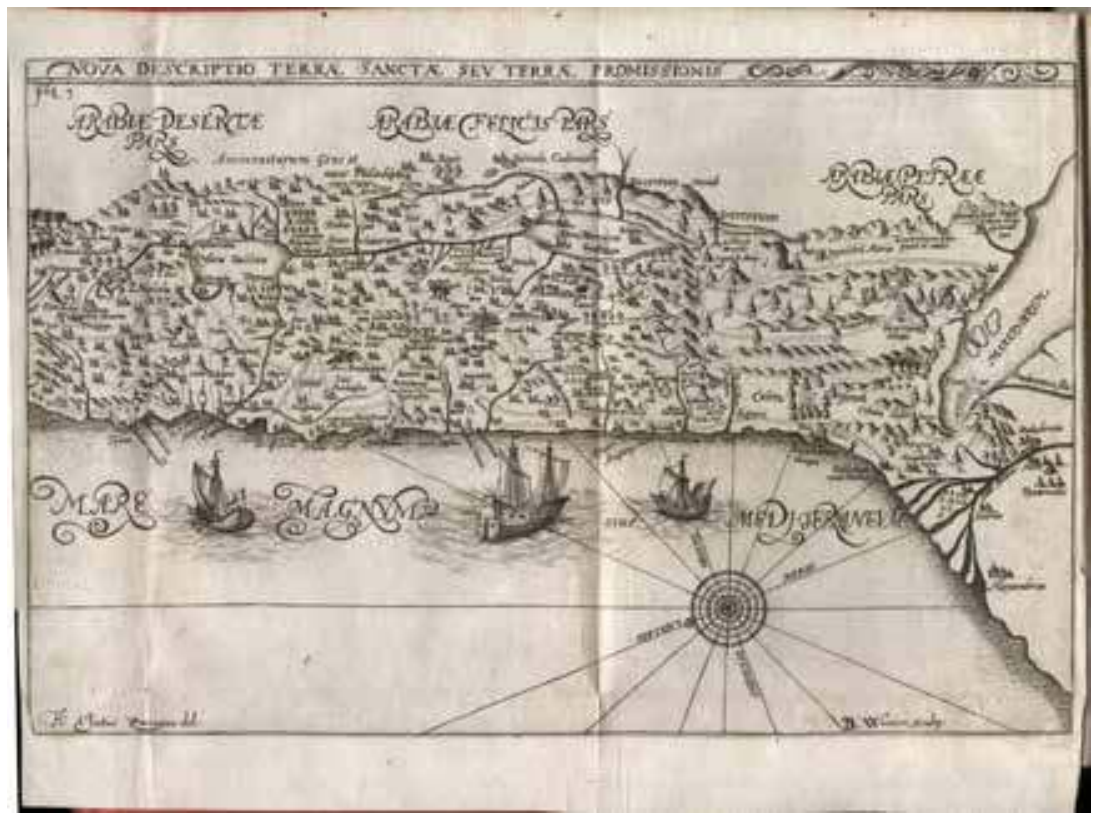

Fig. 12.8. Map of the Holy Land in Zwinner's Blumenbuch des H. Lands Palestinae (1661). $278 \mathrm{x}$ $180 \mathrm{~mm}$. Source: Public domain image from the digital collection of the National Library of Israel, courtesy of Amir Cahanovitc.

Latins, and finally Maronites). ${ }^{68}$ However, this section is 400 pages removed from the map within the book, and the map's immediate textual context therefore likely does not suggest a territorial claim.

The same seems to hold for subsequent Holy Land maps in Franciscan publications, including the Dutch adaptation of Roger's map in Bernardinus Surius's Den Godtvruchtighen Pelgrim, ofte Ierusalemsche Reyse, first published in Brussels in $165^{\circ}$ (Fig. 12.7b). ${ }^{69}$ This, many times reprinted, Holy Land travelogue has three parts: the pilgrim setting out, standing still (in the Holy Land), and returning home.$^{70}$ The fold-out map of the Holy Land, together with its legend, was intended to appear at the beginning of its Book 2, which deals with the Holy Land proper. ${ }^{71}$ The legend is followed by a topographical description of the Holy Land divided in tribal regions,

68 Roger, La Terre Sainte, pp. 427-474.

69 Surius, Den Godtvruchtighen Pelgrim, I shall refer to the pagination of 4 th edition of 1665 here, because this may be consulted on GoogleBooks.

70 Houbaert, 'Surius'.

71 Surius, Den Godtvruchtighen Pelgrim, pp. 321-322. This goes for the 1661 edition (Brussels, Mommaert) preserved at the University of Amsterdam Special Collections. The 1665 edition (Brussels, Mommaert) preserved at the Leiden University Special collections has the map at 


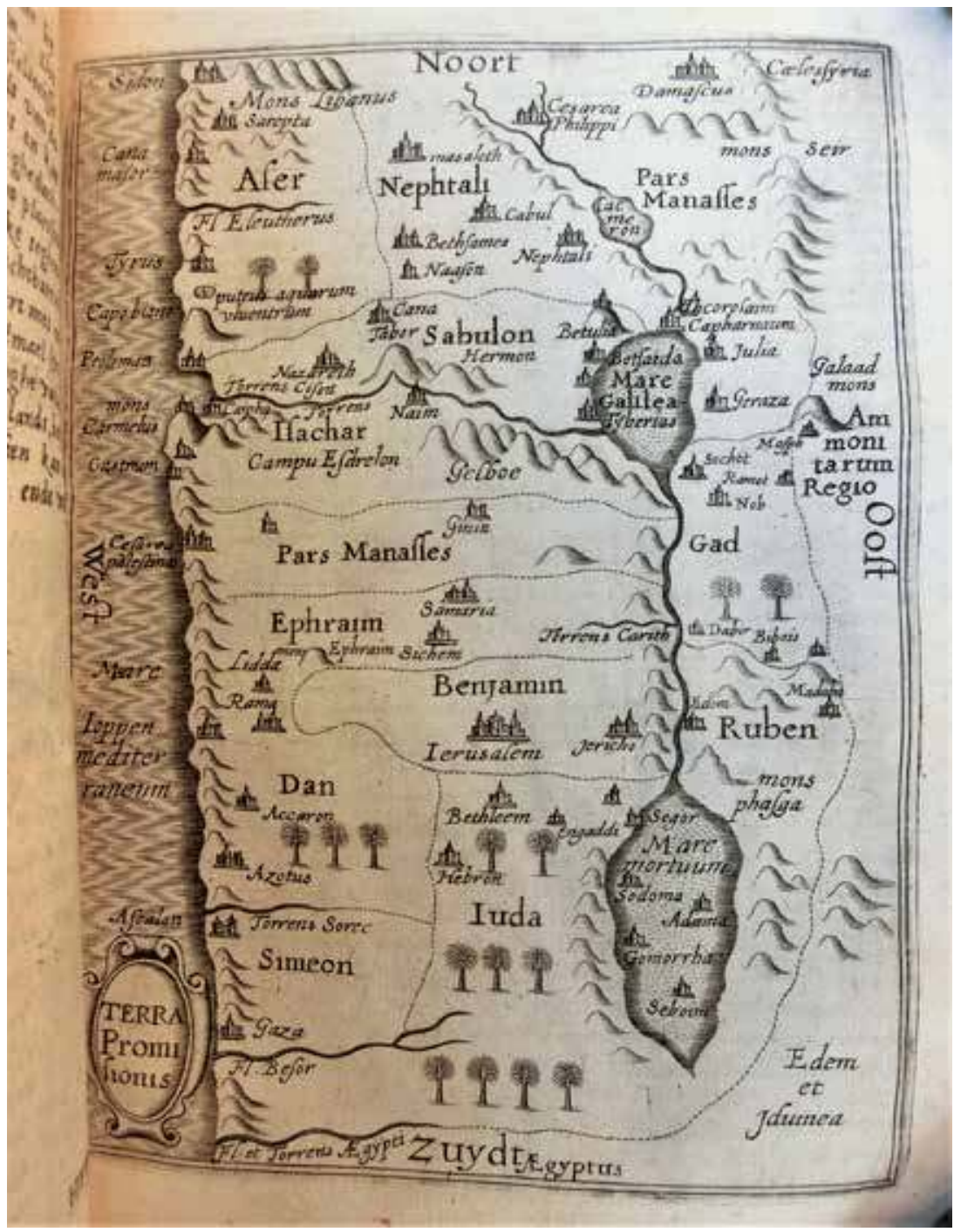

Fig. 12.9. Map of the Holy Land in Gonsales's Hierusalemsche Reijse (1673). 170 x 135 mm. Source: Leiden University Libraries, 456 B 3-4.

largely based on/copied from Book 1 of Roger's La Terre Sainte. While Surius subscribes to Franciscan Holy Land territoriality in line with Quaresmio, he does not do so in the part of his book that is close to the map. ${ }^{2}$

the start of the book, after the prefatory materials. The legend is still found at the beginning of Book 2: it seems this where the map was meant to go.

72 Surius, Den Godtvruchtighen Pelgrim, pp. 157-162. 


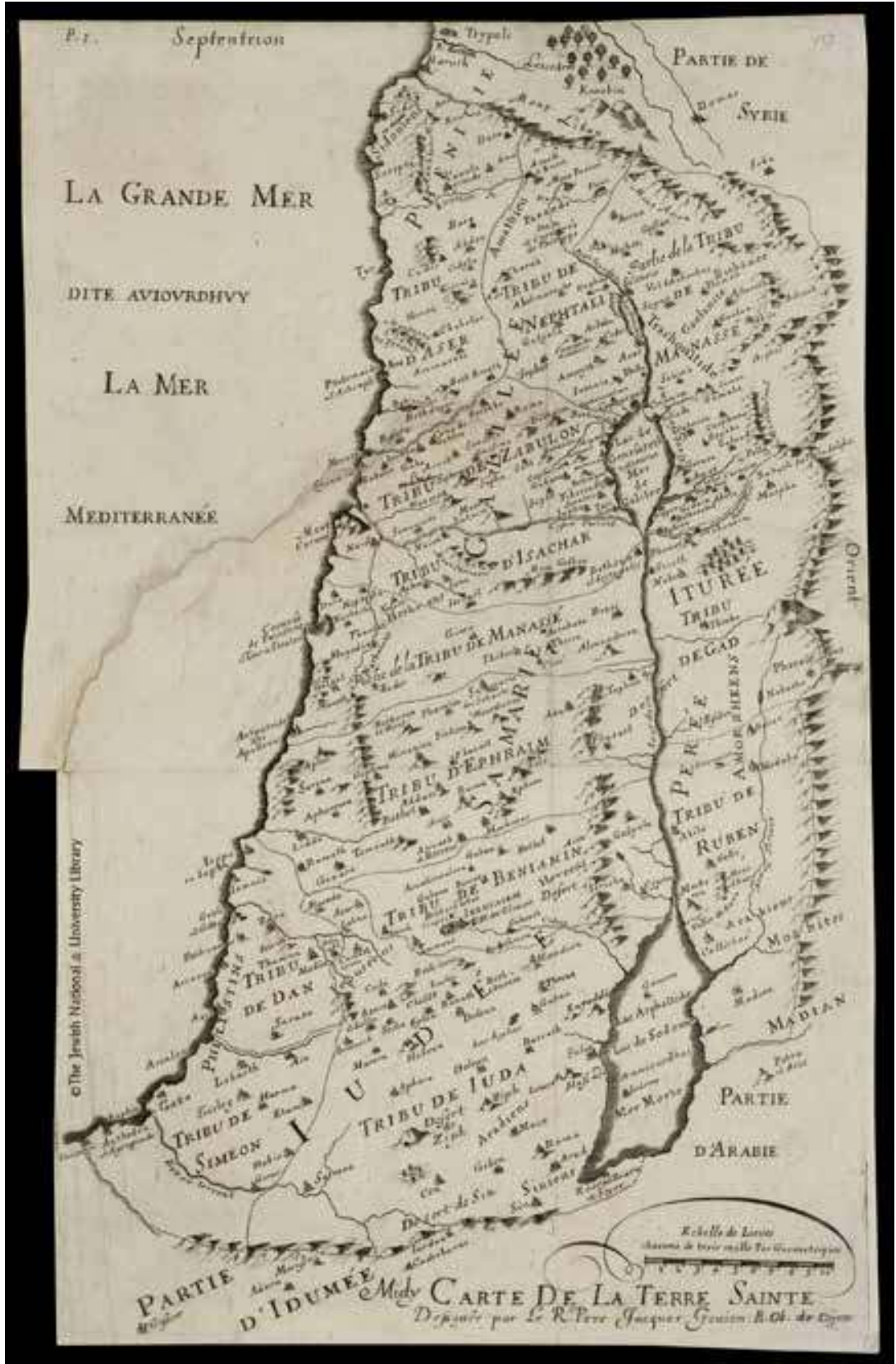

Fig. 12.10. Map of the Holy Land in Goujon's Histoire et voyage (1670). 362 × $224 \mathrm{~mm}$. Source: Public domain image from the collection of the National Library of Israel, Eran Laor Cartographic collection. 
Similarly, while the first part of Friar Electus Zwinner's tripartite Blumenbuch des H. Lands Palestinae (Munich, 1661) is effectively an abbreviated rehashing of Quaresmio's territorial message in German, the location of its Holy Land map (Fig. 12.8) within the book suggests it primarily functioned as a visual complement to Zwinner's verbal geographical description. Even though this map is modelled on Quaresmio's Chorographia (including the Exodus route through the Red Sea that differs slightly from Tirin's), it accompanies a brief geographical description many pages removed from his discussion of the Franciscan claim on the Holy Land. ${ }^{73}$ The Holy Land map in Friar Antonius Gonsales's Hierusalemsche Reijse (1673), a Holy Land travelogue in Dutch, likewise accompanies a general description of the Holy Land, articulated by the territories of the twelve tribes and oriented with north at the top (Fig. 12.9). Yet again, the territorial sentiments expressed do not seem to influence the map's contextual significance directly. ${ }^{74}$

Finally, Friar Jacques Goujon's Histoire et voyage de la Terre-Sainte (1670, rep. 1681) seems to be the exception. This lavishly illustrated guide for virtual pilgrimage, before the start of its first prayerful visite, contains a preface that introduces the Holy Land as distinctly Franciscan territory. ${ }^{75}$ The Holy Land map (Fig. 12.10) heading this preface is thus arguably 'filled in' with the territorial sentiments expressed in the text directly after. Possibly, this map, oriented with north at the top, also served to aid the imagination of the virtual pilgrim traversing the land in spirit, but this seems less likely since the illustrations of Holy Sites accompanying the visites are more clearly intended for this purpose. This map, ostensibly designed by Goujon himself, is also the only one discussed in this section that claims to be made to scale.

\section{Conclusion}

Early modern Franciscan Holy Land cartography has often been characterised in terms of detail, accuracy, and 'realism', and placed within the narrative of progressively 'better' maps. This essay has sought to complement this characterisation by examining the contextual significance of some lesser known Franciscan Holy Land maps in books. Rather than through visual content only, the territory these maps project was also produced through interaction between map and textual content of the book in which 
it appears. As has become clear, Quaresmio's allegedly 'new' Chorographia of the Holy Land was not based on empiricism, but copied from a Jesuit Bible commentary. Nevertheless, the map still ingeniously and poignantly represents the Holy Land as Franciscan territory, by functioning as an atemporal mirror for the vision of salvation history central to the Elucidatio.

While the publications by Roger, Surius, Zwinner, Gonsales, and Goujon form part of the same territorial literature of Franciscan geographia sacra as Quaresmio's Elucidatio, these later Franciscan maps are to a lesser extent informed by the 'territorial' overtones, and mainly aim to help readers find their feet in the context of general descriptions of the Holy Land. This difference between Quaresmio's and these later Franciscan maps may be at least partly explained on the basis of their diverse intended audiences. Quaresmio above all sought to convince scholarly prelates that the unique privileges of the Observant Franciscans in the Holy Land ought to be maintained (excluding other Catholic orders), while Roger, Surius, Gonsales, and Goujon primarily aimed to entertain and educate a much wider and diversified readership with broader interests, including travel stories and virtual pilgrimage.

A supposed Franciscan mission of fact-finding and modern cartographical 'accuracy' is not generally substantiated by these maps. Only Quaresmio's and Goujon's maps invoke the conceit of being to scale, and while such a mission may be present in Roger's idea of a solid historico-geographical exposé modelled on Adrichem's Theatrum, it is not represented in his map. Overall, my discussion suggests that the representation of territory on pre-modern maps did not necessarily require the visualisation of to-scale miniatures of geo-political territory delimited by boundaries. Instead, territory could be negotiated and 'imagined' through a complex interaction of map and (con)text. All six Franciscan maps discussed in this chapter project the 'imagined territory' of the biblical topography of the twelve tribes, a versatile cartographical topos which was deftly employed by the friars to suit a variety of purposes, territorial or otherwise.

\section{Bibliography}

\section{Primary sources}

Adrichomius, Christianus, Theatrum Terrae Sanctae et Biblicarum Historiam cum Tabulis Geographicis aere Expressis (Cologne: Birckmann [Arnold Mylius], 1593). British Library, MS. Additional 27376. Marino Sanudo, Liber Secretorum Fidelium Crucis, with maps by Pietro Vesconte. 
Francesco Caccia, Francesco, Jerusalem, sue Palaestina Nova (Vienna: Lercher, 1706). Fedanzola da Perugia, Giovanni di, Descriptio Terrae Sanctae:Ms. Casantense 3876 , ed. by Ugolino Nicolini and Renzo Nelli (Jerusalem: Franciscan Printing Press, 2003). Gonsales, Antonius, Hierusalemsche Reijse, 2 vols (Antwerp: Michiel Cnobbaert, 1673).

Goujon, Jacques, Histoire et voyage de la Terre-Sainte (Lyon: Pierre Compagnon \& Robert Taillandier, 1670).

Ortelius, Abraham, The Theatre of the Whole World, Printed for John Norton and John Bill, London 1606, facs. ed. by R.A. Skelton (Amsterdam: Theatrum Orbis terrarum, 1968).

Ortelius, Abraham, Theatrum Orbis Terrarum (Antwerp: Aegidius Coppenius, 1570).

Quaresmio, Francesco, Historica Theologica et Moralis Terrae Sanctae Elucidatio, 2 vols (Antwerp: Plantin Press [Balthasar Moretus], 1639).

Roger, Eugène, La Terre Sainte: ou description topographique trés-particuliere des saints Lieux, \& de la Terre de Promission (Paris: Antoine Bertier, 1646).

Surius, Bernardinus, Den Godtvruchtighen Pelgrim ofte Ierusalemsche Reyse (Brussels: Ian Mommaert, 1650).

Surius, Bernardinus, Den Godtvruchtighen Pelgrim ofte Ierusalemsche Reyse, $4^{\text {th }}$ ed. (Brussels: Ian Mommaert, 1665).

Zwinner, Electus, Blumenbuch des H. Lands Palestinae so in dreij Biecher getheilet (Munich: Wilhelm Schell, 1661).

\section{Secondary sources}

Agnew, John, 'The Territorial Trap: The Geographical Assumptions of International Relations Theory', Review of International Political Economy 1, no. 1 (1994), 53-80.

Akerman, James R., 'The Structuring of Political Territory in Early Printed Atlases', Imago Mundi 47, no. 1 (1995), 138-154.

Antonsich, Marco, 'Rethinking Territory', Progress in Human Geography 35, no. 3 (2010), 422-425.

Campopiano, Michele, 'Écrire/décrire la Terre sainte: les Franciscains et la représentation des lieux sacrés (début du XIV e-début du XVI siècle)', in Orbis Disciplinae, ed. by N. Bouloux, A. Dan and G. Tolias (Turnhout: Brepols, 2017), pp. 167-182.

Campopiano, Michele, 'Islam, Jews and Eastern Christianity in Late Medieval Pilgrims' Guidebooks: Some Examples from the Franciscan Convent of Mount Sion', Al-Masāq: Journal of the Medieval Mediterranean 24, no. 1 (2012), 75-89.

Cardini, Franco, and Guido Vannini, 'San Vivaldo in Valdelsa: Problemi Topografici ed Interpretazioni Simboliche di una "Gerusalemme" Cinquecentesca in Toscana', in Religiosità e Società in Valdelsa nel Basso Medioevo, ed. by Sergio Gensini (Castelfiorentino: Società Storica della Valdelsa, 1980), pp. 11-74. 
Crampton, Jeremy W., 'Maps as Social Constructions: Power, Communication and Visualization', Progress in Human Geography 25, no. 2 (2001), 235-252.

Delaney, David, Territory: A Short Introduction (Malden, MA: Blackwell, 2005).

Delano-Smith, Catherine, 'Milieus of Mobility: Itineraries, Route Maps and Road Maps', in Cartographies of Travel and Navigation, ed. by James R. Akerman (Chicago: University of Chicago Press, 2006), pp. 16-68.

Dalché, Patrick, 'Maps, Travel and Exploration in the Middle Ages: Some Reflections about Anachronism', The Historical Review/La Revue Historique 12 (2015), 143-162.

Della Dora, Veronica, 'Performative Atlases: Memory, Materiality, and (Co-)Authorship', Cartographia 44, no. 4 (2009), 240-255.

Elden, Stuart, The Birth of Territory (Chicago: University of Chicago Press, 2013).

Elden, Stuart, 'Land, Terrain, Territory', Progress in Human Geography 34, no. 6 (2010), 799-816.

Farish, M., 'Maps and the State', in International Encyclopedia of Human Geography, ed. by Rob Kitchin and Nigel Thrift (Amsterdam: Elsevier, 2009), pp. 442-454. Harley, J.B., 'The Map and the Development of the History of Cartography', in The History of Cartography, Volume 1: Cartography in Prehistoric, Ancient, and Medieval Europe and the Mediterranean, ed. by J.B. Harley and David Woodward (Chicago: University of Chicago Press, 1987), pp. 1-42.

Harvey, P.D.A., 'Local and Regional Cartography in Medieval Europe', in The History of Cartography, Volume 1: Cartography in Prehistoric, Ancient, and Medieval Europe and the Mediterranean, ed. by J.B. Harley and David Woodward (Chicago: University of Chicago Press, 1987), pp. 464-501.

Harvey, P.D.A., 'Medieval Maps: An Introduction', in The History of Cartography, Volume 1: Cartography in Prehistoric, Ancient, and Medieval Europe and the Mediterranean, ed. by J.B. Harley and David Woodward (Chicago: University of Chicago Press, 1987), pp. 283-285.

Houbaert, A., 'Surius (de Soer), Bernardinus, minderbroeder en schrijver', in Nationaal Biografisch Woordenboek, deel V. (Brussel: Paleis der Academiën, 1972), pp. 873-876.

Jacob, Christian, 'Toward a Cultural History of Cartography', Imago Mundi 48 (1996), 191-198.

Klauser, Francisco R., 'Thinking through Territoriality: Introducing Claude Raffestin to Anglophone Socio-spatial Theory', Environment and Planning D: Society and Space 30 (2012), 106-120.

Korzybski, Alfred, Science and Sanity: An Introduction to Non-Aristotelian Systems and General Semantics (Lancaster/New York: The International Non-Aristotelian Library, 1933).

Laor, Eran, and Shoshanna Klein, Maps of the Holy Land: Cartobibliography of Printed Maps, 1475-19oo (New York/Amsterdam: Liss \& Meridian, 1986). 
Lemmens, Leonhard, Die Franziskaner aufdem Sion (1335-1552), $2^{\text {nd }}$ ed. (Münster: Aschendorffschen Verlagsbuchhandlung, 1925).

Leslie, Camilo Arturo, 'Territoriality, Map-mindedness, and the Politics of Place', Theory and Society 45 (2016), 169-201.

Moldovan, Alfred, 'The Lost De Angelis Map of Jerusalem, 1578', The Map Collector 24 (1983), 17-25.

Moore, Kathryn Blair, 'Seeing through Text: The Visualization of Holy Land Architecture in Niccolò da Poggibonsi's Libro d'Oltramare, $14^{\text {th }}-15^{\text {th }}$ Centuries', Word \& Image 25, no. 4 (2009), 402-215.

Murphy, Alexander B., 'Entente Territorial: Sack and Raffestin on Territoriality', Environment and Planning D: Society and Space 30, no. 1 (2012), 159-172.

Paasi, A., 'Political Boundaries', in International Encyclopedia of Human Geography, ed. by Rob Kitchin and Nigel Thrift (Amsterdam: Elsevier, 2009), pp. 217-227.

Paquot, Jean Noël, Mémoires pour servir a l'histoire litteraire des dix-sept provinces des Pays-Bas (Louvain: Imprimerie Académique, 1765).

Peri, Oded, Christianity under Islam in Jerusalem: The Question of the Holy Sites in Early Ottoman Times (Brill: Leiden, 2001).

Piccirillo, Michele, 'La Raffigurazione di Gerusalemme nei Conventi Francescani', in Religioni e Sacri Monti, ed. by Amilcare Barbero and Stefano Pian (Ponzano Monferrato: ATLAS, 2006), pp. 141-152.

Piccirillo, Michele, 'The Role of the Franciscans in the Translation of the Sacred Spaces from the Holy Land to Europe', in New Jerusalems: Hierotopy and Iconography of Sacred Spaces, ed. by A. Lidov (Moscow: Indrik, 2009), pp. 363-394.

Raffestin, Claude, 'Space, Territory, and Territoriality', Environment and Planning D: Society and Space 30, no. 1 (2012), 121-141.

Ritsema van Eck, Marianne P., 'Encounters with the Levant: The Late Medieval Illustrated Jerusalem Travelogue by Paul Walter von Guglingen', Mediterranean Historical Review 32, no. 2 (2017), 153-188.

Ritsema van Eck, Marianne P., The Holy Land in Observant Franciscan Texts (c. 1480-1650): Theology, Travel, and Territoriality (Brill: Leiden, 2019).

Ritter, Michael, 'Die Karte des Heiligen Landes von Johann Ulrich Stapf (1691) und ihr Neudruck durch Johann Georg Koller', Cartographica Helvetica 42 (2010), 29-37.

Rubin, Rehav, Image and Reality:Jerusalem in Maps and Views (Jerusalem: Magnes Press, 1999).

Rubin, Rehav, 'One City, Different Views: A Comparative Study of Three Pilgrimage Maps of Jerusalem', Journal of Historical Geography 32 (2006), 267-290.

Rubin, Rehav, 'Quaresmius's Novae Ierosolymae et Locorum Circumiacentium Accurata Imago (1639): An Image of the Holy City and Its Message', in Visual Constructs ofJerusalem, ed. by B. Kühnel, G. Noga-Banai and H. Vorholt (Turnhout: Brepols, 2014), pp. 277-284. 
Sack, Robert David, Human Territoriality: Its Theory and History (Cambridge: Cambridge University Press, 1986).

Saletti, Beatrice, I Francescani in Terrasanta (1291-1517) (Padova: Libreria Universitaria, 2016).

Sassen, Saskia, Territory, Authority, Rights: From Medieval to Global Assemblages (Princeton: Princeton University Press, 2008).

Segre, Vera, 'New Research on a Rare Fresco Map of Jerusalem', Imago Mundi 66, no. 2 (2014), 224-235.

Shalev, Zur, 'Early Modern Geographia Sacra in the Context of Early Modern Scholarship', in The Oxford Handbook of the Bible in Early Modern England, c. 1530-1700, ed. by Kevin Killeen, Helen Smith and Rachel Willie (Oxford: Oxford University Press, 2015), pp. 196-208.

Shalev, Zur, Sacred Words and Worlds: Geography, Religion, and Scholarship, 1550-1700 (Leiden: Brill, 2012).

Somaini, Francesco, 'Territory, Territorialisation, Territoriality: Problems of Definition and Historical Interpretation', Plurimondi 10 (2012), 19-47.

Strandsbjerg, Jeppe, Territory, Globalization and International Relations: The Cartographic Reality of Space (Basingstoke: Palgrave Macmillan, 2010).

Tolan, John, Saint Francis and the Sultan: The Curious History of a Christian-Muslim Encounter (Oxford: Oxford University Press, 2009).

Woodward, David, 'Cartography and the Renaissance: Continuity and Change', in The History of Cartography, Volume 3: Cartography in the European Renaissance, Part 1, ed. by David Woodward (Chicago: University of Chicago Press, 2007), pp. 3-24.

Woodward, David, 'Medieval Mappaemundi', in The History of Cartography, Volume 1: Cartography in Prehistoric, Ancient, and Medieval Europe and the Mediterranean, ed. by J.B. Harley and David Woodward (Chicago: University of Chicago Press, 1987), pp. 286-358.

\section{About the author}

Marianne Ritsema van Eck completed her PhD at the University of Amsterdam and is currently Postdoctoral Fellow at the Norwegian Institute in Rome (University of Oslo). She specialises in religion, particularly its expressions at the intersection of visual, material, and textual culture. 



\title{
Constructing and Representing Territory in Late Medieval and Early Modern Europe: A Conclusion
}

\author{
Mario Damen and Kim Overlaet
}

This volume contributes to ongoing debates on the nature and character of territory as a meaningful spatial category and analytical tool for historical studies on power relations in late medieval and early modern Europe. As a concept, territory is often associated with state-formation processes and (perhaps unwittingly) with modern ideas of the nation state. This association makes it difficult for historians of pre-modern Europe to use the term without risking an ahistorical approach. Inspired by the historical geographer Stuart Elden, who in his work shows the usefulness of the concept of territory as an analytical tool, we invited several historians and literary historians to tackle these conceptual and methodological challenges via analyses of the ways in which different political actors were involved in the construction and representation of (feudal, judicial, fiscal, and military) territories and boundaries. The idea central to this volume is that the concept of territory allows us to grasp pre-modern relations between power, people, and space, as long as its meaning is not narrowed down to simply an enclosed geographical area. Moreover, to grasp territorial practices and the perception of territory by different political actors in society, it is important not to limit case studies to administrative sources, but also to include narrative texts, heraldic images, and cartographic sources.

The first section of this volume addresses the methodological and conceptual challenges that historians face when studying the construction of territory by political actors with both divergent and convergent interests. All authors of the chapters in this section problematise the use of spatial concepts related to territory, such as 'territorial practices' and 'territorial integrity'. Duncan Hardy rightfully stresses that our modern 'territorial vocabulary' is closely linked to ideas on state-formation processes and

Damen, M. and K. Overlaet (eds.), Constructing and Representing Territory in Late Medieval and Early Modern Europe. Amsterdam: Amsterdam University Press, 2022 DOI 10.5117/9789463726139_CONC 
present-day cartographical conventions and rules. To avoid an ahistorical approach, he confronts this modern vocabulary with pre-modern spatial concepts and categories like terra $(e)$ and land $(e)$ in administrative sources produced by the most important political actors in the late medieval and early modern Holy Roman Empire. Hardy demonstrates that the political power of both the imperial monarchy and the many princes, nobles, and cities claiming 'quasi-sovereignty' was not primarily spatially determined. Instead, in this patchwork of entities with overlapping administrative, jurisdictional, and political authority, political power was based on constant negotiations and interactions on the one hand, and on shared cultural structures and particularities on the other. According to Hardy, labelling the semi-autonomous principalities like the Palatinate and cities in the Holy Roman Empire as 'territories' stricto sensu falls short of the reality, which was more complex and dynamic. He proposes a more dynamic approach, which pays closer attention to the ways in which actors could simultaneously maintain overlapping (and sometimes contradictory) alliances and affiliations, and to the fact that spatial claims in this period often were 'more rhetorical than tangible in practice, and always had to be negotiated' (p. 47).

In his essay on different phases and processes of 'territory-making' in late medieval Italy, Luca Zenobi likewise shows that late medieval 'territorial practices' relating people and power to space were essentially the result of intensive negotiations between seigneurial lordships, rural communities, towns, and other semi-autonomous political entities claiming authority in a specific space. Such negotiations - and disputes - typically involved the jurisdictional and fiscal rights and privileges granted by superior lords to the rulers and inhabitants of specific regions. These rights and privileges - together with the inhabitants' social interactions (including, for example, their participation in religious ceremonies or civic militias), the formalisation of institutions for self-government, and the increasing importance of demographic information (e.g. population censuses and lists) - were key to a process of region-based identity formation. Hence, according to Zenobi, territory-making in late medieval Italy (and beyond) must be understood as mainly driven by the social, political, economic, and cultural interaction and negotiations between individuals and power groups. Finally, and in comparison to the situation in the Holy Roman Empire, these interactions and discussions could be both vertical and horizontal. Much like the communities and power groups involved, areas of jurisdiction could exist alongside each other and often overlapped.

Taking a social approach to the construction of territory, Bram van den Hoven van Genderen stresses the importance of the clerics as an 
often-neglected power group in late medieval and early modern Europe. The Church had both a religious and a practical approach to space. His analysis of the writings by two mid-fifteenth-century clerics, (the later) Pope Pius II and Cardinal Nicholas of Cusa, reveals that the societas christiana formed 'the basis of the ecclesiastical administrative division of the world, with Christian dioceses under an acting bishop' (p. 9o). Although both geographers and historians tend to focus on secular spaces ruled by (city-) states, he notes that kings and emperors, popes, cardinals, and bishops governed, controlled, and managed their papal dominions, (arch)dioceses, and parishes surprisingly independently. Moreover, as Van den Hoven van Genderen demonstrates, these ecclesiastical institutions had a remarkably stable spatial basis throughout the pre-modern period, and even employed various territorial practices often associated with lay rulers, such as taxation and population censuses. The author shows that - like the formation of lay 'territories' - the establishment of new bishoprics and parishes in the late medieval Low Countries (1559) was the outcome of the interaction between various power groups, from the papal court and secular princes to bishops and urban governments, who sometimes shared jurisdictional and fiscal authority in a specific region.

In his contribution, Jim van der Meulen proposes the concept of 'territorial integrity' to add an interactive dimension to research on the construction of territory. As Van der Meulen puts it, this term refers to 'the long-term stability of loosely defined spatial bounds of the ruler's area of jurisdiction', which was the result of cooperation between princes, lords, and urban elites who could have similar or different military, fiscal, and economic motives (p. 118). His analysis of the negotiations between the princes ruling the Duchy of Guelders and the manifold seignorial lords and ruling elites of the towns and shires constituting this small composite state in the Low Countries confirms that all power groups shared a keen interest in spatial stability and the maintenance of the duchy's borders. Moreover, the noble holders of high lordships in this region often owed allegiance to several neighbouring princes, which allowed them to function as 'territorial buffer zones' for negotiations about the duchy's territorial integrity. In other words, Van der Meulen argues that 'the lordship became an intermediate link in a chain connecting local spatial politics to the level of the principality' (p. 130). In this he joins the other authors in this section by strongly arguing for a social approach to territorial practices and the relations between people, power, and space in the past.

Continuing this line of thought, the second section of this volume focuses on the construction, management, and contestation of space (whether by 
military or other means) by different stakeholders and political actors as expressed in princely and urban administrative sources, as well as via cartography. Indeed, if pre-modern territories should be understood as social constructs, different social groups had different perceptions of the links between people, power, and space. The question central to this section is how inhabitants, trespassers, and rulers or conquerors of pre-modern towns, principalities, and composite states experienced, constructed, and managed these areas' political, economic, and juridical rights, privileges, and spatial boundaries. In the first chapter of this section, Arend Elias Oostindiër and Rombert Stapel focus on the way in which fiscal relations could bind a territory together as a coherent relational space. Concentrating on the Duchy of Brabant, their hypothesis is that the Burgundian dukes, who had integrated Brabant into their composite state in 1430, acquired unprecedented 'territorial knowledge' due to the fiscal reform they introduced in the course of the fifteenth century. By combining an analysis of administrative sources with a GIS reconstruction of the boundaries of the towns and villages in Brabant, Oostindierr and Stapel show that the fiscal reform, which introduced hearth counts, was instrumental in the construction (and perception) of the fiscal internal borders of the duchy. Clearly, the reform did more than merely stabilise the dukes' sources of income. Since the hearth counts required contributions based on economic resources rather than on political power, the reform went hand in hand with a detailed mapping of the wealth of all Brabantine towns and villages. Using their political power to master the duchy's socio-economic space, the Burgundian dukes gained much more detailed territorial knowledge than their predecessors, which greatly influenced their bargaining position during (fiscal) negotiations. Oostindiër and Stapel show that the power to acquire and use specific knowledge (in this case, fiscal information) was key to both the construction and management of pre-modern territories.

The next case study confirms the paramount importance of information for rulers and those engaged in managing and administrating territories. Via a detailed study of military law, court records, and fiscal accounts, Sander Govaerts analyses the evolution of the territorial practice of 'foreign military service' in the medieval Meuse and Rhine regions (1250-1550) and demonstrates the medieval origins of this modern concept. According to Govaerts, the sixteenth-century official ban on military service in the army of a ruler of a territory other than the one where a soldier was born or lived must be seen in the context of two interlinked developments. First, fiscal and juridical sources illustrate that both urban authorities and noble lords found it increasingly important to be able to control the movement of soldiers 
and others, 'linking people to spaces' (p. 193). Second, Govaerts links this 'territorial' evolution to the gradual transition of a military recruitment system based on feudal obligations, to a military service based on a formal contract stipulating conditions and payment. Men-at-arms often maintained ties of loyalty to multiple and sometimes competing lords and cities, as is demonstrated in other chapters of this volume. In theory, a soldier could not fight against his own lord, but the feudal system allowed many loopholes and could cause confusion. This gradually changed, as a soldier's connection to a specific space by birth or residence became more important than other (more personal) ties of loyalty.

In a military conflict it was crucial to acquire 'spatial' information, and this information was crucial for the construction of a territory. Neil Murphy demonstrates this in his chapter on the invasion of France by the English king Henry VIII (1491-1547) in the summer of 1544. In the following years (1544-1546), Henry conquered the town of Boulogne and the surrounding area of the Boulonnais. The latter was partially leased out to English settlers and carefully mapped by Henry's military engineers using the latest geometric methods. Inspired by Henri Lefebvre's idea that the production of space can be closely linked to violence, Murphy argues that this conquest was a turning point in the development and use of cartography in the Late Middle Ages. Through an analysis of maps and plans, and the associated letters, surveys, and treaties, the author shows how cartographic images and texts were used during the military campaign and the following peace negotiations, which eventually culminated in the Treaty of Camp (June 1546). The English maps are highly detailed and reveal which landmarks were considered vital for the exercise of power and control in a specific region: mills, rivers, and harbours. Moreover, one of these maps is considered as perhaps the earliest example of a cartographic representation of a boundary, in the form of a dotted line. According to Murphy, this confirms that Henry's maps and plans did not serve a purely representative or informative goal, as they were also used to convert (or to 'construct') the conquered lands into a demarcated English territory, in France.

Given that the centralisation of information and institutions proved vital to exercising territorial power, the establishment of one central capital city can be expected to be an important way to exercise 'territorial power'. This issue is addressed by Yannick De Meulder for the Habsburg composite state, where the concept of a 'capital' was perhaps absent. Through a reconstruction of the residence patterns of two important regents of the Low Countries, Margaret of Austria (r. 1507-1515) and Mary of Hungary (r. 1530-1555), he analyses whether Brussels could function as a capital city in 
the Habsburg composite state, despite the absence of the ruling monarchs, Maximilian of Austria (r. 1493-1519) and Charles V (r. 1515-1555). It appears that regardless of the presence of central institutions and a spacious royal palace, the Coudenberg, Brussels remained just one of the multiple political and economic centres (hoofdsteden) of the Low Countries, together with other major cities such as Mechelen, Antwerp, and Ghent. According to De Meulder, Maximilian and Charles V's physical absence largely explains, on the one hand, why they had to continue the tradition of Joyous Entries in the multiple towns of the Low Countries, explicitly recognising the lack of a capital, and on the other hand, why they were unable to establish a single administrative centre in the Low Countries. At the same time, local elites were eager to invite their princes to visit their principalities, as they expected them to confirm the local rights and privileges on these occasions. In other words, despite the centralising efforts of both regents, in the composite Habsburg state an itinerant court largely remained the most efficient way to exercise power over people.

The chapters in the first two sections of this volume demonstrate that the construction of late medieval and early modern territories should be studied in the context of the constant interaction between the political actors involved (e.g. kings, princes, clerics, nobles, and urban elites). It is important to remember that territorial integration was not a linear process involving the development of clear borders and 'a capital'; the development of manifold kinds of information channels and administrative systems proved vital tools for rulers to take control of the construction of territory. Analysis of these tools and their application contributes to and informs our understanding of how rulers could exercise control over people in a specific territory.

Focusing on the concept of territory as manageable land or terrain fails to do justice to the fact that territories were above all lived spaces, which were perceived and imagined quite differently by different actors. Therefore, the third and final section of this volume addresses the question of how rulers, power groups, and inhabitants in pre-modern Europe perceived and represented the territories they were living in or travelling through. Analyses of contemporary representations of territorial affiliations in different media confirm that territories were socially constructed, and that claims over a territory needed to be communicated (and acknowledged) in order to be effective. Mario Damen and Marcus Meer advocate the study of heraldry as a dynamic means of territorial communication. In cities and principalities in the Burgundian Low Countries and the Holy Roman Empire, as well as elsewhere in Europe, coats of arms acquired spatial meanings in the course 
of the Late Middle Ages, which allowed them to represent territorial claims. Damen and Meer show how political actors in this period used various media to communicate the links between princes, noblemen, or even towns, and certain territories they possessed or claimed to possess: from armorials, stained-glass windows, chronicles, and architectural decorations to the tableaux vivants constructed on the occasion of Joyous Entries. Political actors used all these media to communicate the nature and grandeur of their territory to a large audience. Moreover, the authors' analysis of several armorials shows that the heraldic representation of territory allowed remarkably great flexibility. Damen and Meer show that heraldic signs were inextricably linked not only to the representation, but also the construction of political structures and authority in a specific space, and were thus vital to communicating territorial claims.

Bram Caers and Robert Stein demonstrate that historiography could have similar communicative functions to heraldry. Chronicles such as Hennen van Merchtenen's Cornike van Brabant (1415) present the Duchy of Brabant as an idealised union of towns and lordships, and as 'an object of recognition and love for its inhabitants' (p. 279). Caers and Stein argue that this Brabantine 'imagined community' was based on a perception of the duchy as a specific territory linked to a specific dynasty. Brabantine chroniclers writing in the context of the ducal court were interested equally in the continuity of the ducal dynasty and in the historical development of titles and the territorial claims that came with them, such as the title dux Lotharingie. Moreover, by confronting courtly 'canonical' historiography with vernacular literature, Caers and Stein show that the dukes of Brabant were not the only ones aware of the communicative function of historiography in relation to claims over territory. The Grimbergse oorlog, an epic tale written in the first half of the fourteenth century, illustrates how local historiographical traditions reflected the point of view of other political actors, such as the bannerets, high noblemen whose titles also laid claim to lordships within the ducal territory. In other words, just like heraldic signs, historiographical texts were used by different political stakeholders - from noble patrons to urban elites - to represent their claims of authority and power (as well as political, economic, and jurisdictional privileges) in a specific space.

The idea that local urban elites could use historiography to communicate their territorial claims is also central to the analysis by Lisa Demets. Her research on the relation between the (de)construction of regional identity politics and territorial entities in late medieval Flanders reveals the political dynamics behind ideological representations of the county in narrative sources. Key to these dynamics were the constant negotiations between 
the ruling dukes, the counts of Flanders, the local nobility, and urban elites. According to Demets, the sentiment of local particularism was relatively high and remained important in Flanders, despite the centralising efforts of the Burgundian dukes and the supposed 'unifying' role of the princely dynasty. In the fifteenth century, urban political elites eagerly sponsored the rewriting of regional chronicles since the inclusion of urban legends and features legitimised the role of the towns in the politics of the county. The reconstruction of the political context in which these urban historiographical texts were produced allowed Demets to link the evolution of this literary genre to the institutionalisation of the Four Members of Flanders, a representative institution in which representatives from Ghent, Bruges, and Ypres, together with the Franc of Bruges, gathered to negotiate with the Flemish counts about, for instance, the rights and privileges tied to specific urban jurisdictions. Her in-depth contextual analysis of two fifteenthcentury historiographical texts shows that in the county of Flanders regional particularism, legitimised in regional chronicles, was the urban answer to the increasing centralising efforts of the Burgundian dukes.

A final chapter expands the geographical span of this volume beyond pre-modern Europe. Whereas historians often tend to focus on the practical purposes of cartography, Marianne Ritsema van Eck considers late medieval and early modern maps primarily as social artefacts, which are to be studied in relation to the specific context in which they were made and used. The central idea of her case study is that maps, no less than heraldic signs and chronicles, could be produced and used to represent abstract imagined (and aspired to) territories, rather than real relationships between people and space. Her careful analysis of Holy Land maps produced by the Franciscans in the course of the seventeenth century shows that a scholarly focus on the often emphasised 'accuracy' of these maps fails to do justice to their important religious goals and meanings. As the hosts and guides of all Western pilgrims, these friars exercised a great influence on perceptions of the Holy Land in Western Europe, not least thanks to their publications, which often included maps of the Holy Land and which reached a relatively wide European audience. However, and in sharp contrast with the maps central to the peace negotiations between the English and the French kings highlighted in Murphy's chapter, the main aim of the maps made by the Franciscans was not to yield an accurate representation of the Holy Land. According to Ritsema van Eyck, these maps rather communicated territorial - and essentially biblical - claims and ambitions, only acquiring meaning through the interaction with the content of the books in which they appeared. 
Van den Hoven van Genderen rightfully stresses that, in constructing the 'birth of territory', Stuart Elden relied heavily on 'the theorists of temporal power and the great names of Western political thought' (p. 104). This volume did not aim to antedate that so-called 'birth' to the (later) medieval period. Rather, it shows how territory 'worked' in practice in the minds of princes, nobles, ecclesiastics, and urban elites. Whereas the ideas and practices of secular powerholders like kings, princes, and urban elites seem relatively well studied, this is definitely not the case for nobles and clerics. Several contributions to this volume show how necessary it is to involve all political actors in the argument, since it was especially the mutual interaction of these actors that influenced territorial notions and practices. Seven of the twelve contributions analyse these practices in the Low Countries and northern Italy, polities where urban power was relatively strong, and royal or princely power was not uncontested. This definitely produces different outcomes from the ideas on, and perceptions of, territory than in the cases of more 'centralised' polities as England or France.

This volume demonstrates that research on the concept of territory in pre-modern Europe should go beyond the 'great thinkers' who operated in princely and royal settings. The focus was rather on power groups such as urban elites, clerics, and the nobility providing mostly 'cadastral' or topdown, views on territory. Future research should pay careful attention to the vocabulary and discourse of not only these but also other more humble groups concerning territory, boundaries, and borders. Still, the question remains how local communities, both in town and countryside, throughout Europe experienced territory. Admittedly, this point of view remains largely unexplored in this volume. Research on the concept of territory in pre-modern Europe would greatly benefit from a bottom-up approach, involving the different social strata in the towns apart from the urban elites, and peasants and daily labourers in the countryside. An example to follow would be Andy Wood's approach towards the ways 'ordinary people' relate to the environments, landscapes, and places they inhibit in his book The Memory of the People (2013). This may give us a better understanding of how the perception of territory changed over time. Finally, an analysis of the negotiations between these groups on a macro, meso, and local level is imperative, since these were vital to both the perception of territory and the maintenance of spatial stability or 'territorial integrity'. In this way the concept of territory may serve as a fruitful hermeneutic tool for historians to study pre-modern relations between people, power, and space. If we perceive territory as a dynamic, or even an imagined, social concept, it allows for a far greater and more nuanced insight into the constructions 
and perceptions of different political actors and 'ordinary people' that would otherwise be overlooked. If potential pitfalls, such as ahistoricity and teleology, are avoided through applying careful methodological and conceptual approaches, we can broaden our understanding of territory beyond a modernistic and somewhat static conception, towards a more dynamic interpretation.

\section{About the authors}

Mario Damen is a Senior Lecturer at the University of Amsterdam. He has published widely on the social and political history of the late medieval Low Countries and is the PI of the research project 'Imagining a Territory: Constructions and Representations of Late Medieval Brabant', financed by the Dutch Research Council (NWO).

Kim Overlaet worked from 2016 to 2019 as a Postdoctoral Researcher at the University of Amsterdam on the research project 'Imagining a Territory: Constructions and Representations of Late Medieval Brabant', financed by the Dutch Research Council (NWO). She currently works as a research manager in the Department of History at Antwerp University. 


\section{Index}

Aarschot

Lordship $\quad 169$

Town 160

Abraham, prophet $\quad 252,327,329,334,336$

Abruzzo 62

Aquitaine 255

Adrichem, Christiaan $\quad 333,335,337,343$

Acre 322

Africa $\quad 85,181$

Aire-sur-la-Lys 83

Albert, duke of Mecklenburg 252

Albrecht 'Achilles', margrave of Brandenburg 41, 49

Albrecht, count of Holland 187, 245

Albrecht, duke of Saxony 186

Aleidis of Burgundy $\quad 281$

Alps 69

Alsace 39

Alva, duke of, see Fernando Álvarez de Toledo y Pimentel $\quad 167$

Ambleteuse 204, 205, see also New Haven

Amersfoort 99

Ammerzoden, lordship $\quad 124,127,129,130$

Amsterdam 99, 259

Andlau, Peter von 29-31

Angelis, Antonio de $\quad 323,324,336$

Ansegisel $\quad 282$

Anthony of Burgundy, duke of Brabant 147

Antwerp

Margraviate $\quad 278,284,286$

Quarter $145,148,156,157,158,163,170,220$

Town $85,147,148,150,153,159,168,169$, $224,226,262,263,279,286,288,354$

Amico, Bernardino $\quad 324,325,333$

Apennines 69

Aquinas, Thomas 83

Aragon

King, see Ferdinand; Ferdinand II

Kingdom 221, 222, 229

Aristotle 83

Arnhem

City 122

Quarter 122

Artois, County $\quad 144,164,208,257,291$

Asia $87-89$

Asse

Bailiwick 170

Augsburg

Bishop 46

Diet of (1555) 40

Town $99,257,25^{8}$

Augustine 19,86

Austrasia

Duchy $\quad 283$

Mayor of the Palace, see Pippin I; Pippin II
Austria

Archduchy $\quad 31,88,252,253,261,263$

Duke, see Rudolf IV

Aytta, Viglius of 98,100

Baesweiler, battle of $\quad 187$

Baden, Margrave, see Bernard; Rudolf

Bar

Duchy 180

Duke, see Henry III

Basel 29, 45, 87

Battel, Jan van 253

Bavaria

Coat of arms $\quad 245,246$

Duchy $41,42,45,48,85$,

Duke, see Albrecht; Louis IX; Ludwig 'the Rich'; Rupert

Princess, see Margret

Begga 282

Bel, Jean le, chronicler 181

Belges, Jean Lemaire des $\quad 228$

Bellenville, armorial $\quad 256,257$

Bergen op Zoom

Lord, see Glimes, Jan II van

Town 85,160

Bergshammer, armorial $\quad 256,257$

Bernard, margrave of Baden 188

Berry, Duke of, see John, duke of Berry

Berthout, house of $288,289,292$

Bertrand de la Tour d'Auvergne, count of

Boulogne 200

Bethune, Robert of, count of Flanders 304

Blackness, see also Cap Griz-Nez

Blanche of England, princess 188

Boendale, Jan van $\quad 279,281,285,286-289,301$

Bologna 65

Bornecolve, Willem 279

Bouillon, Godefroi of $\quad 284$

Boulogne

Count, see Bertrand de la Tour d'Auvergne

County, see Boulonnais

Town 199-205, 207, 353

Boulonnais, County $144,164,199-208$, 210-212, 353

Bovet, Honoré, Benedictine 184

Boxmeer 166

Brabant

Bailiwicks 169-171

Clergy 146,160

Duchess, see Johanna

Duchy 22, 85, 97, 122, 125, 126, 128-130, 132, $141-150,153,154,156-157,160,163-168$, $181,185,187,219,225-227,233,234,251$, 255-257, 263, 277-287, 292, 293, 297, $300-302,306,352,355$ 
Duke, see Anthony of Burgundy; Charles the Bold; Godfried I; Hendrik III; Hendrik IV; Jan I; Jan II; Jan III; Jan IV; Philip of Saint-Pol; Philip the Good; Wenceslas of Luxembourg

Duke-consort, see Wenceslas of Luxembourg

Estates $143,144,146,148,153,154,160,164$, $220,277,288,292$

Lordships 129

Margaret of 278

Nobility $\quad 288,289,292,301$

Quarters $145,148,149,156,157,160,163$

Receiver-General, see Eiken, Peter van der

Seneschal, see Nassau, Jan IV van

Towns $146-149,153,154,156,158,160,163$, $165,166,301,35^{2}$

Brabon 287

Bracciolini, Poggio 30

Brandenburg

Margrave of, see Albrecht 'Achilles'

Breda

Margraviate $35,37,44,48$

Lord, see Nassau, Jan IV van

Lordship 160, 291

Town 154, 224

Brescia 324

Bruges

Bishopric 97

City $224,230,231,300,302-312,356$

Franc 303

Prinsenhof 231

Saint Donatian church 307

White bear 308, 309.311

Bruges, Galbert of 298

Brunembert 209

Brussels

Auditing chamber 219

Bailiwick 169

Coudenberg 218, 226, 227, 231, 233, 235, 354

Count, see Lambert

Quarter $145,148,156-158,160,220$

Town $147,148,150,153,154,156,158,159$, $163,169,217-219,221,223-228,231-233$, $235,260,288,339,353,354$

Buc, Liederik of, forestier of Flanders 306308,311

Burgau 261

Burgundian Low Countries $18,31,134,142$, $143,164,217-235,243,246,255,257,259,262$, $266,300,354$

Burgundy

Duchess, see Mary of Burgundy

Duchy $126,144,153,156,189,219$,

Duke, see Charles the Bold; John the

Fearless; Philip the Bold; Philip the Fair; Philip the Good

Valois Dukes 126
Burgundy, Aleidis of $\quad 281$

Bylandt, lordship $\quad$ 130,131

Caccia, Francesco $\quad 336,337$

Cairo 313

Calais, Pale of 204, 208, 211

Caltagirone 324

Cambrai, (Arch)bishopric 95, 97, 98, 100, 103, 287

Campine area (de Kempen) $\quad 150,171$

Capet, Hugues, king of France $\quad 283,288$

Cap Griz-Nez, see Blackness

Carinthia $\quad 261$

Carniola $\quad 261$

Castiglione, Balthasar 203

Castile and Leon

King, see Ferdinand III; Peter I; Philip the Fair

Kingdom 221, 222, 248, 249

Princess, see Constance

Champagne 255

Champmol, Carthusian monastery of 245

Charlemagne $\quad 253,283,289$

Charles, duke of Lower Lotharingia $\quad 282,284$

Charles the Bold, duke of Burgundy 97,164 , $180,190,219,220,231,233,243,252,264-266$, 308

Charles V, Holy Roman Emperor $\quad 97,99,186$, 191, 200, 202, 217, 218, 221-223, 227, 229, 232, $233,253,354$

Cicero 19

Clairmarais, abbey $\quad 304,305$

Cleves

County $121,129,130,132$

Duchy $125,128,148$

Land of (in Brabant) $\quad 148$

Cologne

Archbishopric 95, 98, 145

City $181,184,187,188,258,264,265$

Conrad, archbishop of Mainz $\quad 184$

Constance

Bishop 46

Council 90

Constance, princess of Castile and Leon $\quad 248$

Constantinople 87

Cranendonck, lordship 129

Cuijk, Land of $121,130,166$

Delft 99

Den Bosch, see 's-Hertogenbosch

Denmark 85

Diest

Lordship 169

Town 153,160

Dijon, Auditing chamber 219

Dinant 189, 264

Donauwörth $\quad 264,265$

Dordrecht $\quad 260$

Douai 309-312 
Dover 307

Drusus 257

Duisburg 208

Eberstein, counts of 43

Edingen 290

Edward III, king of England 266

Eeckhout

Abbey 304-309, 311

Abbot, see Hautscilt, Lubert

Eiken, Peter van der (Pierre du Chesne), receiver-general of Brabant 154

Elyot, Thomas 203

Emilia 66

England

King, see Edward III; Henry VIII; William III

Kingdom $17,88,92,95,96,133,143,153$, 179, 181, 199, 200, 202, 203, 205-208, 211, 212, 302, 303, 307, 309, 310, 357

Princess, see Blanche

Enzklösterle, lords of 43

Erfurt 259

Euclid 206

Europe $13,15,16,20-22,33,36,37,54,56,67$, $68,86-90,92,118,134,141,142,144,146,177$, $179,184,202,203,206,208,210,212,246,248$, 250, 260, 322, 349, 351, 354, 356, 357

Ezekiel 334

Fedanzola da Perugia, Giovanni di 322

Ferdinand, king of Aragon $\quad 222$

Ferdinand II, king of Aragon 253

Ferdinand III, king of Castile and Leon 248

Fernando Álvarez de Toledo y Pimentel, 3 rd duke of Alba (Grand Duke of Alva, Iron Duke) $\quad 167$

Finard, giant, lord of Lillebuc 307

Flanders

Count, see Guy of Dampierre; Lodewijk van Male

Countess, see Margaretha van Male

County $95,100,103,122,144,164,181,219$, $224,226-228,231,234,255,257,280$, 297-299, 301, 302, 303, 304, 305, 306, 307, 308, 309, 310, 311, 355

Estates 227

Four members $\quad 303,309,312,356$

Florence / Florentine

Commune 66

Dominion 15,265

France

Court 22, 301

King, see Capet, Hugues; Francis I; Louis IX; Louis XIV; Philip IV

Kingdom $15,17-19,22,88,92,95,96,119$, $141,144,148,153,179-181,183,190,191$, 199, 200-205, 207-212, 226, 227, 229, 285, $301,303,307,309,310,353,357$

Franche-Comté 18
Francis I, king of France $\quad$ 186, 200

Francis, saint $322,327,329$

Franconia $39,41,44$

Francus 258

Frankfurt 181, 263

Frederick III, Holy Roman Emperor $\quad 87,88$, $253,254,261,263$

Frederick V, landgrave of Leuchtenberg $\quad 252$

Frignano, Universitas of 69

Frisia $88,92,93,186,187,280$

Friuli 61

Froissart, Jean $\quad 181,190,278$

Fynderne, Sir Thomas 211

Gaasbeek

Lords 290

Lordship 170

Galle, Cornelis 332

Gascony 200

Geldenaken, see Jodoigne

Gelre, armorial 256, 257

Gembloux (Gembloers), abbey $\quad 146$

Gemert $\quad 166$

Genappe

Bailiwick 170

Town 170

Gendt, lordship $\quad 126,130,132,133$

Gent, see Ghent

Gerberga of Lower Lotharingia $\quad 282,283$

Germany 16, 29-34, 36, 38, 42-44, 47-49, 88,93

Ghent

Bishopric 97

City $88,126,217,224,227,228,231,245$, $260,264,298,300,302,303,305,306$, $308-312,354,356$

Hof ten Walle 231

Gian Galeazzo, duke of Milan 68

Glimes, Jan II van, lord of Bergen-op-Zoom, chamberlain-councillor to Philip the Good 160

Godfried I, duke of Brabant $\quad 283,284,286,287$, 290, 291, 292

Gonsales, Antonius $\quad 336,337,340,342,343$

Gouda 93, 99

Goujon, Jacques $336,337,341-343$

Granvelle, Antoine Perrenot de, Cardinal and Archbishop of Mechelen 100, 102

Graven, see Grez

Greece 88

Grez (Graven) $\quad 170$

Grimbergen, lords of $\quad 288-292$

Groenendaal, monastery $\quad 225$

Grotius, Hugo 207

Guelders

Border poles $127,129,131,133$

Court of (Hof van Gelre en Zutphen) 120, $123,124,128,131,132$ 
Duchy $20,98,117-130,132,133,144,164$, $180,186,187,255,297,299,35^{1}$

Duke, see Charles of Egmont

Estates 121, 122, 127, 128

Feudal Chamber (leenkamer) $\quad 125$

Knighthood 122

Lords-Banneret 122,128

Princes 120, 121, 125-129, 131-133, $35^{1}$

Sheriffs (ambtmannen) 123, 133

Shires (ambten) 120, 121, 123, 126, 351

Guglingen, Paul Walther von 323

Guicciardini, Lodovico $\quad 120,121$

Guînes

Lieutenant 211

Town 207, 209, 210

Guy of Dampierre, count of Flanders $\quad 183,304$

Habsburg, Dynasty $31,98,126,142,143,164$, $186,190,192,193,217,221-223,225,226,228$, $230-235,252-254,259,261-263,353,354$

Haggenberg, armorial of 253,254

Hainaut

Count 183

County 144, 164, 190, 255, 257, 291, 300, 301

Halen 170

Hals, county of $\quad 25^{2}$

Ham 334

Hannut 170

Hautscilt, Lubert, abbot of Eeckhout abbey $304-306,308-311$

Hebron 323

Hector 258

Hedel, lordship $\quad 129,130$

Heelu, Jan van 301

Heessel, Hendrik van 244

Helfenstein, counts of 46

Hendrik III, duke of Brabant $\quad 281$

Hendrik IV, duke of Brabant $\quad 281$

Hendrik, duke of Limbourg 286

Hennequart, Jehan 243

Henry III, count of Bar 180

Henry VIII, king of England $\quad 22,191,199-212,353$

Herent 170

Herentals 169,170

's-Hertogenbosch

Bailiwick $153,171,185-187,191$

Quarter $145,148,156-158,160,220$

Town $147,151-155,160,163,169,224,281$

Hesbaye 290

Hessen, landgrave of 191,192

Heynen zoon, Claes, herald 182

Hildesheim, Bishopric 85

Hirsau, abbey of 43

Hochdorf 43, 44

Holland

Count, see Albrecht, Willem VI

County $84,88,92,93,97-99,122,125,128$, $130,132,143,144,153,164,166,181,186$, $187,219,224,227,244,245,252,255,257$, $25^{8}, 280$
Holy Land $\quad 23,319-327,329-343,356$

Holy Roman Empire $\quad$ 18, 20, 29-34, 36, 37, 39,

$43,45,47-49,120,153,179,181,187,222,243$, 246, 250, 251, 253, 263, 264, 285, 301, 350, 354 Emperor, see Charles V; Frederick III; Louis IV; Maximilian I; Sigismund imperial cameral court

(Reichskammergericht) 48 imperial circles (Reichskreise) $\quad 48$

leagues 44,48 peacekeeping (Landfrieden) $\quad 48$

Hoogstraten 224

Horn 290

Hulhuizen, lordship $\quad$ 129, 130

Hulpe, La (Terhulpen)

Bailiwick 170

Town 160,170

Hungary, Kingdom $\quad 88,181,263$

Ida of Lower Lotharingia $\quad 284$

Ireland 211, 212

Italy $18,20,29-34,36,37,39,43,45,47-49$, 120, 153, 179, 181, 187, 222, 243, 246, 250, 251, $253,263,264,285,301,350,354$

Central 59

Northern 59, 61, 181, 357

North-West 60

Southern $59,60,144$

Jacoba of Bavaria 244

Jagiellonians, dynasty $\quad 260,261$

Jan I, duke of Brabant $\quad 250,251,281,286$

Jan II, duke of Brabant 250

Jan III, duke of Brabant 97

Jan IV, duke of Brabant $\quad 163$

Jan, lord of Arkel 186

Jan of Bavaria 244

Jerusalem $\quad 322-326,333,336,337$

Franciscan custodia $\quad 322,325$

Fransiscan convent library 322

Jesus Christ $\quad 86,87,329$

Jodoigne (Geldenaken)

Bailiwick 170

Town 169, 170

Johanna, duchess of Brabant 277, 302

John, count of Salm $\quad 183$

John, count of Zweibrücken-Bitsche $\quad 183$

John, duke of Berry $\quad 305,306$

John of Gaunt, duke of Lancaster 248, 249

John of Salisbury 83

John the Fearless, duke of Burgundy $\quad 305-307$

John XXII, pope 322

Juana the Mad, queen of Castile 221

Jülich, Duke, see William

Julius Caesar 308

Justinian, Emperor $\quad$ 19, 30, 105

Kampenhout $\quad 169$

Kapellendorf $\quad 259$

Kapelle-op-den-Bos $\quad 169$ 
Karel van Egmond, duke of Guelders

Kempen, de, see Campine area

Kempenland 171

Kennemerland $\quad 143,153$

Kerpen 145

Kölderer, Jörg $\quad 261$

Kontich 170

Kumtich 170

Kyburg $\quad 261$

Lambert, count of Leuven and Brussels 283

Lancaster, Count, see John of Gaunt

Landrecies 202

Lannoy, Guillebert de, councilor of Philip the Good 163

Lazio 62

Léau, see Zoutleeuw

Lee, Sir Richard $\quad$ 203, 206, 209

Legnano, John of, jurist $\quad 179,184$

Leiden 97

Leon, see Castile

Leuchtenberg

Landgrave, see Frederick V; Louis I

Leuven

Count, see Lambert

County 278, 283, 290, 291,

Quarter $145,148,156-158,170,220$

Town $97,98,147,148,150,15^{2-154}, 156,158$, $159,163,169,224,228$

Leyden, Philip of 105

Liane, river $\quad 205,207-210$

Liège

$$
\text { City } 264
$$

Prince-Bishop 183,185

Prince-Bishopric $\quad 95,97,103,144,145,160$, $164,180,185,189,257$

Lier (Lierre) $\quad 169$

Lille 224, 230, 245, 260, 305, 307, 309-312

Auditing chamber 219

Lillebuc

Castle $\quad 307$

Lord, see Finard

Limbourg

Duchy $98,144,164,250-252,257,263$

Duke, see Hendrik

Locke, John 19

Lodewijk van Male, count of Flanders $\quad 278$

Lombard, Willem 154

Lombardy $\quad 61-63,66,68$

Lommersum 145

Lomprez, fortress $\quad 189$

London 218

Loon, county of $\quad 185$

Lorraine

Duchy 180

Duke 183

Lotharingia $251,283,284,290,292$

Louis I, duke of Orléans 188,307

Louis IV, Holy Roman Emperor, 31

Louis IX, duke of Bavaria $\quad 264,265$
Louis IX, king of France 190

Louis XIV, king of France 203

Louis I, landgrave of Leuchtenberg $\quad 252$

Low Countries $18,20,22,23,31,81,84,85,92$,

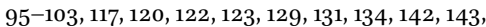

$147,153,164,168,186,217-235,246,255,257$,

$259,262,266,280,297,300,303,310,351,353$,

354,357

Northern 93, 103

Southern 18, 103

Lower Lotharingia

Duchy 277, 282-287, 290, 292

Duke, see Charles

Lower Saxony 85

Lubbeek 170

Lübeck 15

Lucca, Valdinievole 65

Ludwig III, Count Palatine 44

Ludwig IV, see Louis IV, Holy Roman Emperor

Ludwig 'the Rich', duke of

Bavaria-Landshut $\quad 41$

Lugano 324

Luik, see Liège

Luxembourg, duchy of 144, 164, 257

Lyncenich, armorial $\quad 257$

Maasland 171

Maastricht $93,145,150,166$

Machiavelli, Nicolò 19, 203

Mainz

Archbishop, see Conrad

Archbishopric 105, 179

Mair, Martin 90

Manesse, codex $\quad$ 250, $25^{1}$

Mantua/Mantuan

Regime 68

Statutes 63

Marche, Olivier de la, chronicler 189

Margaret of Austria, Duchess-dowager of Savoy and governess of the Low Countries of Habsburg 217, 221-224, 227-230, 232-235, 353

Margaretha van Male, countess of Flanders 277,303

Margaret, princess of Bavaria $\quad 245$

Mark, county $\quad 261$

Mark, evangelist $\quad 263$

Mary of Hungary, Regent of the Low Countries 100, 217, 218, 223, 225, 227, 229, 233-235, 353

Mary, duchess of Burgundy $\quad 262,263,300$

Maximilian I, Holy Roman Emperor 31, 97, 186, 190, 227-230, 233, 261-263, 354

Mechelen

Archbishop, see Granvelle, Antoine Perrenot de

Archbishopric 103

Auditing chamber 219

Lordship 166, 168

Palace of Savoy $\quad 221,232,233$ 
Parliament 219

Town 150, 217, 219, 220, 221, 223-226, 228, $229,232-235,253,281,288,292,354$

Mecklenburg, Duke of, see Albert

Medici, Florence family $\quad 265$

Mediterranean 331

Megen 166

Mercator, Gerardus 208

Merchtem

Bailiwick 170

Town 16o, 169

Merchtenen, Henne van $\quad 250,279,355$

Metz $180,181,183,185,189$

Meuse $\quad 22,95,177,179-182,184,185,189,192$, $193,286,287,290,292,35^{2}$

Middelburg, Bishopric 97,99

Milan

Countryside 66

Duke, see Gian Galeazzo

Millingen, lordship $\quad$ 130,131

Milonis, Paulus 324

Modena 69

Mongols 88

Montclair, fortress $\quad 183$

Montreuil 202

Mont-Saint-Guibert $\quad 170$

Mons 190, 228, 245

Mülich, Hector 257

Munich 342

Muslims 88, 337

Namen, see Namur

Namur (Namen)

Bishopric 97

County $144,164,183,257$

Margrave 183

Namur-Ardennes, house of 283

Nassau, Jan IV van, lord of Breda, seneschal of Brabant 155,160

Neckar, River 43

Nederhemert, lordship 127

Neuss 180

New Haven

County 205

Town 204, see also Ambleteuse

Nicea 258

Nicholas, count of Schwerin and

Tecklenburg $\quad 252$

Nicholas of Cusa, Cardinal $\quad 81,85^{-87}, 89,35^{1}$

Nijmegen

Lordships with high jurisdiction $\quad 122$, 130,132

Quarter 120,122, 124, 125, 127, 128, 132

Town 98,287

Nivelles (Nijvel)

Bailiwick 170

Town 147, 16o, 169, 170

Quarter, see Walloon Brabant

Noah 334
Norway 203

Nuremberg $\quad 42,258,263$

Octavian, Roman emperor $\quad 257$

Oettingen, counts of 46

Oisterwijk 171

Ooij 130, 132, 133

Orléans

Duke, see Louis I

Ortelius, Abraham 208, 334, 335

Ottoman State 88

Outreau 204

Overijse 148

Padua 258

Paget, Sir William $\quad 206$

Palatinate (of the Rhine) $45,46,35^{\circ}$

Count, see Ludwig III

Elector, see Rupert II; Rupert III

Palestine, Crusader States 91

Palmer, Sir Thomas 203

Paris 218, 226, 324

Paulinus of Venice 322

Peelland 171

Peter I, king of Castile and Leon $\quad 248$

Petit, Thomas 206

Petre, Sir William 206

Philip II, king of Spain $\quad 96,100,181$

Philip IV, king of France 180

Philip the Bold, duke of Burgundy $\quad 277,278$, $288,303,305,306$

Philip the Fair, duke of Burgundy, king of Castile 221, 222, 230

Philip the Good, duke of Burgundy $\quad 141,143$, $144,15^{2-154}, 158,160-164,218,229,231,243$, 245, 250, 252, 256, 259, 292, 300, 305

Philip of Saint-Pol, duke of Brabant 148,155 , 163

Picardy 144, 164, 200, 208

Piccolomini, Aeneas Silvius, see Pius II

Pictor, Petrus $\quad 298,299,303,312$

Piedmont $\quad 61,62$

Borghi franchi 63

Eastern $\quad 58$

Villenuove 69

Pippin I, Mayor of the Palace of Austrasia $\quad 282$, 283

Pippin II of Herstal, Mayor of the Palace of Austrasia 282

Pisan, Christine de, writer $\quad 184,190$

Pius II, Pope, see Piccolomini, Aeneas Silvius

Plato 19

Poggibonsi, Niccolò da 323

Poland 88, 26o, 261

Ponthieu 257

Pordenone $\quad 261$

Portugal 203

Poyers 253, 255

Priamus, King of Troy $\quad 281$ 
Promised Land 334

Ptolemy 202

Pufendorf, Samuel von 33

Quaresmio, Francesco $\quad 319-321,324-337,340$, $342-344$

Ramée, abbey of La $\quad 146$

Rapperswil $\quad 261$

Ravenstein $\quad 166$

Red Sea 332,342

Reggio $65,66,69$

Reich, see Holy Roman Empire

Reichenbach, priory of 43

Rhine $44,95,102,177,179-182,184,189,192$, $193,253,255,285^{-287}, 292,35^{2}$

Roermond

Bishopric 98

Quarter 122

Roger, Eugène $\quad 336-340,343$

Rogers, John $\quad 203^{-208}$

Rome $85,86,100,323,326$

Rotselaar, Jan IV van, lord of Rotselaar and Vorselaar 154

Rudolf, margrave of Baden $\quad 183$

Rudolf IV, duke of Austria $\quad 261$

Rupert, duke of Bavaria $\quad 183$

Rupert II, elector Palatine 188

Rupert III, King of the Romans, elector Palatine 188

Ruyers 253, 255

Saint-Omer

Bishopric 103

City 298, 304

Our Lady's church $\quad 298$

Saint Bertin abbey 304

Sale, Antoine de la 253, 255

Salm, Count of, see John, count of Salm

San Vivaldo 324

Sanudo, Marino $\quad 322,323,326,333$

Sassoferrato, Barolo da 19

Saarbrücken, count of 183

Saxony

Duchy $39,42,44,45,48,88$

Duke, see Albrecht

Scandinavia 88,181

Schedel, Hartmann $\quad 258$

Scheldt 285, 286, 287, 290, 292, 301

Schwerin, Count, see Nicholas

Scotland 119, 123, 126, 133, 211, 212

Scythians 88

Shem 334

Sept Fontaines, monastery $\quad 225$

Seymour, Edward, earl of Hertford 204

Siena $\quad 63-65$

Sigismund of Luxembourg, Holy Roman

Emperor 188,263

Sion, Mount 322
Simon III Wecker, count of

Zweibrücken-Bitsche 183

Sint-Genesius-Rode 170

Sonian forest 225

Sonnius, Franciscus $\quad$ 97-100, 102

Spain, King, see Philip II

Speyer 46, 263

Stavelot, Jean de, chronicler $\quad 189$

Stavelot-Malmédy 144

Steenbergen 148

Stokkem 185

Strasbourg

City $181,183,188$

Prince-bishopric 179

Styria $\quad 261$

Surius, Bernardinus $\quad 336-340,343$

Swabia 39,179

Swiss Confederacy 180, 191

Taube von Selbach, Heinrich 31

Tecklenburg, Count, see Nicholas

Tervuren (Le Vure) 148, 225

The Hague 219, 224, 230, 243, 245

Binnenhof 243-244

Princely chapel $\quad 243-244$

Thérouanne, Bishopric 97, 98, 210

Tiel 124

Tienen

Bailiwick 170

Quarter 145, 148,158

Town $145,147,153,169,170$

Tirin, Jacques $\quad 332-335,337,342$

Tournai

Bishopric 95, 98

City 97,185

Trent

Council 98

Town 99

Trier

Archbishopric $\quad 37,179$

Archbishops 45

Troy 258,281

Turks 87,88

Tuscany $58,62-64,66,324$

Terre nuove 64

Utrecht

(Arch)bishopric 94-96, 98, 99, 101, 103

Prince-Bishopric 92, 93, 125, 130, 257

Town $88,93,98,99,105$

Umbria 62

Valachia (Wallachia) 88

Valkenburg, lord of 183

Vargula 259

Vauban, Sébastien Le Prestre de 203

Velthem, Lodwijk van, chronicler 181

Vermandois 257

Vianden $\quad 291$ 
Vieselbach 259

Viglius, see Aytta

Vilvoorde (Vilvorde) $148,169,170$

Vinxtbach 285

Visconti

Dynasty 66

Duke, see Gian Galeazzo

Vippach 259

Veneto 62,66

Venice 15,65

Vesconte, Piero $\quad 322,323,326,333$

Waal 95, 102

Wales 212

Walloon Brabant (Nivelles), Quarter $\quad 145,148$, $150,158,160,170$

Wallop, Sir John 202

Waterland 170

Warwickshire, Gentry 125

Wassenberg, Count 121

Wegberg 93,

Wenceslas of Luxembourg, duke-consort of Brabant 302

Westphalia $33,35,39$

Wezemaal, Jan II van, lord of Wezemaal 154

Wiener Neustadt $\quad 261$

Wijnbergen, armorial $\quad 256,257$
Willem VI, count of Holland $\quad 243^{-245}$

William, duke of Jülich $\quad 187$

William III, king of England 199

Wittelsbach dynasty 31,41

Woeringen, battle of $\quad 250,286$

Württemberg, Duke $43,45,46,191$

Ypres

Bishopric 97, 103

Town $298,301,303,309-312,35^{6}$

Ypres, Bernard of 304

Zandhoven $\quad 170$

Zeeland 97, 99, 227, 244, 245, 252, 255, 257

Zeeuws-Vlaanderen 95

Zichem

Lordship $\quad 169$

Town 160

Zoelen 124

Zollern, counts of $\quad 46$

Zoutleeuw (Léau) 147, 153, 169

Zutphen

City 122

Quarter 122,125-127, 132-134

Zweibrücken-Bitsche

Count, see John; Simon III Wecker

Zwinner, Electus $\quad 336,337,339,342,343$ 
In recent political and legal history, scholars seldom specify how and why they use the concept of territory. In research on state-formation processes and nation building, for instance, the term mostly designates an enclosed geographical area ruled by a central government. Inspired by ideas from political geographers, this book explores the layered and constantly changing meanings of territory in late medieval and early modern Europe before cartography and state formation turned boundaries and territories into more fixed (but still changeable) geographical entities. Its central thesis is that assessing the notion of territory in a pre-modern setting involves analysing territorial practices: practices that relate people and power to space(s). The essays in this book not only examine the construction and spatial structure of pre-modern territories but also explore their perception and representation through the use of a broad range of sources: from administrative texts to maps, from stained-glass windows to chronicles.

Mario Damen is senior lecturer at the University of Amsterdam. He has published widely on the social and political history of the late medieval Low Countries and is the PI of the research project Imagining a territory. Constructions and representations of late medieval Brabant, financed by the Dutch Research Council (NWO).

Kim Overlaet worked from 2016 till 2019 as a postdoctoral researcher at the University of Amsterdam on the NWO project 'Imagining a territory'. She currently works as a research manager at the Department of History at Antwerp University. 